\title{
Copyright, fan generated contents, and open society in China
}

Citation for published version (APA):

He, T. (2016). Copyright, fan generated contents, and open society in China: Towards an open innovation mechanism of copyrighted contents with fans. [Doctoral Thesis, Maastricht University]. Maastricht University. https://doi.org/10.26481/dis.20160701th

Document status and date:

Published: 01/01/2016

DOI:

$10.26481 /$ dis.20160701th

Document Version:

Publisher's PDF, also known as Version of record

\section{Please check the document version of this publication:}

- A submitted manuscript is the version of the article upon submission and before peer-review. There can be important differences between the submitted version and the official published version of record.

People interested in the research are advised to contact the author for the final version of the publication, or visit the DOI to the publisher's website.

- The final author version and the galley proof are versions of the publication after peer review.

- The final published version features the final layout of the paper including the volume, issue and page numbers.

Link to publication

\footnotetext{
General rights rights.

- You may freely distribute the URL identifying the publication in the public portal. please follow below link for the End User Agreement:

www.umlib.nl/taverne-license

Take down policy

If you believe that this document breaches copyright please contact us at:

repository@maastrichtuniversity.nl

providing details and we will investigate your claim.
}

Copyright and moral rights for the publications made accessible in the public portal are retained by the authors and/or other copyright owners and it is a condition of accessing publications that users recognise and abide by the legal requirements associated with these

- Users may download and print one copy of any publication from the public portal for the purpose of private study or research.

- You may not further distribute the material or use it for any profit-making activity or commercial gain

If the publication is distributed under the terms of Article $25 \mathrm{fa}$ of the Dutch Copyright Act, indicated by the "Taverne" license above, 


\title{
COPYRIGHT, FAN GENERATED CONTENTS, AND OPEN SOCIETY IN CHINA: TOWARDS AN OPEN IN- NOVATION MECHANISM OF COPYRIGHTED CON- TENTS WITH FANS
}

\author{
DisSERTATION \\ to obtain the degree of Doctor \\ at Maastricht University, \\ on the authority of the Rector Magnificus, \\ Prof. dr. L. L. G. Soete \\ in accordance with the decision of the Board of Deans, \\ to be defended in public at the Aula, \\ on Friday 1 July, 2016, at 10:00 hours
}

by

Tianxiang He

Born in Changsha, P. R. China, on 1 April 1984 



\section{Supervisor:}

Prof. dr. Anselm Kamperman Sanders

\section{Co-supervisor:}

Dr. Ana Ramalho

\section{Assessment Committee:}

Prof. dr. Bruno de Witte (Maastricht University) (Chair)

Prof. dr. Dick van Engelen (Maastricht University)

Prof. dr. Michael Faure (Maastricht University)

Dr. Rogier Creemers (University of Oxford)

Prof. dr. Masabumi Suzuki (Nagoya University)

NUR-Code: 828

ISBN: 9789462954458

(C) 2016 Tianxiang He, Maastricht 



\section{ACKNOWLEDGEMENTS}

This book is the final result of my 4 years $\mathrm{PhD}$ life in the Institute for Globalisation and International Regulation (IGIR) of the Faculty of Law of Maastricht University. This could never have happened without the patience, guidance, and support of my supervisor Prof. Anselm Kamperman Sanders, who led me to this beautiful country and showed me my potential as an academic. He gave me chances to see how academia and things run differently between countries, and provided me with vast opportunities to practice my teaching skills and to forge my thesis with the finest materials that I could access. He has always been a source of inspiration, a true friend, and a mentor to me. I am indebted to him for the considerable freedom that he has offered me in choosing my topic and writing my thesis, his tolerance of all my sudden ideas and requests, and all the beautiful moments that we have spent in discussing music, art, and my topic in different corners of the world.

My special thanks go to Dr. Ana Ramalho who kindly offered me her help in the final stages of my thesis. Our discussions over the structure and outline of the book, and her careful proofreading and comments regarding the early manuscripts helped me rethink the architecture of this book and improve the manuscript substantially. A special word also goes to my once officemate, colleague, and friend Dr. Agustín Parise, who has kindly shared with me his valuable research experiences such as drafting articles and how to get them published in American journals during our office time, without which I may not have had the courage to try in the first place. I will always remember the days that we have spent in D0.223 and our friendship which reminds me that I am not alone in this country. And Dr. Patrick Smit, I owe you a beer for your beautiful Dutch translation of the summary of this book.

This book is supported by the China Scholarship Council (CSC) and the Faculty of Law of Maastricht University. Without the funding from my motherland, I could never get this far. Sincere and faithful research could only repay its love a little. In the second year of my PhD, I had the 
honor to receive a generous grant from the Japan Foundation Fellowship program, which supported me in a one-year research (2012-2013) stay in Waseda University in Tokyo, to investigate the cultural market of Japan and the fan activities within. With the invaluable guidance and help from Prof. Takabayashi Ryu, the final result of that research, which also forms part of this book and which obtained for me an honorable mention in the Ius Commune Prize 2014, was published in volume 62, issue 4 of the American Journal of Comparative Law in 2014. I would like to thank the Waseda University for its hospitality, and the Japan Foundation for the grant of the fellowship, and the jury of Ius Commune Research School for their appreciation of my paper.

I am grateful to Dr. Rogier Creemers and Prof. Eric Priest for inviting me to the United States to present a paper on the solution design of my research for transnational copyright problems raised by fan activities at the Symposium on Copyright and Media Pluralism in China organized by the School of Law, University of Oregon in 2014. That allowed me to discuss part of the solution design of this book with eminent scholars in the field of intellectual property (IP) law, and to get that article published on the volume 16, issue 2 of the Oregon Review of International Law in 2014. I have also had the privilege to present part of my research findings in the Ius Commune Research School conferences and workshops and the $\mathrm{PhD}$ sections of the European Intellectual Property Institutes Network (EIPIN) Congresses, and discuss them with many renowned international scholars. These fruitful discussions helped me to improve my manuscript a lot. My deep gratitude goes to, inter alia, Prof. Madeleine de Cock Buning, Prof. Benjamin van Rooij, Prof. Peter Yu, Prof. Wendy Gordon, Prof. Josef Drexl, Prof. Manuel Desantes, Dr. Noam Shemtov, for their helpful insight and ideas.

There are many friends that I would like to thank sincerely. Once again, Rogier, you are the one that introduced me to Maastricht and offered me many opportunities to testify my thoughts; Jie shared the same office with me for almost four years, Yaojin and Tian joined us subsequently, and I benefited greatly from our daily discussions on my thesis and other IP issues; Dr. Anke Moerland, Dr. Cees Mulder, and Dr. Dalindyebo Shabalala are my colleagues and tutors in IGIR, and they helped me enormously with their enthusiasm, guidance and encouragement; Sophie, Suzanne, and Licette, you are the best administrative personnel I have ever met; All my friends in and around our faculty, Viorelia Gasca, Julieta Marotta, Xiahong and Haiyan with their little angel Kankan, Stef- 
an, Jing Liu, Can Huang and Jinjin Zhao, Wenqing and Zhenglong, Wencheng, Chien-Chih, Xiang Li, Jinyang Han, Yuan Gao, Yuan Tian, Taotao, Huizhen, Xuesong Li, Junping Liu, Hongguang Nie, Jiangqiu, Xiaowei, Yingying, Mengxing, Yu and Xi, Liang, Liuhu, Mengmeng, Ancui, Wei Zhao, Wenzhao, Kai Liu, thank you for all your support and joyful moments that made me feel at home during this long and winding road.

I would like to sincerely thank Professor Jun Feng, my PhD supervisor in Renmin University of China. He encouraged me to pursue a doctoral degree outside China back in 2010 , and he is also a fatherly role model for me. Special thanks also go to Prof. Ying Liu, my supervisor during my master studies. He treated me as his son and he makes me feel that he is always there for me.

Last but certainly not least, I would like to thank my family. My wife Yuzhe inspired me to pursue an academic career. Her unconditional and continuous love and support are the reason that I was able to devote myself to a $\mathrm{PhD}$ project during these four years. Although she is far away in Japan, I can always feel her love, without which the conclusion of this thesis would have been unimaginable. My love also goes to my father Xiuwen He and my mother Xinjie Wang, they let me know that a safe harbor will always be there for me. I dedicate my book to them, for their love, support, and endless care. 



\section{TABLE OF CONTENTS}

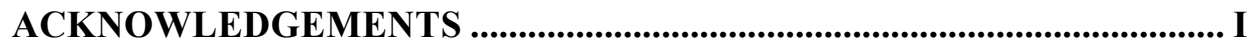

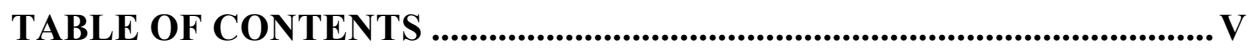

LIST OF ABBREVIATIONS ...................................................................... IX

LIST OF PUBLICATIONS ...................................................................... XI

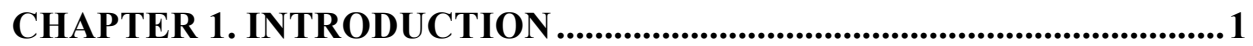

1.1 Challenges For CoPyright IN THE Digital AgE ............................ 3

1.1.1 The Inadequacy of Regulating Fan Behavior by Law....................... 5

1.1.2 Prosumer vs. Consumer .............................................................. 5

1.1.3 Fans and the Expansion of Copyright ............................................. 7

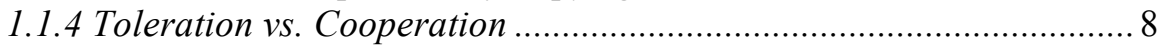

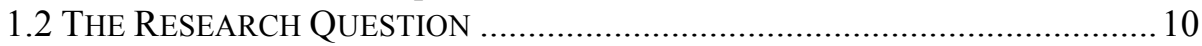

1.3 MethodologY AND OUtLINE Of THE BoOK …....................................... 12

CHAPTER 2. FIGHT WITH THE DRAGON ..........................................15

2.1 BARRIERS OR DEFENDERS: THE FAILURE CAUSED BY THE GREAT

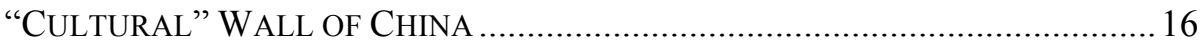

2.1.1 Chinese Political Culture ............................................................... 18

2.1.1.1 Imperial China Period (Before 1912) ................................................................. 18

2.1.1.2 Modern War Period (1913-1949) ……………………………………………....24

2.1.1.3 Revolutionary Period (1950-1979) …………………………………………....24

2.1.1.4 Transitional Period (1980-1990) ...................................................................2

2.1.1.5 Open Up Period (1991-present) ...............................................................................

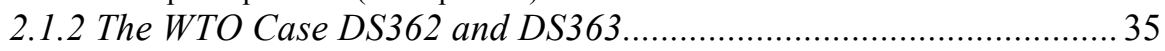

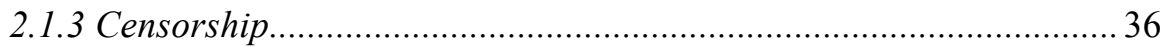

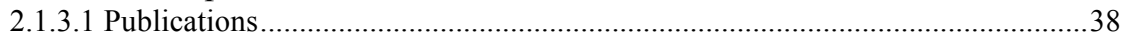

2.1.3.2 Traditional Broadcasting Channels...............................................................4

2.1.3.3 Online Streaming …………………………………………………………....52 


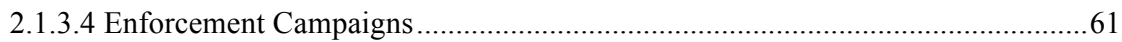

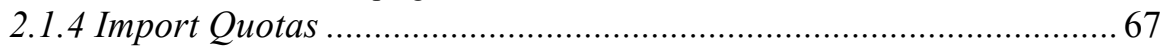

2.1.5 Participatory Culture and Civic Engagement............................. 72

2.1.6 Market and Fans ...................................................................... 84

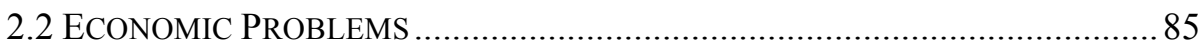

2.2.1 Information Asymmetry ....................................................... 86

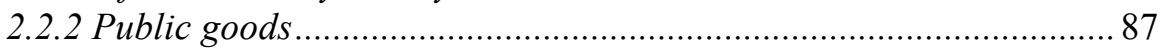

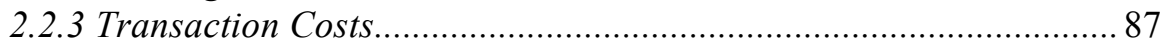

2.3 CONCLUSION ........................................................................... 90

CHAPTER 3. THE RISE OF FAN ACTIVITIES ......................................93

3.1 The New Media And FAn ACtivities ......................................... 94

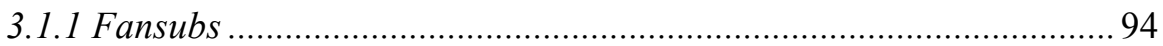

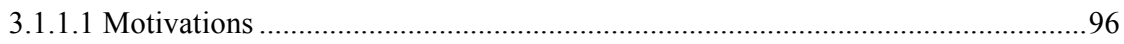

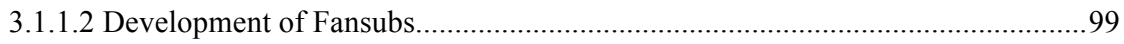

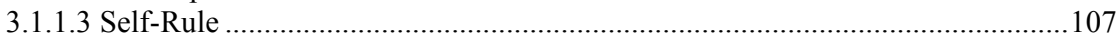

3.1.2 Fanfics, Doujinshis, and Scanlations....................................... 110

3.1.3 Fanvids, AMVs, and Video Parodies ....................................... 113

3.2 BeHind the Fans ACtivities: Challenges of the Digital

REVOLUTION.................................................................................... 114

3.2.1 Challenges to the Copyright System ...................................... 115

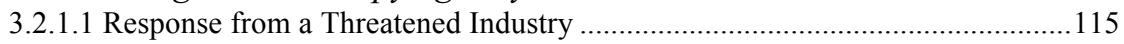

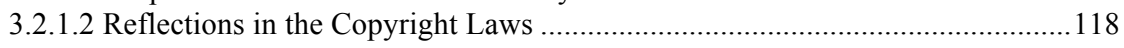

3.2.2 Behind the Challenges: Technology Developments..................... 122

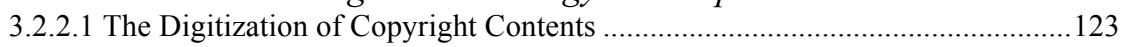

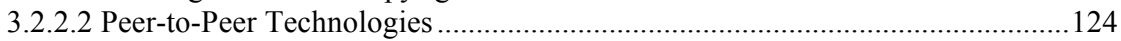

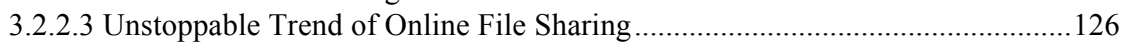

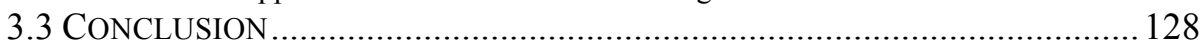

\section{CHAPTER 4. A COMPARATIVE EXAMINATION OF FAN ACTIVITIES UNDER CURRENT LEGAL FRAMEWORKS OF THE UNITED STATES, CHINA, AND JAPAN .}

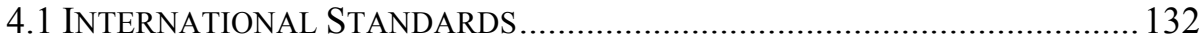

4.2 LEGAL DETERMINATION AT NATIONAL LEVEL................................... 133

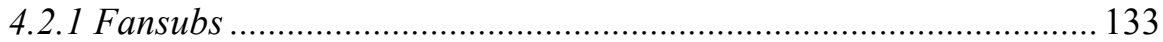

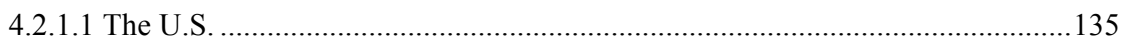

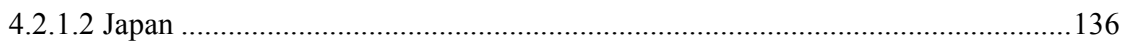

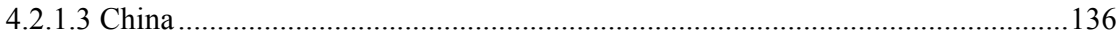

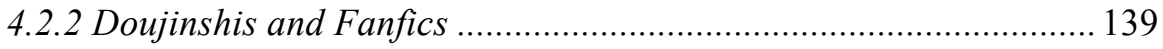




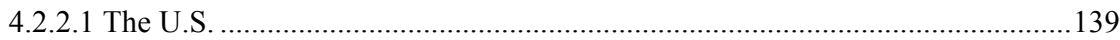

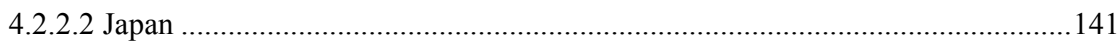

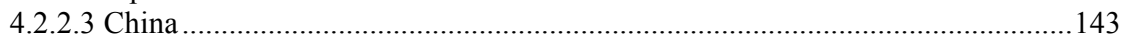

4.2.3 Fanvids, AMVs, and Video Parodies ......................................... 146

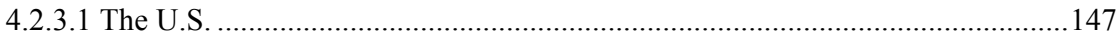

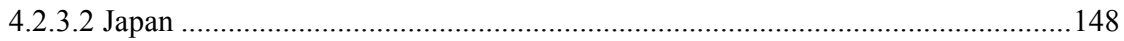

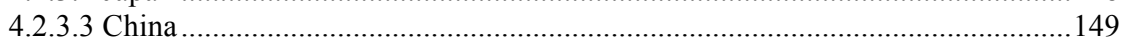

4.3 POSSIBLE DEFENSES ..................................................................... 150

4.3.1 Constitutional Defenses ......................................................... 151

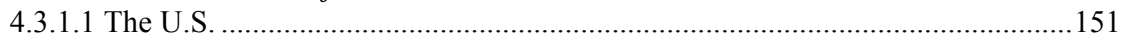

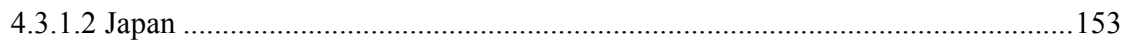

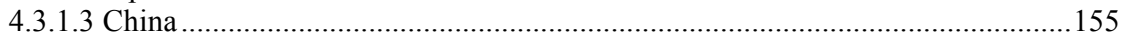

4.3.2 Civil Law Defenses................................................................. 158

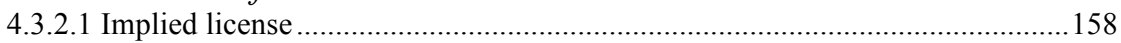

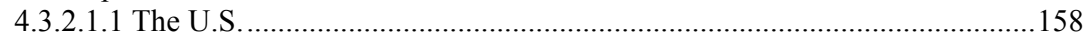

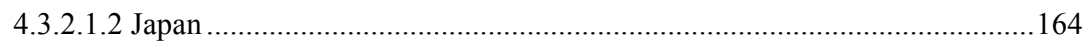

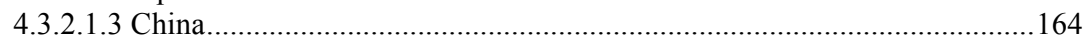

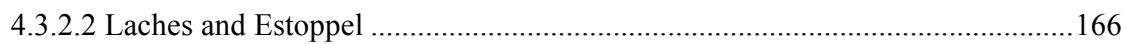

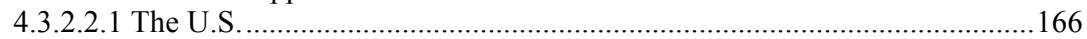

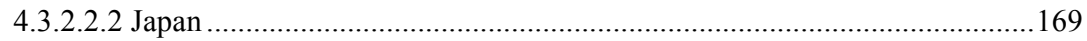

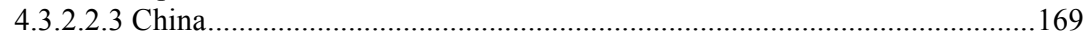

4.4 THE EXISTING SOLUTIONS........................................................ 170

4.4.1 Governmental Solutions ..................................................... 171

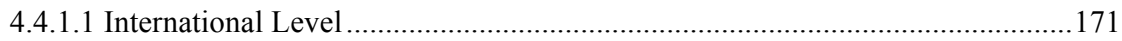

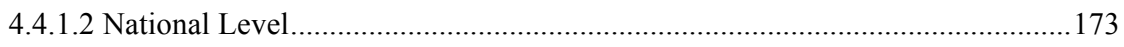

4.4.1.2.1 Fair Use and Copyright Exceptions .................................................... 174

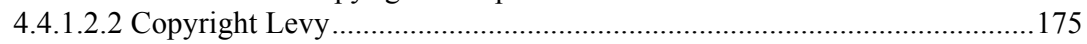

4.4.1.2.3 Reintroduction of Copyright Formalities ...............................................178

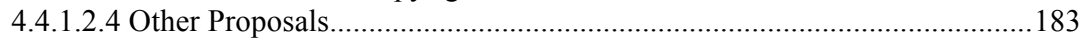

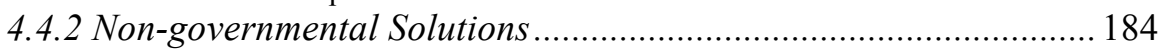

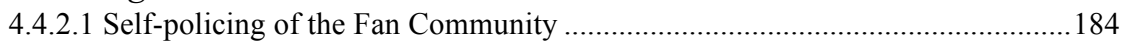

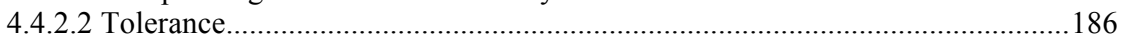

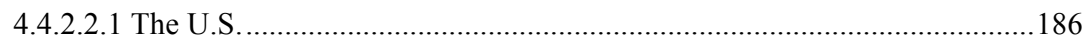

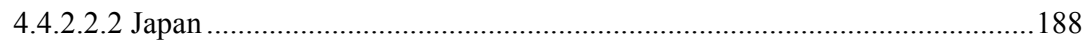

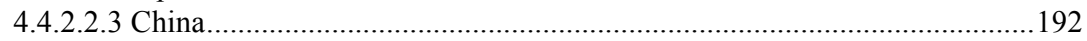

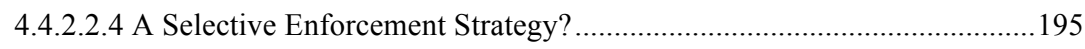

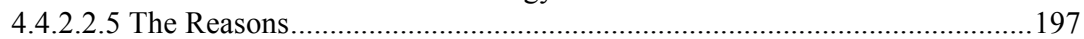

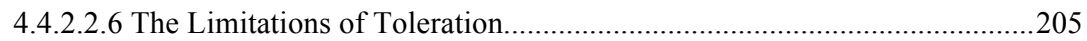

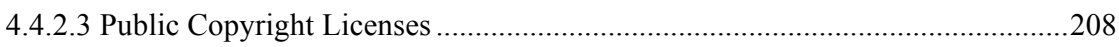

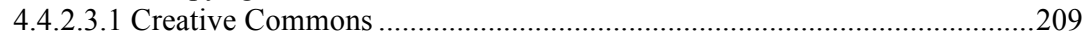

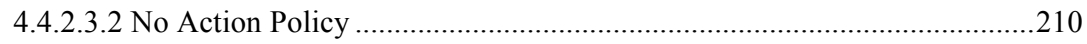

4.5 CONCLUSION ............................................................................ 210

CHAPTER 5. CONCLUSIONS AND RECOMMENDATIONS ................215

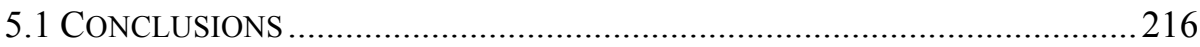




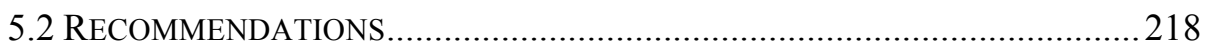

5.2.1 A Feasible Solution ................................................................... 221

5.2.2 Part I: An Open Innovation Mechanism ..................................... 224

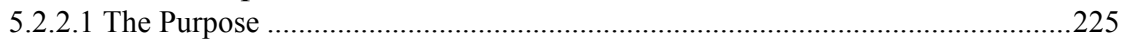

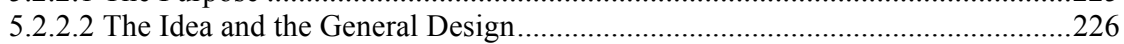

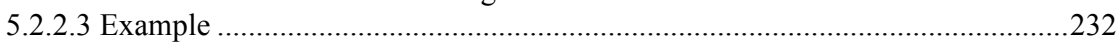

5.2.3 Part II: The Copyright Law of China in the Near Future............... 239

5.2.3.1 Legal Status of Derivative Works.....................................................................240

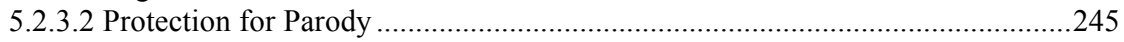

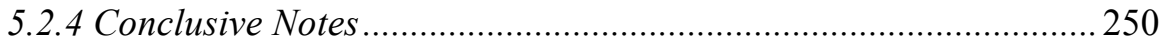

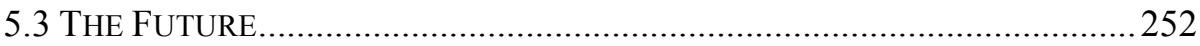

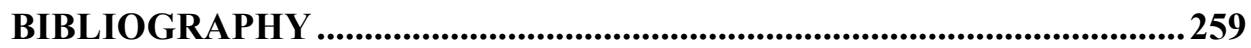

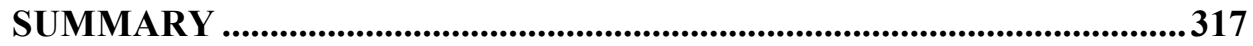

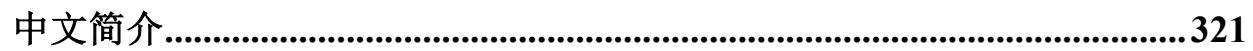

NEDERLANDSE SAMENVATTING .......................................................325

VALORIZATION ADDENDUM .....................................................................3329

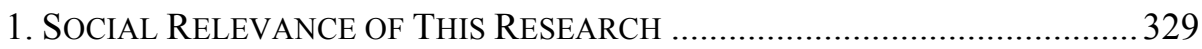

2. AUDIENCE BESIDES ACADEMIC COMMUNITY ………................................330

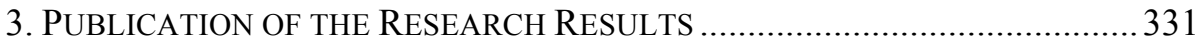

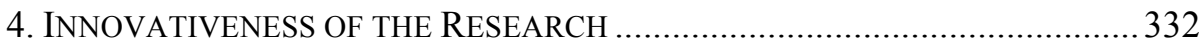

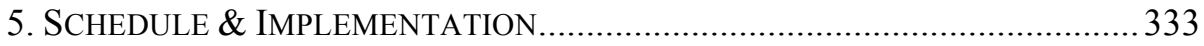

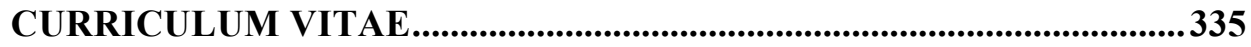




\section{List OF ABbREVIATIONS}

\begin{tabular}{|c|c|}
\hline ACTA & Anti-Counterfeiting Trade Agreement \\
\hline AMV & Anime Music Video \\
\hline BBS & Bulletin Board System \\
\hline Conven- & Berne Convention for the Protection of Literary and \\
\hline & Artistic Works \\
\hline $\mathrm{CC}$ & Creative Commons \\
\hline CCL & Copyright Law of the People's Republic of China \\
\hline $\mathrm{CCP}$ & Chinese Communist Party \\
\hline CCTV & China Central Television \\
\hline $\mathrm{CD}$ & Compact Disc \\
\hline CD-R & Compact Disc-Recordable \\
\hline CJEU & Court of Justice of the European Union \\
\hline CNNIC & China Internet Network Information Center \\
\hline DMCA & Digital Millennium Copyright Act \\
\hline DMZ & Demilitarized Zone \\
\hline DRM & Digital Rights Management \\
\hline DVD & Digital Versatile Disc \\
\hline EU & European Union \\
\hline FTP & File Transfer Protocol \\
\hline GATT & General Agreement on Tariffs and Trade \\
\hline IP & Intellectual Property \\
\hline IRC & Internet Relay Chat \\
\hline ISP & Internet Service Provider \\
\hline JASRAC & $\begin{array}{l}\text { Japanese Society for Rights of Authors, Composers } \\
\text { and Publishers }\end{array}$ \\
\hline JAILED & Japanese Animation Legal Enforcement Division \\
\hline $\mathrm{JCL}$ & Japanese Copyright Law \\
\hline LD & Laserdiscs \\
\hline $\mathrm{MFN}$ & Most-Favored Nation \\
\hline NAP & No Action Policy \\
\hline $\mathrm{P} 2 \mathrm{P}$ & Peer-to-Peer \\
\hline PC & Personal Computer \\
\hline SAPPRFT & State Administration of Press, Publication, Radio, \\
\hline
\end{tabular}


Film and Television of the People's Republic of China

SARFT

SOPA

SPC

TBS

TRIPS

TVWF

UCC

U.K.

U.S.

USC

VCD

VOD

VHS

WIPO

WTO
State Administration of Radio, Film, and Television of the People's Republic of China

Stop Online Piracy Act

Supreme People's Court of the People's Republic of China

Tokyo Broadcasting System Television

Agreement on Trade-Related Aspects of Intellectual

Property Rights

Television without Frontiers

Universal Copyright Convention

United Kingdom

The United States of America

United States Code

Video Compact Disc

Video on Demand

Video Home System

World Intellectual Property Organization

World Trade Organization 


\section{List of Publications}

Parts of Chapter 2 in relation to the economical problems and some endemic problems of the Chinese market, Chapter 3 in relation to fan activities, and Chapter 4 in relation to legal determinations of fan activities and toleration from the copyright owners are updated versions of corresponding parts in:

Tianxiang He: What Can We Learn from Japanese Anime Industries? The Differences Between Domestic and Overseas Copyright Protection Strategies Towards Fan Activities

published in the American Journal of Comparative Law, Volume 62, Number 4, December 2014, pp. 1009-1042.

Parts of Chapter 3 in relation to fansubs and challenges of the digital revolution, Chapter 4 in relation to possible defenses and existing solutions, Chapter 5 in relation to the example are updated versions of corresponding parts in:

Tianxiang He: Fansubs and Market Access of Foreign Audiovisual Products in China: The Copyright Predicament and the Use of No Action Policy

published in Oregon Review of International Law, Volume 16, issue 2, 2014, pp. 307-346. 



\section{CHAPTER 1. INTRODUCTION}

With the development of new digital technologies, online piracy is becoming a greater and greater problem at breakneck speed. ${ }^{1}$ The current global copyright regime is therefore facing critical challenges stemming from worldwide piracy activities. Thousands of millions of unauthorized copies are made and distributed online globally each year, but seemingly the world lacks proper counter-measures.

If we take a careful look at the online piracy, we might discover something interesting: Fan activities. Fans of certain copyrighted titles associate with each other, often producing and exchanging amateur creations. Nowadays, fan activities of audio-visual products are deeply entwined with online copyright piracy. Specifically, fans appropriate segments or core elements from the original copyrighted works, and use them to create something new: it could be a creative translation of the subtitles of a movie; it could also be a parody, or a proposal video using a copyrighted romantic song. Typical fan creations include fansubs, fanfics, doujinshi, scanlation, fanvids, AMVs, video parodies, and the fact that they all borrowed at least segments from existing works makes them vulnerable to lawsuits. Moreover, "Fan" is a word with a lengthy history and is often evoked in a negative way. ${ }^{2}$ Fans of all kinds have been depicted as "a scandalous category" in contemporary culture. ${ }^{3}$ In modern days, although the prevailing attitude towards fans has not changed much, fans themselves, with the help of modern technologies, have emerged as a force that cannot be ignored. As the number of fans continues to mount (or, more precisely, to be acknowledged), fan activities, along with their

\footnotetext{
${ }^{1}$ However, economic research indicated that countries with higher levels of IT infrastructure have lower levels of movie piracy. See W. D. Walls, Cross-country Analysis of Movie Piracy, 40 APPLIED ECONOMICs 625, 630 (2008).

${ }^{2}$ Henry Jenkins, TeXtual Poachers: Television Fans \& Participatory Culture 12-3 (Routledge. 1992).

${ }^{3} I d$. at 15 .
} 
values, are gradually changing our understanding of dominant cultural hierarchies. ${ }^{4}$ Some of these activities may be justified under fair use doctrines or similar regimes in copyright laws; however, some of them are deemed derivative and unauthorized, and therefore condemned by our laws. Interestingly, evidence shows that many fan activities are not detrimental to the original copyright works. Some cases show that, due to economic considerations and cultural policies of China, foreign audio-visual industries are tolerating most fan activities there. As previous studies have indicated, the piracy problems in China are extremely complex: they involve historical, cultural and political considerations, which all contribute to the lax copyright enforcement of government agencies there. ${ }^{5}$ Many research studies have also demonstrated that the existence of some unauthorized activities is crucial to the development of civic engagement and democratic participation in China. ${ }^{6}$ Nevertheless, our copyright system is incapable of distinguishing these beneficial activities from piracy. Fan communities are still deemed to be pirates, and their labors are not fully recognized. $^{7}$

In order to illustrate why fan activities are a problem for copyright and why the options we have are limited in the digital age, it is reasonable to delineate first the challenges that copyright faces today. For that purpose, the next section of this chapter summarizes the problems that copyright has encountered in the digital era and how these problems interact with fans and market interests (para. 1.1). The research question is explained in detail after (para. 1.2), and the methodology and the outline of the book are delineated in the last section (para. 1.3).

\footnotetext{
${ }^{4}$ Id. at $17-24$.

5 See generally William P. Alford, To Steal a Book is an Elegant OfFense : Intellectual Property Law in Chinese Civilization (Stanford University Press. 1995); Eric Priest, The Future of Music and Film Piracy in China, 21 BERKELEY TECH. L.J. 795, 821-829 (2006)(Summarized the problems that copyright owners will face if they were to crack down hard on piracy in China); see also CHRIS ANDERSON, FrEE: THE FUTURE OF A RADICAL PRICE 165 (Hyperion 1st ed. 2009)("Piracy extends to virtually every industry in China, a combination of the state of development of the country and its legal systems and a Confucian attitude toward intellectual property that makes copying the work of others both a gesture of respect and an essential part of education.").

${ }^{6}$ See generally, William Hennessey, Deconstructing Shanzhai-China's Copycat Counterculture: Catch Me If You Can, 34 Campbell L. Rev. 609 (2012); See also Robert S. Rogoyski \& Kenneth Basin, The Bloody Case That Started From a Parody: American Intellectual Property and the Pursuit of Democratic Ideals in Modern China, 16 UCLA ENT. L. REV. 237 (2009).

7 See Hye-Kyung Lee, Participatory Media Fandom: A Case Study of Anime Fansubbing, 33 Media, CULTURE \& SOCIETY $1131,1141(2011)(“ . .$. the industry is framing fansubbing as piracy...”).
} 


\subsection{Challenges for Copyright in the Digital Age}

The current problems raised by fan activities are firmly connected with the advent of digital technologies. However, it is hard to find a solution. On one side, the structural design of the Internet enables the free flow of information. On the other side, the development of new technologies also enables copyright owners to exert a higher degree of control on that flow. Some believe in Network Neutrality ${ }^{8}$ thus are wary of total control over the content layer that can come about by the combination of law and technology. ${ }^{9}$ Marci Hamilton pointed out that a legal setting based on rules from the pre-internet age "could be used unfairly by publishers to restrict the free-flow of ideas as a means of profiting from their copyrights." ${ }^{\prime \prime}$ According to Hamilton, the copyright law should find a balance between the need to access information and copyright values, and she further argued that more freedom should be given to users of copyright contents. ${ }^{11}$ However, today we can clearly see that her hopes (in 1996) have been dashed: since 1996, after almost two decades, access to information and copyright contents are still firmly controlled by copyright owners.

All the transgressors are deemed to be copyright infringers from the outset, since technology has replaced the law in judging whether an action is copyright infringement or not, and only a few accused of copyright infringement will be resilient enough to resort to the courts to defend their innocence. Just like Lessig had indicated, the "code" embedded in the software or hardware is becoming a potential threat to liberty. ${ }^{12}$ Moreover, technology development has enabled ordinary people to easily seize and copy that information and use it to create something new. But the majority of these appropriations of copyright contents are unauthorized. Seemingly it is not economically viable for copyright owners to control all these online infringement activities. Nevertheless, the content indus-

\footnotetext{
${ }^{8}$ Network neutrality is best defined as a network design principle. The idea is that a maximally useful public information network aspires to treat all content, sites, and platforms equally. See Tim Wu, Network Neutrality FAQ, at http://www.timwu.org/network_neutrality.html; See also Lawrence Lessig, In Support of Network Neutrality, 3 ISJLP 185 (2007).

${ }^{9}$ LaWrence Lessig, The Future of Ideas: the Fate of the Commons in a Connected World 249 (Random House 1st ed. 2001).

${ }_{10}$ Marci A. Hamilton, The TRIPS Agreement: Imperialistic, Outdated, and Overprotective, 29 VAND. J. TRANSNAT'L L. 613, 613 (1996).

${ }^{11} I d$. at 622.

12 LAWrence Lessig, Code: Version 2.0121 (Basic Books 2nd ed. 2006).
} 
tries push for higher standards of copyright protection, as they believe that the new technologies are threatening their current commercial model, which consists of high prices, unfair income distributions among artists, and a narrow range of the mass-market products. ${ }^{13}$ However, that argument fails to provide an answer too, as legislative change heading toward the extreme of total protection will arguably provoke a backlash from the consumers. ${ }^{14}$ This is what Prof. Balkin called the "conflict about control". ${ }^{15}$ Moreover, many consumers are fans, and their consumption pattern has changed dramatically in the digital age. They desire to access and utilize copyrighted contents freely, but also to become part of a community (online) where information is shared and copyright content is re-appraised, discussed and adopted for further use. This leads to 'fan creations'. Copyright does not, however, distinguish between these ideas and its constraints lead to great conflict.

This section gives an overview of these interweaving problems and the inner link between these fundamental issues and the fan activities, and it also explains why fan activities are inevitable in the digital era and why the law needs to respond. For that purpose, subsection 1.1.1 delineates how the current copyright law system fails to address the problem of fan creations, and elaborates the difficulties which society encounters when trying to regulate the unauthorized online utilization of copyright contents such as fan actions by law alone. Next, subsection 1.1.2 provides an historical overview of the consumer's role in content consumption and examines the subsequent problems of unauthorized utilization of pre-existing copyright works caused by the role changing of consumers, which is condemned by copyright law, and it further discerns the beneficial aspects of it. Subsection 1.1.3 explains the interrelation between fan activities and the expansion of copyright. Finally, subsection 1.1.4 explains a shift in the attitude of the content industries towards these fan activities.

\footnotetext{
${ }^{13}$ William W. Fisher, Promises to Keep: Technology, LaW, And The Future of Entertainment 7 (Stanford Law and Politics. 2004).

${ }^{14}$ For instance, In the U.S., the pushing of two anti-piracy bills was met with a fierce backlash from its nationals. See Jenna Wortham, Public Outcry Over Antipiracy Bills Began as Grass-Roots Grumbling, N.Y. TiMES, Jan. 19, 2012, at http://www.nytimes.com/2012/01/20/technology/public-outcry-over-antipiracy-bills-began-as-grass-roots-grumbling.h $\mathrm{tml}$ ? $\mathrm{r}=0$. Prof. Reidenberg has indicated that "there will be a significant regulatory backlash against digital rights management for intellectual property." See Joel Reidenberg, Commentary on Digital Rights Management, 7 INT'L INTELL. PROP. L. \& POL'Y 53-1, 53-2 (2002).

${ }_{15}$ Jack M. Balkin, Digital Speech and Democratic Culture: A Theory of Freedom of Expression for the Information Society, 79 N.Y.U. L. REV. 1, 15 (2004).
} 


\subsubsection{The Inadequacy of Regulating Fan Behavior by Law}

Being afraid of losing revenue due to massive online copying, copyright owners around the world are pushing for increasingly tough standards of copyright protection. As a result, more and more daily online activities that involve copying, including fan activities, are treated as copyright infringements presumptively. ${ }^{16}$ In terms of fan creations, it is clear that many of them are infringeing the copyright laws in many countries. According to Lessig, a certain kind of behavior, such as fan activity, is regulated by four modalities-the law, the market, the norms, and the architecture. ${ }^{17}$ Each modality, if properly designed, may exert a certain degree of control over fan activities. The law can give people a set of comparatively vague rules about what is the legitimate way to utilize another's copyright content, and through the deterrent effect to enforce them; the market will tend to filter out questionable fan works in order to avoid legal problems, therefore the latter can never go mainstream; fan community norms are also regulating the behavior of fans; or, the architecture of the Internet could be redesigned so that fans could not physically "borrow" copyright contents. However, that is being challenged in the digital era. The amount of online infringement renders copyright law enforcement uneconomical; the market cannot control everything perfectly since the cost of creating and distributing fan work is so low and the cost of policing is extremely high; fan community norms are constantly changing; and, a total control architecture is in conflict with the law in many aspects. It is noted that "solutions in the context of cyberspace" require "a mix of at least two modalities". ${ }^{18}$ Therefore, copyright cannot solve the problems of fan creations alone. Besides, our copyright law system has many gaps and gray areas. $^{19}$

\subsubsection{Prosumer vs. Consumer}

Amidst all the unauthorized utilization of copyright contents, fan problems are closely related to the changing role of consumers. Nowadays,

\footnotetext{
${ }^{16}$ Edward Lee, Warming up to User-Generated Content, 2008 U. ILL. L. REV. 1459, 1471-72 (2008).

${ }^{17}$ LESSIG, supra note 12, at 94.

${ }^{18} I d$. at $223-24$.

19 Lee, supra note 16, at 1473.
} 
consumers are not merely receivers of contents anymore, as they are turning into "prosumers". ${ }^{20}$ The prosumers who are fans of certain works are known to create 'fan works' derived from pre-existing copyright contents. This kind of behavior is not unconventional and belongs to a certain level of fandom. According to Jenkins, the concept of fandom includes five levels of activity: a particular mode of reception; a particular set of critical and interpretive practices; a base for consumer activism; particular forms of cultural production, aesthetic traditions and practices; an alternative social community. ${ }^{21}$ However, the nature of fan creation challenges the copyrights of the mass-market audio-visual products, as many of these creations have appropriated snippets from their favorite works.

However, these fan activities could serve as a better vehicle for criticism through new media. The development and actual complexities of relations between audience and text has made the traditional way of treating the audience as a passive receiver undesirable. ${ }^{22}$ Moreover, they represent a certain type of "user innovation", which "offers opportunities for self-fulfilment." ${ }^{, 2}$ Some have highlighted the ethos and the social value of fan translations, the needs of the consumers, ${ }^{24}$ and their beneficial effect on dissolving national boundaries and promoting creativity. ${ }^{25}$ Some even discovered the beneficial interaction between fan comic writers and the manga industry in Japan, ${ }^{26}$ and the flexible copyright enforcement of the Japanese audio-visual industry regarding copyright infringement by fans, which has resulted in a thriving industry. ${ }^{27}$ It is also observed that fans are different from pirates and other free riders because fans will stick to canonicity, and therefore their wish is not to replace but

\footnotetext{
${ }^{20}$ Alvin Toffler, The Third WAVE: The Classic Study of TOMORRow 11 (Bantam 1st ed. 1984)(“...Third Wave civilization begins to heal the historic breach between producer and consumer, giving rise to the "prosumer" economics of tomorrow.").

${ }^{21}$ JENKINS, supra note 2, at 284-286.

22 Id. at 291.

${ }^{23}$ William W. Fisher, The Implications for Law of User Innovation, 94 MiNN. L. REV. 1417, 1471 (2010).

${ }^{24}$ LaToya D. Rembert-Lang, Reinforcing the Tower of Babel: The Impact of Copyright Law on Fansubbing, 2 INTELL. PROP. BRIEF 21 (2010).

${ }^{25}$ Jaime E. Muscar, A Winner is Who? Fair Use and the Online Distribution of Manga and Video Game Fan Translations, 9 VAND. J. ENT. \& TECH. L. 223 (2006); Nathaniel T. Noda, Copyrights Retold: How Interpretive Rights Foster Creativity and Justify Fan-Based Activities, 20 SETON Hall J. SpORTS \& ENT. L. 131 (2010). Joshua M. Daniels, “Lost in Translation": Anime, Moral Rights, and Market Failure, 88 B.U. L. REV. 709 (2008).

${ }^{26}$ Salil Mehra, Copyright and Comics in Japan: Does Law Explain Why all the Cartoons My Kid Watches are Japanese Imports?, 55 RUTGERS L. REV. 155 (2002).

${ }^{27}$ Sean Kirkpatrick, Like Holding a Bird: What the Prevalence of Fansubbing Can Teach Us About the Use of Strategic Selective Copyright Enforcement, 21 TEMP. EnvtL. L. \& TECH. J. 131 (2003); Nathaniel T. Noda, Perpetuating Cultures: What Fan-Based Activities Can Teach Us About Intangible Cultural Property, 44 CREIGHTON L. REV. 429 (2011).
} 
rather be accepted by the originals. ${ }^{28}$ Moreover, literature also shows that some fan activities are even contributing to the openness of certain countries, ${ }^{29}$ in that they engender civic engagement with information and media.

The above findings suggest that fan activities and their creations are both allegedly infringeing and contributory, which troubles the copyright owners when enforcing their rights. Furthermore, the problem of fan activities is firmly connected to the expansion of copyright.

\subsubsection{Fans and the Expansion of Copyright}

Fan communities tend to have existed long before the general public became aware of their existence. Fandom as a subculture arises when a consumer is fond of a certain product, then s/he will establish their major identities based upon the most attractive "genre" and "medium" to them, and after that, $\mathrm{s} /$ he will discover the community when $\mathrm{s} /$ he meets more fans. ${ }^{30}$ Fans within this community will then exchange information on, and ideas about, the work, spread comments, and even create derivative works based on the original. In a mass media era, fans as media consumers have gradually become much more active, critically engaged, and creative, ${ }^{31}$ as they are able to access more materials and tools.

In the face of challenges brought by the digital era, copyright conglomerates have chosen to pursue greater copyright protection levels, whereas the space for users to freely use their copyright works is shrinking fast. The shrinking free use space of the users leads to the debate about whether our copyright setting is of the "author's right" or of the

\footnotetext{
${ }^{28}$ Sean Leonard, Celebrating Two Decades of Unlawful Progress: Fan Distribution, Proselytization Commons, and the Explosive Growth of Japanese Animation, 12 UCLA ENT. L. REV. 189 (2005); Nathaniel T. Noda, When Holding on Means Letting Go: Why Fair Use Should Extend to Fan-based Activities, 5 U. DeNV. SporTs \& ENT. L.J. 64 (2008).

${ }^{29}$ See e.g., Jean Burgess, et al., Everyday Creativity as Civic Engagement: A Cultural Citizenship View of New Media, Paper presented at the 2006 Communications Policy and Research Forum, Sydney, Australia, Sep. 25-26, available at http://www.networkinsight.org/verve/_resources/BurgessFothKlaebe.pdf.

30 CAmille Bacon-Smith, Enterprising Women: Television Fandom And the Creation of Popular Myth 7-8 (University of Pennsylvania Press. 1992).

${ }^{31}$ Ito Mizuko, Japanese Media Mixes and Amateur Cultural Exchange, in Digital GENERATIONS: CHILDREN, Young People, AND THE NeW Media 49 (David Buckingham \& Rebekah Willett eds., 2013)(noted that young people are "capable of active and critical engagement and interpretation, rather than uncritical and passive viewing of mass media messages.").
} 
"user's right" nature, ${ }^{32}$ as the stand we take will decide in which direction our copyright laws are heading.

Due to the expansion of copyright, many fan activities, along with fan creations, are deemed as copyright infringements. However, they are only a creative fraction of the massive amount of online infringements, which are caused by both the technology development and the law. Yet the law has failed so far to provide a satisfactory answer. Many of these transformative expressions of fans are backed by the very core values such as freedom of speech and the progress of art and knowledge that our law and society embraces. ${ }^{33}$ And if the number of infringers grows indefinitely, it is economically unfeasible for copyright owners to put a stop to every infringement.

\subsubsection{Toleration vs. Cooperation}

Considering the facts mentioned above, copyright owners in China today are actually tolerating most of these private unauthorized utilizations in practice for various reasons. However, merely tolerating fan activities fails to consider their legal status and their beneficial aspects. Apart from the fact that fan creations are beneficial in many aspects, whether piracy is directly linked to sales decline in copyright contents is highly debated as well. ${ }^{34}$ Some economic studies also note that an era full of unauthorized online distribution of copyright works might not be too bad a thing if a proper commercial model has been established, in which the unauthorized distribution became an integral part of it and the copyright owners can still make profits. ${ }^{35}$ More specifically, with regard to domestic copyright enforcement in China, cultural factors play an important role. It is believed that the enactment of new copyright laws will not change Chi-

\footnotetext{
${ }^{32}$ For a "users right" perspective, See L. RAY PATTERSOn \& STANLEY W. LindBERG, THE NATURE OF COPYRIGHT: A LAW OF UsERS' RIGHTS (1991); see also Jane C. Ginsburg, Authors and Users in Copyright, 45 J. COPYRIGHT SOC'Y U.S.A. 1 (1997).

${ }^{33}$ See generally, Balkin, supra note 15.

${ }^{34}$ William M. Landes \& Richard A. Posner, The Economic Structure of InTellectual Property LaW 47 (Harvard University Press. 2003). Felix Oberholzer-Gee \& Koleman Strumpf, File Sharing and Copyright, in InNOvation Policy AND the Economy (Josh Lerner \& Scott Stern eds., 2010); Tatsuo Tanaka, Does File Sharing Reduce Music CD Sales? A Case of Japan Version 0.1, ConfERENCE On IT InNOVATION Hitotsubashi UnIVERSITY, Dec. 13, 2004, at http://core.ac.uk/download/pdf/6451470.pdf.

${ }^{35}$ Chris Anderson, The Long TAIL: Why the Future OF Business is SElling Less of More (Hyperion Rev. and updated ed. 2008); ANDERson, supra note 5; DAN ARIEly, Predictably IRrational: the Hidden Forces that SHAPE OUR DECISIONS 49 (Harper 1st ed. 2008).
} 
nese life dramatically. ${ }^{36}$ In order to understand the high piracy rate in China, one should look beyond the rules and take political culture into consideration when analyzing copyright problems in China. ${ }^{37}$ Practical problems in China, such as censorship, import quotas, and local protectionism, are all reasons why copyright owners tolerate fan activities in the Chinese market. Furthermore, the new technologies help fan activities survive and flourish in a digital environment. If the law plus the industry keep on tolerating, if not fostering, this participatory culture, they will eventually be redefined by it.

In the meantime, some have noticed that the content market is transforming, and suggested that the content industry should strive to structure their business models to maximize interests, while minimizing the associated harms such as income loss and the threat to the personality interests of creators. ${ }^{38}$ Scholars have noticed that the emergence of the so-called hybrid economies, those that build upon both the sharing and commercial economies, could help us decriminalize youth. ${ }^{39}$ According to Prof. Tushnet, the current copyright regime could not sufficiently justify all the beneficial fan activities, and therefore the hybrid forms of partially or incompletely commodified, unauthorized but tolerated, creative production are very important for the future of our creative industry. ${ }^{40}$ It is also noted that, with all the players engaged, a stalemate is inevitable, and the inclusion of more stakeholders will inevitably lead to better policies and a more perfectly balanced copyright system. ${ }^{41}$ In other words, if the content industry could figure out a way to cooperate with fans, and include sharing and remixing in their commercial model thereby legitimizing them in the future, the copyright problems of fan creations in China could be solved.

\footnotetext{
${ }^{3}$ ALFORD, supra note 5, at 116.

37 Id. at 117-119.

38 FISHER, supra note 13 , at 37.

39 LaWrence Lessig, Remix: Making Art and Commerce Thrive in the Hybrid Economy 293 (Penguin Press. 2008).

${ }^{40}$ Rebecca Tushnet, Payment in Credit: Copyright Law and Subcultural Creativity, 70 LAW \& CONTEMP. PROBS. 135 (2007).

${ }^{41}$ Peter Decherney, HollywoOd's Copyright WARS: From EDISON to the INTERNET 242 (Columbia University Press. 2012).
} 


\subsection{THE RESEARCH QUESTION}

This book aims to answer a main research question: whether a flexible cooperative mechanism, in which latter could have a degree of control over the former and their works, and the activities of the former could be legally justified to a certain degree, can be established between the fan creators and copyright owners in China in order to solve the complex problem of fan activities.

In order to answer the main research question, this book examines three hypotheses of it:

- The problems that copyright works encounter in a transnational scenario are unique and complex, since they concern the general problems of law enforcement against fan activities in different countries, and the specific endemic problems copyright owners face in China.

- The copyright deadlock and fan problems are caused by advancements in digital technology, and it is very difficult to determine the social desirability of fan activities, and to enforce copyright against fans via traditional means.

- $\quad$ For foreign copyright holders in the Chinese market, cooperation with fan creators is the only possible solution at the moment.

It is clear from the above research objectives that China is of major concern of this book. The reason for this, as has already been partly touched upon in the previous section, is as follow: China, the U.S., and Japan are three countries that fan activities within are most visible, but China is the only authoritarian country that upholds a harsh cultural censorship system, which gives the problem of fan activities in China its unique flavor. In other words, China is a unique sample to show how complex the legal problems of fan activities could be when political control over social production of cultural goods is in place. Compared with the situations in the U.S. and Japan, in China, the collision and interaction among the critical issues of fan activities, such as copyright, freedom of speech, and civic engagement, are amplified, which could provide observers a better understanding of the fan related problems and a more vivid and clear picture of the future of our copyright system. 
This book explores the history, rationales, beneficial aspects, and possible future of fan activities. The objective is to examine whether the industry could better achieve their goals of profit by establishing a mutual understanding with the fans, while maintaining the balance between the protection of copyright owners and the public in copyright law. For that purpose, this research explores the historical background of fan activities in the U.S., Japan, and China, studies the difficulties they are facing in the digital era and the specific challenges they are encountering in the Chinese market. Additionally, it scrutinizes fan activities under the legal frameworks of the U.S., Japan, and China, and analyzes the existing solution proposals that concern massive infringement problems in the digital era such as fan creations.

This book focuses only on derivative works which are not only created by amateurs like fans, but also are built on foreign copyright titles in the Chinese market. Similar fan problems of domestic works within a country and other forms of unauthorized appropriation, such as derivative works that are created for commercial purposes, are not of the main focus of this book but are addressed partly. Furthermore, the "foreign copyright titles" that this book is concerned with, are limited to commercially released songs, audio-visual works, and publications including novels and comics, as these types of works are the sources of fan creativity. In terms of the "derivative works" that this book discusses, it takes fansub activity as its main example to demonstrate the complexity of copyright problems concerning fan creations, notwithstanding other fan activities such as fanfics and fanvids are nevertheless mentioned as well. Finally, the sample countries that this book compares are limited to the U.S., Japan, and China, as fan activities within these three countries are most typical, and they have taken different attitudes towards fan issues that this book considers respectively.

This research provides an alternative solution to the transnational copyright problems caused by fan activities, which can be categorized as a specific type of online unauthorized utilizations of works. It is noteworthy that it is China's sovereign right to determine its own cultural policies, as long as they are consistent with China's international obligations. Therefore, rather than to wait for the Chinese government to change their related laws as requested by foreign copyright owners, the recommendations and proposition resulting from the study contained in this book offers the foreign content industry an instant way to cooperate with Chinese fan contributors, thereby lowering the general piracy rate in 
China. Once that kind of cooperation is established, foreign copyright owners in China can more effectively benefit from their fan prosumers, and the tension between copyright and free expression could thus be relieved.

\subsection{Methodology AND OUTLINE OF THE BOOK}

In questioning whether a cooperative mechanism can be established between the fan creators and copyright owners in China, this book employs black letter analysis and comparative law as the general methodologies.

Chapter 2 employs legal-historical analysis to illustrate the endemic obstacles of China and the economic considerations that are in the way of effective enforcement of foreign copyright in China. Black letter law analysis is conducted to explain the legal foundations and political considerations behind these obstacles. This book examines China's perception of copyright in the perspective of law and culture, the WTO case DS362 and DS363 and their influence over China's censorship system and movie import quotas, and the beneficial aspects of fan activities in China in terms of product marketing and building an open society. Furthermore, how fan activities affect the marketing and copyright protection of foreign works in the Chinese market is also analyzed. Finally, this book provides economic explanations for the copyright owners' hesitation in enforcing their rights over individual unauthorized users such as fan creators. In order to know the status quo in practice and explain how the gray area of unauthorized use develops and why the law fails to provide a solution, resources related to political and media research are examined in this chapter. It helps to explain why the best choice at present is to urge the industry to do something, and narrates the reasons why the industries should offer an olive branch to fan groups.

A historical analysis is conducted in Chapter 3 to show the history of different fan activities and the challenges that copyright owners faced when trying to enforce their rights against fans in the digital age. The result of this analysis shows that fan groups and their creations are unique and creative. It also reveals that, although fan creations are challenging our copyright system, the cause behind it is the development in digital technology. It shows that it is the new advancements in technology that urge copyright owners to push for a higher standard of copyright protec- 
tion and upset the "delicate balance" in copyright law, and that development is irrevocable.

After the introduction of fan activities and creations, and the explanation about the challenges that the copyright law and the content industry are facing in the digital age in detail, the first half of Chapter 4 of this book conducts comparative analysis of several fan creations, including fansubs, doujinshis, fanfics, fanvids, AMVs, and video parodies, under the copyright laws of the U.S., Japan, and China. Moreover, general defenses, including constitutional and civil law defenses that fan creators can invoke are also examined. This part of comparative analysis demonstrates that, under the current setting of copyright law within these countries, problems caused by fan creations can never be solved by sweeping measures but can only be settled on a case-by-case basis. The result of the comparative analysis echoes with Chapter 3 in its findings on the inability of the copyright system to deal with the problem that "everyone infringes".

Bearing in mind that this Internet-related problem cannot be solved by law alone, the second half of this chapter compares the countermeasures of the content industries in the U.S., Japan, and China, and examines all the existing academic proposals of solutions. This chapter questions the idea that tolerance is an ideal solution. As an enforcement strategy, merely tolerating will not suffice because it fails to distinguish fan creators from other unauthorized users, to exert a degree of control over fan works, and to further utilize the ideas behind them. Moreover, tolerance as a solution shares a common defect with existing academic proposals such as Lessig's Creative Commons (CC) and Tim Wu's No Action Policy (NAP), ${ }^{42}$ as they all fail to consider transnational problems.

The findings of Chapter 3 and 4 pave the way for the recommendations and conclusions presented in Chapter 5. In consideration of the challenges that our copyright system is facing in the digital age, as evidenced in Chapter 3, and the practical and theoretical conundrums when enforcing a foreign copyright against fan activities in China, as identified in Chapter 2 and 4, this chapter concludes with a detailed solution for the industry to employ, as well as a revision proposal for the Copyright Law

\footnotetext{
42 Lawrence Lessig, Free Culture: How Big Media Uses Technology and the Law to Lock Down Culture and control Creativity 284 (Penguin Press. 2004); Tim Wu, Tolerated Use, 31 Colum. J.L. \& ARTS 617, 633 (2008).
} 
of the People's Republic of China (hereinafter, CCL). ${ }^{43}$ This chapter deduces from Chapter 2 to 4 that, in order to effectively control and sustainably develop the Chinese market and the fan activities within it, foreign copyright owners should cooperate with fans using legal instruments such as licenses, and the CCL should as well be revised in order to make sure that derivative works of a critical nature which copyright owners of the pre-existing works are not happy with, can still be freely created. A revision to the CCL can also offer fan creators a degree of certainty in that they could be shielded from legal threats from the copyright owners, and the beneficial effects of the fan works in the Chinese market could thus be utilized and rewarded officially.

\footnotetext{
${ }^{43}$ Zhonghua Renmin Gonghe Guo Zhuzuo Quan Fa (中华人民共和国著作权法) [Copyright Law of the People's Republic of China] (promulgated by the Nat'l People's Cong., Sept. 7, 1990, amended Feb. 26, 2010 by the Standing Comm. of the Nat'l People's Cong., amendments effective Apr. 1, 2010), Standing Comm. NAT'L PeOPLE's Cong. GaZ., 2009, at 159, translated at WORld Intellectual Property Organization, WIPO Lex No. CN031, http://www.wipo.int/wipolex/en/text.jsp?file_id=186569 (hereinafter 2010 Copyright Law of the People's Republic of China).
} 


\section{CHAPTER 2. Fight WITH THE DRAGON}

"Ruthless censorship of literature, art, music and science prevents even the creative few from living self-sufficient lives."

$$
\text { - Eric Hoffer }{ }^{44}
$$

"All peoples have the right of self-determination. By virtue of that right they freely determine their political status and freely pursue their economic, social and cultural development."

- Article 1, International Covenant on Civil and Political Rights ${ }^{45}$

As this research is aimed at solving the problem of fan creations in China, it is necessary to first delineate the legal environment and the endemic problems such as the censorship legislations of China, which foreign copyright owners in the Chinese market face when enforcing their copyright.

It is well observed that the issues such as "profound market reform in media and cultural sectors, explosive growth of the Internet, a copyright system transplanted from the West" are creating new problems that are unique to China. ${ }^{46}$ Apart from the possibilities and pitfalls brought by the information revolution, foreign copyright owners of audio-visual works will also have to handle endemic problems such as censorship and local

\footnotetext{
${ }^{44}$ Eric Hoffer, The True Believer: Thoughts on the Nature of Mass Movements 128 (Harper Perennial Modern Classics. 2010).

45 International Covenant on Civil and Political Rights, Dec. 16, 1966, S. Treaty Doc. No. 95-20, 6 I.L.M. 368 (1967), 999 U.N.T.S. 171

${ }^{46}$ Dong Han, 'Use' is an Anagram of 'Sue': Cultural Control, Resistance, and the Role of Copyright in Chinese Cyberspace, 7 GLOBAL MEdia AND COMMUNICATION 97, 99 (2011).
} 
protectionism, if they are to enter a foreign market like China. ${ }^{47}$ Even though more and more Chinese content conglomerates are requesting stronger copyright protection in both legislation and enforcement, ${ }^{48}$ these endemic factors are in the way of meaningful enforcement of the government agencies and contributing to the rampant piracy in China. ${ }^{49}$ Moreover, foreign cultural works are in many ways exposed to copying due to under protection in China compared to local productions. ${ }^{50}$

In such circumstances, to raise litigations against fan creators in China is arguably not a priority for foreign copyright owners. Without an ideal solution, they will be forced to ignore or tolerate most of these unauthorized uses and chase only the commercial pirates and contributors of infringement instead.

Hence, the problems of fan creations with respect to copyright enforcement are partly caused by the endemic obstacles that foreign copyright owners are encountering in China, and the economic problems they are facing in general. In order to better understand the transnational problems of fan creations and to pave the way for detailed discussion of fan activities in the next chapter, possible endemic (para. 2.1) and economic problems (para. 2.2) that foreign copyright owners may face when enforcing their rights against fan activities are examined respectively. The last subsection draws some conclusions regarding the implications of these obstacles on copyright protection in China (para. 2.3).

\subsection{Barriers or Defenders: the FaIlure Caused by the Great "Cultural" Wall of China}

In an imaginary global market without restrictions, or at least in one with minimum restrictions such as the European Union (EU) internal market is trying to achieve, the problem of unauthorized online distribution of cop-

\footnotetext{
${ }^{47}$ Priest, supra note 5, at 821-829; there is similar censorship in other areas such as the publishing market, see generally, Hongsong Song, Dancing in Shackles: Copyright in China's Highly Regulated Publishing Market, 60 J. COPYRIGHT SOC'Y U.S.A. 285 (2013).

48 See general, Joseph A. Massey, The Emperor Is Far away: China's Enforcement of Intellectual Property Rights Protection, 1986-2006, 7 CHI. J. INT'L L. 231 (2006). Accord Lucy Montgomery \& Brian Fitzgerald, Copyright and the Creative Industries in China, 9 InTERNATIONAL JOURNAL OF CuLTURAL STUDIES 407, 418 (2006).

${ }^{49}$ See Jordana Cornish, Cracks in the Great Wall: Why China's Copyright Law Has Failed to Prevent Piracy of American Movies Within Its Borders, 9 VAND. J. ENT. \& TECH. L. 405, 424 (2006).

${ }^{50}$ Tianxiang He, What Can We Learn from Industries? The Differences Between the Domestic and Oversea Copyright Protection Strategies towards Fan Activities, 62 AM. J. CoMP. L. 1009, 1032-33 (2014)(note that it is extremely hard to download local productions in famous sharing sites in China whereas for foreign productions it is not the case.).
} 
yrighted contents could be limited to an acceptable level. But in China, if we consider the problem of private infringers in a transnational perspective, it is obvious enough that copyright owners face two major problems in the Chinese market when they wish to conduct business: massive copyright infringement and market access. In other words, once a copy of work has been publicly uploaded online, the volume of possible infringement appears infinite; market access is also a big problem with respect to transnational licensing, since China has its domestic political considerations regarding its cultural market. A solution to private infringement will have to tackle these two problems. However, a correlation exists between these two problems. According to a U.K.-wide survey conducted by Ofcom, almost 50 percent of interviewees claimed their reason for downloading unauthorized copies was because it was the fastest and most convenient way to obtain this material. ${ }^{51}$ This partly explains why people infringe other's copyright online today. In China, the problem is not speed of access, but freedom to access. The government has set certain limitations regarding the access to foreign works and simultaneously to foreign providers of works to release them on to the Chinese market. These conditions have limited the ability of Chinese consumers to access the foreign titles they desire, whereas online piracy offers people a way to access things they are not allowed to have. That is one of the major reasons why Chinese people tend to acquire pirated editions of foreign titles instead of purchasing legitimate products, as legitimate products are simply not offered for sale. Therefore, it is necessary to examine what exactly the endemic problems are in China, and come up with a corresponding solution.

For this purpose, this subsection first goes through China's history about political culture (para. 2.1.1), to see whether or not traditional thinking actually affects China's intellectual property protection, and analyzes two WTO cases (para. 2.1.2), and their influence over China's censorship system (para. 2.1.3) and import quotas (para. 2.1.4). The civic engagement enabled by fan participation (para. 2.1.5), and the relation-

\footnotetext{
${ }^{51}$ Alistair Charlton, Illegal Downloaders Spend More on Music, Film and TV Than Legal Downloaders, INTERNA$\begin{array}{lllll}\text { TIONAL BUSINESS } & \text { TIMES, } & \text { Nov. } & 23, & \text { 2012, }\end{array}$ http://www.ibtimes.co.uk/illegal-downloaders-pirates-spend-more-music-films-407888 ("When asked why they download pirated content 54 percent said because it is free, 48 percent said they pirate because it is convenient, and 44 percent said because it is quick.").
} 
ship between market and fans (para. 2.1.6) are also explored in this subsection.

\subsubsection{Chinese Political Culture}

The Chinese culture has long been accused of being one major reason why intellectual property rights, especially copyright, cannot land smoothly in China. According to Alford, in order to understand the endless piracy problems in China, we need to consider "the political culture within which law arises and within which it must operate". ${ }^{2}$ And the "political culture" of China that Alford was referring to has a special focus on controlling rather than promoting the flow of ideas for purposes of "legitimation and power", 33 which is fundamentally incompatible with the idea of the modern (western) intellectual property law setting. ${ }^{54}$ Things in China have not changed much. Today, Alford's claim is still true as harsh content censorship is still the norm in China. This will be addressed in subsection 2.1.3.

For the purpose of this subsection, the book explores the historical development of the Chinese political culture in chronological order: the imperial China period (para. 2.1.1.1), the modern war period (para. 2.1.1.2), the revolutionary period (para. 2.1.1.3), the transition period (para. 2.1.1.4), and the open-up period follows with a concluding note (para. 2.1.1.5).

\subsubsection{Imperial China Period (Before 1912)}

The tradition of information control in China has a long history: it is noted that the deliberate burning of a library was recorded in China as early as $221 \mathrm{BC},{ }^{55}$ and the first censorship law was introduced in $300 \mathrm{AD} .^{56}$ Of course it is universal for every country to control the publication sec-

\footnotetext{
52 Alford, supra note 5, at 119.

${ }^{53} \mathrm{Id}$.

${ }^{54}$ Alford believe the political culture of China is fundamentally incompatible one of strong intellectual property rights in which individuals have the authority to determine how expressions of their ideas may be used and ready access to private legal remedies to vindicate such rights." Id.

55 Mette Newth, The Long History of Censorship, BEACON FOR FREEDOM OF EXPRESSION, 2010, at http://www.beaconforfreedom.org/liste.html?tid=415\&art_id=475.

${ }^{56} \mathrm{Id}$.
} 
tor in the feudal times. For example, before the Statute of Anne, the publishing business in England was nothing but a combination of publishing privilege and government censorship that was controlled by the crown. ${ }^{57}$ The publishing sector was a cause for concern in imperial China as well, ${ }^{58}$ as it might have hindered the imperial governments from consolidating their power. Therefore, it is not hard to understand why imperial China was absorbed by controlling publications and censoring dangerous contents throughout history. ${ }^{59}$ With the introduction of the Statute of Anne in the U.K., the concept of "copyright" as an economic right in a competitive market soon swept the globe and influenced many copyright laws in several other nations, including the U.S. However, arguably, the modern concept of copyright is missing in imperial China. ${ }^{60}$

The reasons for that are more than complex. However, for the purpose of this research, it is possible to offer some explanations:

First, the emperors of imperial China had to gain legitimacy from the past, but history itself is a shared memory, therefore they must make sure their subjects have a degree of access to the existing knowledge.

Second, in order to preserve imperial power, ancient Chinese rulers had to tailor the history to their needs. This means that the access to existing knowledge must be somehow limited, otherwise the understanding of the past cannot be manipulated. ${ }^{61}$ For example, the imperial examination system which lasted almost 1300 years in China, ${ }^{62}$ picked officials with tests about the knowledge of the past. It is also noted that "the compilation of history, the interpretation of its lessons, and the characterization of the current dynasty for historical purposes" is another form of manipulation. ${ }^{63}$ Therefore no wonder xue er you ze shi (学而优则仕), ${ }^{64}$ which means that the best intellectual should apply himself to be a bureaucrat, became the credo of most ancient Chinese intellectuals. Because

\footnotetext{
${ }^{57}$ Karl-Nikolaus Peifer, The Return of the Commons - Copyright History as a Common Source, in PRIVILEGE AND PROPERTY: ESSAYS ON THE HISTORY OF COPYRIGHT 351-52 (Ronan Deazley \& Martin Kretschmer \& Lionel Bently eds., 2010).

${ }^{58}$ Cynthia J. Brokaw, On the History of the Book in China, in Printing AND Book Culture In LATE IMPerial ChinA 17-8 (Cynthia J. Brokaw \& Kai-wing Chow eds., 2005).

${ }^{59}$ However, Chow argued that at least in the late Ming dynasty, commercial printing was not bound by a censorship system. See Kai-wing Chow, Writing for Success: Printing, Examinations, and Intellectual Change in Late Ming China, 17 LATE IMPERIAL CHINA 120, 135 (1996).

${ }^{60}$ Alford, supra note 5, at 9-29.

${ }^{61}$ See, e.g., Ken Shao, Monopoly or Reward: The Origin of Copyright and Authorship in England, France and China and a New Criticism of Intellectual Property, 41 HoNG KONG L.J. 731, 745 (2011).

${ }^{62}$ Chengsi Zheng \& Michael D. Pendleton, Copyright law in China 2 (CCH Australia Limited. 1991).

63 Alford, supra note 5, at 23.

${ }^{64}$ Verse 13, Chapter 19, ANALECTS OF CONFuCius.
} 
of that, the intelligentsia became more and more dependent on the imperial power, and thus were unable to confront government for the purpose of claiming their rights over their works. ${ }^{65}$ Moreover, the emperors were the only ones to determine the right answers in terms of the examination. That also reveals a characteristic of Chinese political culture: according to traditional Chinese knowledge, the ruler is conceived to be fiduciary. ${ }^{66}$ Another example is the compilation of the si ku quan shu (四库全书), which means the complete library of the four treasuries, initiated by Emperor Qian Long (乾隆) of the Qing dynasty in 1772. The purpose was to search and make copies of all rare and valuable manuscripts within the country. ${ }^{67}$ However, during this process, the imperial court also launched a campaign of censorship, which destroyed approximately 2,400 titles, and revised the contents of four or five hundred titles. ${ }^{68}$

Third, in imperial China, copying was not understood in a way that the western countries conceived it to be. Although arguably the technique of printing had first emerged in China and Korea, ${ }^{69}$ and moveable printing types were invented after the Song Dynasty from $1042 \mathrm{AD},{ }^{70}$ in most cases the matter of copying only concerns the publishers and the imperial government, rather than the authors. ${ }^{71}$ If we consider copying as a technique of creation, then in terms of almost all intellectual creations at that time-such as classical poetry and literature-the Chinese reverence for the past has made copying "more affirmative and more essential" in China. ${ }^{72}$ Just as Fairbank and Goldman indicated, "[h]aving memorized vast sequences of the classics and histories, they constructed their own works by

\footnotetext{
${ }^{65}$ Just like Unger had put it, "the concentration of governmental power and the corresponding subordination of all aristocratic or third estate groups-commercial, bureaucratic, or scholarly-to the interests of the state, made it difficult for prophecy or an independent priesthood to emerge." ROBERTO MANGABEIRA UNGER, LAW IN MODERN SOCIETY: TOWARD A CRITICISM OF SOCIAL THEORY 66 (The Free Press. 1976).

${ }^{66}$ Id. See also ZHENG \& PENDLETON, supra note 62, at 2-3 (“...the charismatic leader...is seen as deserving of the Mandate of Heaven"). Alford, supra note 5, at 23 (“...the ruler had not only the authority but also a responsibility to ascertain how best to nurture the populace. Central to that responsibility was the need to determine which knowledge warranted dissemination and which ought to be circumscribed in the best interests of the commonwealth.").

${ }^{67}$ R. KENT GuY, THE EMPEROR's Four TREASURIES: SCHOLARS AND THE STATE IN THE LATE CH'IEN-LUNG ERA 1 (Harvard University Asia Center. 1987). ${ }^{68} I d$.

${ }^{69}$ The ABC of Copyright, UNESCO CULTURE SECTOR, at 11, at http://www.unesco.org/fileadmin/MULTIMEDIA/HQ/CLT/diversity/pdf/WAPO/ABC_Copyright_en.pdf.

70 ZHENG \& PENDLETON, supra note 62, at 14.

${ }^{71}$ In fact, there are cases that show the ancient Chinese authors did show their concerns about unauthorized reprinting. See id, Ke Shao, An Alien of Copyright? A Reconsideration of the Chinese Historical Episodes of Copyright, 4 INTELL. Prop. Q. 400, 423-29 (2005). However, one should always bear in mind that the first copyright law (Statute of Anne) was also about publishing privileges.

${ }^{72}$ Alford, supra note 5, at 27-29.
} 
extensive cut-and-paste replication of phrases and passages from those sources..., the Chinese writers from early times saw themselves as preservers of the record more than its creators." ${ }^{73}$ Moreover, it is also believed that the "the Confucian disdain for commerce" has fostered a cultural understanding that "true scholars wrote for edification and moral renewal rather than profit". 74 On the other side, notwithstanding the efforts to establish an official copyright-like protection made by the publishers at that time, nothing similar to the modern concept of copyright was established, because the purpose of the imperial government to grant a publishing privilege is to censor heterodox materials rather than to create a right. ${ }^{75}$ As a result, the ancient Chinese market for publication was always underdeveloped, and all the discovered copyright-like efforts were deemed "scattered" and "ad hoc". 76 Apparently no written law or any clauses in statute law for the protection of copyright had ever been created until 1903, the year when the U.S. inserted the word "copyright" to imperial China's vocabulary book via the Renewed Sino-American Treaty of Trade and Navigation. ${ }^{77}$

In all, because the ruler was believed to be the "son of heaven" in imperial China, all his actions were treated as providence: on the one hand, in order to maintain his rule, the ruler had to make sure the favorable knowledge of the past could be accessed, but he also had to make sure the right of interpretation was under his control, and no harmful information could be accessed easily; on the other hand, as fiduciary, the ruler was believed to be the right person "to filter out and destroy harmful knowledge" for his subjects, which in turn also gave him a right to control the access to knowledge. ${ }^{78}$

\footnotetext{
73 John King Fairbank \& Merle Goldman, China: a New History 101 (Belknap Press of Harvard University Press 2nd enl. ed. 2006).

${ }^{74}$ Alford, supra note 5, at 29; See also YufENG Li (李雨峰), QIANGKOU XIA DE FALV ZHONGGUO BANQUAN SHI YANJIU (枪口下的法律: 中国版权史研究), [Teaming the Law at Gunpoint: on the Chinese Copyright History] 73 (Intellectual Property Publishing House Co., Ltd. 2006); see also RAY HuANG, ChinA: A MACro History 223-24 (M.E. Sharpe Turn of the century ed. 1997)(“...in China it was to apply to thousands of bureaucrats and millions of peasants amidst a cultural tradition that paid little attention to the civil law, and where property rights had always been rendered ambiguous by the custom that gentlemen never spoke of profit, which was unbecoming in the face of the spirit of self-restraint and mutual deference.")

${ }^{75}$ Alford, supra note 5, at 18. But see Shao, supra note 71, at 409-10 (arguing that the pre-publishing censorship only existed for a relatively short period).

${ }^{76} I d$. at 14 .

77 ZHENG \& PENDLETON, supra note 62, at 16.

78 Alford, supra note 5, at 23.
} 
Furthermore, theoretically speaking, there are two major reasons why the modern concept copyright first appeared in western countries but not in China:

The first one is the difference in social structure. ${ }^{79}$ The situation in imperial China was different from the circumstances in the U.K. at that time. The three powers, "king, aristocracy, and rich middle class" as Russell indicated, tended to play down each other's role during that period, ${ }^{80}$ so that there is no single "permanently dominant" position in the U.K.; on the contrary, the emperor of China had absolute power, other classes such as merchants were powerless in the face of the arbitrary power of the king and his servants. ${ }^{81}$ Apparently, merchants as a force were extremely weak in imperial China, not to mention its influence over intellectuals. For instance, in terms of the ancient creators, the traditional understanding of creative activities was to treat them as "a type of spiritual exercise", 82 rather than a commercial exercise aiming for profit. Because in Confucian thought, merchants were at the bottom of the four classes known as the $\operatorname{simin}$ (四民), according to Kuhn. ${ }^{83}$ In addition, the royal family's total control over academic matters and the Confucious tradition of Shuerbuzuo, xinerhaogu (述而不作, 信而好古) (which means "I have transmitted what was taught to me without making up anything of my own, I have been faithful to and love the Ancients" ${ }^{94}$ ), in creative intellectual activities had hampered the formation of the idea of owning one' own creation. ${ }^{85}$ Although merchants' status had been greatly raised after the Ming Dynasty, ${ }^{86}$ for merchants in the imperial China, there was no motivation or possibility to fight for their own interests and to set up their own rules; therefore there was no way for a relatively independent "third estate" to emerge. ${ }^{87}$ On the other hand, the Confucian-

\footnotetext{
${ }^{79}$ According to Unger, the rule of law relies on two historical conditions: First, "there must be a situation in which no group occupies a permanently dominant position or is credited with an inherent right to govern"; second, the "reliance on a 'higher' universal or divine law as a standard by which to justify and to criticize the positive law of the state." UNGER, supra note 65 , at 66 .

${ }^{80}$ Bertrand Russell, History of Western Philosophy and Its CONNECTION With Political AND SOCIAL Circumstances from the Earliest Times to the Present Day 645 (G. Allen and Unwin ltd. 1946).

${ }^{81} \mathrm{LI}$, supra note 74 , at 63.

82 Susan Bush, The Chinese Literati on Painting; Su ShiH (1037-1101) To Tung CH‘I-CH‘ANG (1555-1636) 50-66 (Harvard University Press. 1971).

${ }^{83}$ The four classes are: scholars, farmers, artisans and merchants. Philip A. Kuhn, Chinese Views of Social Classification, in ClASS AND SOCIAL STRATIFICATION IN POST-REVOLUTION CHINA 20 (James L. Watson ed. 1984).

${ }^{84}$ KONG ZI, The ANALECTS OF CONFuCIUS 123 (Arthur Waley trans., Psychology Press. 2005).

${ }^{85}$ Alford, supra note 5, at 25; See also LI, supra note 74, at 64.

${ }^{86}$ LI, supra note 74, at 68; Shao, supra note 71, at 427.

${ }^{87}$ UNGER, supra note 65, at 99.
} 
ization of law had made the $l i$ (礼)-the "rites" which defined morality and propriety-the orthodoxy of Chinese law. ${ }^{88}$ Therefore it was impossible to assess $l i$ independently from the ancient Chinese laws since the relation between them was obviously close. ${ }^{89}$ Apparently, there was no higher standard that could be used to justify the laws in imperial China, since sometimes $l i$ could be law as well. ${ }^{90}$ Just as Tongzu Qu has indicated, "what $l i$ permits and advocates, is what law permits and legitimizes". 91

Another reason is much deeper and concerns the economic structure. As Professor Chen Li has claimed, "why imperial China had no copyright" is a pseudo-proposition, because the copyright paradigm is the reflection of the interests of modern industry. ${ }^{92} \mathrm{Li}$ argues that reasons such as the under-development of the commercial sector and the lack of the sense of entitlement of the ancient authors, are part of a bigger picture of ancient society but not just China, so therefore it is a problem of ancient and modern rather than a problem of Chinese and western. ${ }^{93}$ The mere existence of publishing interest alone is not enough to spawn a new law, unless it is strong enough to a sufficient degree. ${ }^{94}$ In other words, it is modern capitalism that fostered the establishment of copyright. ${ }^{95}$ The decisive factor is the economical structure, whereas the above-mentioned factors are not. ${ }^{96}$ A similar position was taken by Prof. Shao. He pointed out that "various essential elements relating to authorship and copyright" are "common traits resulting from cultural, commercial and technological evolution." $" 97$

The above discussions explain clearly why a modern copyright system was never in place in China, even though technically speaking imperial China was ready for one.

\footnotetext{
${ }^{88}$ TongZu Qu (翟同祖), QU TongZu FAXUE LunZHU Ji (翟同祖法学论著集)[Qu Tongzu's Analects on Legal Study], 381 (China University of Political Science and Law Press. 1998).

${ }^{89}$ TongZu Qu, LaW AND SOCIETY In TRAditional China 279 (Hyperion Press. 1980).

${ }^{90}$ Id. See also LI, supra note 74, at 77.

91 TongZu Qu (翟同祖), ZHongGuO FALV YU ZHongGuO SheHUI (中国法律与中国社会)[Laws and Society of China] 322 (Zhonghua Book Company. 1996).

${ }^{92}$ Chen Li (李琛), Guanyu Zhongguo Gudai Yinhe Wu Banquan Yanjiu de Jidian Fansi (关于“中国古代因何无版权” 研究的几点反思) [Several Reflections on the Researches about “Why Ancient China has no Copyright”], FAXUEJIA (法学家)[JURIST], no.1, 2010, at 58 .

${ }^{93} I d$.

94 Id.

${ }^{95} I d$.

${ }_{96} \mathrm{Id}$.

97 Shao, supra note 71, at 430.
} 


\subsubsection{Modern War Period (1913-1949)}

Whether the above-mentioned cultural factors have been inherited by modern China or not is another question. In 1910, the Qing Dynasty published the very first Chinese copyright law, under the pressure of western countries. ${ }^{98}$ Two years after, the Qing Dynasty was overthrown, and the fact that this law only applied for one year shows that its significance was extremely limited. Two other subsequent copyright laws were published in 1915 and 1928, prior to the proclamation of the People's Republic of China in 1949, by different governments. However, considering the time period these legislations were in, the fact that these concepts were mostly exotic and imposed, and the fact that the "legal consciousness" that the copyright law presumed was never there, ${ }^{99}$ these legislative efforts were destined to fail. Take the 1928 Copyright Law of the Republic of China as an example: its content was highly westernized, but in practice when the protection of author's rights and the need of information control collide, the latter will always prevail. ${ }^{100}$ Therefore, it is fair to say that even in the Guomindang era, people were not allowed to have rights that could be invoked to vindicate their claims against the ruling party as well.

\subsubsection{Revolutionary Period (1950-1979)}

After the establishment of the People's Republic of China, copyright-related issues became complicated to a degree, since the guiding ideology of the creative activities in the early stages of China was communism. Interestingly, Marx's view on intellectual creation is similar to Confucius's: first, although based on different ideological foundations, they both deem it as "fundamentally a product of the larger society from which it emerged", 101 a "public good that offered the greatest benefits to society if used and shared without restriction"; ${ }^{102}$ second, they all be-

\footnotetext{
98 Alford, supra note 5, at 42.

${ }^{99}$ Id. at 53. See also LI, supra note 74, at 133-34.

100 Alford, supra note 5, at 54-55.

101 Id. at 57.

102 Lucy Montgomery \& Michael Keane, Learning to love the market: Copyright, Creativity and China, in COMMUNICATIONS, INTELLECTUAL PROPERTY AND THE PUBLIC DOMAIN IN THE ASIA-PACIFIC REGION: CONTESTATIONS AND CONSENSUS 130-49 (P. Thomas \& J. Servaes eds., 2006).
} 
lieved that the control of the flow of information is necessary. ${ }^{103}$ All these thinkings can be verified in Mao's (毛泽东) talk at the Yanan forum on literature and art. ${ }^{104}$ Apparently Mao's view echoes with Confucius's, as they all believe intellectual creation belongs to the masses rather than individuals.

However, in spite of Mao's view and the communist ideology, a number of legislative documents that address copyright issues did emerge. During that period, the Chinese Communist Party (CCP) believed that for the purpose of economic development, they needed to give intellectuals some rights in exchange for their cooperation. The consequent laws and regulations from 1949 to 1979 did concern copyright issues, but all of these were about contracts and remuneration, and did not touch upon the contents of the core of copyright concept things such as the details of the rights and the remedies for copyright infringement. ${ }^{105}$ The legal instruments provided during this period merely copied those of the USSR, and treated authors as workers by remunerating them according to standards like size and the number of printed copies rather than the number of actual sales. ${ }^{106}$ At the end of this period several draft documents were proposed, but they never came to pass as a series of political campaigns beginning in the summer of 1957 disrupted the plan. The 1957 Anti-Rightist Campaign aimed to adjust intellectuals' ideology, so that they could be politically correct and serve a greater purpose rather than making money; and the 1958 Great Leap Forward movement triggered a "passion for 'pure' communism" that tended to draw a clear line between communism and capitalism, and anything that was deemed capitalism would be treated with contempt, including the desire for individual rights of the intellectuals. ${ }^{107}$ However, having witnessed the chaos in national economics caused by these radical movements and the 1960 Sino-Soviet

\footnotetext{
103 Alford, supra note 5, at 57.

104 "What is the source of all literature and art? Works of literature and art, as ideological forms, are products of the reflection in the human brain of the life of a given society. Revolutionary literature and art are the products of the reflection of the life of the people in the brains of revolutionary writers and artists. The life of the people is always a mine of the raw materials for literature and art, materials in their natural form, materials that are crude, but most vital, rich and fundamental; they make all literature and art seem pallid by comparison; they provide literature and art with an inexhaustible source, their only source... the literary and artistic works of the past are not a source but a stream; they were created by our predecessors and the foreigners out of the literary and artistic raw materials they found in the life of the people of their time and place." ZEDONG MAO, TALKS AT THE YENAN FORUM ON LITERATURE AND ART 18-19 (Foreign Languages Press. 1967).

105 ZHENG \& PENDLETON, supra note 62, at 19

${ }^{106}$ Id. Alford, supra note 5, at 60.

107 See Rogier Creemers, Explaining Audiovisual Media Piracy in China 67 (Feb. 2, 2012) (unpublished Ph.D. dissertation, Maastricht University), available at $\mathrm{http}$ //arno.unimaas.nl/show.cgi?fid=24067.
} 
split, ${ }^{108}$ the CCP suddenly realized the importance of intellectuals in compensating for the losses caused by these campaigns, and they did consider providing more material incentives to Chinese authors. ${ }^{109}$ These resulted in economical development, for instance, the nominal value of trade regained its 1959 value by $1966 .{ }^{110}$ But soon the Rectification campaign in 1964 put intellectuals in an unfavorable situation again. As a matter of fact, Mao's perspective on social strata had a great impact upon the party's copyright policy. Mao's famous 1957 speech Beat Back The Attacks Of The Bourgeois Rightists reflected these considerations explicitly. ${ }^{111}$ The fight with "bourgeois" in China soon reflected badly on its copyright-related plans. A 1966 report from the Ministry of Culture had articulated that, "too much remuneration" is harmful to an author's "healthy growth", and the "remuneration under socialism is of an encouragement nature", thus "the arrangement of remuneration" should be "fundamentally different from one under capitalism." "112 Later in 1966, when the Cultural Revolution began, China had entered into a lawless state, any legislation plans related to copyright were shelved.

The Great Proletarian Cultural Revolution (1966-1976) caused devastating damage to China's cultural sector: intellectuals were persecuted as they were treated as the Stinking Number Nine (臭老九), ${ }^{113}$ and not

\footnotetext{
108 Thirukodikaval Nilakanta Srinivasan, External Sector in Development: China and India, 1950-89, 80 THE AMERICAN ECONOMIC REVIEW 113, 114 (1990)(“Soviet aid ceased in 1960. The failures of the Great Leap Forward turned China from a modest net exporter of grain to a net importer. The share of food in exports dropped dramatically and that of manufactures rose to around 50 percent, where it remained on average for more than two decades from 1959. Imports of machinery had to be cut sharply. During the period 1963-65, the economy recovered from the ravages of the Great Leap and a famine that killed more than 20 million people.").

${ }^{109}$ See e.g., Guanyu Zhengque Zhixing Gaochou Zhidu Qiadang Zhangwo Gaochou Biaozhun de Tongzhi (关于正确 执行稿酬制度, 恰当掌握稿酬标准的通知) [Notice on the Correct Enforcement of the Remuneration Regime, and Proper Mastery of the Remuneration Standard] (promulgated by Ministry of Culture Decree (61) wenchuqizi No.1216, Aug. 28, 1961, repealed Mar. 1, 2011) (China).

110 Srinivasan, supra note 108 , at 114.

111 "Intellectuals are teachers employed by the working class and the labouring people to teach their children. If they go against the wishes of their masters and insist on teaching their own set of subjects, teaching stereotyped writing, Confucian classics or capitalist rubbish, and turn out a number of counter-revolutionaries, the working class will not tolerate it and will sack them and not renew their contract for the coming year." Zedong Mao (毛泽东), Datui Zichan Jieji Youpai de Jingong (打退资产阶级右派的进攻) [Beat Back the Attacks of the Bourgeois Rightists], in SELECTED Works of Mao Zedong Volume 5, 469-70 (The People’s Publishing House, 1977).

${ }^{112}$ Wenhua Bu Dangwei Guanyu Jinyibu Jiangdi Baokan Tushu Gaochou de Qingshi Baogao (文化部党委关于进一 步降低报刊图书稿酬的请示报告) [The Request Report of the Party Committee of Ministry of Culture on Further Reducing Newspapers and Books Remunerations], in ZHONGGUO BANQUAN SHI YANJIU WENXIAN (中国版权史研究 文献)[Historical Documents of China’s Copyright Law], 330 (Lin Zhou \& Mingshan Li eds., 1999).

${ }^{113}$ The Stinking Number Nine is a Chinese dysphemism for intellectuals. See KU-CH'ENG Li, A GLOSSARY OF Political Terms of the People's Republic of China 27 (Chinese University Press. 1995)(“During the Cultural Revolution, the Gang of Four and other ultra-leftists list nine categories of political-social undesirables; intellectuals were at the bottom of the list and were called the 'stinking Number Nine."').
} 
permitted to claim their economic rights. A popular saying during the Cultural Revolution epitomized this in a clear way:

Is it necessary for a steel worker to put his name on a steel ingot that he produces in the course of his duty? If not, why should a member of the intelligentsia enjoy the privilege of putting his name on what he produces? ${ }^{114}$

Apparently, the way the CCP treated intellectual creations was similar to the traditional practice during this period: they all deemed intellectual creations as legacies of past wisdom. However, during the Cultural Revolution, not only their right to claim remuneration, but also the moral rights of the author-such as the publication right, the right to the integrity of the work, and the right to have the author's name mentioned-were "completely denied". 11

After Mao's demise, the Cultural Revolution ended, and all neglected matters were yet to be dealt with. In order to get back on the right track, China needed to motivate the intellectuals once again. Technology and economic development were pushed back to the agenda. After 1977, China gradually restored the copyright system that they used to have before the Cultural Revolution. ${ }^{116}$

It is obvious that during this revolution period, the cultural link with the past was cut, traditional knowledge such as Confucianism was deemed "rubbish", 117 and totally rejected in the Cultural Revolution. ${ }^{118}$ The most famous case is the campaign against the Four Olds (破四旧), which turned on the old thought, old culture, old tradition and old custom. ${ }^{119}$ The idea behind this campaign was that, since Confucius "em-

\footnotetext{
114 It was cited by numerous pieces. See e.g., Chengsi Zheng, The Future Chinese Copyright System and its Context, 15 IIC 141, 152 (1984); ALFORD, supra note 5, at 56; LI, supra note 74, at 157; D. VAVER, INTELLECTUAL PROPERTY Rights: Critical ConcePts In Law $68 \S 1$ (Routledge. 2006); Peter K. Yu, Piracy, Prejudice, and Perspectives: An Attempt to Use Shakespeare to Reconfigure the US-China Intellectual Property Debate, 19 BU INT'L LJ 1, 22 (2001).

${ }_{115}$ Zheng, supra note 114, at 152.

116 ALFORD, supra note 5, at 65.

117 That is indicated in Mao's speech. See Mao, supra note 111 ("At present what kind of skin do intellectuals attach themselves to? To the skin of public ownership, to the proletariat. Who provides them with a living? The workers and peasants. Intellectuals are teachers employed by the working class and the labouring people to teach their children. If they go against the wishes of their masters and insist on teaching their own set of subjects, teaching stereotyped writing, Confucian classics or capitalist rubbish, and turn out a number of counter-revolutionaries, the working class will not tolerate it and will sack them and not renew their contract for the coming year.").

118 Tong Zhang \& Barry Schwartz, Confucius and the Cultural Revolution: a Study in Collective Memory, 11 INTERNATIONAL JouRnAL OF POLITICS, CULTURE, AND SOCIETY 189, 197 (1997). 119 Id.
} 
bodied the Old", he then "inevitably became the personification of capital and foreign influence" and "was no longer inheritable."120 Every aspect of Confucius's thought was attacked, ${ }^{121}$ and his views on intellectual creations were no exception.

\subsubsection{Transitional Period (1980-1990)}

The downfall of the Gang of Four, ${ }^{122}$ and the demise of Mao had ushered in a new era of China, an era in which Xiaoping Deng (邓小平) soon assumed power and yearned for stable and sustainable development in China. Evidently, the need to develop and catch up was the driving force that pushed China to follow the international standard of copyright protection, as copyright is not only an individual right, it is also a tool to create a market for information that is otherwise a public good. Moreover, it provides authors with incentives to create and reproduce their works. After China and the U.S. signed two bilateral agreements in $1979,{ }^{123}$ and provided mutual most-favored-nation (MFN) treatment in 1980, China was obligated to provide an intellectual property law system that takes international practice into account. And, simultaneously, to "dignify and stabilize a backward society seeking a place in the modern world" with the help of Confucianism. ${ }^{124}$

These two legal and cultural objectives were met separately:

In terms of the establishment of a modern copyright law, in April 1979, Yaobang $\mathrm{Hu}$ (胡耀邦), the then Propaganda Minister received a report concerning the proposal to establish a legal system of Copyright and to gradually accede to the Universal Copyright Convention (UCC). ${ }^{125}$ He replied with consent and requested a draft of copyright law to be ready

\footnotetext{
${ }^{120} I d$. at 198.

121 Id. at 200.

${ }^{122}$ Including ideologues Hongwen Wang (王洪文), Chunqiao Zhang (张春桥), Qing Jiang (江青), and Wenyuan Yao (姚文元). See generally, Lowell Dittmer, Bases of Power in Chinese Politics: A Theory and an Analysis of the Fall of the "Gang of Four", 31 WORLD POLITICS 26, 27 (1978).

${ }^{123}$ It is believed that the intellectual property-related terms in U.S.-China Agreement on High Energy Physics Cooperation, and Agreement on Trade Relations Between the United States of America and the People's Republic of China that were signed in 1979 have actually promoted the planning and establishment of modern Chinese intellectual property laws. See e.g., Luo Li, Intellectual Property Protection of Traditional Cultural Expressions: FOLKLORE IN CHINA 98 (Springer. 2014).

${ }^{124}$ Zhang \& Schwartz, supra note 118, at 202-3.

125 Universal Copyright Convention as revised at Paris on 24 July 1971, 25 U.S.T. 1341, 943 U.N.T.S. 178 [hereinafter UCC]. The United States acceded to the revised UCC in 1972, China in 1992, and Japan in 1977.
} 
for consideration "as soon as possible". ${ }^{126}$ This reply is believed to be the starting point of China's contemporary copyright law-making process. ${ }^{127}$ Starting from here, the subsequent Chinese copyright-related legislations were all greatly influenced by western concepts, and copyright is treated as a private right thereof. ${ }^{128}$

It is no doubt a great achievement that within a decade's time, a genuine modern copyright law was established in 1990. But one must not lose sight of the fact that the ideological debates within the CCP about the concept of copyright were fierce during this transitional period. Generally speaking, after the 1979 Sino-US agreements were concluded, and before the promulgation of the 1986 General Principles of the Civil Law, ${ }^{129}$ which contains an article that directly provided that "citizens and legal persons shall enjoy rights of authorship (copyrights)", ${ }^{130}$ authors were treated with a pre-Cultural Revolution way: they were provided, again, with remuneration rather than private rights. ${ }^{131}$ After 1986, legislators got bogged down in ideological debates over the upcoming copyright law: more than 20 drafts were proposed, and the end product was deemed to be the result of contradiction. ${ }^{132}$ Interestingly, article 4 of the 1990 CCL, which was later revoked in 2010, explicitly denied the copyright protection for "illegal" works, and warned copyright owners not to violate the Constitution or laws of China, or prejudice the public interests when utilizing their copyright. ${ }^{133}$ It is counted as the direct evidence which reflects the ideological concerns of some legislators within the CCP who believed that the spread of heterodox ideas should be limited and controlled. It also unintentionally echoed the historic efforts of China, which

\footnotetext{
${ }^{126}$ HAIMIN Wu (吴海民), SHENPAN HAIDAO (审判海盗)[The Trial of the Pirates] 9 (Hua Yi Publishing House, 1995).

${ }^{127}$ Lin Zhou (周林), Zhongguo Banquan Shi Yanjiu de Jitiao Xiansuo(中国版权史研究的几条线索)[Several Clues of Research on Copyright History of China], in ZHONGGUO BANQUAN SHI YANJIU WENXIAN (中国版权史研究文 献)[ Historical Documents of China’s Copyright Law] 330 (Lin Zhou \& Mingshan Li eds., 1999).

${ }^{128}$ Chengsi Zheng (郑成思), Zhishi CHANQUAN BAOHU Shiwu QuANSHu (知识产权保护实务全书) [The Pandect of Intellectual Property Protection Practice] preface (China Yan Shi Press, 1999).

${ }^{129}$ Minfa Tongze (民法通则) [the General Principles of the Civil Law of China] (Adopted at the Fourth Session of the Sixth National People's Congress on April 12, 1986 and promulgated by Order No. 37 of the President of the People's Republic of China on April 12, 1986), translated at WORLD INTELLECTUAL PROPERTY ORGANIZATION, WIPO Lex No. CN135, http://www.wipo.int/wipolex/en/text.jsp?file_id=182628.

${ }^{130}$ Id. art. 94.

131 ALFORD, supra note 5, at 76-77.

132 Id. at 78. LI, supra note 74, at 168 .

${ }^{133}$ Copyright Law of the People's Republic of China (promulgated by Decree No. 31 of Sep. 7, 1990, of the president of People's Republic of China) art. 4. translated at WORLD INTELLECTUAL PROPERTY ORGANIZATION, WIPO Lex No. CN001, http://www.wipo.int/wipolex/en/text.jsp?file_id=336460 (hereinafter 1990 Copyright Law of the People's Republic of China).
} 
used copyright as a means to control the flow of information. ${ }^{134}$ Nevertheless, with the $1990 \mathrm{CCL}$, copyright was officially confirmed as a private right.

The revival of traditional culture came about in a different way: during this transitional period, ideological debate over economic plans within the CCP was unprecedented, since Xiaoping Dengopened the door of China by making a conclusion that "there is no fundamental contradiction between socialism and a market economy" in $1985,{ }^{135}$ which would have been unthinkable just a decade earlier, and had consequently triggered an "earthquake" within the CCP. ${ }^{136}$ It is also noted that the traditional foundation of the political culture was at risk during this period. ${ }^{137}$ Therefore, it was also an urgent matter for the CCP to find a supportive theoretical basis to avoid that risk, especially when the CCP realized that, in the late 1980s, many young scholars saw traditional Confucian culture as an "insular hindrance" to the development of a modern China, and they believed that the only way forward for China was to replace the influence of Confucianism with western individualism. ${ }^{138}$ As expected, in order to re-inforce the moral order of China, Confucianism was picked up again by the CCP. ${ }^{139}$ More importantly, it also functioned as a barrier against the erosion of western ideologies. This is evident as the CCP started the "Anti bourgeois liberalization Campaign" aiming at the former General Secretary Yaobang Hu, political liberalization, and western-inspired ideas in general in 1987. ${ }^{140}$ The Tiananmen Square Massacre in 1989 is also viewed as an example of the threat posed by anti-traditional trends which embrace democratic ideas. Interestingly, the country condemned the democracy campaign by broadcasting quotations from Confucius. ${ }^{141}$ And soon after that event, the CCP decided to make explicit its recognition of

\footnotetext{
134 ALFORD, supra note 5, at 79; LI, supra note 74, at 168.

135 Selected Words of Deng Xiaoping Volume III 1982-1992, Oct. 23, 1985 (Excerpt from an interview with a delegation, including senior American entrepreneurs, organized by Time Inc.), at http://english.peopledaily.com. cn/dengxp/vol3/text/c1480.html.

${ }^{136}$ Dwight H. Perkins, China's Economic Policy and Performance, in The CAmBridge History of China. Volume 15, The People’s Republic, PART 2: Revolutions Within the Chinese Revolution 1966-1982 510, (Denis Crispin Twitchett \& John King Fairbank eds., 1991).

${ }^{137}$ Mac Farquhar noted that "the deep-rooted attachment in the Chinese political culture to the concept of an elite bureaucracy sanctioned simply by its commitment to and mastery of a totalist ideology that claimed to explain the world and man's place in it" is "at risk". Roderick MacFarquhar, The succession to Mao and the end of Maoism, in The Cambridge History of China. Volume 15, The People's Republic, Part 2: Revolutions within the ChiNESE REVOLUTION 1966-1982 399 (Denis Crispin Twitchett \& John King Fairbank eds., 1991).

${ }^{138}$ Zhang \& Schwartz, supra note 118, at 203.

${ }^{139} I d$. at 202.

140 Jonathan D. Spence, The SeArCh For Modern China 685 (W.W. Norton 2nd ed. 1999).

${ }^{141}$ Christian SCIENCE MONITOR, Oct. 12, 1989, at 6, as cited in Zhang \& Schwartz, supra note 118, at 204.
} 
the Confucian tradition by commemorating the 2540th anniversary of Confucius's birth. ${ }^{142}$ In his speech, $\mathrm{Mu} \mathrm{Gu}$ (谷牧), the then member of the State Council of the Peoples Republic and nominal head of the Confucius Foundation, articulated that "[n]either communism nor Confucianism are responsible for China's under-development." ${ }^{143} \mathrm{Gu}$ further stressed the Confucian concept of "the preciousness of harmony" and emphasized that the correct attitude towards Confucianism is to "inherit it critically". ${ }^{144}$

\subsubsection{Open Up Period (1991-present)}

After the 1990 CCL, China revised its Copyright Law twice, in 2001 and 2010. In the aftermath of the Tiananmen Square Crackdown, the party's control over the flow of ideas was tightened after 1993. ${ }^{145}$ At the same time, China signed a Sino-US memorandum on intellectual property, ${ }^{146}$ and acceded to the Berne Convention for the Protection of Literary and Artistic Works (Berne Convention) ${ }^{147}$ and the UCC in 1992, under pressure mainly from the U.S. However, it is observed that the CCP put much more emphasis on its effort to put a strong degree of direct state control over the flow of ideas than its attempts to promote the protection of intellectual property. ${ }^{148}$ In view of the above, the U.S. had repeatedly threatened China with a series of economic sanctions, trade wars, non-renewal of MFN status, and opposition to entry into the World Trade Organization (WTO) in the late 1990s. ${ }^{149}$ This pressure along with the challenges posed by the new advancements in digital technologies urged the Chinese government to revise its copyright law in 2001. And, as discussed in the previous sections, the 2010 revision of the CCL was pushed by the WTO case DS362, which was also an end product of pressure from the U.S.

\footnotetext{
142 Id. at 203.

${ }^{143} \mathrm{Mu} \mathrm{Gu}$, Speech at the Opening Ceremony Commemorating the 2540th Anniversary of Confucius' Birth and a Symposium on Confucianism. 4 STUDY OF CONFUCIUS, 1989, as cited in id. at 204.

${ }_{144}$ Id.

145 ALFORD, supra note 5, at 92.

146 Memorandum of Understanding on the Protection of Intellectual Property, Jan. 17, 1992, P.R.C.-U.S., T.I.A.S. No. 12036 (1995).

${ }^{147}$ Berne Convention for the Protection of Literary and Artistic Works (Paris Act of July 24, 1971, as amended on September 28, 1979), WIPO Publication No. 287(E) (Geneva: World Intellectual Property Organization, 1992), 828 U.N.T.S. 221 [hereinafter Berne Convention] The United States acceded in 1989, China in 1992 and Japan in 1899.

148 ALFORD, supra note 5, at 92.

149 Peter K. Yu, From Pirates to Partners: Protecting Intellectual Property in China in the Twenty-First Century, 50 AM. U. L. REV. 131, 133 (2000).
} 
Although technically speaking, after two revisions, the latest CCL appears to be sophisticated enough to cover all the major problems such as online piracy which both foreign and local content industry are facing, it is not the case in practice, considering all the factors discussed within this chapter, and the fact that the public awareness of intellectual property rights is still very weak in China. ${ }^{150}$

Nevertheless, whether a system that was forced upon it is effective or not is certainly a question, ${ }^{151}$ but whether the traditional culture still has a direct bearing on the copyright laws of China is another. For example, during the 16th Party Congress in 2002, Zemin Jiang (江泽民), the then Chairman of the PRC emphasized that the country should be run by combining rule of law (法治) with rule of virtue (德治). The latter is believed to be a pure Confucian concept. ${ }^{152}$ We have also witnessed Jiang's successor, Jintao $\mathrm{Hu}$ (胡锦涛) who stressed once again the Confucian idea of "harmony", and used it to proclaim an aspiration to the concept of "a harmonious society” (和谐社会). ${ }^{153}$ If we scrutinize the recent activities and the published speeches of Jinping Xi (习近平), the incumbent President of China, one can easily find his insistence on "learning from the past": For the first time, Xi acting as the President of the State, has participated the 2565th anniversary of Confucius's birth on September 25th 2014. Just as Gu did in 1989, Xi has underscored the importance of Confucianism during his opening remarks almost in the same way. Xi noted that the "Chinese Communists will always be the loyal successor and promoter of great Chinese traditional culture" "154_albeit revised and vetted to support the current CCP interests, and "Confucianism contains valuable inspirations about solving problems of the contemporary world." Nonetheless, to what extent the traditional culture will affect the public

\footnotetext{
${ }^{150} \mathrm{LI}$, supra note 74 , at $179-80$.

${ }^{151}$ For a vivid discussion over this topic, see generally, Yu, supra note 149; ALFORD, supra note 5, at 117-119; LI, supra note 74 , at $185-86$.

${ }^{152}$ See generally Li Sun (孙莉), Dezhi Yu Fazhi Zhengdangxing Fenxi Jianji Zhongguo Yu Dongya Fawenhua Chuantong Zhi Jiansheng (德治与法治正当性分析一一兼及中国与东亚法文化传统之检省)[A Study on the Justification of Rule of Virtue and Rule of Law-With a Review of Legal Cultural Tradition of China and East Asian Countries], ZHONGGUO SHEHUI KEXUE (中国社会科学)[SOCIAL SCIENCES IN CHINA], no.6, 2002, 95-104.

${ }_{153}$ Orville Schell, Person of the Year 2007: Hu Jintao, TIME, Dec. 19, 2007, at http://content.time.com/time/specials/2007/personoftheyear/article/0,28804,1690753 1695388 1695753,00.html.

${ }^{154}$ Xiaosu Cui (崔小粟), Yiniannei Sanci Qinjin Rujia Xi Jinping Weihe Ruci Qiangdiao Chongshi Chuantong Wenhua? (一年内三次亲近儒家 习近平为何如此强调重拾传统文化? ) [Approach Confucianism three times a year, why Xi Jinping put so much stress on regaining the traditional culture?], Renmin Wang (人民网) [PEOPLE.COM.CN], Sep. 25, 2014, at http://cpc.people.com.cn/n/2014/0925/c164113-25731729.html.

${ }^{155} I d$.
} 
awareness of copyright is far from clear, since it should, according to Chinese leaders' views, be inherited critically. ${ }^{156}$ But it is evident from the current censorship mechanism discussed above that the Chinese political culture of information control, which Alford regarded as "the most important factor" in explaining why intellectual property had gone through a long and winding road in China in $1995^{157}$, is inherited perfectly within legislative and enforcement level and continually affecting the official attitude towards copyright protection in China.

As to the question of whether and to what degree the Confucius thinking about creative activity affects the current Chinese public perspective as a whole, the answer is (although many scholars have provided positive answers ${ }^{158}$ ) so far ambiguous. It is true that the traditional Chinese way of understanding the relationship between the past and current and the concept of copyright are somewhat contradictory. However, just as Posner had put it, "borrowing" as a creative method in the Renaissance was also "a way of expressing, in a tradition-oriented society, respect for illustrious predecessors". ${ }^{159}$ Therefore, that kind of thinking is not exclusive to China but rather a commonality of traditional societies' collectivist culture. ${ }^{160}$ If we take into account the history of copyright in modern western countries, and hold that the copyright regime is the reflection of industrial interests, then it is to be expected that the influence of that tradition over the public will be considerably weaker if fundamental changes occurred in the Chinese society.

The political attitude of China is reflected in its judicial activities as well. For instance, an important guideline entitled Decision of the CPC Central Committee on Major Issues Pertaining to Deepening Reform of the Cultural System and Promoting the Great Development and Flourishing of Socialist Culture, which was passed by the Communist Party of China in its Sixth Plenary Session of the Seventeenth Committee on Oct. 18, 2001, deems socialist culture an important part of China's comprehensive competitiveness today. The main theme in the "Decision" is to

\footnotetext{
156 See e.g., Id (according to Xi's view, "for those contents in the traditional culture that are suitable for social relationship adjustment and encourage people to seek goodness, we should inherit and promote them, and give them new meanings combining the conditions of the times").

157 ALFORD, supra note 5, at 119.

${ }^{158} I d$. at 123 . LI, supra note 74 , at 72-73, 186.

159 Richard A. POSNER, LAW AND Literature 529 (Harvard University Press 3rd ed. 2009).

${ }^{160} \mathrm{Li}$, supra note 92, at 60; See also Peter K. Yu, Intellectual Property and Confucianism, in DIVERSITY IN InTELleCtUAl PROPERTY: IDENTITIES, INTERESTS AND INTERSECTIONS 264 (Irene Calboli \& Srividhya Ragavan eds., Cambridge University Press, 2015); Shao, supra note 71, at 429-31.
} 
boost China's soft power and maintain "cultural security" in the wake of its ongoing economic boom. On Dec. 16, 2011, the Supreme People's Court of China (SPC) issued a related directive document entitled Several Opinions of the Supreme People's Court on Some Issues in Fully Giving Rein to the Function of Intellectual Property Rights Adjudication in Promoting the Great Development and Flourishing of Socialist Culture and Stimulating the Indigenous and Coordinated Development of Economy (hereinafter SPC Opinions on Socialist Culture). It is a major new guideline for courts in China on how to deal with intellectual property cases, though its real purpose is to deepen the reform of China's cultural system and promote the development of China's cultural industry, thereby raising China's national strength and international competitiveness. However, there is a potential danger that the courts may treat local and foreign products differently under the aim of developing and promoting "socialist culture" when copyright interests are in conflict.

From the above discussion it is obvious that many scholars believe that nowadays traditional culture is affecting Chinese people's perception of copyright in China, and traditional Chinese culture is mostly responsible for China's rampant piracy and lax enforcement in its government agencies. ${ }^{161}$ However, that conclusion seems to be over-hasty for many reasons:

According to Peter Yu's observation, it is the transformative use, rather than verbatim copying of pre-existing works, that Confucianism has called for. ${ }^{162}$ Moreover, considering Confucianism itself has had many different developments over time, and the fact that the introduction of Marxism and Socialism has greatly complicated the debate over the influences of Confucianism on contemporary China, even the supporters who believe Confucianism has presented a threat to the building of a modern copyright regime will find it extremely hard to prove the existence of that connection. ${ }^{163}$ Therefore it is very hard to assert that Confucianism alone is responsible for China's massive piracy problems, since "Chinese culture" is a phrase with many meanings. ${ }^{164}$ These observations

\footnotetext{
${ }^{161} I d$. at $248-49$.

162 Id. at 255.

163 Id. at 257-61.

${ }^{164} I d$. at 265 ("the greater diversity in Chinese culture has made explanations based on this culture even more difficult and incoherent.").
} 
are partly echoed by Prof. Shao, who believes that Confucianism is not just about imitation but also innovation. ${ }^{165}$

However, we could arguably conclude from the above that, rather than Confucianism or any other minority cultures such as Buddhism and Daoism, it is in fact the political culture, which Alford has described as "incompatible" with a system of strong intellectual property rights, ${ }^{166}$ that is currently functioning as the biggest barrier to meaningful piracy control. ${ }^{167}$ In other words, it is a fact that the Chinese government is using the slogan "fighting piracy" as an excuse to serve its own purpose of controlling the flow of ideas, which is fundamentally against the purpose of copyright.

\subsubsection{The WTO Case DS362 and DS363}

On April 10, 2007, the U.S., piqued at China's failure to protect intellectual property rights, filed two complaints against China before the WTO Dispute Settlement Body (DSB) ${ }^{168}$-also known as the DS362 and DS363 case. DS362 concerns China's inadequate intellectual property right enforcement, while DS363 focuses on China's limitations on market access to U.S. audio-visual products.

One of the core findings of the Panel report of DS362 case is that, Article 4 of the $2001 \mathrm{CCL}^{169}$ is inconsistent with Art. 9.1 and Art. 41.1 of the Agreement on Trade Related Aspects of Intellectual Property Rights (TRIPS), ${ }^{170}$ as it explicitly denied the possibility of copyright enforce-

\footnotetext{
${ }^{165}$ Shao, supra note 71 , at $412-16$.

166 ALFORD, supra note 5, at 119.

167 Anne Stevenson-Yang \& Ken DeWoskin, China Destroys the IP Paradigm, 168 FAR E. ECON. REV. 9,10 (2005)("In fact, China's failure to protect has little to do with stages of development or cultural attitudes. It has everything to do with the government's ownership and control over the economy, which undermines private property rights-especially the intangible kind. This creates economic instability that makes it difficult for innovation by domestic companies to be rewarded, and thus be sustained.").

${ }^{168}$ Panel Report, China-Measures Affecting the Protection and Enforcement of Intellectual Property Rights, WT/DS362/R (Jan. 26, 2009) [hereinafter DS362 case]; Panel Report, China--Measures Affecting Trading Rights and Distribution Services for Certain Publications and Audiovisual Entertainment Products, WT/DS363/R (Aug. 12, 2009) [hereinafter DS363 case].

${ }^{169}$ Copyright Law of the People's Republic of China (as amended by the Decision of October 27, 2001, of the Standing Committee of the National People's Congress on the Amendment of the Copyright Law of the People's Republic of China; promulgated by the Presidential Order No. 31 of People's Republic of China) art. 4, translated at WORLD INTELLECTUAL PROPERTY ORGANIZATION, WIPO Lex $\quad$ No. http://www.wipo.int/wipolex/en/text.jsp?file_id=125980 (hereinafter 2001 Copyright Law of the People's Republic of China)(Works the publication or distribution of which is prohibited by law shall not be protected by this Law.).

${ }_{170}$ Agreement on Trade Related Aspects of Intellectual Property Rights, Apr. 15, 1994, Marrakesh Agreement Establishing the World Trade Organization, Annex 1C, 1869 U.N.T.S. 299, 33 I.L.M. 1125, 1197 (1994) art. 9(1) [hereinaf-
} 
ment for works that were unable to pass the censorship of the Chinese government. ${ }^{171}$ Subsequently, Article 4 of the 2001 CCL was revoked in 2010 in response to the DS362 case. $^{172}$ Article 4 of the 2001 CCL not only reflects that China uses copyright law to dispel unorthodox works by denying them copyright protection, but also shows that before 2010, copyright enforcement, and even the copyright protection of most foreign audio-visual works such as Japanese anime were reliant on decisions of the Chinese government. In other words, in order to claim copyright protection, foreign copyright owners must first prove to the Chinese government that their works are not "prohibited by law". ${ }^{173}$ Researchers from Hong Kong have also confirmed that even Hong Kong editions of movies were not able to claim copyright protection if they were not subjected to the proper censorship regime by the appropriate powers before the 2010 revision. ${ }^{174}$

According to the reports of the Panel and the Appellate Body of DS363 case, a series of Chinese measures, which regulate activities relating to the importation and distribution of certain publications and audio-visual entertainment products, were found inconsistent with many China's TRIPS obligations and commitments. In order to implement the recommendations of the DSB, China had amended most measures at issue, and signed a Memorandum of Understanding with the U.S. regarding films for theatrical release. These newly revised measures are in close connection with China's censorship system, and the memorandum signed by China and the U.S. concerns the import quota of films. These new developments are introduced in the following subsections, along with the discussion about the impact of China's censorship system and import quota over its copyright enforcement.

\subsubsection{Censorship}

China is renowned for its harsh censorship system. Generally speaking, in terms of content distribution activities, the Chinese censorship mecha-

\footnotetext{
ter TRIPS Agreement].

${ }_{171}$ Rogier Creemers, The Effects of WTO Case DS362 on Audiovisual Media Piracy in China, 31 EUR. INTELL. PROP. REV. 568, 570 (2009).

${ }^{172}$ Panel Report, China-Measures Affecting the Protection and Enforcement of Intellectual Property Rights, WT/DS362/R (Jan. 26, 2009) [hereinafter DS362 case].

1732001 Copyright Law of the People's Republic of China, art. 4.

${ }^{174}$ Hao Dong \& Minkang Gu, Copyrightable or Not: A Review of the Chinese Provision on "Illegal Works" Targeted by WTO DS362 and Suggestions for Legal Reform, 4 ASIAN J. WTO \& INT'L HEALTH L. \& POL'Y 335, 344 (2009).
} 
nism functions in two directions: ex ante and ex post. Ex ante censorship concerns the official publication and distribution channels. Cultural goods such as books and audio-visual products all have to undergo a strict review process, and those titles that fail the censorship test, no matter whether they be foreign or local, are banned from the Chinese market. When it comes to the ex post censorship of the cultural sector in China, the focus is on information and works in circulation, both online and offline. For example, since many dissidents in China utilize the Internet to express their political opinions, and many other issues such as pornography and terrorism are taking the form of cultural products, the Chinese government has invested heavily in policing the Internet. The 2010 Nobel Peace Prize winner, the famous dissident Xiaobo Liu (刘晓波), was sentenced to 11 year's imprisonment for, amongst other things, publishing articles on foreign websites, such as "Observe China" and "BBC Chinese Net", which were deemed as "inciting subversion of state power". According to the verdict, it was the police department censor team that had determined his crime. ${ }^{175}$ As to the officially published cultural works concerning this research, in some rare cases, if the authorities find a published work or its author "inappropriate", or believe it may cause unnecessary problems, they can ban the underlying work, and recall all marketed items at any time. ${ }^{176}$ Therefore, it is not hard to understand why the Chinese government has long been cautious about cultural goods, especially the importation of foreign cultural goods, and their online distribution. In the following subsections, the problematic aspects of the censorship of China are unfolded according to different distribution channels, including the publication sector (para. 2.1.3.1), the traditional broadcasting channels (para. 2.1.3.2), online streaming (para. 2.1.3.3), and the enforcement campaigns (para. 2.1.3.4).

\footnotetext{
175 See Verdict against Liu Xiaobo, Dec. 25, 2009, translated at USC US-CHINA INSTITUTE, at http://china.usc.edu/ShowArticle.aspx?articleID=2319\&AspxAutoDetectCookieSupport=1.

${ }^{176}$ What happened to the books of the famous Chinese writers such as Shuo Wang (王朔) and Weihui Zhou (周卫慧) in the Chinese market is a good example. See Xhingyu Chen, Gray Areas: Book Banning and Censorship in China, FAIR OBSERVER, Aug. $\quad 15, \quad 2014, \quad$ at http://www.fairobserver.com/region/asia_pacific/grey-areas-book-banning-and-censorship-in-china-62007/ ("For example, the writer Wang Shuo has had his books labeled as "spiritual pollutants" for his frank depiction of a generation of wayward youth in the post-Mao era. There are efforts to ban his books and while some have been successful, others are freely available. Meanwhile, Zhou Weihui's Shanghai Baby, which chronicled the turbulent love life of a young Chinese woman, was banned and copies were publicly burned. The decision to ban one but not the other is open to interpretation; one can argue that authorities were uncomfortable with a female writer's blunt portrayal of sexuality in Shanghai Baby, although the works of Mian Mian, a contemporary of Zhou Weihui who also writes openly about sex and drugs, has never been banned.").
} 


\subsubsection{Publications}

China has a long history of censoring books and other publications. Although other countries around the world have had periods of such censorship in their history, ${ }^{177}$ in modern times, the censorship of publications in China is quite unique.

Publishing businesses in China include newspapers, periodicals, books, audio-visual products, and electronic publications. ${ }^{178} \mathrm{~A}$ recent study has indicated that China's publishing business is still heavily state-monopolized, and that its running is different from in free markets. ${ }^{179}$ In 1987, the State Council issued a notice stressing that "[e]xcept for those publishing units approved by the State, no unit or individual may publish to society for open distribution any book, periodical or audio/visual publication. Violators shall be deemed to have engaged in illegal publishing activities". ${ }^{180}$ This position was re-iterated in 1996, ${ }^{181}$ and was later adopted by State Council Regulations in 1997 and 2001. ${ }^{182}$ It is evident that state-owned publishing houses have exclusive rights in publishing, along with other monopoly resources. This situation means that only by illegal means or by cooperation with state-owned publishers can private publishers enter the publishing business. ${ }^{183}$

For foreign publishers, their ability to do business in the Chinese publishing sector was extremely limited before 2011. Post 2011, the year in which the decision of the WTO case DS363 took effect and the Chi-

\footnotetext{
177 Newth, supra note 55.

178 Chuban Guanli Tiaoli (出版管理条例) [Regulation on the Administration of Publications] (promulgated by the St. Council, Mar. 19, 2011, by St. Council Decree No. 594) art. 2, ST. CouncIL GAZ., 2011, no. 9 (China), translated at LAWINFOCHINA, http://www.lawinfochina.com/display.aspx?lib=law\&id=8705 (hereinafter the 2011 Regulation on the Administration of Publications).

${ }^{179}$ Song, supra note 47, at 324.

180 “Guowuyuan Guanyu Yanli Daji Feifa Chuban Huodong de Tongzhi” (国务院关于严厉打击非法出版活动的通 知) [Notice Regarding Striking Hard Against Illegal Publishing Activities], art. 1, State Council of China, Jul. 6, 1987, at http://www.people.com.cn/electric/flfg/d4/870706.html.

${ }^{181}$ Guowuyuan Bangongting Guanyu Jianjue Qudi Feifa Chuban Huodong de Tongzhi(国务院办公厅关于坚决取缔 非法出版活动的通知) [Notice Regarding Resolutely Clamping Down on Illegal Publishing Activities] (promulgated by the St. Council, Jan. 25, 1996) art. 1 (China).

${ }_{182}$ Chuban Guanli Tiaoli (出版管理条例) [Regulation on the Administration of Publications] (promulgated by the St. Council, Jan. 2, 1997, by St. Council Decree No. 210, repealed Dec. 25, 2001 by St. Council Decree No. 343) art. 8, ST. CounCIL GAZ., 1997, no. 2, at 38 (China); Regulation on the Administration of Publications (promulgated by the St. Council, Dec. 25, 2001, by St. Council Decree No. 343, repealed Mar. 19, 2011 by St. Council Decree No. 594) art. 9, ST. COUNCIL GAZ., 2002, no. 4, at 15 (China), translated at WORLD INTELLECTUAL PROPERTY ORGANIZATION, WIPO Lex No. CN065, http://www.wipo.int/wipolex/en/text.jsp?file_id=182153 (hereinafter the 2001 Regulation on the Administration of Publications).

${ }^{183}$ Song, supra note 47 , at 324.
} 
nese government was forced to take action ${ }^{184}$, they are able to compete in the publishing market to a degree. In the DS363 case, the Panel and the Appellate Body found that certain provisions and measures China had were inconsistent with its WTO obligations, as they restrict trading rights with respect to imported films for theatrical release, audio-visual home entertainment products, sound recordings and publications, and market access for, or discrimination against, foreign suppliers of distribution services for publications and foreign suppliers of audio-visual services for audio-visual home entertainment products. As a result, the U.S. entertainment industry should have "a full chance to compete" in China "under agreed WTO rules". ${ }^{185}$ A number of reasons were used to support that assertion:

Firstly, according to the new rules, electronic publications, as requested by the U.S. in the DS362 case, are now an option for foreign companies in China. Article 9 of the 2011 Regulation on the Administration of Publications stipulates that:

The State allows the establishment of Sino-foreign equity joint venture companies, Sino-foreign contractual joint venture companies and wholly foreign-owned companies that engage in the distribution of books, newspapers, periodicals and electronic publications. ${ }^{186}$

Before 2011, foreign investors were only allowed to conduct business in relation to "the distribution of books, newspapers and periodicals". However, the "specific measures and their implementation procedures", which determined how foreign investors could engage in the above-mentioned business in practice, were subject to further discussion by the "publication administration department of the State Council jointly with the competent foreign trade and economic cooperation department of the State Council." ${ }^{\prime 87}$ After the 2011 revision of the Regulation on the Administration of Publications, "electronic publications" were added, and the paragraph

\footnotetext{
${ }^{184}$ Panel Report, China-Measures Affecting Trading Rights and Distribution Services for Certain Publications and Audiovisual Entertainment Products, WT/DS363/R (Aug. 12, 2009).

${ }^{185}$ WTO Appellate Body Confirms Finding Against China's Treatment of Certain Copyright-Intensive Products, Office of the United States Trade Representative, Dec. 2009, at http://www.ustr.gov/about-us/press-office/press-releases/2009/december/wto-appellate-body-confirms-finding-against -china.

${ }_{186} 2011$ Regulation on the Administration of Publications, art. 9.

1872001 Regulation on the Administration of Publications, art. 39.
} 
relating to the "specific measures and their implementation procedures" was deleted. Moreover, in order to clarify the new regulation, three implementing documents were published as well. ${ }^{188}$

Secondly, the right to import publications is no longer limited to a "wholly State-owned enterprise". The 2001 Regulation on the Administration of Publications provides:

For establishment, a publications importation unit shall meet the following conditions...

(2) is a wholly State-owned enterprise and possesses a sponsoring unit which is recognized by the publication administration department of the State Council, and the competent agency at the higher level. ${ }^{189}$

That requirement is also abolished in the 2011 revision:

For establishment, a publications importation unit shall meet the following conditions...

(2) have a sponsoring unit and competent authority that is recognized by the competent publication administration department of the State Council. ${ }^{190}$

Furthermore, the special requirement on the "importation of newspapers or periodicals" set by article 41 of the 2001 Regulation was also removed from its 2011 version. The Article 41 of the 2001 Regulation on the Administration of Publications provides that:

The publications importation business shall be conducted by the publication importation units, and those engaged in the impor-

\footnotetext{
${ }^{188}$ Dinghu Dinggou Jinkou Chubanwu Guanli Banfa (订户订购进口出版物管理办法) [Measures for the Administration on Subscribers' Subscription for Imported Publications] (promulgated by the General Administration of Press and Publication No. 51, Mar. 25, 2011)(China), translated at LAWINFOCHINA, http://www.lawinfochina.com/display.aspx?lib=law\&id=8646\&CGid=. Chubanwu Shichang Guanli Guiding (出版物 市场管理规定) [Provisions on the Administration of Publications Market] (promulgated by the General Administration of Press and Publication and the Ministry of Commerce Order No. 52, Mar. 25, 2011)(China), translated at LAWINFOCHINA, http://www.lawinfochina.com/display.aspx?lib=law\&id=8636\&CGid=. Yinxiang Zhipin Jinkou Guanli Banfa (音像制品进口管理办法) [Measures for the Administration of Import of Audio and Video Recordings] (promulgated by the General Administration of Press and Publication and General Administration of Customs Order No. 53, Apr. 6, 2011)(China), translated at PKULAW, http://en.pkulaw.cn/display.aspx?cgid=149796\&lib=law.

1892001 Regulation on the Administration of Publications, art. 42 (2).

1902011 Regulation on the Administration of Publications, art. 42 (2).
} 
tation of newspapers or periodicals shall be designated by the publication administration department of the State Council.

No unit or individual may, without approval, engage in the publications importation business; no unit or individual may, without being designated, engage in the importation of newspapers or periodicals. ${ }^{191}$

However, in the 2011 Regulation on the Administration of Publications, Article 41 provides:

The publication importation business shall be conducted by the publication importation units established under this Regulation. No other units or individuals may engage in the publication importation business. ${ }^{192}$

Thirdly, since audio-visual products are considered as publications in China, several legislative documents were amended in order to match the major revisions. For example, in some regulations, the word "designated" (指定的) which had appeared in the previous versions was changed to “approved” (批准的). ${ }^{193}$

It appears from the above points that the Chinese market is now opening its arms to foreign works, and many foreign import entities might appear in China in the near future. However, this may not be the case if we consider the bureaucratic procedures which must be gone through before an import unit can be established and foreign titled be successfully introduced to the Chinese market. Even if we assume foreign companies can now easily establish an import unit in China, there are still many restrictions on the content too. According to Article $25^{194}$ and Article $26^{195}$

\footnotetext{
1912001 Regulation on the Administration of Publications, art. 41.

1922011 Regulation on the Administration of Publications, art. 41.

193 See e.g., Yinxiang Zhipin Guanli Tiaoli (音像制品管理条例) [Regulations on the Administration of Audio and Video Products] (promulgated by the St. Council Decree No. 341, Mar. 19, 2011) art. 27, ST. CounCIL GAZ., 2011 , no. 9 (China), translated at LAWINFOCHINA, http://www.lawinfochina.com/display.aspx?lib=law\&id=8815. Measures for the Administration of Import of Audio and Video Recordings, art. 7-8.

194 Article 25 provides that:
}

The following contents are prohibited from being included in any publication:

(1) Those which object to the basic principles determined in the Constitution;

(2) Those which endanger the unity of the nation, sovereignty or territorial integrity;

(3) Those which divulge secrets of the State, endanger national security or damage the honor or benefits of the State; 
of the 2011 Regulation on the Administration of Publishing, the publisher is responsible for censoring works of domestic literature in accordance with a long list of sensitive topics.

As to imported goods, the same regulation provides very detailed restrictive provisions in its Articles 45 to 48. According to Article 45, the prohibited content listed in Article 25 and Article 26 also apply to foreign works, and it further indicates the responsibilities of the "import unit", and the specific procedures regarding submitting foreign works for state censorship. ${ }^{196}$ Article 46 further delineates the consequences if the imported product is deemed inappropriate. ${ }^{197}$ Article 47 prescribes that only

(4) Those which incite the national hatred or discrimination, undermine the solidarity of the nations, or infringe upon national customs and habits;

(5) Those which propagate evil cults or superstition;

(6) Those which disturb public order or destroy public stability;

(7) Those which propagate obscenity, gambling, violence or instigate crimes;

(8) Those which insult or slander others, or infringe upon the lawful rights and interests of others;

(9) Those which endanger public ethics or the fine folk cultural traditions;

(10) Other contents prohibited by laws, administrative regulations or provisions of the State.

See 2011 Regulation on the Administration of Publications, art. 25.

195 Id. art. 26:

Publications catering to minors shall not include any content enticing minors to imitate the acts in violation of public ethics or illegal or criminal acts, nor shall they include such contents harming the physical and mental health of minors as terror, cruelty, etc.

(Translation from LAWINFOCHINA.)

${ }^{196}$ Id. art. 45.

The publications imported by a publication import entity shall not include any content prohibited by Articles 25 and 26 of these Regulations.

A publication import entity shall be responsible for examining the contents of the publications which it has imported. The administrative department for publication under the people's government at the provincial level or above may directly examine the contents of the publications imported by a publication import entity. Where a publication import entity is unable to identify whether the imported publications include any content prohibited by Articles 26 and 27 of these Regulations, it may request the administrative department for publication under the people's government at the provincial level or above to examine the contents. The administrative department for publication under the people's government at the provincial level or above may, when examining upon the request by the publication import entity the contents of the imported publications, charge fees in accordance with the rates approved by the department in charge of price under the State Council.

The administrative department for publication under the State Council may forbid the import of certain publications.

(Translation from LAWINFOCHINA.)

${ }^{197} I d$. art. 46.

A publication import entity shall, before importing publications, submit the catalogue of the publications subject to planned import to the administrative department for publication under the people's government at the provincial level or above for record; where the administrative department for publication under the people's government at the provincial level or above finds that the import of any publication shall prohibited or deferred, it shall notify the publication import entity in time and shall inform the customs. A publication import entity shall not import any publication which has been prohibited or deferred in notices, and the customs shall not release such a publication.

The specific measures for the registration of imported publications shall be enacted by the administrative department for publication under the State Council. 
those "publication import units established in accordance with the laws" are eligible to import foreign publications. ${ }^{198}$ Article 48 sets specific restrictions on the exhibition of foreign publications. ${ }^{199}$

Apart from these responsibilities that publishing entities in China must undertake, if the scheduled publications involve "key selected titles" (重大选题) which concern national security or social stability, then the entities must submit their annual publishing plan for scrutiny as well. ${ }^{200}$ Moreover, scheduled publications concerning the above-mentioned "key selected titles" cannot be published if they have not been submitted for inspection beforehand. ${ }^{201}$ In fact, according to one former employee of the Encyclopedia of China Publishing House, a state-owned publisher in China, many of their publishing projects are stuck in the administrative stage of record submission and are thus unavoidably delayed. ${ }^{202}$ And, in the worst case scenario, publishers and their staff might receive criminal sanctions if they have failed to censor inappropriate content and published it consequently. ${ }^{203}$ Further, the publisher could be shut down if it fails to undertake its filing responsibility. ${ }^{204}$ From this single legislative document, we can see how restricted the publishing sector is in China. In terms of imported foreign works, similar censorship requirements have been re-iterated in many associated regulations as well. For instance, with respect to the importation of foreign audio-visual works, although the entitlement to import such titles is no longer limited to govern-

(Translation from LAWINFOCHINA.)

198 Id. art. 47.

Those who distribute imported publications must receive goods from the publication import entities established in accordance with the law.

(Translation from LAWINFOCHINA.)

199 Id. art. 48.

A publication import entity that intends to hold an exhibition of overseas publications inside the territory must report to the administrative department for publication under the State Council for approval. No entity or individual shall hold exhibitions of overseas publications without being approved.

Where the overseas publications exhibited in accordance with the preceding paragraph need to be sold, the relevant formalities shall be gone through in accordance with the relevant provisions of the State.

(Translation from LAWINFOCHINA.)

200 In that case, after the involved subjects have been examined and verified by "the administrative department for publication under the people's government of the province, autonomous region or municipality directly under the Central Government at its locality." they should be submitted to "the administrative department for publication under the State Council for record", Id. art. 20.

201 Id.

${ }^{202}$ Interviewed and documented by the author in Oct.1, 2014.

${ }^{203} 2011$ Regulation on the Administration of Publications, art. 62-69.

${ }^{204}$ Id. art. 61. 
ment-controlled entities, the importer still faces rigid content censorship. $^{205}$

Besides these ex ante publication censorship requirements that can be easily found in official documents, the ex post censorship mechanism in this sector is just as crucial but subtler. In addition to the cases of the books of Shuo Wang and Weihui Zhou that we have discussed above, ${ }^{206}$ a more recent case exemplifies this latent censorship: because of their sympathetic views on Hong Kong's Occupy Central sit-ins and Taiwan's "Sunflower" student movement in late 2014, a banning order was issued "orally", according to one source in a state-owned publisher, against the books of many famous authors, including the Tang Prize recipient and Chinese American historian Ying-shih Yu (余英时). ${ }^{207}$ Their books have thus been banned and removed from the Chinese market. Many independent publishers have confirmed this unofficial order as well. ${ }^{208}$ In Yu's case, we can see that it is not only the content that is the target of publication censorship in China but that the political attitude or sensitivities of the author are also considered.

\subsubsection{Traditional Broadcasting Channels}

In terms of traditional broadcasting channels, local censorship is just as strict. Generally speaking, the traditional way for the public to gain access to audio-visual works is through broadcasting channels, such as movie theatres and television stations. These are all highly restricted and government-controlled areas as well. Accordingly, these channels face strict management and content restrictions.

In terms of market entry, the right to broadcast one's work through traditional channels is controlled by the state-owned television stations. According to Article 10 of the 1997 Regulations on Broadcasting and Television Administration, only the "departments of broadcasting and television administration of people's governments of counties and mu-

\footnotetext{
${ }^{205}$ Regulations on the Administration of Audio and Video Products, art. 3, art. 28. Measures for the Administration of Import of Audio and Video Recordings, art. 5-6, art. 13-9.

${ }^{206}$ Chen, supra note 176.

207 Books by Writers Sympathetic to Hong Kong and Taiwan Student Movements Available 'While Stocks Last', SOUTH CHINA MORNING POST, Oct. http://www.scmp.com/news/china/article/1615308/books-writers-sympathetic-hong-kong-and-taiwan-student-movem ents. ${ }^{208} I d$.
} 
nicipalities without subordinate districts and above" can establish radio and television stations. ${ }^{209}$ That requirement was later reiterated by a regulation issued by the State Administration of Radio, Film, and Television (hereinafter, SARFT) ${ }^{210}$ seemingly no exception can be made to this. $^{211}$ Once a broadcasting institution is established, a license for a broadcasting station and television station (广播电台、电视台许可证) will be issued to the successful applicant. Furthermore, according to another SARFT regulation, in order to engage in the business of transmitting "radio and TV programs by cables", the broadcasting institution must acquire "a Permit for the Business of Transmission of Radio and TV Programs” (广播电视节目传送业务经营许可证). ${ }^{212}$ It should be noted that only those state-owned institutions, or those institutions and groups "established upon approval of the SARFT" are entitled to apply for the abovementioned permit, ${ }^{213}$ and that institutions involving foreign capital are prohibited from engaging in the business of transmitting radio and television programs. ${ }^{214}$

Not only is the privilege of content broadcasting in the hands of state-owned institutions, but the production and distribution of radio and television programs are heavily state-controlled as well. According to the Radio and Television Program Production Business Management Regulations, although private parties can participate in the production of radio and television programs, the involvement of foreign capital

\footnotetext{
${ }^{209}$ See Guangbo Dianshi Guanli Tiaoli (广播电视管理条例) [Regulations on Broadcasting and Television Administration] (promulgated by the St. Council Decree No. 228, Aug. 11, 1997) art. 10 (China), translated at LAWINFOCHINA, http://www.lawinfochina.com/display.aspx?lib=law\&id=6313\&CGid= ("Broadcasting stations and television stations shall be established by departments of broadcasting and television administration of the people's governments of counties and municipalities without subordinate districts and above, among which educational television stations may be established by departments of education administration of people's governments of municipalities with subordinate districts and autonomous prefectures and above. No other units or individuals shall establish broadcasting stations and television stations. The State prohibits the establishment of foreign capital operated, Sino-foreign joint venture and Sino-foreign cooperative venture broadcasting stations and television stations.”).

${ }^{210}$ Guangbo Diantai Dianshitai Shenpi Guanli Banfa (广播电台电视台审批管理办法) [Measures for the Administration of Examination and Approval of Radio Stations and Television Stations] (promulgated by SARFT Decree No. 37, Aug. 18, 2004) art. 4-7 (China), translated at LAWINFOCHINA, http://www.lawinfochina.com/display.aspx?lib=law\&id=3722\&CGid=.

${ }^{211}$ See Xiaohan Shi (师小涵) \& Songli Guo (郭宋立), Minying Dianshitai de Haiwai Shengcun (民营电视台的海外 生存) [The Chinese Private-run TV stations are Making a Living in Foreign Countries], Nanfang Zhoumo (南方周末) [SOUTHERN WEEKLY], Oct. 14, 2013, http://www.infzm.com/content/94935.

${ }^{212}$ Guangbo Dianshi Jiemu Chuansong Yewu Guanli Banfa(广播电视节目传送业务管理办法) [Administrative Measures for the Business of Transmission of Radio and TV Programs] (promulgated by SARFT Decree No. 33, Jul. 6, 2004) art. 5 (China), translated at http://www.lawinfochina.com/display.aspx?lib=law\&id=4550\&CGid=.

${ }_{213}$ Id. art. 6.

${ }_{214}$ Id. art. 7.
} 
is highly restricted in this field. ${ }^{215}$ Furthermore, in order to produce television programs, every production entity must first obtain a "Radio and Television Program Production Business Permit" (广播电视节目制作经 营许可证) from the administrative radio and television organ of the government. ${ }^{216}$ As for television drama productions, an additional "Television Drama Production Permit” (电视剧制作许可证) is needed. ${ }^{217}$ In addition, news about current politics and similar topical and special column programs can only be broadcast by state-controlled radio and television organs, so other privately-run businesses cannot produce such products, even when a Radio and Television Program Production Business Permit has been obtained. ${ }^{218}$ The broadcasting of productions produced by entities without a Radio and Television Program Production Business Permit is prohibited. ${ }^{219}$ In terms of the new Video on Demand (VOD) service through radio and television systems, it is clearly indicated that only approved radio and television stations can apply for a Permit for the Business of Video Broadcasting by Order (广播电视视频点播业务许可 证). ${ }^{220}$

In terms of movie production and theater display channels, the level of state control is even stricter. First, in order to establish a "film produc-

\footnotetext{
${ }^{215}$ Guangbo Dianshi Jiemu Zhizuo Jingying Guanli Guiding(广播电视节目制作经营管理规定) [Radio and Television Program Production Business Management Regulations] (promulgated by SARFT Decree No. 34, Jul. 19, 2004) art. 5 (China), translated at CHINA COPYRIGHT AND MEDIA (Rogier Creemers trans.), http://chinacopyrightandmedia.wordpress.com/2004/07/19/radio-and-television-programme-production-business-man agement-regulations/ ("The State encourages domestic social organizations, enterprise and undertaking organs (not including wholly-foreign invested enterprises or Sino-foreign cooperatives or contractual enterprises established within the borders) to establish radio and television program production business organs or engage in radio and television program production business activities.”).

${ }^{216}$ Id. art. 4.
}

${ }^{217}$ Id. art. 12.

The State establishes a permit system over establishing radio and television programme production business organs and engaging in radio and television programme production business activities. For establishing radio and television program production business organs and engaging in radio and television program production business activities, a "Radio and Television Program Production Business Permit" must be obtained.

For television dramas produced by organs holding a "Radio and Television Program Production Business Permit", prefecture / city-level (included) or higher television stations (including radio and television stations, radio and television groups) and film production organs holding a "Film Shooting Permit", it is necessary to obtain a television drama production permit sepa-

218 Id. art. 21. rately in advance.

219 Id. art. 25.

${ }^{220}$ Guangbo Dianshi Shipin Dianbo Yewu Guanli Banfa(广播电视视频点播业务管理办法) [Measures for the Administration of Radio \&TV Video Broadcasting by Order] (promulgated by SARFT, Jul. 6, 2004, effective Aug. 10, 2004, by SARFT Decree No. 35) art. 7 (China)("The following institutions may apply for a Permit (Category A): (1)The radio stations and TV stations at the prefecture (city) level or above established upon approval; and (2)The radio, film and television groups (headquarters) established upon approval."). 
tion entity", the application for establishment "shall be examined and consented to by the administrative department for film under the people's government of the province, autonomous region or municipality directly under the Central Government where the applicant is located before being submitted to the administrative department for radio, film and television under the State Council for examination and approval."221 After approval, the qualified entities can thus gain a License for Producing Movies (摄 制电影许可证). ${ }^{22}$ Entities other than film production companies can also participate in film production, but they have to ask for approval from the administrative department for radio, film and television under the State Council, and obtain from that body a one-off License for Producing Movies (摄制电影片许可证 (单片) ). ${ }^{223}$ Foreign practitioners cannot participate in film production independently but have to cooperate with a film production entity, under the approval of the same department mentioned above. ${ }^{224}$ Furthermore, they have to obtain a different one-off license, entitled the License for Producing Films through Chinese-foreign Cooperation (中外合作摄制电影片许可证), ${ }^{225}$ and have to face a series of procedural restrictions. ${ }^{226}$ Second, the distribution and projection of movies are all subject to licenses issued by the administrative department for movies under the Chinese government. ${ }^{227}$ Only after obtaining the License for Operating the Distribution of Movies (电影发行经营许可证) and the License for Operating the Projection of Movies (电影放映经营许 可证) can entities engage in the underlined business in China. ${ }^{228}$ As can be seen, the movie business and the theater channel are firmly controlled by the Chinese government.

In the light of the influence of the DS363 case on the movie sector, no major revision to the related legislative documents has yet been released, which means no changes have been made regarding the entities that are eligible to import films for public screening. However, if we take

\footnotetext{
221 Dianying Guanli Tiaoli(电影管理条例) [Regulations on the Administration of Movies] (promulgated by St. Council Decree No. 342, Dec. 25, 2001) art. 9 (China), translated at WORLD INTELLECTUAL PROPERTY ORGANIZATION, WIPO Lex No. CN067, http://www.wipo.int/wipolex/en/text.jsp?file_id=182159.

${ }^{222}$ Id. art. 10.

${ }^{223} I d$. art. 16.

${ }^{224}$ Id. art. 18.

${ }^{225} I d$. art. 19.

${ }^{226}$ Id. art. 20-23.

${ }^{227}$ Id. art. 37.

${ }^{228}$ Id. art. 37-38.
} 
the movie quota set by the Chinese government into consideration, ${ }^{229}$ whether a foreign entity can import foreign films for screening is not the only issue. Therefore, it is understandable why the U.S. chose to make China extend its annual film import quota from 20 to 34 in 2012 instead of forcing China to lift its limitations on import entities. ${ }^{230}$ This is because making the cake larger is a more urgent mission for foreign film companies, especially since they have already noticed that co-production is a much faster way of turning their products into money in China. ${ }^{231}$

As to the content of the above-discussed articles, what can be produced or accepted seems to be another tricky question in China. In the light of the ex ante censorship, Japanese anime products in China serve as a good example: Japanese animes are renowned for their undiscriminating nature, normally containing sexual and violent elements. ${ }^{232}$ For instance, in an online interview, Ma Kai (马凯), director of the program “Comic World" on the Children's Channel of China Central Television (CCTV), revealed that imported animation works on their channel were under multiple levels of censorship, for the purpose of filtering inappropriate works for children. ${ }^{233}$ Past and current legislation and regulations regarding foreign titles also indicate that topics such as sensitive political content, obscenity, and violent content are included on the censorship lists too. ${ }^{234}$ In terms of local TV productions, the censorship requirement is almost the same. ${ }^{235}$ Those works that fail to pass the censorship examination are unable to obtain the Television Drama Distribution Permit (电视剧发行

\footnotetext{
229 See infra chapter 2.1.4.

230 Olivia Goldhill, Hollywood Switches Focus to China's Billions, THE Telegraph, Jul. 7, 2013, at http://www.telegraph.co.uk/finance/newsbysector/industry/10165352/Hollywood-switches-focus-to-Chinas-billions.ht $\mathrm{ml}$.

${ }^{233}$ Guowai Donghua Pian Dui Zhongguo Ertong Jiazhi Guan de Yingxiang (国外动画片对中国儿童价值观的影响) [Imported Anime's Influences on the Values of Chinese Children], Zhongyang Dianshi Tai (中央电视台) [CCTV], Oct. 12, 2004, http://www.cctv.com/tvguide/tvcomment/special/C11876/20041012/101985 4.shtml.

${ }^{234}$ See Guangbo Dianying Dianshibu Guanyu Yinjin Haiwai Dianshiju De Shencha Biaozhun(广播电影电视部关于 引进海外电视剧的审查标准) [Examination Standards Concerning Imported Foreign Television Dramas] (promulgated by the St. Admin. of Radio, Film \&Television, Nov. 28, 1990, repealed Dec. 17, 2003) art. 4 (China). See also, e.g., Jingwai Dianshi Jiemu Yinjin Bochu Guanli Guiding (境外电视节目引进、播出管理规定) [Foreign Television Program Import and Broadcast Management Regulations] (promulgated by SARFT, Sept. 23, 2004, effective Oct. 23, 2004, by SARFT Decree No. 42) art. 15 (China).

${ }^{235}$ Radio and Television Program Production Business Management Regulations, art. 22; Administrative Measures for the Business of Transmission of Radio and TV Programs, art. 17; Measures for the Administration of Radio \&TV Video Broadcasting by Order, art. 21; Dianshiju Shencha Guanli Guiding (电视剧审查管理规定) [Television Drama Examination Management Regulations] (promulgated by SARFT, Sept. 20, 2004, effective Oct. 20, 2004, by SARFT Decree No. 40, repealed July 1, 2010) art. 5 (China).
} 
许可证) or Television Cartoon Distribution Permit (电视动画片发行许 可证), and any production without these permits cannot be distributed, broadcast, imported or exported. ${ }^{236}$ Taking movie production in China as another example, no productions can be distributed, projected, imported or exported without the License for Public Projection of Movies (电影片 公映许可证) first having been obtained. ${ }^{237}$ In order to obtain that license, all movies in China must be examined in accordance with a long list of censorship criteria, ${ }^{238}$ and those failing to pass the examination "shall not be distributed, projected, imported or exported" in China. ${ }^{239}$

In terms of content censorship in the television and movie screening sectors, China is certainly not alone: although Japan has a relatively close relationship with the U.S., as both countries have a strong partnership and share interests in multilateral cooperation, Japanese anime and related products in the U.S. market have also faced strict censorship. However, the purpose there is to filter violence and sexual content and to adapt it to the local language environment. ${ }^{240}$ Some believe that these harsh editing criteria may even encroach on the moral rights and integrity of the Japanese copyright holders and that their censorship requirements have in fact triggered some fan-based activities such as fansubs. ${ }^{241}$ However, the situation in the U.S. is different from that in China, where most of the censorship rules focus on political considerations. ${ }^{242}$ By contrast, the main motivation in the U.S. is the desire to treat Japanese anime as if they were only for child consumption. ${ }^{243}$

The criteria of the ex post censorship system in the field of public broadcasting channels are relatively similar to those in the publishing sector. According to the related regulations, the broadcasting of certain TV programs, ${ }^{244}$ and the distribution and projection of certain movies

\footnotetext{
${ }^{236}$ Id. art. 15. See also Dianshiju Guanli Guiding(电视剧管理规定) [Television Drama Management Regulations] (promulgated by SARFT Decree No. 2, Jun. 15, 2000, repealed Jan. 1, 2008) art. 20 (China), translated at CHINA COPYRIGHT AND MEDIA Creemers trans.), https://chinacopyrightandmedia.wordpress.com/2000/06/15/television-drama-management-regulations-2/.

${ }^{237}$ Regulations on the Administration of Movies, art. 42.

238 Id. art. 25.

${ }^{239} I d$. art. 24.

${ }^{240}$ Sean Leonard, Progress Against the Law: Anime and Fandom, with the Key to the Globalization of Culture, 8 INT'L J. OF CULTURAL STUD. 281, 285 (2005).

${ }^{241}$ Daniels, supra note 25, at 714-16.

${ }^{242}$ Shalia Sakona, Frankly, My Dear America, We Don't Give a Damn: Comparing Chinese and European Trade Barriers to American Audiovisual Works and the American Response, 54 B.C. L. REV. 1385, 1391-92 (2013).

${ }^{243}$ Leonard, supra note 28, at 198.

${ }^{244}$ Regulations on Broadcasting and Television Administration, art. 43 (The department of radio and television administration under the State Council may, under extraordinary circumstances, make a decision to suspend the broad-
} 
can be stopped by the administrative department for radio, movie and television under the State Council at any moment under "particular circumstances". 245 However, what these "particular circumstances" are is comparatively unclear, and that has created space for the authorities to operate. For example, the State Administration of Press, Publication, Radio, Films and Television of The People's Republic of China (SAPPRFT, formerly known as SARFT) issued an official notice in late September 2014, asking local television stations to remove those audio-visual productions featuring actors that had been arrested for drug and prostitution reasons. ${ }^{246}$ After Jinping $\mathrm{Xi}$, the President of China, pointed out in a meeting on arts and literature that "creative works should be patriotic and moral", ${ }^{247}$ the SAPPRFT and China Television Arts Committee soon organized a symposium to study his talk, and explicitly indicated that no persons with a criminal record or who had been involved in a scandal could be allowed in future productions. ${ }^{248}$ Therefore, it is notable that, although these officially released productions have no doubt already been "sanitized" (The contents themselves are theoretically "safe".), the participants of a work could be the "particular circumstance" that can cause fatal damage to the commercial life of these products as well. Another famous example is the "cleavage ban" imposed on the television series The Saga of Wu Meiniang (武媚娘传奇), in which the production had already been passed for censorship and been broadcast but was soon withdrawn after controversy over the actresses' revealed cleavage. ${ }^{249}$ This show reappeared several days after it had been withdrawn but now with ridiculously tightened scenes with head and shoulder shots of the actresses. $^{250}$

\footnotetext{
cast, change a particular program or designate the relay of a particular program.).

${ }^{245}$ Regulations on the Administration of Movies, art. 42 (With respect to a movie for which the "License for Public Projection of Movies" has been obtained, the administrative department for radio, movie and television under the State Council may, under particular circumstances, make a decision on ceasing the distribution or projection or, prohibiting distribution or projection before the amendment).

${ }^{246}$ Clifford Coonan, China Bars Stars with "Bad" Moral Records from TV, THE Hollywood RePORTER, Sep. 17, 2014, at http://www.hollywoodreporter.com/news/china-bars-stars-bad-moral-733690.

${ }^{247}$ Russell Leigh Moses, Lurking in Mao's Shadow, China's Xi Looks Undecided on Reforms, THE WALL STREET JOURNAL, Oct. 20 , 2014 , http://blogs.wsj.com/chinarealtime/2014/10/20/lurking-in-maos-shadow-chinas-xi-looks-indecisive-on-reforms/.

${ }^{248}$ Lu Liu (刘路), Zongju Yanjin Chouwen Lieji Zhe Fasheng Chujing Jiang Baohan Chugui (总局严禁丑闻劣迹者 发声出镜 将包含“出轨”) [SAPPRFT Says no Show for Practitioners with Scandal and Bad Reputation, “Unfaithful” may be Included], Xinhua Wang ( 新 华 网 ) [XINHUA NET], Oct. 24, 2014, at http://www.js.xinhuanet.com/2014-10/24/c_1112962178.htm.

${ }^{249}$ Sui-Lee Wee, Sexy China TV Drama Busted, Returns to Air More Sedate, Reuters, Jan. 3, 2015, at http://www.reuters.com/article/2015/01/03/china-television-idUSL3N0UI04P20150103.

${ }^{250}$ Lilian Lin, Venus De Milo, Scarlett Johannson Get Cropped After Chinese Cleavage Ban, THE WALL STREET
} 

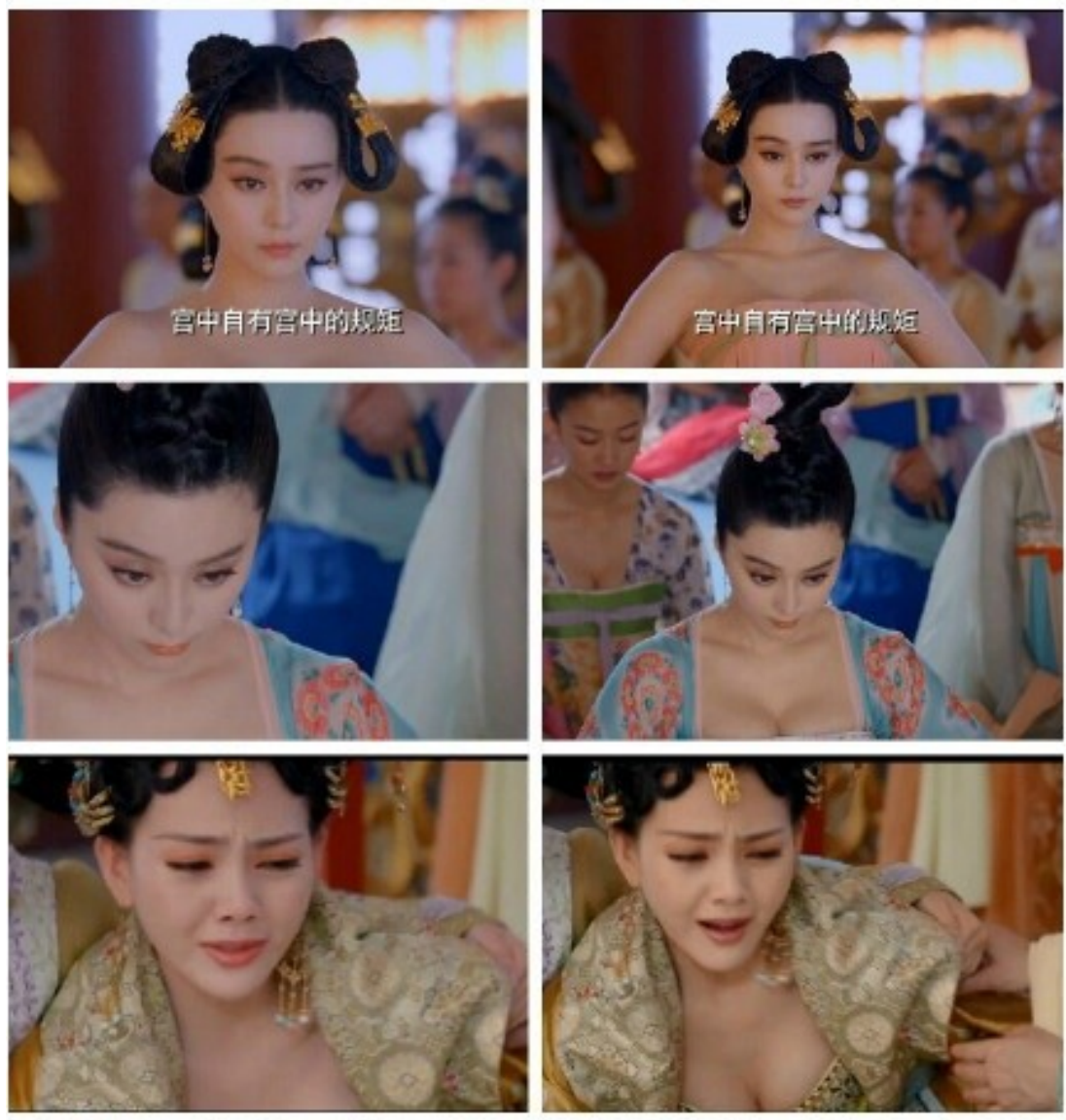

Figure 1: Snapshot comparison between the old and new version of the broadcast show "The Saga

$$
\text { of Wu Meiniang,"251 }
$$

Commentators questioned whether revealing cleavage can really be considered pornographic. ${ }^{252}$ However, in China, this is a question with no clear answer.

\footnotetext{
JOURNAL,

Jan.

5 ,

2015 ,

at

http://blogs.wsj.com/chinarealtime/2015/01/05/venus-de-milo-scarlett-johannson-get-photoshopped-after-chinese-clea vage-ban/.

${ }^{251}$ Hong Qin (秦宏) \& Chang Lu (鲁畅), Guanli Bumen shi Wangyou Yitouwushui (管理部门使网友一头雾水) [Netizens are Confused by the Administrative Department], Fenghuang Wang (凤凰网) [IFENG.COM], Jan. 5, 2015, at http://news.ifeng.com/a/20150105/42863346_0.shtml?_share=sina\&tp=1420387200000.

${ }^{252}$ Wee, supra note 249.
} 


\subsubsection{Online Streaming}

Online streaming is a new distribution conduit for copyrighted content that has only emerged recently in China. With the rapid development of broadband Internet service since the late $1990 \mathrm{~s},{ }^{253}$ it has been estimated that more than 90 percent of Chinese Internet users (270 million) have broadband Internet access, ${ }^{254}$ and the State Council of China even estimated that by 2015 the Internet speed for cities would be as fast as 20 megabits per second, while rural Internet speeds would be around 4 megabits per second. ${ }^{255}$ According to the 2014 Statistical Report on Internet Development in China, as issued by the China Internet Network Information Center (CNNIC), about 428 million Internet users in China had used online video services by the end of December 2013. There is evidently a huge market for online streaming services. ${ }^{256}$

However, the once less controlled online streaming sector is now facing increased restrictions. Under the Administration Procedures of Internet Information Services, in order to conduct Internet information services, interested parties, according to their type (commercial or non-commercial), must obtain an Internet Information Services Value-added Telecommunications Service Operating Permit (互联网信息服 务增值电信业务经营许可证, hereinafter the Operating Permit) or carry out record-filing procedures. ${ }^{257}$ The telecommunication administration authorities at different levels are in charge of issuing this permit and inspecting the record-filing procedures. ${ }^{258}$ Further, all cooperation plans

\footnotetext{
${ }^{253}$ China's international data bandwidth has expanded by a factor of 20 and more than 300 cities obtained high-speed connections to the network around 2000. See Eric Harwit \& Duncan Clark, Shaping The Internet in China: Evolution of Political Control over Network Infrastructure and Content, 41 ASIAN SURVEY 377, 377 (2001).

${ }^{254}$ Bin Liang \& Hong Lu, Internet Development, Censorship, and Cyber Crimes in China, 26 JOURNAL OF CONTEMPORARY CRIMINAL JUSTICE 103, 105 (2010).

${ }^{255}$ See Guowuyuan Guanyu Yinfa “Kuandai Zhongguo” Zhanlue Ji Shishi Fangan De Tongzhi (国务院关于印发“宽 带中国”战略及实施方案的通知) [The Notice of State Council on the “Broadband China” Strategy and its Implement Plan], (promulgated by the St. Council, Aug. 1, 2013, Guofa No. 31); see also Jingting Shen, Faster broadband by 2015, CHINA DAILY, Aug. 18, 2013, at http://usa.chinadaily.com.cn/china/2013-08/18/content_16902042.htm.

${ }^{256}$ Statistical Report on Internet Development in China, CHINA INTERNET NETWORK INFORMATION CENTER, Jan. 2014, at http://www1.cnnic.cn/IDR/ReportDownloads/201404/U020140417607531610855.pdf.

${ }^{257}$ Hulianwang Xinxi Fuwu Guanli Banfa (互联网信息服务管理办法) [Administration Procedures of Internet Information Services] (promulgated by St. Council Decree No. 292, Sep. 25, 2000) art. 4, art. 7 (China), translated at WORLD INTELlECtUAL PROPERTY ORgANIZATION, WIPO Lex No. CN111, http://www.wipo.int/wipolex/en/text.jsp?file_id=182426.

${ }^{258}$ Id. art. $7-8$
} 
involving foreign capital are under government supervision, ${ }^{259}$ and the Internet service providers (ISPs) are responsible for censoring a list of unwanted information. $^{260}$ Failure to censor such information on their website can lead to criminal sanctions. ${ }^{261}$

In terms of eligibility, in order to conduct audio-visual online streaming services, private ISPs must also obtain another permit, ${ }^{262}$ which is called the Permit for Spreading Audio-Visual Programs via Information Network (信息网络传播视听节目许可证, hereinafter $\mathrm{Au}$ dio-visual Service License). ${ }^{263}$ In stark contrast, state-owned radio and television stations only have to follow record-filing procedures. ${ }^{264}$ And, it is stipulated that only the "wholly State-owned or State-controlled work unit" can apply for an Audio-visual Service License, ${ }^{265}$ which means no businesses involving foreign capital can enter this field of business. ${ }^{266}$

Interestingly, the Ministry of Culture of China revised many legislative documents in 2011 in response to the WTO DS363 case. The Interim Provisions on the Administration of Internet Culture, ${ }^{267}$ which covers the "Internet cultural products and activities", is one of them. According to its Article 2, "Internet cultural products" include:

1. Internet cultural products specially produced for the Internet, such as online music entertainment, online games, online shows $\&$ plays (programs), online performances, online works of art, online cartoons, etc.; and

\footnotetext{
259 Id. art. 17.

260 Id. art. 15.

261 Id. art. 20, art. 25.

${ }^{262}$ Hulianwang Deng Xinxi Wangluo Chuanbo Shiting Jiemu Guanli Banfa (互联网等信息网络传播视听节目管理 办法) [Measures for the Administration of the Publication of Audio-Visual Programs through the Internet or Other Information Network] (promulgated by SARFT Decree No. 39, Jul. 6, 2004) art. 6 (China), translated at LAWINFOCHINA, http://www.lawinfochina.com/display.aspx?lib=law\&id=3734\&CGid=; Hulianwang Shiting Jiemu Fuwu Guanli Guiding (互联网视听节目服务管理规定) [Administrative Provisions on Internet Audio-Visual Program Service] (SARFT and Ministry of Information Industry of the People's Republic of China, Decree No. 56, Jan. 31, 2008), art. 11, translated at LAWINFOCHINA, http://www.lawinfochina.com/display.aspx?lib=law\&id=6582.

263 Id. art. 7.

264 Id. art. 10.

265 Id. art. 8(1).

266 Measures for the Administration of the Publication of Audio-Visual Programs through the Internet or Other Information Network, art. 7 ("No solely foreign-owned, Sino-foreign joint venture or Sino-foreign cooperative institution may undertake the business of publication of audio-visual programs through information network.").

${ }^{267}$ Hulianwang Wenhua Guanli Zanxing Guiding (互联网文化管理暂行规定) [Interim Provisions on the Administration of Internet Culture] (promulgated by the Ministry of Culture Order No. 51, Feb. 17, 2011) (China), translated at LAWINFOCHINA, http://www.lawinfochina.com/display.aspx?lib=law\&id=8618\&CGid= (hereinafter the 2011 Internet Culture Interim Provisions).
} 
2. Internet cultural products produced from such cultural products as music entertainment, games, shows \& plays (programs), performances, works of art, cartoons, etc. by certain technical means and reproduced on the Internet for dissemination. ${ }^{268}$

Its Article 3 provides that "Internet cultural activities" covers all types of online businesses which are related to copyrighted works. ${ }^{269}$ Moreover, the requirements preventing foreign investors from establishing "Internet cultural business unit" 270 and preventing foreign invested Internet information service providers from engaging in "Internet cultural activities", 271 as had appeared in the previous version and related documents, were modified. According to the new regulations, foreign invested Internet information service providers are still not eligible to participate in all Internet cultural activities "at the moment" except for in the "music" business. ${ }^{272}$ The 2006 Network Music Opinion was not repealed in general, as the government had indicated that if there is "any discrepancy" between the 2006 Network Music Opinion and the 2011 Internet Culture

$268 I d$. art. 2.

269 Id. art. 3.

1. The activities of producing, reproducing, importing, publishing or broadcasting Internet cultural products;

2. The on-line acts of publishing cultural products on the Internet, or sending cultural products through the Internet, mobile communication network and other information networks to such terminals as computers, fixed telephones, mobile phones, TV sets, game players, etc. and Internet bars and other business places of Internet service for users' browse, appreciation, use or downloading; and

3. The activities of exhibitions and competitions of Internet cultural products.

Internet cultural activities can be divided into two categories, namely, operational and non-operational. Operational Internet cultural activities refer to the profit-making activities of providing Internet cultural products and services by charging fees from Internet users or by electronic commerce, advertisement, financial supports, etc. Non-operational Internet cultural activities refer to the non-profit-making activities of providing Internet users with Internet cultural products and services.

${ }^{270}$ Wenhuabu Guanyu Shishi Hulianwang Wenhua Guanli Zanxing Guiding Youguan Wenti de Tongzhi (文化部关于 实施〈互联网文化管理暂行规定〉有关问题的通知) [Notice of the Ministry of Culture on Some Issues Relating to the Implementation of the "Interim Rules on the Management of Internet Culture"] (The Ministry of Culture, WSF[2003]27, Jul. 4, 2003) art. 2 (China)(“....application from foreign invested Internet information service providers to participate Internet cultural activities will not be accepted at the moment.").

${ }^{271}$ Wenhuabu Guanyu Wangluo Yinyue Fazhan yu Guanli de Ruogan Yijian (文化部关于网络音乐发展与管理的若 干意见) [Several Opinions of the Ministry of Culture on the Development and Management of Network Music] (The Ministry of Culture, WSF[2006]32, Dec. 11, 2006) art. 8 (China)(“The establishment of foreign capital invested Internet Cultural business unit is prohibited.")(Hereinafter the 2006 Network Music Opinion).

${ }^{272}$ Wenhuabu Guanyu Shishi Xin Xiuding Hulianwang Wenhua Guanli Zanxing Guiding de Tongzhi (文化部关于实 施新修订〈互联网文化管理暂行规定〉的通知) [Notice of the Ministry of Culture on the Implementation of the New Amended "Interim Rules on the Management of Internet Culture"] (The Ministry of Culture, WSF[2011]14, Mar. 21, 2011) art. 6 (China)(“....application from foreign invested Internet information service providers to participate in Internet cultural activities will not be accepted at the moment (except music).”)(hereinafter the 2011 Internet Culture Implementation Notice). 
Implementation Notice, "the latter shall prevail."273 Therefore, the requirement of the 2006 Network Music Opinion that "no foreign investors could set up an Internet cultural business unit" remains valid but with an exception: foreign invested Internet information service providers can now engage in Internet cultural activities related to music. However, they still have to apply for a Network Cultural Business Permit (网络文化经 营许可证) from the culture administrative department in order to conduct business. ${ }^{274}$ Furthermore, the 2011 Internet Culture Interim Provisions requires that only the unit with the Network Cultural Business Permit can import Internet cultural products, ${ }^{275}$ which is a new addition compared with its 2003 version. ${ }^{276}$ However, since foreign invested Internet information service providers are unable to participate in most "Internet cultural activities" except currently for music, they cannot be assured of obtaining this permit if their businesses involve other cultural products than merely musical products, as that permit is designated for successful applicants who want to establish a commercial Internet cultural entity. ${ }^{277}$ Therefore, it is possible for foreign copyright conglomerates to establish music-related "Internet cultural business units", and they could then start to import musical products thereafter. As to other cultural products, the door is currently closed to foreign capitals.

Furthermore, services similar to those offered by radio and television stations and audio-visual news services about current events and political affairs, private ISPs must also acquire the afore-mentioned Permit for TV Business, along with the Internet News Information Service License (互 联网新闻信息服务许可证). ${ }^{278}$ Moreover, to produce and offer programs involving the hosting, interviewing, and reporting of news requires the

\footnotetext{
273 Id. art. 14.

2742011 Interim Provisions on the Administration of Internet Culture, art. 9.

275 Id. art. 15 ("The importing of Internet cultural products shall be conducted by commercial Internet cultural entities that have obtained Network Cultural Business Permits from cultural administrative departments...”).

${ }^{276}$ Hulianwang Wenhua Guanli Zanxing Guiding (互联网文化管理暂行规定) [Interim Provisions on the Administration of Internet Culture] (promulgated by the Ministry of Culture Order No. 27, May 10, 2003, repealed Feb. 17, 2011 by the Ministry of Culture Order No. 51) (China), translated at LAWINFOCHINA, http://www.lawinfochina.com/display.aspx?lib=law\&id=2801\&CGid=.

2772011 Interim Provisions on the Administration of Internet Culture, art. 9 ("Whoever applies to establish a commercial Internet cultural entity... If the application is approved, a Network Cultural Business Permit shall be issued to the applicant...").

${ }^{278}$ Administrative Provisions on Internet Audio-Visual Program Service, Art. 9; Hulianwang Xinwen Xinxi Fuwu Guanli Guiding (互联网新闻信息服务管理规定) [Regulations on Administration of Internet News Information Services] (promulgated by St. Council Info. Office \& Ministry of Indus. \& Info. Tech. Decree No. 37, Sep. 25, 2005) art. 11 (China), translated at World Intellectual Property Organization, WiPO Lex No. CN345, http://www.wipo.int/wipolex/en/text.jsp?file_id=337976.
} 
previously discussed Radio and Television Program Production Business Permit and the Internet News Information Service License. ${ }^{279}$ And those who wish to offer "micro" movie or drama production streaming services have to obtain the Radio and Television Program Production Business Permit as well. ${ }^{280}$ These terms indicate that politically sensitive programs are highly restricted in this area, an observation which can be further confirmed by Article 17 of the same regulation which states that:

...Internet audio-visual program service work units, when disseminating current political news audio-visual programs, shall make sure that these programs are produced and disseminated by a local (city) level or higher radio station, television station and current political news audio-visual programs published on the website of central news work units...

Work units not having obtained the "Permit" may not provide uploading audio-visual programs for dissemination services to individuals. Internet audio-visual program service work units may not permit individuals to upload current political-type audio-visual news programs... ${ }^{281}$

Those certified audio-visual service providers are subject to many obligations regarding content censorship as well. Many of these filters, such as the "content endangering social virtue", or "damaging good ethnic cultural traditions", are vague enough to the extent that considerable content could inevitably be included if they were applied rigorously. ${ }^{282}$ Therefore, in practice, many service providers in the traditional distribution channels tend to exercise self-censorship before putting their content on air, regardless of whether they are local or foreign. ${ }^{283}$ That situation also applies to online streaming service providers. However, previous in-

\footnotetext{
279 Administrative Provisions on Internet Audio-Visual Program Service, Art. 9.

${ }^{280}$ Id.

${ }^{281} I d$. art. 17.

${ }^{282}$ See e.g., Measures for the Administration of the Publication of Audio-Visual Programs through the Internet or Other Information Network, art. 19; see also Administrative Provisions on Internet Audio-Visual Program Service, art. 16; Measures for the Administration of Import of Audio and Video Recordings, art. 6; Regulations on Administration of Internet News Information Services, art. 19; 2011 Interim Provisions on the Administration of Internet Culture, art. 16.

${ }^{283} 2011$ Interim Provisions on the Administration of Internet Culture, art. 15 ("The importing of Internet cultural products shall be conducted by commercial Internet cultural entities that have obtained Network Cultural Business Permits from cultural administrative departments and such imports shall be reported to the Ministry of Culture for examination of the contents.").
} 
dustry practice has shown that there existed at least one loophole in introducing foreign titles for online streaming purposes. Since the Chinese government had not been treating online streaming in the same way as it had traditional broadcasting channels, such as television stations and theaters, online video platforms in China had been able to exploit policy loopholes to broadcast far more foreign works than would be allowed on traditional broadcasting channels. ${ }^{284}$

In spite of the levels of bureaucracy, in practice many foreign titles have managed to enter the Chinese market without being censored by the government. ${ }^{285}$ Take, for example, the show My Love From The Star, which Iqiyi, one of the official online streaming platform partners of the South Korean show, simulcast it together with SBS, its South Korean copyright holder in China. ${ }^{286}$ It would be practically impossible for that kind of live broadcast to happen were video streaming platforms first to submit the show to the government's lengthy approval process. Actually, it has been reported that most foreign television shows are not censored and edited at all before being streamed. ${ }^{287}$ It is believed that the loophole exists because the Chinese government has tried to avoid stifling its own promising high-tech industry. ${ }^{288}$ In other words, it is more a result of lax enforcement and policy consideration.

However, doing so was still violating the law. According to the existing legislation, no foreign audio-visual works can be introduced without going through the formal censorship procedure, ${ }^{289}$ and obtaining the corresponding licenses. ${ }^{290}$ Recently the Chinese government has noticed the

\footnotetext{
${ }^{284}$ Bree Feng \& Shanshan Wang, China Orders 4 U.S. Shows Off Streaming Sites, N.Y. TimeS, Apr. 27, 2014, at http://www.nytimes.com/2014/04/28/business/international/china-orders-4-us-shows-off-streaming-sites.html?_r= (last visited Jun. 19, 2014).

${ }^{285}$ Shanshan Wang (王珊珊), Zhongguo Shipin Wangzhan yu Guangdian Zongju de Maoshu Youxi (中国视频网站 与广电总局的“猫鼠游戏”)[The “cat and mouse game” between the Chinese online streaming service providers and SAPPRFT], Niuyue Shibao Guoji Shenghuo (纽约时报国际生活)[CN.TMAGAZINE.COM], Apr. 30, 2014, at http://cn.tmagazine.com/film-tv/20140430/tc30shows/.

286 See Jie Wang, Looking to the Cosmos, SHANGHAI DAILY, Feb. 21, 2014, at http://www.shanghaidaily.com/feature/Looking-to-the-cosmos/shdaily.shtml (...millions of Chinese are tuning in for the new episodes live on Iqiyi.com every Wednesday and Thursday at 8:30pm even though most don't speak Korean). ${ }_{287}$ Feng \& Wang, supra note 284.

${ }^{288}$ Louise Watt, China Video Site: US TV Show Ban Not Policy Change, The Washington Times, Apr. 28, 2014, at http://www.washingtontimes.com/news/2014/apr/28/china-video-site-us-tv-show-ban-not-policy-change/.

${ }_{289}$ Foreign Television Program Import and Broadcast Management Regulations, art. 15 ("Foreign television programs that have not been through the SARFT or entrusted administrative radio and television department examination and approval procedure must not be imported or broadcast").

${ }^{290}$ It is clearly stated in the related regulation that, all the TV plays and movies that were put online for streaming use should either have the License for Public Projection of Movies or Television Drama Distribution Permit. See Measures for the Administration of the Publication of Audio-Visual Programs through the Internet or Other Information Network, art. 17 (The audio-visual programs of the film and TV play category published to the public through infor-
} 
loophole and tried to use policy instruments instead of the law to regulate the market. SAPPRFT issued a new notice in 2014 to restate the regulations relating to online foreign audio-visual program management. According to SAPPRFT's reiteration, no foreign audio-visual works can be streamed online without the broadcaster having obtained the License for Public Projection of Movies or Television Drama Distribution Permit. ${ }^{291}$ It mentioned that only those audio-visual platforms, which had acquired the license for publishing audio-visual programs through information networks, are entitled to introduce foreign audio-visual programs for the purpose of online-streaming. And only after having obtained a "Television Drama Distribution License" (Special Use for Online Broadcasting) through examination and verification by a provincial-level or higher administrative press, publications, radio, film and television department, are audio-visual platforms allowed to broadcast foreign audio-visual titles on their sites. The notice also indicated that, any such foreign audio-visual titles should be "healthy and positive" and have a proper license from the copyright holder. Nevertheless, it also indicated that any Chinese audio-visual platforms concerned should register all foreign titles they had acquired with the relevant administrative body before 31 March 2015. Any foreign television dramas that had not been registered may not be distributed online after 1 April 2015. ${ }^{292}$ Apparently, to obtain the license for a foreign audio-visual work requires the product to pass through the government censorship process. Moreover, unlike common practice in countries such as the U.S. ${ }^{293}$ and South Korea, ${ }^{294}$ China's requirement of submitting the complete production for censorship before it can be broadcast means that, with respect to the original broadcasting date, Chinese audiences have to wait for at least several months to watch their fa-

\footnotetext{
mation network must be TV plays under the "Permit for Issuance of TV Plays" or films under the "Permit for Public Projection of Films".).

${ }^{291}$ Guojia Xinwen Chuban Guangdian Zong Ju Chongshen Wangshang Jingwai Yingshiju Guanli de Youguan guiding (国家新闻出版广电总局重申网上境外影视剧管理的有关规定) [SAPPRFT Reiterates Provisions concerning the Management of Online Foreign Television Dramas], SAPPRFT, Sep. 5, 2014, at http://www.sarft.gov.cn/articles/2014/09/05/20140904102409770812.html, translated in CHINA COPYRIGHT AND (Rogier Creemers trans., 2014), http://chinacopyrightandmedia.wordpress.com/2014/09/05/sapprft-reiterates-provisions-concerning-the-managementof-online-foreign-television-dramas/.

292 Id.

293 Winifred Fordham Metz, How TV Production Works, HowSTUFFWorKs.com, Nov. 29, 2007, at http://electronics.howstuffworks.com/tv-production.htm.

${ }^{294}$ Dae-oh Kim, The Making of Korean Dramas: Tantalizing Flexibility Comes at a Cost, 25 KoreANA 78, 78-9 (2011), at http://www.koreana.or.kr/months/news_view.asp?b_idx=1756\&lang=en\&page_type=list\#k (described the flexible production model of Korean drama which could respond to audience's feedback on the previous episode).
} 
vorite foreign audio-visual works. An industry insider raised his concern that SAPPRFT's decision may result in the return of commercial piracy and unauthorized online distribution, which have been restrained by the online simultaneous broadcasting service. ${ }^{295}$ It appears that the "happy hours" are about to end.

As to the ex post censorship of online streaming contents, it is also clear that, according to the existing legislation, the investors and managers of online streaming service platforms are responsible for the content within, ${ }^{296}$ and the controlling bodies and the providers themselves must deal with any inappropriate content immediately once found. ${ }^{297}$ This means that, as a last resort, the authorities can then use those vague criteria to pull any officially launched works. The reason why the government has chosen to pull popular U.S. television shows, such as The Big Bang, from its official online streaming provider remains unknown, ${ }^{298}$ even to the CEO of the officially licensed provider SOHU. ${ }^{299}$ And SAPPRFT, the department that issued the take down order, has refused to give a clear answer. ${ }^{300}$ Recent reports have shown that the controlling bodies, such as SAPPRFT and Ministry of Industry and Information Technology that are in charge of the online streaming business, have built an "information pool". The controlling bodies of the government will upload unsuitable titles to this pool, and online streaming service providers, as observers will know what to remove immediately. ${ }^{301}$ For example, several episodes of the famous American television series The Blacklist that had been officially introduced to China by many video platforms were removed by "pool" order after their debut. ${ }^{302}$ Furthermore, due to the absence of a

\footnotetext{
${ }^{295}$ Keyu Chen (陈柯羽), Jingwaiju Xianshenhoubo Xinzheng Yizai Shipin Wangzhan Bufen Shixing (境外剧先审后 播新政已在视频网站部分施行) [The New “Censor First Broadcast After” Policy Is Now Implemented In Video Platforms], Chongqing Wanbao (重庆晚报) [CHONGQING EvenING News], Jan. 15, 2015, at http://www.cqwb.com.cn/cqwb/html/2015-01/15/content_423043.htm.

${ }^{296}$ Administrative Provisions on Internet Audio-Visual Program Service, Art. 18.

297 Id.

${ }^{298}$ Paul Mozur, China Forces Four U.S. TV Shows Off Web 'Big Bang Theory' and 'Good Wife' are among Programs Taken Down, THE WALL STREET JOURNAL, Apr. 28, 2014, at http://www.wsj.com/articles/SB10001424052702304163604579527683976216624.

${ }^{299}$ Paul Mozur \& Laurie Burkitt, China Won't Tune Out All U.S. TV Shows, Executive Says, The WALL STREET Apr. 28 , 2014

http://blogs.wsj.com/chinarealtime/2014/04/28/china-wont-tune-out-all-u-s-tv-shows-executive-says/.

${ }^{300}$ Bing Sun (孙冰), Meiju Xiajia Guangdian Zongju Cheng Bu Jieshou Caifang: Bushi Suoyou Xinxi Ke Gongkai (美剧下架广电总局称不接受采访: 不是所有信息可公开) [SAPPRFT Refused to Give Comments on the Taken Down U.S. Shows, Claimed that not all Information could Go Public], Renmin Wang (人民网) [PEOPLE.COM.CN], May 13, 2014, at http://media.people.com.cn/n/2014/0513/c14677-25010185.html.

301 Wang, supra note 285.

302 Id.
} 
rating system, many Japanese anime works have recently been pulled from video platforms by order of the Ministry of Culture, which has stated that these works contain pornographic and violent elements which are unsuitable for children. ${ }^{303}$

These requirements have also compelled Chinese video platforms to "self-censor" their licensed content, which is understandable since online channels are much more complicated and harder to control than traditional ones, so the government has to rely on ISPs doing part of their job. A related SAPPRFT notice has ordered ISPs to hire qualified staff to undertake their censoring work, ${ }^{304}$ and that they should follow a list of more detailed standards in doing so. ${ }^{305}$ However, it is evidently a major burden

\footnotetext{
${ }^{303}$ Duobu Riman Weixian Guangdian Huojiang Jinbo Baokong Dongman (多部日漫危险! 广电或将禁播暴恐动漫) [Many Japanese Anime Works are in Danger! SAPPRFT may Prohibit Anime Works with Violent and Horrific Elements from Online Streaming], Wang Yi 163( 网 易 163) [NETEASE], Mar. 31, 2015, at http://ent.163.com/15/0331/22/AM2MUUSN00031H2L.html (China).

${ }^{304}$ Guangdian Zongju Guanyu Jiaqiang Hulianwang Shiting Jiemu Neirong Guanli de Tongzhi (广电总局关于加强 互联网视听节目内容管理的通知) [SARFT Notice Concerning Strengthening Internet Audio-visual Programme Content Management], SARFT, Mar. 3, 2009, http://www.sarft.gov.cn/articles/2009/03/30/20090330171107690049.html, translated at CHINA COPYRIGHT AND MEDIA (Rogier Creemers trans., https://chinacopyrightandmedia.wordpress.com/2009/03/03/sarft-notice-concerning-strengthening-internet-audiovisua 1-programme-content-management-2/.

${ }^{305}$ Id. art. 2.
}

All Internet audio-visual program service work units must timely conduct editing or deletion of audio-visual program with the following circumstances:

(1) those maliciously distorting Chinese culture, Chinese history and historical facts; those maliciously distorting other countries' history, not respecting human culture, other countries' culture and social customs and habits;

(2) those with imagery deliberately denigrating or vilifying revolutionary leaders, heroic persons, important historical persons, Chinese and foreign famous books and important characters in famous books;

(3) those with imagery maliciously denigrating the People's Army, the Armed Police, Public Security and the judiciary, those having circumstances such as abusing prisoners, extracting confessions by torture from criminals or criminal suspects, etc.;

(4) those with imagery and sounds displaying unlawful and criminal aggressiveness and arrogance, concretely revealing details of criminal activities, revealing special investigation methods, revealing informers and witnesses who should receive protection, etc;

(5) those advocating religious extremism, provoking controversies and conflicts between all religions and religious denominations, and between religious believing masses and non-believing masses, harming the feelings of the masses;

(6) those propagating feudal superstition activities such as physiognomy, fortune telling, geomancy practicing, divination practicing, healing by exorcise, etc.;

(7) those with vile methods depicting calamity scenes such as major natural disasters, accidents, terrorizing incidents, wars, etc.;

(8) those concretely showing circumstances such as promiscuity, rape, incest, necrophilia, prostitution, visiting prostitutes, sexual perversion, masturbation, etc.;

(9) those displaying or obscurely displaying details such as sexual activities, sexual process, sexual methods and excessive bodily contact related to this, etc.;

(10) those intentionally showing, or only using one's body to cover, or using very little covering to cover human private parts;

(11) those containing sexual suggestions, sexual provocations, etc., which easily cause people to make sexual associations; 
for online streaming service providers, some of whom have reportedly had to hire hundreds of employees to self-censor their content. ${ }^{306}$ Nevertheless, because of the vagueness of the ex post censorship standards and the economic damage that a take-down can cause, video platforms are more inclined to introduce pure entertainment rather than politically sensitive content.

\subsubsection{Enforcement Campaigns}

Besides general copyright legislation, cultural products in China are heavily regulated by a set of censorial rules as well. China has also regularly employed enforcement campaigns to address "problems that regular enforcement strategies have failed to address adequately", 307 since many traditional regulatory measures are frequently challenged in the digital era. It is not new for the Chinese government to regulate the cultural market by using enforcement campaigns; it did so in the pre-Internet era. For example, in 1986, three years after the famous 1983 yanda (Strike Hard) campaign, the then National Publication Bureau, the State Administration of Industry and Commerce (SAIC), and the Ministry of Public Security (MPS) jointly issued an Emergency Notice Regarding Striking Hard Against Illegal Publishing Activities. ${ }^{308}$ It revealed an unobtrusive

(12) those propagating unhealthy content such as extramarital affairs, group sex, one-night stands, sexual abuse and wife swapping;

(13) those using adult movies, sexual movies, X-rated movies, voyeurism, indecent exposure, exhibitionism and all sorts of prevocational writing or images to function as audio-visual programme titles or classifications;

(14) those having circumstances such as strongly stimulating murder, blood and gore, violence, suicide, abduction, drug use, gambling, occultism, etc.;

(15) those having excessive scary and terrifying images, subtitles, background music and sound effects;

(16) those concretely showing maltreatment and killing of animals, catching, killing and eating animals protected by the State;

(17) those having content violating individual privacy;

(18) those with an approving and praising tone or in a way that leads people to imitate, showing fights and brawls, humiliation of others, and filthy speech;

(19) those propagating negative or decadent views of life, worldviews and value systems, sedulously playing up and magnifying ethnic ignorance and backwardness or the dark side of society;

(20) audio-visual programs and films, television programs and deleted extracts of which the dissemination was prohibited by the State Administration of Radio, Film and Television;

306 Wang, supra note 285.

(21) those violating the spirit of relevant laws and regulations.

${ }^{307}$ Sarah Biddulph, et al., Rule of Law with Chinese Characteristics: The Role of Campaigns in Lawmaking, 34 LAW \& POL'Y 373, 373-74 (2012).

308 “Guanyu Yanli Daji Feifa Chuban Huodong de Jinji Tongzhi” (关于严厉打击非法出版活动的紧急通知) [Emer- 
but similar campaign against unlawful publications in terms of yanda. In 1987, the State Council subsequently issued the Notice Regarding Striking Hard Against Illegal Publishing Activities, stressing that "[e]xcept for those publishing units approved by the State, no unit or individual may publish to society for open distribution any book, periodical or audio/visual publication. Violators shall be deemed as engaging in illegal publishing activities". 309 This position was reiterated by the SPC and the Supreme People's Procuratorate of China (SPP) in 1987 and 1991 respectively, ${ }^{310}$ by the State Council of China in $1996,{ }^{311}$ and was incorporated into the 1997 and 2001 versions of the Regulation on the Administration of Publications. During this period, that policy was implemented nationwide and produced considerable results. For instance, according to the Summary of the Symposium on the Work of Punishing Illegal Publishing Criminal Activities in 1988, which was jointly hosted by the State General Administration of Press and Publication (GAPP), SPC, SPP, MPS, the Ministry of Radio, Film and Television, and SAIC, some 16.13 million copies of illegal books, 4.74 million copies of illegal periodicals, 6.56 million copies of illegal newspapers, 1.51 million copies of illegal audio tapes, and approximately 90 thousand copies of illegal video tapes were seized. ${ }^{312}$ These practices were later regularized by the establishment of the so-called saohuang dafei campaign in $1989 .{ }^{313}$ The aim of this campaign is to "sweep away pornography" (saohuang) and to "strike out against illegal publications" (dafei). ${ }^{314}$ It is led by the National Saohuang Dafei Working Office (hereinafter the Office), which includes

\footnotetext{
gency Notice Regarding Striking Hard Against Illegal Publishing Activities], promulgated by the National Publication Bureau, the State Administration of Industry and Commerce, and the Ministry of Public Security, CZZ no.165, Mar. 4, 1986, St. CounCIL GAZ., 1986, no. 9, at 271-272 (China).

${ }^{309}$ Notice Regarding Striking Hard Against Illegal Publishing Activities, art. 1, State Council of China, Jul. 6, 1987, at http://www.people.com.cn/electric/flfg/d4/870706.html.

310 “Guanyu Yifa Yancheng Feifa Chuban Fanzui Huodong de Tongzhi” (关于依法严惩非法出版犯罪活动的通知) [Notice Regarding Severely Punishing Illegal Publishing Criminal Activities According to Law], promulgated by the SPC and SPP, FYF no. 33, Nov. 27, 1987, Sup. PeOPlE's CT. GAZ., 1987, no.4, at 17 (China); "Guanyu Yanli Daji Feifa Chuban Fanzui Huodong de Tongzhi” (关于严厉打击非法出版犯罪活动的通知) [Notice Regarding Severely Punishing Illegal Publishing Criminal Activities], promulgated by the SPC and SPP, FYF no. 33, Nov. 27, 1991, SUP. PEOPLE's Ct. GAZ., no.3, at 22 (China).

${ }^{311}$ Notice Regarding Resolutely Clamping Down on Illegal Publishing Activities (promulgated by the St. Council, Jan. 25, 1996) art. 1 (China).

312 GAPP, SPC, SPP, MPS, Ministry of Radio, Film and Television, and SAIC, Summary of the Symposium on the Work of Punishing Illegal Publishing Criminal Activities, Renmin Wang (人民网) [PEOPLe.COM.CN], Mar. 8, 1988, at http://www.people.com.cn/electric/flfg/d4/880308.html.

313 Andrew Mertha, The Politics of Piracy: Intellectual Property in CONTEMPorary China 142 (Cornell University Press. 2005)

${ }^{314}$ Id.
} 
representatives from 28 national departments such as the Propaganda Department of the Chinese Communist Party (CPC) and the MPS. ${ }^{315}$ Since its establishment, the Saohuang Dafei Office has launched numerous campaigns on a annual basis, aiming to eradicate illegal publications, including piracy. Therefore, these campaigns are more like a subtle form of ex post censorship, as they help to clean out illegal and unorthodox materials in general, rather than on a piecemeal basis.

After entering the Internet era, the saohuang dafei campaign has been severely tested by digital technologies, as now the major distributors of these illegal materials are no longer commercial publishers and pirates but individuals. Hence, the Chinese government is facing the same problem as copyright owners in preventing unauthorized content from entering the market. Interestingly, but not surprisingly, in the face of massive amounts of nearly untraceable illegal content online, they both focus and rely on ISPs to do part of their jobs. ${ }^{316}$ To some extent, free online distribution, as done by private individuals, is arguably destroying the business of physical piracy. ${ }^{317}$ Moreover, the challenge raised by digital technologies has created a degree of freedom, as many individual critics of the government were tolerated. ${ }^{318}$ The wider latitude allows ISPs to enjoy a degree of flexibility with regard to the censorship rules since the vague criteria in practice leave them a degree of discretion. ${ }^{319}$

Despite these divergences, top-down campaigns have been launched at the beginning of each year in China, without exception. ${ }^{320}$ The 2009 campaign aiming at vulgar content shut down more than 9,000 pornographic websites alone. During the national campaign named "Eliminate Pornography and Illegal Publications-Cleanse the Internet 2014" (hereinafter 2014 Cleanse the Internet Campaign), ${ }^{321}$ according to a recent report from the Office, government agencies have confiscated some 12 million illegal copies of all kinds of cultural goods, and shut down more than

\footnotetext{
${ }^{315} I d$; See also Liang Shen (沈亮), “Tanmi Saohuang Dafei Ban” (探秘扫黄打非办) [Investigating the Saohuang Dafei Office], Nanfang Zhoumo ( 南 方 周末 ) [SOUTHERN WEEKLY], Jan. 21, 2010, at http://www.infzm.com/content/40655.

${ }^{316}$ Id; see generally Gary King, et al., How Censorship in China Allows Government Criticism but Silences Collective Expression, 107 AMERICAN POLITICAL SCIENCE REVIEW 326, 339 (2013).

317 Priest, supra note 5, at 830.

${ }_{318}$ King, et al., supra note 316 , at 339.

319 Feng \& Wang, supra note 284.

320 Shen, supra note 315.

321 This campaign was initiated by China's National Saohuang Dafei Office, the National Internet Information Office, Ministry of Industry and Information Technology, and the Ministry of Public Security.
} 
750 infringeing websites. ${ }^{322}$ In the first three months of 2015 , the newest "Cleanse the Internet Campaign 2015" had already confiscated 1.74 million illegal publications and nearly 1 million pirate copies, ${ }^{323}$ and that trend looks set to continue.

The policy considerations behind the enforcement campaigns launched by the Saohuang Dafei Office are identical to those behind the censorship system. Indeed, campaigns are actually a flexible policy tool which the government can employ to assist its censorship system. The aim is to wipe out illicit works (including pirate copies in the market) from a different angle, but apparently anti-piracy is not the main concern. For instance, in the 23d National Saohuang Dafei Work Conference by Videophone, Yunshan Liu (刘云山), the former Minister of the Propaganda Department of the CPC, indicated that the missions of the Saohuang Dafei office in 2010 could be divided into three priority levels: cracking down on illegal publications, tackling pornography content, and fighting piracy. ${ }^{324}$ Interestingly, the purpose of these campaigns is seemingly consistent with the request of the anxious foreign copyright owners in the Chinese market: to remove infringeing copies from the market. However, campaigns are guided by national policies, which are represented by the staff from different departments within the Saohuang Dafei Office, so the policy considerations behind them vary greatly. For instance, units such as the Propaganda Department of the CPC and the Ministry of Culture tend to focus on the widespread online distribution of unorthodox and pornographic content, whereas units such as SPC and the National Copyright Administration focus more on cracking down on piracy. The SAPPRFT might also take the cultural market in general into consideration. Apparently the Chinese government is seeking a dynamic balance in between these goals. Piracy is of course a matter of concern for China, but when it overlaps with "heterodox" content, no doubt the Chinese government puts greater focus on the latter. On the other hand, the copyright of illegal content is vulnerable in the face of censorship as well. In that case, although the copyright protection of such work is no longer rejected by the $\mathrm{CCL}^{325}$ copyright owners cannot exercise their economic

\footnotetext{
${ }^{322} 16.44$ Million Copies of Infringing and Illegal Publications Nationwide were Destroyed, National Saohuang Dafei Office, Apr. 20, 2015, at http://www.shdf.gov.cn/shdf/contents/767/249181.html.

323 Id.

324 Shen, supra note 315.

${ }^{325}$ See infra Chapter 4.3.1.3.
} 
rights in China, but can only enforce their rights when being infringed upon, or enjoy the incidental enforcement effects brought by the saohuang dafei campaigns, irrespective of whether they want these rights enforced or not. Furthermore, illegal content, which means it is either uncensored or has failed to pass censorship, possibly carries ideas and thoughts which are not welcomed by the CPC, and, in the form of mass-market products, is apparently more popular to many Chinese citizens than China's local productions. ${ }^{326}$ Hence, striking hard on such content-sometimes in the name of foreign copyright owners-not only serves the purpose of protecting China's nascent market, but can also subtly serve the purpose of blocking foreign cultural influences over Chinese citizens.

In sum, censorship in the cultural sector is but part of the larger picture of China's information censorship, whose main purpose is to identify and remove information that poses a threat to the powers that be. For the online censorship, the main purpose is to filter out the dangerous content rather than merely the unauthorized copyrighted contents. Take, for example, the case of download software called Xunlei (Thunder) during the Cleanse the Internet Campaign 2014. ${ }^{327}$ The owner of that software, the Xunlei company offered a paid download speed boost service to its registered users. During the campaign, that service was always available when downloading "safe" works such as unauthorized copies of entertainment audio-visual productions, but not for politically sensitive content or pornography. It suggests that in the enforcement level, the self-censorship of the Chinese ISPs' main focus is on "heterodox" rather than "infringeing" content.

From the consequences of the recent enforcement campaign aiming at "pornography and illegal publications" which were initiated by the Chinese government, ${ }^{328}$ it appeared that seemingly both local and foreign copyright owners' interests were "protected" by these campaigns. If we take into account the copyright of those foreign titles that failed to satisfy the governmental censorship requirements, they are of course "protected" by the copyright law, ${ }^{329}$ but in fact, what they have lost, is their influence

\footnotetext{
326 Evan Osnos, "Prison Break" catches on in China, The SeATtLe Times, Jan. 25, 2007, at http://seattletimes.com/html/nationworld/2003540226_chinatv24.html.

327 See infra Chapter 3.2.2.3.

${ }^{328}$ Id.

${ }^{329}$ It would make more sense if we take the WTO case DS362 into consideration as well.
} 
on the Chinese market. It is obvious that the main purpose of the Chinese government in initiating such a campaign was to regain control over distribution channels, so that they could once again decide what content could be distributed, via which channel, and thus could influence its people. The ultimate goal behind this will to be in control is to safeguard the stability of the society (维稳), and that goal has not changed much throughout the history of China. ${ }^{330}$ On the surface of Chinese political culture is the idea that “stability is of overriding importance” (稳定压倒 一切), ${ }^{331}$ below it is a mixture of thinking from different schools of traditional Chinese culture which puts harmony ahead of private rights. As a side effect of this current campaign, many fan sites were shut down. Now the majority of the Chinese fan creators were forced to go underground once again, which will eventually make them undistinguishable from other copyright infringements. Furthermore, if fan creators cannot actively participate in a legitimate platform, a new type of civic engagement will not be possible. ${ }^{332}$ If we bear in mind the purpose of copyright and that whether an article is infringeing or not is based on a case-by-case judgment, then the purpose of these kinds of campaign is highly suspicious.

The Chinese government is very open in terms of the content being distributed across different channels. It is also clear that the possibility for foreign capital to conduct business is severely restricted in China. Therefore, foreign copyright holders have to rely on local service providers. However, given the ambiguous ex ante censorship criteria and the pun-

\footnotetext{
${ }^{330}$ See ALFORD, supra note 5, at 24 ("the state's emphasis clearly was focused far more on political order and stability than on issues of ownership and private interests."), at 92 ("in the words of Vice Minister of Radio, Film and Television Wang Feng, it is 'beneficial to... maintaining social stability."'). See also Shannon Tiezzi, Xi Jinping Leads China's New Internet Security Group, THE DIPLOMAT, Feb. 28, 2014, at http://thediplomat.com/2014/02/xi-jinping-leads-chinas-new-internet-security-group/ ("While in theory these campaigns are designed to eliminate slander and pornography, it's hardly a secret that censors also remove information they believe might be harmful to China's stability...").

${ }^{331}$ The idea was first brought forward by Deng Xiaoping in Dec. 24, 1990, and "stability" was considered as the pre-requisite of socialist modernization thereafter. See Wending Yadao Yiqie (稳定压倒一切) [Stability is of overriding importance], Renmin Wang ( 人 民 网 ) [PEOPLE.COM.CN], at http://cpc.people.com.cn/GB/64162/64170/4467121.html; See also Zhengyi Wang, China Confronts Globalization: Conceptualizing Economic Security and Governance, in GLOBALISATION AND ECONOMIC SECURITY IN EAST ASIA: GOVERNANCE AND INSTITUTIONS 76 (Helen Sharmini Nesadurai ed. 2006); Ming Wan, Democracy and Human Rights in Chinese Foreign Policy: Motivation and Behavior, in ChINA RISING: Power AND Motivation IN ChINESE ForEIGN PoliCY 289 (Yong Deng \& Fei-Ling Wang eds., 2005). For more detailed discussion on the notion of Stability, please see Duncan Freeman, Stability and Change: The EU, China and Preceptions of Stability, in CONCEPTUAL GAPS IN China-EU Relations: Global Governance, Human Rights and Strategic Partnerships (Zhongqi Pan ed. 2012).

${ }^{332}$ See infra Chapter 2.1.5 Participatory Culture and Civic Engagement.
} 
ishment officially licensed local distributors will receive for letting "bad stuff" in, many foreign works are denied entry de facto, simply because no practitioners would dare take the risk. Even for those works that have passed the harsh censorship examination and have already entered the Chinese market via traditional means, they still have to face explicit and implicit restrictions, such as discrimination between local and foreign works in broadcasting hours, and import quotas. Moreover, that they are "safe" now does not mean that they will be "safe" in the future, since the ex post censorship, along with enforcement campaigns, will ensure that when a once "safe" object becomes a threat to the "socialist culture and society", it will soon disappear from public view.

\subsubsection{Import Quotas}

Importation quotas limit the appearance of foreign cultural works in the Chinese market from a different angle. For publishers of tangible goods, such as books and audio-visual publications, their number of importation is not limited. However, the direct importation of foreign publications, as we have seen in the discussion above, is strictly controlled by the state. ${ }^{333}$ For example, with respect to imported titles, not only the establishment of an importation unit, but also the content of these titles falls under the Chinese government's strict state control. Although the requirement that the import unit must be a "wholly State-owned enterprise" was deleted in $2011,{ }^{334}$ the importation units themselves are still responsible for the content they import, and they must ensure that the content of the imported works is inoffensive, as "[ $\mathrm{t}]$ he publication administration department of the people's government at or above the province level may directly carry out the content examination of the imported publications". ${ }^{335}$ However, in cases where the importation units are unsure about their judgment on certain imported titles, they can voluntarily submit them to "the publication administration department of the people's government at or above the province level" for content censorship. ${ }^{336}$ Last but not least, "[t]he publication administration department of the State Council may prohibit

\footnotetext{
333 See infra Chapter 2.1.3.1.

3341997 Regulation on the Administration of Publications, art. 42; 2011 Regulation on the Administration of Publications, art. 9 .

3352011 Regulation on the Administration of Publications, art. 44

${ }^{336}$ Id.
} 
the importation of particular publications". ${ }^{337}$ Indirect imports, such as adaptations of foreign works by local production companies are considered local productions and, thus, must undergo the same procedures as direct publications. It is notable that tangible audio-visual products are considered as publications under the existing legislation, ${ }^{338}$ which means foreign audio-visual products, such as television dramas and movies, can enter the Chinese market without a quota limit in the form of tangible goods such as DVD and Blu-ray discs, but they will nevertheless be strictly censored as well.

As we have seen, the Chinese government operates a strict censorship system but it has other implicit restrictions in terms of audio-visual products, which have been frequently discussed elsewhere. ${ }^{339}$ Unlike import quotas in other fields, China's movie import quota is more explicitly delineated. China's quota system has long restricted the import of foreign movies. For example, between 1994 and 2001, the importation quota for Hollywood revenue sharing films was a mere 10; it was raised to 20 after $2001 .^{340}$ In 2012, in compliance with its international obligations, China increased that number again to $34,{ }^{341}$ but in terms of the number of films released in U.S. and Canadian theaters, which was estimated to be 659 in $2013,{ }^{342}$ the number permitted by China is negligible. It is of course the right of a country to have screen quotas, according to Article IV (Special Provisions relating to Cinematograph Films) of the General Agreement on Tariffs and Trade (GATT) $1994 .{ }^{343}$ Nevertheless, in terms of the

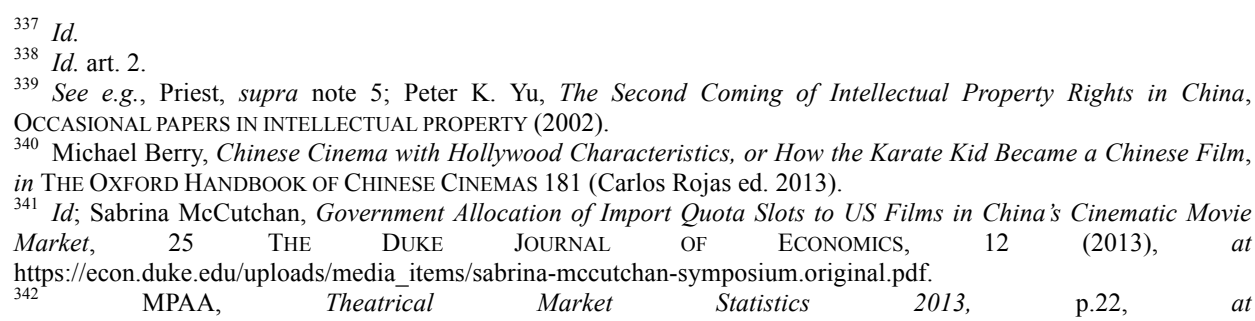
http://www.mpaa.org/wp-content/uploads/2014/03/MPAA-Theatrical-Market-Statistics-2013_032514-v2.pdf.

${ }_{343}$ General Agreement on Tariffs and Trade 1994, Apr. 15, 1994, Marrakesh Agreement Establishing the World Trade Organization, Annex 1A, The Legal TeXts: The Results Of The Uruguay Round Of Multilateral Trade NEGOTIATIONS 17 (1999), 1867 U.N.T.S. 187, 33 I.L.M. 1153 (1994) [hereinafter GATT 1994], art. IV:

If any contracting party establishes or maintains internal quantitative regulations relating to exposed cinematograph films, such regulations shall take the form of screen quotas which shall conform to the following requirements:

(a) Screen quotas may require the exhibition of cinematograph films of national origin during a specified minimum proportion of the total screen time actually utilized, over a specified period of not less than one year, in the commercial exhibition of all films of whatever origin, and shall be computed on the basis of screen time per theatre per year or the equivalent thereof;

(b) With the exception of screen time reserved for films of national origin under a screen quota, 
transnational licensing of foreign movies, the screen quota China enforces no doubt limits the ability of foreign copyright owners to enter the market. Therefore, it came as no surprise when the U.S. requested consultation with China in the WTO concerning these quotas on 10 April 2007. ${ }^{344}$ As with the previous discussions on censorship and import quotas, though, it is clear that foreign companies still face severe restrictions five years after the WTO case DS363. Nevertheless, another way to enter the Chinese market without worrying about the quota limit is through Chinese-foreign cooperative film production. ${ }^{345} \mathrm{~A}$ co-production film is deemed to be a domestic product and, thus, can bypass the strict quota limit China imposes. ${ }^{346}$

In terms of television stations, foreign audio-visual works are under more restrictions in comparison with local productions. In order to import a foreign title for television broadcast, the state-owned television stations must navigate a series of complicated procedures. For instance, the particular types of imported content are limited, so no foreign news report program is allowed. All the audio-visual works are divided into two types: foreign films and dramas provided to television stations for broadcast (hereafter foreign film and television dramas); and educational, scientific, cultural and all other categories of television programs (hereafter other television programs). ${ }^{347}$ All importations must first be submitted to provincial administrative departments, and then to the SAPPRFT for examination; the SAPPRFT makes the final decision as to whether a foreign

screen time including that released by administrative action from screen time reserved for films of national origin, shall not be allocated formally or in effect among sources of supply;

(c) Notwithstanding the provisions of sub-paragraph (b) of this Article, any contracting party may maintain screen quotas conforming to the requirements of sub-paragraph (a) of this Article which reserve a minimum proportion of screen time for films of a specified origin other than that of the contracting party imposing such screen quotas; Provided that no such minimum proportion of screen time shall be increased above the level in effect on April 10, 1947;

(d) Screen quotas shall be subject to negotiation for their limitation, liberalization or elimination.

${ }^{344}$ Panel Report, China-Measures Affecting Trading Rights and Distribution Services for Certain Publications and Audiovisual Entertainment Products, WT/DS363/R (Aug. 12, 2009).

345 See generally, Zhongwai Hezuo Shezhi Dianyingpian Guanli Guiding (中外合作摄制电影片管理规定) [Measures for the Administration of Chinese-Foreign Cooperative Film Production] (promulgated by SARFT Decree No. 31, Aug. 6, 2004) (China), translated at LAWINFOCHINA, http://www.lawinfochina.com/display.aspx?lib=law\&id=3647\&CGid=.

${ }^{346}$ George Szalai \& Clarence Tsui, U.K.'s Pinewood Shepperton, China's Seven Stars Ink Joint Venture Deal, THE HOLLYWOOD REPORTER, Apr. $\quad$ 17, 2013, at http://www.hollywoodreporter.com/news/pinewood-shepperton-chinas-seven-stars-440687 ("Chinese co-productions have long been an alluring proposition to Hollywood studios, as they are classified as domestic Chinese productions, rather than foreign imports, meaning they aren't included under the country's strict import quota...”).

${ }^{347}$ Foreign Television Program Import and Broadcast Management Regulations, art. 2. 
production can be imported. ${ }^{348}$ The provincial-level administrative radio and television departments are in charge of the first instance of checking foreign film and television dramas and most other television programs, and they must submit their opinions to the SAPPRFT for final approv$\mathrm{al}^{3}{ }^{349}$ in cases where the applicants are district level television stations and provincial television stations, and the object they intend to import belongs to the category of other television programs, the provincial-level administrative radio and television departments can make the final decisions themselves. ${ }^{350}$ If the theme of these programs involves politically sensitive content, the provincial-level administrative radio and television departments must submit it to SAPPRFT for final decision. ${ }^{351}$ These departments have to make a quarterly report to SAPPRFT for archiving as well. ${ }^{352}$ In any other cases, the SAPPRFT has the final say on whether a foreign audio-visual title can be imported or not. ${ }^{353}$

In terms of importing foreign titles for television broadcasting, there is also a strict limit on the broadcast hours for foreign audio-visual productions. $^{354}$ A regulation document from the SARFT indicates that "the number of foreign animated works imported by the qualified institutes must equal their own production, and an institute without its own domestic productions will be disqualified from importation". ${ }^{355}$ The existence of this policy has also been confirmed by the Japanese anime industry. ${ }^{356}$ Furthermore, the SARFT has promised to support "Chinese original production" with regard to "funding, broadcasting recommendations, intellectual property protection, etc." 357 In global terms, these requirements

\footnotetext{
348 Id. art. 3.

349 Id. art. 11

${ }^{350}$ Id. art. 13.

${ }^{351} I d$.

352 Id. art. 16.

${ }^{353}$ For the censorship criteria, see id. art. 15.

${ }^{354}$ Id. art. 18 ("Foreign film and television dramas broadcast by television stations, shall indicate the distribution permit number in the titles. All foreign film and television dramas broadcast every day by television channels, may not exceed 25 per cent of the total film and television drama broadcast time of the said channel on that day; other foreign television programs broadcast every day, may not exceed 15 per cent of the total broadcast time of the said channel on that day. Without SARFT approval, no foreign film and television dramas may be broadcast during the golden hours (19:00-22:00).').

${ }^{355}$ Guanyu Fazhan Woguo Yingshi Donghua Chanye De Ruogan Yijian (关于发展我国影视动画产业的若干意见) [Several Opinions of the Development of China's Animation Industry) (promulgated by the St. Admin. Radio, Film \& Television, Apr. 20, 2004) art. 21, http://www.sarft.gov.cn/articles/2007/02/27/20070914165147430508.html (China). 356 TOEI Animation Co., Presentation for The Third Quarter Period of FY Ending March 2011 (April 2010 - December 2010 at 6-2, http://corp.toei-anim.co.jp/pdf/201103_3Q_presen_e.pdf)(noting that in China, the "import of TV license is limited").

${ }^{357}$ Press Release, Guojia Guangbo Dianshi Zong Ju (国家广播电视总局) [St. Admin. Radio, Film \& Television], Guangdianzongju Jiang Tuidong Yingshi Donghua Chanye Fazhan (广电总局将推动影视动画产业发展) [SARFT
} 
are beyond reproach and are not new. Take the "Television without Frontiers" (TVWF) Directive of the European Union (EU) as an example, which requires television channels within the internal market to reserve, whenever possible, more than half of their transmission time for European works. ${ }^{358}$ However, they are of great importance for foreign copyright owners in helping them understand the barriers they will face in the Chinese television sector. Moreover, there is an alternative way to enter the Chinese market without the quota limit: Sino-foreign joint venture productions. Co-productions are deemed to be domestic productions and, thus, not subject to quota limits. ${ }^{359}$

With regard to the Chinese online streaming sector, the situation is more complex. According to current legislation, to provide online streaming services of audio-visual products (both foreign and local) in China, the service providers must acquire the corresponding licenses or permits without exception. ${ }^{360}$ However, there existed a loophole, as discussed above, by which the online streaming service providers could introduce many more foreign works without worrying about quotas. Many foreign titles were not even censored by the authorities before their online debut, and that actually gave the online streaming platforms a competitive advantage: it is possible for them to simulcast foreign content with their foreign copyright owners. This advantage made online streaming platforms much more competitive than the state-owned television stations in China, since the latter have to endure a much longer censorship procedure. $^{361}$ Moreover, they are much more competitive than unauthorized distributions as well, ${ }^{362}$ since online streaming platforms can also offer copyright content free in a stable quality standard, and in a much faster way than the time-consuming process of illegal downloading. During the

\footnotetext{
Will Promote the Development of the Animation Industry], Mar. 5, 2008, http://www.chinasarft.gov.cn/articles/2008/03/05/20080305142134390111.html (last visited Nov. 23, 2012).

${ }_{358}$ See Directive 2007/65/EC of the European Parliament and of the Council of 11 December 2007 amending Council Directive 89/552/EEC on the coordination of certain provisions laid down by law, regulation or administrative action in Member States concerning the pursuit of television broadcasting activities.

${ }^{359}$ Zhongwai Hezuo Zhizuo Dianshiju Guanli Guiding (中外合作制作电视剧管理规定) [Provisions on the Administration of Sino-foreign Cooperation in the Production of TV Plays] (promulgated by SARFT Decree No. 41, Sep. 21, 2004) art. 18 (China), translated at $\mathrm{http} / / /$ www.lawinfochina.com/display.aspx?lib=law\&id=3757\&EncodingName=gb2312.

${ }^{360}$ Measures for the Administration of the Publication of Audio-Visual Programs through the Internet or Other Information Network, art. 17.

${ }^{361}$ Hui Lu, China Demands Licenses for Overseas Series Streaming, XINHUA NewS, Sep. 5, 2014, at http://news.xinhuanet.com/english/china/2014-09/05/c_133624057.htm.

${ }^{362}$ Xiang Bu (卜祥), Yinjin Ju Shenhe Shengsi Jue (引进剧审核生死决) [Imported Foreign Dramas' Last Fight with Censorship], Caijing Tianxia Zhoukan (财经天下周刊) [ECONOMIC WEEKLY], Oct. 6, 2014, no. 67, at 22.
} 
2014 Chinese People's Political Consultative Conference, the famous Chinese director, Guoli Zhang (张国立), noted that the current online streaming market was unfair to local productions, because foreign titles could "get into our online streaming sites without limitations". 363 However, the SAPPRFT has subsequently closed that window with an official notice in late $2014,{ }^{364}$ as well as by setting an online streaming quota for foreign audio-visual works in early 2015 .

\subsubsection{Participatory Culture and Civic Engagement}

One challenge we are being confronted with is that the way people consume audio-visual products nowadays has changed dramatically. This is universal because new developments in technologies have enabled private parties around the world to not just consume those products but also to respond to the ideas behind them. While in the past people could only sit in front of their television set and passively receive whatever came out, they can now make themselves heard by generating something new from the source works and sharing it with others. The idea of "control your purchase" is similar to how some fans of Apple products try to jail-break their purchases and add something new of their own. The only difference here being that virtual objects, such as audio-visual works, will cause more problems as they could be easily copied and distributed via the Internet.

According to Rheingold's summary, participatory media include, but are not limited to "blogs, wikis, RSS, tagging and social bookmarking, music-photo-video sharing, mash-ups, podcasts, digital storytelling, virtual communities, social network services, virtual environments, and

\footnotetext{
${ }^{363}$ Yu Zhou (周豫), Guochan Yingshi Ju Heshi Paichu Xingni Zhipaiwu (国产影视剧何时拍出《星你》《纸牌屋》?) [When Can Our Own Industry Produce Something Equal to "My Love from Another Star" and "House of Cards"?], Nanfang Ribao ( 南 方 日 报 ) [NANFANG DAILY], Mar. 12, 2014, A08, at http://epaper.southcn.com/nfdaily/html/2014-03/12/content_7281719.htm.

${ }_{364}$ SAPPRFT Reiterates Provisions concerning the Management of Online Foreign Television Dramas, SAPPRFT, Sep. 5, 2014, at http://www.sarft.gov.cn/articles/2014/09/05/20140904102409770812.html.

${ }^{365}$ Ling Jun (聆君), Jingwaiju Eryue Shiri Qian Xu Dengji Bude Chao Guochanju Baifenzhi Sanshi (境外剧 2 月 10 日前须登记 不得超国产剧 30\%)[Foreign dramas must Register Before Feburary 10th and the Quota Shall be Limited to Local Production's 30\%], Xin Lang ( 新 浪 )[SINA.COM], Jan. 21, 2015, at http://ent.sina.com.cn/v/u/2015-01-21/doc-icczmvun5286071.shtml (reporting that a leaked notice from SAPPRFT provides that, the annual amount of video platforms for online broadcasting of foreign audio-visual works is limited to $30 \%$ of its broadcast plans for local production after 2015).
} 
videoblogs."366 These new ways of consuming audio-visual media online could be best described as a participatory culture-a concept that was advanced by media scholars such as Henry Jenkins-within which the barriers to artistic expression and civic engagement are relatively low; creating and sharing one's creations with others is strongly supported; knowledge and skills inside are highly valued and completely transparent to participators; and the participators are somehow socially connected to each other. ${ }^{367}$ Mirko Tobias Schäfer developed the definition of participatory culture further by recognizing not only explicit participation, but also implicit participation. ${ }^{368}$ The latter even covers those comparatively subtler and unconscious participations that are deeply entwined with new advancements in social media applications.

It is clear from the above that fan activities are one form of that culture. It is also obvious that most fan activities do involve the unauthorized utilization of copyrighted contents. Furthermore, since the roles of consumers, fan contributors, and free riders are now merging, and stakeholders are incapable of distinguishing consumers from free riders (let alone distinguishing free riders from potential consumers), copyright owners are more inclined to ignore or tolerate these fan activities. Moreover, our copyright laws are perceived as being too arcane for us to understand these subtleties. ${ }^{369}$ If we assume that contributive participation is a common practice in the social media industry, not confronting these users may be in the best interests of copyright owners, otherwise they may have to be prepared for the inevitable backlash from the internet-related industry and fan groups. ${ }^{370}$

\footnotetext{
${ }^{366}$ Howard Rheingold, Using Participatory Media and Public Voice to Encourage Civic Engagement, in CIVIC LIFE ONLINE: LEARNING HOW DIGITAL MEDIA CAN ENGAGE YOUTH 100 (W. Lance Bennett ed. 2008).

${ }^{367}$ Henry Jenkins, Confronting the Challenges of Participatory Culture: Media Education for the 21st CENTURY 5-6 (The MIT Press. 2009); Or read/write culture as Lawrence Lessig advocates, in which the consumers are not just consuming content but also, using it to create. See LESSIG, supra note 39, at 28; See also ANDERSON, supra note 35, at 63 (noted that "we're starting to shift from being passive consumers to active producers").

368 Mirko TOBIAS SchäFer, BASTARD CULTURE!: HOW USER PARTICIPATION TRANSFORMS CULTURAL PRODUCTION 51-53 (Amsterdam University Press. 2011).

369 Leslie A. Gordon, Conference to Highlight Copyright Law's "Creaky Aspects”, UC BERKELEY SCHOOL OF LAW NEws ARCHIVE, Mar. 25, 2014, at http://www.law.berkeley.edu/16932.htm ("the Copyright Act is also widely considered too long, too complicated, and too difficult to understand.").

${ }^{370}$ Leanne Stendell, Fanfic and Fan Fact: How Current Copyright Law Ignores the Reality of Copyright Owner and Consumer Interests in Fan Fiction, 58 S.M.U. L. REV. 1551, 1580-81 (2005)(“It makes little sense to attack one's most devoted fans...if there is no need to do so when fan fiction is not damaging the copyright holder financially, and if failure to act is of no consequence legally."). See also Mikhail Koulikov, Fighting the Fan Sub War: Conflicts between Media Rights Holders and Unauthorized Creator/Distributor Networks, 5 TRANSFORMATIVE WORKS AND CULTURES (2010), at http://journal.transformativeworks.org/index.php/twc/article/view/115/171 (“...predictably, the result has been public resistance, including criticism of the company's own business practices.”).
} 
The judgment above is also true in terms of the Chinese market, since the new generation of Chinese citizens was also greatly influenced by the digital technology advancements and the information explosion as its U.S. counterparts were after entering the digital era. In that sense there is not much difference between media consumers in China and in other countries in terms of massive unauthorized utilization of copyright contents online. As the small coterie of fans grew bigger than anyone could expect, the fans will soon find themselves in a position that is capable of challenging the dominant cultural hierarchies. ${ }^{371}$ And as the technologies available could help them do what they want and still remain anonymous, it is even possible for them to refuse the authorial authority, including the legal norms that related to copyright. ${ }^{372}$

Fan consumers, when possible, will try to possess the text of a copyrighted work, and to control the interpretation of its meanings against the copyright owners to the best of their ability. ${ }^{373}$ However, just as Jenkins had indicated, fans in the early stage "lack direct access to the means of commercial cultural production and have only the most limited resources with which to influence the entertainment industry's decisions." ${ }^{, 74}$ In other words, they are "powerless and dependent" in their relationship to the culture industries. ${ }^{375}$ During that stage, fans who are discontented with the industry's decisions on certain copyright-related products will have to band together in order to influence the production process. Although unauthorized copies were already circulating among fans during the early stage, considering their scale, these early fan activities did not pose a threat to the copyright owners. At this point of time, it was piracy, rather than fan distribution of copyrighted contents, that troubled copyright owners.

However, the Internet, which offers "relatively unlimited, low-cost capacity for communication of all kinds", ${ }^{376}$ provides mass media fans with advanced production and communication tools. Soon after mass media fans had acquired and mastered these tools, fan communities started to emerge as a force which could make a real impact on the decisions of the cultural industry. If we ponder a while on the motivation of integrity

\footnotetext{
371 JENKINS, supra note 2, at 18-9.

${ }^{372} I d$.

373 Id. at $24-5$.

374 Id. at 27.

${ }^{375} \mathrm{Id}$.

${ }^{376}$ Reno v. ACLU, 521 U.S. 844, 870 (1997).
} 
that fansubbers advocate, ${ }^{377}$ it is evident that nowadays fans could say no to modifications which they do not like because with the help of the Internet, fans now have their own distribution channels. On the other side, the process of fan creation, which is a form of new media participation, has indeed significant value in terms of civic engagement in a cyber space.

The classical definition of the word "civic engagement" means "working to make a difference in the civic life of our communities and developing the combination of knowledge, skills, values and motivation to make that difference" and "promoting the quality of life in a community, through both political and non-political processes." "378 Traditionally, the understanding of civic engagement was limited to "rational" discussion of topics that are related to the traditional public sphere, but not entertainment, leisure and consumption activities. ${ }^{379}$ However, just as we have discussed above, in a participatory culture, the practice of citizenship could as well be conducted through interactive content consumption. ${ }^{380}$ As commentator had put it, "[p]articipatory culture describes the background in which a new form of civic engagement is taking form." 381

Like other forms of new media participation, that process, which is summarized by Deuze as "participation, remediation and bricolage", 382 represents a shift from a "common cultural public sphere" in which "politics and identity can be dramatized and affect can be politicized", to "everyday active participation in a networked, highly heterogeneous and open cultural public sphere". ${ }^{383}$ Furthermore, according to Rheingold, all kinds of participatory media that involve civic engagement share three common, interrelated characteristics, namely the technical-structural characteristic, the psychological and social characteristic, and the economic and political characteristic. ${ }^{384}$ From the description of these char-

\footnotetext{
377 See infra Chapter 3.1.1.1 Motivations.

378 Thomas Ehrlich, Preface, in Civic Responsibility AND Higher EduCATION vi (Thomas Ehrlich ed. 2000).

379 Burgess, et al., supra note 29; Balkin, supra note 15, at 32.

${ }^{380}$ Id ("bona fide citizenship is practised as much through everyday life, leisure, critical consumption and popular entertainment as it is through debate and engagement with capital 'P' politics.").

${ }^{381}$ Lindsay Pettingill, Engagement 2.0? How the New Digital Media can Invigorate Civic Engagement, Goodwork Project Paper Series, Sep. 2007, at https://www.thegoodproject.org/pdf/50-Engagement-2.0.pdf, at 9.

382 Mark Deuze, Participation, Remediation, Bricolage: Considering Principal Components of a Digital Culture, 22 THE INFORMATION SOCIETY 63, 63 (2006).

${ }^{383}$ Burgess, et al., supra note 29.

384 Rheingold, supra note 366, at 100 ("Many-to-many media now make it possible for every person connected to the network to broadcast as well as receive text, images, audio, video, software, data, discussions, transactions, computations, tags, or links to and from every other person. The asymmetry between broadcaster and audience that was dictated by the structure of pre-digital technologies has changed radically. This is a technical-structural
} 
acteristics one could deduce that fans of certain copyrighted works could of course utilize these participatory media to exchange, modify, and promote their fan creations for various purposes. In order to demonstrate that through participatory media, civic engagement is also possible, ${ }^{385}$ even in China. ${ }^{386}$ Many examples, such as Flickr, ${ }^{387}$ have been listed by previous research. Since these participatory media could be used by anyone, therefore it is no surprise that in participatory platforms all around the world, fan activities along with their fan creations could also play an important role in promoting civic engagement. ${ }^{388}$ If we believe that the purpose of creation, even reiteration is to express one's ideas, ${ }^{389}$ then it makes perfect sense to say fan works could also serve that goal, as a vehicle of self-expression, which deserves protection as well. ${ }^{390}$

It is noted that, at least in the U.S., civic engagement, as a core value of a democratic society, was entwined with the original rationale of copyright. ${ }^{391}$ However, the Chinese government is not willing to, or at least hesitates to foster that kind of civic engagement in some specific situations. According to our previous discussion, the ultimate goal of the Chinese government to control the flow of ideas is to safeguard the stability

\footnotetext{
characteristic; Participatory media are social media whose value and power derives from the active participation of many people. Value derives not just from the size of the audience, but also from their power to link to each other, to form a public as well as a market. This is a psychological and social characteristic; Social networks, when amplified by information and communication networks, enable broader, faster, and lower cost coordination of activities. This is an economic and political characteristic.").

385 See generally Burgess, et al., supra note 29; See also Rheingold, supra note 366; Liesbet Van Zoonen, Imagining the Fan Democracy, 19 EuRopean Journal of CommuniCATION 39(2004).; See Pettingill, supra note 381.

${ }^{386}$ For a case study on using Weibo (the Chinese version of Twitter) for civic engagement, see Yan Wang, Civic Engagement and Motivation Factors of Participants in SNAPSHOT, an Online Anti-Human Trafficking Initiative in China, Center for Public Policy Administration Capstones. Paper 1, at $\mathrm{http} / / /$ scholarworks.umass.edu/cgi/viewcontent.cgi?article=1015\&context=cppa_capstones; See also Luyue Ma, A Comparative Analysis of Weibo and Xinhua in Framing Chinese Civic Engagement (May. 2013) (unpublished M.A. thesis, Bowling Green State University), at https://etd.ohiolink.edu/rws_etd/document/get/bgsu1363569701/inline; Michael Chan, et al., Microblogging, Online Expression, and Political Efficacy Among Young Chinese Citizens: the Moderating Role of Information and Entertainment Needs in the Use of Weibo, 15 CYBERPSYCHOLOGY, BEHAVIOR, AND Social Networking 345, 345 (2012). Wenhong Chen, Taking Stock, Moving Forward: the Internet, Social Networks and Civic Engagement in Chinese Societies, 17 InFormation, COMMUNICATION \& SociETy 1 (2014).

${ }^{387}$ Flickr is an online photo management and sharing application. About Flickr, https://www.flickr.com/about/.

388 See generally, Henry Jenkins, From Participatatory Culture to Participatory Democracy (Part Two), Mar. 6, 2007, at http://henryjenkins.org/2007/03/from_participatatory_culture_t_1.html.

389 See Balkin, supra note 15, at 5 ("Even when people repeat what others have said, their reiteration often carries an alteration in meaning or context."). See Rebecca Tushnet, Copy this Essay: How Fair Use Doctrine Harms Free Speech and How Copying Serves It, 114 YALE L.J. 535, 562-86 (2004).

390 See Pamela Samuelson, The Copyright Principles Project: Directions for Reform, 25 BERKELEY TECH. LJ 1175, 1230 (2010)(“...members of the public often express themselves through personal uses of copyrighted works-some of which may be transformative in nature and some non-transformative-and copyright law should respect user self-expression as well as the interests of authors in protecting their works.").

${ }^{391}$ Malla Pollack, What is Congress Supposed to Promote?: Defining "Progress" in Article I, Section 8, Clause 8 of the United States Constitution, or Introducing the Progress Clause, 80 NEB. L. REv. 754, 785 (2001).
} 
of the society. ${ }^{392}$ Hence, any creation or activity that interferes with the government's efforts to achieve that goal will be wiped out.

On one hand, foreign cultural products capable of conveying ideas, such as movies, TV series, and even music tracks, are all potential threats to the stability of the society of China, since many of them carry "Western influences" that the Chinese government is worrying about. ${ }^{393}$ However, according to Netanel, a democratic culture, which is central to the process of democratization, is "supported by the widespread dissemination of information and opinion, an independent and pluralist media, and a belief in the efficacy of individual contributions to public discourse". 394 Therefore it is not hard to understand why the Chinese government places a significant amount of importance on the political impact of audio-visual productions such as TV drama. For example, according to the former deputy director of the SARFT, Bingxuan Ji's (吉炳轩) speech in 2000, TV drama workers are "Party's journalists" first, and "TV media art workers" second. ${ }^{395}$ They have to "take a clear-cut stand against capitalism and every decadent ideology of the exploiting class" and be "firmly opposed to worship and copy the concept of values and cultural patterns blindly" in order to create good dramas. ${ }^{396}$

On the other hand, the new type of civic engagement, which was made possible by fan activities based on foreign titles in the Chinese market, has drawn attention from the powers that be as well. Ancient Chinese creators, especially writers, have a long history of quoting Confucius classics in their creations (books, articles, calligraphies, etc.) to voice their political criticism of the incompetent imperial government. ${ }^{397}$

\footnotetext{
${ }^{392}$ See supra Chapter 2.1.1 Chinese Political Culture.

393 See e.g., Hennessey, supra note 6, at 627-28 (“...modern "Chinese culture" must adamantly resist and avoid "Western influences" (especially so-called "Western" liberal democratic influences) in the process because the current globalization game is stacked against China."). See also CNN Wire Staff, China Sees Culture as a Crucial Battleground, CNN, Jan. 5, 2012, at http://www.cnn.com/2012/01/05/world/asia/china-western-culture/index.html.

394 Neil Weinstock Netanel, Asserting Copyright's Democratic Principles in the Global Arena, 51 VAND. L. REV. 217 , 329 (1998).

395 Bingxuan Ji (吉炳轩), Changxiang Zhu Xuanlv Duochu Jinping Ju (唱响主旋律多出精品剧——吉炳轩同志在 2000 年电视剧题材规划会上的讲话要点) [Proclaim the mainstream melody, produce more quality dramas, comrade Ji Bingxuan's speech to the 2000 Television Drama Topic Advisory Meeting], ZHONGGUO DiAnSHI (中国电 视)[CHINESE TELEVISION], no.7, 2000, 4.

${ }^{396}$ Id. at 9 .

397 As Alford indicated, "the first measure he would advise a ruler to institute on assuming power... it involved the expectation that current rulers would carry out their responsibilities in a manner consistent with the moral standards set by their most worthy predecessors", and "rulers failing to discharge their responsibilities in keeping with such standards... might lose the Mandate and, with it, their claim to rule.” ALFORD, supra note 5, at 21.
} 
However, such criticism must be carried out in a prudent way. ${ }^{398}$ For example, in the first and most famous literary inquisition (文字狱) case of the Qing Dynasty, Tinglong Zhuang (庄廷鑨), a rich merchant in northern Zhejiang who funded the compilation of the history of Ming (the preceding dynasty before Qing) was found guilty of treason in $1663,{ }^{399}$ because the Qing government believed that the book he published implied that the Qing government was an illegitimate usurper of Ming. ${ }^{400}$ In response, nearly eighty people, even the buyers, were executed. ${ }^{401}$ It is obvious that Zhuang had crossed the line by expressing his criticism of the "pretenders" of the throne by innuendo in the book he published. But what is more important is, for the purpose of this research, the method Zhuang chose to voice his criticism. In this case, Zhuang and his compilers had demonstrated a way of literary dissent via historical inference. Ancient Chinese writers are well known for their unique understanding of creation and attitude towards copying. According to Frederick Mote's understanding of Confucian values, the ancient Chinese "regarded the world and man as uncreated", "unless we use the word 'creation' as is sometimes done in the more general sense of 'genesis." "402 The consequence of that, just like Peter $\mathrm{Yu}$ has put it, is that people believe that the Chinese "considered creativity and innovation as a collective benefit to their community and posterity" instead of private property. ${ }^{403}$ Moreover, just as a commentator has observed, in ancient China, if an author quoted from a classic work without attribution, the reader who failed to recognize the source should be the one to blame, not the author. ${ }^{404}$ This prac-

\footnotetext{
398 According to Steven Kan, "[d]efamation of the throne in the form of political criticism became a serious threat to emperors in China after significant innovations were made in paper-making and printing technologies because printing allowed faster and wider dissemination of criticism of an emperor's policies and extravagant conduct in the palace", and "[b]oth the gruesome secret service of Ming Dynasty and literary inquisition in [Q]ing Dynasty are notorious in Chinese history because intellectuals were ostracized and many people were killed." Steven S. Kan, Corporal Punishments and Optimal Incapacitation, 25 J. LEGAL STUD. 121, 124 (1996).

${ }^{399}$ FredericK W. Mote, IMPERIAL ChINA, 900-1800 864-65 (Harvard University Press. 2003); See also Lawrence D. Kessler, Chinese Scholars and the Early Manchu State, 31 HARV. J. ASIAT. STUD. 179, 182-83 (1971).

${ }^{400}$ Joanna Waley-Cohen, Collective Responsibility in Qing Criminal Law, in THE Limits OF THE RULE OF LAW IN CHINA 120 (Karen Turner-Gottschang, et al. eds., 2000).

${ }^{401}$ Id. See also GUY, supra note 67, at 158 (provided a detailed examination of the censorship movement of the late Qing, Qian Long era, and showed that the censorship regarding publication at that time is sporadic, not systematic.).

${ }_{402}$ Frederick W. Mote, The Cosmological Gulf Between China and the West, in Transition AND PERMANENCE: Chinese History AND Culture 7 (David C. Buxbaum \& Frederick W. Mote eds., 1972).

${ }^{403} \mathrm{Yu}$, supra note 160 , at 250.

${ }^{404}$ Charles R. Stone, Comment, What Plagiarism Was Not: Some Preliminary Observations on Classical Chinese Attitudes Toward What the West Calls Intellectual Property, 92 MARQ. L. REV. 199, 202-03 (2008)( "[w]hen traditional Chinese authors borrow from a pre-existing text, and especially from a classic, the reader is expected to recognize the source of the borrowed material instantly...If a reader is unfortunate enough to fail to recognize such quoted material, it is his fault, not the author's.").
} 
tice can be best described by a well known Chinese axiom “引经据典” (refer to the classics and quote scripture).

If we acknowledge that "refer to the classics and quote scripture" was a common technique of the artistic practice of ancient Chinese authors to express their views, then historical inference, or "drawing upon the past to satirize the present" (借古讽今) within the artistic practice was a special technique used not only by them, but also by modern authors to utter their dissent. ${ }^{405}$ Chinese writers, both ancient and modern, tend to use metaphors in their work and encourage readers to read between the lines. In a more recent case, Han Wu (吴晗), the then deputy major of Beijing and the author of the play “The Dismissal of Hai Rui” (海瑞罢官 ), was attacked during the Cultural Revolution for that play. Rui Hai (1513-1587) was a Chinese official of the Ming Dynasty known for his integrity and honesty, and he was one of numerous officials who risked their lives as critics of government administration, a fact appreciated by historically knowledgeable Chinese readers. ${ }^{406}$ The initiator of that attack is believed to be Wenyuan Yao (姚文元), who was one member of the “Gang of Four". In Yao's article that was published in 1965, Wu's play was referred to as "poisonous weeds". Chairman Mao himself introduced the analogy of Dehuai Peng (彭德怀) during his 1965 speech in Hangzhou. ${ }^{407}$ Later in 1966, many party organs, including the People's Daily, published articles that brought this campaign further by indicating that Wu's play was actually criticizing Maoist policies during 1958-59, especially the punishment of Peng and the Commune program of the Great Leap. ${ }^{408} \mathrm{Wu}$ was actually drawing upon the past to satirize the present with his play, just like Zhuang did. Compare to Zhuang and $\mathrm{Wu}$, others, who have done that more subtly, survived.

After more and more ways of artistic creation such as music and movie were industrially developed, they soon became a new vehicle for

\footnotetext{
${ }^{405}$ Hong Yin, Meaning, Production, Consumption: The History and Reality of Television Drama in China, in MEDIA In CHINA: CONSUMPTION, CONTENT AND CRISIS 35 (Stephanie Hemelryk Donald et al. eds., 2002)(“Using the past to mirror the present, and drawing upon the past to satirize the present are complementary historiographical traditions in China."); It was decried as being a "historiography by political inference” (影射史学) during the cultural revolution period. See Geremie R. Barme, Red allure and the crimson blindfold, ChINA PERSPECTIVES 29, 33 (2012).

406 Hai Rui was regarded by many with "almost religious feeling as a saviour of the people and dispenser of justice." See Tom Fisher, 'The Play's the Thing': Wu Han and Hai Rui Revisited, in Using the PaSt to SERVE THE PRESENT: HISTORIOGRAPHY AND POLITICS IN CONTEMPORARY CHINA 23, 29 (Jonathan Unger ed. 1993).

407 Zedong Mao, Talks at the Hangzhou Conference on 21 December, in MAO TSE-TUNG UnReHEARSED 238 (S. Schram ed. 1974)(“...in 1959 we dismissed Peng Dehuai from office. And Peng Dehuai is Hai Rui too”).

${ }^{408}$ Fisher, supra note 406, at 11.
} 
authors to deliver their covert messages. For instance, contemporary historical dramas in China were also deemed as a channel for Chinese people to shed light on the present by reviewing the past. ${ }^{409}$ In addition, "drawing upon the past to satirize the present", along with other similar rhetorical techniques like sarcastic metaphors, puns, anagrams and innuendoes, have all been widely used in contemporary China, especially among Chinese youngsters. They apply these techniques in every aspect of their modern creative life: music sampling, video parodies, fanfics, and even fan translation of movie subtitles. Hence it is easy to find interesting fan works such as fansubs which contain translations with distinct Chinese characteristics. For example, in the fansubs of many audio-visual productions, fan translators have tried to express their discontent with the government via their translation, even for science documentary TV series such as Through the Wormhole. ${ }^{410}$ In episode 3 (entitled "Is Time Travel Possible?") of the first season of that series, the famous YYeTs fansub team (人人影视) had translated the original English dialogue "So, alas, I had to give up my dream of creating a time machine" (in 0:18:33) into " 时间机器是水中月, 镜中花 发改委说要降油价——没戏” (time machine is the moon in the water, the flower in the mirror, just like we can never trust National Development and Reform Commission's promise on lowering the price of gas). ${ }^{411}$ In China, criticism in video parody is more obvious. Interestingly, this feature is not so common in fan works in other countries such as the U.S., but it is understandable since comparatively U.S. citizens have more channels to express their criticisms. Due to the differences in regimes and concept of governing between China and other democratic countries, the freedom of speech and civic engagement are highly regulated and limited in China, ${ }^{412}$ forcing its citizens to voice their concerns through more subtle ways. To put it bluntly, in order to express their discontent publicly, Chinese citizens will have to employ the above-mentioned rhetorical techniques in expressing themselves through state-controlled channels. Fortunately, with the introduction of the Inter-

\footnotetext{
409 Yin, supra note 405, at 35.

410 Through the Wormhole is an American science documentary television series that is narrated by Morgan Freeman (Science channel broadcast Jun. 9, 2010).

411 This translation was captured and posted in the page of Through the Wormhole in an IMDB-linked Chinese site called Douban (豆瓣) as an interesting case of fan translation, at http://movie.douban.com/photos/photo/1577134342/.

412 Chan, et al., supra note 386, at 345 ("In a one-party state, Chinese citizens have few opportunities to formally influence the government. Therefore, online discussion is one of the very few outlets available for citizens to express opinions about government and politics.”).
} 
net, social networks in China-such as Weibo and Renren-emerged as a public platform for communication. ${ }^{413}$ Social networks provide more freedom than the traditional channels. ${ }^{414}$ But many Chinese users of these platforms who want to express their discontent tend to do it subtly, so it is not strange that previous research found that, compared to Twitter users, Chinese Weibo users tend to avoid profiling themselves in the public discussions. ${ }^{415}$ More specifically, because the rich media feature and the fact that "Chinese characters are based on a logogram rather than an alphabet system", thus "it is possible to include comparatively more information under the 140-character limit", ${ }^{416}$ Weibo, along with other social network service providers are now acting as a platform for subtle expressions such as fan creations. However, under an authoritarian regime, the history of China shows that, artistic creations in China including amateur creations such as fan work will inevitably be colored with a strong but subtle ideological and political discourse. Furthermore, the invasion of all kinds of copyrighted works from the western world with the help of piracy had not only enlightened the Chinese people with their value, but also provided them (especially the youngsters) with first hand material to work on, to draw upon the past (existing works) to satirize the present, by creating something new. However, since the ultimate purpose of the Chinese government is to maintain a stabilized society, then social media themselves along with esoteric metaphors, puns, anagrams and innuendoes within have posted considerable threats to that goal. ${ }^{417}$ More specifically, Chinese youngsters nowadays are not mainly drawing upon a shared past, which the government is familiar with and able to control, to satirize the present. In other words, the younger generation of China is

\footnotetext{
${ }^{413}$ Weibo is a Chinese microblog website similar to Twitter run by Sina Cooperation. Renren is a Chinese social network similar to Facebook run by Beijing Thousand Oaks Internet Technology Development Co., Ltd., both of them are widely used in China.

${ }^{414}$ Prof. Weifang He from Beijing University indicated that, by writing and publishing in blog form one could enjoy a wider degree of freedom, compared with traditional media. See Weifang He (贺卫方), Blog Writing and Other, in XiAOYAOFAWAI (逍遥法外) [AT LARGE] 112 (2009).

415 Qi Gao, et al., A Comparative Study of Users' Microblogging Behavior on Sina Weibo and Twitter, in USER MODELING, ADAPTATION, AND PERSONALIZATION: 20TH INTERNATIONAL CONFERENCE, UMAP 2012, MONTREAL, CANADA, July 16-20, 2012. ProceEdings 96 (Judith Masthoff, et al. eds., 2012)(“... users on Sina Weibo avoid talking about organizations such as political parties or other institutions."). "Twitter users... seem to have... a higher demand to profile themselves in the public discussions...". Id. at 100.

${ }^{416}$ Chan, et al., supra note 386 , at 345 .

417 Id. at 345 ("...its decentralized structure poses a serious challenge to the central government by circumventing centralized information control and censorship."). Chen, supra note 386, at 1 ("The prevalent political control and aggressive commercialization notwithstanding, a vast, ephemeral, online communicative space has been formed where users comment and discuss public and private affairs, greatly enhancing the individualization of civic engagement while making censorship difficult.”).
} 
now more focused on popular content rather than history. They often use subversive puns such as “river crab" (河蟹) and "grass mud horse" (草泥 马) to air their discontentment about governmental censorship and online keyword filters. ${ }^{418}$ These modern puns, metaphors, even clips from famous works (both foreign and local) were also used by fan creators to express their disapproval of excessive government control, and the government's response to that is thus to be expected. ${ }^{419}$ According to a recent SARFT Notice, no level of state-owned radio and television organ can broadcast radio and television programs which use "non-standard" language, as compared to national standard spoken and written language, such as "willful distortions and the messy use of proverbs". 420

All in all, although fan activities which involve copyright issues are only a small part of this participatory phenomenon, they certainly have a profound impact on our legal system. Therefore, as commentators have indicated, the policy which concerns fan participatory activities should strike a balance between "ownership, content regulation and controls" and "platforms, technologies and practices that enable the flowering of the unpredictable forms of everyday and ephemeral creativity and engagement that make up active participation in the networked cultural public sphere." ${ }^{21}$ Unfortunately but not surprisingly, the recent campaigns and policies in China which concern this new type of civic engagement had demonstrated that, the policy maker had put its main focus on "stable" and "control", all the other concerns, such as copyright and civic engagement, are secondary. Under this scenario, it may not be wise for foreign copyright owners to put pressure on the Chinese government for copyright enforcement. Furthermore, according to commentators, that is also "in conflict with American democratic ideals and democratic foreign

\footnotetext{
418 "River crab" is an understated play on the characters for "harmonious", they share "similar sounding albeit entirely different characters to take the place of banned words." See Seth Wiener, Grass-mud Horses to Victory: The Phonological Constraints of Subversive Puns, in PROCEEDINGS OF THE 23RD NORTH AMERICAN CONFERENCE ON Chinese Linguistics 158 (Zhuo Jing-Schmidt ed. 2011).

${ }^{419}$ Guangdian Zongju Guanyu Guangbo Dianshi Jiemu he Guanggao Zhong Guifan Shiyong Guojia Tongyong Yuyan Wenzi de Tongzhi (广电总局关于广播电视节目和广告中规范使用国家通用语言文字的通知) [SARFT Notice concerning the Standardized Use of the National Common Spoken and Written Language in Radio and Television Programs and Advertising"], SARFT, Nov. 27, $2014, \quad$ at http://www.sarft.gov.cn/articles/2014/11/27/20141127143826180126.html, translated at CHINA COPYRIGHT AND MEDIA (Rogier Creemers trans., https://chinacopyrightandmedia.wordpress.com/2014/11/27/notice-concerning-the-standardized-use-of-the-national-co mmon-spoken-and-written-language-in-radio-and-television-programmes-and-advertising/ .

${ }_{420} I d$.

${ }^{421}$ Burgess, et al., supra note 29.
} 
policy objectives", ${ }^{422}$ which aim to push democratic development in countries like China. However, it is very hard even for the Chinese government, at least at the early stages, to control all of these new ways of expressions, since cyberspace is unavoidably free by nature. ${ }^{423}$

However, the Chinese government has also learned to accommodate to new circumstances. For instance, social media in China is believed to be a good way to "to obtain effective measures of the views of the populace about specific public policies and experiences with the many parts of Chinese government and the performance of public officials", if only "collective action is prevented". ${ }^{2} 4$ In other words, the Chinese government will not consider "unstable" speeches from individuals as a threat to the stability of the society, as long as they have no collective action potential. Therefore, it is not so hard to understand why it is difficult for the Chinese government to handle fan groups and their related transformative speeches, as they are potentially collective, and thus could be out of control. The 2014 Cleanse the Internet Campaign underlines this point: The Chinese government had shut down several big fansub sites during this campaign, including the famous subtitle-sharing platform Shooter.com and one of the biggest fansub groups YYeTs. A Chinese commentator believes that the shut down of these sites may be attributed to a MPAA report, ${ }^{425}$ in which Xunlei.com and YYeTs.com are listed as Chinese sites with serious copyright problems. ${ }^{426}$ However, it is also noted that this move "was connected more to the desire to limit viewing of foreign content than tackle pirated content". ${ }^{427}$ As a matter of fact, many more similar sites opened after the Chinese government shut down Shooter and YYeTs in the name of fighting piracy, ${ }^{428}$ and the government took no measures against these successors. It could be attributed to lax enforcement, but however, one of the reasons behind this could be that the poten-

\footnotetext{
${ }^{422}$ Rogoyski \& Basin, supra note 6, at 239

${ }^{423}$ LESSIG, supra note 12, at 3; Id. at 236 (stated that "features and consequences of the Internet protocol make it difficult to control speech in cyberspace").

${ }^{424}$ King, et al., supra note 316 , at 339.

${ }^{425}$ Li Zhao (赵力), Renren Yingshi Yongjiu Guanbi Beihou de Gushi (人人影视永久关闭背后的故事) [The Story Behind the Shut Down of the YYeTs], Xin Jing Bao (新京报) [The BEIJING NEws], Dec. 21, 2014, available at http://help.3g.163.com/14/1221/09/ADVSD28A00963VRO.html.

${ }_{426}$ MPAA, Re: Request for public comment on the 2014 Special 301 Out of Cycle Review of Notorious Markets, $\begin{array}{llllll}\text { Docket No. USTR-2014-0017, } & \text { MPAA, 24, } & \text { Oct. }\end{array}$ http://www.mpaa.org/wp-content/uploads/2014/10/MPAA-Filing-to-USTR-on-Worlds-Most-Notorious-Markets.pdf. ${ }^{427}$ Lilian Lin, As China Cracks Down on Illegal Videos, Lovers of Foreign TV Mourn, THE WaLl StREet JouRnaL, Nov. 25 , 2014,

http://blogs.wsj.com/chinarealtime/2014/11/25/as-china-cracks-down-on-illegal-videos-foreign-tv-lovers-mourn/.

${ }^{428}$ Examples including Sub.makedie.me and Subom.net.
} 
tial danger of collective action was eliminated, as the flow had been diverted to multiple small sites successfully. In a word, the Chinese government has been waving the flag of intellectual property protection against unpleasant voices in foreign works and their fan derivatives.

\subsubsection{Market and Fans}

The starting point for discussions about law enforcement is that, when people in one country are interested in the works of another, then if the copyright owners are aware of that situation, they will naturally seek promotion there and enforce their rights if infringement happens. Interestingly, according to the long-tail theory, when the search costs are close to zero, theoretically any niche market, including the Japanese anime market, will benefit from the vast opportunities offered by the Internet and grow bigger. ${ }^{429}$

Japanese anime is a good example here. Nevertheless, the power of Japanese anime productions should not be exaggerated. It is true that anime has attracted the attention of many people worldwide, but it is still a niche market in comparison to Hollywood productions, and it is struggling to increase profits from overseas markets and to cater to the different cultural demands of the targeted countries as well. ${ }^{430}$ Consequently, if Japanese works want to succeed in a foreign market today, they must gain a certain degree of publicity first. To achieve that goal, traditionally the owners of Japanese anime would not only have to have the same status as their local competitors in terms of distribution, but also be able to access a large promotional budget. However, this has not been the case for the Japanese. The preconceived idea that "animation is only for child consumption" in countries such as China and the U.S. is one of the reasons that are hindering it from becoming part of mainstream culture, and instead have made it a comparatively fringe group. If countries like China are censoring anime works for purposes such as child protection, it will definitely affect their future market. Interestingly, research suggests that

\footnotetext{
429 ANDERSON, supra note 35, at 24.

${ }^{430}$ Dan Kanemitsu, Analysizing [sic] the State of the Anime and Manga Industry in 2012, Dan Kanemitsu's Paper Trail, Mar.

19 , 2012 . http://dankanemitsu.wordpress.com/2012/03/19/analysizing-the-state-of-the-anime-and-manga-industry-in-2012/.
} 
reasons such as fans themselves being actually "socially maladjusted" are also making it harder for anime to become a mainstream culture. ${ }^{431}$

In terms of most Japanese anime products, their copyright protection in China was not clear before 2010. After the 2010 revision of the CCL, their copyright protection has been confirmed. However, the practical protection of Japanese anime is still unresolved in China because of the potential judicial bias, political intervention, and other factors such as transaction costs and marketing, which have led so far to market failure. $^{432}$ It is foreseeable that some of these factors will affect their U.S. market as well, as studies have found that the problems of incomplete information and externalities will possibly cause market failure there, at least in the case of fan creations. ${ }^{43}$ That is to say, Japanese copyright owners will neither be able to maintain the balance with fan-produced work in foreign countries that they enjoy domestically, nor will they be able to invest heavily in foreign promotion. Furthermore, with respect to foreign works, the motivations of fan activities and the fan community ethos are changing rapidly nowadays in countries like China. In the absence of a mutual trust between local fans and copyright owners, fan groups in China contribute with various motivations rather than merely fandom. $^{434}$ Therefore, the fan community ethos that this research focuses on is not as stable as it is in a closed market like Japan.

\subsection{EConomic Problems}

\footnotetext{
431 See Mark I. West, The Japanification of Children's Popular Culture: From Godzilla to MiYaZAKI 123-24 (Scarecrow Press. 2009)(“....anime fan subculture's worth as being "normal” is derived only from its similarities to mainstream culture...However...there is no room for social acceptance of those who actually do fit the stereotype of the socially maladjusted fan.").

${ }^{432}$ See e.g., Priest, supra note 5, at 821-29 (noted that endemic problems such as local protectionism are standing in the way of protecting copyright against unauthorized distributions); Wu, supra note 42, at 628 (explained the problem of transaction costs); Michael Geist, The Truth About Pirates and Profits: A Market Failure, Not Legal One, MicHAEL Geist Personal Home PaGe, Mar. 22, 2011, http://www.michaelgeist.ca/2011/03/ssrc-piracy-report-column-post/ (summarized that in many developing countries, "piracy is primarily a function of market failure".).

${ }_{433}$ Daniels, supra note 25, at 718-26.

${ }^{434}$ For example, it is believed that the primary motivation for fansubbing is fandom. See e.g., Tiffany Lee, Fan Activities from P2P File Sharing to Fansubs and Fan Fiction: Motivations, Policy Concerns, and Recommendations, 14 TEX. REV. ENT. \& SPORTS L. 181, 194 (2013)(“...motivations for sharing anime illegally among non-Japanese are... to promote the anime industry."); Leonard, supra note 28, at 221 ("The Kiotsukete member pointed out that the prevailing motivation was to interest more people in anime."). However, as digisubs arose and fansubbing became an international phenomenon, it is noted that at least for fansubbers of U.S. TV shows in China, their motivation varies. See Peng Qiu, Audience Activity in the New Media Era: Chinese Fansubs of U.S. TV Shows (Dec. 2010)

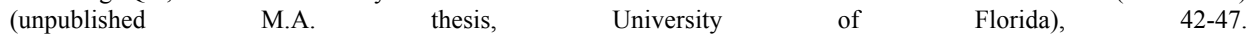
http://ufdcimages.uflib.ufl.edu/UF/E0/04/26/11/00001/qiu_p.pdf.
} 
While other countries might experience the same phenomena, the following economic problems should not be disregarded in the context of this research. The economic problems of information asymmetry (para. 2.2.1), public goods (para. 2.2.2), and transaction costs (para. 2.2.3) are discussed in turn under this subsection.

\subsubsection{Information Asymmetry}

The transnational unauthorized distribution of copyrighted contents also results in information asymmetry, as those unauthorized copies and fan creations abroad will probably induce the adverse selection problem.

Information asymmetry and the subsequent adverse selection problem are also economic terms: the former describes a situation in which one party "knows more about what is going on than another," they have "[a] difference in access to knowledge"; ${ }^{435}$ the latter delineates "a problem that arises in markets in which the seller knows more about the attributes of the goods being sold than the buyer does." 436 For example, it is reported that pirate CDs of foreign works could be bought at legitimate music stores in China, and they look so good that hardly anyone could tell the difference between them and the genuine ones, ${ }^{437}$ and pirates are appropriating fansubs in their illegal copies of foreign works as well. ${ }^{438}$ In such a case, the seller certainly knows the true condition of their goods, but ordinary uninformed consumers, especially those in the rural areas, may not be able to distinguish "good" from "bad" and will probably choose the cheaper ones. It is possibly a trademark infringement as well, if the copyright owners can prove that the behavior of the creators of the pirate copies or fan creations is likely to cause confusion concerning the source or affiliation within a significant group of consumers. ${ }^{439}$ However, it is also noteworthy that, some research has indicated that the presence of unauthorized copying "has the potential to solve the resultant ad-

\footnotetext{
435 N. Gregory Mankiw, Principles of MaCroeconomics 462 (CENTGAGE Learning Seventh Edition. ed. 2014). 436 Id. at 464.

${ }^{437}$ See Kevin Maney, If Pirating Grows, It May Not Be the End of Music World, USA TodaY, May. 3, 2005, at http://usatoday30.usatoday.com/tech/columnist/kevinmaney/2005-05-03-music-piracy-china_x.htm.

${ }^{438}$ See Jie Zou (邹捷) \& Jianzhang Yuan (袁建彰), Zimuzu Laodong Guoshi Bei Daoban Shang Qiequ (字幕组劳动 果实被盗版商窃取) [Fansub Groups' Fruit of Labour are being Stolen by Commercial Pirates], Xinxishibao (信息时 报) [INFORMATION TIMES], Dec. 11, 2009, at http://tech.sina.com.cn/i/2009-12-11/09183669753_2.shtml (China).

${ }^{439}$ Fisher, supra note 23, at 1443.
} 
verse selection problem" in certain conditions. ${ }^{440}$ But it is nevertheless a considerable threat for foreign copyright owners doing business in China.

\subsubsection{Public goods}

"Public goods" is an economic term that used to describe goods which are "neither excludable nor rival." 441 Although it is generally believed that intellectual property is a public good, ${ }^{42}$ debates over whether copyrightable works are public goods or not still exists. ${ }^{443}$ Nevertheless, it is a fact that they are non-rivalrous and to some extent non-excludable, considering the development of file copying and sharing technologies. Non-rivalrous means that the ideas in the intellectual goods can be consumed at the same time: one's full enjoyment of an intellectual work will not diminish another's utilities; a copyrightable work is also quasi-non-excludable, because the owner of "the physical instantiation of an intellectual object" can prevent others from taking his copy. ${ }^{444}$ However, it is also noted that the ready availability of copying technologies has made the once powerful authors now unable to prevent non-paying customers from obtaining access to those works, therefore legal remedies were provided to keep the works excludable to some extent, in order to correct the market failures associated with non-excludability. ${ }^{445}$ But this exclusion is in the end imperfect, considering the cost of enforcement. ${ }^{446}$ For that reason, Internet-based technologies have initiated an endless "cat and mouse game" in which the copyright holders target countless unauthorized online distributors but achieve little. This is especially so in terms of transnational copyright enforcement.

\subsubsection{Transaction Costs}

\footnotetext{
${ }^{440}$ See Lisa N. Takeyama, Piracy, Asymmetric Information and Product Quality, in THE ECONOMICs OF COPYRIGHT: DEVELOPMENTS IN RESEARCH AND ANALYSIS 62 (Wendy J. Gordon et al. eds, 2003).

${ }^{441}$ MANKIW, supra note 435, at 216.

442 LANDES \& POSNER, supra note 34, at 14.

${ }^{443}$ Some have claimed that they are club goods or impure public goods. See generally James M. Buchanan, An Economic Theory of Clubs, 32 ECONOMiCA 1 (1965). See also Christopher S. Yoo, Copyright and Public Good Economics: A Misunderstood Relation, 155 U. PA L. REV. 635 (2007). But see LANDES \& POSNER, supra note 34, at 172 (indicated that copyrighted work is "a classic public good".)

${ }^{444}$ Francis Raven, Copyright and Public Goods: An Argument for Thin Copyright Protection, 8 M/C JOURNAL (2005), at http://journal.media-culture.org.au/0507/06-raven.php.

445 Yoo, supra note 443, at 645 (noting that legal remedies were provided to keep the works excludable to some extent).

${ }^{446}$ Id.
} 
As indicated above, one of the major challenges we should consider about copyright enforcement in China is purely economic. ${ }^{447}$ On the one hand, it is uneconomic to pursue and sue each infringer, ${ }^{448}$ and this is particularly true considering that many online copyright infringements of copyrighted audio-visual works are happening in different countries. Notably, most of the existing solutions relied heavily on local courts, but just as the U.S. court had noted, the "impracticability or futility of a copyright owner suing a multitude of individual infringers" 449 had already decided that eliminating piracy through traditional means is a mission that can hardly be accomplished. ${ }^{450}$ This is especially the case in terms of copyright enforcement abroad. That is why it is common today for large content conglomerates to initiate litigation against companies such as Google, but it is much harder to find cases involving individuals who have facilitated illegal downloading by creating something new based upon copyrighted works. ${ }^{451}$ This is very much the case when we talk about audio-visual works owned by large media companies, where existing litigations are merely initiated for the purpose of deterrence. As Professor Tim Wu has noted, the transaction costs are the "determining factor", as "the number of uses" are "approaching infinity". ${ }^{452}$ In other words, the costs of enforcement are far greater than the benefit from doing so. ${ }^{453}$ On the other hand, considering the value of most unauthorized daily utilizations by individuals, the transaction costs for them to obtain permission are simply too high. ${ }^{45}$

Furthermore, whether the conclusion that "piracy is harmful" is correct or not is still unclear. The content industry's way of calculating their damages is questionable. ${ }^{455}$ Oberholzer-Gee and Strumpf conducted an

\footnotetext{
${ }^{447}$ LI, supra note 74, at 180.

448 Joseph P. Liu, Copyright Law's Theory of the Consumer, 44 B.C. L. REV. 397, 417 (2003).

449 Aimster Copyright Litigation, 334 F.3d 643, 645 (7th Cir. 2003), cert. denied, 540 U.S. 1107 (2004)

${ }^{450}$ Even economical analysis is supportive of that view. See Wu, supra note 42, at 628.

${ }^{451}$ Mark A. Lemley \& R. Anthony Reese, Reducing Digital Copyright Infringement without Restricting Innovation, 56 STAN. L. REV. 1345, 1346 (2004)(“Copyright owners tend not to sue those who trade software, video, or music files over the Internet. Indeed, such claims are so rare that the Recording Industry Association of America's (RIAA) recent suits against some actual infringers on peer-to-peer (p2p) networks sent shock waves through the legal community."). ${ }^{452} \mathrm{Wu}$, supra note 42 , at 630.

${ }^{453}$ See Samuelson, supra note 390, at 1230 (“...it is generally infeasible to regulate personal uses of copyrighted works because it would be difficult and costly to enforce copyrights in spaces where personal uses take place.”).

${ }^{454}$ Lee, supra note 16 , at 1486.

455 Karsten Strauss, TV and Film Piracy: Threatening an Industry?, FoRBES, Mar. 6, 2013, at http://www.forbes.com/sites/karstenstrauss/2013/03/06/tv-and-film-piracy-threatening-an-industry/ (“...it does seem fair to assume that not every pirated copy of an audiovisual work represents lost revenue to the content producer.").
} 
empirical research into the music industry, and their results are somewhat contrary to the claims coming from the music industry: piracy and music sales are largely unrelated. In contrast, there is clear evidence that the income of genuine sales has risen in recent years. ${ }^{456}$ With respect to audio-visual products, the situation could be similar, since movie production companies can still earn a lot from theatres, and the visceral viewing experience of theatres cannot be pirated. In the case of music products, though, pirate copies can act as perfect substitutes. However, if the music industry can manage to thrive considering the aforesaid fact, then probably the audio-visual industry will do so as well. A study conducted by Ofcom (a government-approved independent regulatory and competition authority for the broadcasting, telecommunications and postal industries of the U.K.) indicates that those who illegally download films and television programs in U.K. tend to spend more money on entertainment purchases than those who do not. ${ }^{457}$ Nevertheless, previous researches have indicated that piracy may have a negative impact on box-office revenue, at least in the U.S., U.K., Spain, and Argentina. ${ }^{458}$ In addition, copyright enforcement abroad is not only problematic but also costly in terms of staff. For instance, Japanese copyright owners lack personnel who are well versed in international intellectual property issues, which has resulted in them having low profitability abroad. ${ }^{459}$

Even if foreign works could enter the Chinese market without worrying about political issues, they would still have to deal with commercial promotion and copyright enforcement matters, especially when trying to break into a nascent foreign market. For example, Toei Animation Corporation tried to establish itself in the U.S. market between 1978 and 1982 , but eventually they failed because anime was still in the early stag-

\footnotetext{
${ }^{456}$ Oberholzer-Gee \& Strumpf, supra note 34, at 19-55.

457 Online Copyright Infringement Tracker Benchmark Study Q3 2012, OFCOM, Nov. 20, 2012, at http://stakeholders.ofcom.org.uk/market-data-research/other/telecoms-research/copyright-infringement-tracker/.

${ }^{458}$ Arthur S. De Vany \& W. David Walls, Estimating the Effects of Movie Piracy on Box-Office Revenue, 30 REVIEW OF INDUSTRIAL ORGANIZATION 291(2007); See also Rich \& Stone, supra note 188 ("Joel Waldfogel...said, piracy tends to displace paid consumption. "The real cost of consuming a movie is the two hours of undivided attention you spend," Mr. Waldfogel said. "If people are able to steal a bunch more, they will purchase less, simply because there isn't time to do all of it."').

459 Japan External Trade Org., Japan Animation Industry Trends, JAPAN ECON. MONTHLY, Jun. 2005, at 2, http://www.jetro.go.jp/en/reports/market/pdf/2005_35_r.pdf (“...the extreme shortage of personnel well-versed in international legal affairs related to intellectual property rights has resulted in low profitability for Japanese anime overseas. When video software is sold in the U.S., for example, the distributor generally provides a minimum guarantee and also makes payments if sales exceeded the minimum. Japanese anime rights owners need people who can negotiate with U.S. counterparts on equal terms, and also audit sales performance, to ensure equitable, profitable arrangements in overseas markets").
} 
es of development in the U.S. at the time. ${ }^{460}$ Marketing costs for animation titles in a foreign market could be extremely high in the early stages. For example, a report indicates that the marketing costs, including promotion and advertising of a foreign cartoon for theatrical release in the U.S. will be in the tens of millions. ${ }^{46}$

\subsection{CONCLUSION}

In short, fan activities are of universal importance but also demonstrate unique characteristics in China. On the one hand, they magnify the problems that the copyright regime encountered when entering the digital age; on the other hand, the collision between government's pursuit of economic growth using copyright law and the need to control public expression in order to maintain a stable society is the very reason that some fan creations exist, and that collision is creating some new and unique problems which are hindering effective copyright enforcement in China.

If foreign copyright owners fail to understand the government censorship of China or cannot bear the risk of losing integrity, then it is inevitable that some of their works can never enter the Chinese market officially, notwithstanding the fact that these works are copyright protected in China. Another aspect worth considering is local protectionism. A manifestation of the local protectionism is the explicit and implicit import limitations on foreign works, especially audio-visual works. The existence of these limitations is ensuring that only a controllable amount of foreign works will be introduced annually, and the censorship system is making sure to the best of its ability that no unorthodox contents are out in the market. The former goal represents a nation's will to protect its nascent entertainment industry; the latter reflects the influences that traditional culture has on the government. The purpose is to be "stable" hence the stress of "harmony" has always been put ahead of the protection of private rights in China. Meanwhile, the Internet has built a "quasi-society"

\footnotetext{
${ }^{460}$ Leonard, supra note 240, at 287.

${ }^{461}$ See Ellen Wolff, Foreign Toonmakers Eye U.S. Market: Language, Marketing Costs Make America a Tough Nut to Crack, VARIETY, June 5, 2011, http:/www.variety.com/article/VR1118037712. ("The challenge, he says, is marketing: "Family films are the most expensive to market. You can't get away with $\$ 10$ million-\$15 million in P\&A. You need to be in the $\$ 25$ million- $\$ 30$ million range to have a chance.’”').
} 
which is embracing a "participatory culture" that is facilitated by the new technologies. $^{462}$

When these two big cultural impacts collapse in China, it is foreseeable that the government's will to control the flow of ideas and the masses' will to connect with others and to express themselves will then evolve into an irreconcilable relationship of confrontation. Considering the fact that the traditional channels for civic engagement remain largely limited (even unavailable) for the masses, in order to engage in civic matters, many Chinese citizens, especially many of the youngest generation find it possible and tend to utilize the Internet-based social networks to express their criticisms. It is also a fact that, once the Chinese government has chosen to open its arms to the Internet, it has chosen to loosen up its regulations on freedom of speech.

Another general side effect of the Internet is that the global amount of possible online infringements is nearly infinite; thus it is economically impossible for copyright owners to identify and enforce their rights against each and every infringer. Considering the fact that copyright works are public goods, and the potential problem of information asymmetry that pirates who sell illegal tangible copies of foreign works in China will cause, it is crucial for foreign copyright owners in the Chinese market to consider whether total enforcement is feasible and whether there are alternatives or not.

It is arguable that actions aiming to push the Chinese government to enforce their laws will lead to an unwanted result: many foreign works will be blocked from entering the Chinese market de facto, and will not be able to influence the market on a mass basis. Furthermore, new forms of expression will then be strangled to a degree due to harsh enforcement attitudes of foreign copyright owners. Apparently, at least for now, the protection of copyright and free expression means less for the Chinese government than content control. China is also cleverly using the discretion in its regulatory net to evade WTO attacks on its trade barriers. Therefore, the Chinese government is clearly trying to develop its cultural industry by protecting copyright and by allowing a degree of free expression in the creative process, but with the premise of controlling the content. Moreover, considering fan base building, the overall and persistent influence on foreign markets like China is crucial for industrial copyright

${ }^{462}$ Lee, supra note 16 , at 1500-01. 
owners. In the light of the above-mentioned problems, it is not easy for foreign copyright owners to enforce their rights in China, and it is very hard for foreign works to enter the Chinese market as well. Fan activities, along with digital piracy, could serve as a medium for transporting many foreign audio-visual works when they are searching for a way to enter the Chinese market. Given that China is such a huge market, many countries, including the U.S., are likely to tolerate most unauthorized private uses such as fan activities. Apparently China does not wish to and cannot go back to being a reclusive country, as Chinese people are already enlightened and China itself needs economic development. Thus we will definitely not see China become another North Korea in which people are willing to "risk their lives" to watch foreign audio-visual works. ${ }^{463}$ But clearly China is seeking a balance in between. In any case, foreign copyright owners could expect a comparatively stable investment climate in China. Therefore, it is crucial to explore the fan phenomenon more deeply first, then to examine the problems of fan creation under the laws of specific jurisdictions, and to see whether existing solution proposals, including toleration, could settle the problems definitively. 463 Simon Mundy, North Korea: Glimmer of Hope, FinANCIAL TIMES, Mar. 11, 2014, at
http://www.ft.com/intl/cms/s/2/f3a5c48c-a94a-11e3-9b71-00144feab7de.html\#axzz2wPJefHUi. 


\title{
Chapter 3. The Rise of FAn ACTIVITIES
}

\author{
"Man, the living creature, the creating individual, is always more important than any \\ established style or system." \\ - Bruce Lee
}

Besides the endemic problems that fan creations face in the Chinese market, fan participation has also raised many critical questions to copyright experts all over the world. Before taking that discussion further, it is necessary to have a deeper understanding of fans and their behavior in the digital era, and the opportunities and challenges thereof. For that purpose, the historical and functional aspects of the fan movement and the interconnections between them, and the major changes brought by the Internet and digital technologies are examined. Studying these topics allows us to have a clear understanding of the true cause behind the problems of fan creations.

This chapter takes the recent development and origin of fan activities in different countries as a basis, to explain the legal problems of fan activities and whether the corresponding solutions are sufficient. It first explores the development of several important fan activities and its correlations with new media (para. 3.1). Further, it examines the challenges of the digital technologies that the copyright system is facing (para. 3.2), and draws several conclusions regarding the impasse that copyright owners face when trying to enforce their copyright against fan creations in the digital era (para. 3.3). 


\subsection{The New Media And FAn ACtivities}

Generally speaking, typical fan works include fansubs, fanfics, doujinshi ( 同人誌), scanlations, fanvids, $A M V s$, and Video Parodies. The glossary below gives an overview of these fan works.

Table 1: Glossary of Fan Works

\begin{tabular}{|l|l|l|}
\hline Term & Definition & Example \\
\hline Fansubs & $\begin{array}{l}\text { A term used to describe the activities in which peo- } \\
\text { ple translate and share the subtitles of a certain au- } \\
\text { dio-visual work (sometimes the subtitles are encoded } \\
\text { into the video file) from one language into another. }\end{array}$ & $\begin{array}{l}\text { Japanese Anime fansubs } \\
\text { (such as Naruto, One } \\
\text { Piece) and fansubs of TV } \\
\text { series from US, Japan } \\
\text { and South Korea. }\end{array}$ \\
\hline Fanfics & $\begin{array}{l}\text { A broadly defined term used to describe the unau- } \\
\text { thorized sequel of existing works using its milieus } \\
\text { and characters, written by a fan rather than the orig- } \\
\text { inal author. }\end{array}$ & $\begin{array}{l}\text { Spockanalia, a fanfic of } \\
\text { the famous Star Trek. }\end{array}$ \\
\hline Doujinshi & $\begin{array}{l}\text { A Japanese term for amateur manga publications, } \\
\text { featuring either a cast of original characters and plot } \\
\text { or characters from another manga or an anime. }\end{array}$ & $\begin{array}{l}\text { Doraemon final episode, } \\
\text { a fan made doujinshi by } \\
\text { Yasue T Tajima. }\end{array}$ \\
\hline Scanlation & $\begin{array}{l}\text { A coined word, for the purpose of describing the } \\
\text { activities in which people scan, translate and edit a } \\
\text { manga or comic from one language into another. }\end{array}$ & $\begin{array}{l}\text { Japanese mangas such as } \\
\text { Naruto and One Piece. }\end{array}$ \\
\hline Fanvids & $\begin{array}{l}\text { A term used to describe the practice in which people } \\
\text { create music videos using one or more copyrighted } \\
\text { visual media sources without permission. }\end{array}$ & $\begin{array}{l}\text { Ranging from the Star } \\
\text { Trek to the Sherlock } \\
\text { fanvids. }\end{array}$ \\
\hline AMVs & $\begin{array}{l}\text { A term used to describe the fan-made music videos, } \\
\text { which consist of clips from one or more animation } \\
\text { shows or movies set to an audio track. }\end{array}$ & $\begin{array}{l}\text { Ranging from AMVs of } \\
\text { the Melancholy of } \\
\text { Haruhi Suzumiya to } \\
\text { to }\end{array}$ \\
\hline $\begin{array}{l}\text { Video paruto. } \\
\text { dies }\end{array}$ & $\begin{array}{l}\text { parody expressed in video forms. } \\
\text { The Bloody Case That } \\
\text { Started from a Steamed } \\
\text { Bun. }\end{array}$ \\
\hline
\end{tabular}

This section examines fansubs (para. 3.1.1); fanfics, doujinshis, and scanlations (para. 3.1.2); and fanvids, anime music videos (AMVs), and video parodies (3.1.3) in turn.

\subsubsection{Fansubs}

Fansub is the most prominent example. It is a coined word short for fan subtitling or fan-subtitled works. It is used to describe a certain activity in 
which groups of media fans translate the subtitles of their favorite foreign audio-visual works into their home language. ${ }^{464}$ In terms of audio-visual outputs, Japan is most famous for its manga and anime products, ${ }^{465}$ as well as other products such as drama and feature films. The so-called "fansubbing" activities can be traced back to the Japanese anime production explosion in the 80's. During that period, a significant number of anime works were produced in Japan, but only a few of them were able to enter into foreign markets. First gaining prominence in the U.S., anime fans there formed in groups to translate anime works into English. Within two decades, Fansub groups grew enormously around the world with the help of digital technologies.

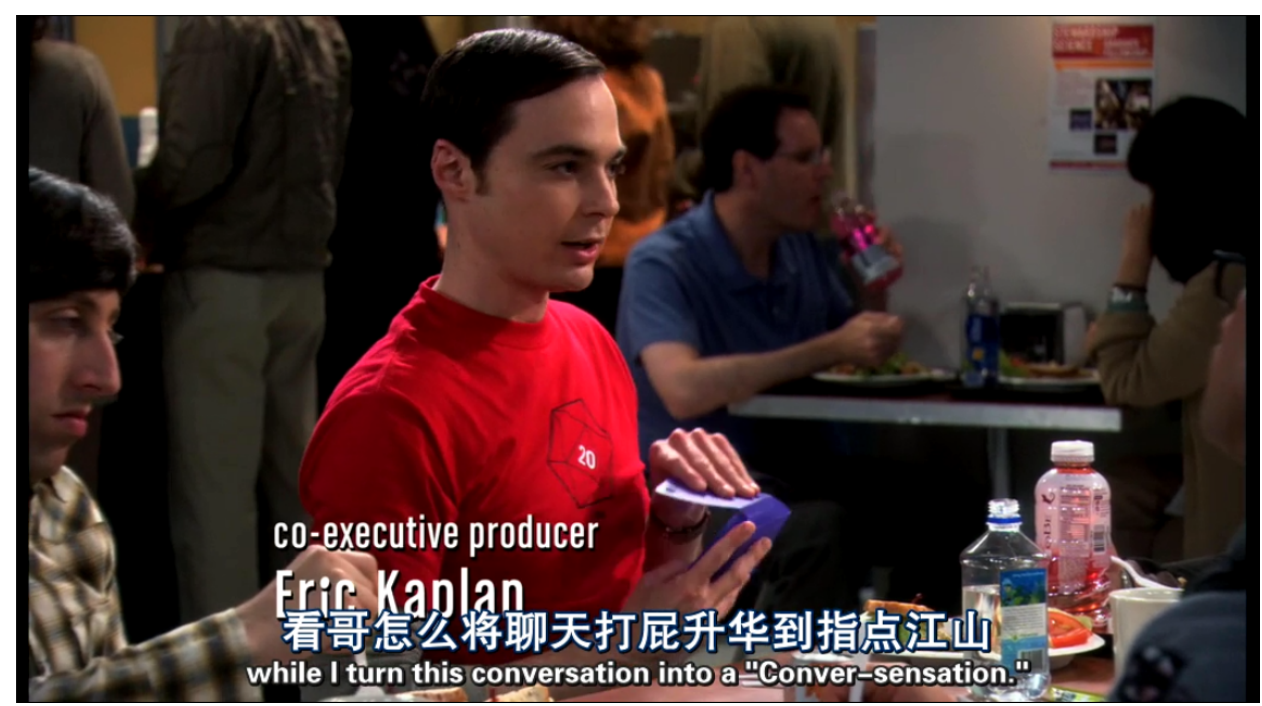

Figure 2: A snapshot of a fansub of the Big Bang Theory ${ }^{466}$

The term "fansub" was initially used to describe the fan-translated Japanese animes that were disseminated among other fans in the U.S., but now it has extended to all types of audio-visual works. In order to present a full view of fansubbing, the following topics are explored: the various

\footnotetext{
${ }^{464}$ Except for some domestic productions that use local dialogues, fansubbers are mainly focused on foreign works that use a foreign language.

465 "Manga" are comics created in Japan. The term "anime," from the Japanese abbreviation for "animation," refers to a style of animation originating in Japan.

466 Snapshot by the author.
} 
motivations for fansubbing (para. 3.1.1.1); the unique development trajectory of fansub (para. 3.1.1.2); and the endeavors of fansub groups to build community norms (para. 3.1.1.3).

\subsubsection{Motivations}

In order to have an idea about why people do fansub in the first place, it is necessary to know their motivations. Jenkins has elaborated on the concept of fandom in the following five levels:

a. It involves a particular mode of reception;

b. It involves a particular set of critical and interpretive practices;

c. It constitutes a base for consumer activism;

d. It possesses particular forms of cultural production, aesthetic traditions and practices;

e. And, it functions as an alternative social community. ${ }^{467}$

From this definition we can see that, first fans are closely related to consumers, and second, the activities which are carried out by a fan community are multilayered and diversified as the community develops, so their motivations could vary a lot over time.

For instance, fansubbing first emerged as a pure fandom activity. Accordingly, the most common motivation of fansubbing at the beginning is to help promoting certain Japanese anime. Study shows that, in order to promote anime more effectively, many international fan clubs of Japanese anime were established in the U.S. between the late 1970s to the end of the 1980s. ${ }^{468}$ Fansubs (in the form of videotapes) were first shared among fan groups, with limited members and distribution methods. This has been changed after entering the digital age: the coverage of fansubs was extended from merely Japanese animes to almost all kinds of audio-visual works. Accordingly, the motivation of fansub groups to share anime works among fans was transformed into the motivation to share their favorite audio-visual works online with everyone. ${ }^{469}$ More specifi-

\footnotetext{
467 JENKINS, supra note 2, at 284-286.

468 Leonard, supra note 28, at 204.

469 Koulikov, supra note 370 ("Nearly all fan subs are now shared digitally, with little or no ties to any established
} 
cally, to practice English and video production, and to have a sense of belonging and community were considered as the dominant motivations of most Chinese fansubbers. ${ }^{470}$ Furthermore, fame and unlimited access to firsthand pirated digital copies of audio-visual works were considered as the motivation of some fansubbers. ${ }^{471}$ In addition, fans of the translations themselves had also emerged. These enthusiasts of translations share their works to improve their translation skills by soliciting feedback from others. ${ }^{472}$

One of the subsidiary motives for fansubbing is that, in the case that a foreign audio-visual work is not officially available in the local market, fansubs enable people to get easy access to that title. ${ }^{473}$ This lack of availability may be caused by market withdrawal or market entry problems. Take as an example foreign audio-visual works that were already out of production, it is very hard to urge film companies who own the copyright of these titles to re-issue them in China, if the cost-benefit analysis of doing so does not look good enough. As for new products, to enter the Chinese market will require dealing with lots of restrictions. ${ }^{474}$ Besides waiting for an unpredictable future introduction of those works, fansubs appeared to be an alternative choice for consumers for the time being.

Moreover, some fans did create and distribute fansubs with the motivation of keeping the integrity of the originals. Previous studies showed that, the integrity of many imported audio-visual works are at risk in different countries. For instance, Japanese animations in the U.S. market are subject to severe censorship, the reason for that being to filter violence and sexual content and to adapt them to the local language environment. ${ }^{475}$ The most notorious case of that will be the rewriting of Hayao

communities... Thus, tightly knit fan subbing groups defined by geography could evolve into essentially global virtual teams defined by working on tasks.").

${ }^{470}$ Donna S. C. Chu, Fanatical Labor and Serious Leisure: A Case of Fansubbing in China, in FrONTIERS IN NEW MEDIA RESEARCH 271 (Francis L. F. Lee ed. Routledge. 2012).

${ }^{471}$ Duo Hao (郝多) \& Yingfei Wang (王颖菲) \& Lei Jia (贾磊), Zimuzu (字幕组) [Fansub Groups], Xiandai Kuaibao (现代快报) [MODERN EXPRESS], Mar. 2, 2014, at http://dz.xdkb.net/html/2014-03/02/content_326140.htm (China).

${ }^{472}$ This is evident as the disclaimer of "for translation practice purposes" is commonly seen at the beginning of many fansub videos.

${ }^{473}$ Koulikov, supra note 370 (“... one of the reasons for the existence of fan subs: the lag between a title's release in Japan and its availability overseas.”). See also B. Dong \& S. Pocock, Chicks On Anime Copyright Enforcement, ANIME News NeTwORK, May 5, 2009, http://www.animenewsnetwork.com/chicks-on-anime/2009-05-05 (“...an overwhelming majority of users said that they'd watch the simulcast if it was available in their country.").

${ }^{474}$ E.g., barrier to trade, screen quota, censorship, government policies, market analysis and company choice, etc. See generally, Priest, supra note 5.

${ }^{475}$ Leonard, supra note 240, at 285. 
Miyazaki's Nausicaä of the Valley of the Wind (1984), which was adapted in 1986 and proved to be a commercial and artistic failure. Isao Takahata, the producer of the original work said: "Censoring them is worse than betraying them" in an open interview. ${ }^{476}$ Moreover, in the U.S., even some of the local cartoons are sanitized for television broadcasting. ${ }^{477}$ Foreign audio-visual works in China are facing the same problem: an interview conducted by the China Central Television (CCTV) shows that imported animation works were under multiple levels of censorship, for the purpose of catering for the works for children. ${ }^{478}$ Some legislation and regulations also indicate that topics such as sensitive political content, obscenity, and violent content are prohibited by the censors too. ${ }^{479}$ The outcome of these policies is that most foreign audio-visual works were sterilized and thus could vary much from their original versions. Some adaptation changed the content to a great extent, leaving the audiences with a vague and misleading version. In this case, neither the copyright owners nor the fans were delighted. In a sense, it is reasonable to say fansubs are a direct result of censorship: fans create and distribute fansubs because they believe that the licensed version may not reflect, and sometimes may even distort, the original expression of the foreign audio-visual works. Fansubs are indeed offering fans who had watched the licensed but censored version and still want to find a way to access the originals. Interestingly, a report shows that some Chinese fansub groups are under the surveillance of SARFT. Every two or three months, the SARFT will send letters to famous fansub groups, telling them to make sure their fansubs avoid certain works with obscene and sensitive contents. ${ }^{480}$

\footnotetext{
476 Interview with Isao Takahata, HAYAO MIYAZAKI WEB, Oct. 1993, at http://www.nausicaa.net/miyazaki/interviews/t_corbeil.html\#fn4.

477 Jason MitTell, Genre and Television: From Cop Shows to Cartoons in American Culture 64 (Routledge. 2004).

${ }^{478}$ Guowai Donghua Pian Dui Zhongguo Ertong Jiazhi Guan de Yingxiang (国外动画片对中国儿童价值观的影响) [Imported Anime's Influences on the Values of Chinese Children], Zhongyang Dianshi Tai (中央电视台) [CCTV], Oct. 12, 2004, http://www.cctv.com/tvguide/tvcomment/special/C11876/20041012/101985_4.shtml.

${ }^{479}$ See Examination Standards Concerning Imported Foreign Television Dramas, art. 4. See also, e.g., Foreign Television Program Import and Broadcast Management Regulations, art. 15; Television Drama Examination Management Regulations, art. 20; Dianshiju Neirong Guanli Guiding (电视剧内容管理规定) [Television Drama Content Management Regulations] (promulgated by SARFT, May 14, 2010, effective July 1, 2010, by SARFT Decree No. 63) art. 5 (China).

${ }^{480}$ Lele (乐乐), Bufen Zimuzu Shouru Da Baiwan Yuan Yingshi Wangluo Fanyi Quzhi Youdao (部分字幕组收入达百 万元 影视网络翻译取之有“道”) [Some Fansub Groups Make Millions a Year: Internet Visual Translation Reap with Their Way], Laodong Bao (劳动报) [LABOUR DAILY], Aug. 6, 2009, http://ld.eastday.com/1/20090806/u1a610796.html (China).
} 


\subsubsection{Development of Fansubs}

It is clear from above that the various motivations for fansubbing have changed over time. This may be due to the worldwide development of fansubs.

With unique style and content, the Japanese animes found their way into the U.S. market around 1975. Although they have to compete with a well-established American cartoon industry and have to live with certain degrees of adaptation, these Japanese animes turned out to be a real success in the American market. ${ }^{481}$ Compared with the co-existent American cartoons, audiences in the U.S. were amazed by the contents and depth of the Japanese animes. Out of their adoration of certain Japanese anime titles, fans started to form groups in which they could translate and distribute their favorite works among other fans.

The emergence of the initial fansub could be traced back to 1986. It was in the late 80 s when fansubbing as a collective action surfaced in America. It is also believed that the video-recordable tapes or cassettes like VHS and Betamax are the first carriers of Fansubs. ${ }^{482}$ During that period, fans first needed to purchase the original copies from Japan, and then use special equipment (which is a heavy investment on fixed assets) to overlay the translated subtitles with the video and record it with tapes. These final products were then circulated within the fan community by post. Due to prohibitively high cost and time investments in producing and sending the fan-made tapes, fansubbed works only reached a limited number of people. ${ }^{483}$ This model of fansub production lasted till the mid 90s, when the personal computer became a mass-consumption item and the Internet became publicly accessible. With costs of fansubbing decreasing, fansubbers in less-developed countries such as China emerged.

In China, audio-visual production went through a unique path when compared to most western countries after the establishment of the People's Republic of China in 1949. Audio-visual production, especially the introduction of foreign titles for the purpose of broadcasting has long been a privilege of the upper class and was firmly controlled by the gov-

\footnotetext{
481 See Trish Ledoux, et al., The COMPlete Anime Guide : JAPANESE ANimAtion Video Directory \& Resource GuIDE 175 (Tiger Mountain Press 1st ed. 1995).

${ }^{482}$ Leonard, supra note 28, at 192.

483 Jordan Hatcher, Of Otakus and Fansubs: A Critical Look at Anime Online in Light of Current Issues in Copyright Law, 2 SCRIPT-ED 551 (2005).
} 
ernment. Furthermore, Chinese history has had an effect with regard to how fansub activity is treated. After 1949, the new Chinese government introduced an “Independence and Self-reliance” (独立自主, 自力更生) policy in the early period of socialist development. The government thus blocked most foreign audio-visual works at certain time periods such as during the Great Proletarian Cultural Revolution. ${ }^{484}$ In other words, China was intent on establishing its own film industry without help, or interference, from Western countries. Of course, there were various reasons for prohibition at that time, such as concerns about the potential problems caused by what was considered by the then Chinese government to be the "bourgeois ideology" in foreign movies, ${ }^{485}$ and the political concern about the influence of the Cold War. It was only after the Chinese Economic Reform, which started from the end of 1978, that a limited number of so-called Western "capitalist" audio-visual works were allowed to enter the Chinese market. However, before the mid 1990s, "entering the market" at that time only meant television broadcasting. ${ }^{486}$ A 2005 report conducted by the China Audio \& Video Association found that the price of VCRs and videotapes was comparatively high for Chinese consumers at that time, and thus the rate of ownership was relatively low as well. ${ }^{487}$ Furthermore, in 1997 the number of authentic titles was 5137 with a circulation of 3.8 million countrywide. ${ }^{488}$ The report also revealed that there was no importation of licensed foreign audio-visual works in tape form in China that year. ${ }^{489}$

The fact is, without any official channel through which to obtain genuine tapes of foreign audio-visual works, the only possible way for Chinese citizens to get access to foreign audio-visual works was through

\footnotetext{
${ }^{484}$ Gary Xu, Edification Through Affection: The Cultural Revolution Films, 1974-1976, in THE OXFORD HANDBOOK OF CHINESE CINEMAS 271 (Carlos Rojas \& Eileen Cheng-yin Chow eds., 2013)(“As soon as the Cultural Revolution began, all the...foregin imports were sealed off...").

${ }_{485}$ It must be noted that, as a convenient term for propaganda slogans, the "bourgeois ideology" notion mentioned here was only used for a short period of time before the open-up period.

${ }^{486}$ According to a 1995 study of the Chinese videotape market, some 20 million Chinese families then owned a videocassette recorder (VCR) nationwide, and the number of videotape theaters and rental shops in China was only around 120,000. See Jianshe Tang (唐建设), Rang Gao Pinwei Di Jiawei De Luxiangdai Jinru Jiating (让高品位低价位的录 像带进入家庭) (Let the Videotape with Higher Quality and Lower Price into Our Family), Chuban Guangjiao (出版 广角) [VIEW ON PUBLISHING], no.2, 1995.

${ }^{487} \mathrm{Ju}$ Wang (王炬), Zhongguo Yinxiang Ye De Fazhan Xianzhuang (中国音像业的发展现状) [Status Quo of the Chinese Audio-visual Industry Development], in ZHONGGUO WENHUA CHANYE FAZHAN BAOGAO (中国文化产业发展 报告) [REPORT ON DEVELOPMENT OF CHINA's CULTURAL INDUSTRY] 151, 151-62 (Xiaoming Zhang (张晓明) et al. eds., 2005).

${ }_{488}$ Id.

${ }^{489} \mathrm{Id}$.
} 
pirated videocassette copies of works officially licensed for Taiwan and Hong Kong. The reason that the pirates could source genuine audio-visual products from there was because the markets in Taiwan and Hong Kong were more open, they faced fewer restrictions and, therefore, many foreign audio-visual works had already been introduced there; another reason that made these products attractive to the pirates was that mainland China shares the same language background as Taiwan and Hong Kong, and those non-Chinese titles which had been officially introduced there already had professionally translated Chinese subtitles. ${ }^{490}$ Given the language barrier in China, it is therefore quite understandable that piracy dealers would prefer to sell copies of foreign audio-visual works with officially well-translated subtitles.

Officially introduced titles could only be found on state-owned television networks in Mainland China. ${ }^{491}$ However, even though increasing numbers of foreign audio-visual works were subsequently introduced into government-controlled television stations, that amount remained rather limited, and they were all dubbed after going through severe censorship, without exception. It was also true, then, that Chinese fans of certain foreign audio-visual works did not possess the necessary equipment, knowledge, sources, and funding to make fansub copies on videotapes as their counterparts in the U.S. were doing; what they did only concerned the distribution of the original copy.

It was only after the mid 1990s that people had access to the Internet which thereby gave them a new means of communication. The Internet has had a tremendous impact on culture and commerce in China. Around the same time, large corporations, such as Sony, Philips, Matsushita, and JVC, developed the Video Compact Disc (VCD) technology, ${ }^{492}$ and established the VCD standard in $1993 .{ }^{493}$ In the U.S., VCDs were not as popular as they were in China from the late 1990s to the early 2000s, with only a few major feature films being released on that format. The invention of the rewritable $\mathrm{CD}$ drive and the CD-R (Compact Disc-Recordable), the CD-RW (Compact Disc Re-Writable) standards,

\footnotetext{
${ }^{490}$ Although there are differences between simplified Chinese and traditional Chinese, they do not cause problems in understanding.

${ }^{491}$ For example, the famous Japanese anime Tetsuwan Atomu (also known as Astro Boy in Western countries) was the first officially introduced title, appearing on China Central Television (CCTV) in December 1980.

${ }^{492} \mathrm{VCD}$ is a standard digital format for storing video on a compact disc.

${ }^{493}$ Philips System Standards and Licensing, Super Video Compact Disc, A Technical Explanation, 1998, at 2, at http://www.datv.de/technische_Infos/SVCD.pdf.
} 
and especially the development of the DVD format explain the reason for the short life of VCDs. ${ }^{494}$ The industry believed that the DVD format was a better choice in terms of protecting their copyrighted content from unauthorized copying, and it replaced VHS tapes as the dominant method of distribution after $2000 .^{495}$ It has been noted that the price of a CD-R recorder (4020i half-height $2 x$ recorder manufactured by Philips) in late 1995 was $\$ 995$, but that that price had dropped to as low as $\$ 99$ by $2000{ }^{496}$ Using these new formats, fansub groups in the U.S. started to distribute CD-Rs via mail in the late 1990s and early 2000s. ${ }^{497}$ However, online distribution quickly supplanted the above-mentioned media as the dominant distribution method by 2002 in the U.S. ${ }^{498}$ It is also believed that most fansubs had turned to digital distribution channels by $2006 .{ }^{499}$

In China, though, fansubs in VCD and DVD forms were never as popular as VHS tapes had become in the U.S. Different types of fan activity took place in China before 2002. The first spate of fansubbers had emerged in China in the late 1990s with the exponential expansion of broadband Internet services. ${ }^{500}$ Before that, due to the natural limits of bandwidth, families in China could only use Internet services with a dial-up modem to handle e-mail, web browsing, and instant chat related issues. Piracy activities were still in their infancy around 2000. What is worth noting is that, in China, because the VCD had quickly become the dominant distribution channel of officially imported foreign titles after $1999,{ }^{501}$ the circulation of videotapes dropped dramatically from 3.8 million to 0.16 million after 1997, with the number of official titles falling from 5137 to 296, in 2003. According to a 2003 survey of the genuine VCD market in China, the total number of foreign audio-visual works in circulation in VCD forms was nearly 100 million. ${ }^{502}$ The VCD standard managed to survive longer in China than it did in the U.S., and this was

\footnotetext{
$494 \quad$ Scot Meyer, Versatile Video CD's Get a Foothold in US, N.Y. $\quad$ TimES, $\quad$ Apr. $\quad 26, \quad 2001, \quad$ at http://www.nytimes.com/2001/04/26/technology/versatile-video-cd-s-get-a-foothold-in-us.html.

${ }_{495}$ Anna Bakalis, It's Unreel: DVD Rentals Overtake Videocassettes, WASHINGTON TIMES, Jun. 21, 2003, at http://www.washingtontimes.com/news/2003/jun/20/20030620-113258-1104r.

${ }^{496}$ Bob Starrett, The History of CD-R, ROXIO NEWSLETTERS, Jan. 17, 2000, at http://mediajet.ru/history-cd-r/.

497 Fansub, BloOMSBURG UNIVERSITY MANGA AND ANIME Club (BUMAC), at http://www.bumac.org/index.php?page=fansub.

${ }_{498}$ Zac Bertschy, 2002 - Fansubs in review, ANIME NEWS NETWORK, Jan. 14, 2003, at http://www.animenewsnetwork.com/feature/2003-01-27/7

499 BUMAC, supra note 497.

${ }^{500}$ Shule Zhang (张书乐), Zumu Zu de Huise Jianghu (字幕组的灰色江湖) [The Grey Coterie of Fansub Groups], Tai Mei Ti (钛媒体) [TMTPOST.COM], Dec. 9, 2013, http://www.tmtpost.com/82623.html (China).

${ }_{501}^{501}$ Wang, supra note 487, at 151-62.

${ }^{502}$ Id.
} 
most probably because the costs of producing pirate VCD copies in China were much lower than VHS tapes. Furthermore, for customers VCDs required less storage space and were cheaper to buy. Considering the general levels of economic development in China in 2002, the late market acceptance of DVDs in comparison with the U.S. is understandable.

Fansub activities using digital technology (Digisubbing) in the U.S. had started early: the cable modem as the signifier of the first broadband opportunity was available in the U.S. in the late $1990 \mathrm{~s},{ }^{503}$ but only after 2001 did the number of subscribers really take off. ${ }^{504}$ In the late 1990 s, the early fansubs being shared through the Internet were merely transformations of earlier VHS fansubs using video capture technologies. ${ }^{505}$ The earliest digisubbing activities in which broadband Internet connection, personal computer (PC), and computer-based software were employed to create and disseminate fansubs were recorded around year $2000 .{ }^{506}$ In China, broadband Internet technology ignited the digisubbing movement from around 2002. By comparison, fansubbers in China started using similar features one year later. ${ }^{507}$ This massive online sharing of fansubs was made possible by the introduction of Peer-to-Peer (P2P) file sharing software such as Napster, Gnutella, Kazaa, Bittorrent, and eMule. In the digital age, raw materials (video files without subtitles) ripped from television recordings, DVDs, even digitalized contents from the earliest Laserdiscs (LDs) and VHS tapes could be shared on the Internet across continents. Fansubbers could locate and download the raw materials, and then use them to produce and distribute fansubs within a very short time. Most of the early fansubbers emerged from certain pre-established BBSs (Bulletin Board Systems), websites, chat rooms, and forums.

The reasons for the fansubbers' switch are apparent: not only do digisubs have better quality pictures and with lower production costs, but also they are much faster distribution channels. They initially started to make fansubs individually, but later several groups were formed, and

\footnotetext{
503 History of Cable Modems, $\quad$ INFORMIT, at http://www.informit.com/library/content.aspx?b=Planet_Broadband\&seqNum=17.

${ }^{504}$ Andrew B. Whinston, IT Policies and Issues: US and the Americas, in INFORMATION TECHNOLOGY POLICY AND THE Digital Divide: Lessons for DEVEloping CounTRIES 66 (Mitsuhiro Kagami, et al. eds., 2004).

${ }^{505}$ BUMAC, Supra note 497.

506 Ask John: What Are Fansubs?, ANIMENATION NEWS BLOG, Dec. 27, 2001, at http://www.animenation.net/blog/2001/12/27/ask-john-what-are-fansubs/.

${ }^{507}$ Yizhen Hu (胡绮珍), Zhongguo Zimu Zu yu Xin Ziyou Zhuyi de Gongzuo Lunli (中国字幕组与新自由主义的工 作伦理) (Chinese Fansub Groups and the Neoliberal Work Ethic), Xinwen Xue Yanjiu (新闻学研究) [MASS COMMUNICATION RESEARCH], no.101, 2009, at 177, 181 (Taiwan).
} 
thereafter fansubbing gradually became a collaborative work. The whole process of creating a fansub then was divided into certain tasks, and different members were assigned to each. ${ }^{508}$ In the late 1990 s, media such as CD-Rs and DVD-Rs were used in fansub distributions. Initially there were several file compression standards relating to the sizes of the fansub files, but for the purpose of maximizing the utility of the carrying media, the most common standard was $700 \mathrm{MB}$, just enough to burn the content onto a typical CD-R disk. With the enormous increase in Internet bandwidth, better optional storage mediums became available, meaning the particular file size for certain media became less important for fansubbers.

Apparently, fansub activities were accelerated by the broadband Internet technology. For instance, whereas previously fansubs had only been circulated within small fan groups with a limited and recordable distribution figure, after entering the digital age, fansub activities were solidified and increased greatly with the help of modern digital technologies. Consequently, fansubs in the digital age could theoretically be shared with countless people, so it is extremely hard to control and monitor the figures related to distribution. Furthermore, we can no longer portray nascent digisubbing activity as merely a fan activity that focuses on Japanese anime. The image of the small coterie has gone, now the word fansub is being used to illustrate fan translation works of all kinds of audio-visual works. Fansubber has thus become a word to characterize those people who translate foreign audio-visual works into their own languages and disseminate them online. Consequently, fan creations in the digital age can theoretically be shared with countless people and, hence, it is impossible to control and monitor the figures related to fan distribution.

According to a previous study, generally a fansubbing process involves 6 participants: raw providers provide the source material; translators are in charge of translation; timers are responsible for fitting the subtitles with the exact dialogues; typesetters decide the font styles and colors of the subtitles; editors and proof-readers take charge of the revision of the translation; encoders use encoding software to produce the final product by combining the subtitles with the raw files. Generally, these tasks are completed by different fansub group members, but practices

\footnotetext{
508 Jorge Díaz Cintas \& Pablo Muñoz Sánchez, Fansubs: Audiovisual Translation in an Amateur Environment, THE JOURNAL OF SPECIALISED TRANSLATION 37, 37 (2006).
} 
with fewer people are common as well. ${ }^{509}$ Generally speaking, raw sources are ripped from certain mediums (TVRips, DVDRips, BDRips, etc.) by specific equipment like analog capture cards and transformed into machine-readable video format. Translators then translate the dialogues with original subtitles and send it to timers and typesetters. ${ }^{510}$ They use software like Sub Station Alpha (SSA) and Virtual Dub to produce subtitle files. ${ }^{511}$ After revision by the editors, the encoders use a set of software packages, including a video codec, to compress the subtitle file and the raw video file into one, and afterwards the group distributes the final product with $\mathrm{P} 2 \mathrm{P}$ software. However, it is also a common practice for fansubbers to avoid the encoding part and only upload the subtitle files to subtitle sharing sites. By doing that fansubbers will receive less pressure from the related industry, as the end-users will do the final compression of the subtitle files with the video file, and boost the transfer speed by reducing the file size tremendously. ${ }^{512}$

At the beginning, digital fansubs were done on an individual basis. It is competition that made fansubbing a group work. Fansubbers realized that by working in groups they could accelerate the process, and thereby snatch the very first flow of audience by fast delivery. For that reason, fansubbers formed different fansub groups to create fansubs of their favorite audio-visual works. At first, the fan community established some rules to allocate different types of work to different groups, according to their preferences. But as more and more fansubbers joined, problems of how to allocate the popular titles popped up. Some fansub groups were not so happy with the assignment of the popular titles, so they started to compete with each other by making fansubs on the same title. As a matter of fact, the enlargement of the fan community and the competition between fansub groups provided better fansubs in terms of quality and variety.

Besides, now fansub groups are not only focused on Japanese animes as they were when VHS tapes were the major carrier of fansubs. With the help of the Internet, fansub groups nowadays on the one hand are having

\footnotetext{
${ }^{509}$ Id. at 38-39.

510 Traditionally, fan translation is usually done via listening, but with the ending of the analog broadcasting and the switchover to digital broadcasting in many countries, many of their channels are now offering extractable subtitles as an option with broadcasting. This will no doubt speed up the translation process.

${ }^{511}$ Existing subtitle formats including .srt, .ssa, .ass, etc.

512 Normally a DVD-rip movie file will occupy 700 megabytes (MB) storage space or more, a BD-rip movie file will take even more than 1 gigabyte (GB) storage space, but a subtitle file only takes less than $1 \mathrm{MB}$ storage space.
} 
a new member explosion; on the other hand, these new comers inevitably have different aims and preferences. Together they challenged the weak concept of fansub and broadened it out from mere Japanese animes into all audio-visual forms. Diversification leads to competition, as members in the same camp began to gather, numerous new fansub groups emerged. Those groups who focus on same genre start to compete with each other in fansubbing by offering faster and higher quality fansubs to the public.

Generally speaking, there are four divisions of fansub groups in China if divided by preferences: The first category is the anime and cartoon fansub group, ${ }^{513}$ which mainly focus on American and Japanese titles. This form of fansub group is most similar to what people called "fansubs" in the U.S. The second type is movie fansub group. They focus on foreign especially English speaking movies, although anime films are within their category, but movie fansub groups usually maintain a delicate distance with that and leave it to anime fansub groups. Most of their movie resources are with various formats, mostly from the so-called "Warez Scene" releases. ${ }^{514}$ The movie fansub group has a close connection with the TV series fansub group-which is the third type that has been continually fansubbing foreign TV series and shows in China. ${ }^{515}$ The U.S productions occupied the biggest part of all the movie and TV series fansubs that were distributed online in China. For instance, Prison Break, an American TV series with a low audience rate initially in its home country, surprisingly gained extremely high popularity in China, and its fansub distribution was deemed as one of the most important factors for that ${ }^{516}$ The last type of fansub groups that can be distinguished is the free source fansub group. Their fansubbing objectives are works with free use licenses like open course videos $^{517}$ and open conference such as TED conferences. ${ }^{518}$

The fansub distribution today can be roughly divided into two categories: sole distribution and package distribution. Sole distribution means

\footnotetext{
513 Although some scholars have understandably claimed that "animation is a medium, not a genre", here Chinese fansub groups are divided by their preferences, but not for the purpose of definition, see e.g., Leonard, supra note 28.

514 The word "warez" is a leetspeak plural form of the word "ware", coined by underground circles of online unauthorized distributions to describe the copyrighted works distributed online without authorization. Warez Scene is used to depict the underground community that specializes in that act.

${ }^{515}$ Most of these TV series and shows are from Japan, Korea, and the U.S.

${ }^{516}$ Sai Chen (陈赛) \& Yu Liu (刘宇), Yueyu de Zhongguo Yinmi Liuxing (《越狱》的中国隐秘流行) [Prison Break's Hidden Popularity in China], Sanlian Shenghuo Zhoukan (三联生活周刊)[LIFEWEEK], no.413, Dec. 21, 2006, at http://www.lifeweek.com.cn/2006/1221/17226.shtml.

${ }_{517}$ Most open course videos are offered by famous universities such as Harvard and Cambridge.

518 Technology, Entertainment and Design conferences are formed to disseminate "ideas worth sharing". The free videos of TED conferences have been offered online in their official site since 2006.
} 
subtitles are distributed separately from raw video files, while in package distribution subtitles and video files are merged into one. Nonetheless, the separable subtitles are often called the "soft" subtitles or soft subs, and they can be easily found in all sole distributions and in some package distributions. In sole distribution, subtitles are separated from video content and uploaded as an individual file, taking the filename extensions of SRT, IDX, and SUB, etc. However, new open standard free container formats such as Matroska can pack multiple files such as subtitle files and video files into a single file, using filename extensions like . $m k v$ and .ogm, etc. The indivisible subtitles in a fansub are often called the "hard" subtitles or hard subs, which are encoded into the footage. The difference between hard subs and free container soft subs is that hard subs cannot be detached from fansubs without losing video quality, while soft subs could be easily extracted from container files like Matroska without quality degradation.

\subsubsection{Self-Rule}

Although with all kinds of good faith and motivations, fansubs are often criticized for their potential copyright infringeing nature. Regarding the fact that commercial pirates are taking advantage of fansubs, seizing the fan-translated subtitles, and even the video files, and sell them directly, and with the concern that they may get into copyright trouble in the future, fansub groups started to put certain warnings and disclaimers into their fansubs, ${ }^{519}$ for the purpose of self regulation and community norm setting.

One part of these notices concerns non-commercial claims such as "Not for Sale or Rent" and "Translation Studies Only, Not for Any Commercial Uses". The non-commercial claims were commonly seen in the preliminary stage of the whole fansub movement. The initial purpose of these is to maintain a pure community of anime sharing for true fans. The fansub groups believe that the existence of a commercial element will breach that purpose, and will lead fansub groups to an unpredictable future. ${ }^{520}$ These non-commercial notices are still a common practice in

\footnotetext{
${ }^{519}$ In most cases, it contains warnings such as "not for commercial purposes". See e.g., The Term of Use, Fansub-share.org, http://fansub-share.org/tou/.

${ }^{520}$ Dichen Yang (杨涤尘) \& Jiaxi Wang (王加喜), Meiju Hanju yu Riju You Yiqun Zhuijuren Jiao Zimuzu (美剧韩剧 与日剧有一群追剧人叫字幕组) [There are a group of people who chase American, Korean, and Japanese dramas called fansub groups], Jing Bao ( 晶 报 )[DAILY SUNSHINE], Aug. 14, 2013, at
} 
today's fansub groups. After entering the digital age, some new disclaimers such as "Translation Studies Only" appeared in China, simultaneously with the practice of distributing the subtitles and raw audio-visual files separately. ${ }^{521}$ Other disclaimers such as "For Internet Services Test Only" and "For Evaluation Purposes Only" were also commonly used by Chinese fansubbers. ${ }^{522}$ The rest of the notices mainly concern the duration of fansubs. The purpose of putting notices like "Cease Distribution When Licensed" and "Please Delete Within 24 Hours" is to avoid direct conflict with the copyright owners' economic interests. According to previous studies, it is evident that in the early days most fansub groups did cease the release of fansubs after the original foreign works were officially launched there. ${ }^{523}$

Fansub groups in China have different perspectives. Most of them put the "Please Delete Within 24 Hours, Please Purchase Licensed Product If You Like It" warning on their fansubs instead of the "Cease Distribution When Licensed" warning. Some fansub groups have continued fansubbing famous titles for the reason of integrity of works, even after those works have been officially licensed in China. ${ }^{524}$

In the era in which the VHS tapes were the main carrier of fansubs, fansub groups that charged for tapes or postages costs are treated as pirates or bootleggers among the fan community. ${ }^{525}$ It also reflects fansub groups' concern about operating costs. Fansub groups nowadays still face the same problem. An estimate shows that the costs of running a fansub site (including the costs of server, bandwidth, and maintenance) in China will take around $60000 \mathrm{RMB}$ (approximately 8800 euros) per year. ${ }^{526}$

\footnotetext{
http://jb.sznews.com/html/2013-08/14/content_2587842.htm.

${ }_{521}$ An argument for copyright infringement exemption like "for translation studies" is only possible, if the subtitle file and audio-visual file are detached.

${ }_{522}$ The original Chinese words will be “仅供网络测试用” and “仅供学习和试看用”.

${ }^{523}$ For instance, the Kiotsukete fansub group in distributing the title "Koko wa Greenwood", and William Chow of the Vancouver Japanese Animation Society in distributing Japanese Animes are following that rule. See Leonard, supra note 28, at 217.

${ }^{524}$ For instance, Toei Animation licensed the famous Japanese Anime One Piece, to Star Group Limited China. But Maplesnow Fansub group (枫雪), which is well known for its fansubs of One Piece, continued their distribution after Star Group started broadcasting the dubbed version of One Piece in mainland China in 2008. The distribution of One Piece fansubs has been parallel with the Star Group broadcast till now. But obviously, in keeping the pace with the original broadcast, fansubs did a better job than Star Group.

${ }_{525}$ Generally, fans used the SASE (self-addressed, stamped envelope) method to deliver fansub copies among fans. See Fansub, ANIME NEWS NETWORK, http://www.animenewsnetwork.com/encyclopedia/lexicon.php?id=63. See also Leonard, supra note 28, at 218-19 (Leonard picked William Chow of the Vancouver Japanese Animation Society as the example).

${ }^{526}$ Lei Wang (王否), Wangluo Zimu Zu Huoli Qudao Fenxi (网络视频字幕组获利渠道分析) (Analysis of Profit Channels of Internet Video Fansub Groups), Dianying Xinzuo (电影新作) [NEW FILMS], no.2, 2012, at 10.
} 
Fansub groups will have to rely on advertising revenues to cover those expenses. However, the legal boundary between just making enough money to keep their sites or forums running and making a profit is quite vague. Although most fansub groups do claim that the advertising incomes are only for maintenance purposes and will be kept in that level, some fansub groups did cross the line evidently. ${ }^{527}$ In addition, a 2009 report illustrated that some of the most popular Chinese fansub groups with a huge member base in hand could earn millions of RMB per year from advertising revenues, sponsors are willing to pay because these big sites could bring in considerable clicks. But only the administrative members could lay their hands on that money, ${ }^{528}$ and apparently the profitability of fansub groups varies a lot. Researchers have also indicated that what constitutes commercialization under the U.S. law is vague and it is hotly debated among fans. ${ }^{529}$

To sum up, fansub groups have adopted multiple rules to regulate their behavior. These rules together formed their community norms. ${ }^{530}$ These norms refer to three major rules: "non-commercial", "cease distribution when licensed", and "continue distribution if licensed products are heavily censored". ${ }^{331}$ For most fansub groups, "non-commercial use" remains the basic principle, ${ }^{532}$ but evidently some fansub groups had al-

\footnotetext{
${ }^{527}$ For example, Btpig, a Chinese fansub group that is famous for fansubbing Japanese TV series and animes such as Naruto, broke down into two groups in 2006 due to differences in the understanding of the fansubbing ethos. The Subpig fansub group (猪猪乐园) now focus on fansubs of Japanese TV series; The Zmpig, later the Jumpcn fansub group (猪猪字幕组) inherited the anime line. When Subpig still adheres to its fansubbing ethos, Jumpcn now had crossed the border of non-commercial use by merging advertising clips of sponsors and their online accessory shop into their fansubs. Moreover, most of the accessories they are selling, such as T-shirts with printed copyrighted anime characters on, are not licensed. However, their "betrayal" triggered discontent among fan communities and audiences. Jumpen was boycotted and alienated by other anime fansub groups, as they believe Jumpen's action will draw too much attention of the copyright owners; audiences dislike Jumpcn's choice because the quality of fansub has deteriorated, as low quality advertising clips were added. Consequently, the fans turned to other fansub groups that were working on the same title, but still Jumpen has its loyal followers.

${ }^{528}$ Lele, supra note 480.

529 Joshua Preston, Georgia Tech Study Reveals Copyright Complexities, Social Norms in Online Media Creation, GEORGIA TECH NEWS CENTER, Feb. 19, 2014, at http://www.news.gatech.edu/2014/02/18/georgia-tech-study-reveals-copyright-complexities-social-norms-online-medi a-creation.

${ }_{530}$ Some call these fansubbing ethos. See Rembert-Lang, supra note 24, at 22-3.

531 Id.

${ }^{532}$ Most famous Chinese fansub groups like TLF (The Last Fantasy) and Maplesnow all have similar warnings. See, e.g., TLF History-the Memoirist of the TLF Fansub Group, The TLF Fansub Group Official Site, http://sub.eastgame.org/wp-content/uploads/2011/03/\%E4\%BA\%86\%E8\%A7\%A3TLF\%E5\%AD\%97\%E5\%B9\%95 \%Е7\%BB\%84-TLF\%E5\%85\%83\%E8\%80\%81\%E5\%9B\%9E\%E5\%BF\%86\%E5\%BD\%95.pdf; see also Disclaimer of Maplesnow Fansub Group, The Maplesnow Official Site, http://bbs.fxdm.net/disclaim.htm.
} 
ready crossed that line. ${ }^{533}$ Fansub groups in China are still evolving but clearly lack proper guidance.

\subsubsection{Fanfics, Doujinshis, and Scanlations}

The term Fanfics is used to describe the unauthorized fan-made sequel of existing works using their milieus and characters. Fan fiction writers take plots, characters and settings mostly from copyrighted books, TV series, and even films, to create their own stories. ${ }^{534}$ Although it is argued that fanfics emerged in the U.S. in the late $1960 \mathrm{~s},{ }^{535}$ scholar has claimed that fanfics has existed for thousands of years. ${ }^{536}$

The Japanese term Doujinshi is the most well-known and interesting analog to fanfics. The initial doujinshi pointed to literal works such as novels, rather than to merely comics and mangas today. ${ }^{537}$ As a phenomenon, doujinshi took off during the 1970s, as low cost self-publication was enabled by the new printing technologies. ${ }^{538}$ Today's doujinshi authors take characters and background elements mainly from pre-existing manga, anime (TV series and movies), or video game sources and develop them with a different story line, and then sell these fan comics for a profit. 539 "Scanlation" is a portmanteau word for scan and translation, it is a word coined to describe activities in which people scan, translate, and edit a manga or comic.

\footnotetext{
${ }^{533}$ Koulikov, supra note 370 (“...the ethical component of the earlier stage of group-controlled fan subbing began to fray as the scene itself grew.").

${ }^{534}$ Rebecca Tushnet, Legal Fictions: Copyright, Fan Fiction, and a New Common Law, 17 LOY. LA ENT. LJ 651 (1997).

${ }_{535} I d$. at 655 .

${ }^{536}$ Stendell, supra note 370, at 1552.

${ }^{537}$ Sharon Kinsella, Japanese Subculture in the 1990s: Otaku and the Amateur Manga Movement, 24 J. JAP. STUD. 289, 295 (1998).

538 Sharon Kinsella, Adult Manga: Culture and Power in Contemporary Japanese Society 104-5 (University of Hawaii Press. 2000).

539 Noda, supra note 28, at 65.
} 


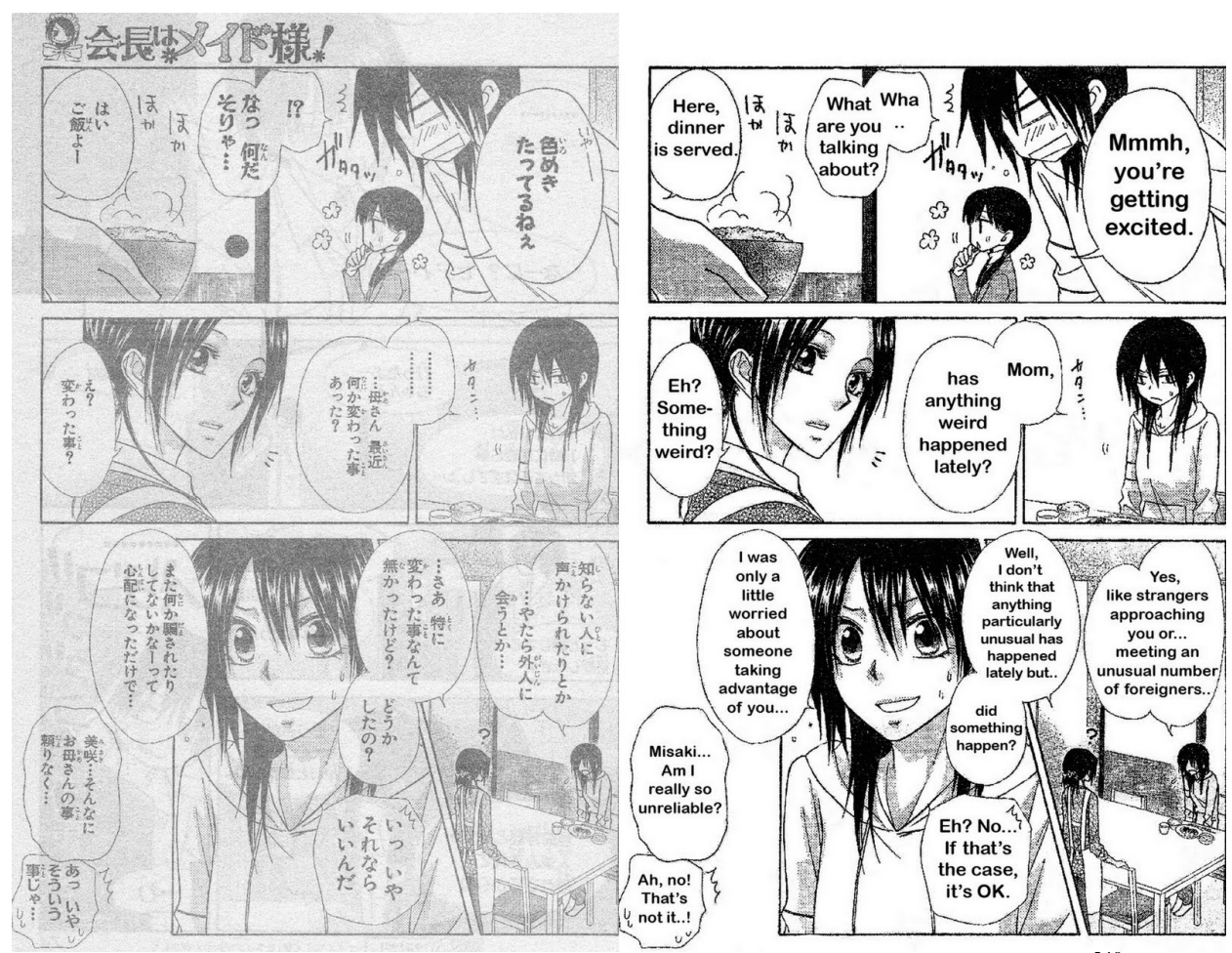

Figure 3: A Comparison between an Original Version and Scanlation of a manga ${ }^{540}$

Since these three types of fan works are all taking the form of books, they are discussed jointly under this subsection. Fanfics and doujinshis are exactly the same thing but with different expressions. Fanfics are literary works whereas doujinshis are generally pictorial. Furthermore, doujinshi authors can sell their works for profit in conventions in Japan whereas fanfic authors cannot. The rationale behind scanlations is similar to fansubs: scanlators merely translated the dialogues and the contents of the manga remain untouched, and they also scan and translate doujinshis as well.

According to Lankshear and Knobel, fanfics today have taken on different forms. The most common ones are in-canon writing, alternative universe stories, cross-overs, relationshipper (or shipper) narratives, and self-insert fanfic. ${ }^{541}$ They summarized these as follow:

\footnotetext{
540 Chris Kincaid, Are Fansubs and Scanlations Piracy?, JAPAN Powered, Oct. 27, 2013, at http://www.japanpowered.com/anime-articles/are-fansubs-and-scanlations-piracy.

${ }^{541}$ Colin Lankshear \& Michele Knobel, Digital Remix: The Art and Craft of Endless Hybridization, Keynote pre-
} 
a. "In-canon writing maintains the settings, characters and types of plotlines found in the original media text as far as is possible, and simply adds new "episodes" or events to the original text. Pre-sequels and sequels are popular versions of in-canon writing.

b. In alternative universe stories, characters from an original media text are transposed into an entirely new or different "world".

c. Cross-overs bring characters from two different original media texts together in a new story.

d. Relationshipper (or "shipper") narratives focus on establishing an intimate relationship between two (often minor) characters where none existed or was downplayed in the original text. These texts can focus on heterosexual relations, or homoerotic/homosexual relations between characters. The latter kind of fanfics is also referred to as "slash fiction."

e. In self-insert fanfic writers insert themselves as recognizable characters directly into a narrative." 542

Theoretically, fanfics and doujinshis do share the same characteristics. Therefore, the forms listed above are also reflected in most doujinshis. For both fanfics and doujinshis, they were only circulated among coteries before the digital age. ${ }^{543}$ However, with the advancement of digital technology, they were digitalized and distributed online, with the help from fans such as scanlators. As fansubs, scanlations are the outgrowth of globalization as well. Just like anime and cartoons, for international audiences comics and mangas are equally attractive. Moreover, the translation of dialogues is a much less burdensome work than translating a whole novel.

\footnotetext{
sented to the International Reading Association Pre-Conference Institute "Using Technology to Develop and Extend the Boundaries of Literacy", Toronto, 13 May 2007, 6-7, at http://extendboundariesofliteracy.pbworks.com/f/remix.pdf.

${ }^{542}$ Id.

${ }^{543}$ For doujinshis, they were sold through regular doujinshi conventions such as the Comiket. For a more detailed discussion on this, see infra Chapter 3.1.2.
} 


\subsubsection{Fanvids, AMVs, and Video Parodies}

Fanvidders create music videos with clips from one or more audio-visual sources, and some of these contents may be copyrighted. They use their fanvid works to express their views on the original work. Some believe that fanvids evolved from fanfics, ${ }^{544}$ Leaving aside the question of whether it is true or not, at least one can infer from the above that fanfics do share similar characteristics with fanvids. Hence the copyright concerns they raise are parallel too. Just as Trombley put it, although most of these fanvids are amateur works, some of these fanvids "display remarkable technical prowess, and aesthetic sophistication". ${ }^{45}$ AMVs are fan-made music videos using anime footages, but the distinction between AMVs and fanvids is only of limited significance with respect to this book. Video parody, as the name suggests, is parody expressed in video form. In a wide sense of the word, video parody includes officially released films such as Charlie Chaplin's The Great Dictator. However, for the purpose of this research, the book only focuses on amateur non-commercial video parodies. Fisher's definition of "digital mash-ups" apparently convers all three fan creations listed above, ${ }^{546}$ since these three types of fan creations are similar in nature as they all build on video segments of pre-existing works. Thus they are examined together under this subsection.

Fanvids are fan created music videos using multiple copyrighted audio and visual snippets from other copyrighted works. In China, most fanvids were created on an individual basis. Comparatively speaking, fanvids, along with AMVs, are less influential and attract less academic attention in China than they do in the U.S. at present. Since many foreign audio-visual titles are being massively and directly infringed upon in China, it is understandable why subtler and more complicated activities, such as fanvids and video parodies, are being ignored to some extent. In short, although theoretically speaking the fanvid is an interesting phenomenon that is worth studying, it has not made much of an impact on the Chinese market yet.

\footnotetext{
${ }^{544}$ Steven A. Hetcher, Using Social Norms to Regulate Fan Fiction and Remix Culture, 157 U. PA. L. REV. 1869, 1870 (2009).

${ }^{545}$ Sarah Trombley, Visions and Revisions: Fanvids and Fair Use, 25 CARDOZO ARTS \& ENT. J. 647 (2008).

${ }^{546}$ Fisher, supra note 23, at 1418 ("Digital mash-ups are created by combining audio, video, graphical, or textual material from pre-existing works into new digital works... Some mash-ups are parodies...”).
} 
Video parodies are more problematic as most of these videos are of a critical nature and, strictly speaking, authors of these works are not merely fans but also critics. The very first well-known case of video parody in China is The Bloody Case That Started from a Steamed Bun (一个 馒头引发的血案, hereinafter, “The Steamed Bun”), a 2006 video parody created by the Chinese video blogger Ge Hu (胡戈). ${ }^{547}$ The author satirized the famous director Kaige Chen's (陈凯歌) epic film The Promise ( 无极) with a twenty-minute video parody which is full of segments of the former. Chen threatened to sue but eventually dropped the idea. ${ }^{548}$ In the wake of The Steamed Bun, numerous forms of video parody have arisen, and some of these have taken the form of both music video and parody. For instance, the famous music video of the South Korean song Gangnam Style inspired countless copycat videos, some of which are only for fun, but some of which utilized the song and its style to satirize what is happening in China. ${ }^{549}$

\subsection{Behind the Fans Activities: Challenges of the Digital ReV- OLUTION}

As a product closely related to digital technologies, fan activities are actually one of the side effects of globalization and digital evolution. As a matter of fact, without the help of new digital technologies, the problems raised by fans would never catch the attention of academia, and fan activities would probably remain in small-scale private form. However, digital developments did change the fan activities and made them a global phenomenon.

In order to clarify the current status of the fandom development, the challenges of the digital evolution behind the law and the fan activities should be further examined. The legal problems of fan activities are rooted in the challenges that our copyright system is currently facing, which are also brought about by advancements in digital technology (pa-

\footnotetext{
${ }^{547}$ See generally, Rogoyski \& Basin, supra note 6.

${ }^{548}$ Seio Nakajima, Film as Cultural Politics, in ReClaiming Chinese Society: The New Social Activism 178 (You-tien Hsing \& Ching Kwan Lee eds., 2010).

${ }_{549}$ See e.g., SFTHQ, Tibetans vs China's Xi Jinping: Gangnam Style, YouTuBE, Nov. 7, 2012, at https://www.youtube.com/watch?v=NxxEo6lEC_U.
} 
ra. 3.2.1). Furthermore, the implications of these advancements on the regulation of the fan problems by law are explored (para. 3.2.2).

\subsubsection{Challenges to the Copyright System}

The existing copyright law regimes are encountering challenges in the face of new advancements in digital technologies. More importantly, the law responded in a way that greatly affected the legal determination of fan activities. This subsection first explores the threatened content industry and its response (para. 3.2.1.1), then the corresponding reflections on copyright laws (para. 3.2.1.2).

\subsubsection{Response from a Threatened Industry}

"We are in the middle of a war. A copyright war." 550 This aphorism is a good description of the situation we are facing now in the copyright field. The "war", as Jack Valenti has suggested, is a "terrorist war" raised by large copyright conglomerates against the invisible individual users, namely the "terrorists." "551 This battle started simultaneously with the emergence of digital technologies at the end of the 1990s. Although copyright protection standards were rising steadily not long before then, never before had copyright owners so earnestly sought the total enforcement of their rights than they did after entering the digital era. This is because the content industries are facing critical challenges brought by the Internet. However, their responses were so traditional and powerless in the face of unauthorized online distributions. Every now and then new campaigns led by Chinese government agencies have appeared and cleaned up some of the illicit copies online. Since these campaigns are just temporary moves and with mixed motives rather than just anti-piracy, and since new methods of file transfer emerge in an endless stream, it is foreseeable that the frequent downloaders and uploaders will keep on distrib-

\footnotetext{
${ }^{550}$ Lawrence Lessig, The Creative Commons, 65 MonT. L. REV. 1, 4 (2004).

551 Amy Harmon, Black Hawk Download: Moving Beyond Music, Pirates Use New Tools to Turn the Net into an Illicit Video Club, N.Y. TIMES, Jan. 17, 2002, at G1, at http://www.nytimes.com/2002/01/17/technology/black-hawk-download-moving-beyond-music-pirates-use-new-toolsturn-net-into.html?src=pm\&pagewanted $=2$
} 
uting as long as the related technologies exist. So this "cat and mouse game" will probably be a story that never ends.

Generally speaking, most of the commercially valuable copyrighted works are controlled by the content industries nowadays. Although most people believe authors of these works should be the major beneficiaries of the related copyright revenues, it is however not the case. Furthermore, economic research had shown that, for the majority of the creators rather than copyright owners, copyright protection is not a guarantee of future profit. ${ }^{552}$ It is more or less a winner-takes-all game which prevails in most cultural industries. ${ }^{553}$ Moreover, the concentration process of the content market enhanced the control power of the industry. For instance, it is noted that five companies control $85 \%$ of the U.S. media sources; five big recording labels control $84.8 \%$ of the U.S. music market; and five cable companies broadcast to $74 \%$ of the U.S. cable subscribers. ${ }^{554}$ Compared to its U.S counterpart, the Chinese market is still in its preliminary stage. However, in most of the cases the copyright of a certain work will be transferred to content conglomerates if it is to be commercially exploited.

These content conglomerates own vast amount of works that fansub groups are interest in. Although fans also appropriate segments from pre-existing works to build their own, fan works in general only take up a small portion of the total amount of all the unauthorized utilizations online. Many practitioners in both academia and the audio-visual industry claim that the online unauthorized distribution of copyright contents is a disaster to the copyright owners, which will not only take away a large proportion of revenue from them but also decrease their incentive to produce. ${ }^{555}$ But at the same time, different voices arose from different areas, claiming that the current situation represents a turning point to a new form of copyright protection, and the unauthorized distribution of copyright contents are harmless, if not beneficial to the copyright owners. ${ }^{556}$ That is to say, whether the unauthorized online distribution of

\footnotetext{
${ }_{552}$ Martin Kretschmer \& Friedemann Kawhol, Chapter 2: The History and Philosophy of Copyright, in MUSIC AND COPYRIGHT 43-44 (Simon Frith \& Lee Marshall eds., Edinburgh University Press. 2004).

${ }^{553}$ Id.

${ }^{554}$ LESSIG, supra note 42, at 162.

${ }^{555}$ For example, the Motion Picture Association of America (MPAA) in their 2011 report claimed that the U.S. economy lost $\$ 58$ billion per year in profits due to content theft. See MPAA Statement on Strong Showing of Support for Stop Online Piracy Act, MPAA, Dec. 16, 2011, at http://www.mi2n.com/print.php3?id=149522.

${ }_{556}$ For instance, author Rob Reid questioned MPAA's \$58 billion number in the recent TED event, and he further indicated that the overall movie revenues are not down but on the contrary, increasing. See Rob Reid, The $\$ 8$ billion
} 
copyright contents is detrimental or not is controversial in both theory and practice. However, the content industry believed that the growing number of online infringements in China is posing a threat to the legitimate market. ${ }^{557}$ Considering both piracy and fan creations are all unstable factors and the copyright owners lack a proper way to distinguish between the two, the profit-driven conglomerates will try to eliminate them both to the best of their abilities and regain control over their works. To that end, copyright owners believe law revision is the perfect solution.

However, in terms of transnational unauthorized distributions, it is the local law and enforcement that really matters. Therefore, much of the efforts have been made to harmonize national copyright laws with international standards. In terms of China, the attitude of the Chinese government towards harmonization is that they will follow suit based on its own needs. ${ }^{558}$ Nevertheless, how to evaluate the copyright law enforcement in different countries is a difficult question. In terms of China, it is believed that it "has a relatively sophisticated legal infrastructure for the grant and enforcement of copyright rights". 559 Most copyright owners resort to courts in response to copyright infringements, ${ }^{560}$ so in that sense China is very active in enforcing copyrights. However, in terms of online infringements, things have not changed very much. But it does not necessarily mean that the Chinese government and the industry are vulnerable in this part. Actually, the Chinese government uses certain national campaigns to fight unauthorized online distribution. Interestingly, it is usually the political considerations rather than economical incentives that are the driving force behind these campaigns. ${ }^{561}$ Notwithstanding the fact that

\footnotetext{
iPod, TED CONVERSATIONS, Mar. 2012, at http://www.ted.com/talks/rob_reid_the_8_billion_ipod.html

${ }^{557}$ See China (PRC), 2014 Special 301 Report On Copyright Protection and Enforcement, IIPA, Feb. 7, 2014, at 24, at $\mathrm{http}: / / \mathrm{www} . i i p a . c o m / \mathrm{rbc} / 2014 / 2014$ SPEC301CHINA.PDF (“...China is fast becoming the largest potential market in the world, and while some progress has been made to license services in China, the challenge of online infringement and illegal web and mobile services harming right holders in (and outside) China has grown faster than the legitimate market.").

${ }^{558}$ Peter K. Yu, Still Dissatisfied after all These Years: Intellectual Property, Post-WTO China, and the Avoidable Cycle of Futility, 34 GA. J. INT'L \& COMP. L. 143, 153 (2005).

${ }_{559}$ Eric Priest, Copyright Extremophiles: Do Creative Industries Thrive or Just Survive in China's High Piracy Environment?, 27 HARV. J.L. \& TECH. 467, 473 (2014).

56051,351 civil copyright cases were litigated in China in 2013. Supreme People's Court (最高人民法院), Zhongguo Fayuan Zhishi Chanquan Sifa Baohu Zhuangkuang 2013 (中国法院知识产权司法保护状况 2013) [Intellectual Property Protection by Chinese Courts in 2013], in Renmin Fayuan Bao (人民法院报) [PEOPLE's CouRT DAILY], Apr. 26, 2014, available at http://rmfyb.chinacourt.org/paper/html/2014-04/26/content_81363.htm?div=-1.

${ }_{561}$ For instance, in 2004 SARFT had issued a regulation that required every participant who engaged in information network dissemination of audio-visual works to obtain a "License for Publication of Audio-Visual Programs through Information Network". See Measures for the Administration of the Publication of Audio-Visual Programs through the Internet or Other Information Network, art. 6. For years online content distributors that have been engaging in unau-
} 
these actions were mostly for purposes of regulating the market and political considerations, they had effectively limited local piracy to a degree. Moreover, CCL was revised frequently and is now undergoing its third major revision. ${ }^{562}$ However, it is also notable that article 46 from the first draft of the recent amendment of $\mathrm{CCL}^{563}$ triggered anger and resistance in the music industry and was removed from the next version. ${ }^{564}$

\subsubsection{Reflections in the Copyright Laws}

The discussion above illustrates that the challenges that the content industry is facing have forced them to push for law reform. However, as its requests are not in accordance with the purpose of copyright, till now the results are far from satisfactory.

The main purpose of copyright law is about maintaining the 'delicate balance' between the interests of the authors or copyright holders and the interests of the public. ${ }^{565}$ That 'delicate balance' was maintained for many years in the pre-digital age, because producing physical copies was costly and time-consuming then. ${ }^{566}$ It is recognized that the legal concept of copyright is firmly connected with technologies, and it is also well known that the concept of copyright was invented after the rapid spread of printing technology. ${ }^{567}$ If we count year 1710, in which the Statute of

\footnotetext{
thorized distributions chose to ignore this clause, simply because no specific enforcement measures were taken after that regulation entered into force. However, at the beginning of 2008, SARFT and Ministry of Information Industry together released a more detailed regulation, which states clearly that Internet content providers without obtaining the above-mentioned "License" cannot engage in any Internet audio-visual program service. See Administrative Provisions on Internet Audio-Visual Program Service, art. 7. Actions were taken soon after the release: without obtaining the "License", famous BT sharing sites like BT China, which is an important platform for the distribution of fansubs, were shut down for that reason.

${ }^{562}$ Hong Xue, A User-Unfriendly Draft: 3rd Revision of the Chinese Copyright Law, INFoJustiCE.ORG, Apr. 25, 2012, http://infojustice.org/wp-content/uploads/2012/04/hongxue042012.pdf.

5632010 Copyright Law of the People's Republic of China, art. 4.

${ }^{564}$ Leslie Pappas, China Hears Music, Issues Second Draft of Copyright Law, BloomBerg BNA, Jul. 12, 2012, at http://www.bna.com/china-hears-music-n12884910625/.

565 Paul Goldstein, Copyright's Highway: From Gutenberg to the Celestial Jukebox 176-77 (Stanford University Press. 2003)(noted that "since copyright allows creators and publishers of literary and artistic works to charge a price for gaining access to these works, the inescapable effect is to withhold the work from people who will not or cannot pay that price, even though giving them free access would harm no one else," but "if society withholds property rights from creative work, the price that its producers can charge for access to it will begin to approach zero; their revenues will diminish and, with them, their incentives to produce more.").

566 Joanna Kostylo, From Gunpowder to Print: The Common Origins of Copyright and Patent, in PRIVILEGE AND PROPERTY: ESSAYS ON THE HISTORY OF COPYRIGHT 31 (Ronan Deazley \& Martin Kretschmer \& Lionel Bently eds., 2010).

567 Mark Rose, Authors And Owners: the Invention of Copyright 142 (Harvard University Press. 1993) ("copyright is.... a specifically modern formation produced by printing technology...").
} 
Anne was passed, as the beginning of the concept of copyright, ${ }^{568}$ then during the intervening three hundred year period, the balance between the interests of the author and the interests of the public in the copyright law regime was roughly maintained. During that period, copyright owners generally kept most private copying activities under control, since their profit-oriented nature and desire for a steady source of income compelled them to eliminate every possible 'threat' they could locate. Besides, many fan activities at that time were not deemed a threat at all, considering the size and number of them. That of course was before the digital age.

However, advancements in technologies will cause new problems in copyright law. Digital technologies today have enabled the digitization and high-speed online dissemination of copyright contents. Our copyright system is being challenged severely, considering the marginal costs of producing and distributing digital copies are almost zero. ${ }^{569}$ Therefore, it is understandable that many copyright owners, most of which are large production companies and media conglomerates, choose to push for stricter copyright protection standards. During this process, many efforts in copyright law have been made. Nevertheless, it seems these efforts are more of a result of global political compromise rather than a considered end product. For example, the U.S. copyright owners have invested a lot on lobbying to get favorable legislation in order to regain control. ${ }^{570}$ Copyright owners have put their lobbying efforts on extending the copyright terms of works in order to prolong the business life of their products. ${ }^{571}$ The copyright protection term in U.S has expanded dramatically since the 1790 Copyright Act, from a maximum of 28 years of protection to more than 100 years of protection. ${ }^{572}$ In China, the situation is more or less similar. For the purpose of joining the Berne Convention, China had

\footnotetext{
${ }^{568}$ The beginning of copyright protection is debatable. Most Chinese intellectual property scholars believed that it starts from the Great Song Dynasty (a piece of a document about copy license in 1190-1194 was found in China), but William Alford in his book to Steal a Book Is an Elegant Offense: Intellectual Property Law in Chinese Civilization claimed that it could not be considered as the start because it is merely a proof of government control over publication. See generally ALFORD, supra note 5.

${ }_{569}$ Martin Peitz \& Patrick Waelbroeck, Piracy of Digital Products: A Critical Review of the Theoretical Literature, 18 INFORMATION ECONOMICS AND POLICY 449, 468 (2006).

${ }^{570}$ LESSIG, supra note 42, at 218-20.

${ }^{571}$ In the U.S., The 1998 Sonny Bono Copyright Term Extension Act is deemed as the result of the extensive lobbying from the Walt Disney Company, which is the largest media conglomerate in the world in terms of revenue. See Richard Siklos, Why Disney wants DreamWorks, CNN/Money, Feb. 09, 2009. http://money.cnn.com/2009/02/09/news/companies/disney_dreamworks.fortune/?postversion=2009020914. As a result, the Act is also known as the "Mickey Mouse Protection Act". See Lawrence Lessig, Copyright's First Amendment, 48 UCLA L. REV. 1057, 1065 (2001).

${ }_{572}$ Tom W. Bell, Escape from Copyright: Market Success vs. Statutory Failure in the Protection of Expressive Works, 69 U. CIN. L. REV. 741, 783 (2001).
} 
enacted its first Copyright Law in 1991, in which the general copyright protection term is 50 years after the author's death. Before that, the general copyright protection term was 30 years after the author's death. ${ }^{573}$ If we trace back to the very first legislation draft of China in 1957, the term was 20 years after the author's death. ${ }^{574}$ Skeptics who believe that most of these changes are biased towards the copyright owners are resurfacing, claiming that the situation is lurching from one extreme to another-from anarchy to total control. ${ }^{575}$ Considering the purpose of copyright law, certainly any copyright legislation and reform in this area will have to run the risk of being criticized severely. Almost every new legislature and trade agreement related to copyright will have to go through slings and arrows, because the critical voices believe that it is the economic factors rather than factors related to public interest that are the driving force behind these laws, and hence they are biased towards copyright owners, ${ }^{576}$ and the standards they set do not provide a clear guidance.

Generally speaking, the main problem we are facing now is public anarchy in utilizing copyrighted materials enabled by the new technologies. Theoretically speaking, the function of copyright is to control the copy and distribution of the copyrighted works and make sure the rightholders could benefit from those exclusive rights. ${ }^{578}$ Before entering the digital age, works could only be conveyed to the public through tangible media, thus the ability to copy and disseminate was highly limited and was largely in the hands of professionals. ${ }^{579}$ However, digital technologies have lowered the barriers to copy, remix and distribute with the

\footnotetext{
573 Xinming Cao (曹新明), Guanyu Zhuzuo Quan Baohu Qixian De Tantao (关于著作权保护期限的探讨) [On the Copyright Protection Term], FAXUE (法学) [Law Science] no.4, 1991, at 22.

${ }^{574}$ Baozhang Chuban Wu Zhuzuo Quan Zanxing Guiding Caoan (保障出版物著作权暂行规定草案) [Provisional Rules on Protection of the Copyrights of Published Works (Draft)] (PRC Ministry of Culture, 1957)(China); accord Wenwei Guan, Intellectual Property Theory and Practice: a CRitical Examination of China’s Trips COMPLIANCE AND BEYOND 55 (Springer. 2014).

${ }^{575}$ LeSSIG, supra note 42, at 173; Glynn S. Lunney, Jr., Fair Use and Market Failure: Sony Revisited, 82 B.U. L. REV. 975, 1015 (2002); Glynn S. Lunney, Jr., The Death of Copyright: Digital Technology, Private Copying, and the Digital Millennium Copyright Act, 87 VA. L. REV. 813, 844 (2001); see also Neil Weinstock Netanel, Copyright and a Democratic Civil Society, 106 YALE L.J. 283, 294-297 (1996).

${ }^{576}$ Martin F Halstead, The Regulated Become the Regulators-Problems and Pitfalls in the New World of Digital Copyright Legislation, 38 TULSA L. REV. 195, 228-229 (2002).

577 Michael A Carrier, SOPA, PIPA, ACTA, TPP: An Alphabet Soup of Innovation-Stifling Copyright Legislation and Agreements, 11 NW. J. TECH. \& INTELL. PROP. 21, 30 (2013).

${ }_{578}$ The function of copyright is believed to be "the marketing of works", and "to protect the materials disseminated". L. RAy PATterson \& StANLEy F. Birch, JR., A Unified TheORY OF COPYRIGHT (Craig Joyce ed., 2009), printed in 46 Hous. L. REV. 215, 286, 310 (2009).

${ }^{579}$ Lunney, supra note 575, at 819 (2001).
} 
help of the Internet. ${ }^{580}$ Once it is possible for everyone to copy and spread the copyrighted contents at a negligible cost, the copyright owners somehow lost their control over the seemingly infinite amount of private copy and distribution actions against their copyrighted contents. In other words, they are now unable to locate every infringer if the number of them becomes infinite, and if we consider the economic costs of doing that, this is even more so. ${ }^{581}$ Therefore, the copyright owners are not only pushing for a higher standard of copyright protection in law globally, but also employing new technologies to set the fence. However, On the other hand, these endeavors are facing a backlash from the public for reasons like possible fundamental rights violation. ${ }^{582}$ The high level of protection the copyright owners advocate, and the Digital Rights Management (DRM) technologies and license terms they use tend to trigger a backlash from consumers and countless copyright litigations. ${ }^{583}$ Yet the limited judicial resources each country possesses means the law cannot respond adequately. ${ }^{584}$ It is also noted that, in the U.S., only a small number of copyright litigations regarding fair use issues have been brought to court, and even fewer resulted in a judgment. ${ }^{585}$ In fact, copyright owners are now mainly focusing on large ISPs such as YouTube, while the massive user groups that have committed copyright infringements have been ignored in general. ${ }^{586}$ The problem which copyright systems are facing now, is that an increasing number of people are ignoring the existing legal norms of copyright and turning themselves into outlaws, even though we do have a valid copyright system. ${ }^{587}$ In that sense, the 'delicate balance' in copyright law has been disrupted.

\footnotetext{
${ }^{580}$ Mathias Klang \& Jan Nolin, Tolerance Is Law: Remixing Homage, Parodying Plagiarism, 9 SCRIPT-ED 172 (2012).

${ }_{581}$ See Wu, supra note 42 , at 617-18.

582 See e.g., Julie E. Cohen, DRM and Privacy, 46 COMmuniCATIONS OF THE ACM 47 (2003).

583 See supra note 14 and accompanying text.

${ }^{584}$ For example, the U.S. courts were found overloaded in handling civil cases, including copyright infringement cases. See Overloaded Courts, Not Enough Judges: The Impact on Real People, PFAW, July 21, 2014, at http://www.pfaw.org/sites/default/files/lower_federal_courts.pdf.

${ }^{585}$ Lee, supra note 16 , at 1476-79.

${ }^{586}$ Just like the Supreme Court has indicated in the Grokster case that, "[w]hen a widely shared product is used to commit infringement, it may be impossible to enforce rights in the protected work effectively against all direct infringers, so that the only practical alternative is to go against the device's distributor for secondary liability on a theory of contributory or vicarious infringement.” See MGM Studios, Inc. v. Grokster, Ltd., 545 U.S. 913, 914 (2005). See also Anselm Kamperman Sanders, Intellectual Property Liability of Consumers, Facilitators and Intermediaries: Comparative Concepts, in INTEllectual Property Liability of CONSUMERs, FACILITATORS AND INTERMEDIARIES 15 (Christopher Heath \& Anselm Kamperman Sanders ed. 2012).

${ }^{587}$ LESSIG, supra note 39, at 111.
} 
The abovementioned cases indicate only one thing: existing legal responses in relation to copyright are problematic. Although endeavors have been made to restore the 'delicate balance' in the copyright law, the legal response in relation to copyright is far from satisfactory. ${ }^{588}$ For example, the revision of the Japanese Copyright Law (hereinafter, JCL) that entered into force on 2012 penalizes even first-time unauthorized downloaders with a maximum of two years' imprisonment or fines of up to $¥ 2$ million (approximately 15,400 euros). ${ }^{589}$ The secretive nature of the revision's legislative history, where the bill had gone through a comparatively brief and aberrant discussion in the Diet of Japan, has set off a wide range of resistance at the grassroots level. ${ }^{590}$ The current CCL has been considered outdated as well, with legislators now drafting the third amendment to it. Meanwhile, fans in China frequently participate in the unauthorized utilization and distribution of copyrighted contents, and they are deemed as outlaws in general. But copyright owners in China are dissatisfied with the current level of protection that the CCL affords and are pushing for higher protection levels. Local courts are doing their best to control the situation, but the copyright litigation is seemingly endless. Evidently in China, the balance in copyright law needs to be restored.

Although controversy is unavoidable when new legislation is promulgated, the global backlash suggests that these end results are not good enough. Nevertheless, as long as the purpose of copyright law is to balance public interest with the rights of the individual author or creator, copyright protection should never be a zero-sum game.

\subsubsection{Behind the Challenges: Technology Developments}

It is clear from the above discussion that it is the new technology advancements that are threatening the content industry, changing our copy-

\footnotetext{
${ }^{588}$ See He, supra note 50, at 1010-2. See also Robert C. Piasentin, Unlawful? Innovative? Unstoppable? A Comparative Analysis of the Potential Legal Liability Facing P2P End-Users in the United States, United Kingdom and Canada, 14 INT. J. LAW INFO. TECH. 195, 220-23 (2006).

${ }^{589}$ Chosakukenho (著作権法) [Japanese Copyright Law], Law No. 48 of 1970, amended by Law No. 43 of 2012, art. 119(3) (2012), translated at COPYRIGHT RESEARCH AND INFORMATION CENTER, COPYRIGHT LAW OF JAPAN 79 (Yukifusa Oyama et al. trans., 2013), http://www.cric.or.jp/english/clj/doc/20130819_July,2013_Copyright_Law_of_Japan.pdf (hereinafter Japanese Copyright Law). See also Japan Introduces Piracy Penalties for Illegal Downloads, BBC News, Sept. 30, 2012, http://www.bbc.co.uk/news/technology-19767970.

${ }_{590}$ See Kazuaki Nagata, Copyright Law with Teeth Leaves Download Masses Puzzled, JAPAN TiMES, Jul. 11, 2012, at http://callcenterinfo.tmcnet.com/news/2012/07/11/6430387.htm.
} 
right law, and pushing and converting fan activities into a world-class phenomenon. Likewise, it is the changing law that makes fan activities a copyright problem. Before digging into the problems of fan creations, it is necessary to check the new technologies that are most responsible for the copyright dilemma and the subsequent fan problems, to see how they function and whether they could be modified in a way which is well harmonized with the current copyright regime. The digitization of copyright contents (para. 3.2.2.1), the P2P technologies (para. 3.2.2.2), and the development of other online distribution channels (para. 3.2.2.3) are examined in turn under this subsection.

\subsubsection{The Digitization of Copyright Contents}

The first challenge encountered is the digitization of copyright protected contents. The process of digitization is to convert copyright contents such as audio-visual works, literature, pictorial and audio objects into a digital format, with the help of certain electronic devices. That process, according to McQuail, "allows information of all kinds in all formats to be carried with the same efficiency and also intermingled." 591 However, it also raises critical questions to the existing commercial model of the content industry and the copyright system. First, digitization involves copy, and copy is restricted under the notion of copyright; second, once a digital copy has been made, making a copy and the distribution of it are both fast (one click plus waiting time) and cheap (almost zero cost); third, pirate copies, genuine digital copies and tangible copies are actually competing with each other in the market. ${ }^{592}$ It comes as no surprise, then, that the Google Book Project, which involves the digitization of a massive amount of existing books, drew immediate fire from copyright owners. ${ }^{593}$ Moreover, the technologies that were employed to distribute the copies were attacked as well.

\footnotetext{
591 Denis MCQuail, MCQuail’s Mass Communication Theory 39 (Sage Publications 6th ed. 2010).

${ }^{592}$ Motoko Rich \& Brad Stone, E-Book Price Increase May Stir Readers' Passions, N.Y. TimES, Feb. 10, 2010, http://www.nytimes.com/2010/02/11/technology/11reader.html?_r=0 (reported the battle over the pricing of digital copies of books between the consumers and the copyright owners.).

${ }^{593}$ For a general discussion about the dispute of the Google Book Project, please see Kate M. Manuel, The Google Library Project: Is Digitization for Purposes of Online Indexing Fair Use Under Copyright Law?, CRS REPORT FOR CONGRESS, Nov. 27, 2009, at http://www.dtic.mil/dtic/tr/fulltext/u2/a511070.pdf.
} 


\subsubsection{Peer-to-Peer Technologies}

It is believed that peer-to-peer (P2P) is one of the technologies that will change the future of the Internet, ${ }^{594}$ which scholars such as Lawrence Lessig called the "next great thing for the Internet". 595 It is no exaggeration to say that the $\mathrm{P} 2 \mathrm{P}$ technologies are most responsible for the fast development of fan groups: without the help of this participatory, anonymous, and untraceable file sharing network setting, works of fan labor would never become a global phenomenon. That is to say, P2P technologies are crucial to the distribution of fansubs, and whether these technologies will be accepted by law or not is one of the main concerns especially for fansub groups.

The P2P network is an internet-related concept opposite to client-server network. Technically speaking, a network is considered to be P2P if the elements (peers) that form the system both provide services to other elements (peers) and request services from them. ${ }^{596}$ Unlike the server based client-server network, P2P technologies are decentralized and thus can lower the costs of the first distributor largely by partitioning tasks among peers. As more peers join the swarm, the available capacities of $\mathrm{P} 2 \mathrm{P}$ network and the stabilities of resources also increase proportionally, while in a client-server network the situation is the other way round. To put it simply, these traits of P2P networks changed the cultural landscape of file sharing entirely, by putting the privilege of content distribution from recognizable distributors to anonymous individuals.

As a matter of fact, although distribution methods like Internet Relay Chat (IRC) channels, File Transfer Protocol (FTP) servers, and file hosting services are also widely adopted by fan groups, P2P tools such as BitTorrent and eMule are still their dominant distribution tools. Unlike a centralized network, a P2P network usually does not have a system administrator. The participatory nature that "everyone is a distributor" makes it more complicated when connected with copyright related issues. A 2005 study on P2P file sharing done by CacheLogic ${ }^{597}$ shows that

\footnotetext{
${ }^{594}$ Erick Schonfeld, Post-Napster, Peer-to-Peer Computing Gets Ready for Prime Time, FoRTunE, Oct. $25,2001$.

595 Lee Bruno, Rights Fielder: Lawrence Lessig on Intellectual Property Rights and Cyberspace, RED HERRING, Dec. 4, 2000 .

${ }^{596}$ Gonzalo Camarillo, Ed, Peer-to-Peer (P2P) Architecture: Definition, Taxonomies, Examples, and Applicability, RFC 5694, IETF Networking Group, Nov. 2009, http://tools.ietf.org/pdf/rfc5694.pdf.

${ }^{597}$ CacheLogic is a British P2P traffic management and network intelligence solution company.
} 
nearly $73 \%$ of the overall P2P traffic worldwide was video and audio file sharing, ${ }^{598}$ and most of these flows were copyright-protected contents. ${ }^{599}$

For a long period of time, P2P technologies have been accused as the promoter of unauthorized online copyrighted content exchanges, including fan distributions. Many copyright owners claimed that the P2P technologies threaten the stability of the current copyright protection regime and endangered the public interest. As a result, copyright litigations against P2P service providers have emerged constantly as well. ${ }^{600}$ However, both sides in the copyright debate over P2P technologies in the existing U.S. case laws have strong arguments to support their positions.

A recent report from IPOQUE shows that P2P file sharing generated the most Internet traffic in 8 major regions they had monitored, ranging from 43 percent in Northern Africa to 70 percent in Eastern Europe. ${ }^{60}$ However, content distribution is only one of the four major services provided by $\mathrm{P} 2 \mathrm{P}$ applications. ${ }^{602} \mathrm{P} 2 \mathrm{P}$ technologies are widely applied in many other areas, ${ }^{603}$ and it can be used as a channel to distribute licit works (e.g. works in the public domain and licensed works) as well.

It is fair to say that P2P technologies have many disadvantages, but just as many scholars have noted, we must not turn a blind eye to the endless possibilities of the P2P technologies. ${ }^{604}$ In short, the concern from fan groups that the $\mathrm{P} 2 \mathrm{P}$ technologies will be terminated for legal reasons is unnecessary.

\footnotetext{
598 ZDNet Research for IT Facts, $61.44 \%$ of $P 2 P$ traffic is video, $11.34 \%$ is audio, ZDNET, http://www.zdnet.com/blog/itfacts/61-44-of-p2p-traffic-is-video-11-34-is-audio/8641.

${ }_{599}$ Report: Movie piracy nearing music levels, MEDIA LifE MAGAzINE, Jul. 14, 2004, http://www.medialifemagazine.com:8080/news2004/Jul04/Jul12/3_wed/news8wednesday.html.

${ }_{600}$ See e.g., A\&M Records, Inc. v. Napster, Inc., 239 F.3d 1004,1029 (9th Cir. 2001); Metro-Goldwyn-Mayer Studios, Inc. v. Grokster Ltd., 380 F.3d 1154, 1161-62 (9th Cir. 2004).

${ }_{601}$ Hendrik Schulze \& K. Mochalski, Internet Study 2008/2009, IPOQUE, at https://www.christopher-parsons.com/Main/wp-content/uploads/2009/04/ipoque-internet-study-08-09.pdf.

${ }^{602}$ Camarillo, supra note 596.

${ }^{603}$ For example, P2P technologies nowadays are firmly connected with lots of mainstream commercial software like Skype and video streaming services and online audio-visual sharing platforms as Joost. Moreover, official authorities like the U.S. Department of Defense launched its modern network warfare strategy research on P2P networks in 2001. See Leslie Walker, Uncle Sam Wants Napster! The WASHINGTON Post, Dec. 8, 2001, at http://pqasb.pqarchiver.com/washingtonpost/doc/409185410.html?FMT=ABS\&FMTS=ABS:FT\&date=Nov $+8 \% 2 \mathrm{C}+2$ 001\&author $=$ Walker\%2C+Leslie\&desc $=$ Uncle+Sam+Wants + Napster\%21. The European Union (EU) has also invested 14 million euros in a $\mathrm{P} 2 \mathrm{P}$ based Internet television research project, aiming to provide video-on-demand functionality and community features for a range of devices. Janko Roettgers, EU Sponsors P2P TV with 14M Euros, GiGAOM, Feb. 9, 2008, at http://gigaom.com/video/eu-sponsors-p2p-tv-with-19m-euros/.

${ }^{604}$ See Alfred C Yen, Sony, Tort Doctrines, and the Puzzle of Peer-to-Peer, 55 CASE W. RES. L. REV. 815, 818 (2005)(mentioning the social benefits of the P2P technologies). See also LESSIG, supra note 42, at 66 (mentioning $\mathrm{p} 2 \mathrm{p}$ sharing is different from piracy, and the industry should find a way to protect artists while enabling $\mathrm{p} 2 \mathrm{p}$ sharing to survive).
} 


\subsubsection{Unstoppable Trend of Online File Sharing}

The P2P distribution method is powerful for sure, but it is not alone, together with other Internet distribution methods, they have formed the new era of online file sharing. With the development of digital technologies, and as more new transmission methods are developed, private file sharing is becoming a seemingly unstoppable trend. ${ }^{605}$ One of the reasons that these new technologies cannot be banned is that they can be used for other purposes than merely copyright infringement. For instance, In the U.S., the ruling of the Sony case made it clear that, as long as a technology has "significant non-infringeing uses", the law should not ban it. ${ }^{606}$ In China the courts hold the same opinion. For example, a study showed that no lawsuit directly concerning P2P technologies had ever been raised in China up to the present, ${ }^{607}$ and related rulings showed that, since the distribution technologies can be used in non-infringeing ways, thus they were deemed legal. ${ }^{608}$ Moreover, there are various online file-sharing

\footnotetext{
${ }^{605}$ For example, study shows that, it is technically impossible to put a stop to BitTorrent ecosystem. See Prithula Dhungel, et al., Is BitTorrent Unstoppable? 2007, at 14, at $\mathrm{http} / / /$ citeseerx.ist.psu.edu/viewdoc/download?doi=10.1.1.414.971\&rep=rep1\&type=pdf; Some also noted that it is destined for digital contents to be free, and no one can stop that process. See Anderson, supra note 5, at 191, 201-02.

${ }^{606}$ The evolutionary product in this case that challenged the copyright regime, was a home video recording machine that could be used to make copies of an entire copyrighted work that had been broadcast via television channels. According to the then contemporary U.S. copyright rules, this kind of time shifting technology created potential dangers for the beneficiaries of copyright: Media conglomerates, such as Universal and Disney, still relied heavily on theaters and television broadcastings at that time, and they feared that with this video recording machine they would lose control over their products and advertising revenues. Together they sued the Sony Corporation, alleging that their machine could potentially be used for copyright infringement activities and, thus, Sony should be held responsible for any further infringements. The rulings of the U.S. courts varied; the American judges knew that their decisions might determine whether the 'delicate balance' could be maintained in the future or not. At first, the District Court considered home use recording as fair use, but later the Court of Appeals for the Ninth Circuit held that Sony was liable for contributory infringement. This ruling was reversed afterwards by the Supreme Court, which considered that the new technology had significant non-infringeing uses and, thus, it was indeed a fair use. The final decision of that established a general test to determine whether a new device with a copy or record function infringes copyright law or not. More importantly, the Sony case paved the way for a new market of home video products, and the world has benefited greatly from their sale and that of prerecorded movies. See Sony Corp. of America v. Universal City Studios, Inc., 464 U.S. 417 (1984).

${ }^{607}$ Dufeng He (何笃丰), Wo Guo Bu Cunzai Zhenzheng Yiyi Shang De P2P Qinquan An (我国不存在真正意义上的 P2P 软件侵权案) [There exist no P2P software infringement lawsuist in China], DIANZI ZHISHI CHANQUAN (电子知识 产权) [EleCtronics INTELLECTUAL PROPERTY] no.5, 2009, at 90.

${ }^{608}$ Chinese courts have demonstrated in several cases that, defendants lost the case due to their contributory infringement actions, rather than the technologies they employed. See e.g., Beijing Ciwen Yingshi Zhizuo Youxian Gongsi Su Beijing Zhenglejia Keji Youxian Gongsi Qinfan Zhuzuoquan Jiufen An (北京慈文影视制作有限公司诉 北京正乐佳科技有限公司侵犯著作权纠纷案) [Beijing Ciwen Video Production Co., Ltd. v. Beijing Zhenglejia Technology Co., Ltd.], (People’s Ct. of Haidian District, Beijing, HMCZ.No.21822, Oct. 29, 2007)(北京市海淀区人 民法院(2007)海民初字第 21822 号), at http://pkulaw.com/fulltext_form.aspx?Gid=117531737\&Db=pfnl. See also Huaxia Shilian Konggu Youxian Gongsi Su Kuaibo Gongsi Lijun Qinfan Zhuzuoquan Jiufen An (华夏视联控股有限 公司诉快播公司、李军侵犯著作权纠纷案) [Huaxia Video \& Connection Holding Co., Ltd. v. Shenzhen Qvod
} 
methods nowadays. No doubt that the P2P distribution method is the most remarkable one in all online file sharing approaches. But the fact is, even if the P2P technologies were banned, fansub groups could find other alternatives easily. Compared with statistics from its previous study, a recent IPOQUE report indicates that, although P2P still produces most Internet traffic worldwide, its proportion has declined significantly across all monitored regions, while web traffic of file hosting sites and media streaming sites has risen. ${ }^{609}$ The increasing popularity of file hosting and media streaming sites among unauthorized distributors can be attributed to bandwidth and data transfer speed upgrades. As for fan distributions, many Chinese fansub groups use file-hosting sites to distribute their fansubs because the services they provide are stable, and since these file-hosting sites are offering private storage spaces, the contents within can also be protected by privacy.

Moreover, once a sharing community is established, the members within will just simply upload the renamed fansub files to file hosting sites and share the download address with their followers, and they then use software to disguise the files in a way that the hosting sites cannot detect. ${ }^{610}$ For example, the 2014 Cleanse the Internet Campaign has forced Chinese ISPs to self-censor their sites since April 2014, and this campaign lasted until November 2014. ${ }^{611}$ The ISPs are now forced to apply additional technical measures to their platforms and software so as to filter out illicit content within their system. However, the users within managed to find a similar way to bypass these technical measures. ${ }^{612}$

Technology Co., Ltd.], (People’s Ct. of Futian Dist., Shenzhen, SFFZCC.No.227, 2009)(深圳市福田区人民法院 (2009)深福法知产初字第 227 号). Guangdong Zhongkai Wenhua Fazhan Youxian Gongsi Su Guangzhou Shulian Ruanjian Jishu Youxian Gongsi An (广东中凯文化发展有限公司诉广州数联软件技术有限公司案) [Zoke Culture Group, Limited. v. Poco Co., Ltd.], (Shanghai First Interm. People's Ct., IPF.No.384, Dec. 12, 2006)(上海市第一中 级人民法院(2006)沪一中民五（知）初字第 384 号).

${ }^{609}$ Schulze \& Mochalski, supra note 601.

${ }^{610}$ A BBC report shows that some distributors even used certain software to split the to-be-distributed content into multiple parts and upload them to different sites. Their followers will receive a list of address where the parts of the files can be downloaded. With common software like WinRAR, the original files could be restored if all the parts were successfully downloaded. Although file names and extensions could reveal some information about the file origin, but when the files are split into multiple parts, it is impossible for service providers to tell which file is unauthorized copyrighted content and which file is not. File-sharers swap more than video, BBC NEWS, Aug. 11, 2005, at http://news.bbc.co.uk/2/hi/technology/4139314.stm.

${ }^{611}$ Jiayi Liu, No to Internet Piracy and Pornography, China Cracks Down on P2P Video Platform, ZDNET, Apr. 24, 2014 ,

http://www.zdnet.com/no-to-internet-piracy-and-pornography-china-cracks-down-on-p2p-video-platform-7000028693 /.

${ }^{612}$ For instance, a popular download application in China, called Xunlei, is also the most common means of unauthorized distribution of copyright contents in China. During the campaign, Thunder had declared that they will be "fully cooperative and resolutely resist any content that involves pornography and copyright issues." Since the down- 
The diversity in file sharing methods and the unstoppable trend brings opportunities: as more and more P2P downloaders were guided to manageable sources such as file hosting sites and legitimate media streaming platforms like YouTube, and P2P technologies are in fact widely used by online streaming platforms, the controversial issues caused by P2P distributions have tailed off to some extent. Nevertheless, challenges come subsequently: unauthorized distributors are merely moving from one network to another due to legal pressure from industry groups; ${ }^{613}$ new online distribution methods and related tools, such as MagNet URI scheme seemingly emerge in an endless stream nowadays; it is much harder for the content industry to protect their audio-visual works from unauthorized online distribution under the current copyright regime. Therefore, the content industry and the law have to respond to these technical facts.

\subsection{CONCLUSION}

As stated above, the fan activities are closely connected with the development of technologies. In the case of fansubs, the videocassettes as VHS and Betamax tapes were the selected media in the early stage of fansub activities. However, they were abandoned soon after the digisubs became available. The U.S. fansubbers switched to digisub production around year 2000 when the broadband Internet service became accessible. The Chinese fansub groups emerged around the same period in which the popularization of high-speed Internet connection began in China. The fansub production is more of a group activity than an individual practice in terms of digisubs. Initially the fansubs in the U.S. emerged as pure fandom activities of Japanese animes. Later with the development of digital technologies and the evolution of fansub groups, many more people with different motivations had joined the fansub campaign. On the other side, fan community norms were developed and ramified likewise. In order to avoid copyright infringement charges, the fansubbing ethos, which

loading speed boost function is based on their cloud storage, they are actually censoring every file that goes through their cloud server. Any file with sensitive words will be marked and cannot enjoy their speed boost function. However, uploaders sensibly opted to split the original file or compress it before they upload it. In that case, the system is unable to identify whether the file contains illicit content or not. See Xunlei declaration, XunLEI.COM, available at http://act.vip.xunlei.com/vip/2014/report/.

File-sharers move from BitTorrent, BBC NEwS, Aug. 30, 2005, at http://news.bbc.co.uk/2/hi/technology/4196642.stm 
worked as the manifesto of fandom purity at the beginning, was turned into self-discipline after the fansub explosion in the late 1990's. Amongst fansub development in other countries, the fansub development in China is of the most significance. Fansub groups in China today are not working on merely Japanese animes but on almost all kinds of audio-visual works; accordingly, different fansub groups that focus on specific categories of audio-visual works can also be found there. In addition, fansubs have two distribution manners. The division of sole distribution and package distribution is crucial because it may affect the future recognition and judgment of fansubs.

To sum up, the fact that fan works caught the world attention is attributed to the digital revolution. As one of its well-known side effects, the explosion of fan works is tightly attached to new file sharing technologies such as Bittorrent and online streaming. All of these new technologies have advantages and disadvantages, but considering the opportunities they have offered, it is unwise and impossible to put a stop to these technologies. Thus it is the responsibility of the law and the market to consider what measures could be taken to solve the existing problem of fan creations. The law had already responded, but obviously those changes were mostly pushed by and in favor of the copyright owners. Moreover, they disrupted the "delicate balance" in copyright law, and the actions taken by the industries were largely ineffective, conservative, and sometimes problematic.

The findings of Chapter 2 and Chapter 3 constitute the basis for the next chapters: together they revealed that a mode of control and copyright aimed at traditional media production is being challenged by new forms of media consumption and production. In other words, fan activities not only upset traditional notions of authorship underpinning copyright in its classical conception, but also the organizational basis for the Chinese censorship regime. In order to demonstrate the problems of the copyright system in dealing with specific fan creations, the next chapter tests the current legal frameworks of the U.S., Japan, and China with different fan activities, and explores the possible defenses fan creators could invoke within these three jurisdictions. It further explains why our laws cannot produce a satisfactory result, and examines the existing solutions to that. 



\section{Chapter 4. A COMParative EXamination OF FAN ACTIVITIES UNDER CURRENT LEGAL FRAMEWORKS OF THE UNITED STATES, CHI- NA, AND JAPAN}

"The reception of foreign legal institutions is not a matter of nationality, but of usefulness and need. No one bothers to fetch a thing from afar when he has one as good or better at home, but only a fool would refuse quinine just because it didn't grow in his back garden.",614

- Rudolf von Jhering

Before digging deep into the options for addressing problems raised by fan activities in the digital age and looking for answers on how to achieve the "delicate balance" that scholars are yearning for in designing our copyright laws, it is useful to go through the laws related to fan activities, and see whether these fan activities are infringeing or not under the law, and what else can be deduced from doing so.

In order to explain the inadequacy of the existing legal remedies in fixing the problems of fan creations, a comparative analysis on the legal determination of various fan creations (para. 4.1) and the legal defenses available (para. 4.2) is conducted. This chapter also explores the existing solution proposals (para. 4.3) with regard to that inadequacy. In the conclusion of this chapter, the shortages of the existing proposals are identified and discussed (para. 4.4), followed by a conclusion (para. 4.5).

${ }^{614}$ See RudOLF VON JHERING, DER GEIST DES RÖMISCHEN RECHTS 8-9 (1955, vol. 1). 


\subsection{INTERNATIONAL STANDARDS}

Theoretically speaking, since Japan, China, and the U.S. are all members of the UCC (lost its significance after TRIPS), the Berne Convention, the Beijing Treaty on Audiovisual Performances (Beijing Treaty) ${ }^{615}$ and the TRIPS Agreement, both of these conventions explicitly prescribe the principle of national treatment, ${ }^{616}$ copyrighted audio-visual products of member countries are all under protection in Japan, China, and the U.S. However, in terms of the fan activities which are related to certain copyrighted audio-visual works, whether their problem can be addressed by existing international agreements or not is a worthwhile issue to probe into.

As a matter of fact, major international agreements such as the UCC, the Berne Convention, and the Beijing Treaty all contain certain terms regarding copyright limitations and exceptions, ${ }^{617}$ through which fan activities may be justified. These terms are important to fan creations, especially if the Beijing Treaty were to be effective in the future, using clips from audio-visual products to produce fan creations without authorization will be increasingly illegal. ${ }^{618}$ However, the terms of international agreements need to be vague enough to attract as many contracting parties as possible; hence they could only provide principle rules and frameworks for signatories regarding specific issues. That is especially so with respect to the fair use terms. If we put fan activities in the scenario, it is obvious that neither Berne's "three-step test" 619 nor the exceptions set by UCC and the Beijing Treaty can give us a clear answer about whether certain fan creations are copyright infringement or not, as the flexible standards in these treaties will inevitably have to depend on the interpretation and implementation of national courts.

\footnotetext{
${ }^{615}$ Beijing Treaty on Audiovisual Performances (adopted by the Diplomatic Conference on the Protection of Audiovisual Performances in Beijing, on June 24, 2012). China ratified in 2014.

${ }^{616}$ UCC, art. II (1); Berne Convention, art. 5(1); Beijing Treaty, art. 4.

${ }^{617}$ UCC, Art. IV bis; Berne Convention, art. 9(2); Beijing Treaty, art. 13; TRIPS Agreement, art. 13

${ }^{618}$ Mike Masnick, WIPO is Quietly Signing an Agreement to Give Hollywood Stars Their Own Special Version of Copyright, TECHDIRT, Jun. 26 , 2012,

https://www.techdirt.com/articles/20120625/20471219474/wipo-is-quietly-signing-agreement-to-give-hollywood-stars -their-own-special-version-copyright.shtml.

${ }^{619}$ Berne Convention, art. 9(2)("It shall be a matter for legislation in the countries of the Union to permit the reproduction of such works in certain special cases, provided that such reproduction does not conflict with a normal exploitation of the work and does not unreasonably prejudice the legitimate interests of the author.").
} 


\subsection{Legal Determination AT NATIONAL LEVEL}

In the following discussion, this book takes doujinshi, fansubs, fanfics, and fanvids as examples to examine their legality under the copyright-related legislation of Japan, China, and the U.S.

Although supported by numerous fans and many scholars, most fan-based activities are undeniably copyright infringement activities in Japan, China, and the U.S. According to previous studies, at least in these three countries, the likelihood of fan activities satisfying copyright exception requirements is slim at best. ${ }^{620}$ Although this legal conclusion is prima facie reasonable and fair, it cannot solve the aforesaid problems such as domestic censorship and import quotas, which current copyright law regime is facing, ${ }^{621}$ especially when we consider the new challenges brought by the fan activities.

This section examines fansubs (para. 4.2.1), doujinshis and fanfics (para. 4.2.2), and fanvids, AMVs, and video parodies (para. 4.2.3) under the legal frameworks of the U.S., Japan, and China in sequence.

\subsubsection{Fansubs}

Amongst other infringeing activities, fansubbing is one of the most representative examples of how deeply entwined copyright issues and public participation are. This fan participation phenomenon has raised many critical questions from copyright experts around the world. ${ }^{622}$ Despite all sorts of motivations and self-regulations, fansub groups still cannot avoid their legal problems. There is no licensing practice available. As a result, they see their freedom to operate severely curtailed. Even though some of the fansub groups do work on works already in the public domain and works with free licenses, the majority of the fansub groups are distributing copyrighted audio-visual works without authorization.

\footnotetext{
${ }^{620}$ See generally, He, supra note 50; see also Kirkpatrick, supra note 27, at 145.

${ }^{621}$ See supra Chapter 2. Fight with the Dragon and Chapter 3.2.1 Challenges to the Copyright System.

${ }^{622}$ According to the official responses of F. Teeven, the State secretary of Safety and Justice of the Netherlands, to the questions raised by the member Oosenbrug (PvdA) of the House concerning the subtitling of films as copyright infringement, fansub as a topic is also highly debated on the parliamentary level in the Netherlands as well. The answers, however, are in favor of copyright owners. See Antwoorden kamervragen over ondertitelen van films als inbreuk op auteursrecht, rijksoverheid.nl, Dec. 19 , 2013 ,

at http://www.rijksoverheid.nl/bestanden/documenten-en-publicaties/kamerstukken/2013/12/20/antwoorden-kamervrage n-over-ondertitelen-van-films-als-inbreuk-op-auteursrecht/lp-v-j-0000004746.pdf.
} 
In the beginning, most fansub groups believed that copyright holders were aware of their distributions and chose to tolerate their action for various considerations, based on the fact that at present no litigation was initiated against fansub groups. They claimed that their fansub activities were therefore justified and the fansub movement is actually beneficial to the copyright owners, as fansubs can serve as free advertisements or developer of foreign markets. ${ }^{623}$ However, recently some copyright owners have demonstrated their discontentment by sending cease-and-desist letters to fansub groups, arguing that fansubs would negatively affect the willingness of foreign licensers to license their audiovisual works, ${ }^{624}$ and their homeland sales. ${ }^{625}$ Fansubs are deemed as a form of piracy, but apparently they are different.

Nevertheless, fansubbers themselves do recognize that fansubbing is a copyright infringeing activity under the current legal regime. Starting from only Japanese anime, fansubbing activity has now spread to almost each and every type of audiovisual work. It is believed that fansubbing is "a particular type of non-commercial translation and subtitling process of foreign mass media products". ${ }^{626}$ Due to the fact that the online distribution of the unauthorized copies of the original works is deeply entwined with most fansubs, the resultant copyright problem is thus to be expected. If we consider the individual elements of it respectively, the only thing that could be deemed as "transformative" is the translation of the subtitles.

This subsection analyzes the fansubs under the current copyright jurisprudences in the U.S. (para. 4.2.1.1), Japan (para. 4.2.1.2), and China (para. 4.2.1.3).

\footnotetext{
${ }^{623}$ Although some argue that "fansubs and illegal video downloading sites have had a deleterious effect on the anime industry, despite fans' attempts to suggest fansubs promote the industry", for new markets "that have not yet gained recognition" like China, "illegal uses may be beneficial". See Lee, supra note 434, at 187-188.

${ }^{624}$ See Leonard, supra note 28 , at 230 (“... granting permission might thwart the incentive of said syndications to be the first to bring the shows to the public.").

${ }_{625}$ See Mikhail Koulikov, ADV films, ANIME NEWS NETWORK, May. 12, 2007, http://www.animenewsnetwork.com/convention/2007/anime-central/advfilms (“...fan subtitling is hurting the industry both in the U.S. and in Japan.").

${ }^{626}$ Y. Tian, Fansub Cyber Culture in China (Apr. 26, 2011) (unpublished M.A. thesis, Georgetown University, UMI No. 1491553), available by subscription in ProQuest Dissertation and Theses database, http://search.proquest.com/docview/865649108?accountid=12339.
} 


\subsubsection{The U.S.}

Translation is categorized as derivative works in the U.S. ${ }^{627}$ Furthermore, Article 103 of the U.S. Copyright Law provides that the "protection for a work employing pre-existing material in which copyright subsists does not extend to any part of the work in which such material has been used unlawfully." 628 It is thus clear that fan creations of a copyrighted work can also be copyright protected in the U.S., with the prerequisite that it is with a degree of originality and its copyright does not prejudice the pre-existing one. ${ }^{629}$ The only difference between the regulations of these countries is that fan creations themselves are denied copyright protection in the U.S. if the usage of the copyrighted material is found to be both unlawful and not justified by the fair use doctrine. Since as derivative works, all fan works fall within the ambit of the original copyright holder, it is therefore crucial to see whether fansubs could be justified by the fair use doctrine or not. However, as previous studies have indicated, attempts to claim fair use will not succeed because most fansubs clearly fail to pass the four-factor test under U.S. copyright law. ${ }^{630}$ For instance, the U.S. courts have noted that, copying factual works such as news articles may have stronger claims to fair use than copying fictional works. ${ }^{631}$ However, in the Nihon keizai Shimbun Inc. v. Comline Bus Data Inc. (the Nihon Case), the court found that even an unauthorized English translation of a Japanese news article, which was done by an American newspaper for the same purpose of news reporting, is not covered by fair use. ${ }^{632}$

\footnotetext{
62717 U.S.C $§ 101(2012)$ (A “derivative work” is a work based upon one or more pre-existing works, such as a translation, musical arrangement, dramatization, fictionalization, motion picture version, sound recording, art reproduction, abridgment, condensation, or any other form in which a work may be recast, transformed, or adapted. A work consisting of editorial revisions, annotations, elaborations, or other modifications, which, as a whole, represent an original work of authorship, is a "derivative work".).

${ }^{628} 17$ U.S.C $\$ 103(\mathrm{a})(2012)$.

${ }^{629}$ For more detailed discussion on this, please see infra Chapter 5.1.3.

${ }^{630}$ Many researches give a negative result when they run the fansubs through the four-factor fair use test. The four factors the U.S. judges will consider are: the purpose and character of your use; the nature of the copyrighted work; the amount and substantiality of the portion taken; and the effect of the use upon the potential market. See Leonard, supra note 28, at 248; See also Rembert-Lang, supra note 24, at 31; Daniels, supra note 25, at 735.

${ }^{631}$ Stewart v. Abend, 495 U.S. 207, 237 (1990); Sony Corp. of America v. Universal City Studios, Inc., 464 U.S. 417 , 455 n.40 (1984).

${ }^{632}$ Nihon keizai Shimbun Inc. v. Comline Bus Data Inc. 166 F.3d 65 (2d Cir. 1999).
} 


\subsubsection{Japan}

As one of the derivative works that is clearly provided for in the law, translation is also subject to the permission of, or license from, the original author, according to the copyright law of Japan. For almost the same reasons as in the case of doujinshi which is discussed in the following section, the translation of movie subtitles is deemed to be a derivative work in Japan. ${ }^{633}$ Simply put, fansub is the translation of an existing work-namely the subtitles of an audio-visual product. As an original and creative part of a copyrighted work, the subtitles are covered by copyright protection, and unlike the situation in the U.S., their translation is certainly subject to the rights of the original work. According to Article 11 of the JCL, the copyright protection granted to derivative works "shall not prejudice the rights of authors of pre-existing works". ${ }^{634}$ What will happen if a derivative work "prejudices" a pre-existing right is that it will be deemed infringeing, unless fansubs can be justified by the copyright exceptions of the JCL. According to Subsection 5 of the JCL, the setting of the "Limitations on Copyright" is an enumerative one. Articles 30 to 50 of the JCL have listed the possible circumstances in which a seemingly infringeing conduct is legally allowed. ${ }^{635}$ Apparently fan creations will fall short of these copyright exceptions listed in the JCL. According to its Article 43, the unauthorized translation of copyrighted works can only be treated as fair use if the translation is for limited purposes such as education. ${ }^{636}$ Therefore, it is clear that fan-translated subtitles, if without permission from the original copyright owner, are copyright infringements, not to mention if their online distribution involves the copyrighted movie files.

\subsubsection{China}

The situation in China is more or less the same as in Japan. Translation of movie subtitles is considered as derivative works in China as well. ${ }^{637}$

\footnotetext{
${ }^{633}$ Japanese Copyright Law, art. 2(xi) (“derivative work means a work created by translating, arranging musically, transforming, or dramatizing, cinematizing or otherwise adapting a pre-existing work").

${ }^{634} I d$. art. 11.

${ }^{635}$ Id. art. 30-50.

${ }^{636}$ See Japanese Copyright Law, art. 43.

${ }^{637} 2010$ Copyright Law of the People's Republic of China, art. 12.
} 
According to Article 10 of CCL, ${ }^{638}$ copyright includes "the right of translation, that is, the right to change the language in which the work is written into another language." Its Article 12 also provides that the copyright of a translated work "shall be enjoyed by the...translator..., provided that the exercise of such copyright does not prejudice the copyright in the pre-existing work." ${ }^{\prime 39}$ Put simply, fan translators in China can translate the copyrighted subtitles and enjoy the copyright of their translation if it is original enough, but so long as their fansubbing activity was not authorized nor permitted by the copyright owner, they cannot exercise their own copyright, unless their activity is covered by the copyright exceptions.

The effect of Article 12 is more or less similar to the result of the decision of the WTO case DS362. As a result of that case, Article 4 of the $2001 \mathrm{CCL}$, which explicitly denied the possibility of copyright enforcement for works that were unable to pass the censorship of the Chinese government, was revised by a 2010 amendment. ${ }^{640}$ According to Article 4 of the 2010 CCL, Copyright holders "shall not violate the Constitution or laws or jeopardize public interest when exercising their copyright," and the Chinese government shall "supervise and administer the publication and dissemination of works in accordance with the law." By which it means that, if the exercise of the copyright of a work is against the laws of China, or the public interest is considered in danger, it will then have problems in the Chinese market. This shows a certain degree of resemblance to derivative works such as translation, as the copyright of the underlying works are all subject to the permission of certain higher powers.

The copyright issue of fansub activities is simple. According to the CCL, translation, as one of the derivative works that has been clearly stated in the law, is also subject to the permission of, or license from, the original author. The translation of a movie's subtitles is no doubt deemed as derivative work in China as well. Apparently unauthorized translation and distribution of the movie subtitles are infringeing the copyrights of the underlined works. According to an interview, Prof. Qian Wang's view of fansubbing is clear: "If a fansubbing activity is without authorization and is not fair use, then in China, they probably will infringe the translation right and the information network transmission right of the foreign

\footnotetext{
${ }^{638} I d$. art. $10(15)$.

${ }^{639} I d$. art. 12.

${ }^{640}$ Creemers, supra note 171 , at 570.
} 
audio-visual product." ${ }^{\circ 41}$ However, the online distribution of the copyrighted works with add-in fansub features is unfortunately a clear copyright infringement, because evidently doing so will substitute the original work, and thus most of them will fall short of the copyright exceptions listed in Article 22 of the CCL. ${ }^{642}$ From this article it is palpable that, unlike the general "fair use" principle that the U.S. has adopted, the CCL contains a clear enumeration of copyright exceptions. Admittedly, online distribution of the original work with added-in fan-translated subtitles definitely constitutes copyright infringement, and does not qualify as one of those highly restricted exceptions. In the case that the distribution of the video files was involved it is all the more so. ${ }^{643}$ As a result, fansubbing is ostensibly illegal, although their non-commercial claims seem fair,

\footnotetext{
${ }^{641}$ See Wenjie Jin (金文婕), Meiju Zimuzu Bei Shoubian Huo Leifeng Yao Zhuanqian (美剧字幕组被收编 “活雷锋” 要赚钱) [Fansub Groups of American Drama were Incorporated, “Living Lei Feng” Needs Money], Xinwen Chenbao ( 新闻晨 报 ) [SHANGHAI MORNING POST], Jun. http://www.jfdaily.com/shanghai/bw/201406/t20140616_448050.html (China).

${ }^{642} 2010$ Copyright Law of the People's Republic of China, art. 22. It provides:
}

In the following cases, a work may be used without permission from, and without payment of remuneration to, the copyright owner, provided that the name of the author and the title of the work are mentioned and the other rights enjoyed by the copyright owner in accordance with this Law are not prejudiced:

(1) use of another person's published work for purposes of the user's own personal study, research or appreciation;

(2) appropriate quotation from another person's published work in one's own work for the purpose of introducing or commenting on a certain work, or explaining a certain point;

(3) unavoidable inclusion or quotation of a published work in the media, such as in a newspaper, periodical and radio and television program, for the purpose of reporting current events;

(4) publishing or rebroadcasting by the media, such as a newspaper, periodical, radio station and television station, of an article published by another newspaper or periodical, or broadcast by another radio station or television station, etc. on current political, economic or religious topics, except where the author declares that such publishing or rebroadcasting is not permitted;

(5) publishing or broadcasting by the media, such as a newspaper, periodical, radio station and television station of a speech delivered at a public gathering, except where the author declares that such publishing or broadcasting is not permitted;

(6) translation, or reproduction in a small quantity of copies of a published work by teachers or scientific researchers for use in classroom teaching or scientific research, provided that the translation or the reproductions are not published for distribution;

(7) use of a published work by a State organ to a justifiable extent for the purpose of fulfilling its official duties;

(8) reproduction of a work in its collections by a library, archive, memorial hall, museum, art gallery, etc. for the purpose of display, or preservation of a copy, of the work;

(9) gratuitous live performance of a published work, for which no fees are charged to the public, nor payments are made to the performers; (10) copying, drawing, photographing or video-recording of a work of art put up or displayed in an outdoor public place;

(11) translation of a published work of a Chinese citizen, legal entity or other organization from Han language into minority nationality languages for publication and distribution in the country; and

(12) transliteration of a published work into braille for publication.

(Translation by WIPO).

${ }^{643} 2010$ Copyright Law of the People's Republic of China, art. 22-23. 
there is still no exception made for fansubs in the law on the grounds of the online publicity they generate and their free accessibility.

\subsubsection{Doujinshis and Fanfics}

If the case of fansubs is somewhat clear, then in the case of doujinshi and fanfiction, the original author's copyright has been encroached upon in a more subtle way. This subsection examines doujinshis and fanfics under the current copyright law jurisprudences in the U.S. (para. 4.2.2.1), Japan (para. 4.2.2.2), and China (para. 4.2.2.3).

\subsubsection{The U.S.}

The copyright problems of doujinshi and fanfics are the same: they both concern the unauthorized utilization of the characters and even plots of pre-existing works.

In terms of doujinshi, although animated characters are under copyright protection in the U.S., ${ }^{644}$ some of the case law shows that the U.S. courts do hold that the copyright in doujinshi-like works have the potential of jeopardizing the original sources. ${ }^{645}$ However, this follows more of a case-by-case analysis in respect of doujinshi, where it is clear that as derivative works under the U.S. copyright law, ${ }^{646}$ their copyright protection will be denied in the United States if the "pre-existing material has been used unlawfully," ${ }^{\prime \prime}$ which is fundamentally different than the regulations of China and Japan. As to a potential fair use claim, although the fair use doctrine in U.S. copyright law is comparatively flexible, the commercial nature of doujinshi and the fact that the fair use claim relies heavily on parody in the U.S. together mean that such a claim is less likely to survive there; most doujinshi offer no criticism of the original works, as they put their emphasis on plot development.

\footnotetext{
${ }^{644}$ See, e.g., Walt Disney Productions v. Air Pirates, 581 F.2d 751, 755 (9th Cir. 1978)(noting that "it is difficult to delineate distinctively a literary character" but that "when the author can add a visual image, however, the difficulty is reduced"). See also Lawrence L. Davidow, Copyright Protection for Fictional Characters: A Trademark Based Approach to Replace Nichols, 8 COLUM.-VLAART \& L. 513 (1983).

${ }_{645}$ Walt Disney Productions v. Air Pirates, 581 F.2d 751, 753-58 (9th Cir. 1978); See also Dr. Seuss Enters. v. Penguin Books USA, Inc., 109 F.3d 1394, 1400 (9th Cir. 1997).

${ }^{646}$ See U.S. Copyright OfFice, Circular 92, Copyright LaW OF the United States of AMERICA AND RELATED LAWS CONTAINED IN TITLE 17 OF THE UNITED STATES CODE (Dec. 2011), http://www.copyright.gov/title17/circ92.pdf.

${ }^{647} 17$ U.S.C. $\$ 103(a)(2012)$.
} 
Correspondingly, copyright holders in the U.S. are much stricter regarding any appropriation of their animated characters compared with in Japan, regardless of whether these usages are commercial or not. For example, fan sites of The Simpsons were shut down because the copyright owners of The Simpsons claimed that they owned all images of the program, and thus to post any images of The Simpsons on the Internet was not permitted by copyright law. ${ }^{648}$ More of these cases could easily be found in the U.S. For example, in 2011, a U.S. comic author produced 200 sketchbooks using the characters of comic works owned by Marvel. Most of these copies were handed out for free, while forty copies were sold. He even gave some to people working in Marvel. Marvel called and asked for ownership of the sketchbooks. They reached a settlement whereby he would remove all infringeing works from his site and stop making any sketchbooks of Marvel-owned characters. ${ }^{649}$ Professor Mehra has thus opined that there is no "significant American commerce in unlicensed use of the cartoon characters of others.",650

As to fanfics, existing case law of the U.S. holds that fanfic-like works do infringe copyright prima facie, because these unauthorized derivative works exhibit literal similarity, and therefore they constitute "substantial similarity" with the original works, ${ }^{651}$ as most of them directly borrow the original characters and even plots from the pre-existing works. ${ }^{652}$ A commentator has also noted that, except for those fanfics that are deemed transformative and original enough, most of them are copyright infringement no doubt. ${ }^{653}$ However, whether the U.S. copyright law protects characters in literature or not is not without controversy. Prof. Nimmer has indicated that, unlike characters in the form of "cartoons or other graphic representations", characters in "word portraits" are not so "readily protectable". ${ }^{654}$ But it is generally agreed that, according to the idea/expression dichotomy, the U.S. copyright law protects literary characters rather than merely names of the characters in general. ${ }^{655}$ In other words, characters must be "distinctly delineated", and

\footnotetext{
${ }^{648}$ LESSIG, supra note 9, at 181-82.

${ }^{649}$ See Sean Gordon Murphy, Grays, DeVIAntART Blog (Feb. 18, 2012, 10:57:22 PM), http://seangordonmurphy.deviantart.com/journal/Grays-285895348.

${ }^{650}$ Mehra, supra note 26, at 171.

${ }^{651}$ Stendell, supra note 370 , at 1554.

${ }_{652}$ See Anderson v. Stallone, 11 U.S.P.Q.2D (BNA) 1161; Copyright L. Rep. (CCH) P22, 665.

${ }^{653}$ Stendell, supra note 370, at 1562-64.

6541 Melville B. NimMER \& DAVID NimMer, Nimmer ON COPYRIGHT, § 2.12, at 2-175 (2002).

${ }^{655}$ See. e.g., 1 Paul Goldstein, Goldstein ON COPYRIGHT \$2 2:92 (Wolters Kluwer Law \& Business 3rd ed.
} 
"the less developed the character, the less they can be copyrighted." 656 And, the alleged infringer must "copy such development and not merely a broader and more abstract outline".

If fanfics are prima facie infringeing, then the question arises of whether they could be justified by the U.S. fair use doctrine or not. Although it is believed that the fair use doctrine in this matter "is most likely an inadequate shield against claims of copyright infringement", ${ }^{658}$ it is believed that most fanfics constitute fair use as well. ${ }^{659}$ However, considering the ambiguity in the fair use test, that kind of judgment depends heavily on the facts of different cases. ${ }^{660}$ For example, in the Suntrust Bank v. Houghton Mifflin Co. case (the Suntrust Bank case), Alice Randall's The Wind Done Gone, which is in fact a fanfic of Margaret Mitchell's Gone with the Wind, was considered as a parody of the latter and thus is protected by fair use. ${ }^{661}$ But in Salinger $v$. Colting the district court found a fanfic of Catcher in the Rye, in which a character was allegedly modeled from the latter "not transformative", because "the character's personality remains intact as derived from the original work". 662

\subsubsection{Japan}

In Japan, whether the JCL protects graphical characters is a difficult question. Although in the K.K. Matsudera v. King Features Syndicate case, the Supreme Court of Japan found that a cartoon character is not a distinct work but an abstract expression, therefore cannot be considered as a copyright protectable work under the then JCL, ${ }^{663}$ in another more

\footnotetext{
2013)("Fully realized characters in literature are little different from fully defined personalities in daily life, and it is no surprise that the test of protectibility that courts apply to literary characters is closely akin to the criterion that individuals apply in daily life to determine whether they in truth know someone. A literary character can be said to have a distinctive personality, and thus to be protectable, when it has been delineated to the point at which its behavior is relatively predictable so that, when placed in a new plot situation, it will react in ways that are at once distinctive and unsurprising."). See also Michael Todd Helfland, Note, When Mickey Mouse is as Strong as Superman: The Convergence of Intellectual Property Laws to Protect Fictional Literary and Pictorial Characters, 44 STAN. L. REV. 623, 630-31 (1991).

${ }_{656}$ Nichols v. Universal Pictures Corporation, 45 F.2d 119, 121, 7 U.S.P.Q. at 87 (2d Cir. 1930).

${ }^{657}$ Columbia Broadcasting Systems., Inc. v. DeCosta, 377 F.2d 315, 321, 153 U.S.P.Q. 649, 654 (1st Cir. 1967), cert. denied, 389 U.S. 1007, 10 L.Ed.2d. 603, 88 S. Ct. 565 (1967).

${ }_{658}$ Stendell, supra note 370 , at 1572.

${ }^{659}$ Hetcher, supra note 544, at 1912.

${ }^{660}$ Tushnet, supra note 534, at 678; See also Kaelyn Christian, Fan Fiction and the Fair Use Doctrine, 65 THE SERIALS LIBRARIAN 277, 284 (2013).

${ }^{661}$ Suntrust Bank v. Houghton Mifflin Co., 268 F.3d 1257, 1276 (11th Cir. 2001).

${ }^{662}$ Salinger v. Colting, 641 F. Supp. 2d 250 (S.D. N.Y. 2009).

${ }^{663}$ K.K. Matsudera v. King Features Syndicate, Inc., Saikō Saibansho [Sup. Ct. of Japan] Jul. 17, 1997, 1992 (O) No.
} 
recent case Keiko Nagita v. Yumiko Igarashi, the Supreme Court of Japan has actually acknowledged that comic characters are copyright protected. ${ }^{664}$ Nevertheless, it is a fact that Japan's legal system is of continental origin, therefore precedents are of no legal binding effect. ${ }^{665}$ But the Supreme Court's attitude shift indicates that, creating doujinshi will probably infringe the copyright of pre-existing works. Judgments of past cases in Japan have made clear that pictorial characters are copyright protected. ${ }^{666}$

Moreover, Article 20 of the JCL, which is a provision that gives authors a right to preserve their integrity ${ }^{667}$, enables them to protect their characters from inappropriate utilizations. As a kind of derivative work, the exploitation of doujinshi is not permitted to encroach upon the rights of the original authors, even though "the adapter's copyright persists irrespective of whether it was created with (the) authorization of the original author or not.",668 Moreover, if we run through the "laundry list" of rights that an author may refer to, from Article 18 to Article 28 of the JCL, it is evident that most doujinshi do actually infringe the right of translation, ${ }^{669}$ the right of preserving the integrity, ${ }^{670}$ and the right of the original author in the exploitation of a derivative work, ${ }^{671}$ unless they could be remitted by the statutory exceptions. ${ }^{672}$ However, it is noted that none of those exceptions perfectly justify doujinshi, ${ }^{673}$ as most such fan works are not for the purpose of criticism and are of a commercial nature.

The copyright problems of fanfics in Japan are similar to those of doujinshis. It can probably be deduced from the above discussion that literary characters alone might not be copyright protected in Japan, as they are even less concrete than visual characters. In that case, if most typical

\footnotetext{
1443, translated at http://www.softic.or.jp/en/cases/popeye.html (Japan).

${ }^{664}$ Keiko Nagita v. Yumiko Igarashi, Saikō Saibansho [Sup. Ct. of Japan] Oct. 25, 2001, Case No. 798 (Ju) of 2000, translated at http://www.tomeika.jur.kyushu-u.ac.jp/ip/pdf/25\%20October\%202001.pdf (Japan).

${ }^{665}$ Kenneth L. Port, Copyright Protection of Fictional Characters in Japan, 7 WIS. INT'L L.J. 205, 213 (1988).

${ }^{666}$ See Peter Ganea, Protected Works, in JAPANESE COPYRIGHT LAW: WritingS IN HONOUR OF GERHARD SCHRICKER 27 n.39 (Peter Ganea et al. eds, 2005).

${ }^{667}$ See Tokimeki Memorial Case, Saikō Saibansho [Sup. Ct., 3d Petit Bench] Feb. 13, 2001, 1999 (RECEIPT) NO.955, translated at http://www.softic.or.jp/en/cases/Tokimemo_Sup.html (Japan). In this case, the court claimed that the defendant's memory card, which could help players of the copyrighted works to steal game credits and directly jump to the end, had infringed the author's "right to preserve the identity of the Game Software."

${ }^{668}$ Ganea, supra note 666, at 28.

${ }^{669}$ Japanese Copyright Law, art. 27.

${ }^{670}$ Id. art. 20.

${ }^{671} I d$. art. 28 .

${ }^{672}$ Id. arts. $30-47$

${ }^{673}$ Yasuhiro Arai \& Shinya Kinukawa, Copyright Infringement as User Innovation, 38 JOURNAL OF CULTURAL ECONOMICS 131, 132 (2014).
} 
fanfics that we have discussed above ${ }^{674}$ only borrowed the characters, they are not copyright infringements. However, if a fanfic borrows not only the characters but also the main plots from a pre-existing work without authorization, then they are arguably infringeing an existing copyright and will probably not qualify as one of the listed copyright exceptions under the JCL. Because under continental copyright jurisprudence which follows the droit d'auteur philosophy, the moral rights of the copyright owners are of essential value. For example, according to the opinion of the Supreme Court of Japan in a case involving parody, "[t]o use another person's work without his permission is legal only when one uses it in such a manner as not to cause the essential characteristics in the expressive form of the work to be perceived directly as such." 775 In other words, the original author's right of preserving the integrity of his work is superior to other's rights in utilizing it. Hence the subsequent work must be transformative enough so that no one could directly distinguish the original elements. In such a case, most fanfics could never satisfy that kind of requirement, because for them obviously it is a way to pay tribute to the original work, and therefore inevitably the audiences will directly perceive "the essential characteristics" of the pre-existing work.

\subsubsection{China}

According to the $2010 \mathrm{CCL},{ }^{676}$ it seems that the Japanese anime works, by virtue of being "[c]inematographic works and works created by a process analogous to cinematography," are under copyright protection in China. ${ }^{677}$ The question of whether an anime character is under copyright protection or not is crucial in the case of doujinshi, since most of them use the original characters of copyrighted works. Previous cases in China have shown that animated characters are under copyright protection there, ${ }^{678}$ thus it would seem that doujinshi constitute copyright infringe-

\footnotetext{
${ }^{674}$ The most common types of fanfics are in-canon writing, alternative universe stories, cross-overs, relationshipper (or shipper) narratives, and self-insert fanfic. See supra Chapter 3.1.2 Fanfics, Doujinshis, and Scanlations.

${ }^{675}$ Supreme Court decision of 28 March 1980, 967 Hanrei Jiho 45, as cited in Keiji Sugiyama, The First Parody Case in Japan, 9 EUR. INTELL. PROP. REV. 285, 287 (1987).

${ }_{676} 2010$ Copyright Law of the People's Republic of China, art. 38.

${ }^{677} I d$. art. 2, art. 3(6).

${ }^{678}$ See Meiguo Woerte Disini Gongsi su Beijing Chubanshe Deng Qinfan Zhuzuo Quan Jiufen An (美国沃尔特·迪斯 尼公司诉北京出版社等侵犯著作权纠纷案) [Walt Disney Co. v. Beijing Publ'n], SuP. PEOPLE's CT. GAZ., 1996, at 136 (Beijing Higher People's Ct. Dec. 19, 1995) (China) (explicitly stating that characters owned by Disney such as Mickey Mouse are all under copyright protection in China). See also Yuangu Zhizuo Zhushi Huishe Su Shanghai
} 
ment, as the original author's right of distribution, ${ }^{679}$ right of adaptation $^{680}$ and right of translation ${ }^{681}$ are all protected by the CCL. As the law explicitly states that, the copyright of these derivatives "may not infringe the copyright in the pre-existing work," ${ }^{\circ 82}$ according to Article 47 of the CCL:

Anyone who commits any of the following acts of infringement shall, depending on the circumstances, bear civil liabilities such as ceasing the infringement, eliminating the bad effects of the act, making an apology or paying compensation for damages:

...

(6) exploiting a work for exhibition or film-making or in a manner analogous to film-making, or for adaptation, translation, annotation, or for other purposes, without permission of the copyright owner, except where otherwise provided for in this Law. ${ }^{683}$

Doujinshi works will clearly be found to be copyright infringements as long as they use the original characters without the permission of the copyright owner.

In the case of fanfics, if they are deemed to be derivative, then according to CCL, they can claim their own copyright, provided that "the exercise of such copyright does not prejudice the copyright in the pre-existing work." will determine whether it can be qualified as copyright exception such as private study. ${ }^{65}$ According to a 2002 interpretation of the SPC, if the expressions of the work are on "the same theme" but are "creative and independently completed," then they are different works and thus could

\footnotetext{
Yuyuan Guoji Shangcheng Gouwu Zhongxin Youxian Gongsi (圆谷株式会社诉上海豫园公司案) [Tsuburaya Productions. v. Shanghai Yuyuan Co.], Selected CASES of THE People’s Court, 2003, at 333 (Shanghai Higher People's Ct. Sep. 11, 2000) (上海市高级人民法院民事判决书沪高知终字第 43 号) (China) (clearly indicating that the anime characters of Ultraman are protected in accordance with the Berne Convention, and the CCL, as the series could be deemed a "painting.").

6792010 Copyright Law of the People's Republic of China, art. 10(6).

${ }^{680} I d$. art. $10(14)$.

${ }^{681}$ Id. art. 10 (15).

${ }^{682}$ Id. art. 12.

${ }^{683}$ Id. art. 47.

${ }^{684} I d$. art. 12.

${ }^{685}$ Id. art. 22.
} 
all enjoy "independent copyright." ${ }^{686}$ For fanfics, it is very hard to assert that they could enjoy independent copyright: they probably will not be considered as "independently completed", as it is true that most fanfics do borrow some elements from other works.

In determining whether fanfics are "derivative" or not in China, two aspects are crucial. The first is "originality," which is the requirement of an adaptation. ${ }^{67}$ By which it means that, in order to be considered as an adaptation with originality, fan works must contribute something original enough. It is very difficult to say that fanfics are without originality, as most of them have developed divergent storylines from the original works. In the light of the causal link between them, a "relevancy" examination is crucial as well, yet to demarcate borders between proper use and copyright infringement is extremely difficult. Generally speaking, the more a fanfic is considered original and departs from the pre-existing works, the less likely it is that it would be found to be a derivative work. Moreover, Chinese courts apply an "access plus substantial similarity" standard to determine whether a fanfic constitutes copyright infringement. ${ }^{688}$ According to this standard, the plaintiff must first prove that the alleged infringer had reasonable chances to "access" his works, and, the work of the latter has "substantial similarity" with his. ${ }^{689}$ In the case of fanfics, it is noted that fanfics like in-canon writing constitute fair use if "limited and appropriate" contents were borrowed. ${ }^{690}$ For instance, a famous work of Chinese fanfiction, Ci Jian de Shao Nian (此间的少年), started to collect its own followers in China around the names of famous

\footnotetext{
${ }^{686}$ Zuigao Renmin Fayuan Guanyu Shenli Zhuzuoquan Minshi Jiufen Anjian Shiyong Falv Ruogan Wenti De Jieshi (最高人民法院关于审理著作权民事纠纷案件适用法律若干问题的解释) [Interpretation of the Supreme People's Court Concerning Several Issues on Application of Law in Hearing Correctly the Civil Copyright] (promulgated by the Supreme People's Court Oct. 15, 2002) (China), translated at WORLD INTELLECTUAL PROPERTY ORGANIZATION, WIPO Lex No. CN038, http://www.wipo.int/wipolex/en/text.jsp?file_id=181509.

${ }^{687} 2010$ Copyright Law of the People's Republic of China, art. 10 (14)(“the right of adaptation, that is, the right to change a work into a new one with originality.").

${ }^{688}$ See e.g., Jiamei Li (李佳梅) \& Mei Du (杜梅), Shizhixing Xiangsi Jia Jiechu Shi Panding Zuopin Qinquan de Hexin Biaozhun (“实质性相似加接触”是判定作品侵权的核心标准) [“Substantial Similarity plus Access” is the core Standard in Copyright Infringement Judgement], in Zhongguo Fayuan Wang (中国法院网) [ChINACOURT.ORG], Feb. 11, 2015, at http://www.chinacourt.org/article/detail/2015/02/id/1554526.shtml. See also Zhuang Yu Yu Guo Jingming Chunfeng Wenyi Chubanshe Zhuzuoquan Qinquan Jiufen An (庄羽与郭敬明、春风文艺出版社著作权侵 权纠纷案) [Zhuang Yu v. Guo Jingming \& Chunfeng Press], (Higher People’s Ct. of Beijing, GMZZ.No.384, May. 22, 2006)( 北 京 市 高 级人 民法院 (2005) 高 民终字 第 539 号 ), at http://bjgy.chinacourt.org/paper/detail/2006/06/id/11071.shtml.

${ }^{689}$ QIAN WANG (王迁), Zhishi Chanquan Fa Jiaocheng (知识产权法教程) [TUTORIALS ON INTELLECTUAL PROPERTY LAW] 246-47 (3rd ed. 2011).

${ }^{690}$ Liang Li (李亮), Lun Xuxie Zuopin de Zhuzuoquan Baohu (论续写作品的著作权保护) [On the Protection of the Copyright of Continuation Works], HEBEI FAXUE (河北法学)[HEBEI LAW SCIENCE], no.2, 2005, at 73.
} 
characters from the works of another reputable writer in 2001. As an "Alternative Universe" fanfiction, the facts of the historical background and story setting were all deliberately altered. ${ }^{691}$ It was published in 2002, reprinted in 2004, and even spawned its own movie in 2011. The copyright owner of those characters (in this case, it is the names of those characters that were actually used by the fan writer) raised no objection.

Furthermore, if scan-copy and online distribution is involved, they might also infringe the author's right of reproduction ${ }^{692}$ and right of information network dissemination. ${ }^{63}$ Any further utilization of the derivative works, such as publication, performance, and audio-visual production, requires a license from both the copyright owner of the derivative work and the copyright owner of the original work, or it would constitute copyright infringement as well. ${ }^{694}$ Considering its purpose and commercial nature, no exceptions prescribed by Chapter 4 of the CCL could be applied.

In all, as a derivative work, most doujinshis and fanfics have undoubtedly crossed the line of private use, and will probably be deemed copyright infringement at least in the U.S., China, and Japan. The chance to invoke a fair use or copyright exception defense within these countries is slim, and it is based on case-by-case judgment.

\subsubsection{Fanvids, AMVs, and Video Parodies}

Fanvids, AMVs, and other audio-visual parodies are more complex when examined under the microscope of copyright law. A fanvid "takes footage from a popular television show or film and reworks it into a music video which comments on or gives a critique on the original source." ${ }^{, 65}$ AMVs can be treated as an offshoot of fanvids: ${ }^{696}$ they both utilize video clips and musical tracks to produce a short video. ${ }^{697}$ Video parodies are actu-

\footnotetext{
${ }^{691}$ Zhanlong Sun (孙战龙), Wangluo Tongren Xiaoshuo de Quanli Jieding (网络同人小说的权利界定) [The Demarcation Between the Rights of Internet Fanfiction Authors and Other Rights], WANGLUO FALÜ PINGLUN (网络法律 评论) [INTERNET LAW REVIEW] 170 (2006).

${ }_{692} 2010$ Copyright Law of the People's Republic of China, art. 10 (5).

${ }^{693} I d$. art. $10(12)$.

${ }^{694} I d$. arts. 35, 37, 40.

695 Trombley, supra note 545, at 649.

${ }^{696}$ Patrick McKay, Culture of the Future: Adapting Copyright Law to Accommodate Fan-Made Derivative Works in the Twenty-First Century, 24 REGENT U. L. REV. 117, 132-33 (2011).

${ }^{697}$ Kirkpatrick, supra note 27, at 136.
} 
ally one kind of fanvids which focus on criticism and satire but do not necessarily take the form of a music video. Therefore, their copyright problems are similar. In the following subsections, the author discusses their copyright problems in the U.S. (para. 4.2.3.1), Japan (para. 4.2.3.2), and China (para. 4.2.3.3).

\subsubsection{The U.S.}

As for the U.S., it is believed that the average fanvid is infringeing if a fair use defense cannot be established. ${ }^{698}$ In terms of the fair use defense, since most fanvids use a full track rather than segments of a music work as their audio track, they will probably fall short of the four-factor fair-use test and be deemed as copyright infringements, if the copyright owner of the music work chooses to sue. ${ }^{699}$ For example, in Grand Upright Music v. Warner Bros. Records, the court found music sampling a "stealing" behavior even though the end product contained a large amount of original created content. ${ }^{700}$ The Sixth Circuit held a similar but more parsimonious attitude towards music sampling in Bridgeport Music, Inc. v. Dimension Films by holding a seven seconds of unauthorized sampling of a copyrighted work infringeing. ${ }^{701}$ However, it is also a fact that sometimes the industry is lenient towards these non-commercial fan activities, as they consider many of these fan videos fair uses and believe they could serve a promotional purpose as well. ${ }^{702}$

The case of video parodies is slightly different: unlike fanvids that "rarely take clips that last more than a few seconds from any given portion of the material," ${ }^{, 703}$ video parodies can consist of footage taken from

\footnotetext{
${ }^{698}$ Trombley, supra note 545, at 660.

${ }^{699} I d$. at 676,684 (" “...the ability of the fanvidder to successfully assert a fair use defense with respect to the video source is irrelevant, except in determining which plaintiffs can actually assert their rights against her; she only needs to be found to infringe on one copyrighted work to be effectively shut down."). See also Kirkpatrick, supra note 27, at 142 ("AMVs use... the song in its entirety. Depending on which owner is claiming infringement, a different finding may result under this factor.").

${ }_{700}$ Grand Upright Music v. Warner Bros. Records, 780 F. Supp. 182, 183 (S.D.N.Y. 1991).

${ }^{701}$ Bridgeport Music, Inc. v. Dimension Films, 410 F.3d 792 (6th Cir. 2005).

702 This is evident from an online interview with the copyright specialists at Funimation. See Dong \& Pocock, supra note 473 ("The main reasons for this are that they can often serve a promotional purpose, and legally, they can sometimes constitute Fair Use. The basic thinking going into fan videos is thus: if it whets the audience's appetite, we'll leave it alone. But if it sates the audience's appetite, it needs to come down."); see also Tim Armstrong, What Gets Created Under a "Tolerated Use" Regime?, INFO/LAW BLOG, Oct. 18, 2007, at https://blogs.law.harvard.edu/infolaw/2007/10/18/what-gets-created-under-a-tolerated-use-regime/ (“...they’ve just found a way to crowdsource their own marketing budgets.").

${ }^{703}$ Trombley, supra note 545, at 667.
} 
only one audio-visual work. For example, in the Steamed Bun case, it was argued that this type of video parody was protected under the fair-use test in the U.S. ${ }^{704}$ However, another case shows that fanvids demonstrated substantial similarity to the original work. ${ }^{705}$ The court has also confirmed that, it tends to give favorable consideration to parodies which comment directly on the resource works, rather than satire works which utilize pre-existing materials to criticize a broader range of issues. ${ }^{706} \mathrm{In}$ that case, most video parodies will not qualify, as most of them are actually satires. $^{707}$ However, in real practice, there is no clear line between what type of fanvids can be considered as a parody which is protected by the law and what is not. Moreover, just as Bradford had put it, "the ambiguity surrounding what exactly constitutes a parody creates uncertain boundaries for innovation using older texts."708

\subsubsection{Japan}

Considering the wholesale "transformative" nature of fanvids, their status is more a matter of subtle judgment than cognizable fact in Japan. Based on the percentages of the appropriation, the court will have to determine whether the work is a new one or a derivative. But most fanvids are probably copyright infringements, because no matter how many segments of other copyrighted video works were appropriated in order to build a single fanvid work, if a whole track of musical work was lifted, it will not be possible to meet the strict standards of copyright exceptions thus it is possibly a copyright infringement. However, fanvid makers today are trying to avoid that danger through heavy editing by taking only small

\footnotetext{
704 Rogoyski \& Basin, supra note 6, at 245 ("Overall, the balance of factors under the fair use analysis clearly indicates that Hu Ge's work would be protected under American copyright law.").

${ }^{705}$ Metro-Goldwyn-Mayer v. American Honda Motor Co., 900 F. Supp. 1287, 1298 (C.D. Cal. 1995) (holding that there was substantial similarity between a commercial video advertisement and the James Bond movies, with regard to "theme, plot, and sequence," "characters," and "mood and pace," as the advertisement had borrowed some elements from the movie series).

706 Campbell v. Acuff-Rose Music, 510 U.S. 569, 580-81 (1994)(“'[p]arody needs to mimic an original to make its point, and so has some claim to use the creation of its victim's... imagination, whereas satire can stand on its own two feet and so requires justification for the very act of borrowing.").

${ }^{707}$ According to Posner, a genuine parody "uses the parodied work as a target rather than as a weapon" and "take[s] so large a fraction (somehow computed) of the copyrighted features of the original work as to make the parody a substitute for that work." Richard A. Posner, When is Parody Fair Use?, 21 J. LEGAL STUD. 67, 71 (1992).

${ }_{708}$ Laura R. Bradford, Parody and Perception: Using Cognitive Research to Expand Fair Use in Copyright, 46 B.C. L. REV. 705, 720 (2004).
} 
parts from multiple pre-existing works, ${ }^{709}$ as this then makes it more ambiguous whether a fanvid is copyright infringement in Japan.

As to video parodies, apparently they will be treated in the same way as fanvids in Japan, as parody is not officially recognized by the JCL as a copyright exception. ${ }^{710}$ According to the existing cases, the Japanese courts have generally evaluated parody under the "quotation" exception in the JCL. ${ }^{711}$ According to that exception, it is required that the "quotation" is "compatible with fair practice and their extent does not exceed that justified by purposes such as news reporting, criticism or research." 712 Combine with the statement made by the Supreme Court of Japan that discussed above, ${ }^{713}$ it is extremely hard for video parodies like the Steamed Bun to survive. However, for satires that were heavily edited and appropriate fiddling contents from multiple sources, it is possible for them to invoke the "quotation" exception, since Japan has not made a clear distinction between parody and satire.

\subsubsection{China}

According to the CCL, if a fanvid work is based on pre-existing works and the fanvidder distributes it online, and it is not one of the copyright exceptions, then it is possible that at least the copyright owner's "right of adaptation" and "the right of communication through information network" are infringed. ${ }^{714}$ Article 22 of the CCL enumerates many copyright exceptions, but, apparently, despite the potential critical nature of fanvids, none of those exceptions could justify fanvids when a whole track of copyrighted musical work is lifted. ${ }^{715}$ Nevertheless, fanvid makers today are trying to avoid doing that through careful editing, ${ }^{716}$ as this then makes it more ambiguous as to whether or not a fanvid is a copyright infringement in China.

\footnotetext{
709 Trombley, supra note 545, at 675.

710 Miya Sudo \& Simon Newman, Japanese Copyright Law Reform: Introduction of the Mysterious Anglo-American Fair Use Doctrine or an EU Style Divine Intervention via Competition Law?, 18 INTELL. Prop. Q. 40, 41 (2014); Mariko A. Foster, Parody's Precarious Place: The Need to Legally Recognize Parody as Japan's Cultural Property, 23 SETON HALl J. SPORTS \& ENT. L. 313, 316 (2013).

${ }_{711} I d$.

712 Japanese Copyright Law, art. 32.

${ }_{713}$ See supra note 675 and accompanying text.

7142010 Copyright Law of the People's Republic of China, art. 10 (12), (14).

715 Id. art. 22.

716 Trombley, supra note 545, at 675.
} 
In terms of video parodies, it is arguable that the Steamed Bun is a copyright infringement under the CCL. ${ }^{717}$ It is also noted that the CCL does not officially recognize parody as a fair use. ${ }^{718}$ Therefore, in any other cases, a video parody is not likely to survive under the copyright exceptions of CCL. However, since nowadays most video parodies involve segments from more than merely one source, and the authors likewise are trying to avoid copyright problems through substantial editing, it will ultimately be a case-by-case judgment. ${ }^{719}$

Table 2: Legal Status of Fan Works in the U.S., Japan and China

\begin{tabular}{|c|c|c|c|c|c|c|c|}
\hline Country & Fansub & Doujinshi & Fanfic & Scanlation & Fanvid & AMV & $\begin{array}{c}\text { Video } \\
\text { Parody }\end{array}$ \\
\hline U.S & illegal & $\begin{array}{c}\text { case-by- } \\
\text { case }\end{array}$ & $\begin{array}{c}\text { case-by- } \\
\text { case }\end{array}$ & illegal & $\begin{array}{c}\text { case-by- } \\
\text { case }\end{array}$ & $\begin{array}{c}\text { case-by- } \\
\text { case }\end{array}$ & $\begin{array}{c}\text { case-by- } \\
\text { case }\end{array}$ \\
\hline Japan & illegal & illegal & $\begin{array}{c}\text { case-by- } \\
\text { case }\end{array}$ & illegal & $\begin{array}{c}\text { case-by- } \\
\text { case } \\
\text { case-by- } \\
\text { case }\end{array}$ & $\begin{array}{c}\text { case-by- } \\
\text { case }\end{array}$ & $\begin{array}{c}\text { case-by- } \\
\text { case }\end{array}$ \\
\hline China & illegal & illegal & $\begin{array}{c}\text { case-by- } \\
\text { case }\end{array}$ & $\begin{array}{c}\text { case-by- } \\
\text { case }\end{array}$ & $\begin{array}{c}\text { case-by- } \\
\text { case }\end{array}$ \\
\hline
\end{tabular}

\subsection{Possible Defenses}

It is obvious that the current standards regarding whether a fan activity is infringeing or not are somewhat ambiguous. However, besides fair use and copyright exceptions, there exist some general defenses such as constitutional defenses (para. 4.3.1) and civil law defenses (para. 4.3.2) which are possible for fan creators to claim.

\footnotetext{
717 Rogoyski \& Basin, supra note 6, at 243 ("Like most parodies, The Steamed Bun relies heavily on the underlying work to convey its message. Though The Steamed Bun case ultimately never went to court, under the likely narrow reading of Article 22(2), The Steamed Bun appears to be a copyright violation.").

${ }^{718}$ See e.g., Rogoyski \& Basin, supra note 6, at 241; Suli (苏力), Xifang de Falu Baohu yu Xianzhi Cong Yige Mantou Yinfa de Xuean Qieru (戏仿的法律保护和限制——《一个馒头引发的血案》切入) [Legal Protection of Parodies and its Limits], ZhongGuo FAXue (中国法学) [ China Legal ScIENCE], no.3, 2006, 11; Weidong Ji (季卫 东), Wangluohua Shehui de Xifang yu Gongping Jingzheng Guanyu Zhuzuoquan Zhidu Sheji de Bijiao Fenxi (网络化 社会的戏仿与公平竞争——关于著作权制度设计的比较分析) [Parody and Fair Competition in the Network Society], ZHONGGUO FAXUE (中国法学)[ CHINA LEGAL SCIENCE], no.3, 2006, 21.

719 For more discussions on parody in China, see infra Chapter 5.1.3.2.
} 


\subsubsection{Constitutional Defenses}

The Constitutions are not directly correlated to fan activities. However, they may contain clauses that relate to intellectual property, which reflect the attitudes of their home countries toward creativity and the development of cultural industry. Moreover, these clauses may provide arguments for the justification for fan activities in a designated country. This subsection checks the possible constitutional defenses in the U.S. (para. 4.3.1.1), Japan (para. 4.3.1.2), and China (para. 4.3.1.3) in turn.

\subsubsection{The U.S.}

The "Copyright Clause" of the U.S. Constitution, a.k.a. Article 1, section 8 , clause 8 explicitly grants the U.S. Congress the power "to promote the progress of science and useful arts, by securing for limited times to authors and inventors the exclusive right to their respective writings and discoveries." One could easily identify from the clause that offering a "limited" exclusive right to authors is only a means; the purpose of doing so is to "promote the progress of science and useful arts". ${ }^{720}$ This illustrates that copyright is a social tool with constitutional depth. For instance, in Twentieth Century Music Corp. v. Aiken, a fast food restaurant in which radio station broadcasts are played was sued by an irritated copyright owner of two copyrighted songs which were played inside the restaurant with a radio station broadcasting. ${ }^{721}$ The Court has held that:

"[C]reative work is to be encouraged and rewarded, but private motivation must ultimately serve the cause of promoting broad public availability of literature, music, and the other arts. The immediate effect of our copyright law is to serve a fair return for an author's creative labor. But the ultimate aim is, by this incentive, to stimulate artistic creativity for the general public good." 722

Also, the U.S. Congress has pointed out that:

\footnotetext{
720 Jenny Lynn Sheridan, Copyright's Knowledge Principle, 17 VAND. J. ENT. \& TECH. L. 39, 45 (2014).

721 Twentieth Century Music Corp. v. Aiken, 422 U.S. 151 (1975).

${ }^{722}$ Id. at 156.
} 
"The enactment of copyright legislation by Congress under the terms of the Constitution is not based upon any natural right that the author has in his writings...but upon the grounds that the welfare of the public will be served... Not primarily for the benefit of the author, but primarily for the benefit of the public, such rights are given...,"723

Judging from the above-mentioned statements, it is very clear that the main purpose of the U.S. Copyright Act is to encourage creativity and to promote public welfare enrichment. In other words, if the monopoly given to the authors turned out to be a hurdle to creativity and therefore endangered the public interest, then this monopoly is to be repudiated. For example, in Twentieth Century Music Corp. v. Aiken we could see that, the court has invoked the "Copyright Clause" of the U.S. Constitution as a defense and rationale, to protect the interests of the public when they are in conflict with the copyright owners'. ${ }^{724}$

Moreover, the First Amendment of the U.S. Constitution-the "Free Speech Clause" can also be a defense for some copyright infringement actions. $^{725}$ It clearly provides that:

"Congress shall make no law respecting an establishment of religion, or prohibiting the free exercise thereof; or abridging the freedom of speech, or of the press; or the right of the people peaceably to assemble, and to petition the government for a redress of grievances." 726

In the Suntrust Bank case, the U.S. Court of Appeals for the Eleventh Circuit has indicated that the "Copyright Clause" and the "Free Speech Clause" are "intuitively in conflict" but "were drafted to work together to prevent censorship". 727 The court further invoked "the shared principles of the First Amendment and the copyright law" to vacate the judgment of the district court, believing that the "issuance of the injunction" was "act-

\footnotetext{
${ }^{723}$ H. R. Rep. No.2222, 60th Cong., 2d, Sess. 7 (1909).

724 Twentieth Century Music Corp. v. Aiken, 422 U.S. 151, at 156 (1975).

${ }^{725}$ Neil Weinstock Netanel, Locating Copyright within the First Amendment Skein, 54 STAN. L. REV. 1, 5 (2001).

${ }^{726}$ U.S. CONST. Amend. I.

727 Suntrust v. Houghton Mifflin Co., 268 F. 3d 1257, 1263 (11th Cir. 2001). For a more detailed discussion about this, see Paul Goldstein, Copyright and the First Amendment, 70 COLUM. L. REV. 983 (1970).
} 
ing as a prior restraint on speech."728 The Suntrust Bank case is believed to be the first case that an appellate court applied the Free Speech Clause to confine the enforcement of a copyright.

In all, it is clear from above that in the U.S., at least two types of constitutional defense are available for fan creators to invoke: the "Copyright Clause" and the "Free Speech Clause". However, it is also a fact that the U.S. judges were prudent in favoring such assertions. ${ }^{730}$ The precedents have demonstrated that, only under the circumstances that public interest, or the freedom to criticize is deemed seriously threatened will the court consider such claims. Therefore, in the case of fan creations, probably most of them cannot rely upon these constitutional defenses directly, but will have to seek the help of fair use. The U.S. courts hold that "the goal of copyright, to promote science and the arts, is generally furthered by the creation of transformative works", 731 and the definition of "transformative" is up to the courts to decide and can be covered fairly by the fair use doctrine. Moreover, the "[f]irst Amendment concerns are protected by and co-extensive with the fair use doctrine", which is also apparently a fair use matter. ${ }^{732}$ However, it is evident in the Suntrust Bank case that only in cases that involve highly transformative uses can the derivative works be covered by fair use. ${ }^{733}$ According to our previous discussion on fan works, the constitutional defenses will not offer too much help in solving the massive online infringement problems caused by fan creations.

\subsubsection{Japan}

The goal of property protection is expressed clearly in the Constitution of Japan. Article 12 of the Constitution of Japan states that, the people of

\footnotetext{
${ }^{728}$ Suntrust v. Houghton Mifflin Co., 268 F. 3d 1257, 1277 (11th Cir. 2001).

${ }^{729}$ Netanel, supra note 725 , at 2.

${ }^{730}$ For example, both the "copyright clause" and the "free speech clause" claims were rejected in the Eldred v. Ashcroft case. See Eldred v. Ashcroft, 537 U.S. 186 (2003). In Eldred v. Reno, the court's assertion that "copyrights are categorically immune from challenges under the First Amendment" was widely accepted. See Eldred v. Reno, 239 F.3d 375 (D.C. Cir. 2001); The court believed that the "idea/expression dichotomy of copyright law, under which ideas are free but their particular expression can be copyrighted, has always been held to give adequate protection to free expression". See Id. at 376; it is also noted that, as long as copyright protected no idea but only expression, "there was no possibility to raise a first amendment challenge." See Lessig, supra note 571, at 1071.

${ }^{731}$ Campbell v. Acuff-Rose Music, 510 U.S. 569, 579 (1994)

${ }_{732}$ Nihon Keizai Shimbun, Inc. v. Comline Bus. Data, Inc., 166 F.3d 65, 74 (2d Cir.1999).

${ }^{733}$ Suntrust v. Houghton Mifflin Co., 268 F. 3d 1257, 1269 (11th Cir. 2001).
} 
Japan shall "refrain from any abuse" of the "freedoms and rights guaranteed" by the Constitution, and "shall always be responsible for utilizing them for public welfare". ${ }^{734}$ Article 13 further indicates that the "right to life, liberty, and the pursuit of happiness" shall not "interfere with the public welfare". ${ }^{735}$ The right to create and to one's creation are rights to liberty in a sense (but sometimes it can be a right to the pursuit of happiness), therefore it is implied in Article 13 that the public interests prevail. A much more clear statement could be found on Article 29, which states "[p]roperty rights shall be defined by law, in conformity with the public welfare". ${ }^{736}$ The embodiment of these constitutional articles in the Japanese Copyright Law is expressed in its Article 1:

"The purpose of this Law is, by providing for the rights of authors and the rights neighboring thereon with respect to works as well as performances, phonograms, broadcasts and wire diffusions, to secure the protection of the rights of authors, etc., having regard to a just and fair exploitation of these cultural products, and thereby to contribute to the development of culture.",737

It can be inferred from the above-mentioned articles that the final goal of the JCL is to promote the "development of culture", because property rights, including "rights of authors", are subject to "public welfare".

However, the "continental European basis" of the Japanese legal system, ${ }^{738}$ and a continental mechanism of defining a limited number of copyright exceptions in the JCL will severely curtail the discretionary power of the Japanese judges. Although Japanese courts have cited Article 1 of JCL to solve fair-use related cases, ${ }^{739}$ they nevertheless had also

\footnotetext{
${ }^{734}$ Nihon Koku Kenpo, (日本国憲法) [The Constitution of Japan], Promulgated on Nov. 3, 1946, Came into effect on May 3, 1947, art. 12. Translation available at http://www.wipo.int/wipolex/zh/text.jsp?file_id=191550.

735 Id. art. 13.

736 Id. art. 29.

737 Japanese Copyright Law, art. 1.

738 Peter Ganea, et al., JAPANESE Copyright LaW: Writings in Honour of Gerhard Schricker 11 (Peter Ganea, et al. eds., Kluwer Law International. 2005).

${ }^{739}$ Nagoya Chiho Saibansho [Nagoya Dist. Ct.] Feb. 7, 2003, H14 (wa) No. 2148, 1840 Hanrei Jiho [Hanji] 126; affd, Nagoya Koto Saibansho [Nagoya High Ct.] Mar. 4, 2004; 1870 Hanrei Jiho [Hanji] 123; petition for jokoku appeal refused, Saiko Saibansho [Sup. Ct. of Japan], 3d Petty Bench, Sept. 28, 2004, as cited in Teruo Doi, Availability of the "Fair Use" Defense under the Copyright Act of Japan: Legislative and Case Law Developments for Better Adapting It to the Digital/Network Environment, 57 J. COPYRIGHT SOC'Y U.S.A. 636 (2010).
} 
noted "there should be no instances of fair use of works aside from express statutory provisions". 740

\subsubsection{China}

The current Constitution of the People's Republic of China ${ }^{741}$ does not provide any term that clearly indicates the protection of intellectual property, and the purpose of it. However, one could infer from its terms that intellectual property rights are protected. According to Article 13 of the Constitution of China, "the rights of citizens to private property" are protected "in accordance with law". No doubt intellectual property is covered by "private property" and thus is protected by the law. Article 47 also provides that:

"Citizens of the People's Republic of China have the freedom to engage in scientific research, literary and artistic creation and other cultural pursuits. The State encourages and assists creative endeavors conducive to the interests of the people that are made by citizens engaged in education, science, technology, literature, art and other cultural work." ${ }^{, 72}$

This term not only confirms that China is supportive towards creative activities and will provide encouragement and assistance, but also points out a key criterion: "the interests of the people". This criterion is further clarified by secondary legislations such as copyright laws. The affirmative interpretation of those interests is Article 1 of the CCL:

"This Law is enacted, in accordance with the Constitution, for the purpose of protecting the copyright of authors in their literary, artistic and scientific works and the rights and interests re-

\footnotetext{
${ }^{740} \mathrm{Id}$.

${ }^{741}$ XIANFA (宪法) [Constitution of the People's Republic of China] (1982), Adopted at the Fifth Session of the Fifth National People's Congress on December 4, 1982 and adopted at the First Session of the Eighth National People's Congress on March 29, 1993, Amended in accordance with the Amendments to the Constitution of the People's Republic of China adopted respectively at the First Session of the Seventh National People's Congress on April 12, 1988, the First Session of the Eighth National People's Congress on March 29, 1993, the Second Session of the Ninth National People's Congress on March 15, 1999 and the Second Session of the Tenth National People's Congress on March 14, 2004. (hereinafter the Constitution of China), translated at http://www.npc.gov.cn/englishnpc/Constitution/node_2825.htm.

${ }^{742}$ Id. art. 47.
} 
lated to copyright, encouraging the creation and dissemination of works conducive to the building of a socialist society that is advanced ethically and materially, and promoting the progress and flourishing of socialist culture and sciences.",743

The most famous negative example of those interests is Article 4 of the former $2001 \mathrm{CCL}$, which explicitly denied the possibility of copyright enforcement for works that were unable to pass the censorship of the Chinese government. ${ }^{744}$ These works include pornographic works and politically sensitive works etc. The reason they failed to pass the censorship is because they were deemed as not "to the interests of the people". However, that provision was subsequently revoked in 2010 by a revision due to the WTO case DS362 China - Measures Affecting the Protection and Enforcement of Intellectual Property Rights. That is to say, copyright enforcement, even the copyright protection of most foreign audio-visual works (such as Japanese anime) was reliant on a decision from the Chinese government before 2010. Some researchers from Hong Kong have also confirmed that even movies from Hong Kong may not be able to claim copyright protection, if they failed to go through the censorship of the Chinese government before $2010 .^{745}$ These were changed after the WTO dispute over the 2010 CCL.

The Chinese equivalent of the "copyright clause" of the U.S. Constitution is Article 1 of the CCL discussed above. It is argued that the emphasis of that clause is on protecting the "copyright of authors", and the promotion of "culture and sciences" were left behind. A Chinese scholar has claimed that the protection that Article 1 of the CCL has given to the authors is "unilateral", thus the right owners may tend to "abuse" their rights and endanger the public interest. ${ }^{746}$ Whereas Professor Xiaoqing Feng (冯晓青) has noted that, the ultimate goal of copyright in China, is to promote the broad spread of knowledge and information, and the development of science, culture and economics, and the protection of the interests of authors is only a "direct purpose" that serves to realize the

\footnotetext{
7432010 Copyright Law of the People's Republic of China, art. 1.

744 Creemers, supra note 171, at 570.

745 Dong \& Gu, supra note 174, at 344.

${ }^{746}$ Lanping Wang (王兰萍), Xianxing Zhuzuoquan Fa Zongze de Zai Dingwei yu Wanshan (现行著作权法总则的再 定位与完善)[The Reorientation and Perfection of the General Provisions of Current Copyright Law], ZHONGGUO ZHISHI CHANQUAN (中国知识产权)[CHINA INTELLECTUAL PROPERTY], no.11, 2010, at 37-41.
} 
ultimate goal. $^{747}$ Whether these judgments are right or not, from the plain texts of Article 1 there is no sign of a hierarchy of the listed purposes of copyright. Moreover, the "limited times" requirement of the copyright clause in the U.S. Constitution, the motivation of which is regarded as "a hostility deeply rooted in Anglo American law and politics to government-conferred monopoly" by Landers and Posner, ${ }^{78}$ is missing in its Chinese counterparts. This fact not only supports the conclusion that China has no preference in the listed objectives of copyright, but also infers that the "hostility" to government-conferred monopoly that Landers and Posner described is not a motivation for the Chinese government to enact a law that restricts copyright.

However, Article 8 of the Supreme People's Court Opinions on Socialist Culture mentioned above ${ }^{749}$ clearly states that "under the special circumstances of the necessity to stimulate technological innovation and commercial development", the court could use factors such as "the nature and purpose of the use, the nature of the copied work, the amount and substantiality of the portion used, and the effect of the use upon the potential market for or value of the copyrighted work" to determine whether a use is fair or not; if the use "does not conflict with a normal exploitation of the work and does not unreasonably prejudice the legitimate interests of the author", it could be deemed as a fair use. ${ }^{750}$ It is clear from the term that, the objective of this judgment is to promote innovation and economic development. Yet, Prof. Li has noted that, unlike the practice of most western countries, the Chinese judges lack relevant judicial experience, and therefore the courts in China rarely use the provisions related to the purpose of copyright to constrain the enforcement of copyright. ${ }^{751}$ That is to say, even if the purpose of copyright is not controversial in China, the possibilities of the court using them as a justification for certain activities are extremely slim. Furthermore, China's enumerative, stiff

\footnotetext{
${ }^{747}$ Xiaoqing Feng (冯晓青), Zhuzuoquan Fa Mudi yu Liyi Pingheng Lun (著作权法目的与利益平衡论)[On the Purpose and the Balance of Interests of Copyright Law], KEJI YU FALV (科技与法律)[SCIENCE TECHNOLOGY AND LAW], no.2, 2004, at 85 .

748 William M. Landes \& Richard A. Posner, Indefinitely Renewable Copyright, 70 U. CHI. L. REV. 471, 472 (2003).

749 See supra Chapter 2.1.1.5 Open Up Period (1991-present).

750 SPC Opinions on Socialist Culture, art. 8.

${ }^{751}$ Chen Li (李琛), Lun Wo Guo Zhuzuoquan Fa Xiuding zhong Heli Shiyong de Lifa Jishu (论我国著作权法修订中 “合理使用”的立法技术)[On the Legislative Technique of “Fair Use” in the Revision of our Copyright Law], ZHISHI CHANQUAN (知识产权)[INTELLECTUAL PROPERTY], no.1, 2013, at 16.
} 
mechanism of copyright exceptions also leaves no room for that kind of interpretation.

\subsubsection{Civil Law Defenses}

Besides the constitutional defenses, there exist some general civil law defenses as well. This subsection examines the major civil law defenses which can be invoked by fan creators in sequence: namely the implied license defense (para. 4.3.2.1), and laches and estoppel (para. 4.3.2.2).

\subsubsection{Implied license}

This subsection explores whether implied license as a defense in the U.S. (para. 4.3.2.1.1), or similar defenses available in Japan (para. 4.3.2.1.2) and China (para. 4.3.2.1.3), can be invoked to exempt fan creators from copyright liabilities.

\subsection{The U.S.}

One of the most relevant defenses for fansubs to a claim of copyright infringement can be found in the field of contract law, more specifically the implied license doctrine. The doctrine, which is essentially viewed as a ramification of contract law, is used to presume the intent of the contracting parties, in order to supplement their agreement. ${ }^{752}$ Implied license is rewarded, when the conduct of the parties can be used to deduce whether an agreement is to be presumed in the absence of an express license between the parties. It is predicted that implied licensing should, and will play an important role in the allocation of intellectual property rights on the Internet. ${ }^{753}$ Generally speaking, fan groups may use implied license doctrine to justify their activities. However, whether it could be invoked as a defense or not depends heavily on the legal framework of a certain country.

\footnotetext{
${ }^{752}$ Kim LeWISON, THE InTERPRETATION OF CONTRACTS 152 (Sweet \& Maxwell 3rd ed. 2004).

753 John S. Sieman, Using the Implied License to Inject Common Sense into Digital Copyright, 85 N.C.L. REV. 885, 890 (2006).
} 
In the U.S., with respect to intellectual property, the implied license was initially introduced to solve patent problems, and it was imported into copyright law later on for similar purposes. ${ }^{754}$ The first application of that doctrine in patent law is the "patent exhaustion" theory. For instance, in Adams v. Burke, the U.S. Supreme Court held that the purchaser of a coffin "acquired the right to use that coffin for the purpose for which all coffins are used," 755 by which it means, the action of purchase contains an implied permission. The second usage of the implied license is to act as a defense against patent infringement claims. ${ }^{756}$ These two aspects are equally recognized in the copyright law: one is the "first sale" doctrine, and the other is the judicial discretion as to the reasonable development of the contract. ${ }^{757}$ That is to say, if there is no express license between the parties, but the conduct of the parties indicates otherwise, the court then may rely on custom and practice of the community to determine the scope of the "implied" license. For copyright cases involving audio-visual works, the case Effects Assocs., Inc. v. Cohen is a good example. Cohen was a director who made a deal orally with Effects to film some special effects for his movie. Effects sued for copyright infringement when Cohen released his movie, claiming that due to the absence of written agreement between them, the copyright of the special effects footage has not been assigned. However, the Trial Court found that Effects had given Cohen an implied license to use the footage. The Appellate Court affirmed and found that since Effects were hired to make the footage according to Cohen's desire, there was an implied license to use the footage. $^{758}$ In that case, the court quoted Nimmer on Copyright to support the position that "[a] non-exclusive license may be granted orally, or may even be implied from conduct." 759 The ruling infused some reason into the case by granting an implied license to the defendant, because any rational man may find the deal unreasonable, if the plaintiff were not to grant the defendant his permission to use the footage that he created for

\footnotetext{
754 Orit Fischman Afori, Implied License: An Emerging New Standard in Copyright Law, 25 SANTA ClARA COMPUTER \& HiGH TECH. L.J. 275, 276 (2008).

755 Adams v. Burke, 84 U.S. (17 Wall.) at 456, as cited by id. at 280, n.11.

${ }^{756}$ Rachel Clark Hughey, Implied Licenses by Legal Estoppel, 14 ALB. LJ SCI. \& TECH. 53, 56 (2003), as cited by Afori, supra note 754 , at 280, n. 13 .

7572 Melville B. Nimmer \& DAVID Nimmer, Nimmer On COPYRIGHT, § 10. 10[B] (2008), as cited by Afori, supra note 754 , at $286, \mathrm{n} .45$.

758 Effects Assocs., Inc. v. Cohen, 908 F.2d 555 (9th Cir. 1990).

7593 Melville B. Nimmer \& DAVID Nimmer, Nimmer ON COPYRight, § 10.03[A], at 10-36 (1989), as cited by Afori, supra note 754 , at 286, n. 45.
} 
him. The Effects case is the earliest copyright case with regard to implied license in the US. Since then, the implied license claim has became one of the defenses of copyright infringement in U.S. copyright litigations.

However, U.S. courts remain prudent in granting an implied license even after entering the digital age. For example, In A\&M Records, Inc. v. Napster, Inc., ${ }^{760}$ the court had rejected Napster's claim that the plaintiff had granted them an "implied license" by creating and providing digital files via the internet, and noted that courts have only found the implied licenses in "narrow' circumstances where one party 'created a work at [the other's] request and handed it over, intending that [the other] copy and distribute it.",761 After that, two methods to determine the existence of an implied license were developed by the courts: in I. A. E., Inc. v. Shaver case, the court summarized three factors that constitute an "implied license", citing the Ninth Circuit's ruling in the Effects case that:

"an implied non-exclusive license has been granted when:

(1) a person (the licensee) requests the creation of a work;

(2) the creator (the licensor) makes that particular work and delivers it to the licensee who requested it, and

(3) the licensor intends that the licensee-requestor copy and distribute his work". 762

This rule has been further supported by other rulings. ${ }^{763}$ Moreover, three factors were further developed by courts in determining whether a non-exclusive license could be implied in certain cases:

(1) whether the parties were engaged in a short-term discrete transaction as opposed to an ongoing relationship;

(2) whether the creator utilized written contracts, providing that copyrighted materials could only be used with the creator's future involvement or express permission; and

(3) whether the creator's conduct during the creation or delivery of the copyrighted material indicated that use of the material

\footnotetext{
${ }^{760}$ A\&M Records, Inc. v. Napster, Inc., 239 F.3d 1004 (2001).

${ }^{761}$ SmithKline Beecham Consumer Healthcare, L.P. v. Watson Pharms., Inc., 211 F.3d 21, 25 (2d Cir. 2000) (quoting Effects Assocs., Inc. v. Cohen, 908 F.2d 555, 558 (9th Cir. 1990)), cert. denied, 121 S. Ct. 173 (2000).

${ }_{762}$ I.A.E., Inc. v. Shaver, 74 F.3d 768, 776 (7th Cir. 1996).

763 Roberto Hevia, Estate of v. Portrio Corp., 602 F.3d 34, 94 U.S.P.Q.2d 1501(1st Cir. 2010); see also SmithKline Beecham Consumer Healthcare, L.P. v. Watson Pharms, Inc., 211F.3d 21, 54 U.S.P.Q.2d 1317 (2d Cir. 2000).
} 
without the creator's involvement or consent was permissible. $^{764}$

If we take a close look at the abovementioned propositions, seemingly their application is highly restricted, and given the changes brought by digital technologies, clearly they lack some degree of flexibility when applying to the scenario of fan creations. However, these were changed after the Field v. Google case. ${ }^{765}$ In that case, Field filed a complaint against Google, claiming that Google's "cached" versions of his works, which were generated by a search program called "Googlebot", infringed the copyright of his work. Google raised multiple defenses, including implied license. The court recognized Google's implied license defense claim, because Field had actual knowledge of the Googlebot technology and was aware of the ways to prevent Google from caching his works. By including a simple code in the HTML, Field could choose to opt out but he failed to do so, therefore he had granted Google an implied, non-exclusive license. ${ }^{766}$

If the above decision is compared with earlier rulings, it is evident that the scope of application has been expanded: in previous cases, an explicit contractual relationship was required for granting an implied license, but in the Field v. Google case, the court held that the permission to use the copyrighted work "need not be manifested verbally and may be inferred based on silence where the copyright holder knows of the use and encourages it." ${ }^{, 767}$ In other words, the scope in terms of determining whether a license is implied or not is now being expanded, requiring only the author with "actual knowledge of the use", 768 but who kept "silent" over that matter and even "encourages it," regardless of whether a contractual relationship exists or not. ${ }^{769}$

The Field v. Google case actually developed an "opt-out" mechanism. The fact sheet of Authors Guild v. Google case demonstrated that, Google was trying to replicate its success in the Field v. Google case through extending its "opt-out" mechanism, which reflects the ruling of the Field $v$.

\footnotetext{
${ }^{764}$ Goldstein, supra note 655, at $\$ 1$ 5:32.2-5:32.3.

${ }^{765}$ Field v. Google, Inc., 412 F.Supp.2d 1106 (D. Nev. 2006).

${ }^{766}$ Id. at $1115-1116$.

${ }^{767}$ Id. at 1116.

768 In here, of course, whether an industry practice exists or not plays an important role in determining the "actual knowledge of the use".

${ }^{769}$ See also Keane Dealer Servs. v. Harts, 968 F. Supp. 944, 947 (S.D.N.Y. 1997)(knowledge of use, coupled with "silence in the face of [the defendant's] use," constituted an implied license).
} 
Google case to the area of books. ${ }^{770}$ However, Google's attempt to broaden the scope of its "opt-out" mechanism proved to be controversial. ${ }^{771}$ Although the last decision of that wave of lawsuits only endorsed Google's scanning program by "bolstering the concept of fair use"772 and has not construed the "opt-out" mechanism and the implied license claim behind, it is believed that Google has used implied license as a defense during the litigation. ${ }^{773}$ The implied license theory "could actually constitute an element of a fair use defense", 774 because Courts have described fair use as an "equitable rule of reason," is considered relevant in assessing the reasonableness of a defendant's conduct". ${ }^{776}$ However, clearly there is a distinction between cases involving webpages and full copies of works such as books. First, in the case of websites, the owner chose to upload his works to his personal site, and Google only cached his site, while in the latter case, Google intentionally copied and uploaded the books at issue; Second, the website publishers using 'meta-tags' to communicate their permissions to internet search engines like Google is an industry practice, while for the latter, to copy a whole book is strictly controlled by copyright owners in publishing practices, let alone to scan and upload a whole book to the Internet. At least for now, so long as that practice is not proved to be a fair use, ${ }^{777}$ it cannot be justified by the implied license.

\footnotetext{
${ }^{770}$ Google had launched its Google Books project along with several major research libraries since 2004, to digitally copy books in their collections. As a consequence, Google has scanned more than twenty million books. Many of these books are copyrighted and scanned without permission from the copyright holders, thus many copyright holders chose to sue Google for copyright infringement in 2005. See Authors Guild v. Google, Case 1:05-cv-08136-DC Document $1088 \quad$ Filed $\quad 11 / 14 / 13, \quad$ at $1, \quad$ at http://www.publishersweekly.com/binary-data/ARTICLE_ATTACHMENT/file/000/001/1887-2.pdf. See also Jonathan Band, Features-The Authors Guild v. The Google Print Library Project, LLRX.com, Oct. 15, 2005, at http://www.llrx.com/features/googleprint.htm; see also Andrew Albanese, Google Wins: Court Issues a Ringing Endorsement of Google Books, PUBLISHER WEEKLY, Nov. 14, 2013, at http://www.publishersweekly.com/pw/by-topic/digital/content-and-e-books/article/60006-google-wins-court-issues-a-r inging-endorsement-of-google-books.html.

${ }_{771}$ The Authors Guild, the publishing industry and Google entered into a settlement agreement on 2008, they amended it in 2009 and it was rejected by Circuit Judge Denny Chin on 2011. See Authors Guild v. Google, Inc., 77o F. Supp. 2d 666 (S.D.N.Y. 2011)( The court held that it would be "incongruous with the purpose of the copyright laws to place the onus on copyright owners to come forward to protect their rights when Google copied their works without first seeking their permission." Id. at 682). And interestingly, this case was dismissed in favor of Google by the same Judge on 2013. See Authors Guild v. Google, Case 1:05-cv-08136-DC Document 1088 Filed 11/14/13.

772 Andrew Albanese, Google Wins: Court Issues a Ringing Endorsement of Google Books, PUBLISHERS WEEKLY, Nov 14, 2013. 2013.

773 Michael Mattioli, Opting Out: Procedural Fair Use, 12 VA. J.L. \& TECH. 1, 2-10 (2007).

774 Band, Features-The Authors Guild v. The Google Print Library Project. 2005.

775 Stewart v. Abend, 495 U.S. 207, 237 (1990), as cited by Id.

776 Band, Features-The Authors Guild v. The Google Print Library Project. 2005.

${ }^{777}$ In the Authors Guild v. Google case the answer is currently yes.
} 
In Germany, implied license related to the Internet has also gone through a difficult and tortuous course of development. In 2003, the District Court of Hamburg ruled against Google, as the court found that it is not a fair use for Google under the Copyright Law of Germany to use thumbnail images in the news excerpts of their news service, but the court did not tackle the possibility of an implied license. ${ }^{778}$ However, in a 2007 case, a different view was expressed by the District Court of Erfurt. The court reached a conclusion which is similar to the Field v. Google case: the court found that the thumbnail images cannot be enhanced into high definition versions and it is beneficial to the copyright owner as they can be located by others in a more convenient way. And the copyright owners can opt-out easily by using a simple code in their webpages. ${ }^{779}$ In 2010 , the German Federal Supreme Court ruled that the reproduction and communication to the public in the form of "thumbnails" by the Google Image search engine are lawful, because the right holder had implicitly consented to such uses, in view of its failure to technically prevent indexing by a search engine. ${ }^{780}$

It seems that the Field v. Google case and the experiences from Germany have opened up the realm of implied license and created possibilities for cases involving fan activities, as many cases do involve a certain degree of tolerance from copyright owners.

However, at this point it is hard to say whether fans in the U.S. could invoke implied license as a defense for copyright infringement claims against them. Although the scope of application of it had been expanded by the Field v. Google case, there might be a silver lining in that these fan activities could be justified on the grounds of implied license: unless the totality of the copyright owner's oral expression or conduct indicates an intent to grant such permission, an implied license defense will not be supported. ${ }^{781}$ Moreover, the scope of an implied license is generally determined by the custom and practice of the society. Considering the currently ambiguous relationship between fans and the content industry, and the fact that the industrial practice of the content industry to cooperate

\footnotetext{
${ }^{778}$ Landgericht Hamburg, Urteil vom 5.9.2003, Aktenzeichen: 308 O 449/03.

779 Google Bildersuche - Thumbnails rechtlich zulässig, LG Erfurt, Urteil vom 15.3.2007, Az 3 O 1108/05.

780 See e.g., "Google Image Search" German Federal Supreme Court, Apr. 29, 2010. Case IZR 69/08, [2010] GRUR 628, as cited by Paul Goldstein \& P. B. Hugenholtz, International Copyright: Principles, LaW, AND Practice 405, n.194 (Oxford University Press 3rd ed. 2013).

${ }^{781}$ It is noted that "the traditional implied license doctrine does not apply where there is no agreement between the parties, or worse, when the copyright holder explicitly refuses to permit the reproduction or other dissemination of his or her work." See Afori, supra note 754, at 277.
} 
with fans officially is consequently not yet established, that might be just wishful thinking.

\subsection{Japan}

There is no explicit term that directly deals with implied license in the JCL and its Civil Code. ${ }^{782}$ However, according to the existing rulings, licenses can be granted orally or implicitly. ${ }^{783}$ But it should be noted that the application of implied license to copyright disputes in Japan is scarce and highly restricted. Notwithstanding that some of the fan activities have been tolerated or even fostered by the audio-visual industry in Japan, it is still extremely hard for fans to invoke implied license doctrine to defend themselves, unless an actual contractual relationship between the fans and the industry can be found by the court. And having a contractual relationship with fans, at least for now, is definitely not the desired result of the content conglomerates.

\subsection{China}

As a country of civil law system, courts in China cannot make case law and base its judgment on precedent. Furthermore, the CCL provides no indications that the license of copyright could be done via implied means. However, according to the terms stipulated in the General Principles of The Civil Law of China ${ }^{784}$ and the Contract Law of the People's Republic of China, ${ }^{785}$ it is possible that a contract be concluded in an implied way. ${ }^{786}$ Nevertheless, taking the traditional understanding of contractual

\footnotetext{
${ }^{782}$ Minpō (民法) [Civil Code of Japan], Act No. 89 of April 27, 1896, amended by Act No. 78 of 2006, translated at JAPANESE LAW TRANSLATION DATABASE SYSTEM, (Ministry of Justice of Japan trans., 2009) http://www.japaneselawtranslation.go.jp/law/detail $/ \mathrm{ft}=2 \& \mathrm{re}=02 \& \mathrm{dn}=1 \& \mathrm{yo}=\% \mathrm{E} 6 \% \mathrm{~B} 0 \% 91 \% \mathrm{E} 6 \% \mathrm{~B} 3 \% 95 \& \mathrm{x}=0 \& \mathrm{y}=0$ $\& \mathrm{ia}=03 \& \mathrm{ky}=\&$ page $=3$ (hereinafter Civil Code of Japan).

${ }^{783}$ Tokyo High Court, 4 August 1998. 1667 Hanrei Jiho 131: the consent to the publication of a Haiku poem is found when it is contributed to the Haiku magazine; Tokyo High Court, 19 December 1991. Hosei Daigaku Kensho Ronbun: the implied consent is found when the author did not show objection to the offer of the publication, as cited by GANEA, et al., supra note 738 , at 78, n.4.

${ }^{784}$ The General Principles of the Civil Law of China.

${ }^{785}$ Hetong Fa (合同法) [the Contract Law of the People's Republic of China] (Adopted by the National People's Congress on March 15, 1999, and promulgated by the Presidential Order No. 15), translated at WorLD INTELLECTUAL Property ORgANiZATION, WIPO Lex No. CN137, http://www.wipo.int/wipolex/en/text.jsp?file_id=182632 (herein after "the Contract Law of China").

${ }_{786}$ See e.g., the General Principles of the Civil Law of China, art. 56 (state that "a civil juristic act may be in written, oral or other form"); See also the Contract Law of the People's Republic of China, art. 10 (state that "a contract may
} 
relationship, it is hard to say that the fans and a copyright owner have reached some sort of contract, if the copyright owner intentionally ignores the fan activities and tries their best to avoid direct contact with fan groups.

It is notable that the State Council had adopted the Regulation on the Protection of the Right to Network Dissemination of Information in $2006{ }^{787}$ Article 9 of the Network Information Regulation has established a kind of "opt-out" mechanism and allows contracts to be concluded in an implied way in specific situations: for the purpose of "aiding poverty-stricken areas", network services providers could provide copyrighted works related to topics such as "cultivation and breeding" for free, as long as they put up a notice and wait for the authors to "opt-out" for a certain period of time, and when that term ends and if no objection is raised, then an implied license is deemed granted.

After the Network Information Regulation came into effect, many related cases emerged subsequently. ${ }^{788}$ In sum, two factors could be extrapolated from the provision for the determination of whether an implied license is granted or not: first, the user should post an "offer" which includes information of the works, the authors, and the rates of remuneration; second, the copyright owners should explicitly or implicitly express their attitude toward the use within the time specified. That is to say, Article 9 of the Network Information Regulation established a preliminary implied license model within the field of copyright law: the clause not only confirmed that an implied license regime could be employed by China in order to fulfil the purpose of copyright law in a digital era, but also illustrated the specific requirements of a possible "opt-out" claim. Even though many restrictions were still placed on it, the clause itself nevertheless could become the example for future implied license-related revisions of copyright legislation of China. However, for the time being,

be made in a writing, in an oral conversation, as well as in any other form").

${ }^{787}$ Xinxi Wangluo Chuanbo Quan Baohu Tiaoli (信息网络传播权保护条例) [Regulation on the Protection of the Right to Network Dissemination of Information], (adopted at the 135th Executive Meeting of the State Council on May 10, 2006, effective as of July 1, 2006)(herein after "the Network Information Regulation") (China), translated at WORLD INTELlectual Property ORganization, WIPO Lex No. CN064, http://www.wipo.int/wipolex/en/text.jsp?file_id=182147.

${ }_{788}$ See Heilongjiang Jin Nong Xinxi Jishu Youxian Gongsi Yu Beijing San Mian Xiang Banquan Daili Youxian Gongsi Ji Haerbin Lang Xin Keji Fazhan Youxian Gongsi Qinfan Zhuzuoquan Jiufen Yi An (黑龙江金农信息技术有 限公司与北京三面向版权代理有限公司及哈尔滨朗新科技发展有限公司侵犯著作权纠纷一案) [Heilongjiang Jinnong Information Technology Co. Ltd. v. Beijing 3rd Mianxiang Banquan Agency Limited Company and Haerbin Langxin Technology Development Co. Ltd.], (Higher People's Ct. of Heilongjiang Province, Heizhizhongzi no.4 decision, Dec. 10, 2008) (黑龙江省高级人民法院 [2008］黑知终字第 4 号民事判决书). 
there is no sign that an implied license regime of copyright, which could be invoked by fans to justify their activities, will be established in China in the near future.

\subsubsection{Laches and Estoppel}

Unlike pure theft, fan activities in some cases do have a close relationship with the copyright owners. It is also obvious enough from the foregoing sections that the industry is lenient to the fans for many reasons, and one of those is to maintain a close relationship with them. Therefore, the lengthy history of interactions between the industry and fans may make it possible for the latter to invoke the defense related to good faith, such as laches and estoppel, if copyright disputes arise in the U.S. (para. 4.3.2.2.1), Japan (para. 4.3.2.2.2), and China (para. 4.3.2.2.3).

\subsection{The U.S.}

Laches and estoppel are equitable defenses that could be asserted by the defendant in the court of U.S. However, the application of these two equitable defenses is tightly restrained. The defendant can invoke the laches defense, in the case that the delay of the copyright owner in pursing an infringement claim is "inexcusable and prejudicial" to the defendant, "by reason of his reliance or change of position as a result of such delay." "789 That is to say, in order to invoke a laches defense, the defendant must prove that, firstly, the plaintiff's delay in claiming his rights is "inexcusable"; secondly, the delay is detrimental to the defendant. Furthermore, the defendant must also prove that he is an innocent infringer, because if the defendant knew of the plaintiff's asserted rights, ${ }^{790}$ or the defendant is a deliberate infringer, ${ }^{791}$ the plaintiff's delay will not be deemed sufficient for a laches defense to arise. This willful exception requirement is based on the equitable maxim that "he who comes into equity must come with clean hands."792

\footnotetext{
7893 Melville B. Nimmer \& DAVID Nimmer, Nimmer On COPYRight, § 12.06, at 12-124.14 (2002).

${ }^{790}$ Famous Music Corp. v. Bay State Harness Horse Racing \& Breeding Ass'n. Inc., 423 F. Supp. 341 (D. Mass. 1976). aff'd, 554 F.2d 1213 (1st Cir. 1977).

${ }^{791}$ Harmony Gold U.S.A. Inc. v. FASA. Corp., 40 U.S.P.Q.2d 1057. 1060 (N.D. III. 1996).

792 Precision Instrument Manufacturing Co. v. Automotive Maintenance Machinery Co., 324 US 806, 814 (1945). Furthermore, some scholars even claimed that courts will not only consider "the length, nature and causes of the delay,
} 
If we run every fan activity through all the explicit requirements of the laches defense, we may reasonably come to the conclusion that most fans cannot invoke laches as their defense. First of all, normally the delay period for laches begins after the plaintiff "first has knowledge of the violation in suit," plus actual knowledge is not required. ${ }^{793}$ That is to say, in terms of fan activities, theoretically the copyright owners should act as fast as they can once they acquired facts that "would lead a reasonably diligent person to infer that a violation of the plaintiff's rights exists". 794 However, whether the copyright owners are capable of identifying every infringement or not is another matter, the burden of proof lies on the defendant's side. ${ }^{795}$ If the fans could not prove that the copyright owners have acquired sufficient facts, the laches defense will not succeed. This is the most likely scenario considering the complexity of online infringements and the difficulty for the fans to gather evidence. Secondly, even if the fans successfully proved that delay existed and was unreasonable, and such delay caused unjust prejudice to them, they still have to demonstrate that their appropriation is not deliberate. ${ }^{796}$ According to Lyons Partnership, LP v Morris Costumes, Inc., ${ }^{797}$ infringement is deemed willful if 'the defendant 'has knowledge,' either actual or constructive, 'that its actions constitute an infringement,' or recklessly disregards a copyright holder's rights." ${ }^{, 798}$ Therefore, considering the loose connections between the fans and copyright owners, and the fact that nowadays most audio-visual products carry explicit copyright claims, generally speaking, fan activities cannot be justified by the laches defense in the U.S.

Estoppel, on the other hand, is a subsequent defense that the defendant can claim in copyright infringement actions. In Hampton v. Paramount Pictures Corp., ${ }^{799}$ the court held that four elements must be present to establish an estoppel defense:

\footnotetext{
the excuses for it, the nature and extent of any prejudice to the defendant caused by the delay, and the defendant's good faith in relation to the delay", they will also consider "any other circumstances relevant to the fairness or equity of relief in the particular case." See 1 JAY DRATLER, LICENSING OF INTELleCtUAL PROPERTY § 3.05[1], at 3-69 (Law Journal Seminars-Press. 2001).

${ }^{793}$ Id. at 3-71.

${ }^{794}$ Id.

795 Id. at 3-70.

796 Vikas K. Didwania, The Defense of Laches in Copyright Infringement Claims, 75 U. CHI. L. REV. 1227, 1230-1232 (2008).

${ }^{797}$ Lyons Partnership, LP v Morris Costumes, Inc., 243 F3d 789 (4th Cir 2001).

${ }_{798}$ Id at 799, quoting Fitzgerald Publishing Co. v. Baylor Publishing Co., 807 F2d 1110, 1115 (2d Cir 1986).

799 Hampton v. Paramount Pictures Corp., 279 F.2d 100 (9th Cir. 1960).
} 
(1) the party to be estopped must know the facts of the defendant's infringeing conduct;

(2) he must intend that his conduct shall be acted on or must so act that the party asserting the estoppel has a right to believe that it is so intended;

(3) the defendant must be ignorant of the true facts; and

(4) he must rely on the plaintiffs conduct to his injury. ${ }^{800}$

More recently, in the afore-mentioned Field v. Google case, the court had also supported this four element test, and held that "all four elements have been established as a matter of law", and Google's estoppel claim is supported by the court. ${ }^{801}$ In this case, the court had successfully expanded the application of the estoppel defense, and incorporated it with the digital environment. Although it is noted that unauthorized users could, in some circumstances, invoke the estoppel principle to defend themselves against the copyright owner's requests, ${ }^{802}$ whether it is applicable in terms of fan activities is still unclear.

First, it is very hard to prove that the copyright owners are aware of the facts of fans' infringeing conduct if they intentionally ignore or turn a blind eye to those fan activities. Second, even if the relationship between the two parties is close to such an extent that the awareness of the copyright owner could be proved, it is still very hard to demonstrate that the copyright owners' conduct can be relied upon, because it is a common practice in the content industry to post or insert clear copyright notices on their works; and considering the fact that these notices are so obvious, fans are in no position to claim that they were not aware of them. Third, it is also difficult to prove that, other than the intention expressed in their copyright notices, the silent copyright owners have a contrary intention behind. According to the existing case law, a plaintiff's copyright claim will be estopped "if he has aided the defendant in infringeing or otherwise induced him to infringe or has committed covert acts such as holding out...by silence or inaction". ${ }^{803}$ However, even if we assume that copyright owners inaction could support fan creators to claim an estoppel defense, the current case laws in the U.S. have already demonstrated that the

\footnotetext{
8004 Melville B. Nimmer \& David Nimmer, Nimmer On COPYRight, § 13.07, at 13-276 (2002).

${ }^{801}$ Field v. Google, Inc., 412 F.Supp.2d 1106, at 1116-1117 (D. Nev. 2006).

${ }^{802}$ Lee, supra note 16, at 1495.

${ }^{803}$ Quinn v. City of Detroit, 23 F. Supp.2d 741. 753 (E.D. Mich. 1998).
} 
mere affixation of the copyright notice is a sufficient assertion of rights, ${ }^{804}$ not to mention that such passive acts were rarely so held. ${ }^{805}$ Last but not least, it is also very hard to prove that the fans had relied on the copyright owners' conduct to their injury (if any), since many copyright owners are merely turning a blind eye to the fan activities.

\subsection{Japan}

In Japan, it is believed that the doctrine of estoppel is embedded in a general principle of civil law called the good faith. ${ }^{806}$ If we look into the Civil Code of Japan, its Article 1(2) clearly provides that the "exercise of rights and performance of duties must be done in good faith."807

Furthermore, the Article 2 of the Code of Civil Procedure of Japan also provides that the courts shall endeavor to ensure that "civil suits are carried out fairly and expeditiously", and "both parties shall conduct civil suits in good faith." 808 There are a few existing copyright cases where the court considered the good faith principle as a defense that the defendant could rely on, against the plaintiff's abuse of rights. ${ }^{809}$ However, estoppel is of a common law nature, and courts in a continental country like Japan have rarely applied principles in the civil law to decide cases. Considering the vagueness of the principle of good faith and the scarcity of related cases, the good faith principle is not yet a stable defense which fan groups can rely on in Japan.

\subsection{China}

In China, the case is more or less similar to Japan. Chinese courts use the good faith principle as an equitable defense to handle difficult cases. Un-

\footnotetext{
804 "The mere affixation of the copyright notice on copies of the work, if seen by the defendant, has been held to constitute a sufficient assertion of the plaintiffs right so as to counter an estoppel based upon a passive holding out". See 4 Melville B. Nimmer \& DAVID NimMer, NimMER On COPYRIGHT, § 13.07, at 13-276 (2002). ${ }^{805}$ Id.

${ }^{806}$ Report Q175 in the name of the Japanese Group, The Role of Equivalents and Prosecution History in Defining the Scope of Patent Protection, AIPPI, at 2, at https://www.aippi.org/download/commitees/175/GR175japan.pdf.

${ }^{807}$ Civil Code of Japan, art. 1(2).

${ }^{808}$ Minji Soshoho (民事訴訟法) [Code of Civil Procedure of Japan], Act No. 109 of 1996, amended by Act No. 36 of 2011, translated at JAPANESE LAW TRANSLATION DATABASE SySTEM, (Ministry of Justice of Japan trans., 2009) http://www.japaneselawtranslation.go.jp/law/detail/?ft=2\&re $=02 \& \mathrm{dn}=1 \& \mathrm{yo}=\& \mathrm{ia}=03 \& \mathrm{x}=16 \& \mathrm{y}=15 \& \mathrm{kn}[]=\% \mathrm{E} 3 \% 81 \%$ $\mathrm{BF} \& \mathrm{ky}=$ \&page $=9$.

${ }^{809}$ The Kewpie case, Tokyo District Court, Nov. 17, 1999. Hanrei Jihô No. 1797: 111, 131.
} 
like the specific equitable rules applied by the U.S. courts such as laches and estoppel, good faith as a fundamental principle is generally applicable throughout the civil laws of China. Like what we have found in the Japanese laws, Article 4 of the General Principles of Civil Law provides that:

In civil activities, the principles of voluntariness, fairness, making compensation for equal value, honesty and credibility shall be observed. ${ }^{810}$

Previous cases show that, if the situation is obviously unfair to one party but there are no directly applicable laws or the applicable laws are somehow ambiguous, the Chinese courts can invoke the principle of good faith to adjudicate copyright-related cases. ${ }^{811}$ However, unlike the U.S. equitable rules such as laches and estoppel, the "equitable" function of the good faith principle is much more vague and unstable. Since it is a general principle, and considering the lack of judicial competence of the contemporary Chinese judges in copyright matters, ${ }^{812}$ rulings based on a general principle can be delivered arbitrarily and without proper analytical reasoning. ${ }^{813}$ Thus, just like in Japan, it is hard to say the principle of good faith is a reliable defense for the fan activities.

In all, we can clearly see from the previous discussions of this chapter that, under the current legal frameworks of the U.S., Japan and China, the problems of fan creations are not settled. Furthermore, there are many potential problems behind the conclusion of pure legal analysis which foreign copyright owners in the Chinese market will have to deal with.

\subsection{The EXISTIng Solutions}

According to the previous discussions in this chapter, most fan creations will probably be deemed copyright infringements, not to mention that this

\footnotetext{
${ }^{810}$ The General Principles of the Civil Law of China, art. 4 (here "honesty and credibility" is equivalent to "good faith".).

${ }^{811}$ Xie Li (李劦思), Chengshi Xinyong Yuanze de Sifa Shiyong - Yi Alexy de Yuanze Lilun Wei Shijiao (诚实信用原则 的司法适用—— 以 Alexy 的原则理论为视角) [Judicial Application of the Principle of Good Faith-From the Perspective of the Principle Theory by Alexy], RENDA FALV PINGLUn (人大法律评论)[ RENMIN UNIVERSITY LAW REVIEW] 131 (2013), available at http://www.civillaw.com.cn/article/default.asp?id=58622.

${ }^{812}$ See Yuwen Li, Professional Ethics of Chinese Judges, PerspeCtives Chinoises 38 (2003); see also Priest, supra note 5 , at $826-828$.

${ }^{813} \mathrm{Li}$, supra note 811.
} 
prima facie conclusion has been repeated again and again by big media conglomerates which own massive amounts of copyright titles. However, hardly any law suits against fansub groups were filed in China, as normally the fan groups will receive a take down notice from the copyright owner, and they will cease the distribution of certain titles after that, but little else. According to the analysis of the previous chapter, foreign copyright owners have no incentives to raise litigations against fansubbers because the costs of doing so are too high. Moreover, they are not so sure about whether to turn on the fans is a good idea, since fansubs do have some sort of promotional effect and most fans are advocates and potential consumers of their titles. 814

In the face of this predicament, many solutions have been proposed. The existing solutions which have been proposed and which address the problem of fan-based activities, can be divided into two categories: governmental (para. 4.4.1) and non-governmental (para. 4.4.2), which are discussed in succession in this section.

\subsubsection{Governmental Solutions}

Governmental proposals can be classified into two levels: international (para. 4.4.1.1) and national level (para. 4.4.1.2). This subsection explores these solution proposals in turn.

\subsubsection{International Level}

The proposals at International level mainly focus on the international obligations of China, and whether we could use international treaties to solve some endemic problems and make the business environment of China better for foreign copyright holders.

The copyright holders of foreign audio-visual products face difficulties in dealing with transnational unauthorized users. However, the best minds in the copyright field have been relying on the existing international legal instruments to devise solutions for that. After an international agreement is reached, the standards relating to intellectual property between the signing parties will then be unified. In an ideal scenario, as the

${ }^{814}$ See Lee, supra note 16, at 1536 (explained the folly of suing one's own fans). 
copyright protection standard rises due to international obligations, and the government is more serious about local law enforcement in China, the local piracy rate could then be lowered there, and the foreign copyright owners will only have to pay attention to infringement facilitators such as ISPs rather than individuals. By doing so the unauthorized online sharing of copyrighted works such as fan works will be limited to a reasonable level, since they all need a platform to exchange audio-visual files, and the platforms are comparatively easier to control.

However, as we have discussed before, local interests and the subsequent lax enforcement will prevent this ideal scenario from happening. ${ }^{815}$ Subsequently, foreign countries will have to resort to international platforms like the WTO via international political bargaining. If the government of China failed to carry out its international obligations, the foreign audio-visual industry could exert pressure on their own governments to initiate disputes with the Chinese government in an international setup such as the WTO. For example, the U.S. had raised two WTO disputes related to several of China's official policies, practices, and enforcement measures related to intellectual property rights protections in 2007 and $2008 .^{816}$

Nevertheless, from the Berne Convention to recent developments such as the Agreement on Trade-Related Aspects of Intellectual Property Rights (TRIPS) and the Anti-Counterfeiting Trade Agreement (ACTA), we have witnessed the shortcomings of these attempts. First, they have set the minimum standard of copyright protection but failed to take into account existing global economic inequalities. ${ }^{817}$ Second, it is believed that the international channels are "not the ideal forum" for content industries in countries like U.S. to gain "meaningful access to Chinese markets

\footnotetext{
815 Donald P. Harris, The Honeymoon is Over: Evaluating the United States' WTO Intellectual Property Complaint Against China, 32 Fordham InT'L L.J. 96, 167 (2009); see also Rogoyski \& Basin, supra note 6, at 252-54; Peter K. $\mathrm{Yu}$, Complex Guoqing and Intellectual Property Reforms in China, Peteryu.com, at http://www.peteryu.com/guoqing.pdf ("...one cannot help but question the effectiveness of the harmonization approach taken by developed countries... that approach often results in the creation of one-size-fits-all templates that ignore local needs and conditions. As a result, most of the existing reforms not only fail to target the crux of the piracy and counterfeiting problems, but have led to apathy and reluctance on the part of the local authorities and resistance and resentment among the local populace.").

${ }^{816}$ Panel Report, China--Measures Affecting the Protection and Enforcement of Intellectual Property Rights, WT/DS362/R (Jan. 26, 2009); Panel Report, China--Measures Affecting Trading Rights and Distribution Services for Certain Publications and Audiovisual Entertainment Products, WT/DS363/R (Aug. 12, 2009).

${ }^{817}$ See e.g., Alan Story, Burn Berne: why the Leading International Copyright Convention must be Repealed, 40 Hous. L. Rev. 763 (2003); Anselm Kamperman Sanders, Intellectual Property Law and Policy and Economic Development with Special Reference to China, in ECONOMIC ANALYSIS OF LAW IN CHINA (T. Eger, et al. eds., 2007).
} 
quickly" because it is a "lengthy process". 818 They are aiming at unifying the standards at a fast speed, but they are at their wits' end with the never-ending negotiations between developed countries and the developing countries. ${ }^{819}$ Third, even if the member states have committed and been obligated to enforce foreign copyrights, the copyright holders still have to face endemic problems such as lax enforcement and implicit preference of local interests. ${ }^{820}$ Fourth, it is also believed that the international pressure that China faces may have little effect on the actual copyright enforcement there. ${ }^{821}$ Fifth, Marci Hamilton's fear that international treaties such as TRIPs, that fail to consider the impact of the Internet, are already "out-dated and over-protective" is not redundant. ${ }^{822}$

In sum, using international treaties to solve problems of fan creations is not ideal; this is not only because the dispute settlement mechanisms set up by international treaties are not so efficient in addressing subtle copyright problems at the domestic level since they are time-consuming, but also because there will always be a problem of uneven compliance as levels of development and understanding of copyright norms vary from country to country.

\subsubsection{National Level}

Proposals at the national level mainly focus on revising the existing laws, e.g. proposals for new fair use or copyright exception terms (para. 4.4.1.2.1), ${ }^{823}$ proposals for a copyright taxation system (para. 4.4.1.2.2), ${ }^{824}$ proposals for the re-introduction of copyright formalities (para. 4.4.1.2.3), and proposals for an exemption period or an interpretive right in the copyright law (para. 4.4.1.2.4). ${ }^{825}$

\footnotetext{
${ }^{818}$ Elanor A. Mangin, Market Access in China--Publications and Audiovisual Materials: A Moral Victory with a Silver Lining, 25 BERKELEY TECH. L.J. 279, 308 (2010).

${ }_{819}$ Arguably some developing nations are moving "intellectual property lawmaking from one international forum to another". See Laurence R. Helfer, Regime Shifting: the TRIPS Agreement and New Dynamics of International Intellectual Property Lawmaking, 29 YALE J. INT'L L. 1, 53 (2004).

${ }_{820}$ See generally Priest, supra note 5; MERTHA, supra note 313, at 187.

${ }^{821} I d$. at 214.

${ }^{822}$ Hamilton, supra note 10, at 613 ("Professor Hamilton argues that the TRIPS Agreement is already outdated because It neglects to address that a great portion of the international intellectual property market will soon be on-line. She suggests that this critical omission could be used unfairly by publishers to restrict the free-flow of ideas as a means of profiting from their copyrights.").

${ }^{823}$ See Daniels, supra note 25, at 735; see also Noda, supra note 28, at 99.

${ }^{824}$ FISHER, supra note 13 , at 199-259.

${ }^{825}$ Leonard, supra note 28, at 256 (suggesting an exemption period for appropriating copyright owners' works right before they themselves begin exploitation in a foreign market); Noda, supra note 25, at 140-48 (suggesting that it is
} 


\subsection{Fair Use and Copyright Exceptions}

However, relying on local legislation to solve the problems caused by fan works is also not an ideal choice either. Existing proposals, which focus on revising copyright exceptions and fair use terms in copyright law, ${ }^{826}$ are not going to work as expected, not just because they still rely heavily on local courts in terms of transnational licensing (thus not avoiding the aforesaid endemic problems as well), but also because they still require a case-by-case judgment. Thus they are unable to provide clear guidance on what is infringeing and what is not. ${ }^{827}$ It is a fundamental problem of all the proposals which focus on copyright exception rules, even for the copyright exemption for non-commercial user-generated content (UGC) which Canada enacted in $2011,{ }^{828}$ as it also requires a case-by-case judgment. ${ }^{829}$ The Non-profit Internet Copyright Exemption (NICE) Act which was proposed by Edward Lee tends to offer comparatively higher stability. It provides much clearer rules, regarding what kinds of utilization of copyrighted works are acceptable, than the concept of "fair use", by offering non-profit entities that develop an Internet platform for UGC an exemption. ${ }^{830}$ However, it is not an ideal solution regarding the aim of this research, not only because it fails to stave off potential lawsuits, ${ }^{831}$ but also because it excludes file sharing and those activities that do not contribute much with regard to creativity, ${ }^{832}$ which, according to this research, are also very important for copyright owners in a transnational context. Furthermore, it could not offer copyright owners the degree of control over those newly created contents which are at least partly based on their copyrighted works either.

The problem of this approach is obvious: if the lawmakers want the copyright exception rules to be fair, it must be flexible in order to cope

\footnotetext{
reasonable to have an interpretive right containing all the permissible fan-base activities).

${ }^{826}$ See e.g., Noda, supra note 28; Muscar, supra note 25.

827 See Wendy J. Gordon, Fair Use as Market Failure: A Structural and Economic Analysis of the "Betamax" Case and its Predecessors, 82 ColuM. L. REV. 1600, 1627 (1982); William W. Fisher, Reconstructing the Fair Use Doctrine, 101 HaRv. L. REv. 1659, 1668 (1988); Samuelson, supra note 390, at 1232; Sheridan, supra note 720 , at 99. ${ }^{828}$ Copyright Modernization Act, S.C. 2011, c. 22, § 29.21(1)(a-d) (Canada).

${ }^{829}$ Id (it requires that the UGC content "does not have a substantial adverse effect, financial or otherwise, on the exploitation or potential exploitation of the existing work or other subject matter.").

${ }^{830}$ See generally, Edward Lee, Copyright-Exempt Nonprofits: A Simple Proposal to Spur Innovation, 45 ARIZ. ST. L.J. 1433 (2013).

${ }^{831}$ Id. at 1466 .

${ }^{832} I d$. at 1455 .
} 
with technology advancements and take into account the interests of all sides, ${ }^{833}$ but if it is flexible then it will never be clear enough for ordinary people to understand and to further use it to guide their activities. Besides, it is extremely difficult to design a "one size fits all" rule to cover all fan activities, while different artistic works have different expectations, and not every author is happy about his work being manipulated by fans.

\subsection{Copyright Levy}

A copyright taxation like the thuiskopieheffing in the Netherlands, ${ }^{834}$ or an "alternative compensation system" as Prof. William Fisher proposed, ${ }^{835}$ could be a better option. These kinds of proposals are similar to those utilizing agencies such as collective societies. ${ }^{836}$ However, apart from the complexity of the design, ${ }^{837}$ this kind of radical step would require a fundamental change in the copyright system of a country as it requires a new form of copyright revenue collection and distribution system that might involve a degree of government intervention, which might be improper to consider during this period of market and technology transition, even for the U.S., ${ }^{838}$ not to mention China.

Moreover, levies such as the thuiskopieheffing are not perfect with regard to the aim of this research. For the purpose of harmonizing the existing copyright exception rules in member states, the EU adopted the Directive 2001/29/EC of the European Parliament and of the Council of 22 May 2001 on the harmonisation of certain aspects of copyright and related rights in the information society. ${ }^{839}$ Its Article 5(2)(b) provides

\footnotetext{
${ }^{833}$ Afori, supra note 754 , at 276.

${ }^{834}$ Thuiskopieheffing is a Dutch tax levied on all devices capable of copying or downloading music or videos, such as smartphones.

${ }^{835}$ FISHER, supra note 13, at 199-258; For a similar proposal, see Neil Weinstock Netanel, Impose a Non-commercial Use Levy to Allow Free Peer-to-Peer File Sharing, 17 HARV. J.L. \& TECH. 1 (2003); For a proposal for China based on Fisher's design, please see Priest, supra note 5, at 846-67.

${ }_{836}$ See e.g., Martin Kretschmer, The Failure of Property Rules in Collective Administration: Rethinking Copyright Societies as Regulatory Instruments, 24 Eur. InTELL. Prop. ReV. 126 (2002). See also Michael Geist, Music Licensing Would Be Viable for All, TORONTO STAR, Mar. 8, 2004, at http://www.michaelgeist.ca/2004/03/music-licensing-would-be-viable-for-all/.

${ }_{837}$ See Martin LaMonica, Debating Digital Media's Future, CNET, Sep. 18, 2003, at http://news.com.com/2100-1025-5079007.html.

${ }^{838}$ LESSIG, supra note 42 , at 301.

${ }^{839}$ Directive 2001/29/EC of the European Parliament and of the Council of 22 May 2001 on the harmonisation of certain aspects of copyright and related rights in the information society, Official Journal L 167, 22/06/2001, P. 0010 0019 (hereinafter the InfoSoc Directive).
} 
that private copying is one of the "exceptions or limitations to the reproduction right" that EU member states should provide for, on the condition that right holders receive "fair compensation". ${ }^{840}$ However, there is no guidance about what constitutes "fair" on the EU level. Therefore, member states that apply the private copying exception continue to develop their own levy systems.

There are several obstacles when applying the EU's experience with regard to this research. On the one hand, these kinds of copyright levies only concern "private copy", which means the purpose of the copy should be for personal use only. This is different from fan activities, as most of them are aiming at sharing their works with others online, and it obviously goes beyond the definition of personal use. On the other hand, they might provide an insufficient channel of income, as the notion of "fair compensation" is not well harmonized within the member states. For the first time, the Court of Justice of the European Union (CJEU) has addressed this issue in the Padawan case. ${ }^{841}$ It has ruled that:

The concept of 'fair compensation', within the meaning of Article 5(2)(b) of Directive 2001/29/EC of the European Parliament and of the Council of 22 May 2001 on the harmonisation of certain aspects of copyright and related rights in the information society, is an autonomous concept of European Union law which must be interpreted uniformly in all the Member States that have introduced a private copying exception, irrespective of the power conferred on the Member States to determine, within the limits imposed by European Union law in particular by that directive, the form, detailed arrangements for financing and collection, and the level of that fair compensation. $^{842}$

However, CJEU has also ruled that:

\footnotetext{
${ }^{840}$ InfoSoc Directive, art. 5(2)(b) ("Member States may provide for exceptions or limitations to the reproduction right provided for in Article 2 in the following cases: (...) (b) in respect of reproductions on any medium made by a natural person for private use and for ends that are neither directly nor indirectly commercial, on condition that the right holders receive fair compensation which takes account of the application or non-application of technological measures referred to in Article 6 to the work or subject-matter concerned;").

${ }^{841}$ Padawan v. SGAE, C-467/08 of 21 October 2010, [2010] ECR I-10055.

${ }^{842}$ Id.
} 
Article 5(2)(b) of Directive 2001/29 must be interpreted as meaning that a link is necessary between the application of the levy intended to finance fair compensation with respect to digital reproduction equipment, devices and media and the deemed use of them for the purposes of private copying. Consequently, the indiscriminate application of the private copying levy, in particular with respect to digital reproduction equipment, devices and media not made available to private users and clearly reserved for uses other than private copying, is incompatible with Directive 2001/29.

In other words, EU member states should interpret the concept of 'fair compensation' uniformly, and, they should make a distinction between private and professional users in collecting the copying levies. In that case, member states should reimburse professional users who were wrongfully charged before, and start to collect the copying levies only from the private users. However, member states such as the Netherlands find it difficult to apply the ruling of the Padawan case, as the re-calculation of the consequential re-imbursement and future tariffs are problematic. $^{843}$ Although the 2013 report of the mediator António Vitorino has put forward some suggestions regarding how to solve this problem by, for example, transferring the liability from the manufacturer's or importer's level to the retailer's level, ${ }^{844}$ these suggestions are facing challenges and will face more in the future. For example, according to a more recent CJEU ruling, the thuiskopieheffing set by the Dutch government must not take into account the harm caused by copies made from unlawful sources, which also made downloading pirate copies of copyrighted works in the Netherlands illegal, ${ }^{845}$ and it could lead to "a reduc-

\footnotetext{
${ }^{843}$ Lucie Guibault, Private Copying Levy: The Aftershocks of Padawan, KLUwER COPYRIGHT BLOG, Sep. 17, 2013, at http://kluwercopyrightblog.com/2013/09/17/private-copying-levy-the-aftershocks-of-padawan/. ANNETTE KUR \& Thomas Dreier, European Intellectual Property Law: Text, Cases \& Materials 306-07 (Edward Elgar Publishing Limited. 2013).

${ }^{844}$ António Vitorino, Recommendations Resulting from the Mediation on Private Copying and Reprography Levies, Brussels, Jan. 31, 2013, at http://ec.europa.eu/internal_market/copyright/docs/levy_reform/130131_levies-vitorino-recommendations_en.pdf. ${ }^{845}$ Case C-435/12, ACI Adam BV and Others v Stichting de Thuiskopie and Stichting Onderhandelingen Thuiskopie vergoeding, Apr. 10 , 2014, $\mathrm{r}=\&$ occ $=$ first\&part $=1 \&$ cid $=384493$.
} 
tion of the overall amount of levies for private copying" and to the phasing out of the levy system in the digital environment. ${ }^{846}$

There would also be concerns about the efficacy of the responsible collecting societies, and, most importantly, the complicity when foreign authors are involved in a levy system is detrimental for it to become a setting that could solve transnational copyright problems. In terms of China, the copyright levy approach is theoretically possible but practically infeasible, because the problems of unauthorized use and piracy are never the top priority in China, nor will they be in the near future. ${ }^{847}$ Therefore, it would be hard to imagine that China will adopt a copyright that advocates free use of copyright contents, as it will make the flow of idea harder to control, not to mention the potential pitfall of having too much government intervention in a solution design of this kind.

\subsection{Reintroduction of Copyright Formalities}

Requirements on formalities are arguably necessary for protecting copyright in the digital age. They will facilitate rights clearance, enhance the free flow of information by enlarging the public domain and thereby provide more legal certainty about copyright claims. ${ }^{848}$ Specifically speaking, one of the main problems of copyright in a digital era is that the threshold for copyright protection is too low, and too many "works" are protected. Most works are not of much commercial value, even for many initially successful works, their values are quickly exhausted, ${ }^{849}$ not to mention that some works were created without the intention to claim protection. It further illustrates a problem that, while we are enjoying the abundance and availability of content brought by the digital technology today, we lack adequate and reliable information about ownership of them. ${ }^{850}$ Therefore, if the world community could reach consensus on a feasible reform on copyright formalities, then it is possible China would

\footnotetext{
${ }^{846}$ João Pedro Quintais \& Alexander de Leeuw, Downloading from Unlawful Sources. Reflections following the Villalón Opinion on AciAdam and Others, KLUWER COPYRIGHT BLOG, Feb. 27, 2014, at

http://kluwercopyrightblog.com/2014/02/27/downloading-from-unlawful-sources-reflections-following-the-villalon-o pinion-on-aciadam-and-others/.

${ }_{847}$ See generally, Yu, supra note 815 .

${ }^{848}$ Stef van Gompel, Copyright Formalities in the Internet Age: Filters of Protection or Facilitators of Licensing, 28 Berkeley TeCh. L.J. 1425, 1456 (2013); Niva Elkin-Koren, Can Formalities Save the Public Domain? Reconsidering Formalities for the 2010s, 28 BERKELEY TECH. L.J. 1537, 1541 (2013).

${ }_{849}$ Christopher Sprigman, Reform(aliz)ing Copyright, 57 STAN. L. REV. 485, 488 (2004).

${ }^{850}$ Samuelson, supra note 390, at 1198.
} 
follow suit. Consequently, most fan problems would be solved, as fan works which draw on those works that fail to satisfy the formality requirements could then be exempted to some extent. And it is to be expected that authors of works with significant commercial value and the authors who believe their works have commercial value will tend to comply with the formality requirements, thereby increasing legal certainty and lowering the infringement rate of the individuals.

However, since Article 5(2) of Berne Convention clearly provides that "the enjoyment and the exercise of these rights shall not be subject to any formality", ${ }^{851}$ these terms are not feasible in terms of solving the transnational problems that this research concerns as it especially focuses on copyright protection of foreign works in China. ${ }^{852}$ Therefore, for a registration system to survive, a country should either choose to withdraw from all the international treaties that require the abolishment of formalities, ${ }^{853}$ or figure out a way to change or meet these requirements in those international treaties. ${ }^{854}$ Considering that both the withdrawal and the correctional proposals are costly and impractical, a Berne-compliant requirement on formalities is thus more reasonable.

In order to propose such terms, the true meaning of "the enjoyment and the exercise of these rights shall not be subject to any formality" in Article 5(2) of the Berne Convention must first be clarified. According to WIPO's Guide to the Berne Convention, the term "formality" must be understood "in the sense of a condition which is necessary for the right to have administrative obligations laid down by national laws, which, if not

\footnotetext{
${ }^{851}$ Berne Convention, art. 5(2). For similar requirement, see also UCC, art. III; WIPO Copyright Treaty, Dec. 20, 1996, S. Treaty Doc. No. 105-17 (1997), 36 I.L.M. 65 (1997), art. 1(4) [hereinafter WIPO Copyright Treaty]. TRIPS Agreement art. 9(1).

${ }^{852}$ It is feasible if the formality requirement only applies to domestic works, as the rights guaranteed under Article $5(2)$ of the Berne Convention only apply "outside the country of origin" scenario. See Berne Convention, art. 5. For existing example, see 17 U.S.C $\S 411(2012)$ (“...no civil action for infringement of the copyright in any United States work shall be instituted until pre-registration or registration of the copyright claim has been made in accordance with this title."); See also Sprigman, supra note 849, at 551 ("Because Berne does not prevent signatories from imposing formalities on the works of domestic authors or authors from non-Berne signatory nations..."). WIPO, GUIDE TO THE BERNe CONVENTION FOR THE PROTECTION OF LITERARY AND ARTISTIC WORKS (PARIS ACT, 1971) 33 (1978)(“country remains absolutely free to subordinate the existence or exercise of the rights on that work in that country to such conditions or formalities as it thinks fit: it is purely a matter of domestic law"). However, restricting domestic authors may raise political and practical problems as well, see Jane C. Ginsburg, With Untired Spirits and Formal Constancy: Berne Compatibility of Formal Declaratory Measures to Enhance Copyright Title-Searching, 28 BERKELEY TECH. LJ 1583,1587 (2013).

${ }^{853}$ Thomas F. Cotter, Prolegomenon to a Memetic Theory of Copyright: Comments on Lawrence Lessig's The Creative Commons, 55 FLA. L. REv. 779, 779-80, n.2 (2003)(“...reintroducing mandatory formalities into U.S. law might require the United States to withdraw from international copyright treaties..."); see also Sprigman, supra note 849 , at 552 .

${ }^{854}$ Id. at $545-54$.
} 
fulfilled, lead to loss of copyright." ${ }^{855}$ "These rights" are described in Article 5(1) of the Berne Convention. ${ }^{856}$ The terms that need to be further clarified are "enjoyment" and "exercise". The term "enjoyment" links to the formalities that condition the existence of copyright. ${ }^{857}$ These formalities include "registration, the deposit or filing of copies, the payment of fees, or the making of declarations." 858 Furthermore, requirements such as "obligations to register and renew copyrights" and "limitations or exceptions" on the scope of rights are also prohibited in general. ${ }^{859}$ The term "exercise" concerns the enforcement of copyright. Therefore, limitations on the copyright owner's ability to access judicial process, injunctive relief, and actual damages are in conflict with Berne's requirements. ${ }^{860}$

In light of the above, several Berne-friendly proposals have been raised. ${ }^{861}$ However, commentators have examined existing proposals that suggest a favorable consideration in granting statutory damages, attorney fees, and fair use judgments related to unregistered works, ${ }^{862}$ and those all rely on the requirements of voluntary formality. ${ }^{863}$ Unfortunately, the results are somewhat negative. ${ }^{864}$ In other words, there is not much room for a general formality requirement, which can release a great deal of works from strict copyright protection and make them easier for subsequent authors to build on, to survive the Berne requirement. In terms of enhancing the free flow of information and enlarging the public domain, one of the possible solutions is to shorten the term of copyright protection. The hidden danger, however, is the expansion of expropriation, considering the fact that copyright is deemed by the law as property right. Nevertheless, the copyright protection term determines both when an existing copyrighted work will enter the public domain, and also the amount of works that fan creators of derivative works, which this research is

\footnotetext{
${ }^{855}$ WIPO, supra note 852 , at 33 . This is a prevailing explanation, see also Ginsburg, supra note 852, at 1589 (“...the term "formality" encompasses both formal and material conditions on the existence or enforcement of rights").

${ }^{856}$ Berne Convention, art. 5(1)(“... the rights which their respective laws do now or may hereafter grant to their nationals, as well as the rights specially granted by this Convention.”).

${ }^{857}$ Ginsburg, supra note 852, at 1590. See also STEF VAN GOMPEL, FORMALITIES IN COPYRIGHT LAW: AN ANALYSIS OF THEIR HISTORY, RATIONALES AND POSSIBLE FUTURE 199 (Kluwer Law International. 2011).

${ }^{858}$ Ginsburg, supra note 852, at 1590.

${ }^{859}$ Id.

${ }^{860}$ Id. See also VAN GOMPEL, supra note 857, at 200.

${ }^{861}$ See e.g., Samuelson, supra note 390, at 1198-202; Sprigman, supra note 849, at 554-67; Ginsburg, supra note 852, at $1613-21$.

${ }^{862}$ Samuelson, supra note 390 , at 1200.

${ }^{863}$ Sprigman, supra note 849 , at 555.

${ }^{864}$ See e.g., Ginsburg, supra note 852, at 1593.
} 
concerned with, can rely upon without worrying about copyright liabilities. That term set by the Berne Convention is 50 years after the death of the author, ${ }^{865}$ China and Japan have followed suit, ${ }^{866}$ yet the U.S. has set the term at 70 years. ${ }^{867}$ Although the Berne Convention believes that formalities are detrimental to copyright, it can be argued that the length of these terms is unrealistic, that they are too long, and therefore that they might have a negative impact on our society, especially regarding the public domain. ${ }^{8}$

Many proposals have been raised with the aim of shortening the copyright protection term de facto (at least for most insignificant creations) by inserting registration-like mechanisms. ${ }^{869}$ However, as proved by many commentators in the field, any formality that prevents the author from "enjoying" his/her rights under the Berne Convention is a clear violation of it. ${ }^{870}$ As arguably the protection to be granted under the rule of national treatment is also subject to the prohibition on formalities, even Berne-plus rights are covered. ${ }^{871}$ Therefore, there is in practice not much room left for a feasible setting, which is capable of putting massive amounts of works into the public domain before their copyright protection terms end. ${ }^{872}$

\footnotetext{
${ }^{865}$ Berne Convention, art. 7.

8662010 Copyright Law of the People's Republic of Chin, art. 21; Japanese Copyright Law, art. 51. Japan may endorse 70 years plus author's lifetime in the future, under the pressure of TPP negotiations. See Ida Torres, Japan Considering Extending Copyright Terms to 70 Years after Author's Death, JAPAN DAILY PRESS, at http://japandailypress.com/japan-considering-extending-copyright-terms-to-70-years-after-authors-death-1032092/.

${ }^{868}$ See e.g., LESSIG, supra note 42, at 135 ("American law no longer had an automatic way to assure that works that were no longer exploited passed into the public domain. And indeed, after these changes, it is unclear whether it is even possible to put works into the public domain. The public domain is orphaned by these changes in copyright law. Despite the requirement that terms be "limited," we have no evidence that anything will limit them."); JAMES BOYLE, The Public DOMAIN: ENClosing THE COMMONS OF THE MIND 131 (Yale University Press. 2008)("Most of the culture of the twentieth century, produced under a perfectly well-functioning system with much shorter copyright terms, is still locked up and will be for many years to come."); Bell, supra note 572, at 786 (Federal lawmakers favor expanding the rights of copyright owners over...the public interest.); JESSICA LiTMAN, DigiTAL COPYRIGHT 77-8 (Prometheus Books Pbk. ed. 2006)(claiming that the past copyright reforms are done "in ways that have expanded copyright's scope and blinded many of us to the dangers that arise from protecting too much, too expansively for too long.”); Yufeng Li (李雨峰), Lun Zhuzuo Caichanquan de Baohuqi (论著作财产权的保护期)[On the Protection Term of Copyright], ZHENGZHi Yu FALU (政治与法律)[PoliticAl SCIENCE AND LAW], no.4, 2008, at 121-2 (“the consequences of a copyright extension are: (1)violation of the rule of law...(2) eroding the public domain...(3)re-construction of social structure").

${ }_{869}$ See e.g., LeSSIG, supra note 9, at 251-2; Landes \& Posner, supra note 748, at 473.

${ }^{870}$ Ginsburg, supra note 852, at 1589-90; VAN GOMPEL, supra note 857, at 167-8.

${ }^{871}$ Ginsburg, supra note 852, at 1602-3; vAN GOMPEL, supra note 857, at 167-8.

872 Although commentator has indicated that, in some rare cases such as Berne-plus rights, it is possible to set certain formalization requirements on works, it is nevertheless not so helpful in terms of releasing massive amount of works to the public domain. See Ginsburg, supra note 852, at 1602-3.
} 
As to the benefit of the formalities of rights clearance or generating information to facilitate licensing, there exist many possible options. ${ }^{87}$ Nevertheless, it is clear that rights management information and the transfer of copyright only concern a small portion of the existing works which are available online de facto, therefore these settings fail to enlarge the public domain or to address those economically insignificant works properly. And, more importantly, many of the existing proposals are especially tailored for the United States. Therefore, apart from the universally applicable findings discussed above, when conceiving a Berne-compliant setting on copyright formalities for China, many endemic factors should be taken into consideration.

Considering Berne-compatibility problems, it is not that simple a question of whether a certain formality is feasible or not in China. It is more of a question about whether China will take the initiative to introduce Berne-compatible rules to the CCL. If the answer is yes, then whether that move will serve the purpose of this research, or not, is unclear. In view of China's purpose in regulating the culture market that was discussed above, it will probably adopt a Berne-free copyright registration system or renewal requirements, as it will encourage most authors to provide the information the government needs for content control and management. It is helpful not so much in commercial works (as they are already highly regulated and by all means "registered" under the current censorship system) but rather in those economically insignificant works. Besides, an expanded public domain will probably do more good than harm to China. However, in the light of the WTO case DS362 China Measures Affecting the Protection and Enforcement of Intellectual Property Rights, it is risky to let a government decide on the copyright protection of a work, if its primary goal in regulating the cultural sector is to control, rather than to promote, creativity.

Therefore, for China, "abide by the Berne rules" appears to be the most feasible suggestion one can possibly make. However, possible Berne-compatible solutions will only offer limited help in rights clear-

\footnotetext{
${ }^{873}$ For example, Stef van Gompel has indicated that it is possible to re-introduce formalities in terms of rights clearance, but not those "for the purpose of enhancing the free flow of information by enlarging the public domain". He further indicates that, in order to promote right clearance, "piecemeal approaches" such as making the protection of rights management information conditional and making the public registration of transfer of copyright possible could be adopted by contracting states. van Gompel, supra note 848, at 1456-7. See also VAN GOMPEL, supra note 857, at 213-88; Similarly, Prof. Ginsburg has found a declaratory measure that "conditioning validity of transfer of copyright on recordation of a note or memorandum of the transfer" is Berne-compatible. See Ginsburg, supra note 852, at 1621, see also van Gompel, supra note 848, at 1457. VAN GOMPEL, supra note 857, at 288.
} 
ance. But rights clearance is not the major concern of fan-generated contents, because the information of the copyright owners is clearly provided in most commercial works they appropriated. Hence it is a problem of "why ask for permission" rather than a problem of "who to ask for permission". That is to say, if the situation that no new blood is allowed to enter the public domain persists, then rights clearance alone cannot offer too much help in addressing the massive online infringement problem.

\subsection{Other Proposals}

The proposals for having an exemption period and an interpretive right in the copyright law might seem attractive, but they rely too much on the notions of "proselytization commons" 874 and "canonical/non-canonical distinction" 875 that were deemed to be the characteristics of the fan-based activities. These proposals are a combination of national law revision proposals and the ethos building of the fan community proposal. They are attractive and interesting, but the expected outcome is questionable, as the afore-mentioned characteristics are hard to prove and, as discussed above, fan contributors now have mixed motivations other than pure fandom. Furthermore, these proposals would not be able to prevent free riders from taking advantage of them.

Another proposal from Japan suggests that the country could establish a "national subtitle center" to recruit professional translators or even part-time international students to translate Japan's audio-visual works into different languages. By doing so, Japan's audio-visual production could be exposed to a wider audience. ${ }^{876}$ This proposal may reduce the role of fansubs to a degree, as it would provide most Japanese audio-visual works with authorized subtitles in multiple foreign languages which would possibly substitute the needs for fansubs. However, whether government will appreciate this kind of proposal or not is still a question, as too much government intervention will cause new problems such as

\footnotetext{
${ }^{874}$ Leonard, supra note 28, at 192 (explaining it as "a space where media and ideas could be freely exchanged to advance a directed cause").

${ }^{875}$ Noda, supra note 25, at 137 (claiming that this distinction "prevents their activities from eroding the copyright holder's incentives").

${ }^{876}$ Kensaku Fukui (福井健策), Chosakuken o Ikasu ni wa Dejitaru kontentsu no kōzai (著作権を活かすにはデジ タルコンテンツの功罪)[In Exploiting Copyright: The Advantages and Disadvanteges of Digital Contents], Hummingheads.co.jp, Oct. 31, 2013, at http://www.hummingheads.co.jp/reports/interview/1310/131031_03.html.
} 
the funding of such an institute and the allocation of consequential profits. Moreover, since this proposal only focuses on solving the problems of fansubs, it fails to consider the problems of other transformative fan creations.

\subsubsection{Non-governmental Solutions}

The non-governmental proposals can be further divided into two groups: those designed for the fan communities to adopt and those designed for the copyright holders. Proposals for fan communities mainly amount to the establishment of a community ethos (para. 4.4.2.1). For example, considering the fact that commercial pirates are taking advantage of fansubs, seizing the fan-translated subtitles, even the video files and selling them directly, and with the concern that they may get in copyright troubles in the future, fansub groups started to put certain warnings and disclaimers into their fansubs, in order to justify their activities. ${ }^{877}$ Proposals for a change from the copyright owners include toleration (para. 4.4.2.2), and public copyright licenses such as CC licenses and a NAP, which refers to revocable exemption notices posted by copyright owners, granting authorization to the public for selective appropriations in a flexible manner (para. 4.4.2.3). ${ }^{878}$

\subsubsection{Self-policing of the Fan Community}

Researchers have noticed that the fans read the copyright rules such as fair use differently from experts in the law field, and suggested that fan communities should have "cohesion to craft codes of best practice". ${ }^{879}$ Advocates for this solution can be found in the fan communities as well. $^{880}$

\footnotetext{
${ }^{877}$ In most cases, it contains warnings such as "not for commercial purposes". See e.g., The Term of Use, Fansub-share.org, http://fansub-share.org/tou/.

${ }^{878} \mathrm{Wu}$, supra note 42, at 633-35.

${ }^{879}$ Preston, supra note 529.

${ }^{880}$ Kincaid, supra note 540 ("We can continue to push for more content releases by sending requests to the companies and, yes, still subbing and scanlating ethically. We need to keep in mind that we are partners with the people who create our favorite anime and manga. If we don't do our part, they cannot continue to make the stories we enjoy.").
} 
Considering the disadvantages of self-regulation such as legal uncertainty and a lack of accountability of the norm setting process, ${ }^{881}$ the idea of building the ethos of the fan community is brilliant but impractical: there are far too many fan groups and they are all trying to build their own ethos, not to mention that with the help of digital technologies, fan groups are much more powerful and could easily deviate from their own fragile ideals. ${ }^{882}$ For example, some Chinese fansub groups have crossed the line of "non-commercial use", which is believed to be the core ethos of fansub community. Moreover, a 2009 report illustrated that some of the distinguished Chinese fansub groups with a huge member base in hand could earn millions of RMB per year from advertising revenues; sponsors are willing to pay because these big sites could bring in considerable clicks. But it is clear from the existing cases that only the core members could lay their hands on that money.

However, self-policing is a crucial part of a practical solution design if the purpose is to regulate a type of online communities effectively. Ideas such as ethos building or self-policing can be boiled down to norms, a concept that Lessig described as one of the four constraints that can regulate people's behavior in cyberspace. ${ }^{883}$ Hugenholtz noted that the self-regulation of private actors is always accompanied by government intervention. ${ }^{884}$ In some cases, it is the result of industry pressure. ${ }^{885} \mathrm{It}$ means that in the case of fan communities, government and the industry could foster their self-regulation by exerting pressure on them. Although Hugenholtz's research was mainly referring to intermediaries such as ISPs, which are comparatively more stable than fan groups, but that experience is also applicable to the latter as well. Therefore, it is very important for the industry, and even the government, to take initiatives to foster norms building of fan communities. However, considering the disadvantages of self-regulation such as legal uncertainty, in terms of this research, it is not an ideal solution but rather an important aspect that needs to be taken into consideration when designing the solution.

\footnotetext{
${ }^{881}$ P. B. Hugenholtz, Codes of Conduct and Copyright Enforcement in Cyberspace, in COPYRIGHT ENFORCEMENT AND THE INTERNET 307 (I.A. Stamatoudi, ed. 2010).

${ }^{882}$ See Lele, supra note 480.

${ }^{883}$ The four constraints are: the law, social norms, the market, and architecture. See LESSIG, supra note 12, at 123.

${ }^{884}$ Hugenholtz, supra note 881 , at 305.

${ }^{885}$ Id. at 306.
} 


\subsubsection{Tolerance}

In the previous chapters, we have discussed challenges which the current copyright law system is facing. ${ }^{886}$ It shows that, collectively, copyright owners such as content conglomerates feel threatened because they have lost control over their works. However, in the face of these problems which they encounter in a foreign market like China, it seems that tolerating most infringements, and focusing on the economically valuable ones is now the common practice of the cultural industries around the world. Their strategic ignorance or toleration, as we could see from the practices of copyright owners from the U.S. (para. 4.4.2.2.1), Japan (para. 4.4.2.2.2), and China (para. 4.4.2.2.3), can be summarized as selective copyright enforcement (para. 4.4.2.2.4), in which the copyright owners tolerate many contributive fan activities and enforce or claim their rights when necessary. The reasons and limitations of toleration are explored in para. 4.4.2.2.5 and para. 4.4.2.2.6 respectively.

\subsection{The U.S.}

In the U.S., the pressure from the industry and its lobbying efforts have directly resulted in the promulgation of the Sonny Bono Act, the Digital Millennium Copyright Act (DMCA), and the recognition and implication of DRM technologies in copyrighted works. The decision of the Sony case was challenged, argued, and even modified thereafter by various cases. In the famous 2001 Napster case, the Ninth Circuit Court of Appeals rejected the "space shifting" argument, which is similar to the "time shifting" argument in the Sony case, reasoning that Napster could use its system to monitor and control its users' activities. ${ }^{887}$ In the 2004 Grokster case, the U.S. Supreme Court further developed the test standard of the Sony decision by judging Grokster liable for inducing copyright infringement, despite recognizing that the program could also be used for non-infringeing uses. ${ }^{888}$ Moreover, the consequential enactments, such as DMCA and the newly proposed Stop Online Piracy Act (SOPA), have been perceived as being heavily biased in favor of copyright owners and,

\footnotetext{
${ }^{886}$ See supra Chapter 3.2.1 Challenges to the Copyright System.

${ }_{887}$ A\&M Records, Inc. v. Napster, Inc. 239 F.3d (9th Cir. 2001).

${ }^{888}$ MGM Studios, Inc. v. Grokster, Ltd. 545 U.S. 913 (2005).
} 
thus, might create new problems. ${ }^{889}$ Conversely, in terms of foreign audio-visual works in a designated market, their copyright owners have tolerated some unauthorized uses. For instance, when Sean Leonard conducted research into the history of Japanese Anime fansubs between 1986 and 1993 in the U.S. he found that the Japanese copyright owners of the infringed titles intentionally ignored, tolerated, and even encouraged fansub activities for market share considerations at that time. ${ }^{890}$

It is easy to find cases where copyright owners have frowned upon fan activities or even raised charges against participators in the U.S. as well. Interestingly, cases can also be found there, in which copyright owners were not against fan activities, or even concurred with them to a certain degree. ${ }^{891}$ Fisher has elaborated and categorized these responses into two: indulgent and prudent tolerance. ${ }^{892}$ The former means that the copyright owners tend to turn a blind eye to fan alterations. ${ }^{893}$ The latter demonstrates a positive attitude of copyright owners to strategically monitor the fan creations, and, when necessary, object to any inappropriate behavior. ${ }^{894}$ Take the J.K. Rowling case as an example. ${ }^{895}$ Rowling, the author of the Harry Potter books, had tolerated, and even praised the series' unofficial fan site which is owned by Steven Vander Ark, until Vander Ark decided to publish and claim copyright on a Harry Potter reference book based on the materials of his site. Rowling sued to enjoin its publication. ${ }^{896}$ Rowling and her partners intentionally ignored Vander Ark's website but only focused on the publication and the commercialization of those materials. In other words, Rowling opted to tolerate the website, but the print publication of those materials had crossed her line and she decided to act. Another recent example is a famous fanfic of the

\footnotetext{
${ }^{889}$ See e.g., Mark A. Lemley, et al., Don't Break the Internet, 64 StAN. L. REV. OnLINE 34, 36-37 (2011); Jie Wang (王杰), Meiguo SOPA Yian Pingxi Jiqi Dui Woguo Wangluo Zhishi Chanquan Lifa De Qishi (美国 SOPA 议案评析及 其对我国网络知识产权立法的启示) [Analysis on SOPA and What Can Be Learned from SOPA for IP Legislation Under the Network Environment in China], ZHISHI CHANQUAN (知识产权) [INTELLECTUAL ProperTy], no.8, 2012, at 90, 92-94.

${ }_{890}$ See Generally Leonard, supra note 28.

${ }^{891}$ Lee, supra note 16, at 1473.

${ }^{892}$ Fisher, supra note 23, at 1436.

${ }^{893} I d$. at 1436 .

${ }^{894}$ Id. at 1437.

${ }^{895}$ Warner Bros. Entm't Inc. v. RDR Books, 575 F. Supp. 2d 513 (S.D.N.Y. 2008)

${ }^{896}$ Geonard F. Buttler II, Case Summary, Warner Bros. Entertainment and J.K. Rowling v. RDR Books and Does 1-10. 575 F. Supp. 2D 513, 19 DePaul J. Art TeCh. \& InTell. Prop. L. 421, 434 (2008). For a similar U.S. case in favor of the copyright owner, please see Castle Rock Entertainment, Inc. v. Carol Publishing Group, Inc. 150 F.3d 132 (2d Cir. 1998).
} 
popular Japanese anime Naruto named In Excess. ${ }^{897}$ It was first posted on Fanfiction.net and was subsequently published in 2012. However, unlike in its online version, the names of the original characters were all changed in the print version. Fifty Shades of Grey, a renowned American erotic romance novel and movie, also began as a fanfic of the Twilight novels which was published online for free initially. ${ }^{898}$ Moreover, recently many representatives of the U.S. audio-visual industries have indicated that they welcome fan creations based on their copyright works, provided that they are made for non-commercial purposes.

\subsection{Japan}

Japan is famous for its cultural products. In the 2000 White Paper of Japanese Government Policies in Education, Science, Sports, and Culture, manga and animation, along with feature films, were described as the "foundation" for "new media arts." domestic market sales for anime (comprising film, television, and video sales) were $¥ 191.2$ billion ( $€ 1.38$ billion); when combined with other anime-related merchandizing rights, the entire domestic market for anime content was estimated to be worth about $¥ 2$ trillion ( $€ 14.4$ billion). ${ }^{901}$ The comparative number of combined Japanese anime and manga sales in the United States in 2010 was calculated to be over $\$ 400$ million. ${ }^{902}$ The animation industry is growing rapidly in China, and the total output value was estimated to be US\$12 billion at the end of 2012. ${ }^{903}$ However, a

\footnotetext{
${ }^{897}$ The title "In Excess" evokes a connotation of N(aruto) and Sas(uke), the names of the two main characters of Naruto.

${ }^{898}$ Natasha Bertrand, 'Fifty Shades of Grey' Started Out as 'Twilight' Fan Fiction Before Becoming an International Phenomenon, BUSINESS INSIDER, Feb. http://uk.businessinsider.com/fifty-shades-of-grey-started-out-as-twilight-fan-fiction-2015-2?r=US.

${ }^{899}$ Lee, supra note 16 , at 1515-18.

900 See Ministry of Education, Culture, SPORTS, ScIENCE AND TECHNOlOGy, JAPANESE GovernMent Policies IN EDUCATION, SCIENCE, SPORTS AND Culture http://www.mext.go.jp/b_menu/hakusho/html/hpae200001/hpae200001_2_079.html (“...film, animation, and manga (comics) have each established their own respective independent fields. They are also the foundation for new media arts, and as such, it will be necessary to further their promotion.")(Japan).

901 Japan External Trade Org., supra note 459.

902 Japan to USA: Anime \& Manga, Japan External Trade Org. U.S., http://www.jetro.org/usa/japanus/animemanga/.

${ }^{903}$ Heng Shao, Animation Start-up 'Light Chaser' Scores Big Hit in China with First Short Film, ForBES, Mar. 27, 2014 ,

http://www.forbes.com/sites/hengshao/2014/03/27/animation-start-up-light-chaser-scores-big-hit-in-china-with-first-s hort-film/ ("The Chinese animation industry that Wang has plunged into is one with high speed growth but low quality products. Since 2010 , its total output value has grown at an average rate of $30 \%$ a year, to $\$ 12$ billion at the end of 2012.").
} 
survey of Chinese youth about their favorite animation in 2010 showed that sixty percent of the selected works were Japanese anime, ${ }^{904}$ suggesting the Japanese potentially owned a large part of that amount. ${ }^{905}$ When Osamu Tezuka raised the curtain on modern Japanese anime in 1963 with his Tetsuwan Atomu (also known as Astro Boy in Western countries), these promising figures were completely unimaginable and would remain so until the late $1980 \mathrm{~s}$.

It is obvious enough that many Japanese cultural products have huge fan bases at least in the U.S. and China. Amongst others, the anime-related industry is the most notable one. As a typical example of a subculture and niche market, the success of the anime-related market is not a coincidence. Apart from the characteristically sophisticated and fascinating narratives of Japanese anime-related products, the copyright strategies of the industry and fan-based activities have also contributed greatly to its success. It is also evident that the Japanese anime and manga industries have tolerated many fan-based activities, and sometimes have even provided them with active support and participation. ${ }^{906}$ Doujinshi, a type of fan-made manga (comic) which uses characters and background elements from other manga, anime, or video game sources and develops them with a different story line, ${ }^{907}$ is a good example. In 2007 , the most famous doujinshi market, the Comiket, had more than 35,000 "circles" of authors. ${ }^{908}$ More recently, in 2012, approximately 560,000 attendees participated in the three-day semi-annual doujinshi market. ${ }^{909}$ It is unquestionably an enormous market that is theoretically competing with the authentic market. But interestingly, even though most of these activities are illegal under Japanese copyright law, copyright owners and the industry

\footnotetext{
${ }^{904}$ Nan Jiang (江南), Zhongguo Dongman Chanye Fazhan Fenxi (中国动漫产业发展分析) [Analysis of the development of China’s Animation Industry], JIN CHUANMEI (今传媒) [TODAY’S MASSMEDIA], no.1, 2014, at 114.

${ }^{905}$ Kuishi Zhongguo Chuangyi Chanye de Bingshan Yijiao - Dongman Chanye (窥视中国创意产业的冰山一角一 动漫产业) [Looking into the Creative Industry of China - the Animation Industry], LING DiAn ZHI BIAO SHU JU (零点 指 标 数 据 ) [HoRIZONKEY], Jul. 26, 2011, available at http://www.horizonkey.com/c/cn/news/2011-07/26/news_1516.html.

${ }^{906}$ Noda, supra note 28 , at 65.

${ }^{907}$ See supra Chapter 3.1.2 Fanfics, Doujinshis, and Scanlations.

908 Ko-Ichi Ichikawa, The Comic Market Today and Overseas Participants, 2009, http://www.comiket.co.jp/info-a/C77/C77CMKSymposiumPresentationEnglish.pdf ("Chronology of General Attendees and Participating Circles Statistics").

909 Comiket 82 Ties 'Turnstile' Attendance Record at 560,000, ANIME NEWS NeTwORK, Aug. 13, 2012, http://www.animenewsnetwork.com/news/2012-08-13/comiket-82-ties-turnstile-attendance-record-at-560000.
} 
have tolerated them, simply because their existence benefits the industry as a whole. . $^{910}$

However, their tolerance is not without limits, and some cases have crossed the boundary of that tolerance. In 1999, a doujinshi author used the characters from a famous media franchise, Pokémon, to create pornographic doujinshi work. After the publication of his work, he was arrested and prosecuted for copyright infringement. Nintendo, the copyright owner of that child-oriented title, claimed that the doujinshi of the original work "were 'destructive' of the Pokémon image."911 Similarly, in 2006, the copyright owner of the famous anime and manga series Doraemon became displeased with one of its fan authors: Doraemon has no official ending because its two authors separated in 1987, and one of them died in 1996 before any decisions regarding how to conclude the storyline were reached. The fan author had drawn a spurious final ending and put it for sale as a doujinshi, soon after which he received a warning from the owner because of a strong resemblance between his work and the original Doraemon manga. ${ }^{912}$ The representative of the copyright owner claimed that the fan work was "so similar to the original one that some people mistakenly thought it was genuine." "13 They believed that even though this fan's works had over-stepped the mark, doujinshi "in general as a base of manga culture" are accepted by the copyright owner as long as the works "remain[ed] within reasonable bounds." "914 Another research study also suggests that the survival of doujinshi depends on the work that is being lifted, and for some the practice is allowable as long as it does not turn into pornography. ${ }^{915}$

\footnotetext{
${ }^{910}$ LESSIG, supra note 42, at 26; See also KInSELLA, supra note 538, at 109 (indicated that making doujinshi is deemed as the first step to become a successful manga artist by many practitioners); Tuuli Bollmann, He-Romance for Her - Yaoi, BL and Shounen-ai, in IMAGINARY JAPAN: JAPANESE FANTASY IN CONTEMPORARY POPULAR CULTURE 45 (Eija Niskanen eds. 2010)(noted that the doujinshi authors tend to produce infringeing articles even after they became professional manga authors).

911 Mehra, supra note 26, at 180 n.136.

912 Fukuda Makoto, Spurious Revival: Doraemon's 'Final' Fanzine Episode Ignites Copyright Alarms, DAILY YOMIURI, Jun. 17, 2007, reprinted at http://www.nationmultimedia.com/2007/07/08/lifestyle/lifestyle_30039868.php. 913 Id.

${ }^{914} I d$.

915 John E. Ingulsrud \& Kate Allen, Reading Japan CoOl: Patterns of Manga Literacy and Discourse 49 (2009).
} 

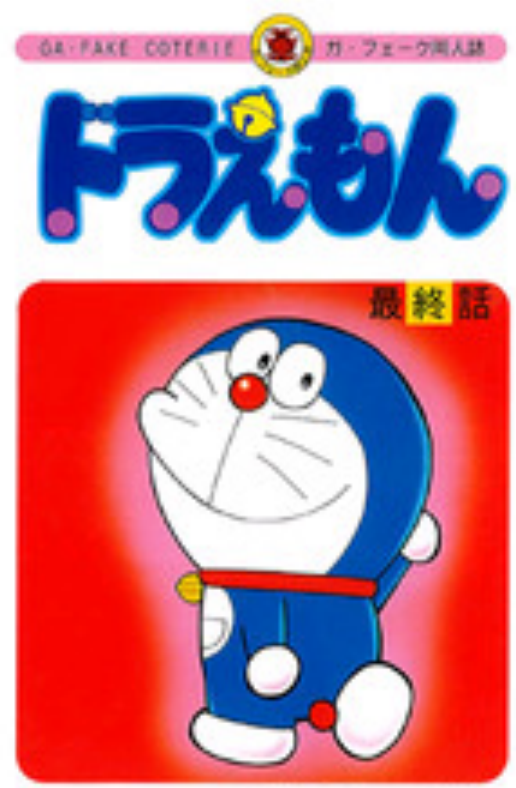

田䳋· T·安惠

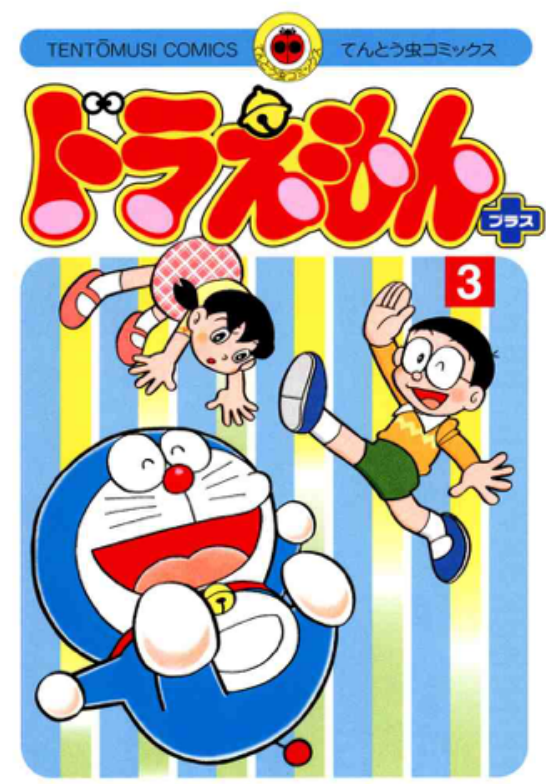

藤子·F・不二雄

Figure 4: Comparison between a Doujinshi ${ }^{916}$ and a Genuine Copy of Doraemon ${ }^{917}$

Another related example could better describe this strategy. "Hatsune Miku," a major virtual female character of a very popular Japanese singing synthesizer game, has inexplicably gained huge fan support and thus spawned many derivative products, including doujinshis and a top selling music album. ${ }^{918}$ A devoted fan of Hatsune Miku named Ryo composed a song for a similar female character, the "Black Rock Shooter," but used Hatsune Miku's voice from the original game. Ryo then collaborated with the author of the Black Rock Shooter to create a music video and posted it on Nico Nico Douga, a Japanese platform similar to YouTube. This has propelled the new virtual idol to a similar level of popularity as Hatsune Miku. ${ }^{919}$ All of this happened without any authorization from the owner of Hatsune Miku, and whether or not the Black Rock Shooter can be con-

\footnotetext{
916 The Truth Behind Shogakukan's Agressiveness[sic] Toward Doraemon Doujinshi?, ComiPress, Jul, 29, 2007, at http://comipress.com/news/2007/07/29/2393.

${ }_{917}$ Luiz Teodosio, Os 20 mangás mais vendidos de todos os tempos, LITERATORTURA, Jun. 9, 2014, at http://literatortura.com/2014/06/os-20-mangas-mais-vendidos-de-todos-os-tempos/11.

${ }_{918}$ Noda, supra note 25 , at 156-57.

${ }^{919}$ Id.
} 
sidered an original character is ambiguous. However, the industry has tolerated this kind of "creation" and even let the creators have their own franchise, ranging from toys to anime series and a shared fan base. ${ }^{920}$

However, the Japanese industry is wary of fansub activities, concerned that the backwash that the fansubs produce abroad might damage and compete with their homeland products. For instance, in 2006, the Japanese Society for Rights of Authors, Composers and Publishers (JASRAC) continually tracked YouTube and in the past has sent notices and takedown letters to posters, asking them to delete fansubs to which domestic Japanese viewers could gain access. ${ }^{921}$ In 2008, the Copyright Network for Comic Authors in the 21st Century, the Association of Japanese Animations, and the Japan Video Software Association, with cooperation from relevant Japanese government ministries, established a countermeasure council to address the issue of Internet piracy, with particular attention paid to fansubs. ${ }^{922}$ However, apart from occasionally sending warning letters to fansub groups, ${ }^{923}$ no litigation against fansub groups has ever been raised by the Japanese owners for various reasons. It is also worth noting that the anime industry structure has ensured its profitability through secondary uses, such as sales of DVDs and toys, on the premise that most TV animation could not profit from broadcast revenue alone due to the high production costs. ${ }^{924}$

The answer to why the "Japanese experience" in copyright protection in this regard is unique is that, compared with the "American experience," which advocates high copyright protection standards, Japan appears to give more space to those usages in the "giant grey zone," and succeeds with that model.

\subsection{China}

Chinese copyright holders have similar problems when they are trying to exploit a foreign market. For example, in terms of feature films, it is al-

\footnotetext{
920 Id

${ }^{921}$ Press Release, Japanese Society for Rights of Authors, Composers and Publishers, Open Letter to Chad Hurley, CEO, and Steve Chen, CTO, YouTube, Dec. 4, 2006, at http://www.jasrac.or.jp/release/06/12_2.html.

${ }_{922}$ See Tokyo Anime Center Posts "Stop! Fan-Subtitle" Notice, Anime News Network, Mar. 29, 2008, http://www.animenewsnetwork.com/news/2008-03-29/tokyo-anime-center-posts-stop-fan-subtitle-notice.

${ }_{923}$ Charles Solomon, File Share and Share Alike, N.Y. TimEs, Aug. 21, 2005, http://www.nytimes.com/2005/08/21/arts/21 solo.html.

${ }^{924}$ Japan External Trade Org., supra note 459.
} 
most impossible to find any American productions, no matter old or new, on U.S. video platforms such as YouTube, but you could easily find a lot of full-length Chinese titles, even the newly released ones on it. Furthermore, many of these titles were actually fansubbed. Whether these titles were uploaded by the copyright owners or not is unknown, but most copyright owners of these titles were either ignorant of this fact that their copyright contents were uploaded to foreign video platforms, or they chose to ignore it, in some extreme cases, they may have uploaded these copyrighted contents themselves. ${ }^{925}$ However, no actions were taken against these videos till now. Furthermore, in terms of cracking down on piracy, the copyright enforcement of the Chinese copyright owners of these titles is much harsher in the Chinese market than in foreign markets. For instance, if we enter one of the most disreputable movie download sites in China ad libitum, we can easily find almost every title imaginable but hardly anything local, especially those newly released local feature movies. ${ }^{926}$ In the meantime, great pressure from international and domestic movie industries has forced some of these famous sites, such as VERYCD.com, which was once a file sharing site based on eMule technology, to transform into an online introductory site that works as a movie encyclopedia with links to other licensed online streaming platforms. ${ }^{927}$ As to fan works such as fansubs of Japanese anime, it is notable that even though official authorization was granted in many cases, ${ }^{928}$ unauthorized fan distributions are still commonly seen coexisting with the official licensed ones. ${ }^{929}$ This shows that these service providers are under more pressure from the local production companies, and thus they are more discreet about the unauthorized uploads of domestic titles. Apparently,

\footnotetext{
${ }^{925}$ For instance, China Hunan TV has opened its own official channel in YouTube and uploaded most its hottest variety shows for free streaming. See China Hunan TV Official Channel, YouTuBE, at https://www.youtube.com/user/imgotv; TV shows such as The Voice of China were also uploaded shortly after the original broadcasting by numerous YouTube users.

${ }^{926}$ In China, some telesync versions of currently screening domestic movies have shown up on some small sites, but this issue is negligible considering its social influence and the purpose of this article.

${ }^{927}$ VeryCD Qi Si Hui Sheng Qi Qishi: Zhuan Xing Wang Ye You Xi Yue Shou Ru Guo Yi (VeryCD 起死回生启示: 转 型网页游戏月收入过亿) [The Inspiration of VeryCD: Making Hundreds of Millions After Transforming], Wang Yi 163(网易 163) [NETEASE], Jan. 13, 2012, at http://tech.163.com/12/0114/09/7NNH9TGK000915BF.html (China).

${ }_{228}$ See, e.g., Tudou Announces Exclusive License Agreement with TV Tokyo to Simulcast Japanese Anime, PR NEWSWIRE, Nov. 28, 2011, http://en.prnasia.com/pr/2011/11/28/USCN1281911.shtml.

${ }^{929}$ For a good example, see the Naruto page on VeryCD.com, http://www.verycd.com/topics/2849835/. To summarize a user can find download pages under the "resource" category; however, if the user is not registered (which is available free), has not contributed to the group up to a certain level, and/or has not earned a "silver medal," he or she will see a notice that says "this resource is lacking the certificate of rights, therefore the download links for it are unavailable." Conversely, if the user is registered and has satisfied all of the above-mentioned criteria, he or she will see all the download links after logging in.
} 
copyright owners of these works are better protected at home than abroad in China.

In terms of fanfics, those online writers who have gained a huge number of fans through the free online publication of their works tend to have a more positive attitude towards fan-appropriation of their later published versions in China. For instance, a famous Chinese historical novel named Those Stories of the Ming Dynasty (明朝那些事儿), which ultimately sold more than five million copies, was first posted chapter by chapter on the author's blog. It was soon published, after it had acquired a considerable number of followers. In the last volume of the series, the author states that he is not a "businessman" and that he will insist on "publishing his works online for free" even though his publisher had warned him that he would lose "millions in revenue" by doing so. He is intent on doing this because he believed the copyright revenue he had gained from free distribution is obvious enough. ${ }^{930}$ A similar situation is that of science fiction writer Cixin Liu (刘慈欣), whose Three Body (三 体) trilogy was first published online for free, attracting many followers and even Hollywood buyers. He permitted the publication of a famous fanfic of his work, the Three Body X (三体X), which is written as a sequel of the original series. ${ }^{931}$ That fanfic was also published chapter by chapter online for free before its print publication. ${ }^{932}$

In another example, a popular rock song, Chun Tian $\mathrm{Li}$ (春天里, In Spring)-which was composed by the famous rock star Feng Wang (汪峰 )-was covered by two migrant workers, and that video recorded millions of hits after it was posted on famous video-sharing platforms. Wang, along with other celebrities, praised their performance and even invited them to perform the song with him during his concert. This promotion eventually led to the duo-known as “Xuriyangang”(旭日阳刚 )_ performing at the CCTV Spring Festival Gala, which is one of China's most important television events. However, Wang Feng decided to enjoin

\footnotetext{
${ }^{930}$ Dang Nian Ming Yue (当年明月), Epilogue, in MingChaO NAXIE SHIER 7 (明朝那些事儿 7) [7 THOSE STORIES OF THE MING DYNASTY] (2009).

${ }^{931}$ During an interview of the Hong Kong Book Fair 2011, Cixin Liu explicitly mentioned that although he "doesn't like fanfics" because they will "block the way" of his future writing of that series, but he had nonetheless given his permission for the publication of Three Body X. The live recording of his interview can be retrieved at: http://115.com/file/dn61573a.

${ }^{932}$ Shanshan Li (李珊珊), Liu Cixin Rang Women Yangwang Xingkong Ba (刘慈欣 让我们仰望星空吧) [Liu Cixin Lets Look into the Sky], Nanfang Zhoumo (南方周末) [SOUTHERN WEEKLY], Jun. 26, 2012, at http://www.infzm.com/content/59075.
} 
them from further exploiting his song commercially after he found that "his kindness was taken advantage of by them." 933

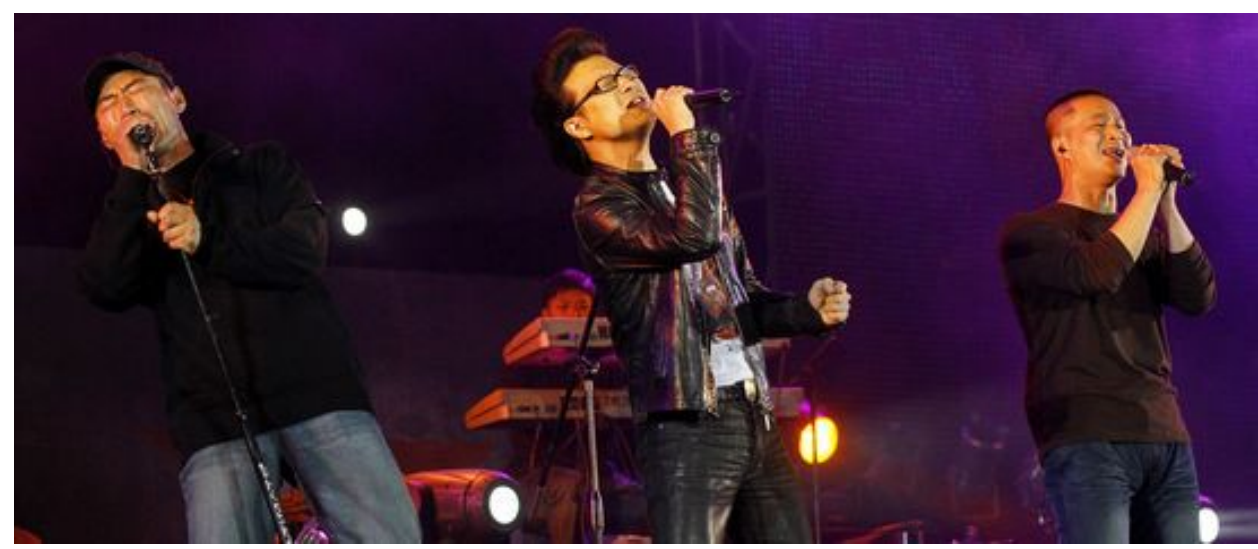

Figure 5: Xuriyanggang performing the song Chun Tian Li with Wang Feng ${ }^{934}$

\subsection{A Selective Enforcement Strategy?}

It is also a fact that the copyright owners in the aforementioned cases have shown a certain degree of tolerance of fan-based activities on their works.

It is obvious from the above discussion that the Japanese anime industry has flexible copyright strategies both at home and abroad, and while it does tolerate some infringeing works such as doujinshi which are already in the market, it remains vigilant with regard to those fan-related activities that involve online distribution. ${ }^{935}$ As for Japan's foreign copyright strategy, it has intentionally ignored most fan-based activities in nascent markets such as China, but in a better-developed market such as

\footnotetext{
933 Copyright Dispute Kicks Migrant Singers Out of Spring, XINHUA News, Feb. 13, 2011, http://news.xinhuanet.com/english2010/china/2011-02/13/c_13730008.htm.

${ }_{934}$ Wang Feng Bans Grass-root Duo Xuriyanggang Singing His Song, AsIANBITE, Feb. 13, 2011, at http://www.asianbite.com/post/Wang-Feng-Bans-Grass-root-Duo-Xuriyanggang-Singing-His-Song-news-3759.

${ }_{935}$ For example, the newly revised Article 119(3) of the JCL proves that the content industry is trying to control the behavior of domestic Internet users, as it criminalizes the private downloading of copyrighted works to some extent. Japanese Copyright Law, art. 119 (3); Moreover, a controversial clause was inserted as an amendment after the original bill had been submitted, by which it escaped the deliberation of the education ministry and was passed by the National Diet. In other words, it is largely an end product of industrial lobbying. See Tomoko Otake, Music Industry Wins a Battle as Antidownloading Bill Gets Some Teeth, JAPAN TIMES, June 21, 2012, http://www.japantimes.co.jp/culture/2012/06/21/culture/music-industry-wins-a-battle-as-antidownloading-bill-gets-so me-teeth/.
} 
the U.S., fan-based activities are under a certain degree of pressure, ${ }^{936}$ as the industry's control over the U.S. market is stronger and the market coverage rate is higher. Nonetheless, these cases are of a domestic nature, and just like the doujinshi case in Japan, they represent the discretionary power of the copyright owners in their internal market, as potential problems there are roughly controllable. Generally speaking, the Japanese copyright owners with whom this research is concerned are capable of controlling their own market. Although most types of fan activities also exist in Japan, comparatively speaking, they are not too big a problem domestically, as by using market strategies and sending cease and desist letters to guide fans, Japanese copyright owners can maintain a balance between the damages and benefits of fan activities to a certain extent. Moreover, copyright holders can also use the law and its corresponding enforcement as effective complements. However, the same is not the case in foreign countries such as China and the U.S., where there are certain notable problems related to market access. For copyright infringements that happened in countries like China, foreign copyright owners have weaker control over their works and face the problems discussed above, if they try to enforce their rights in a foreign country. It is also one of the reasons why Japanese copyright owners tolerate fan activities abroad, even though they know that they will have less control in the foreign market. These need to be considered in terms of content exportation and copyright enforcement.

In many countries, such as China, Brazil, and even the U.S., all manner of fan communities have been established and the fans within them are engaging in various fan activities. Fansubbing, owing to its very nature, is one of the most remarkable fan activities. Foreign audio-visual works, such as American TV drama and Japanese anime are some of the most typical subjects in fansub production. Many foreign productions are famous not only in their homeland but also in many other countries. For instance, as a previous study revealed, fan communities of Japanese anime were formed in the U.S. between 1976 and $1993,{ }^{937}$ and since 1990 numerous fan groups have been engaged in producing and ex-

\footnotetext{
${ }^{936}$ For instance, in 2011, Funimation, a large animation streaming website in the United States that has released a considerable amount of Japanese anime since 1994, sued 1,337 downloaders over one of their imported titles, One Piece, for which the company had acquired licenses from Toei in 2009. The beginning of similar legal actions can be traced back to 2005. A full list of their licensed works can be found here: http://www.funimation.tv/shows/, for a cache version of the old page: http://changedmy.name/funimation-license-mirror/.

${ }^{937}$ Leonard, supra note 28, at 196.
} 
changing fansubs of anime. ${ }^{938}$ It is believed that most of the unauthorized fan distribution of anime throughout the 1970s through the 1990s, which were tolerated by the Japanese owners, had promoted the development of a nascent domestic industry for anime in the U.S. ${ }^{939}$ Meanwhile, the fan production and distribution of foreign audio-visual works in China started in 2001, with the exponential spread of broadband connection services and the development of fast file transferring tools such as P2P file sharing software.

The above-mentioned facts reflect the copyright strategies of many foreign content industries: they have tolerated most fan activities related to their copyright works in a foreign country for different reasons. Furthermore, if we consider domestic copyright strategies towards fan activities as an outcome of deliberate choice, then by contrast, most of the foreign copyright strategies towards fan activities abroad appear more of a reaction or a last-ditch move.

In general, fan communities outside the home country of the copyright works are more active and unregulated than their domestic counterparts. The case in developing countries with burgeoning content industries, such as China and Brazil is all the more so. Some economists call these countries "the frontiers of free," in which they believe brand new business models which utilize rather than eliminate all unauthorized usages could arise. ${ }^{940}$ Many others, however, still consider those usages to be theft. Like other unauthorized usages, fan activities of foreign works in these countries are deemed piracy. However, they have survived and flourished for multiple reasons.

\subsection{The Reasons}

Before digging deep into the question of whether toleration can actually solve the problem that this research concerns or not, a brief summary of the possible reasons behind industries' toleration could be helpful in providing an answer. The reasons can be summarized as follows:

First, global synchronous copyright protection is theoretically tenable but in practice not feasible. On the one hand, the costs of enforcing, espe-

\footnotetext{
${ }^{938} I d$. at 192.

939 Id.

940 ANDERSON, supra note 5, at 162-70.
} 
cially in the case of overseas enforcement, are much higher than the benefits that copyright owners can get from doing so. If we examine this issue from an economic perspective, the transaction costs will be the determining factor, because any transaction cost becomes unbearable, as the number of potential users is infinite. ${ }^{941}$ In other words, it is impossible for the copyright owners to identify each usage/user (most of them have a very low value) and enforce their rights accordingly. This, according to Gordon, results in a market barrier of transaction costs. ${ }^{942}$ Moreover, taking doujinshi as an example, one of the reasons why the industry has chosen to allow these copycat works to survive within limits, is that the legal resources in Japan are insufficient; ${ }^{943}$ research has also shown that they are facing the same problem in transnational licensing, ${ }^{944}$ which means they are shorthanded even if they want to enter a foreign market in traditional ways. On the other hand, besides the economic issues, the protection of local and foreign audio-visual products may actually be unequal in some countries.

Second, unlike commercial pirates and free riders, fans are potential consumers. It is well established that fan-based activities are beneficial in many ways if they can be controlled (c.f. doujinshi). The doujinshi community has a strong ethos, and the mutual trust and interaction between fans and the industry has ensured that business, the fan community, and the entire society benefit equally from doujinshi activities. Furthermore, a 2009 survey indicated that nearly sixty-seven percent of doujinshi authors had lost money in Comiket transactions, ${ }^{945}$ which means most doujinshi works do not qualify as substitute goods. On the contrary, in terms of foreign markets, it is believed that some fan-based activities will help to "curb piracy" if properly regulated. ${ }^{946}$ As the case of anime fansubs in the U.S. demonstrated, when "the scope and enforcement of copyright are relaxed in nascent markets and on undervalued properties," the result can

\footnotetext{
${ }^{941} \mathrm{Wu}$, supra note 42 , at 630.

942 Gordon, supra note 827 , at 1628 .

943 LESSIG, supra note 42, at 27.

944 Leonard, supra note 28, at 239 ("They lacked expertise in the field of international intellectual property law.").

${ }^{945}$ How Much Money Do Doujinshi Creators Actually Make? Some Statistics from Comiket, FAnHACKERS BloG, Jun. 10 , 2012,

http://fanhackers.transformativeworks.org/2012/06/how-much-money-do-doujinshi-creators-actually-make-some-stati stics-from-comiket/.

${ }^{946}$ Leonard, supra note 28, at 257.
} 
be "overwhelmingly successful" in pursuing the progress of the arts, which is the ultimate purpose of copyright in most countries. ${ }^{947}$

The third challenge is that fan activities are potentially valuable, which forces copyright owners to respond in a way different from one that was originally designed by the copyright law. It is common for the commercial world, especially the audio-visual content industry, to cultivate brand loyalty among customers and turn them into fans, since loyal consumers are deemed an integral part of a successful and enduring business. ${ }^{948}$ Just as Jenkins said, fan groups are actually "testing the market for new genres, producers, and series" for copyright owners in a foreign market. 949

The one thing that has changed for the audio-visual industry is that the ability of most fan consumers to utilize and distribute the copyrighted contents online has increased dramatically. ${ }^{950}$ This change raises potential copyright problems because fans' utilizations and distributions may infringe upon existing copyrights, or cause a sales decrease. Yet the fan activities of certain copyrighted works may also bring great opportunities for the copyright owners as well. ${ }^{951}$ Take the South Korean pop song "Gangnam Style" as an example: the copyright owner YG Entertainment and the songwriter PSY uploaded the full music video of the song to YouTube for free, and it became the first YouTube video to attract a billion views. ${ }^{952}$ The copyright protected video and the song were praised by many celebrities and utilized by numerous people to generate new content in the U.S., ${ }^{953}$ as well as making their way into the Chinese mar-

\footnotetext{
${ }^{947} I d$. at 265 .

948 Matthew P. McAllister, Consumer Culture and New Media: Commodity Fetishism in the Digital Era, in MEDIA PERSPECTIVES FOR THE 21ST CENTURY : CONCEPTS, TOPICS AND IsSUES 161-62 (S. Papathanassopoulos ed. 2010).

949 Henry Jenkins, When Piracy Becomes Promotion, ReAson, Dec. 2006, at http://reason.com/archives/2006/11/17/when-piracy-becomes-promotion.

${ }_{950}$ McAllister, supra note 948, at 161-62.

951 Lee, supra note 16, at 1486-87.

952 William Gruger, PSY'S 'Gangnam Style'Video Hits 1 Billion Views, Unprecedented Milestone, Billboard, Dec 21, 2012 ,

http://www.billboard.com/biz/articles/news/1483733/psys-gangnam-style-video-hits-1-billion-views-unprecedented-m ilestone.

${ }_{953}$ Celebrities such as Britney Spears and Katy Perry had given their props to the song through tweeter and blog, see Bary Alyssa Johnson, 'Gangnam Style' Fans Include Britney Spears, Katy Perry, Vanessa Hudgens; What They LATINOS POST,

Aug

29 , 2012 ,

http://www.latinospost.com/articles/3457/20120829/celeb-tweets-show-gangnam-style-taking-over-hollywood.htm; for fan-made videos of the song, see e.g., Mischievious Studios, Gotham Style, YouTuBE, at https://www.youtube.com/watch?v=YSsCU3FcOkw; WhatsUpELLE, Baby Gangnam Style Parody, YouTuBE, at https://www.youtube.com/watch?v=7iheCrwQQ1I; popking161, I Love Beijing Style, YouTuBE, at https://www.youtube.com/watch?v=z7xfAfa4W7E.
} 
ket. ${ }^{954}$ Although many of these fan works are deemed copyright infringements, ${ }^{955}$ the South Korean copyright owner chose to ignore this and took a relaxed attitude towards subsequent fan activities. It is believed that the copyright owner's laid-back approach was a key to their $\$ 8.1$ million success. ${ }^{956}$ Rick Cotton, NBC Universal's General Counsel also indicated that, the involvement of fans is something that most major content owners want to see today. ${ }^{957}$

There are many similar cases in China as well. In the In Spring case discussed above, ${ }^{958}$ it is an ironic fact that the copyrighted song gained more popularity after the fan video became famous. In this case, the author's tolerant attitude towards the duo was crucial to the wider acceptance of the song. It is worth noting that there are at least two conditions to be met for these kinds of added values to be generated. First, it depends greatly on the quality of the product. In terms of audio-visual products, this means only those works with high potential are able to attract sufficient contributive followers. Second, there will always be a degree to which the copyright owner can enjoy the benefits of the fan contributions. Therefore, copyright owners have the ability to connect with their fan contributors, and by doing so they can demonstrate their will in a proper way when necessary. Unfortunately, in terms of the Chinese market, foreign copyright owners do not do very well in meeting the second condition.

The preceding cases demonstrate that, firstly, it is possible for fan activities to bring conspicuous benefits to the copyright owners of good audio-visual productions; secondly, the experience is universally applicable since this fan phenomenon complements the existing business strategies, and business is without borders. In other words, it is also possible for for-

\footnotetext{
954 Psy Gangnam Styles His Way to the Bank in China, WANTChinATimes, Feb. 6, 2013, at http://www.wantchinatimes.com/news-subclass-cnt.aspx?id=20130206000001\&cid=1304.

${ }_{955}$ Deborah L. Jacobs, Parodies of Rap Artist Psy's Gangnam Style are Fun. But are They Legal?, ForBES, Sep. 10, 2012 ,

http://www.forbes.com/sites/deborahljacobs/2012/10/09/parodies-of-rap-artist-psys-gangnam-style-are-fun-but-are-the y-legal-2/.

956 Glyn Moody, Psy Makes \$8.1 Million by Ignoring Copyright Infringements of Gangnam Style, TECHDIRT, Dec. 10 , 2012 ,

https://www.techdirt.com/blog/casestudies/articles/20121209/07431921317/psy-makes-81-million-ignoring-copyright -infringements-gangnam-style.shtml.

${ }^{957}$ Saul Hansell, Bits Debate: On the Rights of Readers and Viewers, N.Y. Times BiTs BLOG, Jan. 18, 2008, at http://bits.blogs.nytimes.com/2008/01/18/bits-debate-on-the-rights-of-readers-andviewers (“... most major content owners today want to see fans fully engage with their favorite content and are working hard to provide legitimate ways to do that.").

${ }^{958}$ See supra Chapter 4.4.2.2.3 China.
} 
eign copyright holders to have fan bases globally, as long as their products are with a certain degree of quality. According to the long tail theory espoused by Chris Anderson, if production and distribution are democratized, and supply and demand are well connected, then the costs of reaching niche products can be reduced. ${ }^{959}$ Since the number of niche products is comparatively huge, collectively they comprise a market rivaling the hits. ${ }^{960}$ In our specific case, this means that most copyrighted audio-visual products have economic potential if put in a global market, and with a bit of luck, fan activities may arise and more economic possibilities may be discovered. The story of the American folk musician Sixto Rodriguez in the Oscar winning movie Searching for Sugar Man is an excellent example. Rodriguez's career as a singer in the U.S. proved unsuccessful initially, with him only publishing two albums that did not sell well. However, possibly with the introduction of pirate copies, his works are now extremely successful and influential in South Africa. ${ }^{961}$ In China, popular foreign audio-visual products are experiencing a similar journey: after more than a decade of content 'dumping' through piracy and related fan activities, suddenly foreign copyright owners are noticing that huge fan bases exist in this vast market for many of the audio-visual titles they hold. Most of these works were never officially introduced into the Chinese market, but the lack of adequate legislation and lax enforcement at that time provided an opportunity for pirates to introduce them into China through illicit channels. Consequently, we can find cases such as Prison Break, ${ }^{962}$ which has done extremely well in the Chinese market; ${ }^{963}$ it is also true that many South Korean and Japanese productions were also able to enter the Chinese market through illegal means. ${ }^{964}$ The

\footnotetext{
959 ANDERSON, supra note 35, at 53-57.

960 Id. at 53.

961 See generally, SEARChING FOR SUGAR MAN (Red Box Film Productions 2012).

962 Prison Break (Fox television broadcast Aug. 29, 2005).

963 See Osnos, supra note 326.

964 See Ingyu Oh, Hallyu: The Rise of Transnational Cultural Consumers in China and Japan, 40 KOREA OBSERVER 425, 440-444 (2009); for the Japanese part, see Joseph M Chan, Toward Television Regionalization in Greater China and Beyond, in TV CHINA 33 (Ying Zhu \& Chris Berry eds., 2009); for a greater China perspective, see Kelly Hu, The Power of Circulation: Digital Technologies and the Online Chinese Fans of Japanese TV Drama, 6 INTER-ASIA Cultural Studies 171, 171-173 (2005); Nissim Kadosh Otmazgin, Contesting Soft Power: Japanese Popular Culture in East and Southeast Asia, 8 InTERnATIONAL RELATIONS OF THE ASIA-PACIFIC 73, 85 (2008)(“East Asia's pirated markets thus paved the way for the Japanese popular culture industries' entry into new markets. The informal circulation of pirated versions of Japanese popular culture has effectively popularized the products in the markets they were legally banned from"); Ming-tsung Lee, Traveling with Japanese TV dramas: Cross-cultural Orientation and Flowing Identification of Contemporary Taiwanese Youth, in FEELING ASIAN MODERNITIES: TRANSNATIONAL CONSUMPTION OF JAPANESE TV DRAMA 132-33 (Iwabuchi Kōichi ed. 2004)(“Owing to...the easy acquisition of various pirated audiovisual products, the spread of Japanese TV dramas in Taiwan became increasingly quick, direct,
} 
resulting low-price or even free availability of these pirated works in China helped them maintain a high level of exposure, ${ }^{965}$ and thereby garnered a considerable fan base around them. ${ }^{966}$ Although the attitudes of foreign governments towards piracy and fan activities are relatively straightforward on the surface, ${ }^{967}$ the copyright issue is rarely a high priority for them when foreign markets are concerned. Since most foreign works cannot enter the traditional Chinese market (TV broadcasting, theater, etc.) anyway, the copyright holders might as well follow the strategy adopted by Microsoft: market first, then the product. In other words, copyright owners should allow their products to flood the foreign market through unauthorized means first, and then determine the best way to collect the revenues later. ${ }^{968}$ For instance, findings show that Japan and South Korea are relatively passive in fighting digital piracy in Asia; ${ }^{969}$ they see it as a transnational marketing strategy to maintain long-term

\footnotetext{
and widespread.").

965 See e.g., Osnos, supra note 326; the success of the so-called "Korean wave" in Asian countries is believed to be partly due to pirate sales. See also Woongjae Ryoo, Globalization, or the Logic of Cultural Hybridization: the Case of the Korean Wave, 19 ASIAN JOURNAL OF COMMUNICATION 137, 139 (2009).

${ }^{966}$ For instance, after more than a decade of pirate dumping, two main Chinese video platforms Iqiyi and PPS had acquired the network broadcasting rights of My Love from The Star-a South Korean television series has been voted as the No.1 TV series among South Koreans. On Iqiyi alone, it has been watched 14.5 billion times since its December debut. See Lilian Lin, Korean TV Show Sparks Chicken and Beer Craze in China, The Wall Street Journal, Feb. 26, 2014, at http://blogs.wsj.com/chinarealtime/2014/02/26/korean-tv-show-sparks-chicken-and-beer-craze-in-china/. Interestingly, a 2013 research done by Seoul University had pointed out that people who watch Korean dramas are at the bottom end of the socio-economic and educational ladder. Jeyup S. Kwaak, South Korean Soap Operas: Just Lowbrow Fun?, THE WALL STREET JOURNAL, Jul. 23, 2013, at http://blogs.wsj.com/korearealtime/2013/07/23/south-korean-soap-operas-just-lowbrow-fun-2/. In 2014, fans of the Star drama had spent more than 20 thousand euros, brought a full-page ad in a Korean newspaper, claiming the conclusion of that research is wrong, and required that professor to apologize. And the author did apologize subsequently. Alex Stevens, The Chinese Are Pissed That Koreans Called Them Dumb for Watching Korean Dramas, SHANGHAIST, Mar. 22, 2014, at http://shanghaiist.com/2014/03/22/chinese-say-we-are-not-stupid-for-watching-korean-dramas.php.

${ }^{967}$ For the US-China copyright debate, See generally, Yu, supra note 149; For South Korea's attitude towards piracy in China, See e.g., Roald Maliangkay, Keep Your Enemies Closer: Protecting Korea's Pop Culture in China, 2 KoREAN HISTORIES 34, 35 (2010); for Japan's actions against piracy in China, See e.g., Kyodo, Crackdown on intellectual property piracy pays off, THE JAPAN TIMES, Mar. 5, 2012, at http://www.japantimes.co.jp/news/2012/03/05/national/crackdown-on-intellectual-property-piracy-pays-off/\#.U7btIo2 SzX0. For fan activities, see e.g., Tokyo Anime Center Posts "Stop! Fan-Subtitle” Notice, ANIMENEWSNETWORK, Mar. 29, 2008, at http://www.animenewsnetwork.com/news/2008-03-29/tokyo-anime-center-posts-stop-fan-subtitle-notice. ${ }^{968}$ Charles Piller, How Piracy Opens Doors for Windows, Los ANGELES Times, Apr. 9, 2006, at http://articles.latimes.com/2006/apr/09/business/fi-micropiracy9 ("Although about 3 million computers are sold every year in China, people don't pay for the software. Someday they will, though," Gates told an audience at the University of Washington. "And as long as they're going to steal it, we want them to steal ours. They'll get sort of addicted, and then we'll somehow figure out how to collect sometime in the next decade.").

${ }_{969}$ See e.g., Kelly Hu, Chinese Re-making of Pirated VCDs of Japanese TV Dramas, in FEeling AsIAN ModERNITIES: TRANSNATIONAL CONSUMPTION OF JAPANESE TV DRAMA 205-226 (Iwabuchi Kōichi ed. 2004); see also Otmazgin, supra note 964, at 85, n.17; Beng Huat Chua, Structure of Identification and Distancing in Watching East Asian Television Drama, in East Asian Pop Culture: Analysing the Korean Wave 86 (Beng Huat Chua \& Kōichi Iwabuchi eds., 2008); Maliangkay, supra note 967, at 35 (“...the Korean government had for long showed little concern over the loss of revenue incurred by foreign companies as a result of domestic piracy or the production of counterfeits...").
} 
overseas exposure of their products. ${ }^{970}$ In other words, fan activities offer foreign copyright owners a way to bypass the harsh local censorship system and to make direct contact with potential customers in a foreign market. ${ }^{971}$

Fourth, the reason that the anime and manga industry of Japan have tolerated fan activities in their domestic market is that they are able to exert effective control on them, according to the copyright laws of Japan. As mentioned above, for the Japanese domestic market, the anime industry, as the representative of the community rather than individuals, has certain copyright strategies that are not parallel with the copyright legislation regarding fan works. According to a senior practitioner in the production field, nowadays the overall economic recession and the competition between commercial authors in Japan have made doujinshi an important income source for lower-tier authors. ${ }^{972}$ Nevertheless, although the border remains vague, the example of Comiket and the enormous number of doujinshi works that are sold there suggest that doujinshis are accepted by the industry. It is also true that Article 28 of the JCL clearly states that the author of the original work shall "have the same rights" as the subsequent author in exploiting the derivative work, ${ }^{973}$ while Article 20(1) of the JCL also indicates that the original author can object to any modification of his work. ${ }^{974}$ In other words, the original authors enjoy greater control over the derivative works of their titles in the Japanese market than in China. Thus, some fan-based activities are allowable in practice. Otherwise, the copyright owners could simply pull out and forbid them, or step in as the author of the derivative work at any time.

Fifth, in terms of foreign markets, the copyright strategy of the Japanese industry is to let go of some of these fan activities, as its control over foreign markets is unavoidably weak due to some endemic problems. ${ }^{975}$ The author has interviewed legal staff from the industry about the current attitude of their companies towards some fan-based activities, and all the responses were negative. For example, Nakamura Kimihiko of the Tokyo Broadcasting System Television (TBS), airing his personal perspective,

\footnotetext{
${ }^{970}$ See e.g., Shuling Huang, Nation-branding and Transnational Consumption: Japan-mania and the Korean Wave in Taiwan, 33 Media, Culture \& Society 3, 8-9 (2011).

${ }_{971}$ See e.g., Otmazgin, supra note 964 , at 83-84.

972 Kanemitsu, supra note 430.

973 Japanese Copyright Law, art. 28.

974 Id. art. 20(1).

${ }^{975}$ See supra Chapter 2.1 Barriers or Defenders: the Failure Caused by the Great "Cultural" Wall of China.
} 
believes that although fan works such as fansubs are beneficial in terms of market cultivation in foreign licensing, the industry will in no way recognize their efforts officially because doing so would be risky. ${ }^{976}$ However, the anime industry is forced to go overseas, since digitalization and online file sharing are unstoppable. And with the high marketing costs abroad, they have no choice but to endure most illegal appropriations in foreign markets, including fan-based activities. Traditional promotion used to be the major way to break into a foreign market, but the endemic problems detailed above have made it very difficult. We should also note that things have changed with the information revolution, for now the Internet offers an alternative - to build from the bottom rather than the top. This means it is possible to generate a market for a product by selectively tolerating foreign fan activities. If the industry really wants to reap overseas profits, considering the overall number of potential titles to license, they will have to rely on fan cultivation. ${ }^{977}$ Moreover, fan-based activities could be the best source for early product evaluation, as they offer another way to introduce copyright works into the targeted market, as cultural works importation is highly restricted in some countries and traditional market research is impractical from a cost-benefit analysis perspective.

The above examples show that, were the copyright owners able to find a way to connect with their fans or exert control over them, it would be possible for the copyright owners to set aside their copyright issues and utilize fan works and the creative ideas behind. The example of the Japanese anime and manga industry has also shown that a good relationship can be maintained between fan creators and copyright owners in the Japanese market. ${ }^{978}$ If we factor in the beneficial aspects of fan activities such as promotional effect, ${ }^{979}$ new creative ideas, and the possibility of circumventing the endemic problems such as censorship and import quotas in a foreign market like China, the choice to cooperate with fans in that market is thus understandable.

Despite the factors discussed above, piracy is still indisputably illegal. It is impossible to justify massive copyright theft by arguing that the cop-

\footnotetext{
${ }^{976}$ Interview with Nakamura Kimihiko via Email, Legal Advisor, Tokyo Broadcasting System Television (Nov. 19, 2012).

977 Leonard, supra note 28, at 217.

${ }_{978}$ See generally He, supra note 50; Mehra, supra note 26.

${ }_{979}$ For a detailed discussion about consumer labour in advertising, please see McAllister, supra note 948, at 158-62.
} 
yright owner's inaction constitutes an implicit permission, considering that most of these thefts were commercially conducted and had no direct contribution in terms of creativity. However, in the case of fan activities, the answer may differ greatly depending on circumstances.

It is clear from the above discussions that our copyright laws fail to provide an answer for massive online infringement activities. Even though according to the black letter laws we could be sure that there will be a judgment for all kinds of fan activities if litigations arise, but that is far from enough to say that the problem of massive online infringement has been solved. It is still there, and if we consider the amount of them, the deterrence effect of litigations will be negligible. In the meantime, countries like Japan and China do enforce their copyrights differently depending on markets and subjects. In terms of fan activities, they have agreed that, to a certain extent, some fan activities should be allowed or tolerated for the shared interests of the industry and the public.

The domestic and foreign copyright strategies taken by the Japanese anime industry and the Chinese entertainment industry in response to most fan activities could be described as tacit tolerance or strategic ignorance, as previous research has concluded. ${ }^{980}$ Correspondingly, the fan-based activities within that category have been deemed tolerated $u_{\text {se. }}{ }^{981}$ The divergence between the domestic and foreign copyright strategies illustrates how the cultural industries have been forced to take their own steps beyond the law, in order to protect their properties both home and abroad and prosper in the digital age. However, merely tolerating is just not enough, and, more importantly, problematic.

\subsection{The Limitations of Toleration}

From the case of the Japanese anime industry we can see that, it has a desirable end product [i.e. anime works themselves], but their domestic experience is inapplicable in foreign markets. In sum, the limitations on the strategy can be summarized as follows.

First, the industry has recognized the power of the fan communities in foreign countries but failed to treat them as being distinct from commercial pirates and free riders, and this will cause many problems. For exam-

\footnotetext{
${ }^{980}$ Leonard, supra note 240, at 287.

$981 \mathrm{Wu}$, supra note 42 , at 619.
} 
ple, the Japanese Animation Legal Enforcement Division (JAILED), which existed between 1995 and 1996 and was led jointly by the U.S. and Japanese anime companies, pursued several video dealers and fan groups, which triggered a backlash from the fans and therefore ceased to operate further. ${ }^{982}$ By choosing to avoid making a distinction and claiming all such activities are illegal, tolerating most of the fan activities is a contradiction. Second, the passive nature of the strategies results in market instability, especially in foreign countries. In other words, the positive results cannot be guaranteed. Merely tolerating oversea fans means the connection between the fans and the copyright owners is not officially established in the designated market, and therefore the copyright owners are incapable of exerting control on foreign fan groups. It is also foreseeable that the copyright owners will not be able to keep track on statistics such as the range of fan distributions, what types of fan works are generated, and whether the fans will cease to exist because they may lose their interest over a specific title. Thus it is fair to say that the positive outcomes we have witnessed so far are unstable. Third, the anime industry still lacks a proper plan to reap profits from foreign fan activities, as it knows so little about them. ${ }^{983}$ With the domestic revenue of the industry decreasing due to shrinking demographics and an overall economic recession in Japan, profitable foreign sources should be of critical importance, but lack of understanding of foreign markets is a barrier. This may as well be ascribed to the "Galápagos syndrome" 984 from which Japan is now suffering, as many of its unique and creative products, such as cellphones and anime, are faltering in overseas markets. Fourth, the boundary between tolerance and acquiescence is blurred, which is a legal risk. $^{985}$

\footnotetext{
${ }_{982}$ See Leonard, supra note 28, at 253-55.

983 See Kanemitsu, supra note 430.

984 See Hiroko Tabuchi, Why Japan's Cellphones Haven't Gone Global, N.Y. TIMES, July 19, 2009 , http://www.nytimes.com/2009/07/20/technology/20cell.html (the report notes that the Japanese cellphone industry has excellent products but failed to go oversea, because that fast development "turned increasingly inward", and the industry was satisfied with the rapid growth of the local cellphone market in the late 1990s and early 2000s, they were in lack of incentives to go abroad. This phenomenon is named the "Galápagos syndrome." The term was initially used to describe the Japanese $3 \mathrm{G}$ cellphones, but now is being used for similar phenomena in other markets). Anime is apparently qualified as one of those: anime is unique to other markets, because Japanese use animation as a media rather than a genre and sometimes their products contain adult features, their anime is facing lots of restrictions outside Japan; the industry was content with its local market, and lack of incentives to explore foreign markets. Accord Leonard, supra note 28, at 229-34.

${ }^{985}$ For a detailed discussion and possible solution regarding this issue, please see infra Chapter 5.2.2.3 Example.
} 
Generally speaking, right holders from Japan and China tend to tolerate most fan activities, and this is especially so in terms of foreign markets. However, it is more or less a last-ditch move. Theoretically speaking, they have insufficient resources to deal with every possible tortfeasor, and since the problems of fan activities are complicated, it is understandable why they would choose to ignore the majority of individual participators and only focus on infringements conducted by commercial practitioners. ${ }^{986}$ However, simply tolerating audio-visual fan activities is not good enough, not only because it is wrong to criminalize "a generation of our kids" as Lessig has pointed out, ${ }^{987}$ but because it also does not conform to the requirements of the copyright owners: the positive effects of fan activities cannot be stabilized as copyright owners do not have a degree of control over them. In that regard, merely tolerating cannot effectively control these fan activities to the extent where the negative effects caused by bad fan works, such as malicious translation, can be located and dealt with immediately; and positive effects such as creative ideas can be properly borrowed. As it stands, transnational licensing has made it far more challenging for copyright owners to exert control over foreign fans. Even if one previous study shows that the audio-visual industry in small countries such as Japan might be able to balance the relationship between copyright owners and fan creators simply by tolerating them, ${ }^{988}$ in the case of transnational licensing that does not necessarily apply.

Moreover, merely tolerating makes no contribution to the improvement of the investment climate in China. If there is no sign that regulations related to censorship there will be discarded in the near future, then it is not beneficial for the foreign copyright owners in the Chinese market to just sit and wait in the long run. Indeed, if we take fansubs into consideration, the promotional effect generated by merely tolerating the copyright owners in a closed market cannot be replicated and utilized in China, if the "advertisement" is out but with no products on the market. Seemingly, the copyright owners will have to "figure out how to collect"

\footnotetext{
${ }_{986}$ See Lee, supra note 16, at 1485.

${ }^{987}$ LESSIG, supra note 39, at 109-114; Chris Anderson also noted this problem from another angle, he described a younger generation that insists "on Free not just in price but also in the absence of restrictions: They resist registration barriers, copyright control schemes, and content that they can't own.” See ANDERSON, supra note 5, at 191.

988 See generally He, supra note 50.
} 
the benefits through other channels in the future, just as Bill Gates put it. ${ }^{989}$

\subsubsection{Public Copyright Licenses}

Bearing in mind the problems that traditional solutions are facing, nowadays many scholars in the copyright field are trying to find a way to artificially insert a large quantity of these works into the public domain or make them "semi-commons". 990 In that case, the creative users will be possible to lay their hands on more contents legitimately. One of the most famous solutions is the Copyleft licensing, which encourages copyright owners to grant parts of their copyrights to the public voluntarily. Recently some audio-visual platforms such as YouTube have tried to offer an alternative solution by negotiating agreements with content providers which allow end users to use a package of copyright-protected contents without asking for separate authorization. Nevertheless, by acting as a third party, such an act is in itself not a perfect solution, as it merely creates new legal problems. ${ }^{991}$ A better solution might still lie in the direct interaction between the content providers and users, namely the licenses issued by copyright owners such as $\mathrm{CC}^{992}$ proposed by Lawrence Lessig, and the NAP ${ }^{993}$ proposed by Tim Wu. These forms of license aim at liberating the creativity of the public by building a reasonable and flexible area in the face of increasingly restrictive copyright laws.

However, both CC licenses (para. 4.4.2.3.1) and NAPs (para. 4.4.2.3.2) have benefits and drawbacks and these must be analyzed further.

\footnotetext{
989 Piller, supra note 968.

${ }^{990}$ See generally, Lydia Pallas Loren, Building a Reliable Semicommons of Creative Works: Enforcement of Creative Commons Licenses and Limited Abandonment of Copyright, 14 GEO. MASON L. REV. 271 (2006).

${ }_{991}$ See generally, Yafit Lev-Aretz, Second Level Agreements, 45 AKRON L. REV. 137 (2012).

992 Creative Commons is a non-profit organization that enables the sharing and use of creativity and knowledge through free legal tools. Creative Commons, About Us, https://creativecommons.org/about (last visited Apr. 4, 2014). 993 "No Action Policy" is "a unilateral, non-exclusive, potentially revocable license from the media owner to all members of the general public who meet its terms." See Wu, supra note 42, at 634.
} 


\subsection{Creative Commons}

The effectiveness of the CC license consists in its simplicity, and it is theoretically very useful. It is a fast and efficient way to simplify some complicated copyright rules, which are crucial to the ordinary Internet users, into short messages that the intended users can quickly understand. However, the design of a CC license is to encourage copyright owners to license some of their copyrights to the public irrevocably, ${ }^{994}$ but since different types of copyright owner have different expectations about their works, it may not persuade the large media conglomerates which own the vast majority of commercially valuable copyrighted materials. ${ }^{995}$ What is more, it has been noted that $\mathrm{CC}$ licenses have more problems in relation to the formation of contracts, the compatibility between different CC licenses and other Copyleft licenses, and the enforceability of public domain dedication licenses. ${ }^{996}$ Moreover, even if a copyright owner does not intend to license his copyrighted works, the symbols of the CC license can be easily placed on a digital copy of his copyrighted works by others, and the fan creators with which this book is concerned may not be willing to dig that far when they see the $\mathrm{CC}$ symbols. Coupled with the fact that the $\mathrm{CC}$ licenses are irrevocable, this may actually cause confusion in a market about whether a CC license attached to a digital copy is issued by the copyright owner or not. It would also be unclear whether confusion is created, when the copyright owner of a licensed work has secretly deleted his CC license but unable to recall all the marked digital copies. It is highly likely that business users who want to use the CC licensed copyrighted contents commercially would have to determine the current legal status of the underlined products, but it is less likely that individual users would be so diligent, as they would be less vigilant and not motivated enough to search for all the details behind the CC marks.

\footnotetext{
${ }^{994}$ Loren, supra note 990 , at 276-277.

${ }_{995} \mathrm{Wu}$, supra note 42, at 634; Todd D. Marcus, Fostering Creativity in Virtual Worlds: Easing the Restrictiveness of Copyright for User-created Content, 55 J. COPYRIGHT SOC'Y U.S.A. 469, 489 (2008).

${ }_{996}$ Christopher S. Brown, Copyleft, the Disguised Copyright: Why Legislative Copyright Reform is Superior to Copyleft Licenses, 78 UMKC L. REV. 749, 766-777 (2009).
} 


\subsection{No Action Policy}

The "No Action Policy" represents something different. According to Tim $\mathrm{Wu}$, it is a "unilateral, non-exclusive, potentially revocable license from the media owner to all members of the general public who meet its terms". ${ }^{997}$ In its entirety, NAPs are designed to be more flexible than CC licenses because they are revocable and, therefore, might be attractive to large media firms. Additionally, NAPs can avoid the "pass off" problem of CC licenses, since they are supposed to be posted on the official sites of the copyright owners rather than on each copy of the copyrighted works. However, as long as NAPs are considered to be licenses, they will still have to face the same questions in relation to formation and compatibility. Furthermore, the original design has also failed to consider transnational licensing problems.

Tim $\mathrm{Wu}$ borrowed the idea of NAPs from the ex post notice regime and the safe harbor regime. ${ }^{998}$ According to his design, "to enforce without deterring complementary use of the underlying work" 999 is the aim of the NAPs. In order to achieve this, the copyright owners will have to give "secondary" creators some clarity and certainty as to what they may and may not do" related to the works they are holding, by "a simple posting on the web or elsewhere that provides details of the secondary uses of a work that a secondary author can make without gaining further permission from the owner."

However, as the matter stands, none of these proposed solutions are perfect. They are not so helpful in the light of the problems this article is trying to solve, mainly because they are helpful in terms of unleashing potential works, but all fail to consider the latter part: how to collect the benefits brought by fan activities.

\subsection{CONCLUSION}

Despite whatever motivations and ethics those fan groups claim to have, most of the fan-based activities that this research is concerned with will

\footnotetext{
${ }^{997}$ Wu, supra note 42, at 634.

${ }^{998} I d$. at 625 .

${ }^{999} I d$. at 628 .

${ }^{1000}$ Id. at 633 .
} 
be deemed as copyright infringements under the copyright laws of Japan, the U.S., and China. Moreover, the majority of the existing general legal defenses within these three jurisdictions are not supportive in terms of fan activities, not to mention that it is helpless in the face of massive loads of online infringements.

Some fan activities, such as fansubs are no doubt copyright infringements. But whether articles such as fanvids and video parodies are infringeing or not is a question that will rely heavily on local courts. Considering the legal analysis that this research has conducted above, it seems that the foreign copyright owners should have confidence in enforcing their rights in countries like China. However, it is naive to assume that transnational copyright enforcement is as unhindered or smooth as it is domestically, because in practice, enforcement is extremely complicated in China. Some problems, as have been discussed in the previous chapters, do stand in the way, serving as reasons why copyright owners have had to alter their copyright strategies in foreign countries, and why fan-based activities could survive and flourish abroad, even though they might be infringeing the local laws.

From the legal analysis in this chapter we can clearly see that, unlike pure copyright theft, fan works are in the "giant gray area", as Tim Wu has described it. ${ }^{1001}$ Considering their mix-and-match nature, most fan works are allegedly copyright infringements in the U.S., Japan, and China. However, it is noteworthy that most of the problems that concern fan creations are highly complex and the legal nature of fan works is indeterminate unless they are brought to court. But when the volume of online copyright infringement on a daily basis is concerned, the cost of enforcement then becomes prohibitive. Therefore, judging from an economic perspective, it may not be wise to try to pinpoint every possible infringer, including the fan creators, considering the fact that the intellectual goods are public goods, and therefore the costs are too high. Furthermore, even if we are convinced that theoretically digital piracy is not simply morally but also economically wrong, it is still very difficult for copyright owners to confront a community which is firmly attached to an economy that Lessig has referred to as a "hybrid economy" in practice. ${ }^{1002}$ Every strong measure against the participators will not only

\footnotetext{
${ }^{1001} I d$. at 618 .

1002 See LESSIG, supra note 39, at 177 (...one that builds upon both the sharing and commercial economies, one that adds value to each.).
} 
trigger a backlash from fan creators but also threaten the foundation of this "hybrid economy". Moreover, it is also a fact that many fan creations are beneficial. That is also one of the reasons that content industries in the U.S., Japan, and China are tolerating most fan activities. But merely tolerating them makes no contribution to lowering the online piracy rate and fully unleashing the potential of copyright works.

Therefore, considering the fact that the current copyright laws are deemed severely biased toward the interests of copyright owners, and the fact that the enigma of the massive online distribution of fan works cannot be solved merely by legal means or tolerance, it is both urgent and necessary to examine the existing proposals for a solution, and to see whether there are better options or not.

The existing traditional legal remedies, both domestically and internationally speaking, are not so helpful in the case of fan activities in China due to various reasons discussed above. ${ }^{1003}$ It is also very hard for foreign copyright owners to reap the direct benefits of fan activities there (which are generated by their indulgent attitude) through traditional legal remedies, because the market access for foreign cultural products there is highly restricted and they are facing various degrees of censorship as well.

Bearing in mind that we are still in a transitional period for the market and technology, solutions from the side of the copyright owners could be much more efficient, if compared with the existing proposals that are mentioned above. Therefore, finding solutions should avoid arbitrariness. Rather than instigating radical reform plans for the legal system, it would be better if the industry could accelerate the transition process from its side. The copyright strategies of the Japanese anime industry against fan-based activities are the paradigmatic example of an alternative choice.

In conclusion, the fact that the problem of fan activities in China cannot be solved well by traditional means forces foreign copyright owners to tolerate most fan activities. Although toleration can benefit the copyright owners in reducing direct conflict with potential consumers and cultivating future fans, but its drawbacks such as failing to distinguish the bad utilizations from the good ones, indeterminate outcome, and being unable to reap the benefit, if any, are also very obvious. That is why CC licenses and NAP were developed. However, for the CC license proposal,

${ }^{1003}$ See supra Chapter 4.4.1 Governmental Solutions and 4.4.2 Non-governmental Solutions. 
it is difficult for large firms to utilize these licenses, as it entails persuading copyright owners to waive some of their rights indefinitely. NAP is a better option since it is revocable and gives copyright owners direct control over the fan-generated content. But since it also does not provide any guidance for reaping the benefits generated by fans, it still has room for improvement in terms of solving fan work problems. This book holds that, considering the purpose of this research, NAP is a more suitable model to be built on than CC licenses, as it is less demanding and comes with a certain degree of flexibility. However, it apparently lacks many things: a platform of communication, a proper way to reap the benefits in the end, and the legal instruments to establish the platform and ensure it is workable. 



\section{Chapter 5. CONCLUSIONS AND RECOMMEN- DATIONS}

"[T] he general enhancement of political and civil freedoms is central to the process of development itself. The relevant freedoms include the liberty of acting as citizens who matter and whose voices count, rather than living as well-fed, well-clothed, and well-entertained vassals.,"1004

- Amartya Sen

Defeating piracy seems to be the major mission of most content providers today, and this is especially so in terms of transnational piracy. Interestingly, the existing law offers little help in this. Some scholars have resorted to traditional solutions, such as international conventions and domestic copyright law revision; others have suggested that copyright owners could protect themselves via alternative enforcement strategies. One such suggestion is to turn those unauthorized but creative uses into contributions. However, it remains unclear how to extract the good ones and turn it into productivity. There is a danger that this goal will be so difficult to achieve that copyright owners will just simply give up and uniformly treat all unauthorized users as pirates.

In fact, the problem of fan-related activities in copyright law is a side effect of globalization. The Internet and state-of-the-art copy and distribution technologies have pushed copyrightable works such as Japanese anime to the world. However, raising the copyright protection standard solely, namely the "top-down" protection pattern, will not be able to fix

1004 Amartya SEN, Development as FreEdom 288 (Oxford University Press. 1999). 
that transnational problem. For that reason, Japanese copyright owners have to envisage a possible way to compete in a global market, because to turn a blind eye to what is happening outside Japan will not provide much help in stopping piracy. But mere toleration, as discussed above, has its limits as well.

This final chapter summarizes the research, and provides a solution proposal for fixing the problems of fan creations in the digital age. For that purpose, it begins with the main findings of the research (para. 5.1), and concludes this book with the proposed solution framework (para. 5.2), and a discussion of its future implications (para. 5.3).

\subsection{Conclusions}

So far, this book has answered its three hypotheses in sequence:

- It has showed that, in terms of copyright enforcement in China, the situation is extremely complex for foreign copyright holders (Chapter 2);

- It has demonstrated that the aforesaid problem is one of the side effects of the information revolution (Chapter 3);

- It has convincingly argued that the problem of fan creations could not be properly addressed in the current legal setting of China (Chapter 4), and the cooperation between users and copyright owners is the best solution at the moment (Chapter 5).

The main research question of this book is thereby addressed. Yes, with the help of a properly designed NAP, a flexible cooperative mechanism can be established between the fan creators and copyright owners in China, so that the latter could have a degree of control over the former and their works, and the activities of the former could be legally justified.

Chapter 1 of this book first narrates some background information. Then it introduces the research question: whether a flexible cooperative mechanism can be established between the fan creators and copyright owners in China, so that the latter could have a degree of control over the former and their works, and the activities of the former could be legally justified to a degree? The structure and methodology are also presented in this chapter. 
Chapter 2 of this book illustrated the endemic problems and general economic obstacles foreign copyright owners will face when trying to enforce their copyright in China. This book went through the legislations and policy related to censorship and import quotas in China, as well as the influence of China's political culture over its copyright policy and legislation. It reveals that although endemic problems such as censorship and import quotas fall under China's autonomy, these problems, along with general economic issues such as transaction costs are restricting the ability of a foreign copyright owner to conduct business and enforce his/her rights in the Chinese market.

Having identified the crux in the Chinese market when one is enforcing his/her copyright, Chapter 3 then gives a historical review of the development of several typical fan activities, and explains why nowadays they are deemed as a threat to copyright owners while in the old days they were not. It further explores the reasons behind fan activities, and why we failed to provide a solution, which can make the best of both worlds. This chapter indicated that it is the development of digital technologies that highlighted the long existing unauthorized private utilizations of copyrighted contents such as fan activities, and it is that same development which provided Internet users with game changing tools and accessible materials, and forced our copyright law system to change and make those activities a problem to copyright owners. The problem lies in the fundamental structure of the Internet, and any change to that structure will inevitably cause more problems.

The conclusions reached in chapter 2 and 3 pave the way for chapter 4, which confirmed that many fan activities are actually potential copyright infringements under the current legal frameworks of the U.S., Japan, and China, whereas the transformative fan creations are highly dependent on case-by-case judgments by the courts of the above countries. Considering that fact and that total enforcement is unrealistic in China, this chapter further examined the existing solution proposals, and demonstrated that they are not ideal in regulating fan problems, as they are either too slow or too indirect, with regard to the purpose of this book.

After presenting the historical and technical background of the problems of fan activities and examining the practical issues that existing legal remedies and solution proposals encountered, Chapter 5 of this book recommended a possible solution which considers the pros and cons of the existing proposals and accommodates the needs of a transition period of copyright jurisprudence. It suggests that, foreign copyright owners in 
the Chinese market should adopt a specially designed NAP, to collect fans and reassure them that no litigation will be initiated, provided that they act according to the rules of the NAP. Moreover, in order to avert copyright owner's manipulation over its fan derivative works, the Copyright Law of China must be revised to provide more clearness to derivative works and accommodate parody as well.

\subsection{RECOMMENDATIONS}

From the discussions on Chapter 4 we can conclude that, an open content production mechanism, which employs a NAP, might solve the current problem of fan creations. Similar open production mechanisms, such as product feedback or bug report during the test period of a certain product, are commonly seen in other IP-related industries, but such mechanisms are less common in copyright-related industry. In some rare cases, authors are willing to ask their fans for opinions about the plots of their works, but in most cases such feedback is generally collected post-production. One of the better-known cases is the Manga (comics) and Anime (animation) market in Japan. The Japanese anime industries have long recognized the advantages of fan-based activities (doujinshi) and tolerated them de facto, in order to reap their benefits. Fans of Anime and Manga from across Japan gather annually under Comiket, ${ }^{1005}$ to sell their derivative works. By allowing this to happen, the related industries can thus maintain their influence over potential customers, and can even identify knowledgeable recruits from among these amateur authors. In other words, a certain degree of third party participation in the innovation process can help build fidelity, which can also catalyze a preaching effect, which will possibly generate future profits.

However, having third parties participate in the production process is a good idea, but where one should draw the line, between a contributory group and a condemnable group, is the question. The copyright-related industry is desperately in need of a well-designed mechanism to utilize the contributory group properly, especially when we consider this in conjunction with transnational piracy in countries such as China.

\footnotetext{
${ }^{1005}$ Comiket, also known as the Comic Market, is the world's largest fair for transformative comic works such as doujinshi, which is held twice a year in Tokyo, Japan.
} 
At the core of fan productivity is a participatory culture, which is facilitated by the new advances in digital technology. ${ }^{1006}$ The solution needed here is one that could exploit fan productivity properly. As previous studies had demonstrated, the cooperation model between copyright owners and the amateur fan contributors or, to put it another way, the combination of market norms and fan community norms must be carefully designed, otherwise the great fan creative power might be turned into a mediocre one. ${ }^{1007}$ What can offer some help here is the idea of a new model of production called "peer production", in which "thousands of volunteers will come together to collaborate on a complex economic project". ${ }^{1008}$ Evidently the fan activities such as fansubbing that we discussed above are in accordance with what Yochai Benkler has described as "commons-based peer production", which is "radically decentralized, collaborative, and non-proprietary; based on sharing resources and outputs among widely distributed, loosely connected individuals who cooperate with each other without relying on either market signals or managerial commands," 1009 and "this open set of agents is likely to be more productive than the same set could have been if divided into bounded sets in firms." synonym for the peer production that Lessig described ${ }^{1011}$-will have to learn to manage "the marriage of money and non-money without making non-money feel like a sucker." 1012

With regard to the advantages of formalities discussed in the previous chapter, ${ }^{1013}$ it is suggested that, if properly designed and employed by copyright owners, the CC licenses and NAPs, which are deemed new-style formalities and voluntary formalities, ${ }^{1014}$ can attain some of

\footnotetext{
1006 Yochai Benkler, The Wealth of Networks: How Social Production Transforms Markets and FREEDOM 372-75 (Yale University Press. 2006).

${ }^{1007}$ See e.g., LESSIG, supra note 39, at 237 (Every company building a hybrid will face exactly the same challenge: how to frame its work, and the profit it expects, in a way that doesn't frighten away the community); for the discussion about the trouble when social and market norms collide, see ARIELY, supra note 42, at 68-88; for the discussion about the trouble when markets reach into spheres of life governed by non-market norms, see MICHAEL J. SANDEL, WHAT MONEY CAN'T BUY: THE MORAL LiMITS OF MARKETS 84-91 (Farrar, Straus and Giroux 1st ed. 2012).

${ }_{1008}$ BENKLER, supra note 1006 , at 59.

${ }^{1009} \mathrm{Id}$. at 60.

1010 Yochai Benkler, Coase's Penguin, or, Linux and the Nature of the Firm, 112 YALE L.J. 369, 422 (2002).

1011 See generally, LESSIG, supra note 39.

1012 Wendy Pollack, Will Volunteers Replace Paid Workers? WSJ Blogs: THE INFORMED READER, Feb. 16, 2007, http://blogs.wsj.com/informedreader/2007/02/16/will-volunteers-replace-paid-workers/.

${ }_{1013}$ See supra Chapter 4.4.1.2.3 Reintroduction of Copyright Formalities.

1014 van Gompel, supra note 848, at 1436-37("New-style formalities include requirements on metadata-tagging of digital works, the storage of rights management information in digital depositories, and virtually all digital tools that, in one way or another, create a link between right owners and their works...voluntary...formalities... are requirements
} 
those advantages. As a matter of fact, content industry has consciously or unconsciously submitted itself to new style or voluntary formalities. ${ }^{1015}$ In that sense, private players such as online platforms that manage massive amounts of copyright contents are actually acting as private registration agencies. Moreover, many small businesses and individual creators are willing to release some of the copyrights of their works to a public domain-alike sphere with the help of legal instruments such as CC licenses and NAPs. In that regard, the new model should build on the idea of the NAPs, since CC licenses are not so flexible as the design of CC is to encourage copyright owners to irrevocably license some of their copyrights to the public ${ }^{1016}$ whereas the NAPs are not. ${ }^{1017}$ The flexible feature of the NAPs will allay the concerns of copyright holders of big commercial titles. Moreover, the new model should consider norms building within the fan communities as well, because a long-existing flexible zone, in which the copyrighted works could be disseminated and utilized to a degree by designated users and copyright owners could exert control over the users, is good for the business and the investment climate in countries like China in the long run.

This section starts by summarizing the reasons why we need an alternative solution to regulate fan creations in the digital age (para. 5.2.1). It then explains the word of the proposed mechanism (para. 5.2.2), and proposes several amendments to the CCL to complement the proposed mechanism (para. 5.2.3). Several conclusive notes are followed (para. 5.2.4).

\footnotetext{
to which authors or right owners voluntarily submit themselves...non-fulfillment of voluntary formalities does not result in a defeat of protection.").

${ }^{1015}$ For example, we could easily find copyright notices and statements on CDs, books, and motion pictures, even though that is no longer mandatory. GOLDSTEIN \& HUGENHOLTZ, supra note 780, at 225; Moreover, content conglomerates do have clear lists of their copyrighted works, and when they cooperate with platforms such as YouTube for the purpose of copyright protection, copyright owners will submit that list or even the sample of their works to them, so that these platforms could use their system to identify suspicious contents within the platform which are uploaded by its users. Besides, individual creators will also submit their independently created works with copyright information. See e.g., Content ID, YOUTUBE, http://www.youtube.com/t/contentid.

1016 See Loren, supra note 990, at 276-77.

1017 See Wu, supra note 42, at 634.
} 


\subsubsection{A Feasible Solution}

In Chapter 3 we have discussed the challenges brought by the digital revolution, ${ }^{1018}$ which concerns the technical possibilities. However, just like the logic of the fact that a person who owns a lot of tools which can be used as weapons, does not automatically turn into a criminal, we have to discern the causes behind this massive disobedience in order to come up with an ideal solution.

Why are fan activities such a problem to copyright owners nowadays, given that they were not in the pre-internet era? Pure legal analysis could not offer a clear answer on this, since it is a question closely connected to globalization, technology development, and the youngest generation's perception on copyright in a digital era. For example, the problem of fansubs in China, to put it bluntly, is a universal problem of high demand and low supply. Part of this failure is due to different political and economical considerations in regulating cultural markets between different countries; another possible reason is that, the current copyright standards give copyright owners the rights to prevent hundreds of millions of copyrighted works from entering the public domain, which will limit the creativeness of the next generation of creators. ${ }^{1019}$ Research shows that the majority of film holdings in the U.S. are orphan works, ${ }^{1020}$ by which it means it is difficult for someone to utilize the copyrighted content, even if he/she is willing to pay. That is happening partly because big copyright conglomerates have been trying to extend the copyright terms of their valuable holdings. Those big productions are enjoying a long commercial life, whereas most works are not. In other words, a great number of audio-visual works do not need such a long protection term: many companies have gone out of business before the copyright life of their works ended, and the copyright status of some film productions are too complicated for average individuals to easily identify their copyright holder. ${ }^{1021}$ However, the copyright laws are unable to acknowledge these differences since a harmonized copyright term of protection applies. For private users on the Internet, in terms of the majority of audio-visual productions, if

\footnotetext{
1018 See supra Chapter 3.2 Behind the Fans Activities: Challenges of the Digital Revolution.

1019 See e.g., BOYLE, supra note 868, at 10.

1020 Id. at 9.

1021 See e.g., id. at 224; See also Mireille van Eechoud et Al., Harmonizing European Copyright Law: The CHALlENGES OF BETTER LAWMAKING 227-31 (Kluwer Law International. 2009).
} 
they want to use a copyrighted content and it is available online, the cost of risk to infringe is far less than the cost to locate the copyright owner and initiate the normal procedure of copyright licensing.

The availability of contents or the accessibility of information is a big problem in a globalized world, but it should never be the justification for possible copyright infringement activities. The reason that teenagers around the world are now keen on "having it all" more than ever is firmly connected with the information explosion and its impact on our next generation. Internet technologies, together with information explosion and globalization have demonstrated that nowadays it is technically possible to digitalize almost all types of cultural products, and theoretically people can easily distribute and download them in a fast speed. However, copyright, an annoying object to the "Generation $\mathrm{D}$ (igital)", is obviously in the way.

Meanwhile, we must also notice the differences between the old and new generation. For example, Mark Bauerlein had brought forward the concern that U.S. teenagers nowadays have put too much of their attention on social networks and their "knowledge and skills haven't kept pace" with the information explosion, and "the intellectual habits that complement them are slipping." "1022 Although Dominique Wolton believes the disparity in pace is caused by the failure of communication in a globalized world, ${ }^{1023}$ it is a fact that the teenagers' pattern of receiving and creating knowledge has changed dramatically in the face of the information explosion. Their new pattern of learning in the digital era makes them capable of multi-tasking, ${ }^{1024}$ yet it deprived them of traditional learning because it is time-consuming and boring. Just like Bauerlein had put it: "The mind online drifts toward simplicity, familiarity, and visibility. It wants the greatest amount of content for the least amount of work." 1025 This "knowledge and skill deficits" 1026 of U.S. teenagers makes them masters of digital life, but the shortage of knowledge caused by distraction has driven them into an intuitive model of creation, a model that requests one to have the mastery of sophisticated software in order to create, but only with accessible materials online, such as pirate contents.

\footnotetext{
${ }^{1022}$ Mark Bauerlein, The Dumbest Generation: How the Digital Age Stupefies Young Americans And JEOPARDiZES OUR FUtURE (OR, DON'T TRUST ANYONE UNDER 30) 32 (Jeremy P. Tarcher/Penguin. 2008).

${ }^{1023}$ See generally, DOMINIQUE WOLTON, INFORMER N'EST PAS COMMUNIQUER (CNRS éditions. 2009).

1024 BAUERLEIN, supra note 1022, at 35.

1025 Id. at 152 .

${ }^{1026}$ Id. at 108 .
} 
That characteristic of the model and the consequential preference for superficial productions will eventually affect the cultural industry, because catering to the vulgar taste of the audience is the fastest way to sell an industrial product. ${ }^{1027}$ In terms of China, the situation is much worse: beneath the glittering surface of its audio-visual industries is a shackled market: due to the ideology censorship and the need for a stable society, creators can produce nothing but mediocre works which are politically safe at the same time. As a result, recently the People's Daily has criticized that "China's aesthetic standards have dropped to an embarrassing degree" that "TV works should be more straightforward" for the mass. ${ }^{1028}$

The above-mentioned facts demonstrate that the intuitive model of online creation that most fan activities employ is the end product of the information explosion and Internet culture. Therefore, in order to properly regulate online unauthorized private utilization of copyright contents, a law revision is not enough, as it involves much deeper issues such as education and freedom of speech. However, if the literacy of teenagers nowadays is not improved or even declining as time passes, ${ }^{1029}$ or the related rules are too abstruse, ${ }^{1030}$ the educational functions of the law and the court judgments ${ }^{1031}$ will be contaminated. In terms of China, research

\footnotetext{
${ }^{1027}$ For instance, during an interview, Mike Medavoy, a famous Hollywood producer claimed that: "Making money is not the main purpose, according to the tradition of the U.S. film industry... Now the majority of film production company in Hollywood are controlled by conglomerates such as Viacom, run by lawyers, bankers, and businessman, these people had destroyed the creativity of Hollywood...(Today) movie no longer cares about the society, people's mind and thoughts, they just go for the lowest standard, cater to audiences, they only do movies that teenagers will like, they make block busters and popcorn movies...In order to lower the risk and make money, production companies only wish to do commercials, therefore a movie's diversity and plurality have been ignored." Medavoy's view is no doubt over-exaggerated, because the market of U.S. is free and big therefore it is obvious that there will always be practitioners who consider film making as an art. See Ying Zhang(张英), Haolaiwu Zhizuoren Maike Maidewo Jiangshu Dianying Guilu (好莱坞制片人迈克·麦德沃讲述电影规律) [Hollywood Producer Mike Medavoy on the Rule of Film], Nanfang Zhoumo (南方周末) [SOUTHERN WEEKLY], Jul. 14, 2012, http://www.infzm.com/content/78431.

${ }^{1028}$ Ke Zhang (张柯), Kan Dian Kanbudong de Dongxi (看点看不懂的东西) [See Something that You Could not Understand], Renmin Ribao （人 民 日 报 ） [PEOPLE'S DAILY], Jan. 16, 2015, at http://paper.people.com.cn/rmrb/html/2015-01/16/nw.D110000renmrb_20150116_5-05.htm.

${ }_{1029}$ BAUERLEIN, supra note 1022, at 29.

1030 See Samuelson, supra note 390, at 1206 (“....assessing whether a particular use will eventually be deemed fair by a court involves a complex and context-specific analysis...”). See also Tim Armstrong, U.S. Government: Fair Use is Too Complex to Explain to Kids, INFO/LAW BLOG, Aug. 10, 2007, at https://blogs.law.harvard.edu/infolaw/2007/08/10/us-government-fair-use-is-too-complex-to-explain-to-kids/; Lee, supra note 16 , at 1480 .

${ }^{1031}$ See e.g., Edward Jenks, The Function of Law in Society, 5 JOURNAL OF COMPARATIVE LEGISLATION AND INTERNATIONAL LAW 169(1923)("For it is the peculiar characteristic of the English system, and of systems derived from it, that the judges, though historically and technically the servants of the State, and bound to enforce its commands, have, almost from the first, also played the important part of educating the community in the ethics of social conduct."); See also Christopher L. Eisgruber, Is the Supreme Court an Educative Institution?, 67 N.Y.U. L. REV. 961 (1992)(“[T]he Supreme Court cannot be fully understood except as an institution with educative responsibilities, responsibilities that depend upon the excellence of its arguments.");
} 
shows that almost half of the interviewed Chinese college students (in Canton Province) claimed that they received no systematic training about copyright, ${ }^{1032}$ and $58 \%$ of them claimed that they have downloaded pirate copies from the Internet. ${ }^{1033}$ Many interviewees admitted that although they know that buying tangible pirated copies of copyrighted works is wrong, they nevertheless choose to download. And, 91\% of the interviewees believe that the concept of copyright is firmly related to social environment, in other words, they tend to follow others. ${ }^{1034}$ And, all the figures related to online piracy listed in another research are sufficient to explain the problems in China. ${ }^{1035}$ Besides the disrespectful attitude towards copyright of many Chinese citizens, those figures also exhibit their hunger for foreign works, especially those foreign works that are not available in the Chinese market. If it is impossible to deter the mass from participating in copyright infringement activities in effect, then, in order to cut the loss, the copyright conglomerates either should find a way to satisfy the world's need or should come up with a legal solution to stall that hunger without making enemies of potential customers, ${ }^{1036}$ and, more importantly, to encourage the free expression of talented people $\mathrm{e}^{1037}$ in a country that paid scant attention to it.

\subsubsection{Part I: An Open Innovation Mechanism}

Based on the above considerations, the problem of massive online infringement and related fan creation issues in China can only be solved thoroughly if we take a comprehensive overhaul of our copyright regime. But that is impractical for now considering all the boundaries that we see

\footnotetext{
${ }^{1032}$ Qun Wang (王群) \& Shibao Deng (邓世豹), Daxuesheng Banquan Yishi Xianzhuang Yanjiu (大学生版权意识现 状研究)[Current Situation of College Students' Awareness of Copyright], DANGDAI QINGNIAN YANJIU (当代青年研 究)[CONTEMPORARY YOUTH RESEARCH], no.1, 2013, 126-27.

${ }^{1033} I d$. at 126.

1034 Id.

1035 Priest, supra note 559, at 472-73.

1036 Viktor Mayer-Schonberger \& Lena Wong, Fan or Foe: Fan Fiction, Authorship, and the Fight for Control, 54 IDEA 1, 11 (2013)(“...those perceived to be a threat to rights holders are very often the same people who are target customers.").

${ }^{1037}$ Burgess, et al., supra note 29, at 12-3(noted that if "Australia is to maximise its ability to capitalise - in both economic and social terms - on these digital 'lifestyle' products, it needs to understand the various dimensions of cultural citizenship and support the creative application of these tools for the purpose of participation, education and innovation. Fostering human talent and digital creativity outside formal school or workplace environments will favourably nurture societal and cultural values-promoting not only an innovation culture and economy but an inclusive society.”).
} 
in international documents for the purpose of unifying the standards globally. Thus, it would be desirable to develop a flexible mechanism, in which a mutual understanding between foreign content providers in the Chinese market and the contributive individuals can be achieved, and the former could have more control over derivative fan works while the latter enjoy a degree of freedom that he/she may not enjoy under copyright law.

Therefore, this book suggests that, foreign content industries in the Chinese market should adopt an open innovation or production mechanism of cultural works, which not only utilizes legal instruments similar to NAPs to stabilize the positive effects generated by contributive individuals such as fans, but also considers the beneficial aspects of the self-rule of the fan community. By doing so, the uncertainties brought by fan activities would be lifted in part, and the creativity of the pubic would be released to a higher level; the tension between the copyright law regime and the digital era would also be relieved to a degree.

This subsection explains the purpose (para. 5.2.2.1), the idea and the general design (para. 5.2.2.2) of the proposed mechanism in sequence. It further uses fansub as an example, to exemplify how the proposed mechanism would work in practice (para. 5.2.2.3).

\subsubsection{The Purpose}

The aim of the proposed open innovation or production mechanism is to build a "safe zone" or "demilitarized zone", which employs a NAP, for contributive users such as fans. The concept of "safe zone" is different from Prof. Hamilton's idea of "free use zone", ${ }^{1038}$ as the latter concerns the right to borrow and browse a work before purchasing, and the right of private use after purchasing in the digital age, which requires legislative actions both at national and international level. To put it simply, Hamilton tried to restore those rights in an online era with her "free use zone". The "safe zone" this research proposes concerns a flexible area created solely by copyright owners. And, more specifically, it is designed mainly for foreign copyright owners in the Chinese market, although it is possible for Chinese copyright owners to apply it as well. The "safe zone" described in this research is not similar to the space created by "safe harbor"

\footnotetext{
1038 Hamilton, supra note 10, at 623-32.
} 
rules either, ${ }^{1039}$ as the latter only concerns user activities that happened within the platform of a third party. There is no direct connection among the three parties: the infringers, the service providers, and the copyright owners in the "safe harbor" scenario, and it made no distinction between contributory "infringers" and condemnable infringers. ${ }^{1040}$

The proposed solution in the first part is purely supplementary: its aim is to fill the gap rather than replace all the existing solutions. Hence, it is acting more like a part of a comprehensive approach, which consists of law, social norms, technology design, and market, which are the four constraints as Lessig had put it. ${ }^{1041}$ Accordingly, the proposed solution will only focus on building a connection with contributory "infringers", that is "infringers" with good faith and the ability and will to contribute; and the fence-sitters, or free-riders, that infringe for reasons such as unavailability of works, who will be likely to pay for the legitimate product or service when available. The malicious infringers thus could be neglected because first, there will always be rule breakers; second, the numbers may be small enough to neglect. The distinction between the contributory groups and the condemnable ones should thus be made.

\subsubsection{The Idea and the General Design}

What is suggested here is something simple. Like most reforms, this book endorses the opinion that the first step should come from the industry rather than the legislature. As Lunney has elaborated, if we consider copyrightable works to be discrete public goods, then government intervention may not be needed even when there is a market failure. ${ }^{1042}$ Thus, the cure for mass disobedience should first come from the industry's side. ${ }^{1043}$ And more importantly, a collaborative relationship between the copyright

\footnotetext{
103917 U.S.C. $\$ 512$ (2012).

1040 Although recently many service providers such as YouTube had signed many package licenses with several big copyright conglomerates such as Warner and Sony. Therefore, it is fair to say that the service providers and copyright owners are somehow connected, but evidently there is no olive-branch offer for the users. See Lev-Aretz, supra note 991, at 139; The neglect of the users in the above-mentioned package licenses will cause many problems, and, more importantly, both "safe harbor" rules and the pre-emptive licenses between the service providers and the copyright owners are getting around the fact that the users are the heart of the matter deliberately. As an emergency measure the "safe harbor" rules will suffice, but without the mutual understanding between the mass and the copyright owners, eventually, it will still be an endless game of hide-and-seek for both parties. Id. at 173-4.

1041 See LESSIG, supra note 12, at 123.

1042 Glynn S. Lunney, Jr., Copyright, Private Copying, and Discrete Public Goods, 12 Tul. J. TeCH. \& INTELL. Prop. 1, 23 (2009).

${ }^{1043}$ Id. at 32 .
} 
owners and the fan community would help the former to discover and further reap the potential benefits of fan activities and define the latitude of the latter.

This proposal first requires the copyright owners to assume a lax attitude towards unauthorized utilizations of their works at the initial stages. They could post revocable exemption statements to exempt foreign fan-based activities, which copyright owners deem tolerable, from copyright liabilities for a certain period of time (e.g., until the given products are officially launched in a foreign market). By doing so copyright owners may attract fans or even have a fan community of their works in a foreign market after certain period of time. Second, copyright owners should foster a relationship between the fan communities and the copyright owners, which is analogous to what the Japanese have managed to achieve domestically. This would create a digital copyright "ecosystem," which directly or indirectly shepherds fan communities toward a bona fide and controllable community. A statement could also be posted on copyright owners' official websites, stating what kinds of fan-based activities are exempted from infringement charges before the market access; this would give fan communities a certain degree of stability. At the last stage, the industry could then unify the fan communities through various levels of cooperation, such as setting up official fan sites, to allow them to participate in certain fan activities, give fans guidance, and help them build their community norms. Fans would join the official sites willingly because they will get a quasi-legal status and yet could still make fan contributions with not just fandom but various motivations. Just like Benkler noted that, "[w] hat makes peer-production enterprises work best has been the capacity to harness many people, with many and diverse motivations, towards common goals in concerted effort." ${ }^{\text {"1044 }}$ In return, industries will then have a free think tank, which is able to constantly provide feedback, new ideas, and fan creations regarding their copyright works. The "safe zone" will also serve as a practice range in which new talents could be located quickly and industries could then convey their attitude and policy changes regarding copyright issues to fans when necessary.

\footnotetext{
1044 Yochai Benkler \& Helen Nissenbaum, Commons-based Peer Production and Virtue, 14 JourNAL OF POLITICAL PHILOSOPHY 394 (2006).
} 
The general design is to let the copyright owners decide what works should go into the safe zone and what should not. The entry criteria of the safe zone should cater to their needs of different stages and should be alterable if circumstance changes. The exempted activities could be limited to prima facie infringeing derivative creations such as fanfics and mash-ups, and they could also extend to cover some clearly infringeing activities such as fansubs and unauthorized distributions.

More specifically, the design should be based on the following thinking:

First, the copyright owners should mark out a safe zone in which fan activities are officially recognized. This could be achieved with the help of NAPs: in terms of fans in a foreign market, copyright owners could either exempt all infringeing fan activities, including free distribution of the underlined audio-visual works, from copyright liabilities in a designated market in general, before the underlined audio-visual products are officially launched there; or they could choose to exempt some or all possible infringeing fan activities in an appointed area, after the underlined audio-visual products have been formally launched there. In either case, a safe zone would be established, and fan contributors who wish to utilize copyrighted contents but fail to satisfy the copyright exceptions listed in the domestic copyright laws, would have a clear understanding of what is the safe way to contribute or to utilize copyright content and what is not. The safe zone could be platforms, or digital tools that are provided or monitored by the copyright owners.

Second, that safe zone could either be considered as part of the production process before the production is deemed complete, or it could be considered as part of customer feedback after the product is in the market. This suggestion is not new, as the idea of "user innovation" is widely known, ${ }^{1045}$ and it has already existed in many layers of our social life, ${ }^{1046}$ and commonly accepted in copyright-related industries such as the software industry. ${ }^{1047}$ It is believed that user innovation has four layers: innovation of use, innovation in services, innovation in the configuration of the products, and innovation of the products themselves. ${ }^{1048}$ In terms of

\footnotetext{
1045 See generally Fisher, supra note 23; Eric Von Hippel, Lead Users: a Source of Novel Product Concepts, 32 MANAGE SCI. 791(1986).

${ }^{1046}$ Fisher, supra note 23, at 1418-30.

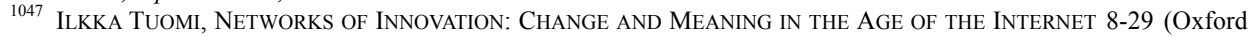
University Press. 2002).

${ }^{1048}$ Pan-European Laboratory Infrastructure Implementation, Considerations on user driven innovation (1st version),
} 
innovation in layers other than the product itself, mechanisms such as product feedback and bug reporting are commonly used; for the innovation of the product, open production is not infrequent as well. In China, many famous writers who are based on the Internet will first publish their works online chapter by chapter before official publication, in order to generate a degree of publicity and collect early feedback to improve their books. ${ }^{1049}$ In the audio-visual production area, 'audience rule' is also part of the game now. ${ }^{1050}$ Given that with the help of digital technologies, many fans today contribute in a more subtle and complex way, the audio-visual companies should build a safe zone in which fans could use various means (including the creation of fan works) to express their ideas about the product, irrespective of which phase it is in (the pre-production and the production phases), or, to demonstrate that there are other possibilities in terms of utilizing copyright contents to serve multiple purposes. This would enable the copyright owners to reap the fan benefits and use them to develop more profit channels.

Third, as mentioned in the first point, a legal instrument, such as a tailored NAP, is necessary for solidifying the mutual trust between the fans and the production companies. If the legal status of some fan contributions is yet to be determined, the power of peer economy or open innovation in audio-visual productions cannot be fully released without a legally binding arrangement. NAP is preferable here due to its revocable nature, as it can therefore offer a degree of flexibility that even large audio-visual production companies might find acceptable.

Fourth, if the copyright owners wish to set a specific term for that exemption, it should be carefully considered. As a general rule, a broader NAP, such as one that allows free distribution of parts of or even the whole work, should be invalid after that work is successfully introduced to the Chinese market. Then it could be replaced by a narrower NAP, in which only supplementary contributions such as transformative fan works

\footnotetext{
Deliverable

D1.2,

PII

CONSORTIUM

REPORT,

2009,

http://www.panlab.net/fileadmin/documents/PII-Deliverables/D1.2-Considerations_on_user_driven_innovation_1 $1 \mathrm{st}$ version_v1.0.pdf ("User-driven innovation, or just user innovation has a number of degrees: innovation of use, innovation in services, innovation in configuration of technologies, and finally the innovation of novel technologies themselves.").

${ }_{1049} \mathrm{He}$, supra note 50, at 623.

1050 See e.g., Owen Gibson, What Happens Next? You Decide, as Channel 4 Launches T's First Interactive Drama, THE GuARDiAn, Sep. 26, 2005, http://www.theguardian.com/technology/2005/sep/26/media.broadcasting; Audience to Decide Plot for 'Mundasuppatti 2', DECCAN CHRONICLE, Jul. 9, 2014, http://www.deccanchronicle.com/140709/entertainment-kollywood/article/audience-decide-plot-mundasuppatti-2.
} 
that utilized only reasonable portions of copyright contents are allowed. That makes sense because not only will it echo with the "Cease Distribution When Licensed" norm that fan communities had once advocated and implemented, but also function as a diverter, so that the fence-sitters will be ushered to the official sites in which the work can be acquired legitimately, and the devoted fans will continue to provide their creative ideas about the work within the narrowed exemption area. The only thing that needs to be adjusted from time to time is the respective catalogs of works. As to the destiny of the fan works created within the zone, they could remain in there under a regular user agreement after the exemption period expired, or, if the platform is not big enough to create a sensational effect, the copyright owners can allow the creators to distribute them to other big sharing platforms non-commercially.

However, for the copyright owners, the utilization of these fan-generated contents should be taken with extra care. Take the Lucasfilm's offer to the fans as an example: Lucasfilm noticed the potential value of fan power and offered fans free Web space for them to engage in fan activities. However, the user contract that Lucasfilm had drafted required that the derivative works created by fans "shall be deemed and shall remain the property of Lucasfilm Ltd. in perpetuity."1051 The result was that the fans believed that there was "nothing innocent" about Lucasfilm's offer, and that kind of request represents the "discouragement" of creativity. ${ }^{1052}$ According to Lessig, "[a] key element to a successful hybrid is understanding the community and its norms. And the most successful in this class will be those that best leverage those norms by translating fidelity to the norms into hard work."1053 As Mark Shuttleworth had pointed out that, for the kind of collaboration that this research proposed to work, copyright owners must make sure three things: first, they should "respect" the fan community; second, they should give fans "responsibility"; third, they should "give people a sense of being part of something that has meaning." 1054 Therefore it is more advisable to treat the space as a long-term project and the fans as partners, and to offer fans various degrees of incentives in order to get the best out of their potential.

\footnotetext{
1051 LESSIG, supra note 39, at 245.

${ }^{1052} I d$. at 246.

1053 Id. at 184

${ }^{1054}$ Id. at $184-5$.
} 
Based on the analysis presented above, an ideal and optimized NAP should at least contain the following terms:

1. The copyright owner should first make clear that utilizations of certain copyrighted works they own which meet the criteria of the safe zone are exempt from copyright liabilities and are encouraged, for the time being;

2. The copyright owner should then go into the particulars about the coverage of the exempted audio-visual works (specific or blanket);

3. The copyright owner should itemize the encouraged utilizations of the copyright works (from free distribution to certain limited fan adaptations);

4. The copyright owner should indicate the duration of this exemption (and, possibly, whether it is renewable or not), or simply indicate that it is revocable.

The difference between the NAP we have examined in this research and a user agreement that everyone would have to agree upon during the registration process of a social platform is that, although many user agreements do contain copyright-related terms which explicitly indicate that they are revocable, and the terms within them can be changed if the service provider believes it is necessary, they could be simplified by extracting the copyright-related parts and turning them into NAPs. The NAP here is a short announcement that only focuses on the copyright issues of the fan activities that happen within a set zone. This NAP is not intended to "license" any rights, it merely acts as a copyright owner's promise on which fan contributors could depend. As a result, it could be posted on the official site since there would be no need for further confirmation from the fan users. The safe zone created by this kind of NAP can be categorized as one form of "collaboration spaces", in which "the product of the participation is intended to be more valuable than the material they found". ${ }^{1055}$ It should be borne in mind as well that a NAP issued by the copyright owner is in itself a set of self-restricted rules and the intention is to build mutual trust, so it is reasonable to expect that copyright owners

${ }^{1055}$ Id. at 196. 
would follow their own rules and, thus, these rules would be seen as dependable.

\subsubsection{Example}

Take fansubs as an example: in order to solve the problem of fansubs and promote cooperation, ${ }^{1056}$ the design could be more specifically and openly delineated. In short, the NAP for audio-visual works should aim to provide an exemption of liability rather than a license to use copyrighted contents in a designed way. Copyright owners could thus set boundaries for the fansubbers without licensing their rights, and fans will know how to act with no copyright liability accordingly. Firstly, fansubs, as discussed above, are actually translations of subtitles of certain audio-visual works, and hence are probably infringeing the translation right of the copyright owners. When the subsequent online distribution involves also the video files of the copyrighted works, or the merged video files encompass the fan-translated subtitles, then in a normative way, they are no different from any other pirate activities. Therefore, if the copyright owners are willing to have their works translated and distributed freely by fansub groups in a foreign market such as China which they cannot gain access to in a way, they could of course state that clearly through a NAP on their official site, and set certain limits on it. However, if they wish the opposite, then their NAP should clearly indicate that the distribution of the video files is out of the question.

The next step is how to regulate the fan creations, namely the translated subtitles properly. Otherwise, the beneficial effects generated by these fan creations may vanish or even be utilized by commercial pirates in China. ${ }^{1057}$ In order to do so, a certain degree of mutual trust and cooperation must be established between foreign copyright owners and the local fan communities. However, it seems that it is not the case in China currently. Unlike the audio-visual market in U.S. and Japan, their Chinese counterpart is an emerging one: the audio-visual industry and the fan communities are all under-developed, and the latter are desperately in

\footnotetext{
${ }^{1056}$ In the light of transnational fansubbing activities, Kensaku Fukui, a copyright expert in Japan, advocated cooperation as a solution. See Fukui, supra note 876 (noted that Japan could utilizes fan groups by encouraging Japanese copyright owners to give them permission, so that fans could produce fansubs voluntarily.).

${ }^{1057}$ Moning Zhang (张墨宁), “Daohuo” de zimu zu (“盗火”的字幕组) [Fansub Groups that “Steal Fire”], in Nan Feng Chuang (南风窗) [SOUTH WINDS], Oct. 19, 2013, available at http://mobile.nfcmag.com/article/4319.html.
} 
need of guidance. But currently copyright owners are reluctant to acknowledge fansub groups officially but would rather tolerate them. ${ }^{1058}$ It is therefore understandable why the mutual trust cannot be established. Nevertheless, since the Internet had lowered the costs of locating fansub groups as well, a customized NAP may solve this problem.

In view of the above discussion, with respect to fansubs in China, the design of the NAP for fansubs should be as follows:

First, foreign copyright owners should distinguish two periods by the degree of market entry: The first period is the "out of market" period. During this period, the underlined audio-visual products are not officially in the Chinese market through channels such as theatre, TV broadcasting and online streaming; in the second period, the products are officially introduced into the Chinese market.

Second, different NAPs should be applied to different periods:

In the first period, if the underlined exotic audio-visual product cannot or does not plan to enter the Chinese market in the near future, then the revocable NAP should exempt fans from copyright infringement liabilities if they plan to freely distribute the copyrighted contents of the copyright owners online. Furthermore, they could set a clear term for that exemption in their NAP declaration, so that they could revoke it or renew it after that term ends, and fansubbers could thus make sure that within that period their fansubbing activities are "safe". The incentive for the copyright owners is clear: it will take a long time for most foreign audio-visual products to get into the Chinese market, by which it means there will always be a dry spell in which the copyright owners will not be able to monetize their copyrighted products in China via official distribution channels, but they nevertheless need exposure.

Moreover, merely tolerating actually offers little help in reaping the benefits which fans generate and deterring unauthorized utilizations. In the era before the Internet, if the copyright owners wished to merely tolerate all the unauthorized private distribution of their copyright contents, it was still workable, ${ }^{1059}$ not to mention that those activities might as well be in the "free use zone" that Prof. Hamilton suggested as well. In terms

\footnotetext{
${ }^{1058}$ See e.g., Leonard, supra note 28, at 201 (in explaining why Japanese anime company refuse to officially give fans a license to reproduce, Leonard states as follows: "The reasons involved protections of copyrights; the impracticality of studios in Japan giving written permission to informal American fan groups to show their animation; the risk of losing the opportunity to sell their programs to American syndicated TV markets if the American TV representatives felt that there were already too many bootleg video copies in circulation; and other cavils of this nature").

1059 Balkin, supra note 15, at 16.
} 
of China, the foreign products somehow gain their publicity through the underground channels. Since compared with fansubs, commercial piracy was easier to locate, and most fans did not have enough resources to reproduce fansubs massively, fansubbing activity was still tolerable. ${ }^{1060}$ And after a decade or so, when they officially launched their audio-visual products in the Chinese market, they might have found that they already had a considerable number of followers in the market. Today, private individuals can easily reproduce, create new contents based on copyrighted contents, and disseminate them online in the digital age. Foreign copyright owners have actually lost their ability to control. Therefore, for the copyright owners, merely tolerating fan groups without giving any guidance to them can be as risky as giving them an official license. ${ }^{1061} \mathrm{It}$ would be welcomed if copyright owners were to guide fan groups and to give them a degree of freedom to engage in fan activities. But if too much freedom over the copyrighted contents were given to fans, as Jenkins said, it will also "threaten the producer's ability to control public response." 1062 Therefore, the design of a hybrid commercial model needs very careful thought.

Furthermore, unlike the old days, there are far more competitors in the Chinese market now. Apart from the local audio-visual production companies, ${ }^{1063}$ foreign content providers such as Japanese and South Korean audio-visual production companies are all competing with each other in the Chinese market. ${ }^{1064}$ The keen competition between foreign products and the rise of local productions will affect the market share of productions of one foreign country. In other words, if foreign audio-visual companies are not going to influence their fans' activities, they may not provide the stable growth in the fan base that the foreign copyright owners had expected. Just as Grant McCracken puts it, the copyright

\footnotetext{
${ }^{1060} I d$.

1061 Leonard, supra note 28, at 201. See also Lee, supra note 16, at 1486.

1062 Henry Jenkins, Convergence Culture: Where Old And New Media Collide 58 (New York University Press. 2006).

${ }^{1063}$ See e.g., Thomas Mentel, China's Film Industry Takes Measures to Compete with Hollywood, MovIESCHEATSHEET, Jun. 20, 2014, available $\mathrm{http} / /$ wallstcheatsheet.com/entertainment/chinas-film-industry-takes-measures-to-compete-with-hollywood.html/?a=v iewall.

${ }^{1064}$ See e.g., Alex Stevens, The Chinese Obsession with Korean Dramas is Making Bad Chinese TV Look Bad, ShAnghaiIST, Mar. 3, 2014, at http://shanghaiist.com/2014/03/03/chinese-obsession-korean-dramas.php; Coco, Chinese Entertainment Faces Tough Competition From Korean Dramas, DrAMAFEVER, Mar. 3, 2014, at http://www.dramafever.com/news/chinese-entertainment-faces-tough-competition-from-korean-dramas/ (last visited Apr. 4, 2014); Gavin J. Blair, China's iQIYI and Japan's Fuji TV Link on Drama Production, THE HoLlYwood REPORTER, Jun. 17, 2014, at http://www.hollywoodreporter.com/news/chinas-iqiyi-japans-fuji-tv-712401.
} 
owners will have to "choose how they will treat their fans, whether to let them in or wish them goodbye." 1065 Therefore, a revocable NAP stating that the copyright owner will exempt the fansubbers from copyright liability in the first period will initiate the communication between the production companies and the fans.

During the second period, in which the foreign audio-visual products have successfully landed in the market, the copyright owners should classify their audio-visual works and determine what specific NAP terms will apply respectively. For NAP that concerns small productions that use free distribution as part of their commercial model. ${ }^{1066}$ Foreign copyright owners could of course stick to the free distribution term; In terms of big productions, the corresponding NAP could put more focus on complementary uses of the underlined audio-visual products, because in that case the promotional effect is secondary. In a nutshell, the next step for foreign copyright owners is to determine in what way they wish their works to be developed by fans. This current design is broader than the original NAP design which Tim $\mathrm{Wu}$ proposes, since it covers more than encouraging secondary creativity: if the copyright owners wish their copyrighted content to be distributed along with the fan-translated subtitles, they could pinpoint that in their NAPs, indicate that the distribution of the video files will not attract legal issues as long as they satisfy the conditions set by the copyright owners; or they could forbid the free distribution if official distribution channels such as online streaming platforms are available. In the latter case, the copyright owners should explicitly delineate the conditions and limitations of that exemption in the subsequent terms, such as whether the audio-visual work could be commercially exploited or not, or define the venue that the exemption covers.

The utilization of fansubs is firmly connected with the last part of this NAP design, which focuses on how the connection between foreign copyright owners and fansubbers can be established, so that the benefits can be identified and reaped. But as previous studies have demonstrated, the cooperation model between copyright owners and the amateur fan

\footnotetext{
1065 GRANT DAVID MCCRACKEN, Plenitude $2.0 \quad 88 \quad$ (Periph.:Fluide. 1998 ), at https://www.scribd.com/doc/61801857/Plenitude-2-0-by-Grant-McCracken.

${ }^{1066}$ For example, BitTorrent have released their new 'Bundles' platform that enables "direct-to-fan" publishing, it "gives the content creators the power of choosing how they want to benefit from their film", you could "give users the film for free if they first share a link to your film's website." See Noam Kroll, Breakdown of The Major Online Indie Film Distribution Platforms, PREMiUMBeAT.COM, Dec. 13, 2013, at http://www.premiumbeat.com/blog/breakdown-of-the-major-online-indie-film-distribution-platforms/.
} 
contributors must be carefully designed. ${ }^{1067}$ In order not to just sit and watch but to make use of these fan efforts, foreign copyright owners will have to maintain a certain degree of direct interaction and control over the fans. Here the function of NAP is to clarify that it is not a license of rights but rather an exemption of liability, so that the copyright owners will allay their concerns about waiving their valuable copyrights in a nascent market. At the same time, the fans will know the bottom lines of the copyright owners and act accordingly. The purpose is to give fan creators a certain degree of freedom and let them develop in a natural way.

Moreover, the copyright owners should provide fans with a platform or utilize the existing platforms via cooperation, such as an online streaming platform or a BBS, or provide them with advanced tools to engage in fansub activities. The purpose is to drive them away from the illicit video resources and provide them with a legitimate one. If the fan translation is deemed good enough for commercial uses, copyright owners could cooperate with local online streaming platforms, or establish an official site for fans, to award and officially license some of these fan translations. Considering subtitles are a minor part of audio-visual products, and the free online streaming of that product is possible in most cases, fan translated subtitle files should be set openly accessible but only compatible with designated platforms and programs. By doing so the fans will be able to practice fansubbing in an official platform, and those people who prefer fan-translated subtitles will be attracted to the designated platform and programs as well. In fact, fansubs are deemed much more nimble than official translations in offering more details about foreign cultures, ${ }^{1068}$ and even some of the official translations were criticized by fan translators as "not professional". ${ }^{1069}$ Besides, at least for now, online streaming is the only channel which enjoys more freedom compared with

\footnotetext{
1067 See supra note 1007 and accompanying text.

1068 See Cintas \& Sánchez, supra note 508, at 46.

1069 Jia Fanyi Fengbo Xu: Wo Meiyou Bei Haolaiwu Fengsha (“贾翻译风波”续: 我没有被好莱坞封杀) [“Translator Jia's Trouble” Continued: I am not blocked by Hollywood], Shidai Zhoubao (时代周报) [TIME WeEKLY], Aug. 23, 2013, available at http://ent.ifeng.com/movie/news/toutiao/detail_2013_08/23/28939468_0.shtml (last visited Jun. 19, 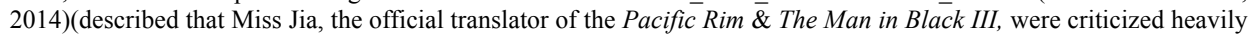 by senior fansubbers as "lacking basic training and experience".); see also Fulian 2 Fanyi zao tucao Wangyou ni Siji Guole Meiyou (《复联 2》翻译遭吐槽 网友: 你四级过了没有) [Official Translations of the Subtitle of Avengers: Age of Ultron were Attacked by Netizens in China], Wang Yi 163(网易 163) [NETEASE], May 13, 2015, at http://ent.163.com/15/0513/07/APFRR1P7000300B1.html\#p=APFUDUQD00AJ0003. But cf. Shuang Yan, Lights, Camera, Captions!, GloBAL Times, Mar. 18, 2012, at http://www.globaltimes.cn/content/700857.shtml (indicated that professional translators and experts believe fan translators "lack basic background in translating and knowledge of Western history and culture").
} 
traditional ones, by which it means that if the foreign copyright owners could create demand on the Chinese market, it would be possible for them to deliver their audio-visual titles to the Chinese audiences, as long as they pass government censorship. ${ }^{1070}$ If we take the motivations of fansubbers into account, it really makes sense as this proposal can meet most of their requirements. However, although it is a fact that Chinese video platforms are now cooperating with fansub groups in order to make better translations, ${ }^{1071}$ considering the fact that these video platforms are only licensees rather than copyright owners, and the cooperation model we have witnessed in China is poorly designed since fan translators are paid very little money, ${ }^{1072}$ it is obviously not good enough. ${ }^{1073}$

Furthermore, good translations could be officially adopted and the fans could thus be rewarded in many ways. For example, the names of the translators could be listed in the cast of audio-visual products as an encouragement, or the online streaming site could add the fan translations to their player. Although too much involvement will increase the copyright owners' legal risk since civil law principles such as good faith and implicit consent may apply, but for private individuals like fans, it is much more important to receive recognition from the copyright owner and avoid law suits, rather than winning a case.

\footnotetext{
${ }^{1070}$ Feng \& Wang, supra note 284 ("the government has indicated in private talks with Internet companies that it plans to close this control gap with new rules this year").

${ }^{1071}$ Zhang, supra note 1057; For example, the department head of the American television series of Tudou has pointed out that, since they have introduced many foreign titles and are in desperate need of subtitle translations, the cooperation between video platforms and fansubbers is a win-win solution. See Fei Lu (陆飞), Shipin wangzhan yinjin meiju shui shu shui ying? (视频网站引进美剧谁输谁赢) [Video Platforms Introduce American TV series, Who's the Winner?], Beijing Qingnian Bao ( 北京青年报) [BEIJING YouTH DAILY], Sep. 30, 2011, B11, at http://bjyouth.ynet.com/3.1/1109/30/6305923.html; During an interview, Zhang Chaoyang, the CEO of SOHU, also noted that digital piracy is still there but that it has little influence over the market now in terms of audio-visual products, and that it has also helped in fostering fansub groups that are capable of delivering high quality translations, so there is no problem between them now. See Xuejing Zhang (张雪静), Sohu Shipin Jiang Daliang Yinjin Meiju Shishui Meizong (搜狐视频将大量引进美剧 试水美综) [Sohu Video will Introduce Massive Amount of American TV Series, and will Test the Waters of American Variety Shows], www.lmtw.com (流媒体网) [STREAMING MEDIA NET], Feb. 19, 2014, at http://sm.lmtw.com/dongtai/201402/101032.html (last visited Jun. 18, 2014).

1072 The payment for translating an episode is 400 Yuan, which is less than 70 dollars. See Zhang, supra note 1057; in some cases, the price for translating an episode is even less than 80 Yuan, and yet that amount has to be divided equally among five people. See Cen Chen (陈岑), Xingxing Fanyi Tuandui: Gongzuo Jiuxiang Dazhang Choulao Budao 20 Kuai (<星星>翻译团队: 工作就像打仗 酬劳不到 20 块) [The Translation Team of the “My Love From the Stars”: Working like Battling but Payment is less than 20 Yuan], JinLing Wanbao (金陵晚报) [JINLING EVENING POST], Mar. 1, 2014, http://www.chinanews.com/yl/2014/03-01/5898503.shtml.

${ }^{1073}$ It is noted that the Chinese fansub groups are hesitating about that kind of "commercialization", because some of the core members believe that the commercialization of the fansub groups is contrary to their original purpose, and "that degree of cooperation means nothing". See Zhang, supra note 1057.
} 
However, seemingly the Chinese government is not so supportive of this kind of diversity. According to related regulations, in order to introduce foreign audio-visual works to China, all the subtitles must be submitted for censorship, ${ }^{1074}$ and "subtitles which have not been submitted along with the reviewed demo tapes cannot be displayed during broadcasting..."1075 Furthermore, as mentioned before, only the "wholly State-owned or State-controlled work unit" can engage in "business of publication of audio-visual programs through an information network."1076 Therefore, considering the fact that not only the business but also the subtitles are highly regulated and under strict censorship as well, fan-translated subtitles as an option might have to be implemented via unofficial means. For instance, the download function of the video source file could be set open, or the video source file could be allowed to stream on third party software in which the subtitle files could be loaded. In that case demanding users can download the fan-translated subtitles and load them into the videos themselves, whereas undemanding parties may just stream videos with subtitles on the official site. This idea is feasible since it is technically possible to set certain limits on the video file to ensure visits of the licensed platform, and it is in fact much more time consuming and complex to download than to stream it online on official sites, so therefore the copyright owners will not have to worry too much about the potential trouble of private distributions. As for those titles that are not accessible in China now or ever, it is advisable for their copyright owners to utilize the first period NAP to exempt fans from copyright liabilities for possible infringeing activities such as distribution of copyrighted contents, since fans will manage to get them anyhow. They could further turn to the second period NAP to exempt fans from liabilities for transforma-

\footnotetext{
${ }^{1074}$ Foreign Television Program Import and Broadcast Management Regulations, art. 9(6)(When applying for importing foreign film and television dramas, the following materials shall be submitted:...Chinese and foreign language subtitles of title and end credit that are consistent with the specimen tape...); Dianying Juben Genggai Beian Dianyingpian Guanli Guiding (电影剧本(梗概)备案、电影片管理规定) [Provisions on the Archival Filing of Film Scripts (Abstracts) and the Administration of Films] (promulgated by SARFT Decree No. 52, May 22, 2006) art. 17 (China), translated at CHINA COPYRIGHT AND MEDIA (Rogier Creemers trans.), https://chinacopyrightandmedia.wordpress.com/2006/05/22/film-script-outline-filing-film-management-regulations/ (The completed film shall be reported to the corresponding film examination organ for examination. For film submission, the following materials shall be provided...7, a complete screenplay set...). Dianshiju Shencha Chengxu (电视 剧审查程序) [Television Drama Examination Procedure], SAPPRFT, Aug. 16, 2007, at http:/www.sarft.gov.cn/articles/2007/08/16/20070913171221490947.html (5. Requirements about demo tapes of various kinds of Television Dramas that are sent for approval....all imported TV dramas (including Animation)...must have Chinese subtitles in the demo tapes that are sent for approval...).

1075 Id.

1076 See supra Chapter 2.1.3 Censorship.
} 
tive uses when the underlined titles are officially introduced, or they could stick to the first period NAP if there is no way for the underlined works to enter the Chinese market, and to direct the passion of fans to related tangible merchandises.

The duration of the NAP for fansubs, especially the second period NAP, should be indefinite. The main purpose of building a safe zone is to communicate with fans in a foreign market. That is to say, even if the copyright owners choose to withdraw their promise about the exemption, it will make not too much difference, since fan activities of contributive individuals in countries like China are likely to continue, as the hunger for information and knowledge and the restriction on access in China will probably persist in the long term, and the cost of copyright enforcement aiming at individuals is too high.

As to the copyright ownership of the fan-generated contents, it is a vexed question that needs to be further clarified by the local copyright law, which is discussed in subsection 5.2.3.

\subsubsection{Part II: The Copyright Law of China in the Near Future}

Of course, expecting the above-mentioned mechanism alone to provide a permanent solution for the existing problems is unrealistic. ${ }^{1077}$ One of the potential threats of the proposed mechanism, as pointed out by Tim Armstrong, is that it will tend to "foster a comparatively impoverished family of follow-on works." "1078 In other words, the setting, which has been described above, will tend to promote only copyright owner-friendly creations. Hence, for the purpose of building a self-consistent and multi-level solution plan, which not only stresses cooperation but also highlights diversity and even contradiction in creativity, a refinement proposal for the CCL is needed as well. However, it is destined to be subsidiary and indirect, since the aim of this research, which is to create a flexible zone in which the foreign ideas and culture could get into China unconstrained, will contravene the will of the government of China to control the flow of ideas and the impact of foreign cultural products on its people.

\footnotetext{
1077 Piasentin, supra note 588, at 233.

1078 Armstrong, supra note 702.
} 
For that purpose, two major issues can and must be addressed in the future CCL: the legal status of the fan-generated derivative works (para. 5.2.3.1), and the protection of parody (5.2.3.2).

\subsubsection{Legal Status of Derivative Works}

As discussed in the previous chapter, the U.S., Japan, and China all have their own standards regarding this matter. ${ }^{1079}$ Article 12 of the CCL provides that, the copyright of a derivative work "shall be enjoyed by the adapter, translator, annotator or arranger, provided that the exercise of such copyright does not prejudice the copyright in the pre-existing work." 1080 As discussed above, Article 11 of the JCL and Article 103(a) of the U.S. Copyright Law all clearly provide that the copyright of the derivative work must not prejudice the pre-existing one. ${ }^{1081}$ However, unlike Japan and the U.S., China does not expound the legal consequences of that "prejudice" in its copyright law, and that creates a vague area in CCL in which the legal status of an infringeing derivative work is unclear. ${ }^{1082}$ Article 11 of the JCL is identical to Article 12 of the CCL. But as discussed above, ${ }^{1083}$ Article 28 of the JCL, which clearly provides that "in the exploitation of a derivative work, the author of the pre-existing work" shall have the same economic rights as "the author of the derivative work", has no counterpart in the CCL. ${ }^{1084}$ Likewise, Article 103 of the U.S. Copyright Law has no counterpart in the CCL too. Article 103 of the U.S. Copyright Law provides that, if a derivative work or part of it consists of different ill-gotten copyright contents, then the work or that part of work cannot enjoy copyright protection, ${ }^{1085}$ unless it could be covered by the fair use doctrine. It also provides that, only "the material contributed by the author" of the derivative work, if distinguishable, can

\footnotetext{
1079 See supra Chapter 4.2 Legal Determination at National Level.

10802010 Copyright Law of the People's Republic of China, art. 12.

1081 Japanese Copyright Law, art. 11; 17 U.S.C § 103(a)(2012).

1082 The commentator believes that without the consent of the original author, derivative works such as fansubs may not enjoy copyright protection in China. See Yunting You, Does Tudou.com Require Permission for the Use of YYeTs' Unauthorized Subtitle Translation in China?, BRIDGE IP LAW COMMENTARY, Oct. 10, 2014, at http://www.chinaiplawyer.com/does-tudou-com-require-permission-use-YYeTs-unauthorized-subtitle-translation-chin a/.

${ }_{1083}$ See supra Chapter 4.4.2.2.5 The Reasons.

1084 Japanese Copyright Law, art. 28.

108517 U.S.C § 103(a)(2012).
} 
be protected by copyright. ${ }^{1086}$ A similar attitude can also be found in several Japanese court decisions. ${ }^{1087}$

Nevertheless, the solutions as provided by the JCL and the U.S. Copyright Law have advantages and disadvantages, and are firmly connected to their domestic social context. Both Article 28 of the JCL and Article 103 of the U.S. Copyright Law aim to promote independent initiative but take different approaches. For instance, Article 28 of the JCL requires not only the author of the derivative work to share his/her work with the pre-existing author, the exploitation of that derivative work by others should ask for permission from both authors of the pre-existing and the derivative works as well. ${ }^{1088}$ This will encourage independent initiative because authors who created a derivative work will lose part of their control over their works, irrespective of whether they are infringeing or not. In the case of a U.S. derivative work, the derivative author will even run the risk of losing his copyright, if his contribution and the pre-existing parts are indistinguishable and if the latter is used unlawfully. On the other side, the JCL is actually promoting a highly integrated market in which the copyright owner of a pre-existing work enjoys full control over their derivative works, as we could see from the example of the Japanese market, the relationship between the original and derivative authors is a "cooperative" one. However, this design tends to work well within a highly integrated market like Japan, whereas for a nascent market like China it is over-protective as it gives the copyright owner of a pre-existing work too much control over the derivative works. Regarding the U.S. market, the "unlawful" requirement will render most derivative works in a digital era unprotected, unless such utilization could be justified as "lawful" under the fair use doctrine or compulsory license. Therefore, it is to be expected that the relationship between the original and derivative authors is a "confrontational" one. This type of old school relationship is unsuited to a digital era, as nowadays the material contributed by the derivative author

\footnotetext{
108617 U.S.C $\$ 103(b)(2012)$.

1087 Popeye Necktie Case, Supreme Court, 17 July 1997, Minshu Vol. 51 No. 6: 2714; Kewpie Doll Case, Tokyo High Court, 30 March 2001, Hanrei Jiho No. 1797: 111, as cited in TransParenCy OF JAPANESE LAW PROJECT, at http://www.tomeika.jur.kyushu-u.ac.jp/ip/index.html ("Since a derivative work receives protection on the basis that new original expression has been added to the existing work, the copyright protection for derivative works extends only to the newly bestowed original expression and does not cover expression that is the same as the existing work. It is obvious that where it is only the expression of the existing work within the derivative work that has been exploited, then the owner of the copyright on the derivative work cannot exercise their rights.”).

${ }^{1088}$ FUMIO SAKKA (作花文雄), Chosakukenhō: kiso to ōyō (著作権法: 基礎と応用)[COPYRIGHT LAW: FOUNDATIONS AND APPLCATIONS] 53 (Tōkyō : Hatsumei Kyōkai, 2005).
} 
and the pre-existing material employed in a derivative work such as mash-ups, cannot be easily distinguished.

This research suggests that foreign cultural industries should try to push for more detailed regulations on derivative work in the CCL by various means. Considering the fact that nowadays the contribution of the derivative author and the pre-existing materials in digital creations such as mash-ups and remixes are mostly indistinguishable, and denying copyright protection to an infringeing derivative title may not be beneficial or may even be detrimental to the original copyright owners because then the derivative authors will be in no position to protect their works from secondary infringements, it is better to draw on the experience of JCL. It is a reasonable inference as well, since after the WTO case DS362, China had abandoned its requirement that " $[\mathrm{w}]$ orks the publication or distribution of which is prohibited by law shall not be protected by this law". ${ }^{1089}$

According to Article 12 of the CCL, an infringeing derivative title shall be protected by copyright as well, but it is also required that it "shall not prejudice the copyright in the pre-existing work." If a derivative work cannot be covered by copyright exceptions and has thus infringed a pre-existing copyright, then it will have to follow the rules set by Article 47 and undertake the corresponding liabilities. According to Article 47(6) of the CCL, anyone who exploits a work "for adaptation, translation, annotation, or for other purposes, without the permission of the copyright owner," shall "depending on the circumstances, bear civil liabilities such as ceasing the infringement, eliminating the bad effects of the act, making an apology or paying compensation for damages." ${ }^{1090}$ Put another way, infringeing derivative works in China will not lose their copyright protection, but will have to undertake civic liabilities instead. It also means that infringeing articles share a similar legal status with the illicit works mentioned in Article 4 of the CCL, with which they are officially copyright protected but the exercise of their copyrights is highly restricted. ${ }^{1091}$ On the face of it, it makes perfect sense since "where there is a legal right, there is also a legal remedy", ${ }^{1092}$ so therefore the copyright owners, no

\footnotetext{
10892001 Copyright Law of the People's Republic of China, art. 4.

10902010 Copyright Law of the People's Republic of China, art. 47(6).

1091 For a detailed discussion on the history of Article 4 of the CCL, see supra Chapter 2.1.1.5 Open Up Period (1991-present).

10923 William Blackstone, Commentaries on the LaWs of England in Four Books, 23 (J. B. Lippincott Company, 1893).

http://oll.libertyfund.org/titles/blackstone-commentaries-on-the-laws-of-england-in-four-books-vol-2.
} 
matter local or foreign, could rely on Article 47(6) to deal with possible infringeing derivative works. Nonetheless, considering the aforesaid challenges brought by the digital revolution, the protection this traditional type of solution offers is arguably weak. Article 12 and Article 47(6) have never been revised since the $1990 \mathrm{CCL}$. Not to mention that it is a "confrontational" model, which is unsuited to a digital era. In order to meet the goal of promoting creativity in the digital age, a "cooperative" model is needed.

A cooperative model will require the law to provide original authors with a similar status as Article 28 of the JCL provides, and to make a clear distinction between derivative works in pre-digital and in digital eras. Therefore, Article 12 should be revised as:

Where a work is created by adaptation, translation, annotation or arrangement of a pre-existing work, the copyright in the derivative work thus created shall be enjoyed by the adapter, translator, annotator or arranger, provided that the exercise of such copyright does not prejudice the copyright in the pre-existing work.

In a case where the exercise of the copyright of a derivative work has prejudiced the copyright in the pre-existing work, the following rules shall apply:

(1) Where the material contributed by the author of a derivative work and the pre-existing material employed in such work can be distinguished, the copyright in the derivative work extends only to the material contributed by the author of such work, and does not imply any exclusive right in the pre-existing material. In that case, the remedies provided in Article 47(6) of this law shall apply.

(2) Where the material contributed by the author of a derivative work and the pre-existing material employed in such work cannot be distinguished, the copyright in the derivative work extends to the whole work. In that case, the author of the pre-existing work shall have the same economic rights as the author of the derivative work in the exploitation of such work, as well as the remedies provided in Article 47(6).

The above design has several advantages. Firstly, it clearly provides that derivative works are copyright protected even if they have infringed a 
prior copyright; secondly, it is able to distinguish between the traditional and modern derivative creations, and to treat them separately; thirdly, it preserves the traditional remedies in the CCL which apply to the distinguishable derivative works, while offers indistinguishable derivative works a full but shared copyright protection; fourthly, it narrows the JCL model by limiting the extended control of the pre-existing copyright owner over the derivative works to only indistinguishable derivative works; last but not least, it encourages cooperation rather than confrontation.

With this design, many endemic problems caused by the original design could be solved. For example, recently the famous fansub group YYeTs posted a claim on its official microblog, accusing Tudou.com, the official licensee of The Voice in China, of using their fan-translated subtitles in its online streaming service without authorization and removed the information of the translators. YYeTs further claims that, when they tried to negotiate it with Tudou, Tudou retorted that YYeTs's fansubbing activities are "illegal". ${ }^{1093}$ According to the previous analysis, fansubs are copyright protected irrespective of whether licensed or not. ${ }^{1094}$ Considering that the old and new elements in a translation are indistinguishable, Tudou has also infringed YYeTs's copyrights such as the right of authorship and broadcasting in their translations. This is a typical example of a "confrontational" relationship. However, under the suggested terms, the copyright of fan translations will be shared with the copyright holders of the pre-existing work. The latter will then have a choice between sueing or collaborating. In this case, since the copyright holders share the economic rights with the derivative author, they could legitimately use the fan translation with the consent of the fansubbers. Asking for permission is not that hard, considering YYeTs's purpose of fansubbing is not pecuniary benefit, ${ }^{1095}$ as long as copyright owners of the pre-existing works bear in mind the moral rights of the derivative work and credit the translators when using their works, a simple "permit or sue" letter to the copyright owners of the derivative works will suffice.

\footnotetext{
1093 See Han Li (李含) \& Fei Chou (仇飞), Weihuo Shouquan Yanyi Zuopin Yeyou Zhuzuoquan (未获授权作品也有 著作权) [Unauthorized creations can enjoy copyright protection as well], Fazhi Zhoumo (法治周末) [LEGAL WEEKLY], Oct. 14, 2014, http:/www.legalweekly.cn/index.php/Index/article/id/6143. See also You, supra note 1082.

${ }^{1094}$ Li \& Chou, supra note 1093.

1095 Id.
} 
Considering the fact that all copyright ownerships are clarified in the new design, there will be no more confusion, and hence all the parties will have a clear knowledge of what to do when a dispute arises. In addition, considering the possible amount of them and the impact they have on the market, and the fact that they share the copyright in the derivative works, the copyright holders will be more likely to ignore the infringeing derivative works created by individuals. When the derivative works became famous enough, it is to be expected that the copyright holders, while retaining the right to sue, will choose to negotiate with the derivative authors for an exclusive license of their copyrights, or to cooperate with them in exploiting their derivative works.

In a more integrated circle such as the "safe zone" proposed above, promising derivative works can be located much more easily, and derivative creators within will not even have to worry about infringement liabilities with a NAP. Considering the beneficial aspects of the latter, and that to sue is neither economically nor socially desirable, copyright owners of the pre-existing works will be more willing to cooperate with their derivative fan creators under the proposed rules.

Even in the opposite situation where the infringeing derivative work is created by a corporation and the author of the pre-existing work is an individual, the design is also effective. Because in that case, the individual creator can act as the copyright owner of the derivative work as well, and all the exploitation of such work will have to be permitted by both sides unless an agreement can be reached prior to that. However, normally the corporate infringers have better skills and resources, and are more aware of copyright issues than individuals. Therefore, it is more likely to be a problem of plagiarism rather than a problem of derivative work.

\subsubsection{Protection for Parody}

Parody as a means of criticism has a long history in China. ${ }^{1096}$ Commentators have even pointed out that the Chinese public generally deems parody a fair use, although the law says differently. ${ }^{1097}$ Parody, as a crucial form of fair use in other countries, is not officially recognized by the

\footnotetext{
1096 Suli, supra note 718, at 6-7; Ji, supra note 718, at 18-20

1097 Suli, supra note 718, at 12.
} 
CCL. ${ }^{1098}$ Unlike the U.S. in which the freedom of speech is protected by the First Amendment which stipulates that the Congress will "make no law...abridging the freedom of speech", ${ }^{1099}$ freedom of speech is only one of the basic rights listed in the Constitution of China. Article 35 of the Constitution of China provides that:

Citizens of the People's Republic of China enjoy freedom of speech, of the press, of assembly, of association, of procession and of demonstration. ${ }^{1100}$

Notably, Article 13 of the Constitution of China also provides that the "[c]itizens' lawful private property is inviolable" when freedom of speech and property rights collide. ${ }^{1101}$ According to Prof. Su Li's view, it is not convincing to say which one is superior in China. ${ }^{1102}$ Therefore, although many cases have shown that Chinese citizens have a long history of using parody as a means of criticism, ${ }^{1103}$ it is nevertheless not a priority for the Chinese government, which views some of this subtle criticism as a potential threat ${ }^{1104}$, to protect parody with law.

However, freedom of speech is firmly connected to democratic development. ${ }^{1105}$ And arguably, countries like the U.S. have policy goals of "spreading freedom". 1106 Therefore, if copyright of foreign works is rigorously enforced against transformative users such as fans, then as discussed in the previous chapters, it may have a negative effect on civic engagement in China, and thereby affect the pursuit of an open society there. ${ }^{1107}$ Therefore, in order to promote civic engagement and to further

\footnotetext{
1098 See e.g., Rogoyski \& Basin, supra note 6, at 241; Suli, supra note 718, at 11; Ji, supra note 718, at 21; Yufeng Li (李雨峰) \& Tirui Zhang (张体锐), Huaji Mofang Yinfa de Zhuzuoquan Wenti (滑稽模仿引发的著作权问题) [The Copyright Problems Caused by Parodies], Renmin Sifa (人民司法)[ PeOPLE’s JudiCATURE], no.17, 2011, at 102.

1099 U.S. CONST. Amend. I.

1100 Constitution of the People's Republic of China, art. 35.

1101 Id. art. 13.

1102 Suli, supra note 718, at 4; Furthermore, considering the influence of parodies on China and the number of them, it is also a fair conclusion that "China does not have much tradition of humorous give and take". See Robert Marquand, A Spoof Hits China's Web-and a Star is Born, The Christian ScIENCE Monitor, Mar. 13, 2006, at http://www.csmonitor.com/2006/0313/p01s03-woap.html.

${ }_{1103}$ Suli, supra note 718, at 6-7; Ji, supra note 718, at 18-20.

${ }^{1104}$ For a detailed discussion, see supra Chapter 2.1.1 Chinese Political Culture and 2.1.5 Participatory Culture and Civic Engagement.

${ }^{1105}$ See e.g., Martin H. Redish, The Value of Free Speech, 130 U. PA. L. REV. 591, 594 (1982)(“....all forms of expression that further the self-realization value, which justifies the democratic system as well as free speech's role in it, are deserving of full constitutional protection.").

${ }_{1106}$ Rogoyski \& Basin, supra note 6, at 245-8

1107 See supra Chapter 2.1.5 Participatory Culture and Civic Engagement. Just as Jack Balkin has indicated, "the
} 
advance openness in China so that we could expect a less restricted market in the near future, it is believed that the lobbying efforts of interested countries should be "directed toward encouraging developments in Chinese intellectual property law consistent with international norms of free expression". ${ }^{1108}$ The protection of parody is no doubt one of them. Moreover, since China has a blank record with regard to parody, and considering the above-mentioned importance of civic engagement in parodies to China, the parody protection design should be a flexible one. In other words, it should leave enough space for the Chinese courts to interpret, if they were to cherish that kind of freedom.

Thus, this research suggests that Article 22 of the CCL should be revised in order to accommodate parody. The proposed Article 22 is as follows:

"In the following cases, a work may be used without permission from, and without payment of remuneration to, the copyright owner, provided that the name of the author and the title of the work are mentioned and the other rights enjoyed by the copyright owner in accordance with this Law are not prejudiced:

(2) when necessary, quotation from another person's published work in one's own work within a reasonable scope, for the purpose of introducing or commenting on a certain work, or explaining a certain point, or other legitimate purposes; ...

(13) other circumstances;

In determining whether the exploitation of a work complies with the reasonable scope listed in Article 22, all factors shall be taken into account, and in particular the following facts shall be noted as the basis for determination:

\footnotetext{
forces of democratization operate not only through regular elections, but through changes in institutions, practices, customs, mannerisms, speech, and dress." Balkin, supra note 15, at 35. According to Balkin, a "democratic" culture means democracy "in which ordinary people gain a greater say over the institutions and practices that shape them and their futures." Id. That echoes with "semiotic democracy" that Fisher among others advocates, which aims to decentralize the power of making cultural meanings. See FISHER, supra note 13, at Chapter 1; See also NEIL WEINSTOCK NetANel, Copyright's PARAdox (Oxford University Press. 2008); Niva Elkin-Koren, Cyberlaw and Social Change: A Democratic Approach to Copyright Law in Cyberspace, 14 CARDOZO ARTS \& ENT. LJ 215 (1996).

1108 Rogoyski \& Basin, supra note 6, at 262.
} 


\section{The purposes and nature of the exploitation, includ- ing whether such exploitation is of a commercial nature or is for non-profit educational purposes.}

2.The nature of the work.

3.The amount and substantiality of the portion exploited in relation to the work as a whole.

4.Effect of the exploitation on the work's current and potential market value.

This proposal is a combination of the officially proposed draft amendment of the CCL ${ }^{1109}$ and the fair use model of Taiwan. ${ }^{110}$ First, it added an item (13) to Article 22, which is a catch-all provision that is flexible for interpretation; second, unlike the third draft amendment which only covers two of the Berne three-step-test, ${ }^{111}$ which makes it too vague a standard for judicial judgments, ${ }^{1112}$ this proposal drew on the experience of Copyright Law of Taiwan, in which the four factor test as the principal rule of the copyright exception judgment is introduced. ${ }^{1113}$ Therefore, the new proposal will be more flexible and tangible for the courts to apply; third, unlike the position that the U.S. courts have taken, ${ }^{1114}$ item (2) is also revised to a degree that both parodies and satires are potentially cov-

\footnotetext{
${ }^{1109}$ Guowuyuan Fazhi Bangongshi Guanyu Gongbu Zhonghua Renmin Gongheguo Zhuzuoquan Fa Xiudingan Songshengao Gongkai Zhengqiu Yijian de Tongzhi (国务院法制办公室关于公布《中华人民共和国著作权法（修 订草案送审稿)》公开征求意见的通知) [Circular of the Legislative Affairs Office of the State Council on Promulgating the Copyright Law of the People's Republic of China (Draft Revision for Review) for Public Comments], LEGISLATIVE AfFAirs OfFice OF THE StATE COuncil P.R. China, Jun. 6, 2014, at http://www.chinalaw.gov.cn/article/cazjgg/201406/20140600396188.shtml.

${ }^{1110}$ Zhonghua Minguo 103 Nian Zhuzuoquan Fa (中華民國 103 年著作權法) [Copyright Act of 2014], Jan. 22, 2014, Zongtongfu GongBao (總統府公報) [Presidential OfFiCE GAZ.], no. 7123, 2014, at 65, translated at INTELLECTUAL PROPERTY OFFICE MINISTRY OF ACONOMIC https://www.tipo.gov.tw/dl.asp?filename=42129352671.docx.

${ }^{1111}$ The Berne Convention provides that "It shall be a matter for legislation in the countries of the Union to permit the reproduction of such works in certain special cases, provided that such reproduction does not conflict with a normal exploitation of the work and does not unreasonably prejudice the legitimate interests of the author." Berne Convention, art. 9(2). However, paragraph 2 of Article 43 of the third draft amendment of the CCL only provides that, "in the exploitation of a work under the circumstances listed in Article 43, such exploitation must not conflict with a normal exploitation of the work and must not unreasonably prejudice the legitimate interests of the author".

${ }_{112}$ Li, supra note 751, at 17; Prof. Qian Wang has also criticized this "copycat" way of copyright legislation in China, indicating that it makes the law outdated and sketchy. See Qian Wang (王迁), Zhuzuoquan Fa Jiejian Guoji Tiaoyue $y u$ Guowai Lifa Wenti yu Duice (著作权法借鉴国际条约与国外立法：问题与对策)[Using International Treaties and Overseas Legislation for Reference for the Copyright Law: Problems and Countermeasures], ZHONGGUO FAXUE (中国 法学)[ CHINA LEGAL SCIENCE], no.3, 2012, at 31-5.

${ }^{1113}$ For similar proposals, see Li, supra note 751, at 17-8; see also Yong Wan (万勇), Meiguo Banquanfa Gaige Fangan Shuping (美国版权法改革方案述评)[Comments on the U.S. Copyright Law Reform Plan], ZHISHI CHANQUAN (知识产权) [INTELLECTUAL PROPERTY], no.1, 2014, at 87.

1114 See supra note 706-707 and accompanying text.
} 
ered, as using the parodied work as a "weapon" to exercise freedom of speech is a "legitimate purpose" too.

As Prof. Su Li has indicated that a "fair use" protection for parody in China must consider at least four issues: first, the definition of "fair" in the case of parody should be broader than that in normal cases; second, whether the parody is comparatively independent, and whether it will substitute the pre-existing work; third, when considering whether a parody is a fair use, the courts' judgment on whether it is of a commercial nature should not only be based on whether the parodist has earned monetary income by doing so, or whether they are doing so for commercial purposes, but also on the above-mentioned substitutability of these parodies, which will possibly bring the parodist monetary income in the future; fourth, as to the courts' judgment on substitutability, it cannot be simply equated with the audience decline in the pre-existing work and the rise of that number in the parody, although that change can be one of the important pieces of evidence of a substitution. ${ }^{1115}$ Evidently, these four issues cannot be deemed practical, unless a flexible copyright exception mechanism like this research proposes is in place. Even if item (2) of the proposed Article 22 uses phrases such as "when necessary" and "within a reasonable scope", with the principle rule of the four factor test, the necessity and the reasonable scope can then be interpreted by the Chinese courts with a degree of flexibility, which, is to be expected, as they also have the needs to address new problems raised by digital technologies. It is also a better plan to compare with proposals such as an additional item to Article 22 only for transformative uses, ${ }^{116}$ or a sui generis right such as "interpretive rights" in the copyright law, ${ }^{1117}$ because the focus is on a more general revision rather than on a specific issue like parody or other forms of transformative uses which is directly connected to free speech, and therefore it will attract fewer problems in China and could thus fit in China's amendment plan of CCL.

\footnotetext{
1115 Suli, supra note 718, at 12-3.

1116 Rogoyski \& Basin, supra note 6, at 262.

1117 Noda, supra note 25, at 140-48.
} 


\subsubsection{Conclusive Notes}

The flexible enforcement strategy this book proposed in Chapter 5.2.2 would cost significantly less than the traditional one. Furthermore, since waiting to see if fans violate the law by simply tolerating copyright infringeing fan activities and taking advantage of that situation is morally incorrect, the suggested strategy serves to remedy this contradiction by demarcating a legal boundary. Moreover, it would not act as a radical reform plan as it is flexible and revocable. With this well-designed cooperation model, it could also distinguish free riders and other tortfeasors from fans, and put the main focus on commercial piracy. Participators such as devoted fans are potential customers and only fans would be keen on official recognition and yearn for the success of their beloved works; fans with other motivations would be more than happy to have an official platform to do what they used to do without being concerned about liability issues.

Nevertheless, the restrictions on foreign works set by the Chinese government have determined that the numbers of foreign works in every legitimate channel, including online streaming, are strictly limited. That means the "seats" are scarce, and all the foreign copyright conglomerates will have to compete for that under the surveillance of the Chinese government. However, it is part of China's sovereignty to do whatever it thinks is good for its people. This means that, in order to do business in China, foreigners will have to follow those rules. For example, for marketing considerations, even Apple has agreed to subject its products to China's Internet security inspection. ${ }^{1118}$ If they feel the situation is unjust, they will have to resort to international platforms such as WTO. Therefore, it is necessary for foreign copyright industries to conceive a better plan, such as the open production mechanism that this research proposed, in order to exert the commercial and cultural influences of their products over the Chinese market.

Last but not least, foreign industries will have to collect the consequential revenue by various means. For example, if the copyright contents themselves cannot effectively enter the Chinese market, it may be a better idea for the copyright owners to treat them as a medium to other mer1118 Jiayi Liu, Apple has Accepted Inspections in China: Report, ZDNET, Jan. 21, 2015, at
http://www.zdnet.com/article/apple-has-accepted-censorship-in-china-report/. 
chandise, as it is evident that the popularity of an audio-visual work could result in healthy sales in related tangible goods and a fame boost for related practitioners such as actors/actresses. Therefore, the proposed mechanism will perform better, if the copyright owner is a conglomerate which runs different businesses like toy manufacturing and talent agency in addition to copyright contents. Last but not least, this industrial practice may eventually become statutory law. Thus, whether audio-visual producers will treat fans more as collaborators and less as copyright infringers in a digital age is crucial to the future of our society. ${ }^{119}$ However, despite all these beneficial aspects of fan activities, whether the industries are willing to foster fan activities or not is unclear. Both the industry and audiences still have a long way to go, if mutual understanding and recognition are desired. ${ }^{1120}$

In all, the recommendations of a NAP setting will make sure that fan contributions-no matter they are derivative works or not-created within the set boundaries are safe. For those fan creations outside the circle, the recommendations related to a revision to the CCL that this book proposed in Chapter 5.2.3 provide a clear standard to distinguish various fan activities: first, with a refined setting of derivative works that this book proposed above, the CCL will be able to solve the problem of fan creations that are deemed derivative but without authorization from the original author, by encouraging consultation and negotiation between the copyright owners of the original and derivative works; second, the proposed parody provisions will make sure that a wide range of fan creations, which serve a critical purpose, can be exempted. For those highly original works, they can certainly defend themselves against any possible claim. For those publicly distributed fan creations only with minor input-which makes them similar to pure copyright infringements-they should seek shelter from a NAP covered zone, or else they will be treated as piracy by copyright owners.

\footnotetext{
1119 Henry Jenkins, Fans, Bloggers, and Gamers: ExPloring Participatory Culture 149 (New York University Press. 2006).

${ }^{1120}$ HENRY JENKINS, supra note 1062, at 92.
} 


\subsection{The Future}

Copyright is but one type of rules that regulates the fan activities. Do we really need copyright? The answer is no doubt yes. ${ }^{1121}$ However, copyright nowadays is becoming more like a winner-takes-all game, and many works for which copyright protections are unnecessary are "protected" by the law because of its low threshold. It is noted that for big-budget productions in which heavy investment is needed, copyright is indispensable. ${ }^{122}$ Needless to say, it is the most important way to ensure a fair return for copyright owners. However, digital technology advancement has lowered the threshold of creation and publication. This leads not only to the abundance of "works", but also to the conflicts between the request for a high protection standard from some successful and corporate copyright owners and the request of a freer environment from copyright owners with a loose attitude, some of which even have no interest in the copyright protection of their works (at least in their preliminary stages). Throughout history, private creation with unauthorized appropriation has always been there, and was long considered as useful in the free zone ${ }^{1123}$ until it was amplified in the digital age. Therefore, it is understandable if people choose to express their opposition via unauthorized utilization, since copyright today has eroded the once "free" zone, and it is also a necessary step for creators to practice skills and to receive feedbacks. But in any case, it is a big problem if most people have no respect for the copyright law. It means that either the people or the rules need a change. Hence we must discuss it and see clearly through the crux of the problem before making our decision.

It is digital technology that is shaping online human behavior. Nowadays the "borrow and remix" way of creativity is becoming part of young people's daily life, ${ }^{124}$ it is also a fact that new and profitable business models have already been built up around it, and the interde-

\footnotetext{
${ }^{1121}$ Some even believe copyright is hampering cultural diversity and creativity. See generally, JOOST SMIERS \& MARIEKE VAN SCHIJNDEL, IMAGINE THERE IS NO COPYRIGHT AND NO CUlTuRAL CONGLOMERATES TOO (Institute of Network Cultures, Amsterdam 2009); but some believe that intellectual property rights, including copyright, will still play a role in the future, but its importance will tend to decrease. See Mark A. Lemley, IP in a World Without Scarcity, 90 N.Y.U. L. REV. 460, 503 (2015).

${ }^{1122}$ Chen Li (李琛), Zhishi Chanquan Fa Jiben Gongneng Zhi Chongjie (知识产权法基本功能之重解) [Reinterpreting the Basic Functions of Intellectual Property Law], ZHISHI CHANQUAN (知识产权)[INTELLECTUAL PROPERTY], no.7, 2014, at 6 .

${ }_{1123}$ Hamilton, supra note 10, at 623.

${ }^{1124}$ See supra Chapter 5.2.1.
} 
pendency of that behavior pattern and the new business models is evident. Moreover, being driven to search for maximum profit in foreign countries, numerous copyrighted works from various industries are reconstructing the copyright framework with their real-life commercial activities. That is to say, it is impossible to rewind the clock. In terms of the existing problems such as unauthorized appropriation in fan creations, fine-tuning is therefore needed.

The problems that lie ahead are manifold. The development of the Internet and related technologies has pushed the global content industries to consider foreign markets in order to protect their works, as many of them became freely accessible online soon after broadcasting. However, as a private right, in most countries any legal action against copyright infringement cannot be initiated unless copyright holders raise formal complaints, and evidently the industry does not have enough resources to do this for each infringeing act, as it is impossible for them in practice to identify and sue every infringer, especially when they are in a foreign market. Moreover, the harmonizing process through international or multilateral agreements is slow, and problems relating to reluctant cooperation and the political considerations of some countries may also weaken copyright owners' control over their works in their markets. It is also true that copyright enforcement is dependent on economic capability and the status of market development.

Thus, copyright owners have been willfully tolerating most fan-based activities and put their main focus on chasing commercial infringements. The reasons for doing so are clear: they were forced to expand their market, and toleration is a good way to access and compete in a nascent foreign market, considering the beneficial aspect of fan-based activities and the unavoidable problems. Theoretically, as a foreign market grows larger, copyright holders can take more initiative in terms of market control, especially as the numbers become more substantial. Thus, in the future they could maximize their profit under those unavoidable barriers with much lower investment. However, it is difficult to calculate whether a potential market is formed or not in practice, as most responses of copyright holders towards foreign fan-based activities are negative; they tolerate most foreign fan activities reluctantly because they have comparatively weaker control over foreign markets than their homeland markets.

The case of Japan illustrates that a certain degree of fan activity should and could be allowed in order to generate beneficial results, even though the law says differently. That is to say, audio-visual content pro- 
ducers should take the voices from fan groups into account, as the latter nowadays will not only consume, but will also contribute. Of course, it is the right of the owners to tolerate and ignore any infringeing activity or to take action selectively, but in the long run, toleration will offer no help in eliminating massive online infringements. Besides, a legal system that has been constantly challenged by global mass online copyright infringement is in itself sufficient proof that something needs to be changed. The Japanese case demonstrates that it is feasible for a content industry to respond effectively. Nevertheless, its responses are still insufficient, given the ambivalent attitude of the industry towards fan-generated work and the anarchic nature of foreign fan-based activities. To shake off the "galápagos syndrome," the industry should take a more active role in transnational licensing transactions by establishing a flexible relationship with its foreign fans and shepherding them toward authorized communities and practices. Such positive interaction would in turn generate increased popularity and create the market demand for copyrighted works that the industry is seeking.

In fact, there are more options for protecting the interests of copyright holders other than simply raising the protection standard blindly. The Japanese anime industry has chosen one and it has succeeded in part, but more needs to be done if a positive relationship between the law, the copyright owners, and the fan communities is to be established. As scholars have indicated, since offering products for free in some way is theoretically feasible, ${ }^{1125}$ the industry should put more focus on how to reap the benefits by multiple means.

Whether we could address the fan creation problems with copyright law is a tough question. An important reason that copyright law cannot solve the fan issue solely is that, the law is only a tool; how it functions is up to its government. In other words, copyright laws in China not only have economic but also political concerns, and political conformity is a code of conduct in all government agencies. Therefore, in China, the right to free speech which westerners have long taken for granted is subject to strict political scrutiny, and if a foreign work fails to pass that scrutiny, theoretically the Chinese people will not be able to get access to it. This has partly led to the problems of piracy and fan creations. ${ }^{1126}$ But just as

\footnotetext{
1125 See ARIELY, supra note 35, at 49-67; See generally ANDERSON, supra note 5.

${ }^{1126}$ Creemers, supra note 107, at 190.
} 
Professor Chen Li noted, the Chinese government should not put undue stress on the policy leverage aspect of intellectual property law and ignore its connection with market. ${ }^{127}$ In the case of foreign audio-visual works in the Chinese market, considering that the numbers of accessible audio-visual works online appear to be infinite (via various means), and the length of time it takes to consume audio-visual works is comparatively short, then consumers there will have to decide for themselves what to choose with regard to foreign audio-visual products, and inevitably there will be new problems. ${ }^{1128}$ However, as Anderson has suggested, "[t]he alternative to letting people choose is choosing for them."1129 Therefore, it is more reasonable for the copyright owners to consider using NAPs to choose for their followers. It could eventually increase their Chinese followers' fidelity, to help them discover more profitable channels, and, most importantly, to insert a certain degree of stability to the copyright system.

Despite the fact that numerous copyrighted materials are being infringed upon in countries like China, if the industry could seize the opportunity and change their business model to an open one accordingly, they might discover more profit channels in the future. By then, the legal problems we are facing now may not be a problem at all. That is increasingly the case, considering the fact that the majority part of the popular foreign audio-visual titles is available on Chinese online streaming platforms now, it indicates that a large proportion of the free riders, who are neither fans nor commercial pirates, will eventually be diverted to legitimate platforms, because all they want is easy and fast access. Those who want to do more with the copyright contents than merely watching will then be clearly divided: the fans within should be treated delicately so that the copyright owners could maintain a good relationship with their votaries, and possible complementary creations and effects could then be discovered, rewarded and officially borrowed; as to the commercial pirates, they will have no place to hide.

Whether the CCL will serve as a constraint on the Chinese government's will to control the flow of ideas in the future is unknown, but

\footnotetext{
${ }_{1127} \mathrm{Li}$, supra note 1122 , at 9.

1128 See generally, BARry SCHWARTz, The PARAdOX OF ChOICE: Why MORE IS LeSs (Ecco 1st ed. 2004); For the artificial choice problems created by censorship in China, please see the discussions in supra Chapter 2.1.3 Censorship.

${ }_{1129}$ ANDERSON, supra note 35, at 171.
} 
seemingly to provide a solution so that Chinese citizens could access and utilize foreign works freely to a degree, and foreign copyright owners themselves could maintain a degree of profitability is crucial to them in the Chinese market. However, that kind of solution requires the subdivision of all the unauthorized users. Considering all the aforesaid technical, economical, and transnational obstacles, it is impossible for foreign copyright owners to deal with every possible online copyright infringement in China via traditional means. Besides, fan activities like fansubs there could actually be of help in different stages. If they are just tolerated but not offered guidance, they may cause damage which may cancel out the benefits they generate; ${ }^{130}$ since the competition in the Chinese market is so fierce that audio-visual works lack of publicity within is equal to products of low competitiveness, the copyright owners may find that their fans are not there in the end. As a matter of fact, the promotion budgets of audio-visual companies are usually limited, and thus could only be spent on big productions; and since the traditional paths of the majority of foreign audio-visual works to profit are somehow hampered in the Chinese market, their potential needs to be developed further in order to create more profit channels, thus using NAPs, which encourages civic engagement, should be a wise choice for foreign audio-visual industries that are doing business in China.

The cooperation with fan groups in China is in progress. However, the fragile cooperation between fansub groups and video platforms will not last long if a consensus on the common goal is not reached between fans and copyright owners. Moreover, according to MPAA's argument, local protectionism has created a piracy market in China, ${ }^{1131}$ one of the reasons is that people are trying to bypass the government censorship and get their desired titles via underground channels, which is uncontrollable for foreign copyright owners. If that situation is true and cannot be changed easily in the short run, maybe now it is the time for a change, to

\footnotetext{
${ }^{1130}$ For instance, most doujinshi works in Japan are tolerated by the copyright owners, but if the fan work contains porn elements that are deemed harmful to the original work (a children's manga), or bears a strong resemblance to the original one, which may cause confusion, the copyright owners will notify the fan authors. See He, supra note 50; in terms of fansubs, online streaming platforms, even commercial pirates constantly lift fan-translations without any permission, and fansubbers can do nothing to change that because they believe they have no rights in their fansubs. See Zhang, supra note 1057.

${ }^{1131}$ See U.S.-China Trade: Preparations for the J. Commission on Commerce and Trade: Hearing Before the Subcomm. on Commerce, Trade, and Consumer Protection, of the H. Comm. on Energy and Commerce, 108th Cong. 45-55 (2004) (testimony of Fritz E. Attaway, Executive Vice President of MPAA), at http://www.gpo.gov/fdsys/pkg/CHRG-108hhrg93302/html/CHRG-108hhrg93302.htm.
} 
seek new revenue streams. ${ }^{1132}$ A specifically designed NAP could help the foreign copyright owners to partly regain that control, to build a closer connection with their adherents in China, so as to promote their works, collect new ideas, and develop new profit channels. It is also in accordance with the purpose of the copyleft movement: to rebalance the current restrictive regime of copyright, to adjust the relationship between the interests of the copyright owners and the public, and to further release the creative power of the masses.

Copyright's future in China lies in its people, as do the solutions of the problems that this research concerns. It is the Chinese citizens who decide its laws, or, at least, whether they are worth complying with. The Chinese government wishes its citizens to be creative but obedient. But it is against the innate needs of living a good life as a human being, ${ }^{1133}$ and arguably, creativity always accompanies freedom and is rooted in education and culture. ${ }^{1134}$ It is evident from China's audio-visual industry that, under the surface of its rising prosperity, numerous mediocre works have been produced annually under China's harsh ideological censorship. It is also true that, it is hard to imagine that Chinese citizens could rationalize their understanding of copyright spontaneously without proper education and culture influence. Fortunately, the Internet has offered Chinese people a degree of freedom in an unofficial way: foreign cultural works are pouring into China in the form of piracy, and many of these contents are actually providing a level of democratic education and exerting influences of foreign cultures. As a result, the traditional media in China, which offer government controlled contents, are thus facing fierce competition from unauthorized distribution. Therefore, all the copyright owners, no matter whether foreign or local, when trying to maximize their benefits in China, should realize the importance of unauthorized downloads to the majority of the Chinese people. If the copyright owners can seize this opportunity and develop an open innovation business model which could best utilize the fan power while also having multiple revenue channels, then it is possible that, in the near future, copyright owners and the now

\footnotetext{
1132 See Priest, supra note 559, at 515 (“...creative works can be consumed-and monetized-in a theoretically unlimited variety of formats and locales, the health of a creative industry ultimately depends on its ability to effectively monetize works for each market in which they are consumed.").

${ }^{1133}$ For a detailed explanation on what constitutes a "good life" for human beings, see e.g., Martha C. Nussbaum, Constitutions and Capabilities: Perception against Lofty Formalism, 121 Harv. L. ReV. 4, $13-16$ (2007). See also Fisher, supra note 827, at 1746-51.

${ }^{1134} \mathrm{Li}$, supra note 1122 , at 9.
} 
infringeing fans could get along very well with each other in a way which conforms to the copyright law. And, with a bit of luck, we might expect that this model could advance the open society development in China. 


\section{BIBLIOGRAPHY}

\section{Books:}

1. Alford, W. P., To Steal a Book is an Elegant Offense: Intellectual Property LaW in Chinese Civilization (Stanford University Press. 1995).

2. Anderson, C., Free: the Future of a Radical Price (Hyperion 1st ed. 2009).

3. Anderson, C., The Long Tail: Why the Future of Business is SElling LeSS OF More (Hyperion Rev. and updated ed. 2008).

4. Ariely, D., Predictably Irrational: The Hidden Forces that SHAPE OUR DECISIONS (Harper 1st ed. 2008).

5. BaCON-Smith, C., Enterprising Women: Television Fandom AND the CReation of Popular Myth (University of Pennsylvania Press. 1992).

6. Bauerlein, M., The Dumbest Generation: How the Digital Age STUPEFIES Young AMERICANS AND JEOPARDIZES OUR FUTURE (OR, DON'T TRUST ANYONE UNDER 30) (Jeremy P. Tarcher/Penguin. 2008).

7. Benkler, Y., The Wealth Of Networks: How Social PRODUCTION TRANSFORMS Markets AND FreEdom (Yale University Press. 2006).

8. Blackstone, W., Commentaries on the Laws of England in Four Books (J. B. Lippincott Company, 1893).

9. Boyle, J., The public Domain: Enclosing the Commons of the Mind (Yale University Press. 2008).

10. Bush, S., The Chinese Literati on Painting; Su Shin (1037-1101) TO TUNG $\mathrm{CH}^{\circ} \mathrm{I}-\mathrm{CH}^{\circ} \mathrm{ANG}$ (1555-1636) (Harvard University Press. 1971).

11. Decherney, P., Hollywood's Copyright Wars: From Edison to THE INTERNET (Columbia University Press. 2012).

12. Dratler, J., Licensing of Intellectual Property (Law Journal 
Seminars-Press. 2001).

13. Fairbank, J. K., Goldman, M., China: A New History (Belknap Press of Harvard University Press 2nd enl. ed. 2006).

14. Fisher, W. W., Promises to Keep: Technology, Law, and the Future of ENTERTAINMENT (Stanford Law and Politics. 2004).

15. Ganea, P. ET AL., Japanese Copyright LaW: Writings in Honour OF GERHARD Schricker (Peter Ganea, et al. eds., Kluwer Law International. 2005).

16. Goldstein, P., Copyright's Highway: From Gutenberg to the Celestial Jukebox (Stanford University Press. 2003).

17. Goldstein, P., Goldstein On Copyright (Wolters Kluwer Law \& Business 3rd ed. 2013).

18. Goldstein, P., Hugenholtz, P. B., International Copyright: Principles, LAW, AND Practice (Oxford University Press 3rd ed. 2013).

19. Guan, W., Intellectual Property Theory and Practice: A CRITICAL EXAMINATION OF CHINA'S TRIPS COMPLIANCE AND BEYOND (Springer. 2014).

20. Guy, R. K., The Emperor's Four Treasuries: Scholars and the StATE IN THE LATE CH'IEN-LUNG ERA (Harvard University Asia Center. 1987).

21. Hoffer, E., The True Believer: Thoughts on the Nature of Mass Movements (Harper Perennial Modern Classics. 2010).

22. Huang, R., China: a Macro History (M.E. Sharpe Turn of the century ed. 1997).

23. Ingulsrud, J. E., Allen, K., Reading Japan Cool: Patterns of MANGA LiTERACY AND DisCOURSE (2009).

24. Jenkins, H., Confronting the Challenges of Participatory Culture: Media Education for the 21st Century (The MIT Press. 2009).

25. Jenkins, H., Convergence Culture: Where Old and New Media COLlide (New York University Press. 2006).

26. Jenkins, H., FAns, Bloggers, AND GAMERs: Exploring PARTICIPATORY CUlture (New York University Press. 2006).

27. Jenkins, H., TeXtual PoAchers: Television Fans \& PARTICIPATORY CUlTURE (Routledge. 1992).

28. Kinsella, S., Adult Manga: Culture And Power in Contemporary Japanese Society (University of Hawaii Press. 2000). 
29. Kong ZI, The analects of Confucius (Arthur Waley trans., Psychology Press. 2005).

30. Kur, A., Dreier, T., European Intellectual Property Law: TeXt, Cases \& Materials (Edward Elgar Publishing Limited. 2013).

31. Landes, W. M., Posner, R. A., The Economic Structure of InTELleCtUAl PROPERTY LAW (Harvard University Press. 2003).

32. Ledoux, T. et Al., The Complete Anime Guide: Japanese Animation Video Directory \& Resource Guide (Tiger Mountain Press 1st ed. 1995).

33. Lessig, L., Code: Version 2.0 (Basic Books 2nd ed. 2006).

34. Lessig, L., Free Culture: How Big Media Uses Technology and the LaW to Lock Down Culture and Control Creativity (Penguin Press. 2004).

35. Lessig, L., Remix: Making Art and Commerce Thrive in the HYBRID ECONOMY (Penguin Press. 2008).

36. Lessig, L., The Future of Ideas: the Fate of the Commons in a CONNECTED WORLD (Random House 1st ed. 2001).

37. Lewison, K., The Interpretation of Contracts (Sweet \& Maxwell 3rd ed. 2004).

38. Li, K., A Glossary of Political Terms of the People's Republic OF ChInA (Chinese University Press. 1995).

39. Li, L., Intellectual Property Protection of Traditional Cultural EXPRESSIONS: FolKLORE IN ChINA (Springer. 2014).

40. Li, Y. (李雨峰), QiangKoU Xia DE FALV ZHONGGUO BANQUAN SHI YANJIU (枪口下的法律: 中国版权史研究), [Teaming the Law at Gunpoint: on the Chinese Copyright History] (Intellectual Property Publishing House Co., Ltd. 2006).

41. Litman, J., Digital Copyright (Prometheus Books Pbk. ed. 2006).

42. Mankiw, N. G., Principles of Macroeconomics (CENTGAGE Learning Seventh Edition. ed. 2014).

43. MaO, Z., Talks at the Yenan Forum on Literature and ART (Foreign Languages Press. 1967).

44. McCracken, G. D., Plenitude 2.0 (Periph.:Fluide. 1998).

45. McQuail, D., McQuail's Mass Communication Theory (Sage Publications 6th ed. 2010).

46. Mertha, A., The Politics of Piracy: Intellectual Property in CONTEMPORARY ChInA (Cornell University Press. 2005). 
47. Mittell, J., Genre and Television: From Cop Shows to CARTOONS IN AMERICAN CULTURE (Routledge. 2004).

48. Mote, F. W., Imperial China, 900-1800 (Harvard University Press. 2003).

49. Netanel, N. W., Copyright's Paradox (Oxford University Press. 2008).

50. Nimmer, M. B., NimMer, D., NimMER On COPYRight (2002).

51. Patterson, L. R., Birch, Jr., S. F., A Unified Theory of CopyRIGHT (Craig Joyce ed., 2009), printed in 46 Hous. L. REV. 215 (2009).

52. Patterson, L. R., Lindberg, S. W., The Nature of Copyright: A LAW OF USERS' RIGHTS (1991).

53. Posner, R. A., LAW AND Literature (Harvard University Press 3rd ed. 2009).

54. QU, T. (篗同祖), QU TONGZU FAXUE LUNZHU JI (篗同祖法学论著 集) $[\mathrm{Qu}$ Tongzu's Analects on Legal Study] (China University of Political Science and Law Press. 1998).

55. QU, T. (篗同祖), ZHONGGUO FALV YU ZHONGGUO SHEHUI (中国法律 与中国社会) [Laws and Society of China] (Zhonghua Book Company. 1996).

56. Qu, T., LaW and Society in Traditional China (Hyperion Press. 1980).

57. Rose, M., Authors and Owners: The Invention of Copyright (Harvard University Press. 1993).

58. Russell, B., History OF Western Philosophy AND Its Connection with Political and Social Circumstances from the Earliest Times to the Present Day (G. Allen and Unwin ltd. 1946).

59. SAKKA, F. (作花文雄), Chosakukenhō: kiso to ōyō (著作権法: 基 礎と応用) [COPYRIGHT LAW: FOUNDATIONS AND APPLICATIONS] (Tōkyō: Hatsumei Kyōkai, 2005).

60. Sandel, M. J., What Money Can't Buy: The Moral Limits of MARKETS (Farrar, Straus and Giroux 1st ed. 2012).

61. Schä̈er, M. T., Bastard Culture!: How User Participation Transforms Cultural Production (Amsterdam University Press. 2011).

62. Schwartz, B., The Paradox of Choice: Why More is Less (Ecco 1st ed. 2004). 
63. Sen, A., Development as Freedom (Oxford University Press. 1999).

64. Smiers, J., van Schijndel, M., Imagine There is no Copyright AND No Cultural Conglomorates ToO (Institute of Network Cultures, Amsterdam 2009).

65. Spence, J. D., The Search for Modern China (W.W. Norton 2nd ed. 1999).

66. Toffler, A., The Third Wave: The Classic Study of Tomorrow (Bantam 1st ed. 1984)

67. Tuomi, I., Networks of Innovation: Change and Meaning in THE AGE OF THE INTERNET (Oxford University Press. 2002).

68. Unger, R. M., LAW IN MOdern SOCIETY: TOWARD A CRITICISM OF SOCIAL THEORY (The Free Press. 1976).

69. van Eechoud, M. et aL., Harmonizing European Copyright LAW: The Challenges of BetTer LAWMAKing (Kluwer Law International. 2009).

70. VAN GOMPEl, S., FormaLities in COPYRight LaW: AN ANALysis of Their History, Rationales and Possible Future (Kluwer Law International. 2011).

71. VAVER, D., InTEllectual Property Rights: CRitical CONCEPTS IN LAW $§ 1$ (Routledge. 2006).

72. VON JHERING, R., DER GEIST DES RÖMISCHEN RECHTS (1955, vol. 1).

73. WANG, Q. (王迁), Zhishi Chanquan Fa Jiaocheng (知识产权法教程 )[TUtORIALs ON INTELLECTUAL PROPERTy LAW] (3rd ed. 2011).

74. West, M. I., The Japanification of Children'S Popular Culture: From Godzilla to MiyazaKi (Scarecrow Press. 2009).

75. WiPO, Guide to the Berne Convention for the Protection of LITERARY AND ARTISTIC WORKS (PARIS ACT, 1971) (1978).

76. Wolton, D., INFORMER N'EST PAS COMMUNIQUER (CNRS éditions. 2009).

77. Wu, H. (吴海民), ShENPAN HAIDAO (审判海盗) [The Trial of the Pirates] (Hua Yi Publishing House, 1995).

78. Zheng, C. (郑成思), ZHISHI CHANQUAN BAOHU SHIWU QUANSHU ( 知识产权保护实务全书) [The Pandect of Intellectual Property Protection Practice] (China Yan Shi Press, 1999).

79. Zheng, C., Pendleton, M. D., Copyright law in China (CCH Australia Limited. 1991). 


\section{Book Contributions:}

1. Berry, M., Chinese Cinema With Hollywood Characteristics, or How The Karate Kid Became a Chinese Film, in THE OXFORD HANDBOOK OF CHINESE CINEMAS (Carlos Rojas ed. 2013).

2. Bollmann, T., He-Romance for Her - Yaoi, BL and Shounen-ai, in IMAGINARY JAPAN: JAPANESE FANTASY IN CONTEMPORARY POPULAR Culture (Eija Niskanen eds. 2010).

3. Brokaw, C. J., On the History of the Book in China, in PRINTING AND Book Culture in Late Imperial China (Cynthia J. Brokaw \& Kai-wing Chow eds., 2005).

4. Chan, J. M., Toward Television Regionalization in Greater China and Beyond, in TV ChINA (Ying Zhu \& Chris Berry eds., 2009).

5. Chu, D. S. C., Fanatical Labor and Serious Leisure: A Case of Fansubbing in China, in Frontiers IN NEW MEdia Research (Francis L. F. Lee ed. Routledge. 2012).

6. Chua, B. H., Structure of Identification and Distancing in Watching East Asian Television Drama, in EAST ASIAN POP CUlTuRE: Analysing the Korean Wave (Beng Huat Chua \& Kōichi Iwabuchi eds., 2008).

7. Dang Nian Ming Yue (当年明月), Epilogue, in MingChaO NaXIE SHIER 7 (明朝那些事儿 7) [7 THOSE STORIES OF THE MING DYNASTY] (2009).

8. Ehrlich, T., Preface, in CiviC Responsibility AND Higher EDUCATION (Thomas Ehrlich ed. 2000).

9. Fisher, T., 'The Play's the Thing': Wu Han and Hai Rui Revisited, in Using the Past to Serve the PResent: Historiography and POLITICS IN CONTEMPORARY CHINA (Jonathan Unger ed. 1993).

10. Freeman, D., Stability and Change: The EU, China and Perceptions of Stability, in CONCEPTUAL GAPS IN CHINA-EU Relations: Global Governance, Human Rights and Strategic PARTNERSHIPS (Zhongqi Pan ed. 2012).

11. Ganea, P., Protected Works, in JAPANESE COPYRIGHT LAW: Writings In HONOUR OF GERHARD SCHRICKER (Peter Ganea et al. eds, 2005).

12. Gao, Q., et al., A Comparative Study of Users' Microblogging Behavior on Sina Weibo and Twitter, in USER MODELING, AdAPTATION, AND Personalization: 20TH InTERNATIONAL 
Conference, UMAP 2012, Montreal, Canada, July 16-20, 2012. ProceEdings (Judith Masthoff, et al. eds., 2012).

13. He, W. (贺卫方), Blog Writing and Other, in XIAOYAOFAWAI (逍遥 法外) [AT LARGE] (2009).

14. Hong, Y., Meaning, Production, Consumption: The History and Reality of Television Drama in China, in MEDIA IN CHINA: CONSUMPTIOn, Content AND CRISIS 35 (Stephanie Hemelryk Donald et al. eds., 2002).

15. Hu, K., Chinese Re-making of Pirated VCDs of Japanese TV Dramas, in FEELING ASIAN MODERNITIES: TRANSNATIONAL CONSUMPTION OF JAPANESE TV Drama (Iwabuchi Kōichi ed. 2004).

16. Hugenholtz, P. B., Codes of Conduct and Copyright Enforcement in Cyberspace, in COPYRIGHT ENFORCEMENT AND THE INTERNET (I.A. Stamatoudi, ed. 2010).

17. Kostylo, J., From Gunpowder to Print: The Common Origins of Copyright and Patent, in PRIVILEGE AND PROPERTY: ESSAYS ON THE HISTORY OF COPYRIGHT (Ronan Deazley \& Martin Kretschmer \& Lionel Bently eds., 2010).

18. Kretschmer, M., Kawhol, F., Chapter 2: The History and Philosophy of Copyright, in MUSIC AND COPYRIGHT (Simon Frith \& Lee Marshall eds., Edinburgh University Press. 2004).

19. Kuhn, P. A., Chinese Views of Social Classification, in CLASS AND Social Stratification in Post-Revolution China (James L. Watson ed. 1984).

20. Lee, M., Traveling with Japanese TV dramas: Cross-cultural Orientation and Flowing Identification of Contemporary Taiwanese Youth, in FEELING ASIAN MODERNITIES: TRANSNATIONAL CONSUMPTION OF JAPANESE TV DrAMA (Iwabuchi Kōichi ed. 2004).

21. MacFarquhar, R., The Succession to Mao and the End of Maoism, in The Cambridge History of China. Volume 15, The People's Republic, Part 2: Revolutions Within the Chinese Revolution 1966-1982 (Denis Crispin Twitchett \& John King Fairbank eds., 1991).

22. Mao, Z. (毛泽东), Datui Zichan Jieji Youpai de Jingong (打退资产 阶级右派的进攻) [ Beat Back the Attacks of the Bourgeois Rightists], in Selected Works OF MAO ZedOng Volume 5 (The People's Publishing House, 1977). 
23. Mao, Z., Talks at the Hangzhou Conference on 21 December, in MAo TSE-TUNG UnREHEARSED 238 (S. Schram ed. 1974).

24. McAllister, M. P., Consumer Culture and New Media: Commodity Fetishism in the Digital Era, in Media PersPeCtives for the 21st CENTURY: CONCEPTS, TOPICS AND Issues (S. Papathanassopoulos ed. 2010).

25. Mizuko, I., Japanese Media Mixes and Amateur Cultural Exchange, in Digital Generations: Children, Young People, and the NeW MEDIA (David Buckingham \& Rebekah Willett eds., 2013).

26. Montgomery, L., Keane, M., Learning to Love the Market: Copyright, Creativity and China, in COMMUNICATIONS, INTELleCtual PROPERTY AND THE PUBlic DOMAIN IN THE Asia-Pacific Region: Contestations And Consensus (P. Thomas \& J. Servaes eds., 2006).

27. Mote, F. W., The Cosmological Gulf Between China and the West, in Transition And Permanence: Chinese History And Culture (David C. Buxbaum \& Frederick W. Mote eds., 1972).

28. Nakajima, S., Film as Cultural Politics, in ReClaiming ChInese Society: The New Social Activism (You-tien Hsing \& Ching Kwan Lee eds., 2010).

29. Oberholzer-Gee, F., Strumpf, K., File Sharing and Copyright, in InNOVATION Policy AND THE ECONOMY (Josh Lerner \& Scott Stern eds., 2010).

30. Peifer, K., The Return of the Commons - Copyright History as a Common Source, in PRIVILEgE AND PROPERTY: ESSAYS ON THE History OF COPYRIGHT (Ronan Deazley \& Martin Kretschmer \& Lionel Bently eds., 2010).

31. Perkins, D. H., China's Economic Policy and Performance, in THE Cambridge History of China. Volume 15, The People's Republic, PARt 2: Revolutions Within the Chinese Revolution 1966-1982 (Denis Crispin Twitchett \& John King Fairbank eds., 1991).

32. Rheingold, H., Using Participatory Media and Public Voice to Encourage Civic Engagement, in CIVIC LIFE ONLINE: LEARNING how Digital Media can Engage Youth (W. Lance Bennett ed. 2008).

33. Sanders, A. K., Intellectual Property Law and Policy and Economic Development with Special Reference to China, in ECONOMIC ANALYSIS OF LAW IN ChINA (T. Eger, et al. eds., 2007). 
34. Sanders, A. K., Intellectual Property Liability of Consumers, Facilitators and Intermediaries: Comparative Concepts, in InTELleCtual PROPERTY LiabiLity of CONSUMERS, FACILITATORS AND INTERMEDIARIES (Christopher Heath \& Anselm Kamperman Sanders ed. 2012).

35. Takeyama, L. N., Piracy, Asymmetric Information and Product Quality, in The ECONOMICS OF COPYRIGHT: DeVElopMents IN RESEARCH AND ANALYSIS (Wendy J. Gordon et al. eds, 2003).

36. Waley-Cohen, J., Collective Responsibility in Qing Criminal Law, in The Limits OF THE RUlE OF LAW IN ChINA (Karen Turner-Gottschang, et al. eds., 2000).

37. Wan, M., Democracy and Human Rights in Chinese Foreign Policy: Motivation And Behavior, in CHINA RISING: POWER AND Motivation in Chinese Foreign Policy (Yong Deng \& Fei-Ling Wang eds., 2005).

38. Wang, J. (王炬), Zhongguo Yinxiang Ye De Fazhan Xianzhuang (中 国音像业的发展现状) [Status Quo of the Chinese Audio-visual Industry Development], in ZhongGuo Wenhua Chanye FAZHAN BAOGAO (中国文化产业发展报告) [REPORT ON DEVELOPMENT OF China's Cultural Industry] (Xiaoming Zhang (张晓明) et al. eds., 2005).

39. Wang, Z., China Confronts Globalization: Conceptualizing Economic Security and Governance, in GLOBALISATION AND ECONOMIC SECURITY IN EAST ASIA: GOVERNANCE AND Institutions (Helen Sharmini Nesadurai ed. 2006).

40. Wenhua Bu Dangwei Guanyu Jinyibu Jiangdi Baokan Tushu Gaochou de Qingshi Baogao (文化部党委关于进一步降低报刊图书稿 酬的请示报告) [The Request Report of the Party Committee of Ministry of Culture on Further Reducing Newspapers and Books Remunerations], in ZhongGuO BANQuAn SHI YANJIU WenXIan (中 国版权史研究文献) [Historical Documents of China's Copyright Law] (Lin Zhou \& Mingshan Li eds., 1999).

41. Whinston, A. B., IT Policies and Issues: US and the Americas, in Information TeChNology Policy And the Digital Divide: Lessons for DeVeloping Countries (Mitsuhiro Kagami, et al. eds., 2004). 
42. Wiener, S., Grass-mud Horses to Victory: The Phonological Constraints of Subversive Puns, in PROCEEDINGS OF THE 23RD North American Conference on Chinese Linguistics (Zhuo Jing-Schmidt ed. 2011).

43. Xu, G., Edification Through Affection: The Cultural Revolution Films, 1974-1976, in THE OXFORD HANDBOOK OF CHINESE CINEMAS (Carlos Rojas \& Eileen Cheng-yin Chow eds., 2013).

44. Yu, P. K., Intellectual Property and Confucianism, in DIVERSITY IN INTELLECTUAL PROPERTY: IDENTITIES, INTERESTS AND InTERSECTIONS (Irene Calboli \& Srividhya Ragavan eds., Cambridge University Press, 2015).

45. Zhou, L. (周林), Zhongguo Banquan Shi Yanjiu de Jitiao Xiansuo( 中国版权史研究的几条线索) [Several Clues of Research on Copyright History of China], in ZHONGGUO BANQUAN SHI YANJIU WENXIAN (中国版权史研究文献) [ Historical Documents of China's Copyright Law] (Lin Zhou \& Mingshan Li eds., 1999).

\section{Articles:}

1. Afori, O. F., Implied License: An Emerging New Standard in Copyright Law, 25 SANTA Clara COMPuTER \& High TeCH. L.J. 275 (2008).

2. Arai, Y., Kinukawa, S., Copyright Infringement as User Innovation, 38 Journal of CUlTURAL ECONOMICS 131 (2014).

3. Balkin, J. M., Digital Speech and Democratic Culture: A Theory of Freedom of Expression for the Information Society, 79 N.Y.U. L. REV. 1 (2004).

4. Barme, G. R., Red Allure and the Crimson Blindfold, CHINA PerspeCtives 29 (2012).

5. Bell, T. W., Escape from Copyright: Market Success vs. Statutory Failure in the Protection of Expressive Works, 69 U. CIN. L. REV. 741 (2001).

6. Benkler, Y., Coase's Penguin, or, Linux and The Nature of the Firm, 112 YALE L.J. 369 (2002).

7. Benkler, Y., Nissenbaum, H., Commons-based Peer Production and Virtue, 14 Journal of Political Philosophy 394 (2006).

8. Biddulph, S. et al., Rule of Law with Chinese Characteristics: The Role of Campaigns in Lawmaking, 34 LAW \& POL'Y 373 (2012). 
9. Bradford, L. R., Parody and Perception: Using Cognitive Research to Expand Fair Use in Copyright, 46 B.C. L. REV. 705 (2004).

10. Brown, C. S., Copyleft, the Disguised Copyright: Why Legislative Copyright Reform is Superior to Copyleft Licenses, 78 UMKC L. REV. 749 (2009).

11. Buchanan, J. M., An Economic Theory of Clubs, 32 Economica 1 (1965).

12. Buttler II, G. F., Case Summary, Warner Bros. Entertainment and J.K. Rowling v. RDR Books and Does 1-10. 575 F. Supp. 2D 513, 19 DePaul J. Art Tech. \& Intell. Prop. L. 421 (2008).

13. Cao, X. (曹新明), Guanyu Zhuzuo Quan Baohu Qixian De Tantao ( 关于著作权保护期限的探讨) [On the Copyright Protection Term], FAXUE (法学) [Law Science] no.4, 1991.

14. Carrier, M. A., SOPA, PIPA, ACTA, TPP: An Alphabet Soup of Innovation-Stifling Copyright Legislation and Agreements, 11 NW. J. TECH. \& INTELL. Prop. 21 (2013).

15. Chan, M. et al., Microblogging, Online Expression, and Political Efficacy among Young Chinese Citizens: the Moderating Role of Information and Entertainment Needs in the Use of Weibo, 15 Cyberpsychology, Behavior, AND SOCIAL Networking 345 (2012).

16. Chen, W., Taking Stock, Moving Forward: the Internet, Social Networks and Civic Engagement in Chinese Societies, 17 INFORMATION, COMMUNICATION \& SOCIETY 1 (2014).

17. Chow, K., Writing for Success: Printing, Examinations, and Intellectual Change in Late Ming China, 17 LATE IMPERIAL CHINA 120 (1996).

18. Christian, K., Fan Fiction and the Fair Use Doctrine, 65 THE SERIALS LIBRARIAN 277 (2013).

19. Cintas, J. D., Sánchez, P. M., Fansubs: Audiovisual Translation in an Amateur Environment, THE JOURNAL OF SPECIALISED TRANSLATION 37 (2006).

20. Cohen, J. E., DRM and Privacy, 46 CommuniCATIOns of THE ACM 47 (2003).

21. Cornish, J., Cracks in the Great Wall: Why China's Copyright Law Has Failed to Prevent Piracy of American Movies Within Its Borders, 9 VAND. J. ENT. \& TECH. L. 405 (2006).

22. Cotter, T. F., Prolegomenon to a Memetic Theory of Copyright: 
Comments on Lawrence Lessig's The Creative Commons, 55 FlA. L. REV. 779 (2003).

23. Creemers, R., The Effects of WTO Case DS362 on Audiovisual Media Piracy in China, 31 Eur. InTELl. Prop. Rev. 568 (2009).

24. Daniels, J. M., "Lost in Translation": Anime, Moral Rights, and Market Failure, 88 B.U. L. REv. 709 (2008).

25. Davidow, L. L., Copyright Protection for Fictional Characters: A Trademark Based Approach to Replace Nichols, 8 COLUM.-VLAART \& L. 513 (1983).

26. Deuze, M., Participation, Remediation, Bricolage: Considering Principal Components of a Digital Culture, 22 THE INFORMATION SOCIETY 63 (2006).

27. Didwania, V. K., The Defense of Laches in Copyright Infringement Claims, 75 U. CHI. L. REV. 1227(2008).

28. Dittmer, L., Bases of Power in Chinese Politics: A Theory and an Analysis of the Fall of the "Gang of Four", 31 WORLD POLITICS 26 (1978).

29. Doi, T., Availability of the "Fair Use" Defense under the Copyright Act of Japan: Legislative and Case Law Developments for Better Adapting It to the Digital/Network Environment, 57 J. COPYRIGHT SoC'Y U.S.A. (2010).

30. Dong, H., Gu, M., Copyrightable or Not: A Review of the Chinese Provision on 'Illegal Works' Targeted by WTO DS362 and Suggestions for Legal Reform, 4 Asian J. WTO \& INT'L HEALTH \& POL'y 335 (2009).

31. Eisgruber, C. L., Is the Supreme Court an Educative Institution?, 67 N.Y.U. L. REV. 961 (1992).

32. Elkin-Koren, N., Can Formalities Save the Public Domain? Reconsidering Formalities for the 2010s, 28 BERKELEY TECH. L.J. 1537 (2013).

33. Elkin-Koren, N., Cyberlaw and Social Change: A Democratic Approach to Copyright Law in Cyberspace, 14 CARDOZO ARTS \& ENT. LJ 215 (1996).

34. Feng, X. (冯晓青), Zhuzuoquan Fa Mudi yu Liyi Pingheng Lun (著 作权法目的与利益平衡论) [On the Purpose and the Balance of Interests of Copyright Law], KEJI YU FALV (科技与法律)[SCIENCE TeChnology and LaW], no.2, 2004.

35. Fisher, W. W., Reconstructing the Fair Use Doctrine, 101 HARV. L. 
REV. 1659 (1988).

36. Fisher, W. W., The Implications for Law of User Innovation, 94 MINN. L. REV. 1417 (2010).

37. Foster, M. A., Parody's Precarious Place: The Need to Legally Recognize Parody as Japan's Cultural Property, 23 Seton Hall J. SPORTS \& ENT. L. 313 (2013).

38. Ginsburg, J. C., Authors and Users in Copyright, 45 J. COPYRIGHT SoC'Y U.S.A. 1 (1997).

39. Ginsburg, J. C., With Untired Spirits and Formal Constancy: Berne Compatibility of Formal Declaratory Measures to Enhance Copyright Title-Searching, 28 BERKELEY TECH. LJ 1583 (2013).

40. Goldstein, P., Copyright and the First Amendment, 70 Colum. L. REV. 983 (1970).

41. Gordon, W. J., Fair Use as Market Failure: A Structural and Economic Analysis of the "Betamax" Case and its Predecessors, 82 Colum. L. ReV. 1600 (1982).

42. Halstead, M. F., The Regulated Become the Regulators-Problems and Pitfalls in the New World of Digital Copyright Legislation, 38 Tulsa L. REV. 195 (2002).

43. Hamilton, M. A., The TRIPS Agreement: Imperialistic, Outdated, and Overprotective, 29 VAND. J. TRANSNAT'L L. 613 (1996).

44. Han, D., 'Use' is an Anagram of 'Sue': Cultural Control, Resistance, and the Role of Copyright in Chinese Cyberspace, 7 GLOBAL MEDIA AND COMMUNICATION 97 (2011).

45. Harris, D. P., The Honeymoon is Over: Evaluating the United States' WTO Intellectual Property Complaint Against China, 32 FORDHAM INT'L L.J. 96 (2009).

46. Harwit, E., Clark, D., Shaping The Internet in China: Evolution of Political Control over Network Infrastructure and Content, 41 ASIAN SURVEY 377 (2001).

47. Hatcher, J., Of Otakus and Fansubs: A Critical Look at Anime Online in Light of Current Issues in Copyright Law, 2 SCRIPT-ED 551 (2005).

48. He, D. (何笃丰), Wo Guo Bu Cunzai Zhenzheng Yiyi Shang De P2P Qinquan An (我国不存在真正意义上的 P2P 软件侵权案) [There exist no P2P software infringement lawsuit in China], DiANZI ZHISHI ChanQuan (电子知识产权) [EleCtronics InTEllectual ProPERTY] no.5, 2009, at 90. 
49. He, T., What Can We Learn from Industries? The Differences Between the Domestic and Oversea Copyright Protection Strategies towards Fan Activities, 62 AM. J. COMP. L. 1009 (2014).

50. Helfer, L. R., Regime Shifting: the TRIPS Agreement and New Dynamics of International Intellectual Property Lawmaking, 29 YALE J. INT'L L. 1 (2004).

51. Helfland, M. T., Note, When Mickey Mouse Is as Strong as Superman: The Convergence of Intellectual Property Laws to Protect Fictional Literary and Pictorial Characters, 44 STAN. L. REV. 623 (1991).

52. Hennessey, W., Deconstructing Shanzhai-China's Copycat Counterculture: Catch Me If You Can, 34 CAMPBELl L. Rev. 609 (2012).

53. Hetcher, S. A., Using Social Norms to Regulate Fan Fiction and Remix Culture, 157 U. PA. L. REV. 1869 (2009).

54. Hu, K., The Power of Circulation: Digital Technologies and the Online Chinese Fans of Japanese TV Drama, 6 INTER-AsIA Cultural Studies 171 (2005).

55. $\mathrm{Hu}, \mathrm{Y}$. (胡绮珍), Zhongguo Zimu Zu yu Xin Ziyou Zhuyi de Gongzuo Lunli (中国字幕组与新自由主义的工作伦理) (Chinese Fansub Groups and the Neoliberal Work Ethic), Xinwen Xue Yanjiu (新闻学研究) [MASS COMMUNICATION RESEARCH], no.101, 2009, at 177 (Taiwan).

56. Huang, S., Nation-branding and Transnational Consumption: Japan-mania and the Korean Wave in Taiwan, 33 Media, Culture \& SOCIETY 3 (2011).

57. Hughey, R. C., Implied Licenses by Legal Estoppel, 14 AlB. LJ SCI. \& TECH. 53 (2003).

58. Jenks, E., The Function of Law in Society, 5 JOURNAL OF COMPARATIVE LEGISLATION AND INTERNATIONAL LAW 169 (1923).

59. Ji, B. (吉炳轩), Changxiang Zhu Xuanlv Duochu Jinping Ju (唱响 主旋律多出精品剧——吉炳轩同志在 2000 年电视剧题材规划会 上的讲话要点) [Proclaim the mainstream melody, produce more quality dramas, comrade Ji Bingxuan's speech to the 2000 Television Drama Topic Advisory Meeting], ZHONGguo DiAnshi (中国电 视) [CHINESE TELEVISION], no.7, 2000, 4.

60. Ji, W. (季卫东), Wangluohua Shehui de Xifang yu Gongping 
Jingzheng Guanyu Zhuzuoquan Zhidu Sheji de Bijiao Fenxi(网络化 社会的戏仿与公平竞争一一关于著作权制度设计的比较分析) [Parody and Fair Competition in the Network Society], ZHONGGUO FAXUE (中国法学) [ CHINA LEGAL SCIENCE], no.3, 2006, at 21.

61. Jiang, N. (江南), Zhongguo Dongman Chanye Fazhan Fenxi (中国 动漫产业发展分析) [Analysis of the development of China's Animation Industry], Jin ChUANMEI (今传媒) [TODAY's MASSMEDIA], no.1, 2014.

62. Kan, S. S., Corporal Punishments and Optimal Incapacitation, $25 \mathrm{~J}$. LEGAL STUD. 121 (1996).

63. Kessler, L. D., Chinese Scholars and the Early Manchu State, 31 HARV. J. Asiat. STUD. 179 (1971).

64. Kim, D., The Making of Korean Dramas: Tantalizing Flexibility Comes at a Cost, 25 Koreana 78 (2011).

65. King, G., et al., How Censorship in China Allows Government Criticism but Silences Collective Expression, 107 AMERICAN Political Science ReVIEW 326 (2013).

66. Kinsella, S., Japanese Subculture in the 1990s: Otaku and the Amateur Manga Movement, 24 J. JAP. STUD. 289 (1998).

67. Kirkpatrick, S., Like Holding a Bird: What the Prevalence of Fansubbing Can Teach Us About the Use of Strategic Selective Copyright Enforcement, 21 TEMP. ENVTL. L. \& TECH. J. 131 (2003).

68. Klang, M., Nolin, J., Tolerance Is Law: Remixing Homage, Parodying Plagiarism, 9 SCRIPT-ED 172 (2012).

69. Kretschmer, M., The Failure of Property Rules in Collective Administration: Rethinking Copyright Societies as Regulatory Instruments, 24 EUR. INTELL. PROP. REV. 126 (2002).

70. Landes, W. M., Posner, R. A., Indefinitely Renewable Copyright, 70 U. CHI. L. REV. 471(2003).

71. Lee, E., Copyright-Exempt Nonprofits: A Simple Proposal to Spur Innovation, 45 ARIZ. ST. L.J. 1433 (2013).

72. Lee, E., Warming up to User-Generated Content, 2008 U. ILL. L. REV. 1459 (2008).

73. Lee, H., Participatory Media Fandom: A Case Study of Anime Fansubbing, 33 Media, Culture \& Society 1131 (2011).

74. Lee, T., Fan Activities from P2P File Sharing to Fansubs and Fan Fiction: Motivations, Policy Concerns, and Recommendations, 14 TEX. Rev. EnT. \& SPORTS L. 181 (2013). 
75. Lemley, M. A., IP in a World Without Scarcity, 90 N.Y.U. L. REV. 460 (2015).

76. Lemley, M. A. et al., Don't Break the Internet, 64 Stan. L. Rev. ONLINE 34 (2011).

77. Lemley, M. A., Reese, R. A., Reducing Digital Copyright Infringement without Restricting Innovation, 56 STAN. L. REV. 1345 (2004).

78. Leonard, S., Celebrating Two Decades of Unlawful Progress: Fan Distribution, Proselytization Commons, and the Explosive Growth of Japanese Animation, 12 UCLA ENT. L. REV. 189 (2005).

79. Leonard, S., Progress Against the Law: Anime and Fandom, with the Key to the Globalization of Culture, 8 InTERNATIONAL JOURNAL OF Cultural Studies 281 (2005).

80. Lessig, L., In Support of Network Neutrality, 3 ISJLP 185 (2007).

81. Lessig, L., The Creative Commons, 65 MonT. L. REV. 1 (2004).

82. Lessig, L., Copyright's First Amendment, 48 UCLA L. REV. 1057 (2001).

83. Lev-Aretz, Y., Second Level Agreements, 45 AKron L. REv. 137(2012).

84. Li, C. (李琛), Guanyu Zhongguo Gudai Yinhe Wu Banquan Yanjiu de Jidian Fansi (关于“中国古代因何无版权”研究的几点反思 )[Several Reflections on the Researches about "Why Ancient China has no Copyright"], FAXUEJIA (法学家)[JURIST], no.1, 2010, at 58.

85. Li, C. (李琛), Lun Wo Guo Zhuzuoquan Fa Xiuding zhong Heli Shiyong de Lifa Jishu (论我国著作权法修订中“合理使用”的立法 技术)[On the Legislative Technique of "Fair Use" in the Revision of our Copyright Law], ZHISHI CHANQUAN (知识产权)[INTELLECTUAL PROPERTY], no.1, 2013, at 16.

86. Li, C. (李琛), Zhishi Chanquan Fa Jiben Gongneng Zhi Chongjie ( 知识产权法基本功能之重解) [Reinterpreting the Basic Functions of Intellectual Property Law], ZHISHI CHANQUAN (知识产权 )[InTEllectual Property], no.7, 2014, at 6.

87. Li, L. (李亮), Lun Xuxie Zuopin de Zhuzuoquan Baohu (论续写作品 的著作权保护)[On the Protection of the Copyright of Continuation Works], HeBeI FAXUE (河北法学)[HeBEI LAw SCIENCE], no.2, 2005.

88. Li, X. (李劦思), Chengshi Xinyong Yuanze de Sifa Shiyong - Yi Alexy de Yuanze Lilun Wei Shijiao (诚实信用原则的司法适用一以 
Alexy 的原则理论为视角)[Judicial Application of the Principle of Good Faith-From the Perspective of the Principle Theory by Alexy], RENDA FALV PINGLUN (人大法律评论)[ RENMIN UNIVERSITY LAW REVIEW] 131 (2013).

89. Li, Y. (李雨峰), Lun Zhuzuo Caichanquan de Baohuqi (论著作财产 权的保护期) [On the Protection Term of Copyright], ZHENGZHI YU FALU (政治与法律)[POLITICAL SCIENCE AND LAW], no.4, 2008.

90. Li, Y. (李雨峰), Zhang, T. (张体锐), Huaji Mofang Yinfa de Zhuzuoquan Wenti (滑稽模仿引发的著作权问题) [The Copyright Problems Caused by Parodies], RenMin SifA (人民司法)[ PeOPLE’S JudiCATURE], no.17, 2011.

91. Li, Y., Professional ethics of Chinese judges, PersPeCtives ChINOISES 38 (2003).

92. Liang, B., Lu, H., Internet Development, Censorship, and Cyber Crimes in China, 26 JOURNAL OF CONTEMPORARY CRIMINAL JUSTICE 103 (2010).

93. Liu, J. P., Copyright Law's Theory of the Consumer, 44 B.C. L. REV. 397 (2003).

94. Loren, L. P., Building a Reliable Semicommons of Creative Works: Enforcement of Creative Commons Licenses and Limited Abandonment of Copyright, 14 GEO. MASON L. REV. 271 (2006).

95. Lunney, Jr., G. S., Copyright, Private Copying, and Discrete Public Goods, 12 TUL. J. TeCH. \& INTELl. Prop. 1 (2009).

96. Lunney, Jr., G. S., Fair Use and Market Failure: Sony Revisited, 82 B.U. L. REV. 975 (2002).

97. Lunney, Jr., G. S., The Death of Copyright: Digital Technology, Private Copying, and the Digital Millennium Copyright Act, 87 VA. L. REV. 813 (2001).

98. Maliangkay, R., Keep Your Enemies Closer: Protecting Korea's Pop Culture in China, 2 Korean Histories 34 (2010).

99. Mangin, E. A., Market Access in China--Publications and Audiovisual Materials: A Moral Victory with a Silver Lining, 25 BERKELEY TECH. L.J. 279 (2010).

100. Marcus, T. D., Fostering Creativity in Virtual Worlds: Easing the Restrictiveness of Copyright for User-created Content, $55 \mathrm{~J}$. COPYRIGHT SOC'Y U.S.A. 469 (2008). 
101. Massey, J. A., The Emperor Is Far away: China's Enforcement of Intellectual Property Rights Protection, 1986-2006, 7 CHI. J. INT'L L. 231 (2006).

102. Mattioli, M., Opting Out: Procedural Fair Use, 12 VA. J.L. \& TECH. 1 (2007).

103. Mayer-Schonberger, V., Wong, L., Fan or Foe: Fan Fiction, Authorship, and the Fight for Control, 54 IDEA 1 (2013).

104. McCutchan, S., Government Allocation of Import Quota Slots to US Films in China's Cinematic Movie Market, 25 The DuKe JournaL OF ECONOMICS, 12 (2013).

105. McKay, P., Culture of the Future: Adapting Copyright Law to Accommodate Fan-Made Derivative Works in the Twenty-First Century, 24 Regent U. L. REV. 117 (2011).

106. Mehra, S., Copyright and comics in Japan: Does Law Explain Why all the Cartoons my Kid Watches are Japanese Imports?, 55 RUTGERS L. REV. 155 (2002).

107. Montgomery, L., Fitzgerald, B., Copyright and the Creative Industries in China, 9 INTERNATIONAL JOURNAL OF CULTURAL STUDIES 407 (2006).

108. Muscar, J. E., A Winner is Who? Fair Use and the Online Distribution of Manga and Video Game Fan Translations, 9 VAND. J. ENT. \& TECH. L. 223 (2006).

109. Netanel, N. W., Asserting Copyright's Democratic Principles in the Global Arena, 51 VAND. L. REV. 217 (1998).

110. Netanel, N. W., Copyright and a Democratic Civil Society, 106 YALE L.J. 283 (1996).

111. Netanel, N. W., Impose a Non-commercial Use Levy to Allow Free Peer-to-Peer File Sharing, 17 HARV. J.L. \& TECH. 1 (2003).

112. Netanel, N. W., Locating Copyright within the First Amendment Skein, 54 STAN. L. REV. 1 (2001).

113. Noda, N. T., Copyrights Retold: How Interpretive Rights Foster Creativity and Justify Fan-Based Activities, 20 Seton Hall J. SPORTS \& ENT. L. 131 (2010).

114. Noda, N. T., Perpetuating Cultures: What Fan-Based Activities Can Teach Us About Intangible Cultural Property, 44 CREIGHTON L. REV. 429 (2011).

115. Noda, N. T., When Holding on Means Letting Go: Why Fair Use Should Extend to Fan-based Activities, 5 U. DENV. SPORTS \& ENT. L.J. 64 (2008). 
116. Nussbaum, M. C., Constitutions and Capabilities: Perception against Lofty Formalism, 121 HARV. L. REV. 4 (2007).

117. Oh, I., Hallyu: The Rise of Transnational Cultural Consumers in China and Japan, 40 KOREA OBSERVER 425 (2009).

118. Otmazgin, N. K., Contesting Soft Power: Japanese Popular Culture in East and Southeast Asia, 8 InTERnAtional Relations of THE ASIA-PACIFIC 73 (2008).

119. Peitz, M., Waelbroeck, P., Piracy of Digital Products: A Critical Review of the Theoretical Literature, 18 INFORMATION ECONOMICS AND POLICY 449 (2006).

120. Piasentin, R. C., Unlawful? Innovative? Unstoppable? A Comparative Analysis of the Potential Legal Liability Facing P2P End-Users in the United States, United Kingdom and Canada, 14 INT. J. LAW INFO. TECH. 195 (2006).

121. Pollack, M., What is Congress Supposed to Promote?: Defining "Progress" in Article I, Section 8, Clause 8 of the United States Constitution, or Introducing the Progress Clause, 80 NeB. L. REV. 754 (2001).

122. Port, K. L., Copyright Protection of Fictional Characters in Japan, 7 WIS. INT'L L.J. 205 (1988).

123. Posner, R. A., When is Parody Fair Use?, 21 J. Legal Stud. 67 (1992).

124. Priest, E., Copyright Extremophiles: Do Creative Industries Thrive or Just Survive in China's High Piracy Environment?, 27 HARV. J.L. \& TECH. 467 (2014).

125. Priest, E., The Future of Music and Film Piracy in China, 21 BERKELEY TECH. L.J. 795 (2006).

126. Redish, M. H., The Value of Free Speech, 130 U. PA. L. REV. 591 (1982).

127. Reidenberg, J., Commentary on Digital Rights Management, 7 INT'L INTELL. PROP. L. \& POL'Y 53-1(2002).

128. Rembert-Lang, L. D., Reinforcing the Tower of Babel: The Impact of Copyright Law on Fansubbing, 2 InTELL. Prop. BRIEF 21 (2010).

129. Rogoyski, R. S., Basin, K., The Bloody Case That Started From a Parody: American Intellectual Property and the Pursuit of Democratic Ideals in Modern China, 16 UCLA ENT. L. REV. 237 (2009).

130. Ryoo, W., Globalization, or the Logic of Cultural Hybridization: the Case of the Korean Wave, 19 ASIAN JOURNAL OF COMMUNICATION 
137 (2009).

131. Sakona, S., Frankly, My Dear America, We Don't Give a Damn: Comparing Chinese and European Trade Barriers to American Audiovisual Works and the American Response, 54 B.C. L. REV. 1385 (2013).

132. Samuelson, P., The Copyright Principles Project: Directions for Reform, 25 BERKELEY TECH. LJ 1175 (2010).

133. Shao, K., An Alien of Copyright? A Reconsideration of the Chinese Historical Episodes of Copyright, 4 InTEll. PROP. Q. 400 (2005).

134. Shao, K., Monopoly or Reward: The Origin of Copyright and Authorship in England, France and China and a New Criticism of Intellectual Property, 41 Hong Kong L.J. 731 (2011).

135. Sheridan, J. L., Copyright's Knowledge Principle, 17 VAND. J. ENT. \& TECH. L. 39 (2014).

136. Sieman, J. S., Using the Implied License To Inject Common Sense into Digital Copyright, 85 N.C.L. REV. 885 (2006).

137. Solum, L. B., Book Review, The Future of Copyright, 83 TEX. L. REV. 1137 (2005).

138. Song, H., Dancing in Shackles: Copyright in China's Highly Regulated Publishing Market, 60 J. COPYRIGHT SOC'Y U.S.A. 285(2013).

139. Sprigman, C., Reform(aliz)ing Copyright, 57 StAN. L. REV. 485 (2004).

140. Srinivasan, T. N., External Sector in Development: China and India, 1950-89, 80 THE AMERICAN ECONOMIC REVIEW 113 (1990).

141. Stendell, L., Fanfic and Fan Fact: How Current Copyright Law Ignores the Reality of Copyright Owner and Consumer Interests in Fan Fiction, 58 S.M.U. L. REV. 1551 (2005).

142. Stevenson-Yang, A., DeWoskin, K., China Destroys the IP Paradigm, 168 FAR E. ECON. REV. 9 (2005).

143. Stone, C. R., Comment, What Plagiarism Was Not: Some Preliminary Observations on Classical Chinese Attitudes Toward What the West Calls Intellectual Property, 92 MARQ. L. REV. 199 (2008)

144. Story, A., Burn Berne: Why the Leading International Copyright Convention must be Repealed, 40 Hous. L. REV. 763 (2003).

145. Su Li (苏力), Xifang de Falu Baohu yu Xianzhi Cong Yige Mantou Yinfa de Xuean Qieru(戏仿的法律保护和限制——《一个馒头引 
发的血案》切入) [Legal Protection of Parodies and its Limits], ZhongGuO FAXUE (中国法学)[ CHINA Legal SCIENCE], no.3, 2006, at 11 .

146. Sudo, M., Newman, S., Japanese Copyright Law Reform: Introduction of the Mysterious Anglo-American Fair Use Doctrine or an EU Style Divine Intervention via Competition Law?, 18 INTELL. PROP. Q. 40 (2014).

147. Sugiyama, K., The First Parody Case in Japan, 9 Eur. InTELL. PROP. REV. 285 (1987).

148. Sun, L. (孙莉), Dezhi Yu Fazhi Zhengdangxing Fenxi Jianji Zhongguo Yu Dongya Fawenhua Chuantong Zhi Jiansheng (德治与 法治正当性分析一一兼及中国与东亚法文化传统之检省) [A Study on the Justification of Rule of Virtue and Rule of Law-With a Review of Legal Cultural Tradition of China and East Asian Countries], ZHONGGUO SHEHUI KeXUE (中国社会科学)[SOCIAL SCIENCES IN CHINA], no.6, 2002.

149. Sun, Z. (孙战龙), Wangluo Tongren Xiaoshuo de Quanli Jieding (网 络同人小说的权利界定) [The Demarcation Between the Rights of Internet Fanfiction Authors and Other Rights], WANGLUO FALÜ PINGLUN (网络法律评论) [INTERNET LAW REVIEW] 170 (2006).

150. Tang, J. (唐建设), Rang Gao Pinwei Di Jiawei De Luxiangdai Jinru Jiating (让高品位低价位的录像带进入家庭) (Let the Videotape with Higher Quality and Lower Price into Our Family), Chuban Guangjiao (出版广角) [VIEW ON PUBLISHING], no.2, 1995.

151. Trombley, S., Visions and Revisions: Fanvids and Fair Use, 25 CARDOZO ARTS \& ENT. J. 647 (2008).

152. Tushnet, R., Copy this Essay: How Fair Use Doctrine Harms Free Speech and How Copying Serves it, 114 YALE L.J. 535(2004).

153. Tushnet, R., Legal Fictions: Copyright, Fan Fiction, and a New Common Law, 17 LOY. LA ENT. LJ 651(1997).

154. Tushnet, R., Payment in Credit: Copyright Law and Subcultural Creativity, 70 LAW \& ConTEMP. ProBs. 135(2007).

155. van Gompel, S., Copyright Formalities in the Internet Age: Filters of Protection or Facilitators of Licensing, 28 BERKELEY TECH. L.J. 1425 (2013).

156. van Zoonen, L., Imagining the Fan Democracy, 19 EUROPEAN JOURNAL OF COMMUNICATION 39 (2004). 
157. Vany, A. S. D., Walls, W. D., Estimating the Effects of Movie Piracy on Box-Office Revenue, 30 REVIEW OF INDUSTRIAL ORGANIZATION 291(2007).

158. von Hippel, E., Lead Users: A Source of Novel Product Concepts, 32 MANAGE SCI. 791 (1986).

159. Walls, W. D., Cross-country Analysis of Movie Piracy, 40 APPLIED ECONOMICS 625 (2008).

160. Wan, Y. (万勇), Meiguo Banquanfa Gaige Fangan Shuping (美国版 权法改革方案述评)[Comments on the U.S. copyright law reform plan], Zhishi ChanQuAN (知识产权) [InTELleCtuAl Property], no. $1,2014$.

161. Wang, J. (王杰), Meiguo SOPA Yian Pingxi Jiqi Dui Woguo Wangluo Zhishi Chanquan Lifa De Qishi (美国 SOPA 议案评析及其对 我国网络知识产权立法的启示) [Analysis on SOPA and What Can Be Learned from SOPA for IP Legislation Under the Network Environment in China], ZHISHI CHANQUAN (知识产权) [INTELLECTUAL PROPERTY], no.8, 2012.

162. Wang, L. (王兰萍), Xianxing Zhuzuoquan Fa Zongze de Zai Dingwei yu Wanshan (现行著作权法总则的再定位与完善)[The Reorientation and Perfection of the General Provisions of Current Copyright Law], ZhongGuO ZHISHI CHANQUAN (中国知识产权 )[China Intellectual Property], no.11, 2010.

163. Wang, L. (王䂞), Wangluo Zimu Zu Huoli Qudao Fenxi (网络视频 字幕组获利渠道分析) (Analysis of Profit Channels of Internet Video Fansub Groups), Dianying Xinzuo (电影新作) [NEW FILMS], no.2, 2012.

164. Wang, Q. (王迁), Zhuzuoquan Fa Jiejian Guoji Tiaoyue yu Guowai Lifa Wenti yu Duice(著作权法借鉴国际条约与国外立法: 问题与 对策) [Using International Treaties and Overseas Legislation for Reference for the Copyright Law: Problems and Countermeasures], ZhongGuo FaXue (中国法学) [ China Legal Science], no.3, 2012, at 31-5.

165. Wang, Q. (王群), Deng, S. (邓世豹), Daxuesheng Banquan Yishi Xianzhuang Yanjiu (大学生版权意识现状研究) [Current Situation of College Students' Awareness of Copyright], DANGDAI QInGNiAN 
YANJIU (当代青年研究)[CONTEMPORARY YOUTH RESEARCH], no.1, 2013.

166. Wu, T., Tolerated Use, 31 Colum. J.L. \& ARTs 617 (2008).

167. Yen, A. C., Sony, Tort Doctrines, and the Puzzle of Peer-to-Peer, 55 CASE W. RES. L. REV. 815 (2005).

168. Yoo, C. S., Copyright and Public Good Economics: A Misunderstood Relation, 155 U. PA L. REV. 635 (2007).

169. Yu, P. K., From Pirates to Partners: Protecting Intellectual Property in China in the Twenty-First Century, 50 AM. U. L. REV. 131 (2000).

170. Yu, P. K., Piracy, Prejudice, and Perspectives: An Attempt to use Shakespeare to Reconfigure the US-China Intellectual Property Debate, 19 BU INT'L LJ 1 (2001).

171. Yu, P. K., Still Dissatisfied After All These Years: Intellectual Property, Post-WTO China, and the Avoidable Cycle of Futility, 34 GA. J. INT'L \& COMP. L. 143 (2005).

172. Yu, P. K., The Second Coming of Intellectual Property Rights in China, OCCASIONAL PAPERS IN INTELLECTUAL PROPERTY (2002).

173. Zhang, T., Schwartz, B., Confucius and the Cultural Revolution: A Study in Collective Memory, 11 InTERnATIONAL Journal OF Politics, Culture, AND SOCIETY 189 (1997).

174. Zheng, C., The Future Chinese Copyright System and its Context, 15 IIC 141 (1984).

\section{Dissertations:}

1. Creemers, R., Explaining Audiovisual Media Piracy in China 67 (Feb. 2, 2012) (unpublished Ph.D. dissertation, Maastricht University), at http://arno.unimaas.nl/show.cgi?fid=24067.

2. Ma, L., A Comparative Analysis of Weibo and Xinhua in Framing Chinese Civic Engagement (May. 2013) (unpublished M.A. thesis, Bowling Green State University), at https://etd.ohiolink.edu/rws_etd/document/get/bgsu1363569701/inli ne.

3. Peng, Q., Audience Activity in the New Media Era: Chinese Fansubs of U.S. TV Shows (Dec. 2010) (unpublished M.A. thesis, University of Florida), at http://ufdcimages.uflib.ufl.edu/UF/E0/04/26/11/00001/qiu_p.pdf. 
4. Tian, T., Fansub Cyber Culture in China (Apr. 26, 2011) (unpublished M.A. thesis, Georgetown University, UMI No. 1491553), available by subscription in ProQuest Dissertation and Theses database, http://search.proquest.com/docview/865649108?accountid=12339.

\section{News Reports and Online Materials:}

1. 16.44 Million Copies of Infringing and Illegal Publications Nationwide were Destroyed, National Saohuang Dafei Office, Apr. 20, 2015, at http://www.shdf.gov.cn/shdf/contents/767/249181.html.

2. Albanese, A., Google Wins: Court Issues a Ringing Endorsement of Google Books, PUBLISHER WEEKLY, Nov. 14, 2013, at http://www.publishersweekly.com/pw/by-topic/digital/content-and-e -books/article/60006-google-wins-court-issues-a-ringing-endorseme nt-of-google-books.html.

3. Antwoorden kamervragen over ondertitelen van films als inbreuk op auteursrecht, rijksoverheid.nl, Dec. 19, 2013, at http://www.rijksoverheid.nl/bestanden/documenten-en-publicaties/k amerstuk-

ken/2013/12/20/antwoorden-kamervragen-over-ondertitelen-van-fil ms-als-inbreuk-op-auteursrecht/lp-v-j-0000004746.pdf.

4. Armstrong, T., U.S. Government: Fair Use is Too Complex to Explain to Kids, INFO/LAW BLOG, Aug. 10, 2007, at https://blogs.law.harvard.edu/infolaw/2007/08/10/us-government-fai r-use-is-too-complex-to-explain-to-kids/.

5. Armstrong, T., What Gets Created Under a "Tolerated Use" Regime?, INFO/LAW BLOG, Oct. 18, 2007, at https://blogs.law.harvard.edu/infolaw/2007/10/18/what-gets-createdunder-a-tolerated-use-regime/.

6. Ask John: What Are Fansubs?, Animenation News Blog, Dec. 27, 2001, http://www.animenation.net/blog/2001/12/27/ask-john-what-are-fans ubs/.

7. Audience to decide plot for 'Mundasuppatti 2', DeCCAN CHRONICLE, Jul. 9, 2014, http://www.deccanchronicle.com/140709/entertainment-kollywood/a rticle/audience-decide-plot-mundasuppatti-2. 
8. Bakalis, A., It's Unreel: DVD Rentals Overtake Videocassettes, WASHINGTON TIMES, Jun. 21, 2003, at http://www.washingtontimes.com/news/2003/jun/20/20030620-1132 58-1104r.

9. Band, J., Features-The Authors Guild v. The Google Print Library Project, LLRX.com, Oct. 15, 2005, at http://www.llrx.com/features/googleprint.htm.

10. Bertrand, N., 'Fifty Shades of Grey' Started Out as 'Twilight' Fan Fiction before Becoming an International Phenomenon, BusINESS INSIDER, Feb. 17, 2015, at http://uk.businessinsider.com/fifty-shades-of-grey-started-out-as-twil ight-fan-fiction-2015-2? $\mathrm{r}=\mathrm{US}$.

11. Bertschy, Z., 2002-Fansubs in Review, Anime News Network, Jan. 14, 2003, at http://www.animenewsnetwork.com/feature/2003-01-27/7.

12. Blair, G. J., China's iQIYI and Japan's Fuji TV Link on Drama Production, THE HollywoOd RePORTER, Jun. 17, 2014, available at http://www.hollywoodreporter.com/news/chinas-iqiyi-japans-fuji-tv712401 .

13. Books by Writers Sympathetic to Hong Kong and Taiwan Student Movements available 'while stocks last', SOUTH CHINA MoRning Post, Oct. 13, 2014, at http://www.scmp.com/news/china/article/1615308/books-writers-sy mpathetic-hong-kong-and-taiwan-student-movements.

14. Bruno, L., Rights fielder: Lawrence Lessig on Intellectual Property Rights and Cyberspace, RED HERrIng, 4, Dec, 2000.

15. $\mathrm{Bu}, \mathrm{X}$. (下祥), Yinjin Ju Shenhe Shengsi Jue (引进剧审核生死决) [Imported Foreign Dramas' Last Fight with Censorship], Caijing Tianxia Zhoukan (财经天下周刊) [ECONOMIC WeEKLY], Oct. 6, 2014, no. 67, at 22 .

16. Burgess, J. et al., Everyday Creativity as Civic Engagement: A Cultural Citizenship View of New Media, Paper presented at the 2006 Communications Policy and Research Forum, Sydney, Australia, Sep. 25-26, available at http://www.networkinsight.org/verve/_resources/BurgessFothKlaebe .pdf. 
17. Camarillo, G., Ed, Peer-to-Peer (P2P) Architecture: Definition, Taxonomies, Examples, and Applicability, RFC 5694, IETF Networking Group, Nov. 2009, http://tools.ietf.org/pdf/rfc5694.pdf.

18. Charlton, A., Illegal Downloaders Spend More on Music, Film and TV Than Legal Downloaders, InTERnATIONAL Business TIMES, Nov. 23, 2012, at http://www.ibtimes.co.uk/illegal-downloaders-pirates-spend-more-m usic-films-407888.

19. Chen, C. (陈岑), Xingxing Fanyi Tuandui: Gongzuo Jiuxiang Dazhang Choulao Budao 20 Kuai (<星星>翻译团队: 工作就像打 仗 酬劳不到 20 块) [The Translation Team of the "My Love from the Stars": Working like Battling but Payment is less than 20 Yuan], JinLing Wanbao (金陵晚报) [JINLING EVENING PosT], Mar. 1, 2014, http://www.chinanews.com/yl/2014/03-01/5898503.shtml.

20. Chen, K. (陈柯羽), Jingwaiju Xianshenhoubo Xinzheng Yizai Shipin Wangzhan Bufen Shixing (境外剧先审后播新政已在视频网站 部分施行) [The New “Censor First Broadcast After” Policy Is Now Implemented in Video Platforms], Chongqing Wanbao (重庆晚报) [CHONGQING EVENING NeWs], Jan. 15, 2015, at http://www.cqwb.com.cn/cqwb/html/2015-01/15/content_423043.ht $\mathrm{m}$.

21. Chen, S. (陈赛), Liu, Y. (刘宇), Yueyu de Zhongguo Yinmi Liuxing (《越狱》的中国隐秘流行) [Prison Break's Hidden Popularity in China], Sanlian Shenghuo Zhoukan (三联生活周刊)[LIFEWEEK], no.413, Dec. 21 , 2006 , at http://www.lifeweek.com.cn/2006/1221/17226.shtml.

22. Chen, X., Gray Areas: Book Banning and Censorship in China, FAIR OBSERVER, Aug.

15 , 2014 , at http://www.fairobserver.com/region/asia_pacific/grey-areas-book-ba nning-and-censorship-in-china-62007/.

23. China (PRC), 2014 Special 301 Report On Copyright Protection and Enforcement, IIPA, Feb. 7, 2014, at 24, http://www.iipa.com/rbc/2014/2014SPEC301CHINA.PDF.

24. China Hunan TV Official Channel, YouTuBe, at https://www.youtube.com/user/imgotv.

25. Coco, Chinese Entertainment Faces Tough Competition from Korean Dramas, DrAMAFEVER, Mar. 3, 2014, at 
http://www.dramafever.com/news/chinese-entertainment-faces-toug h-competition-from-korean-dramas/.

26. Comiket 82 Ties 'Turnstile' Attendance Record at 560,000, ANIME NeWs NETWORK, Aug. 13, 2012, http://www.animenewsnetwork.com/news/2012-08-13/comiket-82-ti es-turnstile-attendance-record-at-560000.

27. Content ID, YOUTUBE, http://www.youtube.com/t/contentid.

28. Coonan, C., China Bars Stars with "Bad" Moral Records from TV, THE Hollywood Reporter, Sep. 17, 2014, at http://www.hollywoodreporter.com/news/china-bars-stars-bad-moral -733690 .

29. Copyright Dispute Kicks Migrant Singers Out of Spring, XINHUA News, Feb. 13, 2011, http://news.xinhuanet.com/english2010/china/2011-02/13/c_137300 08.htm.

30. Creative Commons, About Us, https://creativecommons.org/about.

31. Cui, X. (崔小粟), Yiniannei Sanci Qinjin Rujia Xi Jinping Weihe Ruci Qiangdiao Chongshi Chuantong Wenhua? (一年内三次亲近儒 家 习近平为何如此强调重拾传统文化? ) [Approach Confucianism three times a year, why Xi Jinping put so much stress on regaining the traditional culture?], Renmin Wang (人民网) [PEOPLE.COM.CN], Sep. 25, 2014, at http://cpc.people.com.cn/n/2014/0925/c164113-25731729.html.

32. Dhungel, P. et al., Is BitTorrent Unstoppable? 2007, at 14, at http://citeseerx.ist.psu.edu/viewdoc/download?doi=10.1.1.414.971\& rep $=$ rep1\&type $=$ pdf.

33. Disclaimer of Maplesnow Fansub Group, The Maplesnow Official Site, http://bbs.fxdm.net/disclaim.htm.

34. Duobu Riman Weixian Guangdian Huojiang Jinbo Baokong Dongman (多部日漫危险! 广电或将禁播暴恐动漫) [Many Japanese Anime Works are in Danger! SAPPRFT may Prohibit Anime Works with Violent and Horrific Elements from Online Streaming], Wang Yi 163(网易 163) [NETEASE], Mar. 31, 2015, at http://ent.163.com/15/0331/22/AM2MUUSN00031H2L.html (China).

35. Fansub,

ANIME

NEWS

NETWORK, http://www.animenewsnetwork.com/encyclopedia/lexicon.php?id=6 3. 
36. Fansub, Bloomsburg University Manga And Anime Club (BUMAC), at http://www.bumac.org/index.php?page=fansub.

37. Feng, B., Wang, S., China Orders 4 U.S. Shows Off Streaming Sites, N.Y. TIMES, Apr. 27, 2014, available at http://www.nytimes.com/2014/04/28/business/international/china-or ders-4-us-shows-off-streaming-sites.html?_r=0.

38. File-sharers move from BitTorrent, BBC NEws, at http://news.bbc.co.uk/2/hi/technology/4196642.stm.

39. File-sharers Swap more than Video, BBC News, Aug. 11, 2005, at http://news.bbc.co.uk/2/hi/technology/4139314.stm.

40. Fukui, K. (福井健策), Chosakuken o Ikasu ni wa Dejitaru kontentsu no kōzai (著作権を活かすにはデジタルコンテンツの功罪) [In Exploiting Copyright: The Advantages and Disadvantages of Digital Contents], Hummingheads.co.jp, Oct. 31, 2013, at http://www.hummingheads.co.jp/reports/interview/1310/131031_03. html.

41. Fulian 2 Fanyi zao tucao Wangyou ni Siji Guole Meiyou (《复联 2 》翻译遭吐槽 网友: 你四级过了没有) [Official Translations of the Subtitle of Avengers: Age of Ultron were Attacked by Netizens in China], Wang Yi 163(网易 163) [NETEASE], May 13, 2015, at http://ent.163.com/15/0513/07/APFRR1P7000300B1.html\#p=APFU DUQD00AJ0003.

42. GAPP, SPC, SPP, MPS, Ministry of Radio, Film and Television, and SAIC, Summary of the Symposium on the Work of Punishing Illegal Publishing Criminal Activities, Renmin Wang (人民网) [PEOPLE.COM.CN], Mar. 8, 1988, at http://www.people.com.cn/electric/flfg/d4/880308.html.

43. Geist, M., Music Licensing would be Viable for All, TORONTO STAR, Mar. 8 , 2004 , at http://www.michaelgeist.ca/2004/03/music-licensing-would-be-viabl e-for-all/.

44. Geist, M., The Truth About Pirates and Profits: A Market Failure, Not Legal One, Michael Geist Personal Home Page, Mar. 22, 2011,

http://www.michaelgeist.ca/2011/03/ssrc-piracy-report-column-post/

45. Gibson, O., What Happens Next? You Decide, as Channel 4 Launches TV's First Interactive Drama, ThE Guardian, Sep. 26, 
2005 ,

http://www.theguardian.com/technology/2005/sep/26/media.broadca sting.

46. Goldhill, O., Hollywood Switches Focus to China's Billions, THE TELEGRAPH, Jul. 7, 2013, at http://www.telegraph.co.uk/finance/newsbysector/industry/1016535 2/Hollywood-switches-focus-to-Chinas-billions.html.

47. Gordon, L. A., Conference to Highlight Copyright Law's "Creaky Aspects", UC BerKeley SCHOOL of LAW News ARChIVE, Mar. 25, 2014, at http://www.law.berkeley.edu/16932.htm.

48. Gruger, W., PSY's 'Gangnam Style' Video Hits 1 Billion Views, Unprecedented Milestone, Billboard, Dec 21, 2012, at http://www.billboard.com/biz/articles/news/1483733/psys-gangnamstyle-video-hits-1-billion-views-unprecedented-milestone.

49. Guibault, L., Private Copying Levy: The Aftershocks of Padawan, Kluwer Copyright Blog, Sep. 17, 2013, at http://kluwercopyrightblog.com/2013/09/17/private-copying-levy-th e-aftershocks-of-padawan/.

50. Guowai Donghua Pian Dui Zhongguo Ertong Jiazhi Guan de Yingxiang (国外动画片对中国儿童价值观的影响) [Imported Anime's Influences on the Values of Chinese Children], Zhongyang Dianshi Tai (中央电视台) [CCTV], Oct. 12, 2004, http://www.cctv.com/tvguide/tvcomment/special/C11876/20041012/ 101985_4.shtml.

51. Guowuyuan Fazhi Bangongshi Guanyu Gongbu Zhonghua Renmin Gongheguo Zhuzuoquan Fa Xiudingan Songshengao Gongkai Zhengqiu Yijian de Tongzhi (国务院法制办公室关于公布《中华人 民共和国著作权法（修订草案送审稿）》公开征求意见的通知) [Circular of the Legislative Affairs Office of the State Council on Promulgating the Copyright Law of the People's Republic of China (Draft Revision for Review) for Public Comments], Legislative AfFairs Office Of the State Council P.R. China, Jun. 6, 2014, at http://www.chinalaw.gov.cn/article/cazjgg/201406/20140600396188 .shtml.

52. Hansell, S., Bits Debate: On the Rights of Readers and Viewers, N.Y. TIMES BITS BLOG, Jan. 18, 2008, at http://bits.blogs.nytimes.com/2008/01/18/bits-debate-on-the-rights-o f-readers-andviewers. 
53. Hao, D. (郝多), Wang, Y. (王颖菲), Jia, L. (贾磊), Zimuzu (字幕组) [Fansub Groups], Xiandai Kuaibao (现代快报) [MODERn EXPRESs], Mar. 2 , 2014 , http://dz.xdkb.net/html/2014-03/02/content_326140.htm (China).

54. Harmon, A., Black Hawk Download: Moving Beyond Music, Pirates Use New Tools to Turn the Net into an Illicit Video Club, N.Y. TIMES, Jan. 17, 2002, at G1, available at http://www.nytimes.com/2002/01/17/technology/black-hawk-downl oad-moving-beyond-music-pirates-use-new-tools-turn-net-into.html? $\mathrm{src}=$ pm\&pagewanted $=2$.

55. History of Cable Modems, INFORMIT, at http://www.informit.com/library/content.aspx?b=Planet_Broadband $\&$ seqNum $=17$.

56. How Much Money Do Doujinshi Creators Actually Make? Some Statistics from Comiket, FANHACKERS BLOG, Jun. 10, 2012, at http://fanhackers.transformativeworks.org/2012/06/how-much-mone y-do-doujinshi-creators-actually-make-some-statistics-from-comiket /.

57. Ichikawa, K., The Comic Market Today and Overseas Participants, 2009 ,

http://www.comiket.co.jp/info-a/C77/C77CMKSymposiumPresentat ionEnglish.pdf.

58. Interview with Isao Takahata, HAYAO MIYAZAKI WEB, Oct. 1993, at http://www.nausicaa.net/miyazaki/interviews/t_corbeil.html\#fn4.

59. Jacobs, D. L., Parodies of Rap Artist Psy's Gāngnam Style Are Fun. But Are They Legal?, FOrBES, Sep. 10, 2012, at http://www.forbes.com/sites/deborahljacobs/2012/10/09/parodies-ofrap-artist-psys-gangnam-style-are-fun-but-are-they-legal-2/.

60. Japan External Trade Org., Japan Animation Industry Trends, JAPAN ECON. MONTHLY, Jun. 2005, at 2, http://www.jetro.go.jp/en/reports/market/pdf/2005_35_r.pdf.

61. Japan Introduces Piracy Penalties for Illegal Downloads, BBC NEWS, Sept. 30 , 2012, http://www.bbc.co.uk/news/technology-19767970.

62. Japan to USA: Anime \& Manga, Japan External Trade Org. U.S., http://www.jetro.org/usa/japanus/animemanga/.

63. Jenkins, H., From Participatatory Culture to Participatory Democracy (Part Two), Mar. 6, 2007, at 
http://henryjenkins.org/2007/03/from_participatatory_culture_t_1.ht $\mathrm{ml}$.

64. Jenkins, H., When Piracy Becomes Promotion, REAson, Dec. 2006, at

http://reason.com/archives/2006/11/17/when-piracy-becomes-promo tion.

65. Jia Fanyi Fengbo Xu: Wo Meiyou Bei Haolaiwu Fengsha (“贾翻译 风波”续: 我没有被好莱坞封杀) [“Translator Jia's Trouble”Continued: I am not blocked by Hollywood], in Shidai Zhoubao (时代周 报 ) [Time WeEKLY], Aug. 23, 2013, available at http://ent.ifeng.com/movie/news/toutiao/detail_2013_08/23/2893946 8 0.shtml.

66. Jin, W. (金文婕), Meiju Zimuzu Bei Shoubian Huo Leifeng Yao Zhuanqian (美剧字幕组被收编“活雷锋”要赚钱) [Fansub Groups of American Drama Were Incorporated, "Living Lei Feng” Needs Money], Xinwen Chenbao (新闻晨报) [Shanghai Morning Post], Jun. 16 , 2014 , http://www.jfdaily.com/shanghai/bw/201406/t20140616_448050.ht $\mathrm{ml}$ (China).

67. Johnson, B. A., 'Gangnam Style' Fans Include Britney Spears, Katy Perry, Vanessa Hudgens; What They Tweeted, LAtinos Post, Aug 29, 2012 , at http://www.latinospost.com/articles/3457/20120829/celeb-tweets-sh ow-gangnam-style-taking-over-hollywood.htm.

68. Kanemitsu, D., Analysizing [sic] the State of the Anime and Manga Industry in 2012, Dan Kanemitsu's Paper Trail, Mar. 19, 2012, at http://dankanemitsu.wordpress.com/2012/03/19/analysizing-the-state -of-the-anime-and-manga-industry-in-2012/.

69. Kincaid, C., Are Fansubs and Scanlations Piracy?, JAPAN Powered, Oct. 27 , 2013, at http://www.japanpowered.com/anime-articles/are-fansubs-and-scanl ations-piracy.

70. Koulikov, M., ADV films, Anime News Network, May. 12, 2007, http://www.animenewsnetwork.com/convention/2007/anime-central/ advfilms.

71. Koulikov, M., Fighting the Fan Sub War: Conflicts between Media Rights Holders and Unauthorized Creator/Distributor Networks, 5 TRANSFORMATIVE WORKS AND CUltures (2010), at 
http://journal.transformativeworks.org/index.php/twc/article/view/11 $5 / 171$.

72. Kroll, N., Breakdown of The Major Online Indie Film Distribution Platforms, PremiumbeAt.COM, Dec. 13, 2013, available at http://www.premiumbeat.com/blog/breakdown-of-the-major-online-i ndie-film-distribution-platforms/.

73. Kuishi Zhongguo Chuangyi Chanye de Bingshan Yijiao - Dongman Chanye (窥视中国创意产业的冰山一角——动漫产业) [Looking into the Creative Industry of China - the Animation Industry], LING DiAn ZHI BIAO SHU JU (零点指标数据) [HoRIZONKEY], Jul. 26, 2011, available

at http://www.horizonkey.com/c/cn/news/2011-07/26/news_1516.html.

74. Kwaak, J. S., South Korean Soap Operas: Just Lowbrow Fun?, THE WALL STREET JOURNAL, Jul. 23, 2013, at http://blogs.wsj.com/korearealtime/2013/07/23/south-korean-soap-o peras-just-lowbrow-fun-2/.

75. Kyodo, Crackdown on Intellectual Property Piracy Pays Off, THE JAPAN TIMES, Mar. 5, 2012, at http://www.japantimes.co.jp/news/2012/03/05/national/crackdown-o n-intellectual-property-piracy-pays-off/\#.U7btIo2SzX0.

76. LaMonica, M., Debating digital media's future, CNET, Sep. 18, 2003, at http://news.com.com/2100-1025-5079007.html.

77. Lankshear, C., Knobel, M., Digital Remix: The Art and Craft of Endless Hybridization, Keynote presented to the International Reading Association Pre-Conference Institute "Using Technology to Develop and Extend the Boundaries of Literacy", Toronto, 13 May 2007, 6-7, available at http://extendboundariesofliteracy.pbworks.com/f/remix.pdf.

78. Lele (乐乐), Bufen Zimuzu Shouru Da Baiwan Yuan Yingshi Wangluo Fanyi Quzhi Youdao (部分字幕组收入达百万元 影视网络翻 译取之有“道”) [Some Fansub Groups Make Millions a Year: Internet Visual Translation Reap with Their Way], Laodong Bao (劳动报 ) [LABOUR DAILY], Aug. 6, 2009, http://ld.eastday.com/1/20090806/u1a610796.html.

79. Li, H. (李含), Chou, F. (仇飞), Weihuo Shouquan Yanyi Zuopin Yeyou Zhuzuoquan (未获授权作品也有著作权) [Unauthorized creations can enjoy copyright protection as well], Fazhi Zhoumo (法 
治 周 末 ） [LegAL WeEKLY], Oct. 14, 2014, http://www.legalweekly.cn/index.php/Index/article/id/6143.

80. Li, J. (李佳梅), Du, M. (杜梅), Shizhixing Xiangsi Jia Jiechu Shi Panding Zuopin Qinquan de Hexin Biaozhun (“实质性相似加接触” 是判定作品侵权的核心标准) [“Substantial Similarity plus Access” is the core Standard in Copyright Infringement Judgement], in Zhongguo Fayuan Wang (中国法院网) [ChINACOURT.ORG], Feb. 11 , 2015 , at http://www.chinacourt.org/article/detail/2015/02/id/1554526.shtml.

81. Li, S. (李珊珊), Liu Cixin Rang Women Yangwang Xingkong Ba ( 刘慈欣 让我们仰望星空吧) [Liu Cixin Lets Look into the Sky], Nanfang Zhoumo (南方周末) [SoUTHERN WEEKLY], Jun. 26, 2012, http://www.infzm.com/content/59075.

82. Lin, L., As China Cracks Down on Illegal Videos, Lovers of Foreign TV Mourn, The Wall Street Journal, Nov. 25, 2014, at http://blogs.wsj.com/chinarealtime/2014/11/25/as-china-cracks-dow n-on-illegal-videos-foreign-tv-lovers-mourn/.

83. Lin, L., Korean TV Show Sparks Chicken and Beer Craze in China, The Wall Street Journal, Feb. 26, 2014, at http://blogs.wsj.com/chinarealtime/2014/02/26/korean-tv-show-spar ks-chicken-and-beer-craze-in-china/.

84. Lin, L., Venus De Milo, Scarlett Johannson Get Cropped After Chinese Cleavage Ban, The Wall Street Journal, Jan. 5, 2015, at http://blogs.wsj.com/chinarealtime/2015/01/05/venus-de-milo-scarle tt-johannson-get-photoshopped-after-chinese-cleavage-ban/.

85. Ling Jun (聆君), Jingwaiju Eryue Shiri Qian Xu Dengji Bude Chao Guochanju Baifenzhi Sanshi (境外剧 2 月 10 日前须登记 不得超国 产剧 30\%)[Foreign dramas must Register Before Feburary 10th and the Quota Shall be Limited to Local Production's 30\%], Xin Lang ( 新 浪 ) [SINA.COM], Jan. 21, 2015, at http://ent.sina.com.cn/v/u/2015-01-21/doc-icczmvun5286071.shtml.

86. Liu, J. No to Internet Piracy and Pornography, China Cracks Down on P2P Video Platform, ZDNET, Apr. 24, 2014, at http://www.zdnet.com/no-to-internet-piracy-and-pornography-chinacracks-down-on-p2p-video-platform-7000028693/.

87. Liu, J., Apple has Accepted Inspections in China: Report, ZDNET, Jan.

21, 2015, available 
http://www.zdnet.com/article/apple-has-accepted-censorship-in-chin a-report/.

88. Liu, L. (刘路), Zongju Yanjin Chouwen Lieji Zhe Fasheng Chujing Jiang Baohan Chugui (总局严禁丑闻劣迹者发声出镜 将包含“出 轨”) [SAPPRFT Says no Show for Practitioners with Scandal and Bad Reputation, "Unfaithful” may be Included], Xinhua Wang (新 华 网 ) [XINHUA NET], Oct. 24, 2014, at http://www.js.xinhuanet.com/2014-10/24/c_1112962178.htm.

89. Lu, F. (陆飞), Shipin wangzhan yinjin meiju shui shu shui ying? (视 频网站引进美剧谁输谁赢) [Video Platforms introduce American $T V$ series, Who's the Winner?], Beijing Qingnian Bao (北京青年报) [BeIJING Youth DAILY], Sep. 30, 2011, B11, available at http://bjyouth.ynet.com/3.1/1109/30/6305923.html.

90. Lu, H., China Demands Licenses for Overseas Series Streaming, XINHUA News, Sep. 5, 2014, at http://news.xinhuanet.com/english/china/2014-09/05/c_133624057.h tm.

91. Makoto, F., Spurious Revival: Doraemon's 'Final' Fanzine Episode Ignites Copyright Alarms, DAILY YOMIURI, Jun. 17, 2007, reprinted at

http://www.nationmultimedia.com/2007/07/08/lifestyle/lifestyle_300 39868.php.

92. Maney, K., If Pirating Grows, It May Not Be the End of Music World, USA TODAY, May. 3, 2005, at http://usatoday30.usatoday.com/tech/columnist/kevinmaney/2005-05 -03-music-piracy-china_x.htm.

93. Manuel, K. M., The Google Library Project: Is Digitization for Purposes of Online Indexing Fair Use Under Copyright Law?, CRS REPORT FOR CONGRESS, Nov. 27, 2009, at http://www.dtic.mil/dtic/tr/fulltext/u2/a511070.pdf.

94. Marquand, R., A Spoof Hits China's Web-and a Star is Born, THE CHRISTIAN SCIENCE MONITOR, Mar. 13, 2006, at http://www.csmonitor.com/2006/0313/p01s03-woap.html.

95. Masnick, M., WIPO is Quietly Signing an Agreement to Give Hollywood Stars Their Own Special Version of Copyright, TECHDIRT, Jun. 26, 2012, at https://www.techdirt.com/articles/20120625/20471219474/wipo-is-q 
uiet-

ly-signing-agreement-to-give-hollywood-stars-their-own-special-ver sion-copyright.shtml.

96. Mentel, T., China's Film Industry Takes Measures to Compete with Hollywood, MOVIESCHEATSHEET, Jun. 20, 2014, available at http://wallstcheatsheet.com/entertainment/chinas-film-industry-takes -measures-to-compete-with-hollywood.html/?a=viewall.

97. Metz, W. F., How TV Production Works, HowStufFWorks.com, Nov. 29 , 2007 , at http://electronics.howstuffworks.com/tv-production.htm.

98. Meyer, S., Versatile Video CD's Get a Foothold in US, N.Y. TimES, Apr. 26, 2001, at http://www.nytimes.com/2001/04/26/technology/versatile-video-cds-get-a-foothold-in-us.html.

99. Ministry of Education, Culture, Sports, Science And TeChNology, JaPANese Government Policies in Education, SCIENCE, SPORTS AND CUlTURE (2000), http://www.mext.go.jp/b_menu/hakusho/html/hpae200001/hpae2000 012 079.htm.

100. Mischievious Studios, Gotham Style, YouTuBe, at https://www.youtube.com/watch?v=YSsCU3FcOkw.

101. Moody, G., Psy Makes \$8.1 Million by Ignoring Copyright Infringements of Gangnam Style, TECHDIRT, Dec. 10, 2012, at https://www.techdirt.com/blog/casestudies/articles/20121209/07431 921317/psy-makes-81-million-ignoring-copyright-infringements-gan gnam-style.shtml.

102. Moses, R. L., Lurking in Mao's Shadow, China's Xi Looks Undecided on Reforms, The Wall Street Journal, Oct. 20, 2014, at http://blogs.wsj.com/chinarealtime/2014/10/20/lurking-in-maos-shad ow-chinas-xi-looks-indecisive-on-reforms/.

103. Mozur, P., Burkitt, L., China Won't Tune Out All U.S. TV Shows, Executive Says, The Wall Street Journal, Apr. 28, 2014, at http://blogs.wsj.com/chinarealtime/2014/04/28/china-wont-tune-outall-u-s-tv-shows-executive-says/.

104. Mozur, P., China Forces Four U.S. TV Shows Off Web 'Big Bang Theory' and 'Good Wife' Are Among Programs Taken Down, THE WALL STREET JOURNAL, Apr. 28, 2014, at http://www.wsj.com/articles/SB10001424052702304163604579527 683976216624. 
105. MPAA Statement on Strong Showing of Support for Stop Online Piracy Act, MPAA, Dec. 16, 2011, at http://www.mi2n.com/print.php3?id=149522.

106. MPAA, Re: Request for Public Comment on the 2014 Special 301 Out of Cycle Review of Notorious Markets, Docket No. USTR-2014-0017, MPAA, Oct. 24, 2014, at http://www.mpaa.org/wp-content/uploads/2014/10/MPAA-Filing-toUSTR-on-Worlds-Most-Notorious-Markets.pdf.

107. MPAA, Theatrical Market Statistics 2013, available at http://www.mpaa.org/wp-content/uploads/2014/03/MPAA-Theatrica 1-Market-Statistics-2013 032514-v2.pdf.

108. Mundy, S., North Korea: Glimmer of hope, Financial Times, Mar. 11 , 2014 , http://www.ft.com/intl/cms/s/2/f3a5c48c-a94a-11e3-9b71-00144feab 7de.html\#axzz2wPJefHUi.

109. Murphy, S. G., Grays, DeviantART Blog (Feb. 18, 2012, 10:57:22 PM), http://seangordonmurphy.deviantart.com/journal/Grays-285895348.

110. Nagata, K., Copyright Law with Teeth Leaves Download Masses Puzzled, JAPAN TIMES, Jul. 11, 2012, available at http://callcenterinfo.tmcnet.com/news/2012/07/11/6430387.htm.

111. Newth, M., The Long History of Censorship, BEACON FOR FREEDOM OF EXPRESSION, 2010, at http://www.beaconforfreedom.org/liste.html?tid=415\&art_id=475.

112. Online Copyright Infringement Tracker Benchmark Study Q3 2012, OfCOM, Nov. 20, 2012, at http://stakeholders.ofcom.org.uk/market-data-research/other/telecom s-research/copyright-infringement-tracker/.

113. Osnos, E., "Prison Break" catches on in China, The SeAtTle TIMES, Jan. 25, 2007, at http://seattletimes.com/html/nationworld/2003540226_chinatv24.ht $\mathrm{ml}$.

114. Otake, T., Music Industry Wins a Battle as Antidownloading Bill Gets Some Teeth, JAPAN TIMES, June 21, 2012, http://www.japantimes.co.jp/culture/2012/06/21/culture/music-indus try-wins-a-battle-as-antidownloading-bill-gets-some-teeth/.

115. Overloaded Courts, Not Enough Judges: The Impact on Real People, PFAW, July 21, 2014, at http://www.pfaw.org/sites/default/files/lower_federal_courts.pdf. 
116. Pan-European Laboratory Infrastructure Implementation, Considerations on user driven innovation (1st version), Deliverable D1.2, PII CONSORTIUM

REPORT, 2009 , http://www.panlab.net/fileadmin/documents/PII-Deliverables/D1.2Considerations_on_user_driven_innovation_1st_version_v1.0.pdf.

117. Pappas, L., China Hears Music, Issues Second Draft of Copyright Law, BlOOMBERG BNA, Jul. 12, 2012, at http://www.bna.com/china-hears-music-n12884910625/.

118. Pettingill, L., Engagement 2.0? How the new digital media can invigorate civic engagement, Goodwork Project Paper Series, Sep. 2007 ,

https://www.thegoodproject.org/pdf/50-Engagement-2.0.pdf.

119. Philips System Standards and Licensing, Super Video Compact Disc, A Technical Explanation, 1998, at 2, at http://www.datv.de/technische_Infos/SVCD.pdf.

120. Piller, C., How Piracy Opens Doors for Windows, Los Angeles TIMES, Apr. 9 , 2006 , at http://articles.latimes.com/2006/apr/09/business/fi-micropiracy9.

121. Pollack, W., Will Volunteers Replace Paid Workers? WSJ Blogs: THE INFORMED READER, Feb. 16, 2007, http://blogs.wsj.com/informedreader/2007/02/16/will-volunteers-repl ace-paid-workers/.

122. Popking161, I Love Beijing Style, YouTuBE, at https://www.youtube.com/watch?v=z7xfAfa4W7E.

123. Press Release, Guojia Guangbo Dianshi Zong Ju (国家广播电视总 局) [St. Admin. Radio, Film \& Television], Guangdianzongju Jiang Tuidong Yingshi Donghua Chanye Fazhan (广电总局将推动影视 动画产业发展) [SARFT Will Promote the Development of the Animation Industry], Mar. 5, 2008, http://www.chinasarft.gov.cn/articles/2008/03/05/200803051421343 90111.html.

124. Press Release, Japanese Society for Rights of Authors, Composers and Publishers, Open Letter to Chad Hurley, CEO, and Steve Chen, CTO, YouTube, Dec. 4, 2006, available at http://www.jasrac.or.jp/release/06/12_2.html.

125. Preston, J., Georgia Tech Study Reveals Copyright Complexities, Social Norms in Online Media Creation, Georgia TeCH News CENTER, Feb. 19, 2014, at 
http://www.news.gatech.edu/2014/02/18/georgia-tech-study-revealscopyright-complexities-social-norms-online-media-creation.

126. Psy Gangnam Styles His Way to the Bank in China, WANTCHINATIMES, Feb. 6, 2013, at http://www.wantchinatimes.com/news-subclass-cnt.aspx?id=201302 $06000001 \&$ cid $=1304$.

127. Qin, H. (秦宏), Lu, C. (鲁畅), Guanli Bumen shi Wangyou Yitouwushui (管理部门使网友一头雾水) [Netizens are Confused by the Administrative Department], Fenghuang Wang (凤凰网) [IFENG.COM], Jan. 5, 2015, at http://news.ifeng.com/a/20150105/42863346_0.shtml?_share=sina\& $\mathrm{tp}=1420387200000$.

128. Quintais, J. P., de Leeuw, A., Downloading from Unlawful Sources. Reflections following the Villalón Opinion on AciAdam and Others, Kluwer Copyright Blog, Feb. 27, 2014, at http://kluwercopyrightblog.com/2014/02/27/downloading-from-unla wful-sources-reflections-following-the-villalon-opinion-on-aciadamand-others/.

129. Raven, F., Copyright and Public Goods: An Argument for Thin Copyright Protection, $8 \mathrm{M} / \mathrm{C}$ JOURNAL (2005), at http://journal.media-culture.org.au/0507/06-raven.php.

130. Reid, R., The $\$ 8$ billion iPod, Ted Conversations, Mar. 2012, at http://www.ted.com/talks/rob_reid_the_8_billion_ipod.html.

131. Report Q175 in the name of the Japanese Group, The Role of Equivalents and Prosecution History in Defining the Scope of Patent Protection, AIPPI, at https://www.aippi.org/download/commitees/175/GR175japan.pdf.

132. Report: Movie Piracy Nearing Music Levels, Media Life MagaZINE, Jul. 14, 2004, http://www.medialifemagazine.com:8080/news2004/Jul04/Jul12/3_ wed/news8wednesday.html.

133. Rich, M., Stone, B., E-Book Price Increase May Stir Readers' Passions, N.Y. TIMES, Feb. 10, 2010, http://www.nytimes.com/2010/02/11/technology/11reader.html?_r=0

134. Roettgers, J., EU Sponsors P2P TV with 14M Euros, GigAOM, Feb. 9, 2008, at http://gigaom.com/video/eu-sponsors-p2p-tv-with-19m-euros/. 
135. Schell, O., Person of the Year 2007: Hu Jintao, TIME, Dec. 19, 2007, at http://content.time.com/time/specials/2007/personoftheyear/article/0, 28804,1690753_1695388_1695753,00.html.

136. Schonfeld, E., Post-Napster, Peer-to-Peer Computing Gets Ready for Prime Time, ForTune, 25, Oct. 2001.

137. Schulze, H., Mochalski, K., Internet Study 2008/2009, IPOQUE, at https://www.christopher-parsons.com/Main/wp-content/uploads/200 9/04/ipoque-internet-study-08-09.pdf.

138. SFTHQ, Tibetans vs China's Xi Jinping: Gangnam Style, YouTuBE, Nov. 7, 2012, at https://www.youtube.com/watch?v=NxxEo61EC_U.

139. Shao, H., Animation Start-up 'Light Chaser' Scores Big Hit in China with First Short Film, FORBES, Mar. 27, 2014, available at http://www.forbes.com/sites/hengshao/2014/03/27/animation-start-u p-light-chaser-scores-big-hit-in-china-with-first-short-film/.

140. Shen, J., Faster broadband by 2015, ChinA DAILY, Aug. 18, 2013, at

http://usa.chinadaily.com.cn/china/2013-08/18/content_16902042.ht $\mathrm{m}$.

141. Shen, L. (沈亮), “Tanmi Saohuang Dafei Ban” (探秘扫黄打非办) [Investigating the Saohuang Dafei Office], Nanfang Zhoumo (南方 周 末 ) [SOUTHERN WEEKLY], Jan. 21, 2010, at http://www.infzm.com/content/40655.

142. Shi, X. (师小涵), Guo, S. (郭宋立), Minying Dianshitai de Haiwai Shengcun (民营电视台的海外生存) [The Chinese Private-run TV stations are Making a Living in Foreign Countries], Nanfang Zhoumo (南方周末) [SOUTHERN WEEKLY], Oct. 14, 2013, http://www.infzm.com/content/94935.

143. Siklos, R., Why Disney wants DreamWorks, CNN/Money, Feb. 09, 2009.

http://money.cnn.com/2009/02/09/news/companies/disney_dreamwo rks.fortune/?postversion $=2009020914$.

144. Solomon, C., File Share and Share Alike, N.Y. Times, Aug. 21, 2005, http://www.nytimes.com/2005/08/21/arts/21solo.html.

145. Starrett, B., The History of $C D-R$, Roxio Newsletters, Jan. 17, 2000, at http://mediajet.ru/history-cd-r/.

146. Statistical Report on Internet Development in China, CHINA INTERNET NETWORK INFORMATION CENTER, Jan. 2014, at 
http://www1.cnnic.cn/IDR/ReportDownloads/201404/U0201404176 07531610855.pdf.

147. Stevens, A., The Chinese Are Pissed That Koreans Called Them Dumb for Watching Korean Dramas, Shanghaist, Mar. 22, 2014, at

http://shanghaiist.com/2014/03/22/chinese-say-we-are-not-stupid-for -watching-korean-dramas.php.

148. Stevens, A., The Chinese Obsession with Korean Dramas is Making Bad Chinese TV Look Bad, SHANGHAIIST, Mar. 3, 2014, at http://shanghaiist.com/2014/03/03/chinese-obsession-korean-dramas .php.

149. Strauss, K., TV and Film Piracy: Threatening an Industry?, ForBES, Mar. 6 , 2013 , at http://www.forbes.com/sites/karstenstrauss/2013/03/06/tv-and-filmpiracy-threatening-an-industry/.

150. Sun, B. (孙冰), Meiju Xiajia Guangdian Zongju Cheng Bu Jieshou Caifang: Bushi Suoyou Xinxi Ke Gongkai (美剧下架广电总局称不 接受采访: 不是所有信息可公开) [SAPPRFT refused to give comments on the taken down of the U.S. shows, claimed that not all information could go public], Renmin Wang (人民网) [PEOPLE.COM.CN], May 13, 2014, at http://media.people.com.cn/n/2014/0513/c14677-25010185.html.

151. Supreme People's Court (最高人民法院), Zhongguo Fayuan Zhishi Chanquan Sifa Baohu Zhuangkuang 2013 (中国法院知识产权司法 保护状况 2013) [Intellectual Property Protection by Chinese Courts in 2013], in Renmin Fayuan Bao (人民法院报) [PEOPLE'S COURT DAILY], Apr. 26, 2014, available at http://rmfyb.chinacourt.org/paper/html/2014-04/26/content_81363.ht $\mathrm{m}$ ?div $=-1$.

152. Szalai, G., Tsui, C., U.K.'s Pinewood Shepperton, China's Seven Stars Ink Joint Venture Deal, The Hollywood Reporter, Apr. 17, 2013, http://www.hollywoodreporter.com/news/pinewood-shepperton-chin as-seven-stars-440687.

153. Tabuchi, H., Why Japan's Cellphones Haven't Gone Global, N.Y. TIMES, July 19 , 2009 , http://www.nytimes.com/2009/07/20/technology/20cell.html. 
154. Tanaka, T., Does File Sharing Reduce Music CD Sales? A Case of Japan Version 0.1, CONFERENCE ON IT INNOVATION HITOTSUBASHI UNIVERSITY, Dec. 13, 2004, at http://core.ac.uk/download/pdf/6451470.pdf.

155. Teodosio, L., Os 20 mangás mais vendidos de todos os tempos, LITERATORTURA, Jun. 9, 2014, at http://literatortura.com/2014/06/os-20-mangas-mais-vendidos-de-tod os-os-tempos/11.

156. The ABC of Copyright, UNESCO Culture SeCtor, at http://www.unesco.org/fileadmin/MULTIMEDIA/HQ/CLT/diversity /pdf/WAPO/ABC_Copyright_en.pdf.

157. The Term of Use, Fansub-share.org, http://fansub-share.org/tou/.

158. The Truth Behind Shogakukan's Agressiveness Toward Doraemon Doujinshi?, COMIPRESS, Jul, 29, 2007, at http://comipress.com/news/2007/07/29/2393.

159. Tiezzi, S., Xi Jinping Leads China's New Internet Security Group, The Diplomat, Feb. 28, 2014, at http://thediplomat.com/2014/02/xi-jinping-leads-chinas-new-internet -security-group/.

160. TLF History-the Memoirist of the TLF Fansub Group, The TLF Fansub Group Official Site, http://sub.eastgame.org/wp-content/uploads/2011/03/\%E4\%BA\%86 $\%$ E8\%A7\%A3TLF\%E5\%AD\%97\%E5\%B9\%95\%E7\%BB\%84-TL F\%E5\%85\%83\%E8\%80\%81\%E5\%9B\%9E\%Е5\%BF\%86\%Е5\%BD $\% 95 . p d f$.

161. TOEI Animation Co., Presentation for The Third Quarter Period of FY Ending March 2011, (April 2010-December 2010 at 6-2, http://corp.toei-anim.co.jp/pdf/201103_3Q_presen_e.pdf.

162. Tokyo Anime Center Posts "Stop! Fan-Subtitle" Notice, Anime News Network, Mar. 29, 2008, http://www.animenewsnetwork.com/news/2008-03-29/tokyo-animecenter-posts-stop-fan-subtitle-notice.

163. Tudou Announces Exclusive License Agreement with TV Tokyo to Simulcast Japanese Anime, PR NEWSWIRE, Nov. 28, 2011, http://en.prnasia.com/pr/2011/11/28/USCN1281911.shtml.

164. U.S.-China Trade: Preparations for the J. Commission on Commerce and Trade: Hearing Before the Subcomm. on Commerce, Trade, and Consumer Protection, of the H. Comm. on Energy and Commerce, 108th Cong. 45-55 (2004), at 
http://www.gpo.gov/fdsys/pkg/CHRG-108hhrg93302/html/CHRG-1 08hhrg93302.htm.

165. Verdict against Liu Xiaobo, Dec. 25, 2009, translated at USC US-CHINA INSTITUTE, http://china.usc.edu/ShowArticle.aspx?articleID=2319\&AspxAutoD etectCookieSupport=1.

166. VeryCD Qi Si Hui Sheng Qi Qishi: Zhuan Xing Wang Ye You Xi Yue Shou Ru Guo Yi (VeryCD 起死回生启示: 转型网页游戏月收入过 亿) [The Inspiration of VeryCD: Making Hundreds of Millions After Transforming], Wang Yi 163(网易 163) [NETEASE], Jan. 13, 2012, at http://tech.163.com/12/0114/09/7NNH9TGK000915BF.html (China).

167. Vitorino, A., Recommendations Resulting from the Mediation on Private Copying and Reprography Levies, Brussels, Jan. 31, 2013, at http://ec.europa.eu/internal_market/copyright/docs/levy_reform/130 131_levies-vitorino-recommendations_en.pdf.

168. Walker, L., Uncle Sam Wants Napster! ThE WAshington Post, Dec. 8 , 2001, http://pqasb.pqarchiver.com/washingtonpost/doc/409185410.html?F $\mathrm{MT}=\mathrm{ABS} \& \mathrm{FMTS}=\mathrm{ABS}: \mathrm{FT} \&$ date $=\mathrm{Nov}+8 \% 2 \mathrm{C}+2001 \&$ author $=\mathrm{Wal}$ ker\%2C+Leslie\&desc $=$ Uncle + Sam + Wants + Napster $\% 21$.

169. Wang Feng Bans Grass-root Duo Xuriyanggang Singing His Song, ASIANBITE, Feb. 13, 2011, at http://www.asianbite.com/post/Wang-Feng-Bans-Grass-root-Duo-X uriyanggang-Singing-His-Song-news-3759.

170. Wang, J., Looking to the Cosmos, Shanghai DaILy, Feb. 21, 2014, at http://www.shanghaidaily.com/feature/Looking-to-the-cosmos/shdai ly.shtml.

171. Wang, S. (王珊珊), Zhongguo Shipin Wangzhan yu Guangdian Zongju de Maoshu Youxi(中国视频网站与广电总局的“猫鼠游戏 ") [The "cat and mouse game" between the Chinese online streaming service providers and SAPPRFT], Niuyue Shibao Guoji Shenghuo (纽约时报国际生活)[CN.TMAGAZINE.COM], Apr. 30, 2014, at http://cn.tmagazine.com/film-tv/20140430/tc30shows/.

172. Wang, Y., Civic Engagement and Motivation Factors of Participants in SNAPSHOT, an Online Anti-Human Trafficking Initiative in Chi$n a$, Center for Public Policy Administration Capstones. Paper 1, 
available

http://scholarworks.umass.edu/cgi/viewcontent.cgi?article=1015\&co ntext=cppa_capstones.

173. Watt, L., China Video Site: US TV Show Ban Not Policy Change, The Washington Times, Apr. 28, 2014, at http://www.washingtontimes.com/news/2014/apr/28/china-video-sit e-us-tv-show-ban-not-policy-change/.

174. Wee, S., Sexy China TV drama busted, returns to air more sedate, REUTERS, Jan. 3, 2015, at http://www.reuters.com/article/2015/01/03/china-television-idUSL3 N0UI04P20150103.

175. Wending Yadao Yiqie (稳定压倒一切) [Stability is of overriding importance], Renmin Wang (人民网) [PEOPLE.COM.CN], at http://cpc.people.com.cn/GB/64162/64170/4467121.html.

176. WhatsUpELLE, Baby Gangnam Style Parody, YouTuBe, at https://www.youtube.com/watch?v=7iheCrwQQII.

177. Wolff, E., Foreign Toonmakers Eye U.S. Market: Language, Marketing Costs Make America a Tough Nut to Crack, VARIETY, June 5, 2011, http://www.variety.com/article/VR1118037712.

178. Wortham, J., Public Outcry Over Antipiracy Bills Began as Grass-Roots Grumbling, N.Y. TIMES, Jan. 19, 2012, at http://www.nytimes.com/2012/01/20/technology/public-outcry-overantipiracy-bills-began-as-grass-roots-grumbling.html?_r=0.

179. WTO Appellate Body Confirms Finding Against China's Treatment of Certain Copyright-Intensive Products, Office of the United States Trade Representative, Dec. 2009, at http://www.ustr.gov/about-us/press-office/press-releases/2009/dece mber/wto-appellate-body-confirms-finding-against-china.

180. Wu, T., Network Neutrality FAQ, at http://www.timwu.org/network_neutrality.html.

181. Xue, H., A User-Unfriendly Draft: 3rd Revision of the Chinese Copyright Law, INFOJUSTICE.ORG, Apr. 25, 2012, http://infojustice.org/wp-content/uploads/2012/04/hongxue042012.p df.

182. Xunlei declaration, XUNLEI.COM, at http://act.vip.xunlei.com/vip/2014/report/.

183. Yan, S., Lights, Camera, Captions!, Global Times, Mar. 18, 2012, at http://www.globaltimes.cn/content/700857.shtml. 
184. Yang, D. (杨涤尘), Wang, J. (王加喜), Meiju Hanju yu Riju You Yiqun Zhuijuren Jiao Zimuzu(美剧韩剧与日剧有一群追剧人叫字 幕组) [There are a group of people who chase American, Korean, and Japanese dramas called fansub groups], Jing Bao (晶报)[DAILY Sunshine], Aug. 14, 2013, at http://jb.sznews.com/html/2013-08/14/content_2587842.htm.

185. You, Y., Does Tudou.com Require Permission for the Use of YYeTs' Unauthorized Subtitle Translation in China?, BRIDGE IP LAW COMMENTARY, Oct. 10 , 2014, at http://www.chinaiplawyer.com/does-tudou-com-require-permissionuse-YYeTs-unauthorized-subtitle-translation-china/.

186. Yu, P. K., Complex Guoqing And Intellectual Property Reforms In China, Peteryu.com, at http://www.peteryu.com/guoqing.pdf.

187. ZDNet Research for IT Facts, $61.44 \%$ of P2P Traffic is Video, $11.34 \%$ is Audio, http://www.zdnet.com/blog/itfacts/61-44-of-p2p-traffic-is-video-1134-is-audio/8641.

188. Zhang, K. (张柯), Kan Dian Kanbudong de Dongxi (看点看不懂的 东西) [See Something that You Could Not Understand], Renmin Ribao（人民日报） [PeOPLE's DAILY], Jan. 16, 2015, at http://paper.people.com.cn/rmrb/html/2015-01/16/nw.D110000renm rb_20150116_5-05.htm.

189. Zhang, M. (张墨宁), “Daohuo” de zimu zu (“盗火”的字幕组) [Fansub Groups that “Steal Fire”], in Nan Feng Chuang (南风窗) [SOUTH WiNDS], Oct. 19, 2013, available at http://mobile.nfcmag.com/article/4319.html.

190. Zhang, S. (张书乐), Zumu Zu de Huise jianghu (字幕组的灰色江湖 ) [The Grey Coterie of Fansub Groups], Tai Mei Ti (钛媒体) [TMTPOST.COM], Dec. 9, 2013, http://www.tmtpost.com/82623.html (China).

191. Zhang, X. (张雪静), Sohu shipin jiang daliang yinjin meiju shishui meizong (搜狐视频将大量引进美剧 试水美综) [Sohu Video will introduce Massive mount of American TV series, and will test the waters of American variety shows], www.lmtw.com (流媒体网) [STREAMING MEDiA NET], Feb. 19, 2014, at http://sm.lmtw.com/dongtai/201402/101032.html (last visited Jun. $18,2014)$. 
192. Zhang, Y. (张英), Haolaiwu Zhizuoren Maike Maidewo Jiangshu Dianying Guilu (好莱坞制片人迈克·麦德沃讲述电影规律) [ Hollywood Producer Mike Medavoy on the Rule of Film], Nanfang Zhoumo (南方周末) [SOUTHERN WeEKLY], Jul. 14, 2012, http://www.infzm.com/content/78431.

193. Zhao, L. (赵力), Renren Yingshi Yongjiu Guanbi Beihou de Gushi ( 人人影视永久关闭背后的故事) [The Story Behind the Shut Down of the YYeTs], Xin Jing Bao (新京报) [The BEIJING News], Dec. 21, 2014 , available at http://help.3g.163.com/14/1221/09/ADVSD28A00963VRO.html.

194. Zhou. Y. (周豫), Guochan Yingshi Ju Heshi Paichu Xingni Zhipaiwu (国产影视剧何时拍出《星你》《纸牌屋》? ) [When Can Our Own Industry Produce Something Equal to "My Love from Another Star" and “House of Cards"?], Nanfang Ribao (南方日报) [NANFANG DAILY], Mar. 12, 2014, A08, at http://epaper.southen.com/nfdaily/html/2014-03/12/content_728171 9.htm.

195. Zou, J. (邹捷), Yuan, J. (袁建彰), Zimuzu Laodong Guoshi Bei Daoban Shang Qiequ (字幕组劳动果实被盗版商窃取) [Fansub Groups' Fruit of Labour are being Stolen by Commercial Pirates], Xinxishibao (信息时报) [INFORMATION TimES], Dec. 11, 2009, at http://tech.sina.com.cn/i/2009-12-11/09183669753_2.shtml.

\section{Cases:}

1. A\&M Records, Inc. v. Napster, Inc., 239 F.3d 1004 (9th Cir. 2001).

2. Adams v. Burke, 84 U.S. (17 Wall.).

3. Aimster Copyright Litigation, 334 F.3d 643 (7th Cir. 2003), cert. denied, 540 U.S. 1107 (2004).

4. Authors Guild v. Google, Inc., 77o F. Supp. 2d 666 (S.D.N.Y. 2011).

5. Beijing Ciwen Yingshi Zhizuo Youxian Gongsi Su Beijing Zhenglejia Keji Youxian Gongsi Qinfan Zhuzuoquan Jiufen An(北 京慈文影视制作有限公司诉北京正乐佳科技有限公司侵犯著作 权纠纷案) [Beijing Ciwen Video Production Co., Ltd. v. Beijing Zhenglejia Technology Co., Ltd.], (People's Ct. of Haidian District, 
Beijing, HMCZ.No.21822, Oct. 29, 2007) (北京市海淀区人民法院 (2007)海民初字第 21822 号) (China).

6. Bridgeport Music, Inc. v. Dimension Films, 410 F.3d 792 (6th Cir. 2005).

7. Campbell v. Acuff-Rose Music, 510 U.S. 569 (1994).

8. Case C-435/12, ACI Adam BV and Others v Stichting de Thuiskopie and Stichting Onderhandelingen Thuiskopie vergoeding, Apr. 10, 2014 ,

http://curia.europa.eu/juris/document/document.jsf?text=\&docid=15

$0786 \&$ pageIndex $=0 \&$ doclang $=E N \&$ mode $=1$ st\&dir $=\&$ occ $=$ first $\&$ part

$=1 \&$ cid $=384493(\mathrm{EU})$.

9. Castle Rock Entertainment, Inc. v. Carol Publishing Group, Inc. 150 F.3d 132 (2d Cir. 1998).

10. Columbia Broadcasting Systems., Inc. v. DeCosta, 377 F.2d 315, 321, 153 U.S.P.Q. 649, 654 (1st Cir. 1967), cert. denied, 389 U.S. 1007, 10 L.Ed.2d. 603, 88 S. Ct. 565 (1967).

11. Dr. Seuss Enters. v. Penguin Books USA, Inc., 109 F.3d 1394 (9th Cir. 1997).

12. Effects Assocs., Inc. v. Cohen, 908 F.2d 555 (9th Cir. 1990).

13. Eldred v. Reno, 239 F.3d 375 (D.C. Cir. 2001).

14. Eldred v. Ashcroft, 537 U.S. 186 (2003).

15. Famous Music Corp. v. Bay State Harness Horse Racing \& Breeding Ass'n. Inc., 423 F. Supp. 341 (D. Mass. 1976). aff'd, 554 F.2d 1213 (1st Cir. 1977).

16. Field v. Google, Inc., 412 F.Supp.2d 1106 (D. Nev. 2006).

17. Fitzgerald Publishing Co. v. Baylor Publishing Co., 807 F2d 1110 (2d Cir 1986).

18. Grand Upright Music v. Warner Bros. Records, 780 F. Supp. 182 (S.D.N.Y. 1991).

19. Google Bildersuche - Thumbnails rechtlich zulässig, LG Erfurt, Urteil vom 15.3.2007, Az 3 O 1108/05 (Germany).

20. "Google Image Search" German Federal Supreme Court, Apr. 29, 2010. Case IZR 69/08, [2010] GRUR 628 (Germany).

21. Guangdong Zhongkai Wenhua Fazhan Youxian Gongsi Su Guangzhou Shulian Ruanjian Jishu Youxian Gongsi An (广东中凯文化发 展有限公司诉广州数联软件技术有限公司案) [Zoke Culture Group, Limited. v. Poco Co., Ltd.], (Shanghai First Interm. People's 
Ct., IPF.No.384, Dec. 12, 2006) (上海市第一中级人民法院(2006) 沪一中民五（知）初字第 384 号) (China).

22. Hampton v. Paramount Pictures Corp., 279 F.2d 100 (9th Cir. 1960).

23. Harmony Gold U.S.A. Inc. v. FASA. Corp., 40 U.S.P.Q.2d 1057 (N.D. III. 1996).

24. Heilongjiang Jin Nong Xinxi Jishu Youxian Gongsi Yu Beijing San Mian Xiang Banquan Daili Youxian Gongsi Ji Haerbin Lang Xin Keji Fazhan Youxian Gongsi Qinfan Zhuzuoquan Jiufen Yi An (黑 龙江金农信息技术有限公司与北京三面向版权代理有限公司及 哈尔滨朗新科技发展有限公司侵犯著作权纠纷一案) [Heilongjiang Jinnong Information Technology Co. Ltd. v. Beijing 3rd Mianxiang Banquan Agency Limited Company and Haerbin Langxin Technology Development Co. Ltd.], (Higher People's Ct. of Heilongjiang Province, Heizhizhongzi no.4 decision, Dec. 10, 2008) (黑龙江省高级人民法院 [2008］黑知终字第 4 号民事判决书) (China).

25. Huaxia Shilian Konggu Youxian Gongsi Su Kuaibo Gongsi Lijun Qinfan Zhuzuoquan Jiufen An(华夏视联控股有限公司诉快播公司 、李军侵犯著作权纠纷案) [Huaxia Video \& Connection Holding Co., Ltd. v. Shenzhen Qvod Technology Co., Ltd.], (People's Ct. of Futian Dist., Shenzhen, SFFZCC.No.227, 2009)(深圳市福田区人民 法院(2009)深福法知产初字第 227 号) (China).

26. I.A.E., Inc. v. Shaver, 74 F.3d 768 (7th Cir. 1996).

27. K.K. Matsudera v. King Features Syndicate, Inc., Saikō Saibansho [Sup. Ct.] Jul. 17, 1997, 1992 (O) No. 1443 (Japan).

28. Keiko Nagita v. Yumiko Igarashi, Saikō Saibansho [Sup. Ct.] Oct. 25, 2001, Case No. 798 (Ju) of 2000 (Japan).

29. Keane Dealer Servs. v. Harts, 968 F.Supp. 944 (S.D.N.Y. 1997).

30. Landgericht Hamburg, Urteil vom 5.9.2003, Aktenzeichen: $308 \mathrm{O}$ 449/03 (Germany).

31. Lyons Partnership, LP v Morris Costumes, Inc., 243 F3d 789 (4th Cir 2001).

32. Meiguo Woerte Disini Gongsi su Beijing Chubanshe Deng Qinfan Zhuzuo Quan Jiufen An (美国沃尔特·迪斯尼公司诉北京出版社等 侵犯著作权纠纷案) [Walt Disney Co. v. Beijing Publ'n], SuP. People's Ct. Gaz., 1996, at 136 (Beijing Higher People's Ct. Dec. 19, 1995) (China). 
33. Metro-Goldwyn-Mayer v. American Honda Motor Co., 900 F. Supp. 1287 (C.D. Cal. 1995).

34. Metro-Goldwyn-Mayer Studios, Inc. v. Grokster Ltd., 380 F.3d 1154 (9th Cir. 2004).

35. MGM Studios, Inc. v. Grokster, Ltd., 545 U.S. 913 (2005).

36. Nichols v. Universal Pictures Corporation, 45 F.2d 119, 121, 7 U.S.P.Q. at 87 (2d Cir. 1930).

37. Nihon keizai Shimbun Inc. v. Comline Bus Data Inc. 166 F.3d 65 (2d Cir. 1999).

38. Padawan v. SGAE, C-467/08 of 21 October 2010, [2010] ECR I-10055 (European Union).

39. Popeye Necktie Case, Supreme Court, 17 July 1997, Minshu Vol. 51 No. 6: 2714 (Japan).

40. Precision Instrument Manufacturing Co. v. Automotive Maintenance Machinery Co., 324 US 806 (1945).

41. Quinn v. City of Detroit, 23 F. Supp.2d 741 (E.D. Mich. 1998).

42. Reno v. ACLU, 521 U.S. 844 (1997).

43. Roberto Hevia, Estate of v. Portrio Corp., 602 F.3d 34, 94 U.S.P.Q.2d 1501 (1st Cir. 2010).

44. Salinger v. Colting, 641 F. Supp. 2d 250 (S.D. N.Y. 2009).

45. SmithKline Beecham Consumer Healthcare, L.P. v. Watson Pharms., Inc., 211 F.3d 21 (2d Cir. 2000).

46. Sony Corp. of America v. Universal City Studios, Inc., 464 U.S. 417 (1984).

47. Stewart v. Abend, 495 U.S. 207 (1990).

48. Suntrust Bank v. Houghton Mifflin Co., 268 F.3d 1257 (11th Cir. 2001).

49. Kewpie Doll Case, Tokyo High Court, 30 March 2001, Hanrei Jiho No. 1797: 111 (Japan).

50. Tokimeki Memorial Case, Saikō Saibansho [Sup. Ct., 3d Petit Bench] Feb. 13, 2001, 1999 (RECEIPT) No.955 (Japan).

51. Twentieth Century Music Corp. v. Aiken, 422 U.S. 151 (1975).

52. Walt Disney Productions v. Air Pirates, 581 F.2d 751 (9th Cir. 1978).

53. Warner Bros. Entm't Inc. v. RDR Books, 575 F. Supp. 2d 513 (S.D.N.Y. 2008).

54. Yuangu Zhizuo Zhushi Huishe Su Shanghai Yuyuan Guoji Shangcheng Gouwu Zhongxin Youxian Gongsi (圆谷株式会社诉上海豫 
园公司案) [Tsuburaya Productions. v. Shanghai Yuyuan Co.], SElected Cases of the People's Court, 2003, at 333 (Shanghai Higher People's Ct. Sep. 11, 2000) (上海市高级人民法院民事判决 书沪高知终字第 43 号) (China).

55. Zhuang $\mathrm{Yu} \mathrm{Yu}$ Guo Jingming Chunfeng Wenyi Chubanshe Zhuzuoquan Qinquan Jiufen An (庄羽与郭敬明、春风文艺出版社 著作权侵权纠纷案) [Zhuang Yu v. Guo Jingming \& Chunfeng Press], (Higher People's Ct. of Beijing, GMZZ.No.384, May. 22, 2006)(北京市高级人民法院(2005)高民终字第 539 号) (China).

\section{National Legislations and Regulatory Documents:}

1. Baozhang Chuban Wu Zhuzuo Quan Zanxing Guiding Caoan (保障 出版物著作权暂行规定草案) [Provisional Rules on Protection of the Copyrights of Published Works (Draft)] (PRC Ministry of Culture, 1957) (China).

2. Chosakukenho (著作権法) [Japanese Copyright Law], Law No. 48 of 1970, amended by Law No. 43 of 2012, art. 119(3) (2012) (Japan).

3. Chuban Guanli Tiaoli (出版管理条例) [Regulation on the Administration of Publications] (promulgated by the St. Council, Jan. 2, 1997, by St. Council Decree No. 210, repealed Dec. 25, 2001 by St. Council Decree No. 343) St. CouncIl GAZ., 1997, no. 2, at 38 (China).

4. Chuban Guanli Tiaoli (出版管理条例) [Regulation on the Administration of Publications] (promulgated by the St. Council, Dec. 25, 2001, by St. Council Decree No. 343, repealed Mar. 19, 2011 by St. Council Decree No. 594) St. CouncIl GAZ., 2002, no. 4, at 15 (China).

5. Chuban Guanli Tiaoli (出版管理条例) [Regulation on the Administration of Publications] (promulgated by the St. Council, Mar. 19, 2011, by St. Council Decree No. 594) St. CounCIL GaZ., 2011, no. 9 (China).

6. Chubanwu Shichang Guanli Guiding (出版物市场管理规定) [Provisions on the Administration of Publications Market] (promulgated by the General Administration of Press and Publication and the Ministry of Commerce Order No. 52, Mar. 25, 2011)(China). 
7. Copyright Modernization Act, S.C. 2011, c. 22, § 29.21(1)(a-d) (Canada).

8. Dianshiju Guanli Guiding (电视剧管理规定) [Television Drama Management Regulations] (promulgated by SARFT Decree No. 2, Jun. 15, 2000, repealed Jan. 1, 2008) (China).

9. Dianshiju Neirong Guanli Guiding (电视剧内容管理规定) [Television Drama Content Management Regulations] (promulgated by St. Admin. of Radio, Film \& Television, May 14, 2010, effective July 1, 2010, by SARFT Decree No. 63) (China).

10. Dianshiju Shencha Chengxu (电视剧审查程序) [Television Drama Examination Procedure], SAPPRFT, Aug. 16, 2007 (China).

11. Dianshiju Shencha Guanli Guiding (电视剧审查管理规定) [Television Drama Examination Management Regulations] (promulgated by St. Admin. of Radio, Film \& Television, Sept. 20, 2004, effective Oct. 20, 2004, by SARFT Decree No. 40, repealed July 1, 2010) (China).

12. Dianying Guanli Tiaoli (电影管理条例) [Regulations on the Administration of Movies] (promulgated by St. Council Decree No. 342, Dec. 25, 2001) (China).

13. Dianying Juben Genggai Beian Dianyingpian Guanli Guiding (电影 剧本(梗概)备案、电影片管理规定) [Provisions on the Archival Filing of Film Scripts (Abstracts) and the Administration of Films] (promulgated by SARFT Decree No. 52, May 22, 2006) (China).

14. Directive 2001/29/EC of the European Parliament and of the Council of 22 May 2001 on the harmonisation of certain aspects of copyright and related rights in the information society (European Union).

15. Dinghu Dinggou Jinkou Chubanwu Guanli Banfa (订户订购进口出 版物管理办法) [Measures for the Administration on Subscribers' Subscription for Imported Publications] (promulgated by the General Administration of Press and Publication No. 51, Mar. 25, 2011)(China).

16. Guangbo Dianying Dianshibu Guanyu Yinjin Haiwai Dianshiju De Shencha Biaozhun (广播电影电视部关于引进海外电视剧的审查 标准) [Examination Standards Concerning Imported Foreign Television Dramas] (promulgated by the St. Admin. of Radio, Film \&Television, Nov. 28, 1990, repealed Dec. 17, 2003) (China). 
17. Guangbo Dianshi Guanli Tiaoli (广播电视管理条例) [Regulations on Broadcasting and Television Administration] (promulgated by the St. Council Decree No. 228, Aug. 11, 1997) (China).

18. Guangbo Dianshi Jiemu Chuansong Yewu Guanli Banfa (广播电视 节目传送业务管理办法) [Administrative Measures for the Business of Transmission of Radio and TV Programs] (promulgated by SARFT Decree No. 33, Jul. 6, 2004) (China).

19. Guangbo Dianshi Shipin Dianbo Yewu Guanli Banfa (广播电视视 频点播业务管理办法) [Measures for the Administration of Radio \&TV Video Broadcasting by Order] (promulgated by St. Admin. of Radio, Film \& Television, Jul. 6, 2004, effective Aug. 10, 2004, by SARFT Decree No. 35) (China).

20. Guangbo Diantai Dianshitai Shenpi Guanli Banfa (广播电台电视台 审批管理办法) [Measures for the Administration of Examination and Approval of Radio Stations and Television Stations] (promulgated by SARFT Decree No. 37, Aug. 18, 2004) (China).

21. Guangbo Dianying Dianshibu Guanyu Yinjin Haiwai Dianshiju De Shencha Biaozhun (广播电影电视部关于引进海外电视剧的审查 标准) [Examination Standards Concerning Imported Foreign Television Dramas] (promulgated by the St. Admin. of Radio, Film \&Television, Nov. 28, 1990, repealed Dec. 17, 2003) (China).

22. Guangdian Zongju Guanyu Guangbo Dianshi Jiemu he Guanggao Zhong Guifan Shiyong Guojia Tongyong Yuyan Wenzi de Tongzhi ( 广电总局关于广播电视节目和广告中规范使用国家通用语言文 字的通知) [SARFT Notice concerning the Standardized Use of the National Common Spoken and Written Language in Radio and Television Programs and Advertising"], SARFT, Nov. 27, 2014.

23. Guangdian Zongju Guanyu Jiaqiang Hulianwang Shiting Jiemu Neirong Guanli de Tongzhi (广电总局关于加强互联网视听节目内 容管理的通知) [SARFT Notice Concerning Strengthening Internet Audio-visual Programme Content Management], SARFT, Mar. 3, 2009.

24. Guanyu Fazhan Woguo Yingshi Donghua Chanye De Ruogan Yijian (关于发展我国影视动画产业的若干意见) [Several Opinions of the Development of China's Animation Industry] (promulgated by the St. Admin. Radio, Film \& Television, Apr. 20, 2004) (China). 
25. “Guanyu Yanli Daji Feifa Chuban Fanzui Huodong de Tongzhi” (关 于严厉打击非法出版犯罪活动的通知) [Notice Regarding Severely Punishing Illegal Publishing Criminal Activities], promulgated by the SPC and SPP, FYF no. 33, Nov. 27, 1991, Sup. PeOPle's CT. GAZ., no.3 (China)

26. Guanyu Yanli Daji Feifa Chuban Huodong de Jinji Tongzhi (关于严 厉打击非法出版活动的紧急通知) [Emergency Notice Regarding Striking Hard Against Illegal Publishing Activities], promulgated by the National Publication Bureau, the State Administration of Industry and Commerce, and the Ministry of Public Security, CZZ no.165, Mar. 4, 1986, ST. CounCIL GAZ., 1986, no. 9 (China).

27. "Guanyu Yifa Yancheng Feifa Chuban Fanzui Huodong de Tongzhi” (关于依法严惩非法出版犯罪活动的通知) [Notice Regarding Severely Punishing Illegal Publishing Criminal Activities According to Law], promulgated by the SPC and SPP, FYF no. 33, Nov. 27, 1987, SuP. PeOPLE's Ct. GAZ., 1987, no.4 (China).

28. Guanyu Zhengque Zhixing Gaochou Zhidu Qiadang Zhangwo Gaochou Biaozhun de Tongzhi (关于正确执行稿酬制度，恰当掌握稿 酬标准的通知) [Notice on the Correct Enforcement of the Remuneration Regime, and Proper Mastery of the Remuneration Standard] (promulgated by Ministry of Culture Decree (61) WCQZ No.1216, Aug. 28, 1961, repealed Mar. 1, 2011) (China).

29. Guojia Xinwen Chuban Guangdian Zong Ju Chongshen Wangshang Jingwai Yingshiju Guanli de Youguan guiding (国家新闻出版广电 总局重申网上境外影视剧管理的有关规定) [SAPPRFT Reiterates Provisions concerning the Management of Online Foreign Television Dramas], SAPPRFT, Sep. 5, 2014.

30. Guowuyuan Bangongting Guanyu Jianjue Qudi Feifa Chuban Huodong de Tongzhi (国务院办公厅关于坚决取缔非法出版活动的 通知) [Notice Regarding Resolutely Clamping Down on Illegal Publishing Activities] (promulgated by the St. Council, Jan. 25, 1996) (China).

31. Guowuyuan Guanyu Yinfa "Kuandai Zhongguo" Zhanlue Ji Shishi Fangan De Tongzhi (国务院关于印发“宽带中国”战略及实施方案 的通知)[The Notice of State Council on the "Broadband China" Strategy and its Implement Plan], (promulgated by the St. Council, Aug. 1, 2013, Guofa No. 31) (China). 
32. Guowuyuan Guanyu Yanli Daji Feifa Chuban Huodong de Tongzhi (国务院关于严厉打击非法出版活动的通知) [Notice Regarding Striking Hard Against Illegal Publishing Activities] (promulgated by the St. Council, Jul. 6, 1987) (China).

33. H. R. Rep. No.2222, 60th Cong., 2d, Sess. 7 (1909).

34. Hetong Fa (合同法) [the Contract Law of the People's Republic of China] (Adopted by the National People's Congress on March 15, 1999, and promulgated by the Presidential Order No. 15) (China).

35. Hulianwang Deng Xinxi Wangluo Chuanbo Shiting Jiemu Guanli Banfa (互联网等信息网络传播视听节目管理办法) [Measures for the Administration of the Publication of Audio-Visual Programs through the Internet or Other Information Network] (promulgated by SARFT Decree No. 39, Jul. 6, 2004) (China).

36. Hulianwang Shiting Jiemu Fuwu Guanli Guiding (互联网视听节目 服务管理规定) [Administrative Provisions on Internet Audio-Visual Program Service] (SARFT and Ministry of Information Industry of the People's Republic of China, Decree No. 56, Jan. 31, 2008) (China).

37. Hulianwang Wenhua Guanli Zanxing Guiding (互联网文化管理暂 行规定) [Interim Provisions on the Administration of Internet Culture] (promulgated by the Ministry of Culture Order No. 51, Feb. 17, 2011) (China).

38. Hulianwang Xinwen Xinxi Fuwu Guanli Guiding (互联网新闻信息 服务管理规定) [Regulations on Administration of Internet News Information Services] (promulgated by St. Council Info. Office \& Ministry of Indus. \& Info. Tech. Decree No. 37, Sep. 25, 2005) (China).

39. Hulianwang Xinxi Fuwu Guanli Banfa (互联网信息服务管理办法) [Administration Procedures of Internet Information Services] (promulgated by St. Council Decree No. 292, Sep. 25, 2000) (China).

40. Jingwai Dianshi Jiemu Yinjin Bochu Guanli Guiding (境外电视节 目引进、播出管理规定) [Foreign Television Program Import and Broadcast Management Regulations] (promulgated by St. Admin. of Radio, Film \& Television, Sept. 23, 2004, effective Oct. 23, 2004, by SARFT Decree No. 42) (China). 
41. Minfa Tongze (民法通则) [the General Principles of the Civil Law of China] (Adopted at the Fourth Session of the Sixth National People's Congress on April 12, 1986 and promulgated by Order No. 37 of the President of the People's Republic of China on April 12, 1986).

42. Minji Soshoho (民事訴訟法) [Code of Civil Procedure of Japan], Act No. 109 of 1996, amended by Act No. 36 of 2011 (Japan).

43. Minpō (民法) [Civil Code of Japan], Act No. 89 of April 27, 1896, amended by Act No. 78 of 2006 (Japan).

44. Nihon Koku Kenpo, (日本国憲法) [The Constitution of Japan], Promulgated on Nov. 3, 1946, Came into effect on May 3, 1947 (Japan).

45. U.S. CONST. Amend. I.

46. U.S. Copyright Office, Circular 92, Copyright LaW of the United States of America and Related Laws Contained in Title 17 OF the United States Code (Dec. 2011), http://www.copyright.gov/title17/circ92.pdf.

47. Wenhuabu Guanyu Shishi Hulianwang Wenhua Guanli Zanxing Guiding Youguan Wenti de Tongzhi (文化部关于实施〈互联网文 化管理暂行规定〉有关问题的通知) [Notice of the Ministry of Culture on Some Issues Relating to Implementation of the "Interim Rules on the Management of Internet Culture"] (The Ministry of Culture, WSF[2003]27, Jul. 4, 2003) (China).

48. Wenhuabu Guanyu Shishi Xin Xiuding Hulianwang Wenhua Guanli Zanxing Guiding de Tongzhi (文化部关于实施新修订〈互联网文 化管理暂行规定〉的通知) [Notice of the Ministry of Culture on the Implementation of the New Amended "Interim Rules on the Management of Internet Culture"] (The Ministry of Culture, WSF[2011]14, Mar. 21, 2011) (China).

49. Wenhuabu Guanyu Wangluo Yinyue Fazhan yu Guanli de Ruogan Yijian (文化部关于网络音乐发展与管理的若干意见) [Several Opinions of the Ministry of Culture on the Development and Management of Network Music] (The Ministry of Culture, WSF[2006]32, Dec. 11, 2006) (China).

50. XIANFA (宪法) [Constitution of the People's Republic of China] (1982), Adopted at the Fifth Session of the Fifth National People's Congress on December 4, 1982 and adopted at the First Session of 
the Eighth National People's Congress on March 29, 1993, Amended in accordance with the Amendments to the Constitution of the People's Republic of China adopted respectively at the First Session of the Seventh National People's Congress on April 12, 1988, the First Session of the Eighth National People's Congress on March 29, 1993, the Second Session of the Ninth National People's Congress on March 15, 1999 and the Second Session of the Tenth National People's Congress on March 14, 2004 (China).

51. Xinxi Wangluo Chuanbo Quan Baohu Tiaoli (信息网络传播权保护 条例) [Regulation on the Protection of the Right to Network Dissemination of Information], (adopted at the 135th Executive Meeting of the State Council on May 10, 2006, effective as of July 1, 2006) (China).

52. Yinxiang Zhipin Guanli Tiaoli (音像制品管理条例) [Regulations on the Administration of Audio and Video Products] (promulgated by the St. Council Decree No. 341, Mar. 19, 2011) St. CouncIL GAZ., 2011, no. 9 (China).

53. Yinxiang Zhipin Jinkou Guanli Banfa (音像制品进口管理办法) [Measures for the Administration of Import of Audio and Video Recordings] (promulgated by the General Administration of Press and Publication and General Administration of Customs Order No. 53, Apr. 6, 2011)(China).

54. Zhonghua Minguo 103 Nian Zhuzuoquan Fa (中華民國 103 年著作 權法) [Copyright Act of 2014], Jan. 22, 2014, ZonGTONGFU GonGBAO (總統府公報) [PRESIDENTIAL OfFICE GAZ.], no. 7123, 2014, at 65, translated at Intellectual Property OfFice Ministry of ECONOMIC AFFAIRS, https://www.tipo.gov.tw/dl.asp?filename=42129352671.docx (Taiwan).

55. Zhonghua Renmin Gonghe Guo Zhuzuo Quan Fa (中华人民共和国 著作权法) [Copyright Law of the People's Republic of China] (promulgated by the Nat'l People's Cong., Sept. 7, 1990, amended Feb. 26, 2010 by the Standing Comm. of the Nat'l People's Cong., amendments effective Apr. 1, 2010).

56. Zhongwai Hezuo Shezhi Dianyingpian Guanli Guiding (中外合作摄 制电影片管理规定) [Measures for the Administration of Chi- 
nese-Foreign Cooperative Film Production] (promulgated by SARFT Decree No. 31, Aug. 6, 2004) (China).

57. Zhongwai Hezuo Zhizuo Dianshiju Guanli Guiding (中外合作制作 电视剧管理规定) [Provisions on the Administration of Sino-foreign Cooperation in the Production of TV Plays] (promulgated by SARFT Decree No. 41, Sep. 21, 2004) (China).

58. Zuigao Renmin Fayuan Guanyu Chongfen Fahui Zhishi Chanquan Shenpan Zhineng Zuoyong Tuidong Shehui Zhuyi Wenhua Da Fazhan Da fanrong he Cujin Jingji Zizhu Xietiao Fazhan Ruogan Wenti De Yijian (最高人民法院关于充分发挥知识产权审判职能 作用推动社会主义文化大发展大繁荣和促进经济自主协调发展 若干问题的意见) [Several Opinions of the Supreme People's Court on Some Issues in Fully Giving Rein to the Function of Intellectual Property Rights Adjudication in Promoting the Great Development and Flourishing of Socialist Culture and Stimulating the Indigenous and Coordinated Development of Economy] (SuP. PEOPLE'S CT., FF No. (2011)18, Dec. 16, 2011).

59. Zuigao Renmin Fayuan Guanyu Shenli Zhuzuoquan Minshi Jiufen Anjian Shiyong Falv Ruogan Wenti De Jieshi (最高人民法院关于 审理著作权民事纠纷案件适用法律若干问题的解释) [Interpretation of the Supreme People's Court Concerning Several Issues on Application of Law in Hearing Correctly the Civil Copyright] (promulgated by the Supreme People's Court Oct. 15, 2002) (China).

\section{International Treaties and Materials}

1. Agreement on Trade Related Aspects of Intellectual Property Rights, Apr. 15, 1994, Marrakesh Agreement Establishing the World Trade Organization, Annex 1C, 1869 U.N.T.S. 299, 33 I.L.M. 1125, 1197 (1994).

2. Berne Convention for the Protection of Literary and Artistic Works (Paris Act of July 24, 1971, as amended on September 28, 1979), WIPO Publication No. 287(E) (Geneva: World Intellectual Property Organization, 1992), 828 U.N.T.S. 221.

3. Directive 2007/65/EC of the European Parliament and of the Council of 11 December 2007 amending Council Directive 89/552/EEC on the coordination of certain provisions laid down by law, regulation 
or administrative action in Member States concerning the pursuit of television broadcasting activities (EU).

4. General Agreement on Tariffs and Trade 1994, Apr. 15, 1994, Marrakesh Agreement Establishing the World Trade Organization, Annex 1A, The Legal Texts: The Results Of The Uruguay Round Of Multilateral Trade Negotiations 17 (1999), 1867 U.N.T.S. 187, 33 I.L.M. 1153 (1994).

5. International Covenant on Civil and Political Rights, Dec. 16, 1966, S. Treaty Doc. No. 95-20, 6 I.L.M. 368 (1967), 999 U.N.T.S. 171.

6. Memorandum of Understanding on the Protection of Intellectual Property, Jan. 17, 1992, P.R.C.-U.S., T.I.A.S. No. 12036 (1995).

7. Universal Copyright Convention as revised at Paris on 24 July 1971, 25 U.S.T. 1341, 943 U.N.T.S. 178.

8. WIPO Copyright Treaty, Dec. 20, 1996, S. Treaty Doc. No. 105-17 (1997), 36 I.L.M. 65 (1997).

9. WTO Panel Report, China-Measures Affecting Trading Rights and Distribution Services for Certain Publications and Audiovisual Entertainment Products, WT/DS363/R (Aug. 12, 2009).

10. WTO Panel Report, China-Measures Affecting the Protection and Enforcement of Intellectual Property Rights, WT/DS362/R (Jan. 26, 2009). 



\section{SUMMARY}

Fighting piracy seems to be the major mission of copyright in the digital era. The advancements in technologies have not only brought opportunities to both individual creators and Internet-related industries, but also expanded the once-narrow concept of piracy into one that covers private utilizations of copyrighted contents, something people enjoyed in the pre-digital age. Fan creations are no doubt one of them. Most fan creations are unauthorized, thus they are potential copyright infringements in China, the U.S., and Japan, if charges are filed. However, despite their legal nature, many copyright owners in China, the U.S., and Japan are actually tolerating them, as fan culture has long been an integral part of copyright-related business and fan activities and creations can bring copyright owners merits. Moreover, besides economic benefits, many online fan activities have the potential to promote civic engagement as well. Considering the endemic problems that foreign copyright owners in the Chinese market face such as strict cultural censorship and import quota limits, they may find fan activities and creations extremely helpful in terms of market cultivation and promoting an open society in China, which in turn could bring a steady income in the long run. Therefore, in order to mitigate the problem of massive online copyright infringement and justify fan activities, this research argues for a cooperative approach which encourages copyright owners to exert a degree of control over their fan creators. Compared with the current approach which treats fan utilizations as theft, copyright owners and the lawmakers should distinguish fan creators from commercial pirates, and unleash the potential of this kind of creators.

Based on the above considerations, Chapter 1 first narrates some background information. Then it introduces the research question: whether a flexible cooperative mechanism can be established between the fan creators and copyright owners in China, so that the latter could have a degree of control over the former and their works, and the activities of the 
former could be legally justified to a degree? The structure and methodology are also presented in this chapter.

Chapter 2 of this book illustrated the endemic problems and general economic obstacles a foreign copyright owner will face when trying to enforce his copyright in China. This work went through the legislations and policy related to censorship and import quotas in China, as well as the influence of China's political culture over its copyright policy and legislation. It reveals that although endemic problems such as censorship and import quotas fall under China's autonomy, these problems, along with general economic issues such as transaction costs are restricting the ability of a foreign copyright owner to conduct business and enforce his/her rights in the Chinese market.

Having identified the crux in the Chinese market when one is enforcing his/her copyright, Chapter 3 then gives a historical review of the development of several typical fan activities, and explains why nowadays they are deemed as a threat to copyright owners while in the old days they were not. It further explores the reasons behind fan activities, and why we failed to provide a solution which can make the best of both worlds. This chapter indicated that it is the development of digital technologies that highlighted the long existing unauthorized private utilizations of copyrighted contents such as fan activities, and it is that same development which provided Internet users with game changing tools and accessible materials, and forced our copyright law system to change and make those activities a problem to copyright owners. The problem lies in the fundamental structure of the Internet, and any change to that structure will inevitably cause more problems.

The conclusions reached in chapter 2 and 3 pave the way for chapter 4 , which confirmed that many fan activities are actually potential copyright infringements under the current legal frameworks of the U.S., Japan, and China, whereas the transformative fan creations are highly dependent on case-by-case judgments by the courts of the above countries. Considering that fact and that total enforcement is unrealistic in China, this chapter further examined the existing solution proposals, and demonstrated that they are not ideal in regulating fan problems, as they are either too slow or too indirect, with regard to the purpose of this book.

After presenting the historical and technical background of the problems of fan activities and examining the practical issues that existing legal remedies and solution proposals encountered, Chapter 5 of this book recommended a possible solution which considers the pros and cons of 
the existing proposals and accommodates the needs of a transition period of copyright jurisprudence. It suggests that, foreign copyright owners in the Chinese market should adopt a specially designed NAP, to collect fans and reassure them that no litigation will be initiated, provided that they act according to the rules of the NAP. Moreover, in order to avert copyright owner's manipulation over its fan derivative works, the Copyright Law of China must be revised to provide more clearness to derivative works and accommodate parody as well. 



\section{中文简介}

在数字时代, 打击盗版似乎成了版权法的第一要务。科技的进步不仅为互 联网相关的产业带来的巨大的机遇, 也为个体创作者提供了前所未有的自由。 此外, 曾经一度狭窄的 “盗版” 之概念也得以扩张, 将许多曾经在前互联网时 代被视为理所当然的个体利用版权作品的行为囊括了在内, 这其中就包括了粉 丝创作这一类本书所研究的行为。由于大部分粉丝作品都未获得作者的正式许 可, 因此, 就中国、美国以及日本的版权相关法律而言, 如果版权所有人对粉 丝创作者提起诉讼的话, 这些粉丝作品很有可能会被法院判定为侵权。然而, 尽管其在法律上面临着这样的负面评价, 在事实上, 中国、美国和日本的许多 版权所有人都在容忍着这类行为的发生。原因就在于, 粉丝文化长期以来就是 版权相关产业的一个不可分割的部分, 而且粉丝活动和粉丝作品也能够给版权 人带来可见的利益。此外, 除了经济利益以外, 事实证明, 许多粉丝活动也能 够为推动 “公民参与” 提供助力。考虑到如文化审查以及进口配额等中国特殊 的制度和政策设定，在中国市场中的外国版权人会更有可能发觉粉丝活动及其 作品的用处：它们对于开拓中国市场并推进国家进一步开放大有禆益。市场的 覆盖率之提高以及开放社会的形成, 从长期来看, 将会反过来给外国版权所有 人带来持续稳定的收益。因此, 为了减轻大规模在线版权侵权问题所带来的困 扰, 以及为粉丝活动提供正当化的理由, 本书采用了一种倡导合作的研究路径 , 即鼓励版权所有者积极介入粉丝活动, 并对其施加一定的影响和控制。与现 有的对抗性路径, 即将粉丝创作利用作品的行为和其他侵权行为不加区别一并 给予法律上负面评价的做法相比, 本书认为, 版权所有人和立法者应当合理区 分粉丝创作者和其他侵权者, 并给予粉丝创作者以正面评价, 以释放这类创作 者的潜能。 
基于上述考量, 本书第一章首先陈列了几项本研究的重要背景信息。其后 , 提出了本书的研究问题: 在中国, 我们是否可以在粉丝创作者与版权所有人 之间建立起一种灵活的合作机制, 从而使得版权所有人能够对粉丝创作者及其 创作过程施加一定的影响, 而粉丝创作活动也能够在某种程度上获得其应有的 正当性？本章最后部分, 对本书的架构以及方法论进行了陈述。

本书第二章对外国版权人在中国行使版权权利时面临的一些特殊政治性、 经济性问题进行了勾画。本书首先全面回顾了中国的与文化审查以及进口配额 等制度有关的法律法规以及政策条文, 并参考分析了中国的政治文化对其版权 政策与法律的影响。本章揭示了, 虽然如文化审查和进口配额等当地特殊安排 是中国国家自治的一个部分, 但对于外国版权人而言, 这些独特的政治和经济 上的问题，将会极大地限制其在中国市场开展业务并行使版权的能力。

在上一章中, 外国版权人在中国市场中行使自己版权所遇到之难题的症结 得到了充分的展示。本书第三章将会对几种具有代表性的粉丝活动的发展进行 历史回顾, 并解释了为何在前数字时代, 这些粉丝活动并没有引起版权所有人 的不安, 而在数字时代却成为了版权所有人心头的隐患。本章进一步探讨了粉 丝活动背后的动机及其出现及难以禁止的理由, 和为何我们无法设计出一个完 美解决方案的原因。本章指出, 正是由于数字技术的长足发展, 原本就长期存 在的、如粉丝活动等对版权内容进行未授权私人利用之行为才进入了大众的视 野。也正是由于数字技术的发展, 越来越多的网络用户获得了前所未有的创作 工具以及唾手可得的大量素材。这些反过来推动了各国版权法律的变革, 法律 变得更为严苛, 而这些行为由此被法律判定为违法, 法律由此站在了版权人的 一边。但是, 由于科技带来的法律问题, 却不能借由封禁某项技术的做法来获 得解决, 因为这种做法最终会导致更多的问题。

第二章和第三章各自的结论, 为第四章的内容铺平了道路。第四章在比较 分析各类粉丝作品在中国、美国和日本三国的相关版权法律中所获得的评价后 
, 得出了 “许多粉丝作品在事实上可能是侵犯他人版权的” 这一结论, 本章也 发现, 许多具有高度转换性的粉丝作品是否侵权, 就中国、美国和日本而言, 仍有待法院的自由裁量。考虑到在中国, 对大面积网络侵权行为逐一行使版权 是不切实际的这一情况, 本章进一步检验了既存的解决方案, 并证明了这些既 存方案要么过于缓慢, 要么过于间接或存在其他的问题。考虑到本书的主旨, 这些解决方案都无法全面解决粉丝创作所带来的问题。

在全面展示了粉丝活动的历史和技术背景, 并检验了现有的法律救济方式 以及解决方案所遇到的现实问题之后, 本书第五章在参考了现有方案的优点和 缺点, 并兼顾了版权法的发展正处于转型时期这一现实后, 提出了一个可能的 解决方案。本书的建议是, 在中国市场中的外国版权所有者, 应当采用一种经 过特殊设计的 “不行动政策”（NAP），通过创设一个特定的平台来收集粉丝 , 并承诺, 只要粉丝按照 NAP 所设定的规则在平台中行事, 就不会对其提起版 权诉讼。这样做的话, 粉丝创作者就会知道版权所有人所设定的底线, 从而能 够安心地从事粉丝活动, 免受侵权之忧的困扰。此外, 为了避免产生版权所有 人可能出现的、由于权力过大而操控衍生粉丝作品的创作过程乃至作品本身的 负面现象, 中国的《著作权法》也应当被修订, 以为衍生作品提供更多的明确 度, 并将戏仿作品纳入。 



\section{NederLANDSE SAMENVATTING}

Het vechten tegen piraterij lijkt de belangrijkste missie in het domein van het auteursrecht in het digitale tijdperk te zijn. De vooruitgang in de technologieën heeft niet alleen geleid tot kansen voor zowel individuele makers en internet-gerelateerde industrieën, maar heeft ook voor uitbreiding gezorgd van het eens zo smalle concept van piraterij in een concept dat ook persoonlijk gebruik van auteursrechtelijk beschermde werken omvat; iets waar mensen het voordeel van genoten in de pre-digitale era. Fancreaties zijn zonder enige twijfel een van hen. De meeste fancreaties zijn niet geautoriseerd, dus zijn het potentiële inbreuken op het auteursrecht in China, de VS en Japan indien er aanklachten worden ingediend. Ondanks de juridische aard van fancreaties, worden ze feitelijk wel getolereerd door veel van de auteursrechteigenaren in China, de VS en Japan. Dit wordt veroorzaakt doordat de fancultuur al voor een lange tijd een integraal onderdeel van de auteursrechtgerelateerde business is en activiteiten en creaties van fans de auteursrechteigenaren ook verdiensten kunnen brengen. Naast de economische voordelen, hebben veel online fanactiviteiten bovendien ook het potentieel om de maatschappelijke betrokkenheid te bevorderen. Gezien de endemische problemen waarmee buitenlandse auteursrechteigenaren op de Chinese markt worden geconfronteerd, zoals strikte culturele censuur en invoerquota, kunnen zij activiteiten en creaties van fans zeer nuttig vinden om de markt aan te boren en de open samenleving in China te bevorderen, wat op zijn beurt zou kunnen resulteren in een vast inkomen op de lange termijn. Om het probleem van de massale online-auteursrechtinbreuk te beperken en fan activiteiten te rechtvaardigen, pleit dit onderzoek daarom voor een gezamenlijke aanpak waarbij auteursrechteigenaren aangemoedigd worden om een zekere mate van controle uit te oefenen over hun creatieve fans. Vergeleken met de huidige aanpak, waarbij gebruik door fans behandeld wordt als diefstal, zouden auteursrechteigenaren en de wetgevers creatieve fans moeten on- 
derscheiden van commerciële piraten en het potentieel van dit soort makers moeten ontketenen.

Op basis van de bovenstaande overwegingen is hoofdstuk 1 gewijd aan de achtergrondinformatie. Vervolgens wordt de onderzoeksvraag geintroduceerd: kan er in China een coöperatief en flexibel mechanisme opgezet worden tussen creatieve fans en de auteursrechteigenaren, zodat de laatsten deels controle kunnen uitoefenen over de creatieve fans en hun creaties, en zijn die activiteiten ook tot op een zekere hoogte wettelijk te rechtvaardigen? In dit hoofdstuk worden ook de structuur en methodologie gepresenteerd.

Hoofdstuk 2 van dit boek zet de endemische problemen en algemene economische obstakels uiteen die een buitenlandse auteursrechteigenaar onder ogen zal moeten zien wanneer die zal proberen zijn rechten in China te handhaven. In dit werk gaan we in op de wetgeving en het beleid met betrekking tot censuur en importquota's in China, evenals de invloed van de Chinese politieke cultuur op het auteursrechtbeleid en auteursrechtwetgeving. Hoewel de endemische problemen, zoals censuur en invoerquota, onder China's autonomie vallen, laat dit werk zien dat deze problemen samen met algemene economische vraagstukken, zoals transactiekosten, beperkend zijn voor het vermogen van een buitenlandse auteursrechteigenaar om zaken te doen en zijn rechten te handhaven op de Chinese markt.

$\mathrm{Na}$ het identificeren van het struikelblok op de Chinese markt wanneer men auteursrechten handhaaft, geeft hoofdstuk 3 vervolgens een historisch overzicht van de ontwikkeling van een aantal typische fan-activiteiten en licht toe waarom die tegenwoordig beschouwd worden als een bedreiging voor de auteursrechteigenaren, terwijl daar in het verleden geen sprake van was. Het legt verder bloot wat de beweegredenen voor fan-activiteiten zijn en waarom alle belanghebbenden niet tot een oplossing kunnen komen die het beste van beide werelden biedt. In dit hoofdstuk wordt aangegeven dat door de ontwikkeling van digitale technologieën de nadruk kwam te liggen op het al lang bestaande ongeoorloofde private gebruik van auteursrechtelijk beschermde inhoud zoals fan-activiteiten. En het is diezelfde ontwikkeling die internetgebruikers voorzag met baanbrekende gereedschappen en toegankelijke materialen, en die het auteursrechtsysteem dwong om te veranderen en die activiteiten tot een probleem te maken voor auteursrechteigenaren. Het probleem ligt in de fundamentele structuur van het internet, en elke wijziging van die structuur zal onvermijdelijk leiden tot meer problemen. 
De conclusies die getrokken zijn in hoofdstuk 2 en 3 maakten de weg vrij voor hoofdstuk 4, waarin bevestigd wordt dat veel fan-activiteiten eigenlijk potentiële inbreuken zijn op het auteursrecht onder de huidige wettelijke regime van de VS, Japan en China, terwijl de inbreuken door transformatieve fancreaties sterk afhankelijk zijn van individuele beoordelingen van de rechters van deze landen. Gezien dit feit en dat de totale handhaving in China onrealistisch is, voorziet dit hoofdstuk in nader onderzoek naar de bestaande oplossingsvoorstellen en wordt er aangetoond dat die niet ideaal zijn voor het reguleren van problemen met fan-activiteiten, dit omdat ze ofwel te langzaam of te indirect zijn met betrekking tot het doel van dit boek; een snelle oplossing bieden voor de problematiek rond fancreaties.

$\mathrm{Na}$ de presentatie van de historische en technische achtergrond van de problemen met de fan-activiteiten en het onderzoeken van de praktische zaken die gedurende de bestaande rechtsmiddelen en oplossingsvoorstellen geïdentificeerd werden, geeft hoofdstuk 5 van dit boek een aanbeveling voor een mogelijke oplossing die de voors en tegens van de bestaande voorstellen in overweging neemt en voorziet in de behoefte aan een overgangsperiode met betrekking tot auteursrechtjurisprudentie. Het hoofdstuk zet uiteen dat de buitenlandse auteursrechteigenaren op de Chinese markt een speciaal ontworpen NAP aannemen om fans te verenigen en te verzekeren dat er geen geschillen tegen hen zullen worden gestart, op voorwaarde dat zij de regels van het NAP naleven. Bovendien, om manipulatie door auteursrechteigenaren van afgeleide fan-creaties af te wenden, moet de Auteurswet van China herzien worden om meer duidelijkheid te verschaffen wat betreft afgeleide werken en tevens een plaats te bieden aan de parodie. 



\section{VALORIZATION ADDENDUM}

\section{Social ReLEVANCE OF THIS RESEARCH}

Defeating online piracy is of top concern for copyright owners nowadays in the digital era, as piracy is deemed detrimental to the profitability of copyright owners. However, the concept of piracy today is broader than before, as it now includes many private utilizations of copyright contents, such as fan activities. However, the conclusion of this research indicates that, unlike pure theft and free-riders, fan activities and creations, if properly guided, are beneficial to copyright owners. This research aims to justify fan activities to a degree, which can benefit the society in three different ways: first, fan activities and creations can thus be separated from piracy, which will mitigate the problem of massive online copyright infringement; second, fan activities tend to generate creative ideas and produce promotional effects for the original products; third, fan activities are not just about producing derivative fan creations for copyright owners, they are about one form of civic engagement and expressing oneself through creation. Hence the justification of fan activities could help in the promotion of an open society in China.

Specifically, if foreign copyright owners in the Chinese market adopted the proposed solution of this book, a flexible and cooperative relationship between the fan creators and copyright owners could thus be established. When fans can be partners, copyright owners will be able to cultivate their fan base, and fan creators will not be deemed as infringers anymore. The copyright owners can thus put their resources on fighting commercial piracy, and enjoy the benefits of cooperation with fans. They will benefit from new derivative works, ideas and emerging authors, as the proposed solution will give them a degree of control over the fans and their derivative fan creations.

The economic gain of the copyright owners makes sure that fan creativity will be officially tolerated and unleashed, and the society could thus 
enjoy a variety of derivative works via a legitimate way in the future, which is in accordance with the purpose of copyright. Moreover, the proposed solution is designed in a way so that the fan creators are all on a voluntary basis, and more freedom to participate in fan activities means that more people are allowed to subtly engage in civic discussions and express themselves via this way, which is beneficial to society as a whole.

\section{Audience besides ACAdemic Community}

Copyright-related industries might be the first group who can benefit from the results of this research. As a matter of fact, copyright-related industries have long been investing a lot on copyright enforcement against infringeing activities, this is especially so in the digital age. Furthermore, cracking down on commercial piracy is one thing, and on fan creators is another. Copyright owners have difficulties when treating infringement cases related to fans. Moreover, as copyright is firmly connected with creativity, they are also in great need of talent and new ideas. In terms of a foreign market like China, copyright owners are keen to find an alternative to bypass the censorship and deliver the products to Chinese consumers. The proposed solution of this research can address these issues. Firstly, in the cooperative setting that this research proposes, fan creators are identified and treated differently from commercial pirates and other free-riders, which will greatly reduce the investment on copyright enforcement. Secondly, copyright owners can find plentiful talents and ideas in fan groups. Thirdly, in a transnational scenario, the proposed design could help the works of copyright owners to enter a restricted foreign market in an unofficial way, which will help them maintain a high level of exposure there and acquire statistics related to their copyright products from fans. These will present a much more precise vision about the market to copyright owners in a low-cost way.

Policy makers might be interested in the results of this research. This research is concerned with a central question regarding how to design our future copyright law so that the fan problems could be properly addressed. It also reminds the policy makers that although copyright is "territorial" in nature, we are in a borderless world that consists of different countries with different cultural policies. Therefore, the design of future copyright policy should not only focus on the protection and enforcement of copyright in a foreign market, but should also consider the actual per- 
formance of the infringed copyright work in there. This research shows how different the policies of different countries can be. In terms of the Chinese market, if strict enforcement is not feasible and can lead to unintended results, policy makers may have to alter their copyright policies regarding a foreign country, in order to get the best results.

Lawmakers will be another group who can benefit from the results of this research. On the one hand, this research has provided a comprehensive overview of China's laws and regulations related to derivative fan creations. It demonstrates the deficiencies of the current design, and proposes several revisions to the Copyright Law of China. Therefore, this research will be helpful for lawmakers in China in revising its copyright law, as China is currently revising its copyright law, and the proposed new rules will benefit the creative industry of China as well. On the other hand, this research is also beneficial to lawmakers at international levels, as it is worth considering whether the fan problems can be addressed further by pushing for new international copyright conventions.

\section{Publication of the Research Results}

First, the results of this research will be published in the form of a book. The book will be available to students and researchers who have special interests in the topics of either media law, copyright law or comparative law.

Second, some chapters or sections in this thesis have already been or are in the pipeline for being published in law journals. For instance, the discussions related to fan creations of Japanese anime and their copyright issues have already been published by the American Journal of Comparative Law, Volume 62, Number 4, December 2014, pp. 1009-1042, with the title of "What Can We Learn from Japanese Anime Industries? The Differences Between Domestic and Overseas Copyright Protection Strategies Towards Fan Activities". And a brief discussion about the proposed solution and its application on fansubs has already been scheduled for publication by the Oregon Review of International Law, Volume 16, issue 2, with the title of "Fansubs and Market Access of Foreign Audiovisual Products in China: The Copyright Predicament and the Use of No Action Policy".

Third, from 2012 to 2015, part of the results of this research have been presented in the Ius Commune Research School conferences and 
workshops, the $\mathrm{PhD}$ sections of the European Intellectual Property Institutes Network (EIPIN) Congresses, the Symposium on Copyright and Media Pluralism in China organized by the School of Law, University of Oregon.

\section{INNOVATIVENESS OF THE RESEARCH}

Legal scholars have long been searching for a solution to address the massive online infringement problem, but the existing proposals are far from satisfactory. Normally the result of most law amendment proposals is a copyright law with a high protection standard which yields to the copyright owners' side. Due to copyright's territorial nature, most current alternative proposals, such as CC licenses and NAPs are aiming on solving the problem on a country-by-country basis. This research studies the fan activities in three different legal systems and their legal status within, and re-tests the existing proposals and proposes a new solution. To summarize, this research is innovative at least from three perspectives.

From a comparative law perspective, this research is the first that compares copyright legislations regarding fan activities of China, the U.S., and Japan, as in these three countries fan activities are commonly seen. The comparison is not just a mere description of the differences and similarities in black letter laws, but it also analyzes whether or not the differences in the policy and enforcement level will influence the foreign copyright owners' choice with respect to the treatment of fan activities. The answer to this question is particularly important before any transnational solution is proposed.

From a theoretical perspective, this research is the first that proposes a solution which can address transnational copyright problems of fan creations. It re-examines the existing proposals which could solve the fan problems, and finds that the focus of the previous solutions has been placed on raising the protection standard or on solving copyright problems of fan creations within national boundaries. As a result, the solutions proposed in previous literature has been heavily criticized for its bias toward copyright owners and inefficiency in terms of addressing transnational copyright problems. By taking those criticisms as well as the endemic problems of the Chinese market into consideration, this research reveals the underlying reasons of the inefficiency of previous proposals, and proposes an alternative solution which is flexible and well balanced, 
and compatible with a transitional period of copyright jurisprudence and China's specific environment. It reconstructs the theory of Creative Common License and No Action Policy and proposes one which can address transnational copyright enforcement problems.

\section{SCHEDULE \& IMPLEMENTATION}

The implementation of the proposed solution of this research is twofold:

First, with the publication of the research results, industrial players might be able to get the core idea of the design and apply it to transnational scenarios. It is to be expected that industrial players will be interested, as the pros and cons of doing so are well presented in this book, the articles which were already published, and the presentations done by the author in various occasions. Moreover, it is easier to accept for the industry side, as the design is flexible, and its copyright rules are concise. The author will also work in close relationship with academia and industrial players in China, to further promote the application of and examine this design, and monitor and record the process and consequential results.

Second, the results of this research can be made available to policy makers as recommendations for law revision as well. This research also contains several amendment proposals, which are related to derivative works and parody, to the Copyright Law of China. After the publication and the promotion of the result, lawmakers such as the National People's Congress in China might be attracted, as the Copyright Law of China is currently being revised and is open for opinions. However, as this research is only aiming for a transitional period, more research should be done in the future if a thorough reform plan is needed for the contemporary copyright jurisprudence. In this sense, this research also stimulates more research over topics closely related to copyright reform. 



\section{CURRICULUM VITAE}

Tianxiang He (1984) holds a Bachelor degree in Laws (Huaqiao University, China, 2007) and a Masters degree in International Law (Jinan University, China, 2009). In year 2010 he joined the Renmin University of China (RUC) as a Ph. D Researcher in the field of Criminal Law. During his studies in China he was a member of the board of the Postgraduate student Union in Jinan University, and the $\mathrm{Ph}$. D coordinator of Grade 2010 in RUC.

Mr. He joined the faculty of Law of Maastricht University as a junior Ph. D Researcher in September 2011 with a CSC scholarship from the government of China, and saw it to conclusion in the Spring of 2016 there. His research in Maastricht focuses on the commercial model of the entertainment industries and intellectual property issues on the one hand, and on IP and media law issues on the other.

From August 2012 to July 2013, Mr. He worked in the Research Center for the Legal Systems of Intellectual Property of Waseda University as a visiting researcher, with the Japan Foundation Fellowship on the research title of "Fansubs and Copyright Protection Levels: A case study into the ANIME Industry of Japan", under the supervision of Prof. Takabayashi Ryu. 